Nevada

Environmental

Restoration

Project

\title{
Closure Report for Corrective Action Unit 543: Liquid Disposal Units, Nevada Test Site, Nevada
}

Controlled Copy No::

Revision: 0

January 2008

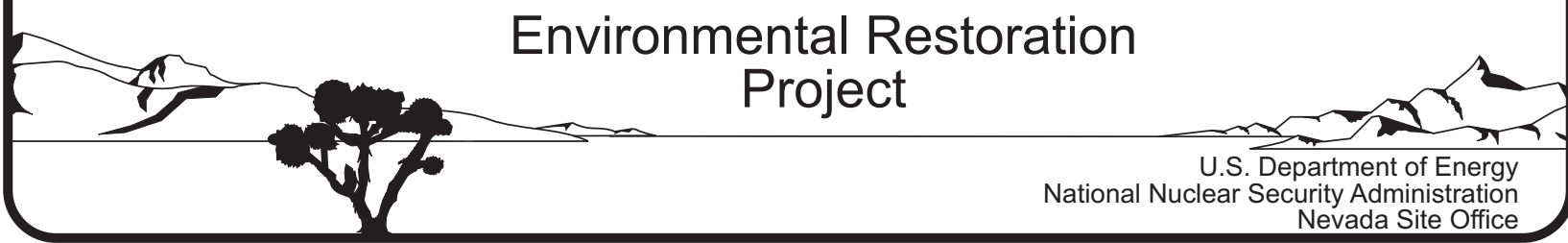




\section{DISCLAIMER}

Reference herein to any specific commercial product, process, or service by trade name, trademark, manufacturer, or otherwise, does not necessarily constitute or imply its endorsement, recommendation, or favoring by the United States Government or any agency thereof or its contractors or subcontractors.

This report has been reproduced directly from the best available copy.

Available for sale to the public from:

U.S. Department of Commerce

National Technical Information Service

5285 Port Royal Road

Springfield, VA 22161-0002

Telephone: (800) 553-6847

Fax: (703) 605-6900

E-mail: orders@ntis.gov

Online ordering: http://www.ntis.gov/ordering.htm

Available electronically at http://www.osti.gov/bridge.

Available for a processing fee to the U.S. Department of Energy and its contractors, in paper, from:

U.S. Department of Energy

Office of Scientific and Technical Information

P.O. Box 62

Oak Ridge, TN 37831-0062

Telephone: (865) 576-8401

Fax: (865) 576-5728

E-mail: reports@adonis.osti.gov 


\title{
CLOSURE REPORT FOR CORRECTIVE ACTION UNIT 543: LIQUID DISPOSAL UNITS, NEVADA TEST SITE, NEVADA
}

\author{
U.S. Department of Energy \\ National Nuclear Security Administration \\ Nevada Site Office \\ Las Vegas, Nevada
}

Controlled Copy No.

Revision: 0

January 2008 
THIS PAGE INTENTIONALLY LEFT BLANK 


\section{CLOSURE REPORT FOR \\ CORRECTIVE ACTION UNIT 543: \\ LIQUID DISPOSAL UNITS, NEVADA TEST SITE, NEVADA}

Approved By: $\frac{\text { /s/ Kevin J. Cabble }}{\text { Kevin J. Cabble }}$

Date: $1-3-08$ Federal Sub-Project Director Industrial Sites Sub-Project

Approved By: /S/ W. R. Wi 1born for J. Jones -John B. Jones Acting Federal Project Director Environmental Restoration Project 
THIS PAGE INTENTIONALLY LEFT BLANK 
ACRONYMS AND ABBREVIATIONS .......................................................................... vii

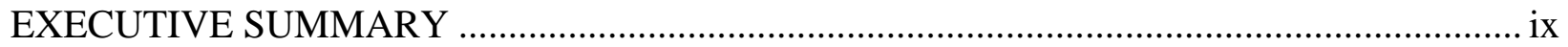

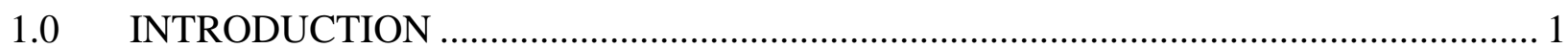

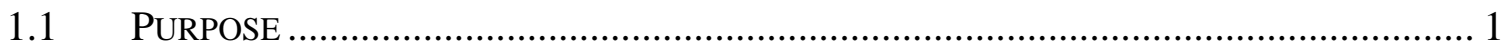

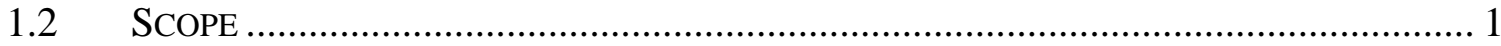

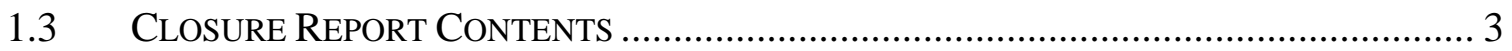

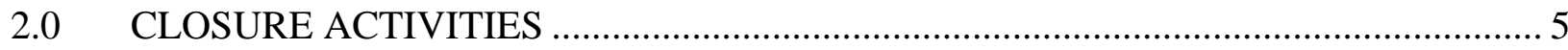

2.1 DESCRIPTION OF CORRECTIVE ACTION ACTIVITIES ........................................ 5

2.1.1 Preplanning and Site Preparation .............................................................. 5

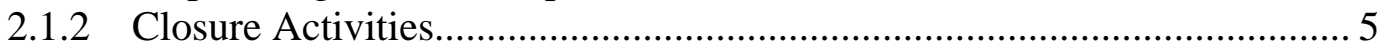

2.1.2.1 CAS 06-07-01, Decon Pad ............................................................... 5

2.1.2.2 CAS 15-01-03, Aboveground Storage Tank ….................................. 11

2.1.2.3 CAS 15-04-01, Septic Tank................................................................ 14

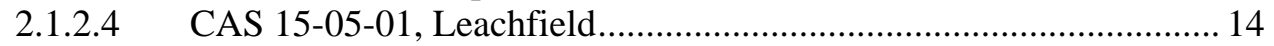

2.1.2.5 CAS 15-08-01, Liquid Manure Tank ..............................................16

2.1.2.6 CAS 15-23-01, Underground Radioactive Material Area ................. 16

2.1.2.7 CAS 15-23-03, Contaminated Sump, Piping..................................... 18

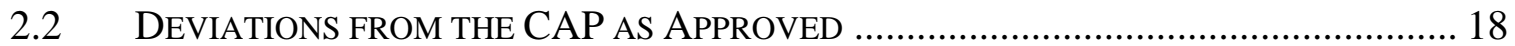

2.3 CoRrective ACTION SCHEDULE AS COMPLETED............................................... 20

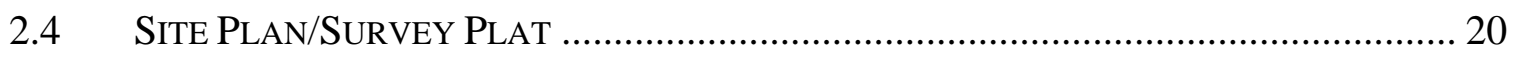

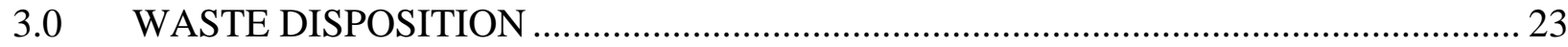

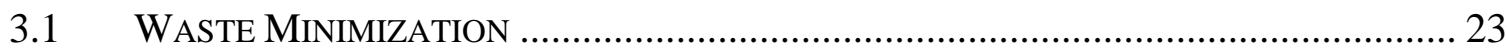

W.2 WASTE MANAGEMENT ….............................................................................. 23

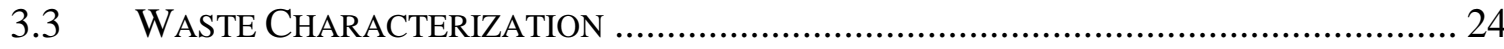

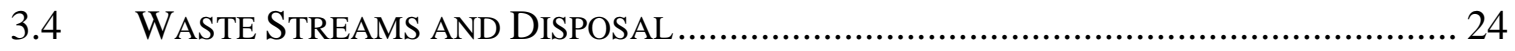

3.4.1 Sanitary Waste ................................................................................ 24

3.4.2 Petroleum Hydrocarbon Waste ......................................................... 26

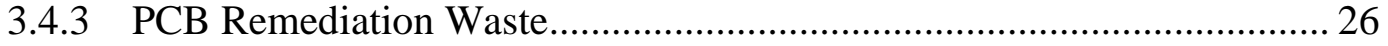

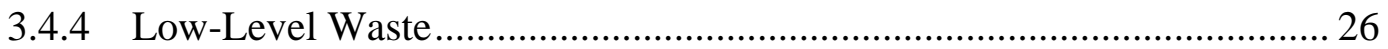

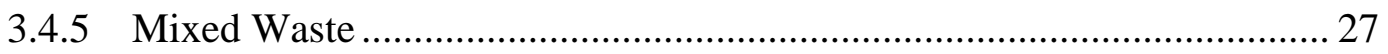

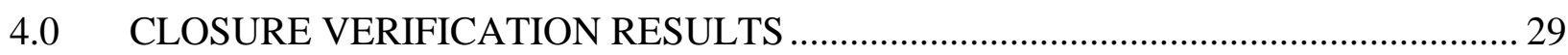

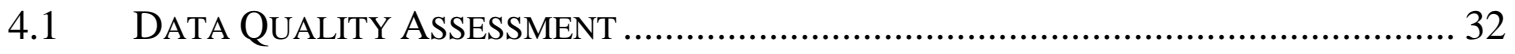

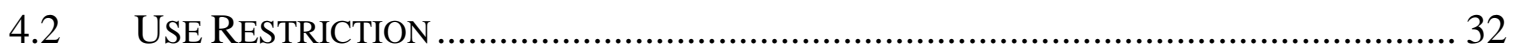

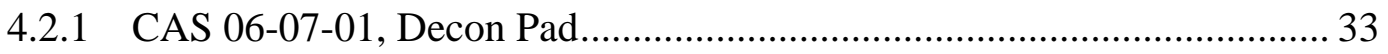

4.2.2 CAS 15-01-03, Aboveground Storage Tank............................................ 33

4.2.3 CAS 15-23-03, Contaminated Sump, Piping ............................................ 33

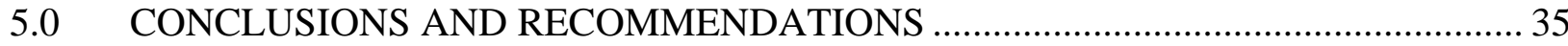

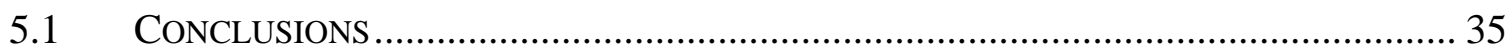

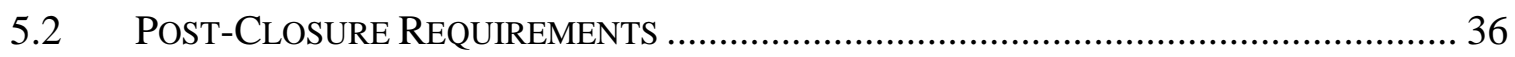

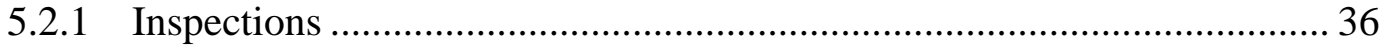

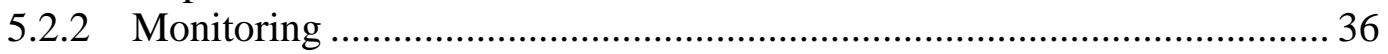




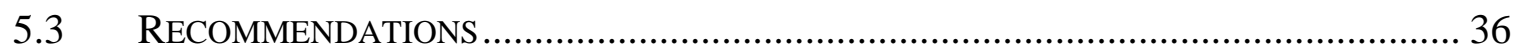

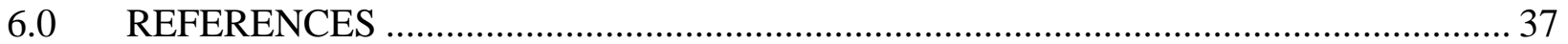

LIBRARY DISTRIBUTION LIST

\section{LIST OF FIGURES}

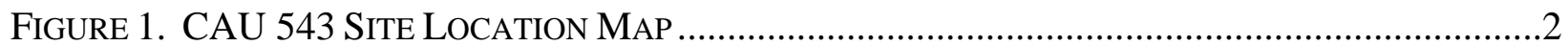

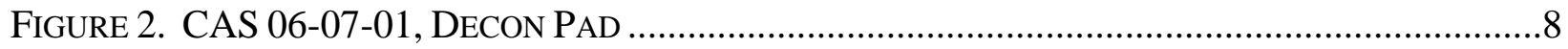

FIGURE 3. CAS 06-07-01 SAMPLE LOCATIONS ……….......................................................10

Figure 4. AREA 15 EPA FARM Closure Activity AREAS ......................................................12

FiguRE 5. CAS 15-01-03, ABOVEgRound STORAGE TANK ……................................................13

FIGURE 6. CASs 15-04-01, SEPTIC TANK, AND 15-05-01, LEACHFIELD ……………………........15

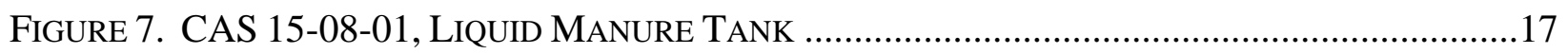

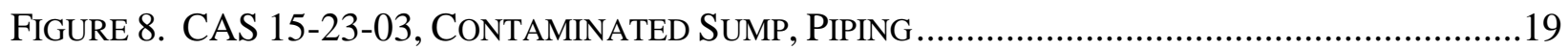

\section{LIST OF TABLES}

TABle 1. SUMmary OF CAU 543 Closure ACTIVITIES .............................................................6

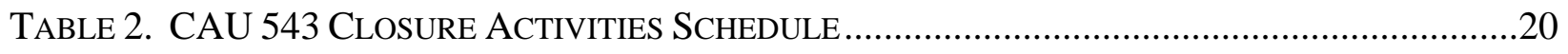

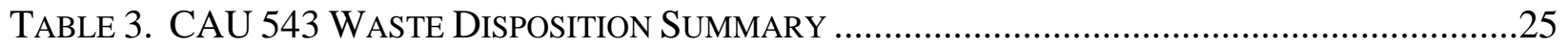

TABle 4. Closure Verification SoIl SAMPLES ColleCted For CAU 543 ...............................30

Table 5. Closure Verification SAmple Analytical Results Greater than the DETECTION LIMITS

\section{APPENDICES}

Appendix A. Data Quality ObJectives

ApPendix B. Sample Analytical Results

APPENDIX C. WASTE DISPOSITION DOCUMENTATION

ApPendix D. Site Closure Photographs

APPENDIX E. USE RESTRICTION DOCUMENTATION 


\begin{tabular}{|c|c|}
\hline Am & americium \\
\hline AST & aboveground storage tank \\
\hline bgs & below ground surface \\
\hline BMP & best management practice \\
\hline CADD & Corrective Action Decision Document \\
\hline CAIP & Corrective Action Investigation Plan \\
\hline CAP & Corrective Action Plan \\
\hline CAS & Corrective Action Site \\
\hline CAU & Corrective Action Unit \\
\hline CFR & Code of Federal Regulations \\
\hline Co & cobalt \\
\hline $\mathrm{COC}$ & contaminant of concern \\
\hline $\mathrm{CR}$ & Closure Report \\
\hline DRO & diesel-range organics \\
\hline EPA & U.S. Environmental Protection Agency \\
\hline FAL & final action level \\
\hline FFACO & Federal Facility Agreement and Consent Order \\
\hline $\mathrm{ft}$ & foot (feet) \\
\hline gal & gallon(s) \\
\hline GRO & gasoline-range organics \\
\hline HEPA & high efficiency particulate air \\
\hline HWAA & Hazardous Waste Accumulation Area \\
\hline ISOCS & In Situ Object Counting System \\
\hline LLW & low-level waste \\
\hline $\mathrm{LT}$ & less than requested detection limit but greater than method detection limit \\
\hline M\&OC & Management and Operations Contractor \\
\hline $\mathrm{mg} / \mathrm{kg}$ & milligram(s) per kilogram \\
\hline MW & mixed waste \\
\hline ND & not detected \\
\hline NDEP & Nevada Division of Environmental Protection \\
\hline
\end{tabular}




\section{ACRONYMS AND ABBREVIATIONS (continued)}

NNSA/NSO U.S. Department of Energy, National Nuclear Security Administration Nevada Site Office

NNSA/NV U.S. Department of Energy, National Nuclear Security Administration Nevada Operations Office

NTS Nevada Test Site

ORO oil-range organics

PCB polychlorinated biphenyl

pCi/g picocurie(s)s per gram

ppm parts per million

$\mathrm{Pu} \quad$ plutonium

QA quality assurance

QAPP Quality Assurance Project Plan

QC quality control

RMA Radioactive Material Area

RWMS Radioactive Waste Management Site

SDG sample delivery group

Sr strontium

TPH total petroleum hydrocarbons

UR use restriction

URMA underground radioactive material area

WMA waste management area

$\mathrm{yd}^{3} \quad$ cubic yard(s) 


\section{EXECUTIVE SUMMARY}

Corrective Action Unit (CAU) 543 is identified in the Federal Facility Agreement and Consent Order (FFACO, 1996) as Liquid Disposal Units. CAU 543 is located in Areas 6 and 15 of the Nevada Test Site, Nevada, and consists of the following seven Corrective Action Sites (CASs):

- CAS 06-07-01, Decon Pad

- CAS 15-01-03, Aboveground Storage Tank

- CAS 15-04-01, Septic Tank

- CAS 15-05-01, Leachfield

- CAS 15-08-01, Liquid Manure Tank

- CAS 15-23-01, Underground Radioactive Material Area

- CAS 15-23-03, Contaminated Sump, Piping

CAU 543 closure activities started in March 2007 and were completed in October 2007. Activities were performed in accordance with the FFACO and the Corrective Action Plan for CAU 543 (U.S. Department of Energy, National Nuclear Security Administration Nevada Site Office, 2007). The corrective action alternatives that were applied at each site consisted of closure in place and no further action with best management practices (BMPs).

CAS 06-07-01, located at the Area 6 Decontamination Facility, was closed in place with implementation of BMPs. The Building 6-605 concrete pad was fenced and posted, and a use restriction (UR) was implemented for polychlorinated biphenyls (PCBs) and radioactivity on and adjacent to the building pad. As BMPs, two septic tanks, two sumps, and their contents were removed and disposed of as mixed waste (MW); sediment from the Building 6-605 floor drain trenches was removed and disposed of as MW; Building 6-605 floor drain trenches, diversion box, and cleanouts were grouted to grade; and numerous containers and other surface debris were segregated according to waste stream and disposed of appropriately as either sanitary waste or low-level waste (LLW).

The remaining CASs are located at the former Area 15 U.S. Environmental Protection Agency Farm. CAS 15-23-03 was closed in place by filling the existing sump with clean fill, posting the perimeter of the sump and buried piping as use restricted, and implementing a UR for PCBs and radioactivity. The other five CASs were closed by taking no further action with implementation of the following BMPs:

- CAS 15-01-03: Underground piping between a fill stand and an aboveground storage tank (AST) and all aboveground piping were removed, size-reduced, and placed inside the AST. The AST was sealed and disposed of as LLW. A distribution box and its contents were excavated, packaged in a soft-sided container, and disposed of as PCB remediation LLW. Sediment was removed from the Building 15-06 floor drain trenches and disposed of as hydrocarbon PCB remediation waste. The floor drain trenches were filled with grout, the 
building foundation was fenced and posted, and a UR was implemented for PCBs for the building pad and underground piping between the building pad and the AST.

- CAS 15-04-01: The septic tank and its contents were excavated, solidified, and disposed of as hydrocarbon PCB remediation waste. The excavation was backfilled to surrounding grade with clean fill.

- CAS 15-05-01: The distribution box, its contents, and piping between the distribution box and the CAS 15-04-01 septic tank were excavated and disposed of as hydrocarbon PCB remediation waste. The excavation was backfilled to surrounding grade with clean fill.

- CAS 15-08-01: Liquid remediation waste from within the liquid manure tank was pumped out and transferred to the Area 12 Sewage Lagoons. Remaining sludge was solidified, and the tank and its contents were excavated and disposed of as hydrocarbon waste. Wood debris on the ground surface was disposed of as hydrocarbon waste, and other surface debris was disposed of as sanitary waste.

- CAS 15-23-01: Surface debris was disposed of as sanitary waste.

Samples were collected as needed for characterization of waste streams. Samples were also collected from below several removed structures (e.g., septic tanks) to verify that the contents had not been released to the surrounding soil. Verification samples were only collected for wastes that would exceed CAU 543 established action levels if the waste was released to the environment from the container. All samples showed that concentrations were less than the established action levels in samples collected from below the removed structures.

Closure activities generated approximately 96 cubic yards $\left(\mathrm{yd}^{3}\right)$ of mixed waste, $173 \mathrm{yd}^{3}$ of LLW, $127 \mathrm{yd}^{3}$ of hydrocarbon waste, $72 \mathrm{yd}^{3}$ of sanitary waste, and 16,250 gallons of liquid remediation waste. Some of these waste streams also contained PCB remediation wastes, for which the landfill operator was notified in advance of shipments as required by Title 40 Code of Federal Regulations Part 761.61, "PCB Remediation Waste.”

This Closure Report documents the activities taken to close this CAU and includes waste characterization and verification sample results, waste disposition paperwork, and other supporting documentation. 


\subsection{INTRODUCTION}

This Closure Report (CR) documents closure activities for Corrective Action Unit (CAU) 543, Liquid Disposal Units, according to the Federal Facility Agreement and Consent Order (FFACO, 1996) and the Corrective Action Plan (CAP) for CAU 543 (U.S. Department of Energy, National Nuclear Security Administration Nevada Site Office [NNSA/NSO], 2007). CAU 543 is located at the Nevada Test Site (NTS), Nevada (Figure 1), and consists of the following seven Corrective Action Sites (CASs):

- CAS 06-07-01, Decon Pad

- CAS 15-01-03, Aboveground Storage Tank

- CAS 15-04-01, Septic Tank

- CAS 15-05-01, Leachfield

- CAS 15-08-01, Liquid Manure Tank

- CAS 15-23-01, Underground Radioactive Material Area

- CAS 15-23-03, Contaminated Sump, Piping

CAS 06-07-01 is located at the Decontamination Facility in Area 6, adjacent to Yucca Lake. The remaining CASs are located at the former U.S. Environmental Protection Agency (EPA) Farm in Area 15.

\subsection{Purpose}

The purpose of this CR is to provide a summary of the completed closure activities, to document waste disposal, and to present analytical data confirming that the remediation goals were met. The closure alternatives consisted of closure in place for two of the CASs, and no further action with implementation of best management practices (BMPs) for the remaining five CASs.

\subsection{SCOPE}

The closure strategy for CAU 543 was as follows:

- CAS 06-07-01 (Decon Pad) was closed in place with administrative controls and implementation of BMPs. The Building 6-605 concrete pad was closed in place by fencing, posting signs, and implementing a use restriction (UR) for polychlorinated biphenyls (PCBs) and radioactivity. As a BMP, (1) two septic tanks, two sumps, and their contents were removed, solidified as necessary, and disposed of as mixed waste (MW); (2) sediment contained within a diversion box and the Building 6-605 floor drain trenches was removed and disposed of as MW; (3) Building 6-605 floor drain trenches, diversion box, and cleanouts were grouted; and (4) containers and other surface debris were disposed of appropriately either as sanitary waste or low-level waste (LLW).

- CAS 15-01-03 (Aboveground Storage Tank) was closed by taking no further action with implementation of BMPs. The following activities were undertaken as BMPs: (1) the aboveground piping connected to the 25,000-gallon (gal) aboveground storage tank (AST) 


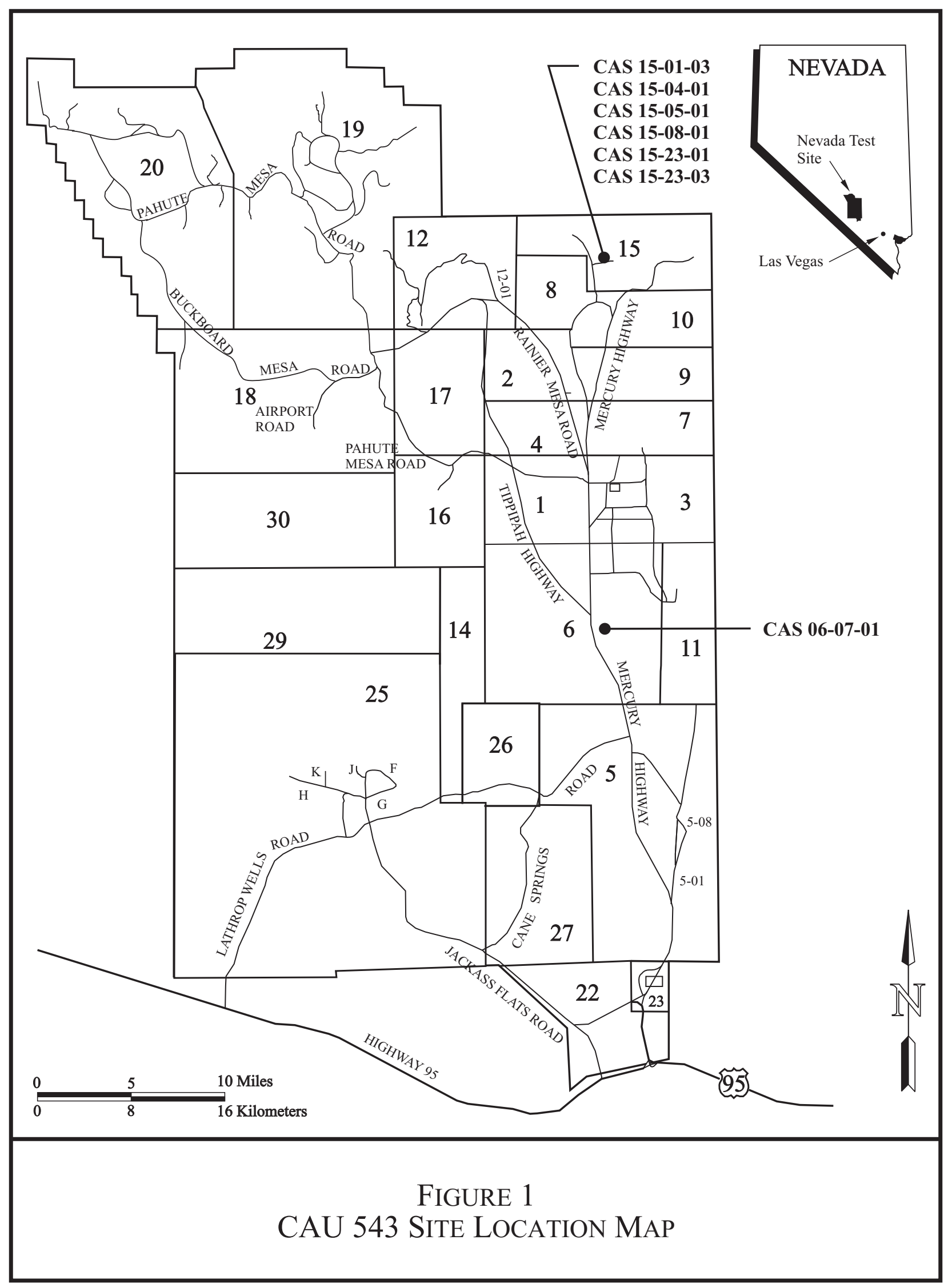


was removed, size-reduced, and placed within the AST; (2) the AST and its contents were removed and disposed of as PCB remediation LLW; (3) a distribution box and its contents were removed and disposed of as LLW; (4) sediment from the Building 15-06 floor drain trenches was removed and disposed of as petroleum hydrocarbon PCB remediation waste; (5) Building 15-06 floor drain trenches were filled with grout and the perimeter of the building foundation was fenced; and (6) a UR for PCBs was implemented for the Building 15-06 concrete pad and underground piping between the pad and the former AST.

- CAS 15-04-01 (Septic Tank) was closed by taking no further action with implementation of BMPs. As a BMP, the septic tank contents were removed and solidified, and both tank and contents were disposed of as hydrocarbon PCB remediation waste.

- CAS 15-05-01 (Leachfield) was closed by taking no further action with implementation of BMPs. As a BMP, the distribution box and its contents were removed and disposed of as hydrocarbon PCB remediation waste.

- CAS 15-08-01 (Liquid Manure Tank) was closed by taking no further action with implementation of BMPs. The following activities were undertaken as BMPs: (1) wood debris on the ground surface was removed and disposed of as hydrocarbon waste, (2) liquid remediation waste within the liquid manure tank was removed and disposed of in the Area 12 Sewage Lagoons, (3) sludge was solidified within the tank, (4) the tank and its solidified sludge were removed and disposed of as hydrocarbon waste, and (5) non-wood surface debris was disposed of as sanitary waste.

- CAS 15-23-01 (Underground Radioactive Material Area) was closed by taking no further action. As a BMP, the steel grate and miscellaneous surface debris in the area were removed and disposed of as sanitary waste at the Area 9 U10c Sanitary Landfill.

- CAS 15-23-03 (Contaminated Sump, Piping) was closed in place with administrative controls and implementation of BMPs. The sump was backfilled, wheel-roll compacted, and graded to prevent precipitation run-on; UR signs were posted around the perimeter of the sump and above the underground piping; and a UR was implemented for PCBs and radioactivity for the sump and the underground piping between the sump and the CAS 15-01-03 distribution box.

\subsection{Closure Report Contents}

This CR includes the following sections:

- Section 1.0 - Introduction

- Section 2.0 - Closure Activities

- $\quad$ Section 3.0 - Waste Disposition

- Section 4.0 - Closure Verification Results

- Section 5.0 - Conclusions and Recommendations

- $\quad$ Section 6.0 - References

- Appendix A - Data Quality Objectives 
- Appendix B - Sample Analytical Results

- Appendix C - Waste Disposition Documentation

- Appendix D - Site Closure Photographs

- Appendix E - Use Restriction Documentation

- Library Distribution List

This report was developed using information and guidance from the following documents:

- CAP for CAU 543, Revision 1 (NNSA/NSO, 2007)

- Nevada Environmental Restoration Project Industrial Sites Quality Assurance Project Plan (QAPP) (U.S. Department of Energy, National Nuclear Security Administration Nevada Operations Office [NNSA/NV], 2002)

All laboratory data were reviewed to ensure that they are useable and complete, in accordance with the QAPP. Data collected during the closure activities showed that removal of the CAU 543 structures successfully removed the waste contained within the structures. Removal of the structures was completed as a BMP. Observations and analytical results obtained during the closure activities did not change the conceptual site models that were presented within the Corrective Action Investigation Plan (CAIP) for CAU 543 (NNSA/NSO, 2004a) and reconciled in the Corrective Action Decision Document (CADD) for CAU 543 (NNSA/NSO, 2005). One UR was implemented in addition to that recommended in the CADD. The additional UR was implemented for CAS 15-01-03 because porous waste structures that were left in place had contained PCBs at concentrations that required fencing and posting with PCB signs per Title 40 Code of Federal Regulations (CFR) Part 761.65, “Storage for Disposal” (CFR, 2006b). 


\subsection{CLOSURE ACTIVITIES}

This section details the specific activities completed during the closure of CAU 543, deviations from the CAU 543 CAP, the schedule of completed activities, and the final site plan. Photographs in Appendix D of this report document the state of the sites before corrective actions were implemented, during field work, and after completion of work.

\subsection{Description of Corrective ACtion Activities}

Closure activities for CAU 543 were completed according to the CAP (NNSA/NSO, 2007), with minor deviations as documented in Section 2.2. Closure activities consisted of removing and disposing structures (i.e., septic tanks, sumps, and similar structures), their contents, contaminated sediment, and debris; backfilling excavations and a sump; grouting floor drain trenches; and implementing URs. The following sections detail the closure activities as completed. Table 1 identifies the activities that were conducted at each CAS.

\subsubsection{Preplanning and Site Preparation}

Prior to closure activities, the following documents were prepared:

- National Environmental Policy Act Checklist

- Site-Specific Health and Safety Plan

- Field Management Plan

- Site Specific Emergency Response and Contingency Plan

- NNSA/NSO Real Estate/Operations Permit

- Work control packages

\subsubsection{Closure Activities}

The following sections detail the closure activities performed at each CAS.

\subsubsection{CAS 06-07-01, Decon Pad}

CAS 06-07-01 is located at the Area 6 Decontamination Facility, adjacent to Yucca Lake (Figure 2). It consisted of the effluent collection and distribution systems for Buildings 6-605, 6-606, and 6-607, which included two 1,000-gal septic tanks, two sumps and associated piping, the concrete foundation of Building 6-605, floor drains, drain trenches, and cleanouts. This CAS was closed in place by implementing administrative controls and implementation of BMPs. 
TABle 1. Summary of CAU 543 Closure Activities

\begin{tabular}{|c|c|c|c|c|}
\hline CAS & CAS Name & $\begin{array}{l}\text { Closure } \\
\text { Method }\end{array}$ & $\mathrm{COC}$ & Closure Activities \\
\hline 06-07-01 & Decon Pad & $\begin{array}{c}\text { Closure in Place } \\
\text { with } \\
\text { Administrative } \\
\text { Controls }\end{array}$ & PCBs & $\begin{array}{l}\text { - } \quad \text { Collected characterization samples needed to characterize waste in containers and trough. } \\
\text { - } \quad \text { Disposed of containers, luggers, and other miscellaneous debris as sanitary waste. } \\
\text { - } \quad \text { Disposed of drums, trough with soil, and personal protective equipment as LLW. } \\
\text { - } \quad \text { Relidified the contents of septic tank 6-605. } \\
\text { - } \quad \text { Excavated septic tank 6-607 and contents, packaged in soft-sided containers, and disposed of as } \\
\text { MW. } \\
\text { - } \quad \text { Solidified the contents of Sump 1. } \\
\text { - } \text { Removed Sumps } 1 \text { and } 2 \text { and their contents, packaged in soft-sided containers, and disposed of as } \\
\text { MW. } \\
\text { - } \quad \text { Rollected verification samples from beneath septic tanks and sumps. } \\
\text { - } \quad \text { fisposed of as MW. } \\
\text { - } \quad \text { Backfilled building floor drain trenches, diversion box, and cleanouts with grout. } \\
\text { Installed a two-strand wire perimeter fence and gate around the perimeter of the Building 6-605 } \\
\text { foundation. } \\
\text { Posted UR and PCB warning signs around Building 6-605 foundation and implemented } \\
\text { administrative controls. }\end{array}$ \\
\hline $15-01-03$ & $\begin{array}{l}\text { Aboveground } \\
\text { Storage Tank }\end{array}$ & $\begin{array}{l}\text { No Further } \\
\text { Action } \\
\text { with BMP }\end{array}$ & None & $\begin{array}{l}\text { - } \quad \text { Removed liquid remediation waste and sediment from building floor drain trenches, solidified, and } \\
\text { - } \quad \text { Filled building floor drain trenches with grout. } \\
\text { - } \quad \text { Excavated distribution box and contents and disposed of as PCB remediation LLW (<50 ppm } \\
\text { PCB). } \\
\text { - } \quad \text { Collected verification sample from below distribution box. } \\
\text { - } \quad \text { Grouted underground piping between distribution box and AST. } \\
\text { - } \quad \text { Opkfilled distribution box excavation to surrounding grade. } \\
\text { - } \quad \text { Removed all aboveground piping, size-reduced, and placed inside AST. } \\
\text { - } \quad \text { Removed underground piping between AST and fill stand, size-reduced, and placed inside AST. } \\
\text { - } \quad \text { Removed AST and disposed of as LLW. } \\
\text { - } \quad \text { Installed a two-strand wire perimeter fence and gate around the perimeter of the Building 15-06 } \\
\text { - } \quad \text { foundation. } \\
\text { Posted UR and PCB warning signs and implemented administrative controls. }\end{array}$ \\
\hline
\end{tabular}


TABle 1. Summary of CAU 543 Closure ACtivities (CONTINUED)

\begin{tabular}{|c|c|c|c|c|}
\hline CAS & CAS Name & $\begin{array}{l}\text { Closure } \\
\text { Method }\end{array}$ & COC & Closure Activities \\
\hline $15-04-01$ & Septic Tank & $\begin{array}{l}\text { No Further } \\
\text { Action } \\
\text { with BMP }\end{array}$ & None & $\begin{array}{l}\text { - } \quad \text { Removed and solidified liquid remediation waste from septic tank. } \\
\text { - } \quad \text { Solidified septic tank liquid remediation waste and sludge. } \\
\text { Disposed of solidified liquid remediation waste and sludge as petroleum hydrocarbon PCB } \\
\text { remediation waste }(<50 \mathrm{ppm} \text { PCB). } \\
\text { - } \quad \text { Excavated and disposed of septic tank and associated piping as PCB remediation hydrocarbon } \\
\text { waste ( }<50 \mathrm{ppm} \text { PCB). } \\
\text { - } \quad \text { Collected verification sample from below tank. } \\
\text { Backfilled excavation to surrounding grade. }\end{array}$ \\
\hline $15-05-01$ & Leachfield & $\begin{array}{l}\text { No Further } \\
\text { Action } \\
\text { with BMP }\end{array}$ & None & $\begin{array}{l}\text { - } \quad \text { Removed and disposed of distribution box and its contents as PCB remediation hydrocarbon waste } \\
\text { (<50 ppm PCB). } \\
\text { - } \quad \text { Collected verification sample from below distribution box. } \\
\text { Backfilled excavation to surrounding grade. }\end{array}$ \\
\hline $15-08-01$ & $\begin{array}{l}\text { Liquid Manure } \\
\text { Tank }\end{array}$ & $\begin{array}{l}\text { No Further } \\
\text { Action } \\
\text { with BMP }\end{array}$ & None & $\begin{array}{ll}\text { - } & \text { Removed and disposed of wood as hydrocarbon waste and miscellaneous debris as sanitary waste. } \\
\text { - } & \text { Removed and disposed of cover from liquid manure tank as sanitary waste. } \\
\text { - } & \text { Pumped liquid remediation waste from tank and disposed of it in the Area } 12 \text { Camp sewage } \\
\text { - } & \text { Solidified sludge in tank. } \\
\text { - } & \text { Excavated and removed solidified sludge and liquid manure tank. } \\
\text { - } & \text { Bisposed of solidified sludge and size-reduced tank as hydrocarbon waste. } \\
\text { - } & \text { De-posted URMA. }\end{array}$ \\
\hline $15-23-01$ & $\begin{array}{l}\text { Underground } \\
\text { Radioactive } \\
\text { Material Area }\end{array}$ & $\begin{array}{l}\text { No Further } \\
\text { Action } \\
\text { with BMP } \\
\end{array}$ & None & - $\quad$ Removed and disposed of perforated steel plank and miscellaneous debris as sanitary waste. \\
\hline $15-23-03$ & $\begin{array}{l}\text { Contaminated } \\
\text { Sump, Piping }\end{array}$ & $\begin{array}{l}\text { Closure in Place } \\
\text { with } \\
\text { Administrative } \\
\text { Controls }\end{array}$ & $\begin{array}{c}\text { PCBs } \\
\text { Plutonium-238 }\end{array}$ & $\begin{array}{l}\text { - } \quad \text { Removed and disposed of miscellaneous debris as sanitary waste. } \\
\text { - } \quad \text { Filled sump with native fill, mounding slightly and wheel-roll compacting. } \\
\text { - }\end{array}$ \\
\hline
\end{tabular}

AST: aboveground storage tank

BMP: best management practice

CAS: Corrective Action Site

COC: contaminant of concern

LLW: low-level waste

MW: mixed waste

PCB: polychlorinated biphenyl

ppm: parts per million

UR: use restriction

URMA: underground radioactive material area 


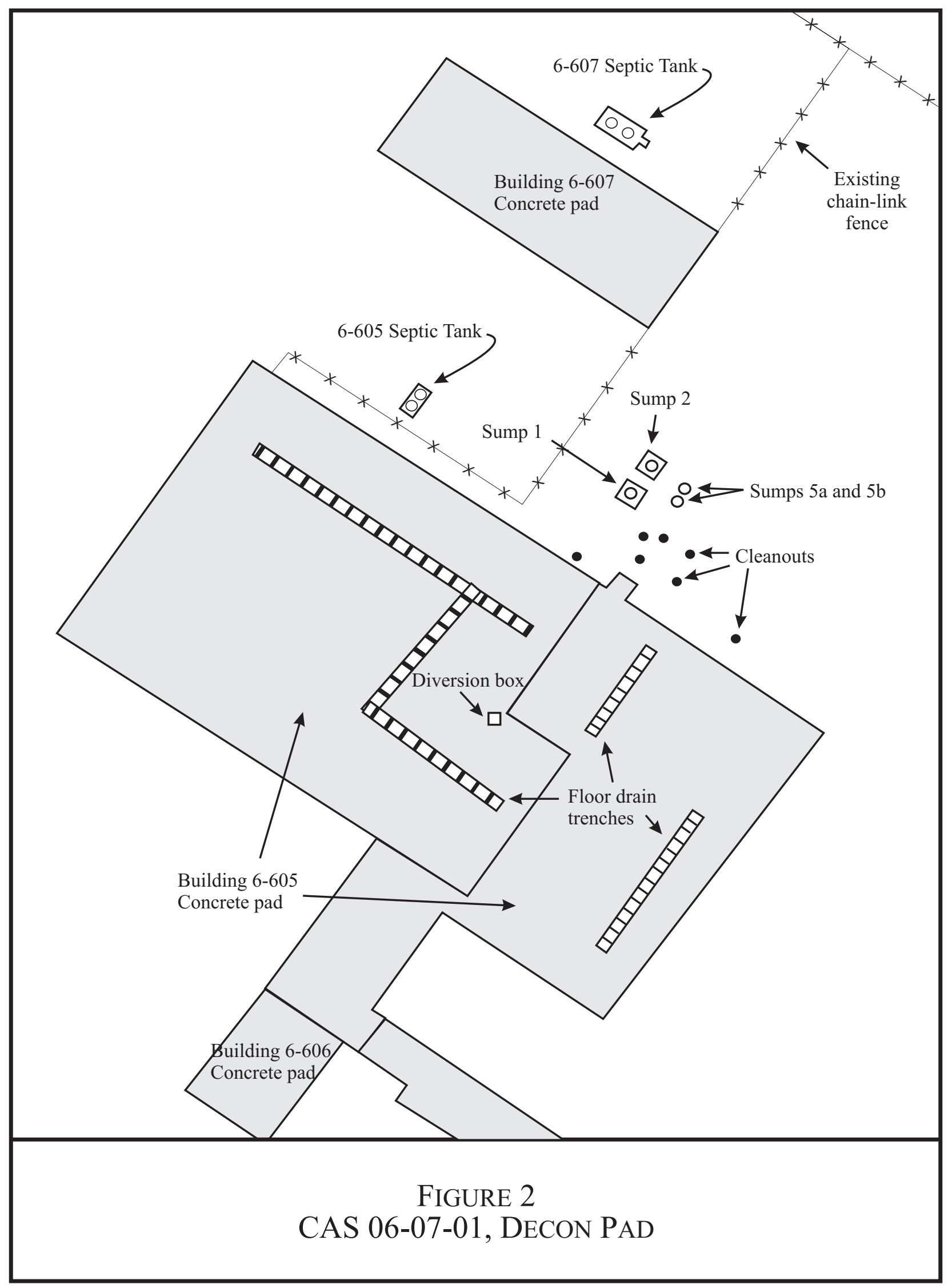


The closure activities for this CAS were completed after the BMPs had been completed. The following activities were performed as BMPs:

- Septic tanks for Buildings 6-605 and 6-607 were opened and the contents were solidified. The septic tanks and their contents were excavated, packaged in soft-sided containers, and disposed of as MW. One sample was collected from beneath each tank (Figure 3) to verify closure of the site. Samples were collected from depths of approximately 4 feet (ft) below ground surface (bgs) for the 6-605 tank and $5 \mathrm{ft}$ bgs for the 6-607 tank. Analytical results showed all concentrations to be less than the final action levels (FALs) for this CAS, and the excavations were backfilled to surrounding grade with clean fill.

- Two sumps (Sumps 1 and 2) and their contents were excavated, packaged in soft-sided containers, and disposed of as MW. One sample was collected from beneath each sump (Figure 3) to verify closure of the site. Approximate sample locations are indicated in Figure 3. Samples were collected from depths of approximately 6 to $7 \mathrm{ft}$ bgs for Sumps 1 and 2. Analytical results showed all concentrations to be less than the FALs for this CAS, and the excavations were backfilled to surrounding grade with clean fill.

- Sediment contained within floor drain trenches and a diversion box in the Building 6-605 concrete foundation was removed, packaged in soft-sided containers, and disposed of as MW. The floor drain trenches, diversion box, and cleanouts adjacent to the foundation were then filled with concrete grout.

- Containers, luggers, troughs, debris, and other miscellaneous items within the Decontamination Facility yard were characterized and disposed of appropriately. Samples were collected when needed to characterize soil or other substances within the containers, luggers and troughs. The items were screened to free-release for radioactivity using hand instruments, in accordance with the NV/YMP Radiological Control Manual (NNSA/NSO, 2004b). Additional screening using the In Situ Object Counting System (ISOCS) was performed on those items where the results of hand instruments did not provide adequate determination on whether items could be free-released. Based on results of sample analytical results, ISOCS, and radiological screening, the items and their contents were disposed of as sanitary waste, LLW, or hydrocarbon PCB remediation LLW.

Activities undertaken for the CAS closure consisted of fencing the Building 6-605 concrete pad. The fencing extends a minimum of $10 \mathrm{ft}$ outside of the perimeter of the pad. A UR was implemented for the fenced area. The UR was implemented for radioactivity and PCBs. UR signs and PCB signs (large PCB signs as defined by 40 CFR 761.45, "Marking Formats” [CFR, 2006b]) were posted at nine locations around the perimeter of the Building 6-605 foundation fencing. Appendix E contains a copy of the completed UR documentation.

Analytical results for samples collected during closure activities are provided in Appendix B and summarized in Section 4.0. Waste disposition documentation is presented in Section 3.0 and is provided in Appendix C. Photographs of the site before, during, and upon completion of closure activities are provided in Appendix D. 


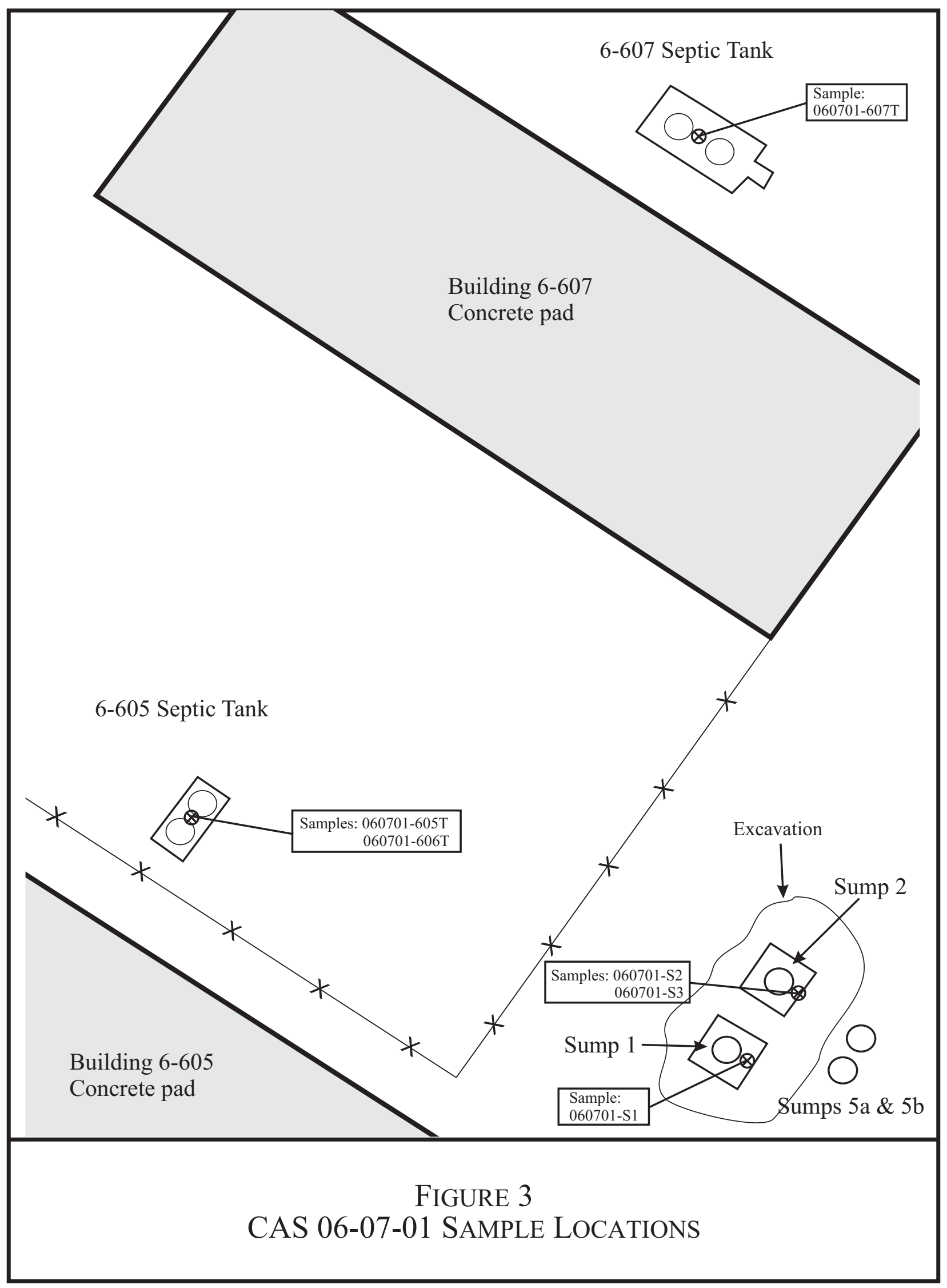




\subsubsection{CAS 15-01-03, Aboveground Storage Tank}

CAS 15-01-03 is located at the former EPA Farm in Area 15 (Figure 4). It consisted of the Building 15-06 concrete foundation, a radiologically contaminated 25,000-gal AST, a radiologically contaminated distribution box, aboveground and underground piping between the AST and the building foundation, and holding pens (Figure 5). This CAS was closed by taking no further action with implementation of BMPs.

The AST was opened and approximately 500 gal of caked sludge, with no free liquid, were present in the bottom of the tank. Aboveground piping was removed, size-reduced, and placed inside of the AST. Underground piping between the AST and a fill stand, located to the east of the AST, was removed, size-reduced, and placed into the AST. The fill stand itself was removed and disposed of at the Area 9 U10c Sanitary Landfill because it met the free-release criteria for radioactivity established in the NV/YMP Radiological Control Manual (NNSA/NSO, 2004b). All openings of the AST were sealed, and the AST itself served as the container for LLW contained within it. The AST was disposed of as LLW in the Area 5 Radioactive Waste Management Site (RWMS) on the NTS.

The distribution box and its contents were excavated, placed into a soft-sided container, and disposed of as PCB remediation LLW at the Area 5 RWMS on the NTS. One sample was collected from beneath the distribution box, at a depth of approximately $5 \mathrm{ft}$ bgs, to verify that concentrations beneath the distribution box are less than the FALs established for this site. Analytical results are provided in Appendix B and are summarized in Section 4.0. Underground piping between the distribution box and the AST was filled with grout, and the excavation was backfilled to surrounding grade.

Because the Building 15-06 floor drains had been sealed so that rainwater would not flow from the drains to the AST, the floor drain trenches contained both liquid (from rainwater) and sediment. The liquid remediation waste was removed and solidified, and the sediment was removed. The solidified liquid remediation waste and sediment were transported to the Area 6 Hydrocarbon Landfill and disposed of as hydrocarbon PCB remediation waste. Floor drains were filled with concrete, and the concrete building foundation was fenced and posted as a use-restricted area.

A UR was implemented for the building pad and underground piping between the building pad and the former AST. The UR was implemented for PCB concentrations between 25 and 50 parts per million (ppm). UR signs and PCB signs (large PCB signs as defined by 40 CFR 761.45 [CFR, 2006b]) were posted on each of the four sides of the Building 15-06 foundation fencing. A pair of UR signs and PCB signs were posted approximately every $100 \mathrm{ft}$ apart above the underground piping. Fencing was not constructed above the piping because the PCBs are buried and the UR prohibits excavation. Underground radioactive materials area (URMA) postings, which were present before CAU 543 activities began, were left in place above the piping. Appendix E contains a copy of the completed UR documentation. 


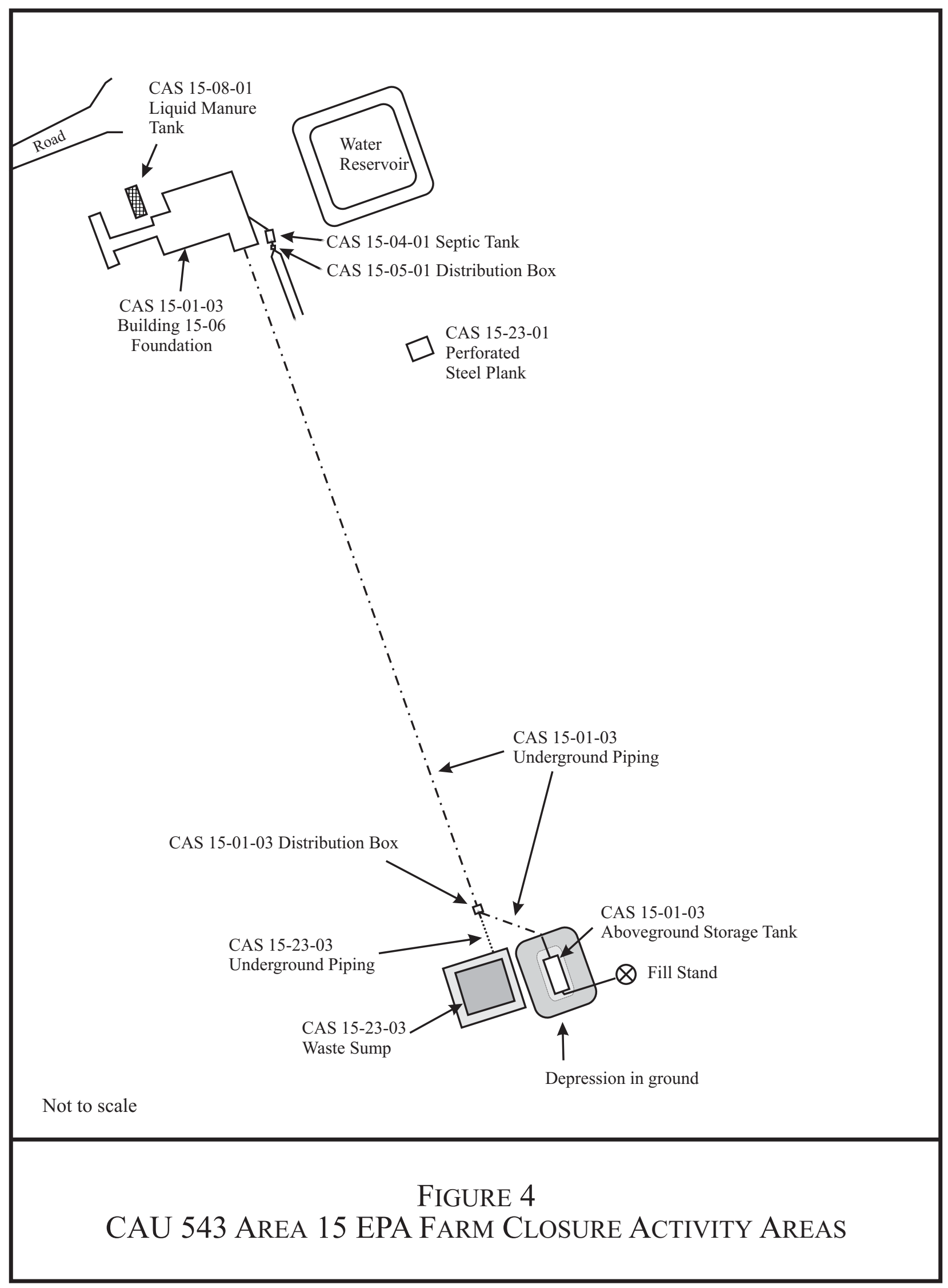




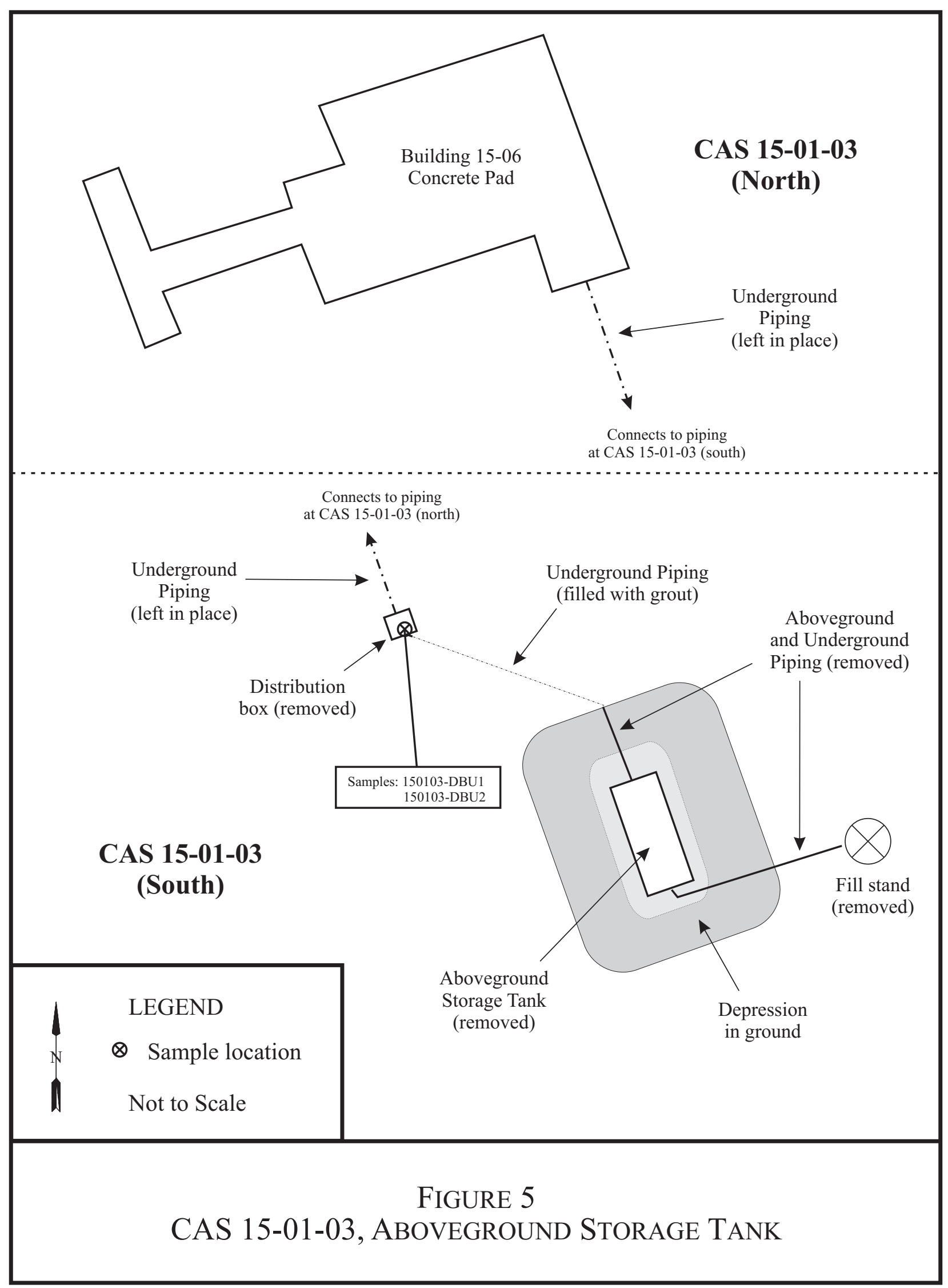


Analytical results for verification samples collected from below the distribution box are provided in Appendix B and summarized in Section 4.0. Waste disposition documentation is presented in Section 3.0 and is provided in Appendix C. Photographs of the site before, during, and upon completion of closure activities are provided in Appendix D.

\subsubsection{CAS 15-04-01, Septic Tank}

CAS 15-04-01 is located at the former EPA Farm in Area 15 and consisted of a 1,000-gal septic tank, piping, and a cleanout located to the southeast of the Building 15-06 foundation (Figure 6). This CAS was closed by taking no further action with implementation of BMPs.

As a BMP, the septic tank and its contents were removed and disposed of appropriately. Liquid remediation waste from the septic tank was pumped into a solidification basin and solidified. Sludge was solidified within the septic tank. The solidified liquid remediation waste, sludge, and the tank itself were then excavated and disposed of as hydrocarbon PCB remediation waste at the Area 6 Hydrocarbon Landfill. One soil sample was collected from below the tank (Figure 6) at a depth of approximately $8 \mathrm{ft}$ bgs, to verify closure of the site. Analytical results showed all concentrations to be less than the FALs for this CAS, and the excavation was backfilled to surrounding grade with clean fill.

Analytical results are provided in Appendix B and summarized in Section 4.0. Waste disposition documentation is presented in Section 3.0 and is provided in Appendix C. Photographs of the site during and upon completion of closure activities are provided in Appendix D.

\subsubsection{CAS 15-05-01, Leachfield}

CAS 15-05-01 is located at the EPA Farm in Area 15 and consisted of a distribution box and leachfield that are connected to the CAS 15-04-01 septic tank (Figure 6). This CAS was closed by taking no further action with implementation of BMPs.

As a BMP, the distribution box, its contents, and piping between the distribution box and the septic tank were removed and disposed of as hydrocarbon PCB remediation waste at the Area 9 U10c Sanitary Landfill, which is permitted to accept limited quantities of hydrocarbon waste. One soil sample was collected from below the distribution box (Figure 6), at a depth of approximately $6 \mathrm{ft}$ bgs, to verify closure of the site. Analytical results showed all concentrations to be less than the FALs for this CAS, and the excavation was backfilled to surrounding grade with clean fill.

Analytical results are provided in Appendix B and summarized in Section 4.0. Waste disposition documentation is presented in Section 3.0 and is provided in Appendix C. Photographs of the site upon completion of closure activities are provided in Appendix D. 


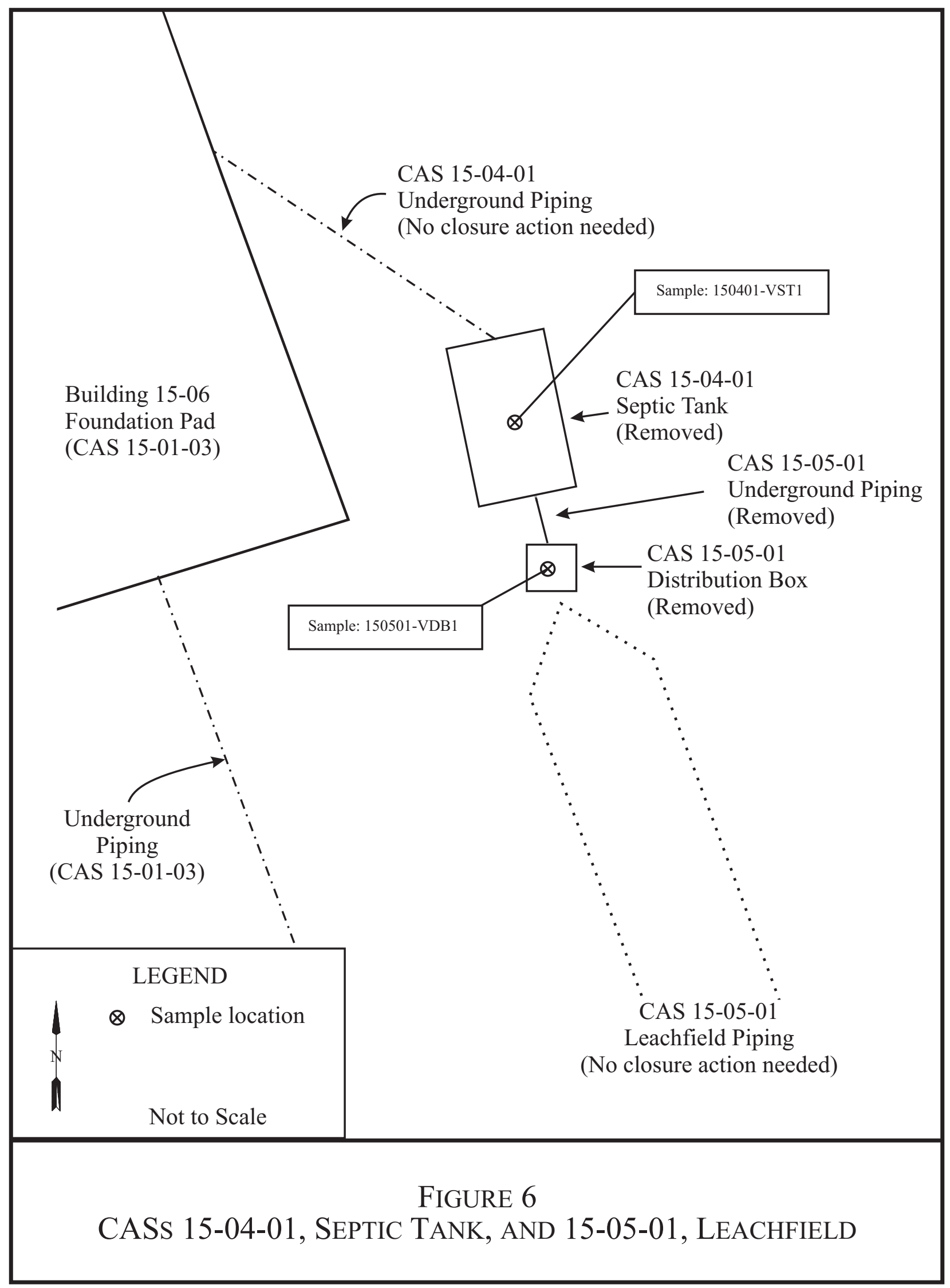




\subsubsection{CAS 15-08-01, Liquid Manure Tank}

CAS 15-08-01 is located at the former EPA Farm in Area 15 and consisted of an underground liquid manure tank, associated piping, and a concrete pad and drain northwest of the Building 15-06 foundation (Figure 7). This CAS was closed by taking no further action with implementation of BMPs.

As a BMP, the liquid manure tank, its contents, and surface debris were removed and disposed of appropriately. Wood debris was disposed of as hydrocarbon waste, and other surface debris was disposed of as sanitary waste. Samples collected of the tank contents confirmed that the liquid remediation waste was suitable for disposal in NTS sewage lagoons and that the sludge was petroleum hydrocarbon waste.

Liquid remediation waste was pumped from the tank and disposed of at the Area 12 Sewage Lagoons. The concrete lid was removed from the tank, and sludge was solidified within the tank. Solidified sludge was removed from the tank and disposed of as hydrocarbon waste at either the Area 6 Hydrocarbon Landfill or to the Area 9 U10c Sanitary Landfill, which is permitted to accept limited quantities of hydrocarbon waste. The excavation was backfilled with clean fill to surrounding grade. The tank area, which had previously been posted as a URMA, was de-posted because the reason for its posting (i.e., the tank and its contents) had been removed.

No samples were collected from beneath the liquid manure tank. The sludge within the tank had 370 milligrams per kilogram (mg/kg) total petroleum hydrocarbons (TPH) in the diesel and oil range. The tank contained approximately 17,000 gal of water before closure activities started. The water was pumped from the tank, the sludge was solidified within the tank, and sludge was removed from the tank as far as was practical before any demolition to the tank was undertaken. Upon removal of the tank, there was no evidence that liquid had been seeping from the tank. The area was over-excavated to a depth of approximately $18 \mathrm{ft}$ bgs to ensure that all parts of the tank and any residual, solidified sludge had been removed from the excavation. Samples were considered not necessary because there was no evidence of any release from the tank, there were no COCs at the site (as documented in the CADD [NNSA/NSO, 2005]), and the tank was being removed merely as a BMP.

Waste disposition documentation is presented in Section 3.0 and is provided in Appendix C. Photographs of the site before and after completing closure activities are provided in Appendix D.

\subsubsection{CAS 15-23-01, Underground Radioactive Material Area}

CAS 15-23-01 is located at the former EPA Farm in Area 15, to the southeast of CASs 15-04-01 and 15-05-01. This CAS consisted of a steel grate, other surface debris, and an area that is posted as a URMA (Figure 4). The CAS was closed by taking no further action with implementation of BMPs. The steel grate and other surface debris were screened for free-release and were disposed of as sanitary waste at the Area 9 U10c Sanitary Landfill. No underground materials were removed; therefore, the URMA was not de-posted. 


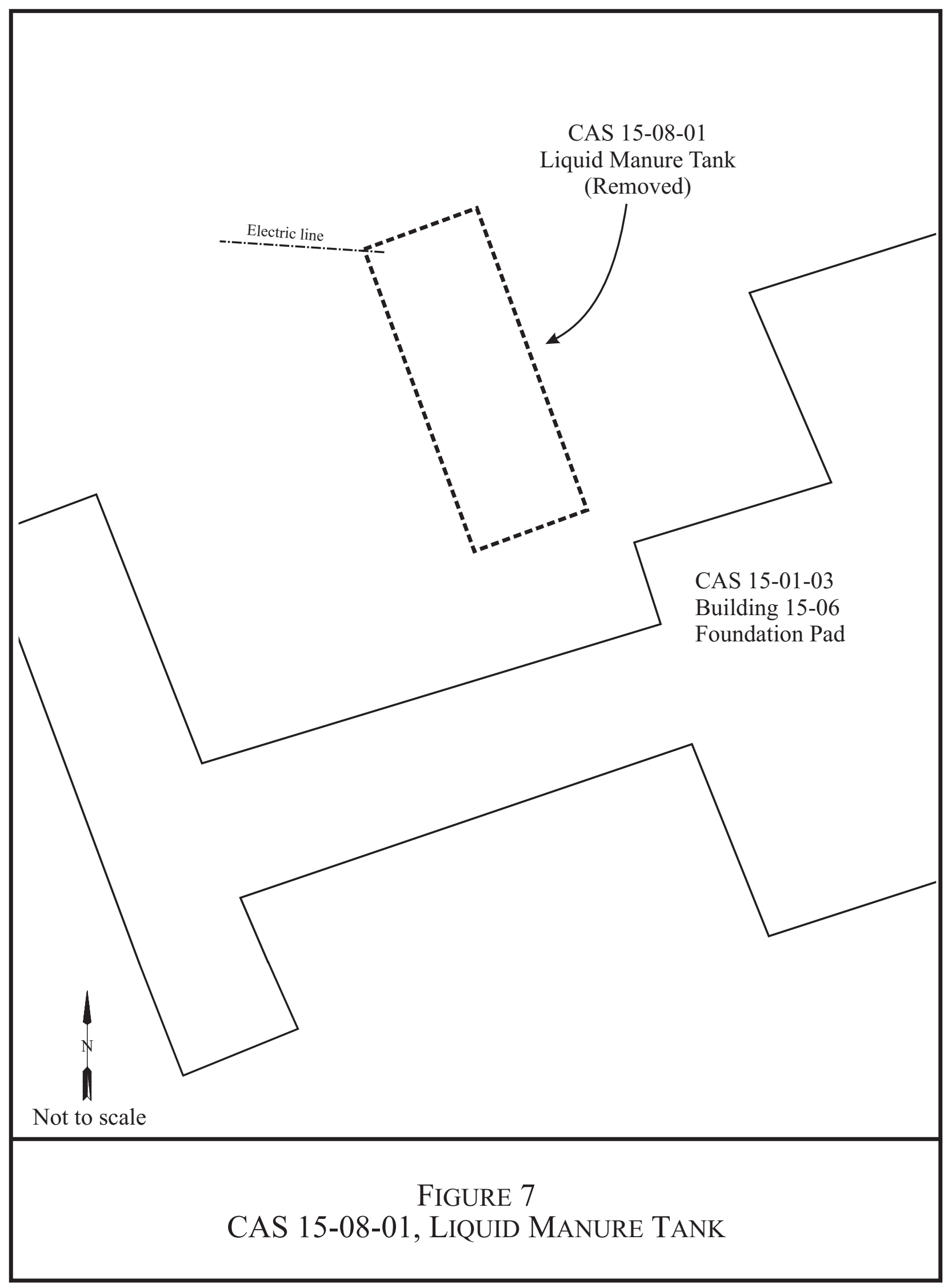


Waste disposition documentation is presented in Section 3.0 and is provided in Appendix C. Photographs of the site before and upon completion of closure activities are provided in Appendix D.

\subsubsection{CAS 15-23-03, Contaminated Sump, Piping}

CAS 15-23-03 is located at the former EPA Farm in Area 15. This CAS consisted of a sump and associated piping between the sump and the CAS 15-01-03 distribution box (Figure 8). CAS 15-23-03 was closed in place with administrative controls.

Closure activities consisted of filling the sump with clean fill and implementing a UR. Vertical supports within the sump, previously used to support fencing that used to be over the top of the sump, were pushed over into the sump so they would not penetrate through the fill material. Clean fill was then brought in from the Area 1 Batch Plant borrow pit and dumped into the sump. The fill material was compacted by wheel rolling as the material was placed into the sump. Fill material was mounded higher than the surrounding sump edges so that water from precipitation will run off of the sump. Existing URMA signs were left in place around the perimeter of the sump. UR signs were posted around the perimeter of the sump and over the top of the underground piping. Surface debris that included wire, fence posts, wood planks, metal cabinets, and cement blocks was screened for radioactivity and was disposed of at the Area 9 U10c Sanitary Landfill.

A UR was implemented for the sump and underground piping between the sump and the CAS 15-01-03 distribution box. The UR was implemented for PCBs and radioactive materials. Appendix E contains a copy of the completed UR documentation. Waste disposition documentation is presented in Section 3.0 and is provided in Appendix C. Photographs of the site before, during, and upon completion of closure activities are provided in Appendix D.

\subsection{DEVIATIONS FROM THE CAP AS APPROVED}

Closure activities that deviated from the approved CAP are presented below.

- CAS 15-01-03: Approximately 24,500 gal of liquid was expected to be present within the 25,000-gal AST; however, there was no free liquid. This change in conditions was evaluated and is expected to be the result of the following: (1) drains in the Building 15-06 building pad, which historically drained rainwater into the AST, were grouted during the corrective action investigation activities thereby preventing additional water from entering the tank; and (2) vented openings were still present and allowed continued evaporation of the liquid over the two years between the corrective action investigation and closure activities.

- CAS 15-04-01: The pipe reported to be located above the septic tank in the CADD for CAU 543 (NNSA/NSO, 2005) was not present at the site when closure activities were conducted.

- CAS 15-05-01: The pipe reported to be located above the distribution box in the CADD (NNSA/NSO, 2005) was not present at the site when closure activities were conducted. 


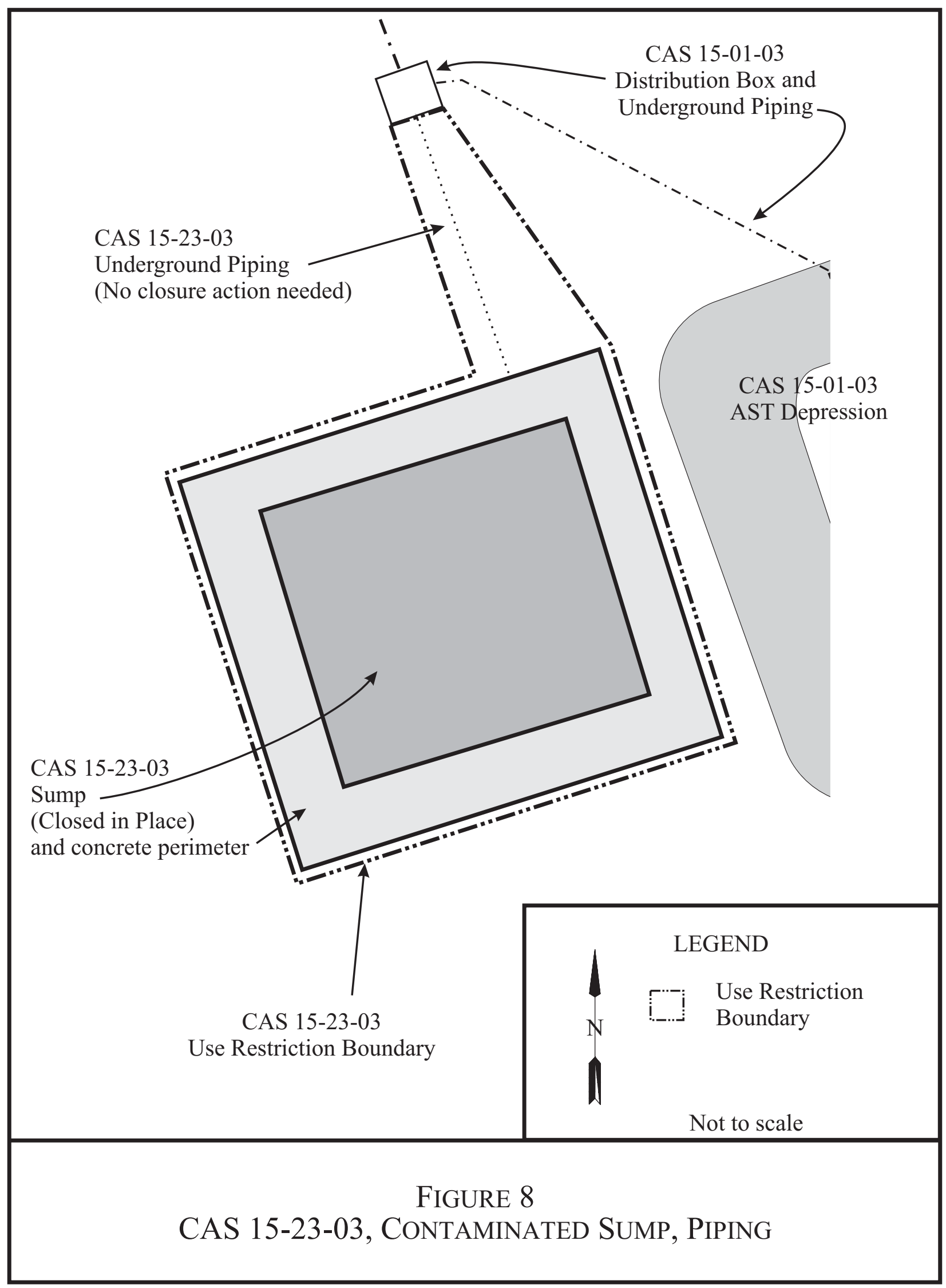


- CAS 15-08-01: Samples were not collected from beneath the liquid manure tank. The sludge within the tank had $370 \mathrm{mg} / \mathrm{kg}$ TPH in the diesel and oil range. The tank contained approximately 17,000 gal of water before closure activities started. The water was pumped from the tank, the sludge was solidified within the tank, and sludge was removed from the tank as far as was practical before any demolition of the tank was undertaken. Upon removal of the tank, there was no evidence that liquid had been seeping from the tank. The area was over-excavated to make sure that all parts of the tank and any residual, solidified sludge had been removed from the excavation. Samples were considered not necessary because there was no evidence of any release from the tank, there were no COCs at the site (as documented in the CADD [NNSA/NSO, 2005]), and the tank was being removed merely as a BMP.

\subsection{Corrective Action Schedule as Completed}

Closure activities for CAU 543 started in March 2007 and were completed in October 2007. Details of the schedule are provided in Table 2.

TABle 2. CAU 543 Closure Activities Schedule

\begin{tabular}{||l|c|c||}
\hline \multicolumn{1}{|c|}{ CAS } & START DATE & END DATE \\
\hline \hline 06-07-01, Decon Pad & April 17, 2007 & October 10, 2007 \\
\hline 15-01-03, Aboveground Storage Tank & April 4, 2007 & September 27, 2007 \\
\hline 15-04-01, Septic Tank & March 28, 2007 & May 30, 2007 \\
\hline 15-05-01, Leachfield & April 3, 2007 & May 30, 2007 \\
\hline 15-08-01, Liquid Manure Tank & May 30, 2007 & August 8, 2007 \\
\hline 15-23-01, Underground Radioactive Material Area & April 2, 2007 & April 2, 2007 \\
\hline 15-23-03, Contaminated Sump, Piping & March 28, 2007 & September 27, 2007 \\
\hline \hline
\end{tabular}

\subsection{Site Plan/Survey Plat}

URs were implemented for the following CASs:

- CAS 06-07-01 (Decon Pad) was use-restricted for radioactivity and PCBs. The 6-605 building foundation was fenced and posted as a use-restricted area.

- CAS 15-01-03 (Aboveground Storage Tank) was use-restricted for PCBs. The 15-06 building foundation was fenced and posted as a use-restricted area. Underground piping between the building pad and the former AST location was also posted as a use-restricted area.

- CAS 15-23-03 was use-restricted for PCBs and radioactivity. The sump and underground piping between the sump and the CAS 15-01-03 distribution box were posted with UR signs. 
Figures showing the locations of the surveyed points delineating the use-restricted areas are provided in Appendix E of this report. 
Closure Report - CAU 543

Section: Closure Verification

Revision: 0

Date: January 2008

\section{THIS PAGE INTENTIONALLY LEFT BLANK}




\subsection{WASTE DISPOSITION}

This section describes the waste streams generated during closure activities and their final disposition.

\subsection{WASTE Minimization}

Waste minimization practices were applied where possible. Septic tanks, piping, and structures (e.g., the fill stand at CAS 15-01-03) were size-reduced before disposal. The CAS 15-01-03 AST became the container for LLW solids within the tank and LLW piping that had been size-reduced and placed within the tank.

Industry standard waste minimization practices were applied throughout the course of closure activities. These practices included the following:

- Using field survey instruments and ISOCS analysis to identify and segregate LLW

- $\quad$ Size-reducing debris and structures before their disposal

- Using an existing AST as a container for LLW solids

- Correctly characterizing waste to allow segregation of waste streams

- Sending liquid remediation waste waste for treatment at the sewage lagoons, where possible based on characterization of those liquids, rather than solidifying and landfilling the waste

\subsection{WASTE MANAgEMENT}

All waste was managed according to applicable federal and state regulations, U.S. Department of Energy orders, and NTS Management and Operations Contractor (M\&OC) procedures. Waste management areas (WMAs) were established throughout the project, as needed. All WMAs were identified with appropriate signs and boundaries to restrict unauthorized access. The WMAs were inspected on a weekly or monthly basis, as required per the waste type, to ensure that all containers were intact, not leaking, and not exceeding storage duration times. Applicable WMAs were posted as Radioactive Material Areas (RMAs) whenever radiological waste was stored in the area, and as Hazardous Waste Accumulation Areas (HWAAs) where hazardous waste was also stored. A contingency plan was developed and implemented for the HWAA that was established at CAS 06-07-01. Upon removal of radiologically impacted waste, the RMAs were surveyed and de-posted.

Waste containers were either purchased new, reconditioned or, in the case with CAS 15-01-03, the AST itself was used as a strong tight container. All containers were inspected prior to use to verify that they were in good condition (e.g., no leaks, rust, or dents), lined or made of material that would not react with the waste, and met U.S. Department of Transportation requirements. The containers remained closed while stored unless waste was being added. Containers were also handled in such a manner that the integrity of the container was not compromised. 
Appropriate labels were affixed, and relevant information was marked on the containers with an indelible marker. All information was legible and clearly visible.

\subsection{WASTE ChaRACTERIZATION}

Most waste streams were identified based on data collected during the corrective action investigation, as was presented in the CADD (NNSA/NSO, 2005). Samples were collected to characterize waste streams where data were insufficient or unavailable, to verify that the waste would be disposed of appropriately. Waste was characterized according to industry standards and M\&OC company procedures.

All samples were collected and managed according to the QAPP (NNSA/NV, 2002). Samples were collected in appropriate containers, sealed with a custody seal, cooled to 4 degrees Celsius, and logged on a chain of custody form. The samples were shipped under chain of custody to an approved offsite laboratory for analysis. A copy of the summary reports for analytical results and the associated chain-of-custody forms are provided in Appendix B.

Characterization samples were collected of the sludge from the CAS 15-08-01 liguid manure tank and of waste within three containers (i.e., a lugger, a horse trough, and drum number 36) at the CAS 06-07-01 Decon Pad. At CAS 15-08-01, characterization samples showed the sludge to be TPH waste, with diesel and oil-range organics at $370 \mathrm{mg} / \mathrm{kg}$. At CAS 06-07-01, the full suite of characterization sampling was required for the contents of the lugger and horse trough.

Results showed the soil in the lugger to be sanitary waste, and the lugger and the soil within were free-released after radiological screening. Soil in the trough was found to be petroleum hydrocarbon PCB remediation LLW. The one sample that was collected from drum 36 (as reported in the CADD [NNSA/NSO, 2005]) emptied the drum, and it was disposed of as LLW with other containers because it did not meet the free-release criteria for radioactivity.

Waste was also screened for radiological contamination using handheld radiological survey instruments and ISOCS analysis, to confirm its appropriate disposal as either LLW or to be free-released as non-radioactive waste.

\subsection{WASTE STREAMS AND DisPOSAL}

Waste streams generated during closure activities at CAU 543 consisted of sanitary waste, liquid remediation waste waste, hydrocarbon waste, PCB remediation waste, LLW, and MW. Appendix C provides copies of the waste disposition documentation. Waste disposition is summarized in Table 3 and discussed in detail in the following sections. Waste disposition documentation is included as Appendix C of this report.

\subsubsection{Sanitary Waste}

Sanitary waste consisted of empty drums and other containers, and construction-type debris (scrap wood, metal, etc.). Approximately 35 cubic yards $\left(\mathrm{yd}^{3}\right)$ of sanitary waste was generated at the Area 6 Decon Pad (CAS 06-07-01) and approximately $42 \mathrm{yd}^{3}$ from closure activities at the Area 15 EPA Farm. All waste was screened to verify that radiological contamination was less 
TABLE 3. CAU 543 WASTE DISPOSITION SUMMARY

\begin{tabular}{|c|c|c|c|c|}
\hline $\begin{array}{l}\text { WASTE } \\
\text { STREAM }\end{array}$ & CORRECTIVE ACTION SITE & $\begin{array}{l}\text { WASTE } \\
\text { TYPE }\end{array}$ & $\begin{array}{l}\text { VOLUME } \\
\qquad\left(\mathbf{y d}^{3}\right)\end{array}$ & DISPOSITION \\
\hline \multirow{6}{*}{$\begin{array}{l}\text { Sanitary } \\
\text { Waste }\end{array}$} & 06-07-01, Decon Pad & $\begin{array}{l}\text { Containers, debris, luggers, } \\
\text { furniture, ladder, iron screens, } \\
\text { aluminum plated covers, } \\
\text { pallets, wood, scrap metal }\end{array}$ & 35 & \multirow{6}{*}{$\begin{array}{c}\text { Area } 9 \text { U10c } \\
\text { Sanitary Landfill }\end{array}$} \\
\hline & 15-01-03, Aboveground Storage Tank & Fill stand, pipes near CAS & 5 & \\
\hline & 15-04-01, Septic Tank & Pipe, metal cover & 10 & \\
\hline & 15-08-01, Liquid Manure Tank & Cover & 5 & \\
\hline & $\begin{array}{l}\text { 15-23-01, Underground Radioactive } \\
\text { Material Area }\end{array}$ & Metal planking & 2 & \\
\hline & 15-23-03, Contaminated Sump, Piping & $\begin{array}{l}\text { Wire, fence posts, wood } \\
\text { planks, metal cabinets, wood } \\
\text { frame, cement blocks }\end{array}$ & 20 & \\
\hline $\begin{array}{c}\text { Liquid } \\
\text { Remediation } \\
\text { Waste } \\
\end{array}$ & 15-08-01, Liquid Manure Tank & Liquid from tank & 16,250 gal & $\begin{array}{l}\text { Area } 12 \text { Sewage } \\
\text { Lagoons }\end{array}$ \\
\hline $\begin{array}{l}\text { Hydrocarbon } \\
\text { Waste }\end{array}$ & 15-08-01, Liquid Manure Tank & $\begin{array}{l}\text { Wood planks, tank and } \\
\text { solidified sludge }\end{array}$ & 90 & $\begin{array}{c}\text { Area } 9 \text { U10c } \\
\text { Sanitary Landfill } \\
\text { and Area } 6 \\
\text { Hydrocarbon } \\
\text { Landfill }\end{array}$ \\
\hline \multirow{3}{*}{$\begin{array}{l}\text { Hydrocarbon } \\
\text { PCB } \\
\text { Remediation } \\
\text { Waste }\end{array}$} & 15-01-03, Aboveground Storage Tank & $\begin{array}{l}\text { Building 15-06 trench } \\
\text { sediment }\end{array}$ & 0.1 & \multirow{2}{*}{$\begin{array}{c}\text { Area } 6 \\
\text { Hydrocarbon } \\
\text { Landfill }\end{array}$} \\
\hline & 15-04-01, Septic Tank & Tank and contents & 35 & \\
\hline & 15-05-01, Leachfield & Distribution box and contents & 2 & $\begin{array}{c}\text { Area } 9 \text { U10c } \\
\text { Sanitary Landfill }\end{array}$ \\
\hline \multirow[t]{2}{*}{ LLW } & 06-07-01, Decon Pad & $\begin{array}{c}\text { Empty drums, HEPA } \\
\text { canisters (2), personal } \\
\text { protective equipment }\end{array}$ & 42 & \multirow[t]{2}{*}{ Area 5 RWMS } \\
\hline & 15-01-03, Aboveground Storage Tank & $\begin{array}{l}\text { AST and contents, piping, } \\
\text { distribution box and contents }\end{array}$ & 130 & \\
\hline $\begin{array}{l}\text { Hydrocarbon } \\
\text { PCB } \\
\text { Remediation } \\
\text { LLW }\end{array}$ & 06-07-01, Decon Pad & $\begin{array}{l}\text { Horse trough with dirt and } \\
\text { contents }\end{array}$ & 0.5 & Area 5 RWMS \\
\hline MW & 06-07-01, Decon Pad & $\begin{array}{c}\text { 6-605 building trench } \\
\text { sediment, 6-605 septic tank } \\
\text { and contents, 6-607 septic } \\
\text { tank and contents, sumps and } \\
\text { contents }\end{array}$ & 96 & Area 5 RWMS \\
\hline
\end{tabular}

gal - gallon(s)

HEPA - high efficiency particulate air

LLW - low-level waste

MW - mixed waste
PCB - polychlorinated biphenyls

RWMS - Radioactive Waste Management Site $\mathrm{yd}^{3}-$ cubic yards 
than the free-release limit established in the NV/YMP Radiological Control Manual (NNSA/NSO, 2004b). Sanitary waste was transported to and disposed of in the Area 9 U10c Sanitary Landfill at the NTS.

\subsubsection{Petroleum Hydrocarbon Waste}

Petroleum hydrocarbon waste was generated from closure activities at several of the Area 15 EPA Farm CASs. Approximately $127 \mathrm{yd}^{3}$ of petroleum hydrocarbon waste was generated from the CAS 15-01-03 Building 15-06 floor drain trench sediment, the contents and structures of CASs 15-04-01 septic tank and 15-05-01 distribution box, and the CAS 15-08-01 liquid manure tank, its contents, and wooden debris. Some of this waste also contained PCBs at concentrations less than $50 \mathrm{mg} / \mathrm{kg}$ or less.

Petroleum hydrocarbon waste was disposed of at either the Area 6 Hydrocarbon Landfill or the Area 9 U10c Sanitary Landfill on the NTS. The Area 9 U10c Sanitary Landfill is permitted to accept limited quantities of hydrocarbon waste. Field personnel worked closely with landfill personnel to verify that the permitted volumes were not exceeded.

\subsubsection{PCB Remediation Waste}

PCB remediation waste at concentrations of $50 \mathrm{mg} / \mathrm{kg}$ or less PCBs was disposed of at the appropriate landfill for other waste characteristics. For example, floor trench sediment from CAS 15-01-03 and solidified septic tank sludge from CAS 15-04-01, both of which contained petroleum hydrocarbon PCB remediation waste, was disposed of at the Area 6 Hydrocarbon Landfill at the NTS.

PCB remediation waste at concentrations greater than $50 \mathrm{mg} / \mathrm{kg}$ were present only at the CAS 06-07-01 floor drain trenches. Because the sediment in the floor drain trenches contained other constituents making it both radioactive waste and hazardous waste, it was disposed of as MW at the Area 5 RWMS.

In all cases, the appropriate landfill operator was notified in advance that PCB remediation waste would be shipped to the landfill.

\subsubsection{Low-Level Waste}

A total of approximately173 $\mathrm{yd}^{3}$ of LLW was generated during closure activities. Radiologically impacted soil and debris were packaged in soft-sided containers stored in RMAs that had been established at CASs 06-07-01 and 15-01-03.

At the EPA Farm (CAS 15-01-03), LLW consisted of the distribution box and its contents, which were placed within one soft-sided container, and the AST and its contents, where the AST served as the container. The AST of CAS 15-01-03 was not stored in an RMA because it was removed from its location and immediately transported for disposal. The AST itself served as a container for LLW from that location. Both containers were transported to the Area 5 RWMS, on the NTS, on September 20, 2007. 
At CAS 06-07-01, LLW consisted of empty drums, HEPA [high efficiency particulate air] canisters, and personnel protective equipment. Seven soft-sided containers of LLW was generated at this location. The waste was transported to and disposed of at the Area 5 RWMS on the NTS on October 10, 2007.

\subsubsection{Mixed Waste}

The CAS 06-07-01 septic tanks, sumps, their contents, and sediment from the Building 6-605 floor drain trenches were MW. All of the waste was hazardous and radioactive, and some of it contained PCBs in concentrations up to $437 \mathrm{mg} / \mathrm{kg}$. The concentrations of hazardous constituents were low and met the criteria for the Area 5 RWMS at the NTS. The waste was managed in an area that was both a HWAA and an RMA, pending shipment for disposal. A total of approximately $96 \mathrm{yd}^{3}$ (16 soft-sided containers) of MW was packaged and disposed of at the Area 5 RWMS on September 27 and 28, 2007. 
Closure Report - CAU 543

Section: Waste Disposition

Revision: 0

Date: January 2008

THIS PAGE INTENTIONALLY LEFT BLANK 


\subsection{CLOSURE VERIFICATION RESULTS}

Site closure was verified by visually observing and taking photographs to document that closure activities had been completed (Appendix D), and by collecting and analyzing samples. Samples were collected to verify that soil beneath removed structures (e.g., septic tanks and sumps) did not contain contaminants in concentrations that exceeded the FALs. Samples were only collected if concentrations within the structure could have contaminated the surrounding soil if the contents were released. Criteria for verification sampling were provided in the approved CAU 543 CAP (NNSA/NSO, 2007).

All samples were collected and managed according to the QAPP (NNSA/NV, 2002). Seven verification samples and three field duplicates were collected. All samples were collected with disposable polyethylene scoops and placed in appropriately labeled sample containers that were secured with custody seals. Because each sample was collected with its own separate, disposable scoop, equipment blank samples were not needed. Samples were labeled with a unique sample number, placed on ice, and transported under chain of custody to the analytical laboratory. Samples were analyzed by certified offsite contract laboratories.

Table 4 identifies the verification samples that were collected after structures had been removed, and the analyses that were performed. Verification samples were collected from below each removed structure in CAS 06-07-01 (i.e., septic tanks 6-605 and 6-607 and Sumps 1 and 2), the CAS 15-04-01 septic tank, and distribution boxes in CASs 15-01-03 and 15-05-01.

Concentrations were less than the CAS-specific FALs for all samples, confirming the no further action decisions for cleanup of these sites.

Table 5 presents verification sample analytical results that exceeded the method detection limits. At CAS 06-07-01, samples collected from below septic tank 6-605 contained low concentrations of gross alpha and diesel-range petroleum hydrocarbons. Samples collected from below septic tank 6-607 were all less than detection limits. Samples collected from below Sump 1 contained low concentrations of gross alpha; however, this was only detected because the sample run for gross beta was also run by the analytical laboratory for gross alpha. Samples collected from below Sump 2 contained low concentrations of diesel-range petroleum hydrocarbons, cobalt-60, and plutonium. For CAS 15-01-03, samples collected from below the distribution box contained very low concentrations of plutonium, with all remaining sample concentrations being less than their respective detection limits. Concentrations in samples collected from below the septic tank at CAS 15-04-01 and the distribution box at CAS 15-05-01 were less than the respective detection limits for all analytes. All concentrations were below the FALs established for the respective CASs.

A copy of the summary reports for analytical results and the associated chain-of-custody forms are provided in Appendix B. The complete data set for all laboratory analytical reports are available on request. These data are maintained in M\&OC project files located at the NTS. Photographs documenting closure activities are presented in Appendix D. 
Table 4. Closure Verification Soil SAMPles Collected for CAU 543

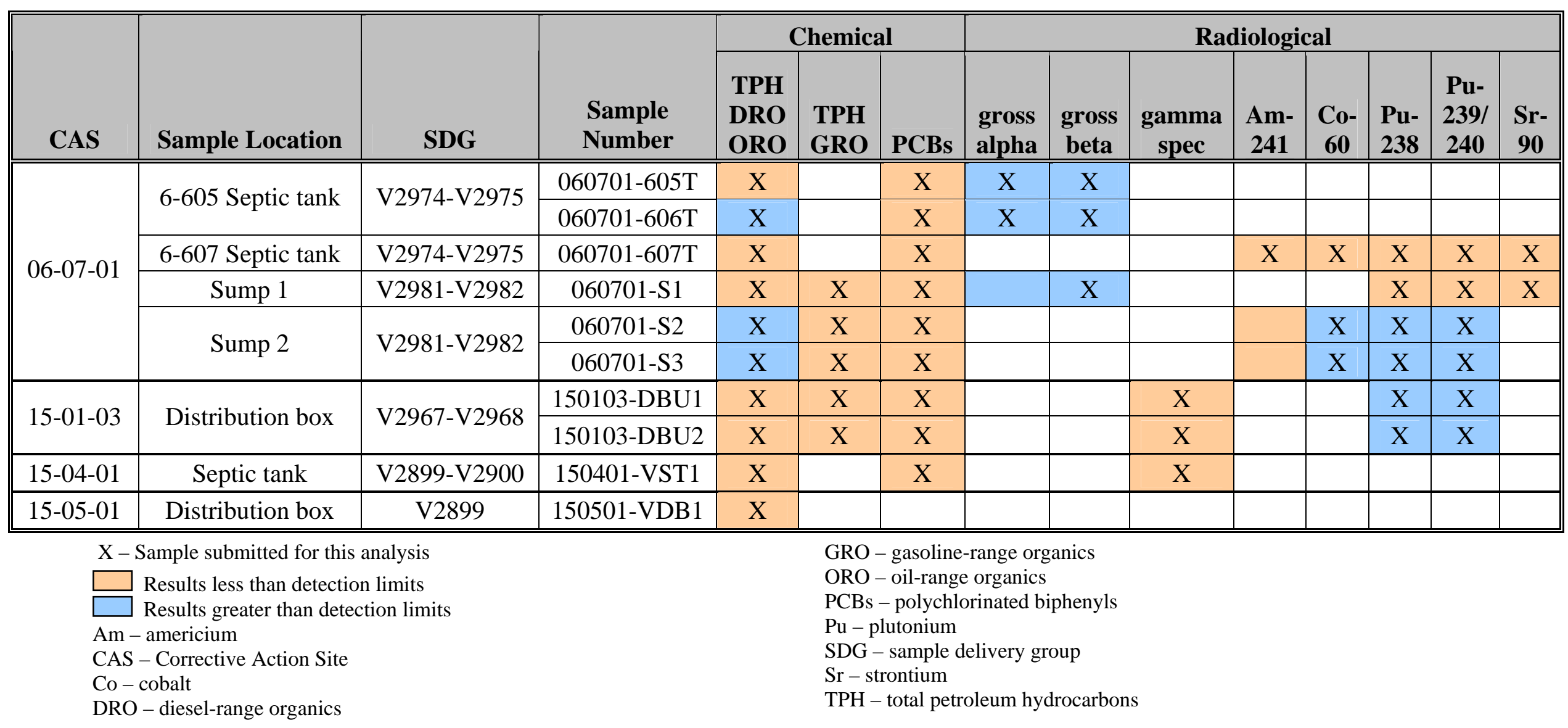


Date: January 2008

Table 5. Closure Verification SAMPle Analytical Results Greater than the Detection Limits

\begin{tabular}{|c|c|c|c|c|c|c|c|c|}
\hline \multirow[t]{2}{*}{ CAS } & \multirow[t]{2}{*}{$\begin{array}{c}\text { SAMPLE } \\
\text { LOCATION }\end{array}$} & \multirow[t]{2}{*}{$\begin{array}{l}\text { SAMPLE } \\
\text { NUMBER }\end{array}$} & $\begin{array}{c}\text { TPH- } \\
\text { DRO/ORO } \\
\text { (mg/kg) }\end{array}$ & $\begin{array}{c}\text { Gross } \\
\text { Alpha } \\
\text { (pCi/g) }\end{array}$ & $\begin{array}{c}\text { Gross } \\
\text { Beta } \\
(\text { pCi/g) }\end{array}$ & $\begin{array}{c}\text { Co-60 } \\
\text { (pCi/g) }\end{array}$ & $\begin{array}{l}\text { Pu-238 } \\
\text { (pCi/g) }\end{array}$ & $\begin{array}{c}\mathrm{Pu}-239 / 240 \\
\text { (pCi/g) }\end{array}$ \\
\hline & & & FAL $=100$ & $* \mathbf{F A L}=15$ & $* \mathbf{F A L}=\mathbf{5 0}$ & FAL $=2.7$ & $\mathbf{F A L}=13$ & FAL $=12.7$ \\
\hline \multirow{4}{*}{ 06-07-01 } & \multirow{2}{*}{ Septic tank 6-605 } & 060701-605T & ND & 5.74 & $5.22(\mathrm{LT})$ & - & - & - \\
\hline & & 060701-606T & 4.1 & 6.58 & $5.78(\mathrm{LT})$ & - & - & - \\
\hline & Sump 1 & 060701-S1 & $\mathrm{ND}$ & 7.39 & $5.03(\mathrm{LT})$ & - & ND & $\mathrm{ND}$ \\
\hline & Sump 2 & 060701-S3 & 14 & - & & 0.205 & $\begin{array}{c}0.00736 \\
(\mathrm{LT})\end{array}$ & 0.0735 \\
\hline & & & FAL $=100$ & & & & FAL $=13$ & $\begin{array}{c}\text { FAL }= \\
2,637\end{array}$ \\
\hline $15-01-03$ & Distribution box & 150103-DBU1 & ND & - & & - & 0.0205 & $\begin{array}{c}0.00577 \\
(\mathrm{LT})\end{array}$ \\
\hline
\end{tabular}

CAS - Corrective Action Site

Co - cobalt

DRO - diesel-range organics

ORO - oil-range organics

FAL - final action level

pCi/g - picocurie(s) per gram

$\mathrm{mg} / \mathrm{kg}$ - milligrams per kilogram

$\mathrm{Pu}$ - plutonium

TPH - total petroleum hydrocarbons

ND - not detected

(LT) - less than requested detection limit but greater than method detection limit

* FAL $=15$ pCi/liter gross alpha (from the National Primary Drinking Water Regulations, Title 40 CFR Part 141.66, "Maximum Contaminant Levels for Radionuclides” [CFR, 2006a]), and 50 pCi/g from Nevada Drinking Water Standards, as identified in the CAU 543 CADD (NNSA/NSO, 2005) 


\subsection{Data Quality Assessment}

Detailed information regarding the quality assurance/quality control (QA/QC) program requirements can be found in the QAPP (NNSA/NV, 2002). All CAU 543 samples were analyzed using stringent QA/QC laboratory procedures that included matrix spike/matrix spike duplicates, spiked surrogate recovery, and other standard QA/QC procedures. Additional data review was conducted by the NTS M\&OC to ensure that samples were appropriately processed and analyzed, and that the results are valid. All data underwent Tier I and II data reviews in accordance with the QAPP (NNSA/NV, 2002), which is based on the EPA functional guidelines for data quality (EPA, 1994; 1999). Data validation was also performed on 100 percent of the data to verify that results were useable and served their intended purpose.

No anomalies were discovered in the data that would discredit any of the CAU 543 waste characterization or verification sample results. One blind duplicate verification sample per twenty samples or one blind duplicate sample per sampling event was collected and submitted for analysis. All of the verification data were useable for making decisions. Data met the required data quality indicators (i.e., precision, accuracy, sensitivity, completeness, comparability, and representativeness) with the following exceptions:

- Precision: The 20 percent relative percent difference was exceeded for plutonium results for CAS 06-07-01 Sump 2 and for the CAS 15-01-03 distribution box; however, all of the sample concentrations were orders of magnitude less than the action levels such that the data were useable for making a decision. Results from most of the duplicate samples were near the detection limit, which is where the relative percent difference calculations are subject to such results and have little impact on the value of the data quality.

- Sensitivity: Recoveries were low (58 to 66 percent) for PCB samples collected below the sumps at CAS 06-07-01; however, the method detection limit was orders of magnitude less than the action level, and the results were all non-detects. Therefore, these results were useable for making a decision and show that the resulting PCB concentrations are much less than the action level.

There were no findings during closure activities that required any modifications to the post-closure plan as proposed in the CAU 543 CAP. The data quality objectives (Appendix A of this report, as originally presented in the CAIP [NNSA/NSO, 2004a]) were confirmed during the corrective action investigation and were reported in the CADD (NNSA/NSO, 2005). Observations and analytical results from the closure activities confirmed what was reported in the CADD (NNSA/NSO, 2005) and any changes made therein to the conceptual site models.

\subsection{USE RESTRICTION}

URs have been implemented for the following CASs:

- CAS 06-07-01, Decon Pad

- CAS 15-01-03, Aboveground Storage Tank

- CAS 15-23-03, Contaminated Sump, Piping 


\subsubsection{CAS 06-07-01, Decon Pad}

CAS 06-07-01 (Decon Pad) was use-restricted for radioactivity and PCBs on and directly adjacent to the Building 6-605 concrete foundation. Two-strand wire rope fencing surrounds and restricts access to the area. UR signs and PCB signs (large PCB signs as defined by 40 CFR 761.45 [CFR, 2006b]) are posted on each of the four sides of the Building 6-605 foundation fencing, to warn against intrusive activity according to the FFACO UR posting guidance (FFACO, 2003). Annual site inspections will be required to ensure that the fencing is intact and functioning, and the UR and PCB signs are intact and legible. The CAU Land-Use Restriction Information form and figures, showing the locations of the surveyed points delineating the use-restricted areas, are provided as Appendix E. Details on the post-closure requirements are included in Section 5.2.

\subsubsection{CAS 15-01-03, Aboveground Storage Tank}

CAS 15-01-03 (Aboveground Storage Tank) was use-restricted for PCBs (at concentrations between 25 and 50 ppm) on the Building 15-06 concrete pad and in underground piping between Building 15-06 and the former AST. Two-strand wire rope fencing surrounds and restricts access to the Building 15-06 concrete pad. UR and PCB signs (large PCB signs as defined by 40 CFR 761.45 [CFR, 2006b]) are posted on each of the four sides of the Building 15-06 foundation fencing. UR and PCB signs are also posted approximately every $100 \mathrm{ft}$ apart above the underground piping, and existing URMA signs also are present above the underground piping. The UR signs warn against intrusive activity according to the FFACO UR posting guidance (FFACO, 2003). Annual site inspections will be required to ensure that the fencing is intact and functioning, and the UR and PCB signs are intact and legible. The CAU Land-Use Restriction Information form and figures, showing the locations of the surveyed points delineating the use-restricted areas, are provided as Appendix E. Details on the post-closure requirements are included in Section 5.2.

\subsubsection{CAS 15-23-03, Contaminated Sump, Piping}

CAS 15-23-03 (Contaminated Sump, Piping) was use-restricted for radioactivity and PCBs. The contaminated sump was filled with clean, native fill and mounded to prevent rainwater ponding on the surface. UR and URMA signs are posted around the perimeter of the sump, on posts adjacent to existing fencing (fencing is not a post-closure maintenance item) and in the middle of the unfenced access to the sump area. The UR signs warn against intrusive activity according to the FFACO UR posting guidance (FFACO, 2003). PCB signs are not posted because PCB concentrations are less than 25 ppm.

Annual site inspections will be required to ensure that the UR and PCB signs are intact and legible. The CAU Land-Use Restriction Information form and figures, showing the locations of the surveyed points delineating the use-restricted areas, are provided as Appendix E. Details on the post-closure requirements are included in Section 5.2. 
Closure Report - CAU 543

Section: Closure Verification

Revision: 0

Date: January 2008

THIS PAGE INTENTIONALLY LEFT BLANK 


\subsection{CONCLUSIONS AND RECOMMENDATIONS}

\subsection{CONCLUSiONS}

The following site closure activities were performed at CAU 543 and are documented in this CR.

- CAS 06-07-01 (Decon Pad) was closed in place with administrative controls and implementation of BMPs. The use-restricted area was fenced and posted, and a UR was implemented for PCBs and radioactivity. As BMPs, two septic tanks, two sumps, and their contents were removed and disposed of as MW; sediment from the Building 6-605 floor drain trenches was removed and disposed of as MW; the floor drain trenches, a diversion box, and seven cleanouts were grouted to grade; and numerous containers and other surface debris was segregated according to waste stream and disposed of appropriately as either LLW or sanitary waste.

- CAS 15-01-03 (Aboveground Storage Tank) was closed by taking no further action with implementation of the following BMPs. Underground piping between the AST and fill stand, and all aboveground piping, were removed, size-reduced, and placed inside the AST. The AST was sealed and disposed of as LLW. A distribution box and its contents were excavated and disposed of as PCB remediation LLW. Sediment was removed from the Building 15-06 floor drain trenches and disposed of as hydrocarbon PCB remediation waste. The floor drain trenches were filled with grout, the building foundation was fenced and posted, and a UR for PCBs was implemented for the building pad and underground piping between the building pad and the AST.

- CAS 15-04-01 (Septic Tank) was closed by taking no further action with implementation of the following BMPs. A septic tank and its contents were removed and disposed of as hydrocarbon PCB remediation waste. The excavation was backfilled to surrounding grade with clean fill.

- CAS 15-05-01 (Leachfield) was closed by taking no further action with implementation of the following BMPs. A distribution box, its contents, and piping between the distribution box and the CAS 15-04-01 septic tank were removed and disposed of as hydrocarbon PCB-remediation waste. The excavation was backfilled to surrounding grade with clean fill.

- CAS 15-08-01 (Liquid Manure Tank) was closed by taking no further action with implementation of the following BMPs. Liquid remediation waste from within the liquid manure tank was pumped out and transferred to the Area 12 Sewage Lagoons. Sludge within the tank was solidified, and the tank and its contents were excavated and disposed of as hydrocarbon waste. Surface debris was disposed of as hydrocarbon waste.

- CAS 15-23-01 (Underground Radioactive Material Area) was closed by taking no further action with the implementation of the following BMP. Surface debris was disposed of as sanitary waste.

- CAS 15-23-03 (Contaminated Sump, Piping) was closed in place with administrative controls by filling the existing sump with clean fill, posting the perimeter of the sump and buried piping as use restricted, and implementing a UR for PCBs and radioactivity. 


\subsection{Post-Closure Requirements}

Post-closure requirements apply only at the following sites, where URs have been implemented:

- CAS 06-07-01, Decon Pad

- CAS 15-01-03, Aboveground Storage Tank

- CAS 15-23-03, Contaminated Sump, Piping

\subsubsection{Inspections}

Inspections will be performed annually to verify that signs are in place and readable; fencing, if present, is in good condition; and the UR is maintained. Maintenance or repair needs that are identified will be scheduled within 90 working days of discovery and documented in writing at the time the work is done. Inspection results will be documented in the combined NTS post-closure annual letter report. The report will include a discussion of observations and will describe any maintenance activities performed since the last inspection was performed.

\subsubsection{Monitoring}

No monitoring other than visual inspections will be required for CAU 543.

\subsection{RECOMMENDATIONS}

Since closure activities for CAU 543 have been completed following the Nevada Division of Environmental Protection (NDEP)-approved CAP (NNSA/NSO, 2007), NNSA/NSO requests the following:

1. Provision of a Notice of Completion from NDEP to NNSA/NSO for the closure of CAU 543

2. Transfer of CAU 543 from Appendix III to Appendix IV, Closed CAUs, of the FFACO (FFACO, 1996) 


\subsection{REFERENCES}

CFR, see Code of Federal Regulations.

Code of Federal Regulations, Title 40, Part 141, “National Primary Drinking Water Standards,” 2006a.

Code of Federal Regulations, Title 40, Part 761, "Polychlorinated Biphenyls (PCBs) Manufacturing, Processing, Distribution in Commerce, and Use Prohibitions,” 2006b.

EPA, see U.S. Environmental Protection Agency.

Federal Facility Agreement and Consent Order, 1996 (as amended January 2007). Agreed to by the state of Nevada; the U.S. Department of Energy, Environmental Management; the U.S. Department of Defense; and the U.S. Department of Energy, Legacy Management.

Federal Facility Agreement and Consent Order, 2003. FFACO Use Restriction Post Guidance for NNSA/NSO and Associated Contractors. Las Vegas, NV.

FFACO, see Federal Facility Agreement and Consent Order.

NNSA/NSO, see U.S. Department of Energy, National Nuclear Security Administration Nevada Site Office.

NNSA/NV, see U.S. Department of Energy, National Nuclear Security Administration Nevada Operations Office.

U.S. Department of Energy, National Nuclear Security Administration Nevada Operations Office, 2002. Nevada Environmental Restoration Project Industrial Sites Quality Assurance Project Plan, Nevada Test Site, Nevada. DOE/NV--372-REV.3. Las Vegas, NV.

U.S. Department of Energy, National Nuclear Security Administration Nevada Site Office, 2004a. Corrective Action Investigation Plan for Corrective Action Unit 543: Liquid Disposal Units, Nevada Test Site, Nevada. DOE/NV--968. Las Vegas, NV.

U.S. Department of Energy, National Nuclear Security Administration Nevada Site Office, 2004b. NV/YMP Radiological Control Manual. DOE/NV/11718--079 Rev. 5. Las Vegas, NV.

U.S. Department of Energy, National Nuclear Security Administration Nevada Site Office, 2005. Corrective Action Decision Document for Corrective Action Unit 543: Liquid Disposal Units, Nevada Test Site, Nevada. DOE/NV--1082. Las Vegas, NV.

U.S. Department of Energy, National Nuclear Security Administration Nevada Site Office, 2007. Corrective Action Plan for Corrective Action Unit 543: Liquid Disposal Units, Nevada Test Site, Nevada. DOE/NV--1168-REV1. Las Vegas, NV. 


\subsection{REFERENCES (continued)}

U.S. Environmental Protection Agency, 1994. Guidance for the Data Quality Objectives Process. EPA QA/G-4. Washington, D.C.

U.S. Environmental Protection Agency, 1999. Contract Laboratory Program National Functional Guidelines for Organic Data Review. EPA540/R-99/008. Washington, D.C. 


\section{APPENDIX A*}

\section{DATA QUALITY OBJECTIVES}

* As presented and published in Appendix A1 of the approved Corrective Action Investigation Plan for Corrective Action Unit 543: Liquid Disposal Units, Nevada Test Site, Nevada. 2004a. DOE/NV--968. Las Vegas, NV. 
Closure Report - CAU 543

Section: Appendix A

Revision: 0

Date: January 2008

THIS PAGE INTENTIONALLY LEFT BLANK 


\section{A.1 Data Quality Objectives Process}

The DQO process is a seven-step strategic planning approach based on the scientific method that is being used to plan data collection activities for each CAS within CAU 543, Liquid Disposal Units. The DQOs are designed to ensure that the data collected will provide sufficient and reliable information to identify, evaluate, and technically defend the recommended corrective actions (i.e., no further action, closure in place, or clean closure). Existing information about the nature and extent of contamination at the CASs in CAU 543 is insufficient to evaluate and select preferred corrective actions; therefore, a corrective action investigation will be conducted.

The CAU 543 investigation will be based on DQOs developed in this Appendix by representatives from NDEP and NNSA/NSO. The seven steps of the DQO process developed for the CASs in CAU 543 and presented in Section A.1.2 through Section A.1.8 were developed based on the CAS-specific information presented in Section A.1.1 and in accordance with EPA Guidance for Quality Assurance Project Plans (EPA, 2002a). This document identifies and references the associated EPA Quality System Document for DQOs entitled Data Quality Objectives Process for Hazardous Waste Site Investigations (EPA, 2000a) and Guidance on Choosing a Sampling Design for Environmental Data Collection (EPA, 2000b) upon which the DQO process presented herein is based.

\section{A.1.1 CAS-Specific Information}

Corrective Action Unit 543 contains seven individual CASs. One CAS is located in Area 6 and the other six CASs are located in Area 15 of the NTS as shown in Figure A.1-1. The CASs within CAU 543 are:

- 06-07-01, Decon Pad

- 15-04-01, Septic Tank

- 15-05-01, Leachfield

- 15-08-01, Liquid Manure Tank

- 15-23-03, Contaminated Sump, Piping

- 15-01-03, Aboveground Storage Tank

- 15-23-01, Underground Radioactive Material Area 


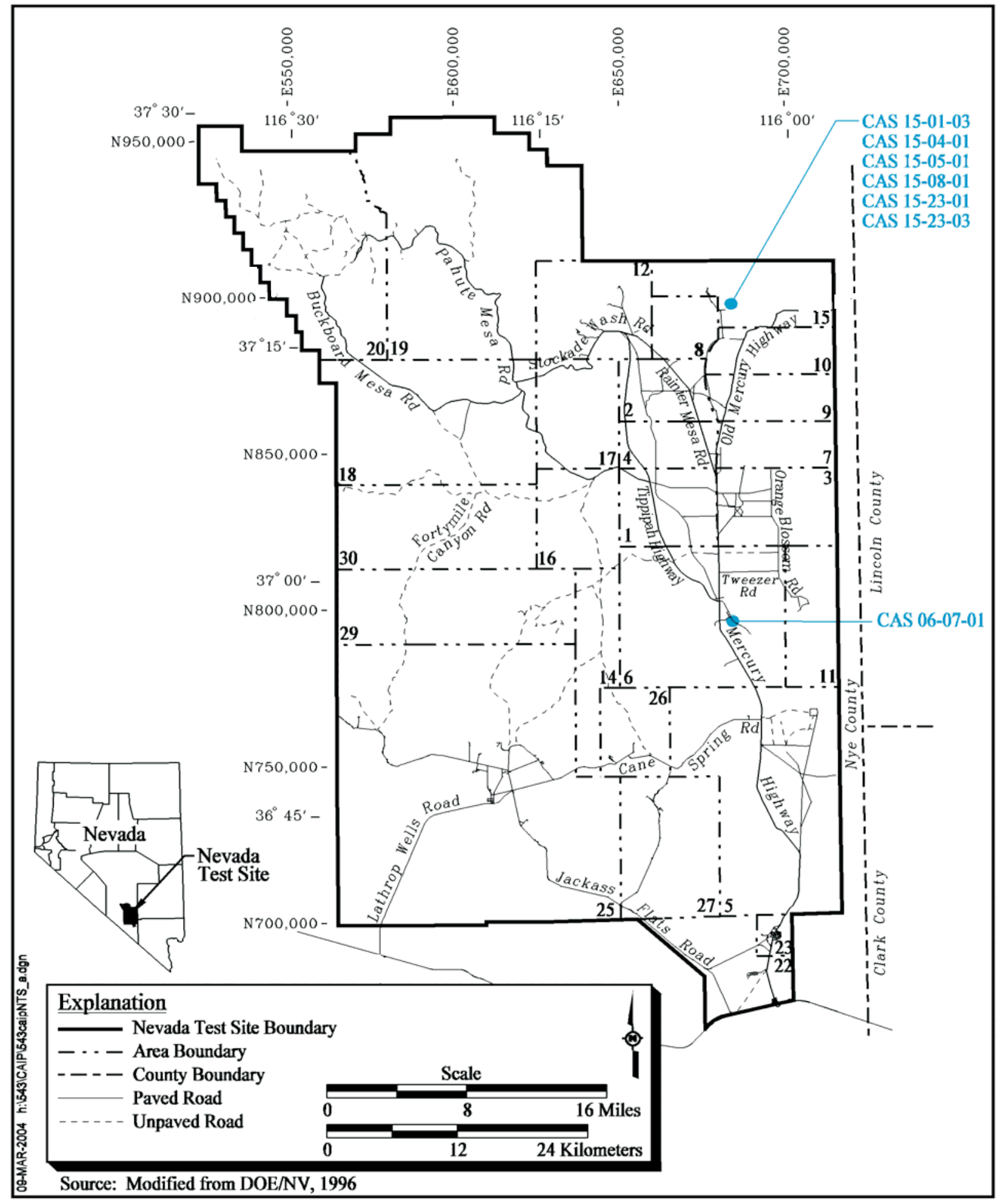

Figure A.1-1 Location of CAU 543 Corrective Action Sites 
Section A.1.1.1 and Section A.1.1.2 provide overviews of the operational histories of the Area 6 Decontamination Facility and the Area 15 EPA Farm, respectively. Processes and activities conducted at each of these separate facilities have created interrelated sources and potential releases common to the CASs or CAS components. Each section is followed by subsections that discuss the CAS or CAS-component physical setting and operational history, sources of potential contamination, any previous investigations, and potential contamination for each CAS.

The CAS-specific critical COPCs are listed in Table A.1-1 and described in the following CAS descriptions. Many of the COPCs are based on process knowledge of activities conducted rather than specific knowledge of a release. As a result, many of the Decision I COPCs for the CAI are considered the class of contaminants for a given analytical suite. Critical COPCs are defined as those contaminants that are known or reasonably suspected to be present within the CAS based on previous sampling, process knowledge, geographic setting, and/or operational site history. Analyses for noncritical COPCs assist in reducing the uncertainty concerning the history and potential release from the CAS and allow for an accurate evaluation of potential contamination. Beryllium, PCBs, and gamma-emitting radionuclides are general COPCs common to every CAS due to process knowledge of the NTS and lack of data to eliminate these from consideration.

\section{A.1.1.1 Area 6 Decontamination Facility}

The Area 6 Decontamination Facility (Figure A.1-2) was built in 1971 and designed to handle mixed and radioactive waste generated from a variety of decontamination processes (DOE/NV, 1984 and 1993; Holmes \& Narver, 1971b). The Area 6 Decontamination Facility is located along the southwest edge of Yucca Lake in Area 6 of the NTS and consisted of several buildings and structures within a fenced area:

- Area 6 Decontamination Pad (Building 6-605) and an associated outdoor concrete pad

- Area 6 Decontamination Laundry (Building 6-607)

- Dyna Drill Repair Shop (Building 6-606)

- Dyna Drill Repair Parts (Building 06-2203A)

- Tent Structure 06-202567

- Trailer TA-20 on a concrete foundation

- An electrical substation

- Various other temporary containers and sheds

- Storage area for contaminated materials 
Table A.1-1

Contaminants of Potential Concern for CAU 543

\begin{tabular}{|c|c|c|c|c|c|c|c|}
\hline \multirow{2}{*}{$\begin{array}{l}\text { Contaminants of } \\
\text { Potential Concern }\end{array}$} & \multirow{2}{*}{$\begin{array}{c}\text { Area } 6 \\
\text { CAS } \\
6-07-01\end{array}$} & \multicolumn{6}{|c|}{ Area 15 - EPA Farm } \\
\hline & & $\begin{array}{c}\text { CAS } \\
15-04-01\end{array}$ & $\begin{array}{c}\text { CAS } \\
15-05-01\end{array}$ & $\begin{array}{c}\text { CAS } \\
15-08-01\end{array}$ & $\begin{array}{c}\text { CAS } \\
15-23-03\end{array}$ & $\begin{array}{c}\text { CAS } \\
15-01-03\end{array}$ & $\begin{array}{c}\text { CAS } \\
15-23-01\end{array}$ \\
\hline Degreasers & $\mathbf{x}$ & & & & & & $x$ \\
\hline Solvents & $\mathbf{x}$ & & & & & & $\mathbf{x}$ \\
\hline Detergents & $\mathbf{x}$ & & & & & & $\mathbf{x}$ \\
\hline Caustics & $\mathbf{x}$ & & & & & & \\
\hline Acids & $x$ & & & & & & \\
\hline Gamma Emitting Radionuclides & $\mathbf{x}$ & $\mathbf{x}$ & $\mathbf{x}$ & $\mathbf{x}$ & $\mathbf{x}$ & $\mathbf{x}$ & $\mathbf{x}$ \\
\hline Cesium-137 & $\mathbf{x}$ & $\mathbf{x}$ & $\mathbf{x}$ & $\mathbf{x}$ & $\mathbf{x}$ & $\mathbf{x}$ & $\mathbf{x}$ \\
\hline Plutonium-238/239 & $\mathbf{x}$ & $\mathbf{x}$ & $\mathbf{x}$ & $\mathbf{x}$ & $\mathbf{x}$ & $\mathbf{x}$ & $\mathbf{x}$ \\
\hline Plutonium-240 & $\mathbf{x}$ & $\mathbf{x}$ & $\mathbf{x}$ & $\mathbf{x}$ & $x$ & $\mathbf{x}$ & $x$ \\
\hline Strontium-90 & $\mathbf{x}$ & $\mathbf{x}$ & $\mathbf{x}$ & $\mathbf{x}$ & $\mathbf{x}$ & $\mathbf{x}$ & $\mathbf{x}$ \\
\hline Americium-241 & $\mathbf{x}$ & $\mathbf{x}$ & $\mathbf{x}$ & $\mathbf{x}$ & $\mathbf{x}$ & $\mathbf{x}$ & $\mathbf{x}$ \\
\hline Uranium-234 & $\mathbf{x}$ & $x$ & $x$ & $\mathbf{x}$ & $x$ & $x$ & $x$ \\
\hline Uranium-235 & $\mathbf{x}$ & $\mathbf{x}$ & $\mathbf{x}$ & $\mathbf{x}$ & $x$ & $\mathbf{x}$ & $\mathbf{x}$ \\
\hline Uranium-238 & $\mathbf{x}$ & $x$ & $\mathbf{x}$ & $\mathbf{x}$ & $x$ & $x$ & $x$ \\
\hline VOCs & $\mathbf{x}$ & $\mathbf{x}$ & $\mathbf{x}$ & $\mathbf{x}$ & $\mathbf{x}$ & $\mathbf{x}$ & $\mathbf{x}$ \\
\hline SVOCs & $\mathbf{x}$ & $x$ & $x$ & $\mathbf{x}$ & $\mathbf{x}$ & $\mathbf{x}$ & $\mathbf{x}$ \\
\hline Metals (Including Beryllium) & $\mathbf{x}$ & $\mathbf{x}$ & $\mathbf{x}$ & $\mathbf{x}$ & $\mathbf{x}$ & $x$ & $x$ \\
\hline TPH & $\mathbf{x}$ & $\mathbf{x}$ & $x$ & $x$ & $\mathbf{x}$ & $x$ & $x$ \\
\hline PCBs & $\mathbf{x}$ & $x$ & $\mathbf{x}$ & $\mathbf{x}$ & $x$ & $\mathbf{x}$ & $x$ \\
\hline Pesticides & & $\mathbf{x}$ & $\mathbf{x}$ & $\mathbf{x}$ & $\mathbf{x}$ & $\mathbf{x}$ & $\mathbf{x}$ \\
\hline Herbicides & & $\mathbf{x}$ & $\mathbf{x}$ & $\mathbf{x}$ & $\mathbf{x}$ & $\mathbf{x}$ & $\mathbf{x}$ \\
\hline Sanitary Waste & $\mathbf{x}$ & $x$ & $\mathbf{x}$ & $x$ & $x$ & $\mathbf{x}$ & \\
\hline Laboratory Wastes & & $x$ & $\mathbf{x}$ & $x$ & $x$ & $x$ & \\
\hline Biological waste & & $x$ & $\mathbf{x}$ & $\mathbf{x}$ & $x$ & $\mathbf{x}$ & \\
\hline
\end{tabular}

Biological waste $=$ Fecal matter, urine, blood, animal organs 


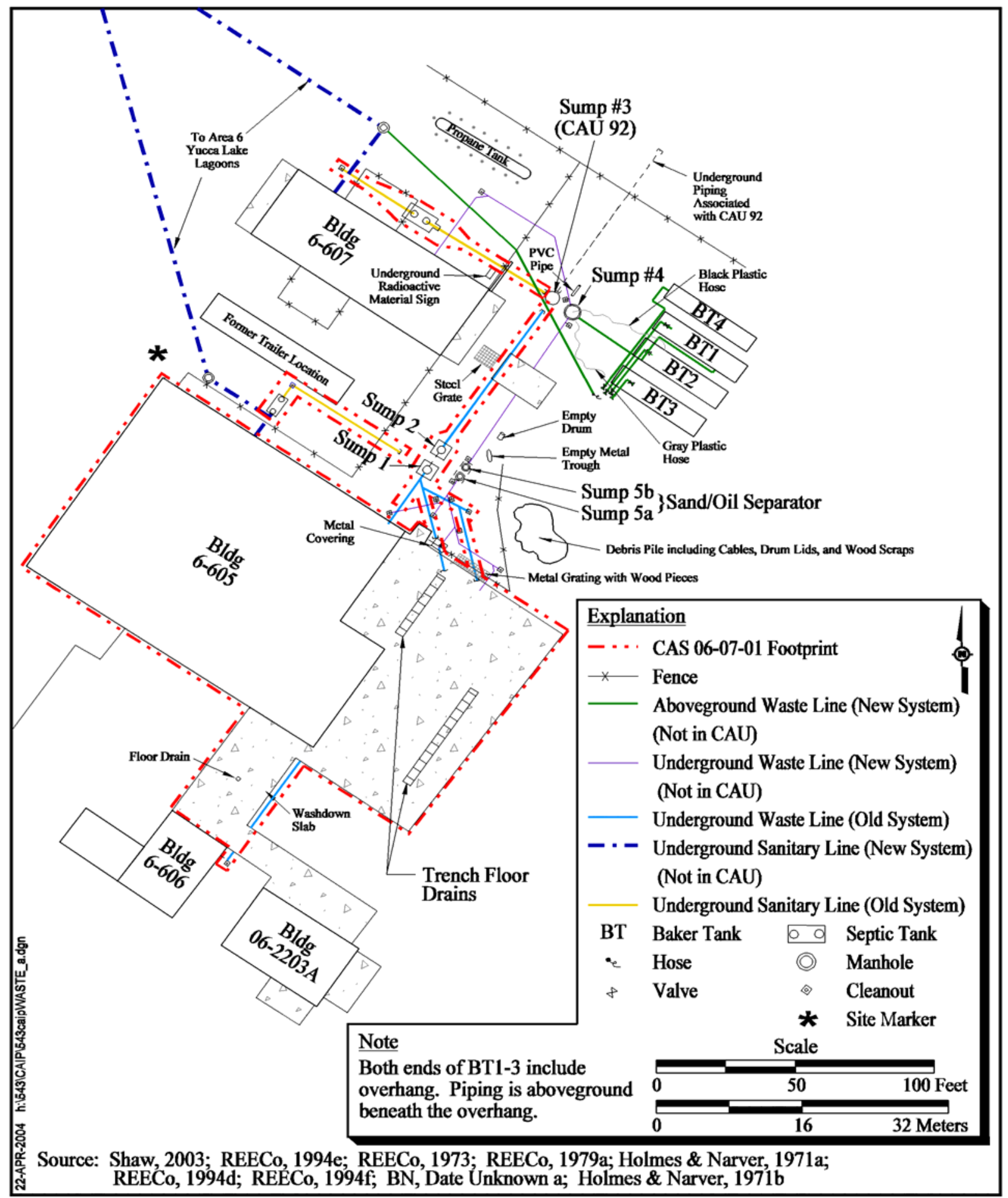

Figure A.1-2

CAU 543, CAS 06-07-01, Decon Pad Site Map 
The Area 6 Decontamination Pond, located $600 \mathrm{ft}$ northeast of the Facility, was the original discharge area for all liquid wastes generated within the Facility buildings until the Pond was closed in 1992 (DOE/NV, 1999). The Area 6 Decontamination Pond, associated piping from the Pond to Sump 3 located within the Facility perimeter fence, and Sump 3 have been remediated and closed under CAU 92 (DOE/NV, 1999).

The Area 6 Decontamination Facility was built to decontaminate vehicles, equipment, and clothing that had become radiologically contaminated during nuclear testing activities (DOE/NV, 1984 and 1993). From 1971 through 1992, hazardous, radioactive, and sanitary wastes were generated within Buildings 6-605, 6-606, 6-607, and Trailer TA-20 and originally discharged via process waste lines, septic systems, and sumps to the Area 6 Decontamination Pond located north of the facility (REECo, 1979a; DOE/NV, 1999). Until November 1988, the waste generated at CAS 06-07-01 contained RCRA constituents; however, after this date, wastes containing RCRA constituents were no longer allowed to be discharged into this waste system (Bicker, 1988). Around 1992, liquid wastes were no longer allowed to be discharged to the Decontamination Pond (Bingham, 1993a). In 1994, the Area 6 Decontamination Facility waste collection/discharge system underwent a significant upgrade in which a new process waste line system and ASTs (i.e., Baker tanks) were installed to contain all liquid wastes generated within the buildings prior to disposal. The sanitary septic tanks were reportedly changed to holding tanks for domestic sewage prior to the new sewer line being installed (Radack, 1992). The Area 6 Decontamination Facility remained operational until approximately 2001 and is currently inactive and abandoned (Soong, 2003).

Building 6-605, built in 1971, is the main decontamination facility and is referred to as the Area 6 Decontamination Pad. The building contains both a high and low bay equipped to accommodate both large (i.e., drill rigs) and smaller vehicles and equipment. The primary decontamination process for radiologically contaminated materials involved spraying water, mixed with cleaning solvents and soaps/detergents, onto contaminated materials inside the bays. Electronic equipment and materials that could be damaged by water were cleaned using solvents, such as alcohol. Three dip tanks, containing hot caustics, were also located within the building and were used to submerge and clean smaller pieces of equipment (REECo, 1971b; DOE/NV, 1984). An outdoor decontamination pad sits adjacent to the building and contains a floor drain. It is assumed decon activities were conducted on this pad as well. The liquid wastes generated by the decontamination activities were collected within 
the floor drains of the building and discharged via a process waste line to the Pond. The building also contained restrooms and personnel decontamination facilities (e.g., showers) that discharged sanitary wastes via a separate sewer line and septic tank before discharging to the Pond.

Building 6-607, the Area 6 Decontamination Laundry, was used to clean clothing and other fabrics contaminated with potentially radioactive and hazardous material from NTS testing activities (Wuellner, 1994). Effluent from the laundry operations was discharged via a process waste line to the Pond, while sanitary effluent from the laundry facility was discharged through an associated sewer line and septic tank before discharging to the Pond.

Building 6-606, the Dyna-Drill Repair Shop, is located south of Building 6-605. The building was used to fix pipes and other drill parts that were decontaminated within the Area 6 Decontamination Facility. Discharges from the Facility entered the process waste line going to the Area 6 Decontamination Pond.

The Dyna-Drill Repair Parts, Building 6-2203A, is located southwest of Building 6-605. The building was used in conjunction with the Dyna-Drill Repair Shop; however, specific activities are unknown (REECo, 1979a). Documentation indicates this building did not contribute or generate a liquid waste stream.

The Trailer TA-20 was an administrative office located northwest of Building 6-605. Activities conducted within this trailer, other than administrative, are unknown. The trailer had an aboveground PVC line that connected directly into Building 6-605 sanitary sewer line and it is believed the trailer discharged only sanitary waste (Radack, 1992). The trailer or PVC piping is no longer present; however, the concrete foundation is.

The Tent Structure, Building 6-202567, is located southwest of Building 6-605 and was used to store various wastes (BN, Date Unknown a). The majority of these wastes were stored in B25 steel boxes. Documentation and process knowledge indicates this building was not directly related to the decontamination activities of Building 6-605; therefore, it did not contribute liquid wastes via a process or sewer waste line. 
The southeast portion of the facility, formerly used to store contaminated materials, is currently posted as a "Contamination Area" (Holmes \& Narver, 1971a).

\section{A.1.1.1.1 CAS 06-07-01, Decon Pad}

The portions of the Area 6 Decontamination Facility piping system that are included in CAS 06-07-01 are those areas that may have been impacted by RCRA or other hazardous constituents from decontamination activities. The entire piping system at the facility underwent significant changes in 1994 after which wastes from Buildings 6-605, potentially 6-606, and 6-607 flowed into sequenced Baker tanks located in the northeast section of the facility (REECo, 1994f; Bertrand, 2003). The last sequenced tank was sampled for RCRA constituents before liquid was allowed to drain to a sanitary sewer manhole located north of Building 6-607 and discharge to the Area 6 Yucca Lake Lagoon System. Since the wastes generated after the upgrades have been analyzed and consistently shown to be nonhazardous (Elle, 1994), the piping, sumps, and tanks installed for the 1994 upgrade are not included in this CAS. However, all portions of the old piping system, including the sumps and septic tanks, are covered as part of CAS 06-07-01.

Physical Setting and Operational History - The portions of CAS 06-07-01 to be investigated under CAU 543 include Building 6-605 and an associated outdoor decontamination pad; portions of the inactive sanitary sewer systems from Buildings 6-605 and 6-607; inactive underground process waste lines and sumps that formerly discharged wastes from Buildings 6-605, 6-606, and 6-607 to the former Area 6 Decontamination Pond, and the soils located in the southeast portion of the Decontamination Facility that was formerly used for the storage of contaminated materials.

Building 6-605, the main decontamination facility, is a slab-on-grade metal building measuring approximately $100 \times 84 \mathrm{ft}$. The building contains a high and low bay capable of accommodating heavy equipment, a dip tank bay containing three heated dip tanks capable of holding pipe stems up to $40 \mathrm{ft}$ in length, a storeroom, a mechanical equipment room, a shower/locker room, and two offices (DOE/NV, 1984). The two bays contain several remaining high-pressure pumps and recirculation tanks (REECo, 1979b and c). The building contains floor drains (most are configured as trenches) that collected various liquids and wastes from decontamination processes occurring inside the building. Currently, the building appears in good condition with no significant spills or staining visible. The dip tanks are still present within the building and believed to be empty. 
The liquids from Building 6-605 drains were piped via a process waste line to two sumps labeled Sump 1 (sand trap) and Sump 2 (oil/water separator) located northeast of Building 6-605 (REECo, 1973). These two sumps were designed to remove the solid and oil components from the liquid waste. Liquid process wastes from Building 6-607 (Laundry) entered the system at Sump 3 via the process waste line, while process waste from Building 6-606 entered the system via the process waste line south of Building 6-605. The liquid then flowed via the process waste line to Sump 3. From Sump 3, wastes were delivered via piping to the Area 6 Decontamination Pond.

Sanitary sewage waste discharged from Buildings 6-605 and 6-607 through separate sewer lines to separate septic tanks. From the Building 6-605 septic tank, the sanitary sewer line ran southeast to Sump 1, joined the process waste line, and then discharged to the Pond. From the septic tank that serviced Building 6-607, the sanitary sewer line joined the process waste line, connected to Sump 3, and then discharged to the Pond (REECo, 1973; Holmes \& Narver, 1981). Trailer TA-20 had a PVC line directly connected to the sewer system at Building 6-605. The PVC line and the trailer have been removed, leaving only the concrete foundation present at the facility. Currently, two metal coverings are present over the Building 6-605 septic tank. Metal grates replaced the two manhole covers over the Building 6-607 septic tank. One manhole cover was noted in the area of Sumps 1 and 2; however, it is not clear which sump was connected to the manhole.

In 1994, a new process waste line system was installed, including new sumps and a new concrete floor in Building 6-605 (REECo, 1994a, b, c, e, and f). The process waste line still originated at the decontamination pad (Building 6-605), but the line continued to Sumps 5a and 5b, and then to Sump 4. From Sump 4, waste was sent to three baker tanks located at the northeast end of the facility. A fourth baker tank was installed sometime later, but it is uncertain if it was ever used. When the last baker tank became full, the wastewater was tested for RCRA hazardous constituents. If all contaminants were below action levels, then the water would be discharged via an aboveground pipe that connected to a sanitary sewer manhole on the north side of Building 6-607 (Bertrand, 2003; Boyd, 2003). Waste entering this manhole was sent to the Area 6 Yucca Lake Lagoon Systems. It is unknown what was done with the water if the action levels were exceeded. These new components included in the reconfigured system are not included in this CAS but are added for knowledge of the current system (Bertrand, 2003; Paradis, 1998). The Baker tanks are still present at the facility. 
Sources of Potential Contamination - Activities conducted at the Area 6 Decontamination Facility included decontaminating vehicles, equipment, and clothing that had become contaminated during nuclear testing activities. Decontamination activities conducted within Building 6-605 created effluent potentially contaminated with cleaning solvents, soaps/detergents, degreasers, hot caustics, acids, and various radionuclides from contaminated materials that were discharged through floor drains to a process waste line system which currently includes subsurface piping and two sumps. Documentation states that due to numerous caustic and acidic spills and abrasive actions caused by drill pipe and heavy equipment, the concrete floor of Building 6-605 started to breakdown. As a result, the product Stonclad was applied over the entire floor to protect the concrete floor from further erosive attacks (Western, 1977).

In addition to the process wastes, Building 6-605 generated sanitary effluent that discharged through drains to a septic tank and eventually to the process waste line at Sump \# 1. Based on process knowledge gained from previous septic system investigations on the NTS, the sanitary effluent may have hazardous and/or radioactive contamination present. In 1992, floating debris and oil were noted in the septic tank adjacent to Building 6-605 and is believed to be the result of overflow from clogged process waste lines (Radack, 1992).

Building 6-607 (Area 6 Decontamination Laundry) used soaps and detergents to clean the contaminated clothing used during testing and drilling activities. Effluent from Building 6-607 that was potentially contaminated with various inorganic, organic, and radiologically contaminated material, entered the septic system at Sump 3. In addition, Building 6-607 generated sanitary effluent that discharged through drains to a septic tank and eventually to the process waste at Sump \#3. Based on process knowledge gained from previous septic systems investigations on the NTS, the sanitary effluent may have hazardous and/or radioactive contaminants present.

Effluent from Building 6-606 likely contained solvents, degreasers, and lubricants that may have been used during equipment repair activities. Effluent discharged through drains and entered the process waste line south of Building 6-605. A concrete pad with a floor drain is located between Building 6-606 and 6-605. It is assumed this drain also contributes effluent to the process waste line but exact activities for this pad are unknown; however, at a minimum surface run-off would be generated. 
Documentation indicates several leaks from the subsurface piping at connection points of the old piping system to Building 6-605 and near Sump 2 may have occurred in the past. It is possible that other leaks occurred along the piping system, sumps, and/or septic tanks (Bingham, 1990 and1993; Bielawski, 1994).

The southeast area of the facility has been identified as a storage area for contaminated items and materials. Engineering drawings identify this area as the "Hot Side" and the "Hot Park Area." The specific details of activities in this area are undocumented. Contaminated equipment and materials staged in this area were exposed to the elements; therefore, release of oil from the equipment and deposition of contamination to the underlying soils was possible. The area is currently posted as a "Contamination Area."

The Closure Report for Petroleum Hydrocarbon Release at the Area 6 Decontamination Facility at the Nevada Test Site: Tank 6-605-1 (NDEM \#990204-3304) (DOE/NV, 2000a) identifies a release of petroleum hydrocarbons from UST 6-605-1. The tank was used to store heating oil for Building 6-605. When activities were stopped in the building the boiler was no longer needed and the UST was removed. The tank was located adjacent to the northwest corner of Building 6-605 and was closed by removing the tank and associated piping. Soil samples collected at the time of the closure indicated the presence of petroleum hydrocarbons in concentrations that exceed the state action level. Some soil was removed, but it is believed that the concentrations exceeding regulatory criteria remain under the building and/or near the electrical substation. The NDEP approved the site for closure in place with use restriction (DOE/NV, 2000a).

Previous Investigation Results - Sampling results from the Area 6 Decontamination Pond, the septic tanks that serviced Buildings 6-605 and 6-607, Sumps 1 and 2, and soil from around the process waste lines indicated the presence of numerous potential contaminants. Results indicate the presence of various solvents, acids, caustics, degreasers, detergents, alcohols, metals, radionuclides, petroleum hydrocarbons, VOCs, and SVOCs (DOE/NV, 1999).

Sampling results from closure of tank 6-605-1 indicate that petroleum hydrocarbons were present in concentrations as high as $13,000 \mathrm{mg} / \mathrm{kg}$ and that contaminants had migrated in the soil underneath Building 6-605 (DOE/NV, 2000a). 
Contaminants of Potential Concern - Chemical and radiological contaminants have been identified for this CAS based on previous investigation results and historical documentation. Various solvents, acids, caustics, degreasers, detergents, alcohols, and metals are parameters identified as COPCs. Based on investigations of similar facilities at the NTS and historical documentation, petroleum hydrocarbons are also COPCs. Beryllium and PCBs are a concern at the NTS and have not been ruled out by process knowledge.

Radionuclides that are associated with the fall-out from the nuclear weapons testing included americium (Am)-241, Barium-127m, cobalt (Co)-60, cesium (Cs)-137, europium (Eu)-152, Eu-154, plutonium (Pu)-238, Pu-239/240, Pu-241, samarium-151, strontium (Sr)-90, yttrium-90, tungsten (W)-181, W-187, and tritium (Adams, 2002; EG\&G/EM, 1986).

The following COPCs are identified for CAS 06-07-01:

- VOCs including methylene chloride, chlorobenzene, acetone, ethanol, xylene, xylene isomers, ethanol, isopropyl alchohol, ethylbenzene, toluene, 1,1,1-trichloroethane, 2-methylnapthalene, 2-(2-ethoxyethoxy)ethanol, and 2-butoxyethanol

- SVOCs including Bis(2-ethylhexyl)phthalate, butylbenzyphthalate, dioctyl ester (a.ka., di-N-octylphthalate), naphthalene, pentachlorophenol, bis(2-ethylhexy)ester, di-n-butylphthalate, and n-nitrosedipheynlamine

- Petroleum hydrocarbons including oil and grease, and petroleum naphtha

- Metals including nickel, antimony, copper, zinc, arsenic, barium, cadmium, chromium, lead, beryllium, silver, thallium, selenium, mercury, and lithium

- PCBs

- Caustics and acids

- Radionuclides to include Am-241, Co-60, Cs-137, Pu-238, Pu-239/240, Sr-90, U-234, U-235, $\mathrm{U}-238$, tritium (for liquids) and gamma-emitting radionuclides

\section{A.1.1.2 U.S. Environmental Protection Agency Farm}

On July 1, 1963, the AEC awarded a contract to the USPHS to study the transport of radioiodine from the environment to man, as well as the uptake by plants of long-lived fission products (SWRHL, 1967). The USPHS Farm was constructed in Area 15 of the NTS as a fully functioning 
diary to support these studies (EPA, 1973; SWRHL, 1967). The location of the farm was chosen based on the UE-15d Well, the location of roads and powerlines, and the fall-out in the area from the Plowshare Program. The radioiodine studies ended in 1970, at which time the USPHS was renamed the EPA (EPA, 1980). Various names have been used interchangeably for both the farm and the main building. The farm has been referred to as the EPA Farm, the USPHS Farm, and the PHS Farm. The main building has been referred to as Building 15-06, the Laboratory Building, the EPA Dairy Barn, and the Experimental Dairy Barn (DRI, 1994). The farm continued to be used until 1981 for other studies including metabolism studies on animals. By 1979, the farm no longer functioned as a full-time dairy and only brought in animals for specific experiments. On December 31, 1981, the DOE decided to decontaminate and decommission the farm. On October 23, 1997, closure activities at the farm were completed (DOE/NV, 1998a). Figure A.1-3 shows the general layout of the Area 15 EPA Farm and its associated CASs.

The majority of experiments occurred inside Laboratory Building 15-06 or nearby in the adjacent property. Corrective action sites 15-01-03, 15-04-01, 15-05-01, 15-08-01, and 15-23-03 received effluents from Laboratory Building 15-06 (Holmes \& Narver, 1971, 1974, 1975, and 1979). The sixth CAS (15-23-01) is associated with decontamination activities that took place in a separate location of the EPA Farm (Hopper, 1995). The rooms within the laboratory building included the hot slaughter room, milk room, milking area, sample control room, metabolism room, small animal laboratory, biology laboratory, autopsy laboratory, holding pen, utility room, rest room, and a change room for the workers (Edward B. Hendricks, 1965a, b, and c). Wastes from the metabolism and slaughter rooms were originally disposed via a waste line into a sump (CAS 15-23-03). In approximately 1974, an AST was installed (CAS 15-01-03) east of the sump to accept higher level radiological wastes (EPA, 1977). The wastes originating from both rooms were diverted at a distribution box between the AST and the sump, with the radiological wastes going to the AST and the nonradioactive or low-level wastes going to the sump (DOE, 1988; Olsen, 1997). The wastes from holding pens were also believed to have been disposed into the AST via the same waste line (Holmes \& Narver, 1971c).

Another waste stream from Building 15-06 consists of wastes from the small animal laboratory, biology laboratory, utility room, and rest room. Those wastes were disposed into the septic tank 


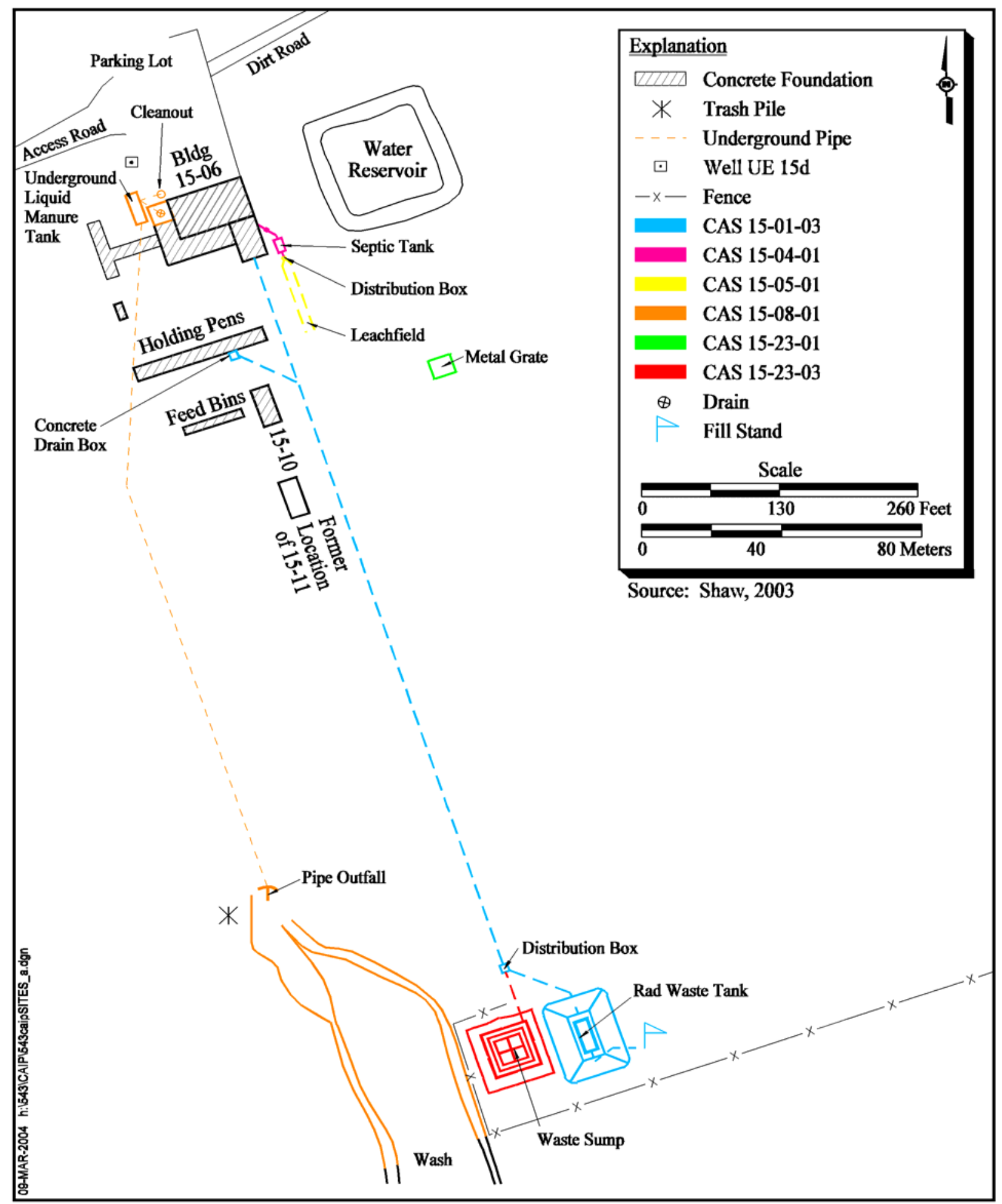

Figure A.1-3

EPA Farm Site MAP 
(CAS 15-04-01) and finally to the leachfield (CAS 15-05-01)(Holmes \& Narver, 1973a and b).

During the planning stages of the farm, there was a concern regarding the disposal of excess milk from the dairy herd and the adverse effects it might have on the biochemical activity in the septic tank. In addressing the concern, a commercially available liquid manure system was installed for the dairy operations. The liquid manure tank was installed in 1965, at the same time the Laboratory Building was constructed (SWRHL, 1967). The liquid manure tank was used for the accumulation of liquid waste and excess milk from the dairy cows. Wastes from the metabolism area, milking parlor, milk room, and holding pen were disposed of to the tank. After 1972, the liquid manure tank only received effluent from the milking area and milk room (EPA, 1977).

General sources of potential contamination common to all CASs within the Area 15 EPA Farm include the pesticides and fertilizers used and stored at the farm (SWRHL, 1967 and Boehlecke, 1997). Fertilizers sprayed on the crops fed to the animals used in the animal experiments consisted of ammonium nitrate, treble superphosphate and urea (SWRHL, 1967) in addition to the nitrogen and phosphorus fertilizers (SWRHL, 1967 and Boehlecke, 1997). As part of the animal studies, cobalt, manganese, and molybdenum were used in the animal feed (EPA, 1973).

There is a potential that waste water discharges from Well UE-15d may have been disposed down drains at the EPA Farm, resulting in the following contaminants being introduced into the EPA Farm waste stream: iron, manganese, lead, and mercury. These four contaminants exceeded the SDWA contaminant levels in 1984 (DOE, 1988).

Radionuclides associated with the fall-out from nuclear weapons testing Plowshare Project may be present in the surface soils of Area 15 and include typical fission products such as Cs-137, Am-241, Sr-90, and Pu isotopes (Adams, 2002; EG\&G/EM, 1986). Radionuclides used for the metabolism study at the EPA Farm include cerium-141, Sr-85, Mn-54, Scandium-46, Pu-238, iodine isotopes (121, 123, and 131), and iron-59 (EPA, 1973 and 1977).

Because the types of activities and disposal practices conducted at the Farm were similar and have the opportunity to affect all the CASs and components in a similar manner, five of the CASs have the same COPC list. For this reason, individual CAS descriptions of COPCs are not included in the 
following subsections but are listed in Table A.1-1. The exception is CAS 15-23-01, Underground Radioactive Material Area, because the nature of activities and release of contaminants is different than the rest of the Farm.

\section{A.1.1.3 CAS 15-04-01, Septic Tank}

Physical Setting and Operational History - This CAS is located adjacent and east of Building 15-06. The CAS consists of a 1,000-gal septic tank, cleanout, and associated piping. The piping consists of 4-in. cast-iron pipe from the building to the cleanout, where the pipe changes to 4-in. VCP from the cleanout to the septic tank (Edward B. Hendricks, 1965a; BN, Date Unknown b). Recent geophysical surveys and field observations were not able to confirm if the septic tank is still present at the site (SAIC, 2003).

The septic tank, piping, and cleanout were constructed in 1965 to service Laboratory Building 15-06 (Frazier, 1987). Originally, four floor drains, four sinks, and one toilet discharged to the septic tank. These drains, sinks, and toilet were located in the small animal laboratory, the biology laboratory, the utility room, and the rest room within Building 15-06 (Bingham, 1992; Olsen, 1997; Edward B. Hendricks, 1965b). In 1972, the waste water collection system was reconfigured to allow for separation of sanitary and nonsanitary wastes. With the exception of the floor drain in the utility room, all floor drains in the shower, and the toilet and sink in the toilet room, were connected to the manure tank. In 1973, two slaughter areas were added to the building. The drains in the slaughter areas were connected to the manure tank (Holmes \& Narver, 1973a and b).

Sources of Potential Contamination - The sources of potential contamination for the septic tank are considered the liquid wastes and effluent discharged through the floor drains and sinks within the Laboratory Building 15-06. The discharged effluent is associated with the sanitary sewage wastes and radioactive wastes from the laboratory testing and slaughter of animals within the laboratory.

Previous Investigation Results - This septic tank was sampled as part of the Preliminary Characterization of Abandoned Septic Tank Systems (DOE/NV, 1995) phase I activities. In this study, this septic system is identified as A15EPA. When sampled on September 12, 1994, the tank contained approximately 800 gal of waste, including an estimated $2-\mathrm{ft}$ layer of sludge. The liquid was relatively clear with floating particles and the sludge was dark brown to black and viscous. One 
liquid sample (A15EPA-T-L) and one sludge sample (A15EPA-T-S) were collected. The analytical results for these samples led to a recommendation that the septic system be closed as a "hydrocarbon containing tank" (DOE/NV, 1995).

A geophysical survey was conducted at CAS 15-04-01 in March 2003 over an area where the septic tanks were shown to be located on engineering drawings (SAIC, 2003). According to the survey, only anomalies consistent with underground piping were identified. No septic tank was located during the survey. It is possible that the tank may have been removed, or the area containing the tank may have fallen outside the boundaries of the survey. No documentation was located that confirms the removal of the septic tank.

\section{A.1.1.4 CAS 15-05-01, Leachfield}

Physical Setting and Operational History - This CAS is located adjacent and east of Building 15-06. The CAS consists of the distribution box, associated piping, and leachfield associated with the 1,000-gal septic tank (CAS 15-04-01) that serviced Building 15-06 (Edward B. Hendricks, 1965a; Holmes \& Narver, 1973a).

The leachfield consists of two subsurface 70 - $\mathrm{ft}$ long leach lines that are $8 \mathrm{ft}$ apart extending south from the distribution box. The leach lines consist of perforated 4-in. VCP. The dimensions for the distribution box are unknown (Edward B. Hendricks, 1965a; BN, Date Unknown c).

Sources of Potential Contamination - The sources of potential contamination for the distribution box and leachfield are the same as the septic tank (15-04-01) and are considered the liquid wastes and effluent collected through the floor drains and sinks within the Laboratory Building 15-06 and discharged to the septic tank.

Previous Investigation Results - The leachfield was sampled as part of the Preliminary Characterization of Abandoned Septic Tank Systems phase I activities (DOE/NV, 1995). In this study, this septic system is identified as A15EPA. On March 27,1995, one soil sample was collected below the first identified leachfield tile perforation. Barium, cadmium, and chromium, as well as oil and grease, were detected in the leachfield soil sample. Barium $(110 \mathrm{mg} / \mathrm{kg})$, was the only metal detected in the TCLP metal analysis at a concentration of $0.22 \mathrm{mg} / \mathrm{L}$. This result correlates with 
background concentrations for the area and was below the TCLP action level $(100 \mathrm{mg} / \mathrm{L})$ and the NDEP guidance level $(10 \mathrm{mg} / \mathrm{L})$. Cadmium was detected at $0.69 \mathrm{mg} / \mathrm{kg}$ and chromium was detected at $4.8 \mathrm{mg} / \mathrm{kg}$. Oil and grease was detected at $0.2 \mathrm{mg} / \mathrm{kg}$ and did not exceed the allowable liquid discharge limits for the Area 23 Sewage Lagoon. Although the sewage lagoon limits refers to liquids only, it is used here to provide an indication of the oil and grease characteristic of the leachfield soils. Tetrachloroethylene was detected at a concentration of $0.00033 \mathrm{mg} / \mathrm{L}$, and was also detected in the reagent blank $(0.00059 \mathrm{mg} / \mathrm{L})$ which suggests analytical interference. This concentration is below the TCLP action level of $0.07 \mathrm{mg} / \mathrm{L}$ and the NDEP guidance level of $0.07 \mathrm{mg} / \mathrm{L}$. In the background soil sample, TCLP barium was detected at $0.19 \mathrm{mg} / \mathrm{kg}$, which is below the TCLP action level $(100 \mathrm{mg} / \mathrm{L})$ and the NDEP guidance level of $10 \mathrm{mg} / \mathrm{L}$. The $\mathrm{pH}$ of the sample was 7.52 units and is not hazardous under 40 CFR 261.22 for corrosivity. Semivolatile organic compounds, TPH, and PCBs were not detected above laboratory reporting limits in the leachfield soil sample.

A geophysical survey, including CAS 15-05-01, was conducted on the NTS in March 2003 (SAIC, 2003). The survey was conducted to determine the location and dimensions of the leachfield. Various anomalies consistent with underground piping were identified that may potentially be the piping associated with the leachfield.

\section{A.1.1.5 CAS 15-08-01, Liquid Manure Tank}

Physical Setting and Operational History - This CAS is located adjacent to the northwest corner of the Building 15-06 foundation and consists of a liquid manure tank and its associated piping. The liquid manure tank consisted of an 18,000-gal underground concrete tank that measures $32 \times 12 \times 8 \mathrm{ft}$ and the top of the tank is even with the ground surface (SWRHL, 1967; BN, Date Unknown b; Edward B. Hendricks, 1965b). Included in the CAS is piping between the tank and the building and the outside floor drain in the center of a concrete pad. Also included in this CAS is outflow piping that extends south from the tank approximately $550 \mathrm{ft}$ to a drainage wash. The 6-in. diameter outflow pipe, south of Building 15-06, surfaces from the ground at the head of the wash. The wash is approximately 4 to $5 \mathrm{ft}$ wide and 2 to $3 \mathrm{ft}$ deep.

The manure tank had a clock-operated agitator to keep the solids in suspension. A special chopper pump emptied the tank into a tank wagon, which was used to spread the contents over the crop fields. An interviewee stated the liquid wastes in the tank were pumped into an outflow pipe and allowed to 
flow south, eventually discharging into the small wash (Hopper, 2003). An outflow pipe was identified during a field visit that was located south of Building 15-06. Further, a geophysical survey conducted in March 2003 identified a line that connects the manure tank to the outflow pipe (SAIC, 2003). It is believed that this outflow line was at some time used to discharge wastes from the liquid manure tank; however, there has been no documentation found that details these activities.

Sources of Potential Contamination - The sources of potential contamination are the activities that were conducted in Building 15-06 and the manure waste and milk from the diary operations.

Originally the liquid manure tank collected wastewater from a drinking fountain drain, a service sink drain, as well as floor drains in the milking parlor, milk room, metabolism area, and the 20- x 20-ft concrete pad off the northwest side of the building (BN, Date Unknown b). The tank was used to collect excess milk and wash down effluent from the dairy operation. In 1972 the building was reconfigured. The metabolism area was moved to the east side of the building and a new drain system was added. After this, waste from the metabolism area was no longer collected in the liquid manure tank (EPA, 1977).

Previous Investigation Results - A geophysical survey was conducted at CAS 15-08-01 during March 2003 (SAIC, 2003). The results identified the underground line associated with the outflow at the southern end of the farm. The line ran north approximately $550 \mathrm{ft}$ to the liquid manure tank (EPA, 1977).

Radiological surveys performed in August 1997 in support of the CAU 95 CADD did not identify any removable-surface or fixed-surface contamination in the areas of Building 15-06 that are associated with the liquid manure tank. Radiological walk-over surveys performed at the NTS during February 18 and 19, 2003, included CAS 15-08-01. No risk to individuals from residual radiological contamination was identified (Nicosia, 2003).

\section{A.1.1.6 CAS 15-23-03, Contaminated Sump, Piping}

Physical Setting and Operational History - Corrective Action Site 15-23-03 is located approximately $875 \mathrm{ft}$ south of the Building 15-06 foundation at the EPA Farm. This CAS consists of a $25 \times 25 \times 6 \mathrm{ft}$ deep sump and subsurface piping extending approximately $60 \mathrm{ft}$ north to a distribution box. The dimensions of the distribution box are approximately $31 \times 36$ in. The sides of the sump are 
constructed of concrete angled at 45 degrees and the bottom is unlined. Currently, there are metal stakes and chicken wire covering the entire sump area.

The contaminated waste sump was not part of the original farm construction plans and was added in 1972 when the large animal metabolism facility was converted from the telemetry, data analysis, and biology rooms (DRI, 1988; Hopper, 2003). The sump was used for the accumulation of liquid waste from the laboratory (Holmes \& Narver, 1972a and b). Documentation indicates the sump was not used for radioactive waste; however, the sump area is posted with "Underground Radioactive Material" signs (Shaw, 2003; DOE/NV, 2000). In 1974, an AST (CAS 15-01-03) was added adjacent to the sump to receive radiologically contaminated waste. The distribution box, located about $60 \mathrm{ft}$ north of the sump, was added to divert the radioactive waste to the tank and nonradioactive waste to the sump.

Sources of Potential Contamination - The sump and associated piping included in CAS 15-23-03 supported the activities in Building 15-06. Engineering drawings indicate floor drains in the metabolism area, the Sample Control Room, and the Shower Room, and the slaughter areas (added in 1973), as well as service sinks in these areas were connected to the piping that terminated at the sump (Holmes \& Narver, 1972a, b, and 1974). The distribution box and tank for collection of highly contaminated liquid waste was not added until 1974 (Olsen, 1997; DOE, 1988). It is not stated what criteria determined when the waste was diverted to the tank from the sump. There is no mention of flushing the line prior to waste being diverted to the sump. There is the potential for all waste entering the drainline from Building 15-06 to contribute to contamination at this CAS.

Previous Investigation Results - A demarcation survey of the EPA Farm area was conducted on August 6, 1998 (DOE/NV, 2000b). The figure that accompanies the report indicates the EPA Farm Pond Underground Radioactive Material Area Boundary and the EPA Farm Storage Tank Contamination Area Boundary as one boundary. This boundary encompasses both the sump and the AST. The radionuclides in the soil are expected to be americium and plutonium. The DOE/NV (2000b) report states that the subsurface soils contained unknown levels of radionuclide activity, but the surface-soil removable activity was well below 10 CFR 835 guidelines. 


\section{A.1.1.7 CAS 15-01-03, Aboveground Storage Tank}

Physical Setting and Operational History - This CAS is located approximately $875 \mathrm{ft}$ south of Building 15-06. This CAS includes the 25,000-gal AST, its contents, and the fill stand located within the bermed area; approximately $875 \mathrm{ft}$ of associated piping originating from Building 15-06 and the holding pens; the distribution box ( $31 \times 36$ in.) located approximately $60 \mathrm{ft}$ from the AST; the concrete drain box located at the holding pens, and the surrounding soil. The cylindrical AST is located within a pit and is approximately $31 \mathrm{ft}$ long and $21 \mathrm{ft}$ in diameter, with an estimated capacity of 25,000 gal. A gauge on top of the AST reads approximately 24,000 gal (Shaw, 2003). If the gauge reads correctly, the tank is full. The exact contents of the AST are uncertain. A pump motor is noted on a drawing at the southern end of the AST (REECo, 1975). The piping also branches northwest from the main line to a concrete drain box located at the holding pens (REECo, 1975).

During a site visit on February 11, 2003, staining was observed on the sides of the tank near the southernmost access ports (Shaw, 2003). Tumble weeds in the pit hinder viewing the bottom of the pit for any possible staining. It is believed that the AST may have released contaminants to the surface soil at some time during the operation of the facility. The piping on the southern end of the tank, near the fill stand, is covered with what may be ACM.

Sources of Potential Contamination - The AST was used to support the disposal of contaminated wastes from the EPA Farm Building 15-06. The wastes in the tank originated from the metabolism and slaughter rooms within Building 15-06 (Holmes \& Narver, 1971c).

The wastes within the tank were periodically transferred into a tanker and disposed in the U8d dump hole (CAU 542) (ERDA, 1976; DRI, 1988). The tank may have been emptied about four or five times during the life of the farm studies. Engineering drawings indicate that the tank was equipped with a pump and motor to aid the transfer of waste from the tank to the tanker (REECo, 1975).

Previous Investigation Results, Experimental Studies, Historical Documentation - No specific investigation results were identified. 


\section{A.1.1.8 CAS 15-23-01, Underground Radioactive Material Area}

Physical Setting and Operational History - This CAS is located southeast of Building 15-06 and approximately $150 \mathrm{ft}$ south of the septic tank. The CAS consists of PSP measuring approximately 22 by $22 \mathrm{ft}$ and the surrounding and underlying soil. Corrective Action Site 15-23-01 was originally identified as a contaminated dry waste well located beneath the grain silo next to Trailer 15-12. Based on the results of interviews, a review of historical documentation, and a geophysical survey, it is believed that the well does not, nor did it ever, exist at the site (Barth, 2003; Giles, 2003). The term "well" may have been used at one time to describe a pit or a sump filled with coarse gravel.

According to interviewees, this CAS was used as a decontamination area for various pieces of farm equipment (Hopper, 1995 and 2003). Activities at the farm included the spraying of iodine-131 and tritiated water on the crop fields that were located on the east side of the farm (Hopper, 1995; Sorom, 1995). Wastes from the liquid manure tank (CAS 15-08-01) were also reported to have been spread on the fields. Pesticides and herbicides were also applied to the fields to manage the weeds and pests. The workers, and potentially the equipment used in the crop fields, would proceed to the metal grate for decontamination after leaving the fields. Decontamination was conducted at this location in order to prevent the spread of contamination from the "hot" east side of the farm, to the "cold" west side of the farm. The RSO would conduct the decontamination process, using equipment and supplies stored in the adjacent RadSafe Trailer 15-12 (Hopper, 1995 and 2003).

Sources of Potential Contamination - Decontamination activities at this site were in support of the work performed during the management of the crops planted at the farm. This may have included decontamination of personnel, tools, and equipment. These activities are considered the source of any contamination that exists in the surface and shallow subsurface soil within the CAS boundary.

Previous Investigation Results - A Site Monitoring/Site Demarcation Survey of Area 15 Site Dry Well was performed in May 1991 (Smith, 1991). The sketch on the checklist indicates an area that is consistent with the description of this CAS. The survey was conducted at four locations at the dry well, 270 degrees west, 180 degrees south, 90 degrees east, and 360 degrees north. The results for beta/gamma were $100 \mathrm{cpm}, 100 \mathrm{cpm}, 120 \mathrm{cpm}$, and $100 \mathrm{cpm}$, respectively. For alpha, the results were $0 \mathrm{cpm}$ at all locations. 
Radiological walk-over surveys performed at the NTS during February 18 and 19, 2003, included CAS 15-23-01. No radiological contamination was identified (Nicosia, 2003).

Geophysical surveys were conducted at various sites at the NTS in March 2003 (SAIC, 2003). Corrective Action Site 15-23-01 was included in the sites surveyed. Four anomalies were identified in the area. Anomaly "D" corresponds with the area for CAS 15-23-01. The anomaly coincided with the PSP that is located at the surface of the site.

Potential Contamination - Gamma-emitting radionuclides and general radionuclides associated with nuclear weapons testing fallout are COPCs. The COPCs that are common to decontamination activities include degreasers, solvents, detergents, and TPH. Based on process knowledge of typical NTS practices and EPA farm practices, additional COPCs include metals with beryllium, herbicides, pesticides, and PCBs.

\section{A.1.2 Seven-Step DQO Process}

This following section presents the seven-step DQO process employed for the development of the sampling and analysis plan for CAU 543.

\section{A.1.2.1 Step 1 - State the Problem}

This initial step of the DQO process identifies the planning team members and decision makers, describes the problem that has initiated the CAU 543 CAI, and develops the CSMs.

\section{A.1.2.2 Planning Team Members}

The DQO planning team consists of representatives from NDEP, NNSA/NSO, SNJV, and BN. The primary decision makers include NDEP and NNSA/NSO representatives. Table A.1-2 lists representatives from each organization in attendance at the February 26, 2004, DQO planning meeting.

\section{A.1.2.3 Describe the Problem}

Corrective Action Unit 543 is being investigated because the activities conducted at the Area 6 Decontamination Facility (CAS 06-07-01) and EPA Farm (CASs 15-01-03, 15-04-01, 15-05-01, 15-08-01, 15-23-01, and 15-23-03) may have released hazardous and/or radiological contaminants 
Table A.1-2

DQO Meeting Participants

\begin{tabular}{||l|l|l||}
\hline \multicolumn{1}{|c|}{ Participant } & \multicolumn{1}{|c|}{ Affiliation } & \multicolumn{1}{c|}{ Function } \\
\hline \hline Dawn Arnold & SNJV & Industrial Sites CAU Lead \\
\hline Stacey Alderson & SNJV & Radiation Services Manager \\
\hline Sabine Curtis & NNSA/NSO & Environmental Restoration Division Task Manager \\
\hline Syl Hersh & SNJV & Quality Processes Technical Staff \\
\hline Brian Hoenes & SNJV & Industrial Sites Project Manager \\
\hline Dave Madsen & BN & Environmental Restoration Task Lead \\
\hline Harry A. Perry & BN & Waste Management Lead \\
\hline Al Wickline & SNJV & Industrial Sites Task Manager \\
\hline Jeanne Wightman & SNJV & Quality Processes Representative \\
\hline Ted Zaferatos & NDEP & Oversight/Representative \\
\hline
\end{tabular}

BN - Bechtel Nevada

NDEP - Nevada Division of Environmental Protection

NNSA/NSO - U.S. Department of Energy, National Nuclear Security Administration Nevada Site Office

SNJV - Stoller-Navarro Joint Venture

into the environment at concentrations that could potentially pose a threat to human health and/or the environment during future use.

The problem statement for CAU 543 is that the existing information on the nature and extent of potential contamination is insufficient to evaluate and recommend corrective action alternatives for the CASs comprising CAU 543.

\section{A.1.2.4 Develop Conceptual Site Models}

Conceptual site models describe the most probable scenarios for current conditions at specific sites and define the assumptions that are the basis for identifying appropriate sampling strategy and data collection methods. They set the stage for assessing how contaminants could reach receptors both in the present and future by addressing contaminant release and migration pathways, transport mechanisms, potential receptors, and potential exposures to those receptors. Accurate CSMs are important as they serve as the basis for all subsequent inputs and decisions throughout the DQO process. Land-use descriptions help define exposure scenarios, which are the basis for assessing how contaminants could reach potential receptors both in the present and future. There are two future 
land-use scenarios for CAU 543. Corrective Action Site 06-07-01 is within the Defense Industrial Zone. The remaining CASs are within the Reserved Zone on the NTS (DOE/NV, 1998b). Based on land use, current and future receptors are limited to industrial and construction workers as well as personnel conducting training maneuvers. These human receptors may be exposed to COPCs through oral ingestion, inhalation, dermal contact (absorption) of soils and/or debris (e.g., equipment, concrete) due to inadvertent disturbance of these materials or irradiation by radioactive material(s).

Two CSMs have been developed for CAU 543 using assumptions formulated from the physical setting, historical background, and potential contaminant sources and release information at Area 6 and Area 15. The components in the Area 6 CAS (06-07-01) and the CASs in the Area 15 EPA Farm are integrated or interrelated as part of a larger system or process with shared sources of potential contamination for each respective area; therefore, a separate CSM has been developed for Area 6 and Area 15. To better illustrate the more complex, integrated process of the Area 15 EPA Farm, Figure A.1-4 has been developed as a Flow Diagram. The Flow Diagram walks through the common sources of contamination and related release points and pathways which help to establish the CSM. The CSMs for CAU 543 are termed:

- $\quad$ Conceptual Site Model for Area 6, Decontamination Processes

- Conceptual Site Model for Area 15, EPA Farm Processes

The following subsections discuss each CSM.

\section{A.1.2.5 Conceptual Site Model for Area 6, Decontamination Processes}

Conceptual Site Model for Area 6 applies to the components of CAS 06-07-01 that were designed to collect and discharge decontamination effluent and sanitary waste streams including septic tanks, sumps, and underground piping. Upon release from the source, the effluent traveled through discharge lines and was routed into the various septic system components and sumps. The designed and accidental release points within the collection and distribution system create potential exposure pathways. Included in this CSM, although not part of the effluent collection system, is the contaminated soils within a designated "Contamination Area." These soils were contaminated from the same equipment and materials that were decontaminated at the Area 6 Decontamination Facility. Figure A.1-5 shows a generalized representation of the Area 6 CSM. 


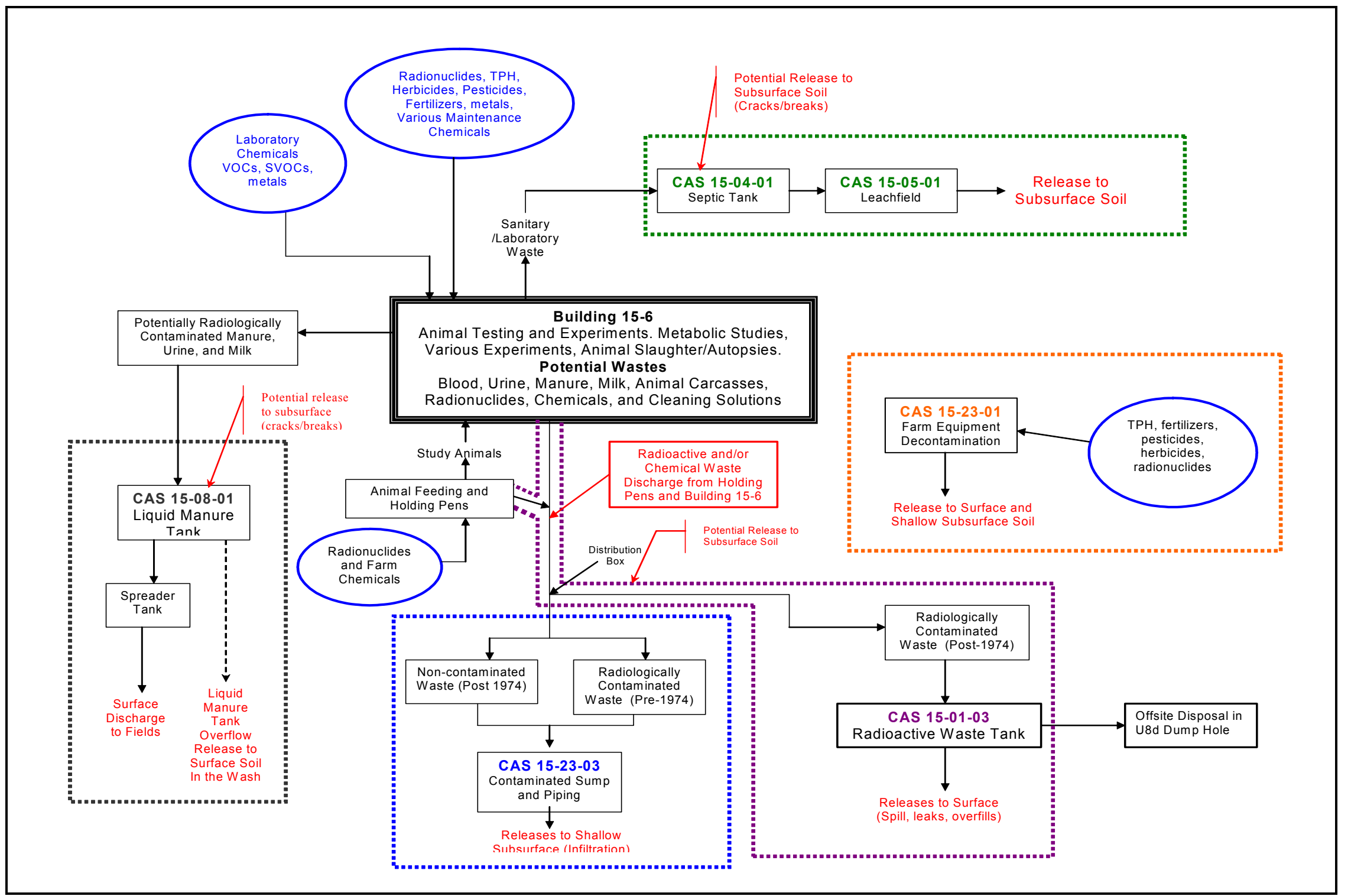

Figure A.1-4

Process Flow Diagram for the Area 15 EPA Farm 


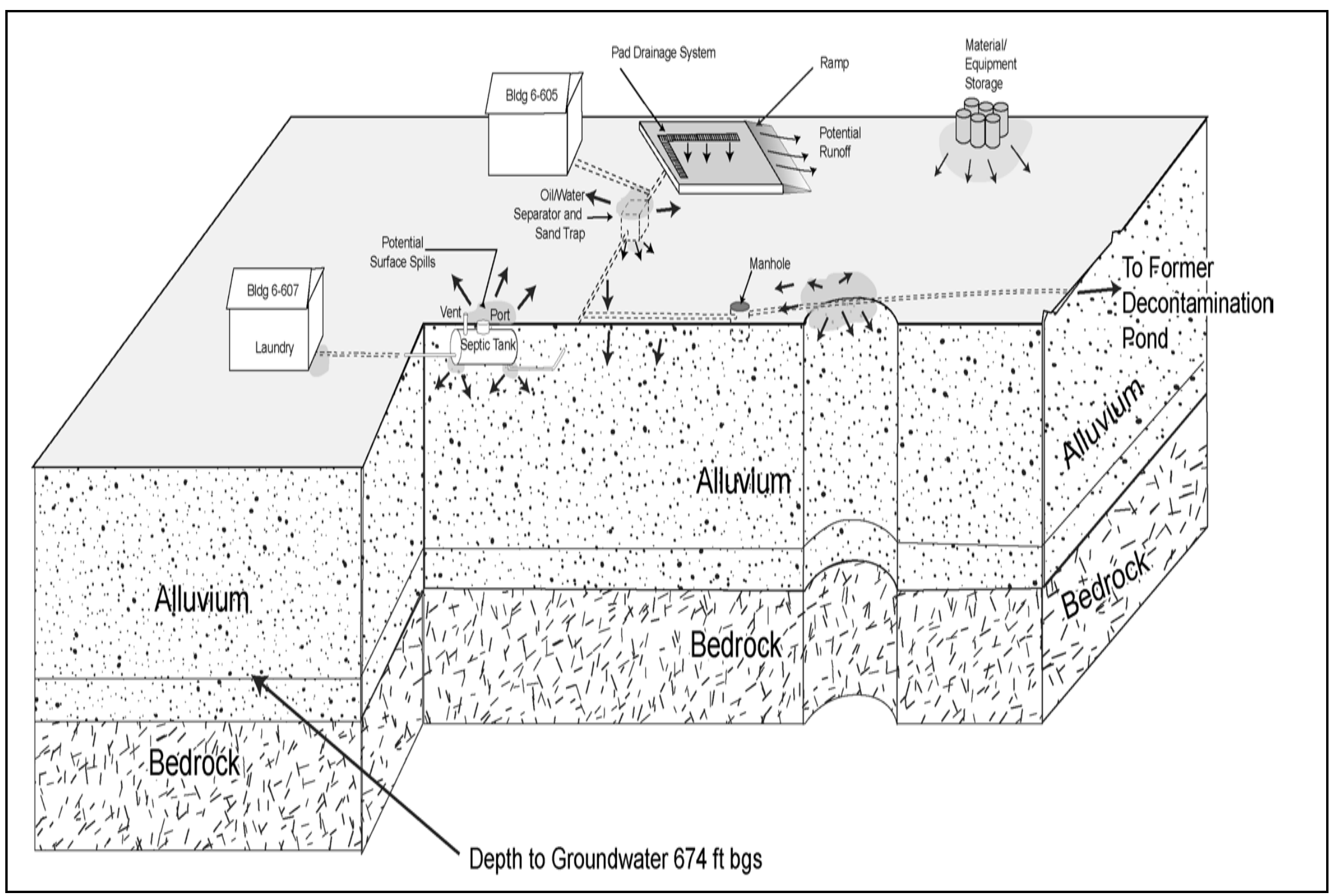

Figure A.1-5

Conceptual Site Model for Area 6 


\section{A.1.2.6 Conceptual Site Model for Area 15, EPA Farm Processes}

Conceptual Site Model for Area 15 applies to CASs and components of each CAS that were parts of an integrated system to collect and discharge waste streams from the activities associated with the EPA Farm animal testing and experiments. The primary source of contamination was generated within one building, the Laboratory Building 15-06; however, several other areas within the Farm also contributed wastes (i.e., holding pens). Upon release from the source, sanitary, hazardous, and radioactive effluent traveled through discharge lines and was routed to various distribution components that include a septic tank and leachfield, an underground storage tank, a sump, ASTs, and an outfall. There are designed and accidental release points in this model. Figure A.1-6 shows a generalized representation of the Area 15 CSM.

Affected Media - Soils beneath and surrounding the sumps, septic tanks, aboveground and underground tanks, and associated piping potentially could be affected by the release of contaminants either by design or accident (i.e, overflow). The components of the piping, tanks, concrete pads, drains, and building structures in direct contact with potential contaminants may be affected. Structures and equipment within Building 6-605 may be affected from direct contact with decontamination fluids (e.g., acids and caustics). Surface and shallow subsurface soils may be affected by contaminants from stored equipment and materials, surface run-off from exposed pads, and outfall effluent.

Location of Contamination/Release Points - Releases of contamination to the environment are most likely to have occurred beneath the outlet and inlet pipe ends and the base of the septic tanks, sumps, distribution box, tanks, along perforated piping (leachfield), or beneath any breaches in underground piping from cracks, breaks, or overflow of the components. Stored contaminated materials in the storage area may have spread contamination onto the surface soils via runoff or erosion. Surface run-off from any of the concrete pads may have contributed contamination to the surrounding soils.

Transport Mechanisms - An important element of a CSM is the expected fate and transport of contaminants, which infer how contaminants move through site media and where they can be expected in the environment (migration pathway). The expected fate and transport is based on distinguishing physical characteristics of the contaminants and media. Contaminant characteristics include solubility, density, and particle size. Media characteristics include permeability, saturation, 


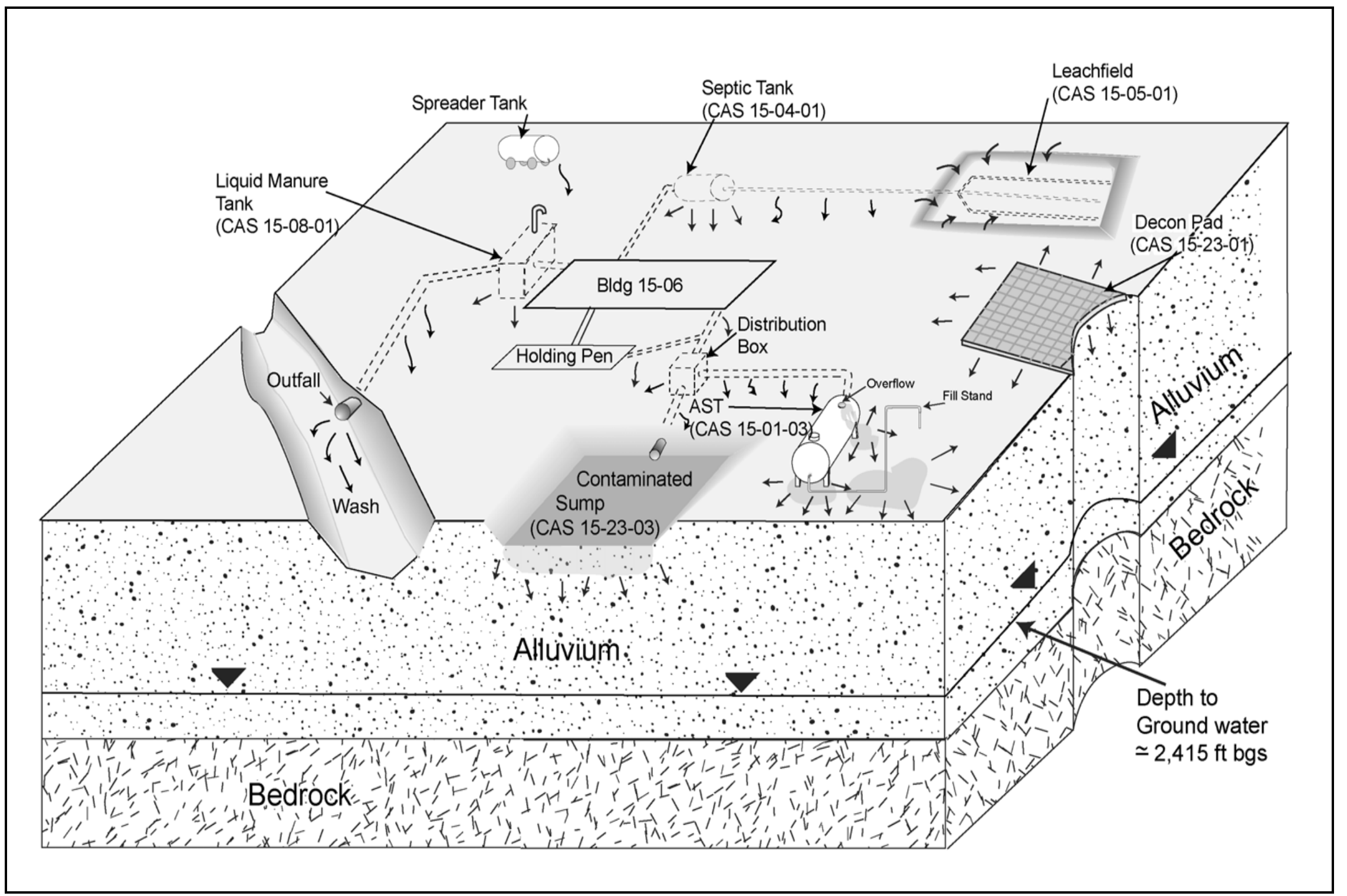

Figure A.1-6

Conceptual Site Model for Area 15, EPA Farm Processes 
sorting, chemical composition, and adsorption coefficients. In general, contaminants with low solubility and high density can be expected to be found relatively close to release points.

Contaminants with high solubility and low density can be expected to be found further from release points or in areas where settling may occur.

Migration of potential contamination is assumed to be minimal based on the affinity of the COPCs for soil particles, and the low precipitation and high evapotranspiration rates typical of the NTS environment. Contaminants may have been transported by infiltration and percolation of precipitation through soil, which would serve as the primary driving force for downward migration. Based on the release points within both Area 6 and Area 15, migration would be expected primarily downward with horizontal migration to a much lesser degree. Mixing of the surface soils as a result of grading or construction activities could also move COPCs into deeper intervals. The migration of organic constituents (e.g., pesticides and TPH) can be controlled to some extent by their affinity of organic material present in the soil. However, this mechanism is considered insignificant because of the lack of organic carbon in the desert soil. Migration of certain inorganic constituents (e.g., metals) is controlled by geochemical processes, such as adsorption, ion exchange, and precipitation of solids from solution.

Contaminants migrating to regional aquifers are not considered a likely scenario at CAU 543 based on the average depth to groundwater, the low annual average precipitation rates, the high potential for evapotranspiration, and the low mobility of expected COPCs (e.g., SVOCs, PCBs, petroleum hydrocarbons, and RCRA metals). The average depth to groundwater in Area 6 is 1,425 ft and $690 \mathrm{ft}$ at the EPA farm in Area 15 (DRI, 1993).

Airborne release subsequent to initial contamination release is not considered a significant release pathway. The main process of migration via the airborne pathway would be through windblown dust with COPCs adsorbed to the fine soil particles. This process could result in the deposition of COPCs beyond the CAS boundaries; however, it would be expected that contaminant levels decrease with distance from the point of release and distributed consistent with prevailing wind direction.

Preferential Pathways - Preferential pathways for contaminant migration at most of CAU 543 sites are expected to have only a minor impact on contaminant migration or none at all. 
Lateral and Vertical Extent of Contamination - The degree of contaminant migration, if any, at these sites is unknown, but it is assumed to be minimal and confined to the surface and shallow subsurface soils. Any contamination at these sites is expected to be contiguous with the source and decrease with distance and depth from the release point. It is believed that groundwater has not been, or would not be, impacted because of the significant depths of groundwater levels, and the high evapotranspiration rates. Because of the relatively flat terrain in these areas, horizontal migration beyond the area of initial impact is expected to be limited, and liquids would primarily infiltrate vertically into the soil at or near the point of release. Although infrequent, surface migration may have occurred as a result of storm events when precipitation rates exceeded infiltration rates (stormwater run-off). The primary lateral migration pathways would be dispersion through the shallow soil and limited migration in the down gradient direction.

\section{A.1.3 Step 2 - Identify the Decision}

The purpose of this section is to develop the decisions that require environmental data to address the presence of contamination and identify appropriate alternative actions for the investigation.

\section{A.1.3.1 Develop a Decision Statement}

Problem statement is: "There is an insufficient amount of information concerning the nature and extent of contamination released at these sites to determine if there is an unacceptable risk to human health and the environment."

The Decision I statement is: "Is a contaminant present within a CAS at a concentration that could pose an unacceptable risk to human health and the environment?"

Any contaminant detected at a concentration exceeding the corresponding PAL defined in Section A.1.4.2 will be considered a COC. A COC is defined as a site-related constituent that exceeds the PAL. The presence of a contaminant within a CAS is defined as the analytical detection of a COC. Samples used to resolve Decision 1 are identified as Decision I samples.

The Decision II statement is: "If a COC is present, is sufficient information available to determine the lateral and vertical extent of the contamination?" 
Sufficient information is defined as the data needs identified during the DQO process to include the lateral and vertical extent of all COCs within each CAS. Samples used to resolve Decision II are identified as Decision II samples.

\section{A.1.3.2 Alternative Actions to the Decision}

If a COC is not present, further assessment of the CAS is not required. If a COC is present, resolve Decision II.

If the extent of a COC is defined in both the lateral and vertical directions, further assessment of the CAS is not required. If the extent of a COC is not defined, re-evaluate site conditions and collect additional samples.

\section{A.1.4 Step 3 - Identify the Inputs to the Decision}

This step identifies the information needed, determines sources for information, determines the basis for establishing the action level, and identifies sampling and analysis methods that can meet the data requirements. To determine if a COC is present, each sample result or population parameter is compared to the PAL. If any sample result or population parameter is greater than the PAL, then the CAS is advanced to Decision II for that parameter. This approach does not use a statistical mean/average for comparison to the PAL, but rather a point-by-point comparison to the established screening criteria to identify COCs.

\section{A.1.4.1 Information Needs and Information Sources}

In order to determine if a COC is present at the CAS, sample data must be collected and analyzed following these two criteria: (1) samples must be collected in areas most likely to contain a COC and (2) the analytical suites and associated MDLs selected must be sufficient to detect any COCs present in the samples below their corresponding PALs. Biasing factors to support these criteria include:

- Documented process knowledge on source and location of release

- Field observations

- Field-screening results

- Historical sample results

- Interpretation of geophysical and/or radiological survey data

- Experience and data from investigations of similar sites

- Professional judgement 
In order to determine the extent of a COC for Decision II, sample data must be collected and analyzed at locations to bound the lateral and vertical extent of COCs. The data required to satisfy the information needed for Decision II for each COC is a sample result that is below the PAL. Step-out locations will be selected based on the CSM, biasing factors, and existing data. Analytical suites may only include those parameters that exceeded PALs (i.e., COCs) in Decision I samples. Biasing factors to support these information needs may include the factors previously listed and Decision I analytical results. Table A.1-3 lists the information needs, the source of information for each need, and the proposed methods to collect the data needed to resolve Decisions I and II. The last column addresses the QA/QC data type and associated metric. The data type is determined by the intended use of the resulting data in decision making.

Data types are discussed in the following text. All data to be collected are classified into one of three measurement quality categories: quantitative, semiquantitative, and qualitative. The categories for measurement quality are defined below.

\section{Quantitative Data}

Quantitative data results from direct measurement of a characteristic or component within the population of interest. These data require the highest level of QA/QC in collection and measurement systems because the intended use of the data is to resolve the primary decision (i.e., rejecting or accepting the null hypothesis) and/or verifying closure standards have been met. Laboratory analytical data are usually assigned as quantitative data.

\section{Semiquantitative Data}

Semiquantitative data is generated from a measurement system that indirectly measures the quantity or amount of a characteristic or component of interest. Inferences are drawn about the quantity or amount of a characteristic or component because a correlation has been shown to exist between results from the indirect measurement and the quantitative measurement. The QA/QC requirements on semiquantitative collection and measurement systems are high, but may not be as rigorous as a quantitative measurement system. Semiquantitative data contribute to decision making, but are not generally used alone to resolve primary decisions. The data are often used to guide investigations toward quantitative data collection and increase the efficiency of the sampling effort. 
Table A.1-3

Information Needs to Resolve the Decision I and Decision II Decisions

\begin{tabular}{|c|c|c|c|}
\hline $\begin{array}{l}\text { Information } \\
\text { Need }\end{array}$ & Information Source & Collection Method & Data Type/Metric \\
\hline \multicolumn{4}{|c|}{$\begin{array}{l}\text { Decision I: Determine if a COC is present. } \\
\text { Criteria I: Samples must be collected in areas most likely to contain a COC. }\end{array}$} \\
\hline \multirow[t]{6}{*}{$\begin{array}{l}\text { Source and location } \\
\text { of release points }\end{array}$} & $\begin{array}{l}\text { Process knowledge compiled } \\
\text { during the preliminary assessment } \\
\text { and previous investigations of } \\
\text { similar sites }\end{array}$ & $\begin{array}{l}\text { Information documented in CSM } \\
\text { and public reports - no } \\
\text { additional data needed }\end{array}$ & $\begin{array}{l}\text { Qualitative - CSM has not been } \\
\text { shown to be inaccurate }\end{array}$ \\
\hline & Site visit and field observations & $\begin{array}{l}\text { Conduct site visits and } \\
\text { document field observations }\end{array}$ & $\begin{array}{l}\text { Qualitative - CSM has not been } \\
\text { shown to be inaccurate }\end{array}$ \\
\hline & Aerial photographs & $\begin{array}{l}\text { Review and interpret aerial } \\
\text { photographs }\end{array}$ & $\begin{array}{l}\text { Semiquantitative - Sampling based } \\
\text { on biasing criteria stipulated in } \\
\text { DQO Step } 3\end{array}$ \\
\hline & Radiological surveys & $\begin{array}{l}\text { Review and interpret } \\
\text { radiological surveys }\end{array}$ & $\begin{array}{l}\text { Semiquantitative - Sampling based } \\
\text { on biasing criteria stipulated in } \\
\text { DQO Step } 3\end{array}$ \\
\hline & Geophysical surveys & Review and interpret surveys & $\begin{array}{l}\text { Semiquantitative - Sampling based } \\
\text { on biasing criteria stipulated in } \\
\text { DQO Step } 3\end{array}$ \\
\hline & Field screening & $\begin{array}{l}\text { Conduct field screening during } \\
\text { the initial sampling to determine } \\
\text { if contamination is present at } \\
\text { suspected locations }\end{array}$ & $\begin{array}{l}\text { Semiquantitative - Sampling based } \\
\text { on biasing criteria stipulated in } \\
\text { DQO Step } 3\end{array}$ \\
\hline \multicolumn{4}{|c|}{$\begin{array}{l}\text { Decision I: Determine if a COC is present. } \\
\text { Criteria 2: Analyses must be sufficient to detect any COCs in samples. }\end{array}$} \\
\hline $\begin{array}{l}\text { Identification of all } \\
\text { potential } \\
\text { contaminants }\end{array}$ & $\begin{array}{l}\text { Process knowledge compiled } \\
\text { during the preliminary assessment } \\
\text { and previous investigations of } \\
\text { similar sites }\end{array}$ & $\begin{array}{l}\text { Information reported in the CSM } \\
\text { and public reports - no } \\
\text { additional data needed }\end{array}$ & $\begin{array}{l}\text { Qualitative - CSM has not been } \\
\text { shown to be inaccurate }\end{array}$ \\
\hline Analytical results & Data packages of biased samples & $\begin{array}{l}\text { Appropriate sampling } \\
\text { techniques and approved } \\
\text { analytical methods will be used }\end{array}$ & $\begin{array}{l}\text { Quantitative - Detection limits will } \\
\text { be less than or equal to PALs }\end{array}$ \\
\hline \multicolumn{4}{|c|}{ Decision II: Determine the lateral and vertical extent of a COC. } \\
\hline $\begin{array}{l}\text { Identification of } \\
\text { applicable COCs }\end{array}$ & $\begin{array}{l}\text { Data packages of Decision I or } \\
\text { other prior samples }\end{array}$ & $\begin{array}{l}\text { Review Decision I analytical } \\
\text { results and compare to } \\
\text { respective PALs to identify } \\
\text { COCs }\end{array}$ & $\begin{array}{l}\text { Quantitative - Only COCs } \\
\text { identified will be analyzed in future } \\
\text { sampling events }\end{array}$ \\
\hline \multirow[t]{3}{*}{$\begin{array}{l}\text { Extent of } \\
\text { Contamination }\end{array}$} & Field observations & Document field observations & $\begin{array}{l}\text { Qualitative - CSM has not been } \\
\text { shown to be inaccurate }\end{array}$ \\
\hline & Field screening & $\begin{array}{l}\text { Conduct field screening with } \\
\text { appropriate instrumentation }\end{array}$ & $\begin{array}{l}\text { Semiquantitative - FSRs will be } \\
\text { compared to FSLs }\end{array}$ \\
\hline & Decision II analytical results & $\begin{array}{l}\text { Appropriate sampling } \\
\text { techniques and approved } \\
\text { analytical methods will be used } \\
\text { to bound COCs }\end{array}$ & $\begin{array}{l}\text { Quantitative - Validated analytical } \\
\text { results will be compared to PALs to } \\
\text { determine COC extent }\end{array}$ \\
\hline
\end{tabular}




\section{Qualitative Data}

Qualitative data identifies or describes the characteristics or components of the population of interest. The QA/QC requirements for qualitative data are the least rigorous on data collection methods and measurement systems. Professional judgement is often used to generate qualitative data. The intended use of the data is for information purposes, to refine conceptual models, and to guide investigations rather than resolve primary decisions. This measurement of quality is typically associated with historical information and data where QA/QC may be highly variable or not known. Metrics provide a tool to determine if the collected data support decision making as intended. Metrics tend to be numerical for quantitative and semiquantitative data, and descriptive for qualitative data.

\section{A.1.4.2 Determine the Basis for the Preliminary Action Levels}

Industrial site workers, construction/remediation workers, and training (i.e., military) personnel may be exposed to contaminants through oral ingestion, inhalation, external (radiological), or dermal contact (absorption) of soil. Laboratory analytical results for soils will be compared to the following PALs to evaluate if COPCs are present:

- EPA Region IX Risk-Based Preliminary Remediation Goals for Industrial Soils (EPA, 2002b).

- For detected chemical COPCs without established PRGs that are listed in the EPA IRIS database (EPA, 2002c), the protocol used by the EPA Region 9 in establishing PRGs (or similar) will be used in establishing the PALs.

- Background concentrations for metals are considered when natural background exceeds the PRG, as is often the case with arsenic. Background is considered the mean plus two times the standard deviation of the mean for sediment samples collected by the Nevada Bureau of Mines and Geology throughout the Nevada Test and Training Range (formerly the Nellis Air Force Range) (NBMG, 1998; Moore, 1999).

- TPH action level of $100 \mathrm{mg} / \mathrm{kg}$ per the NAC 445A.2272 (NAC, 2002).

- The PALs for radionuclides, except those covered by DOE Order 5400.5 (DOE, 1993), were taken from the construction, commercial, industrial land-use scenario in Table 2.1 of the NCRP Report No. 129, Recommended Screening Limits for Contaminated Surface Soil and Review Factors Relevant to Site-Specific Studies (NCRP, 1999). The values provided in this source document are based on a $25 \mathrm{mrem} / \mathrm{yr}$ dose but have been scaled to a $15 \mathrm{mrem} / \mathrm{yr}$ dose for the purpose of this investigation.

- The PALs for Ra-226, Ra-228, Th-230, and Th-232 and their progeny in secular equilibrium 
are the generic guidelines for residual counteractions as found in Chapter IV of DOE Order 5400.5 Change 2, Radiation Protection of the Public and Environment (DOE, 1993).

- For radiologically contaminated materials and structures, the total residual surface contamination for unrestricted release of materials and equipment to the general public allowed by DOE Order 5400.5 (DOE, 1993) and as defined in the NV/YMP RadCon Manual (DOE/NV, 2000c).

The selected PALs are based on the EPA Region 9 Industrial Land Use PRGs. The PRGs are risk-based tools for evaluating and cleaning up contaminated sites that estimate contaminant concentrations in environmental media (i.e., soil, air, and water) that EPA considers protective of humans (including sensitive groups) over a lifetime. The toxicity based PALs have been calculated for an Industrial Use scenario. The Industrial Use scenario is applicable to sites at the NTS based on future land-use scenarios as presented in Section A.1.2.3 and agreements between NDEP and NNSA/NSO.

The conservative level of $100 \mathrm{ppm}$ for TPH is based on a regulatory mandate from the State of Nevada and is used as a "clean-up" level.

Radiochemistry PALs are based on a scaling of the NCRP 25 mrem/yr dose-based levels (NCRP, 1999) to a conservative $15 \mathrm{mrem} / \mathrm{yr}$ and the recommended levels for certain radionuclides in DOE Order 5400.5 Change 2 (DOE, 1993). These PALs are based on the Construction, Commercial, Industrial land-use scenario provided in the guidance and are appropriate for the NTS based on future land-use scenarios as presented in Section A.1.2.3. These established PALs have been accepted by the regulatory agency for use.

\section{A.1.4.3 Potential Sampling Techniques and Appropriate Analytical Methods}

As discussed in Section A.1.4.1, the collection, measurement, and analytical methods will be selected so results will be generated for all of the suspected contaminants as well as all other possible contaminants. This effort will include field screening, soil sampling, and laboratory analysis to determine the presence of COPCs and extent of identified COCs.

Waste characterization sampling and analysis has been included to support the decision-making process for waste management, and to ensure an efficient field program. Specific analyses required for the disposal of IDW are identified in Section 5.0. 


\section{A.1.4.3.1 Field Screening}

Field-screening activities may be conducted for the following analytes and/or parameters:

- Alpha and Beta/Gamma Radiation - Handheld radiological survey equipment may be used based on process knowledge, previous radiological surveys, and analytical results that detect radiological activity. The radiological (alpha and beta/gamma) FSL of the mean background activity plus two times the standard deviation of the mean background activity collected from undisturbed locations within the vicinity of the site (Adams, 1998).

- Gamma Radiation - Gamma spectroscopy, or an equivalent instrument or method, may be used based on process knowledge, previous radiological surveys, and previous analytical results indicate the potential for gamma-emitting radionuclides to be present.

- VOCs - A photoionization detector, or an equivalent instrument or method, may be used to conduct headspace analysis because VOCs are commonly used in degreasers and based on process knowledge decontamination/degreasing activities were potentially conducted at many of the CASs. The VOC FSL is established as 20 ppm or 2.5 times background, whichever is greater.

- $T P H$ - A gas chromatograph, or an equivalent instrument or method, may be used because TPH may be present as a result of decontaminating drilling and farm equipment. The TPH FSL is established as $75 \mathrm{ppm}$.

- Phosphates - A phosphate detection kit, or an equivalent instrument or method, may be used because phosphates are commonly used in detergents and fertilizers and based on process knowledge, decontamination/degreasing activities were potentially conducted at some of the CASs as well as fertilizers used on crops used in animal studies.

Based on the results of previous CAU investigations and common NTS practices, the aforementioned field-screening techniques may be applied during the Decision I and Decision II sampling activities. These field-screening techniques will provide semiquantitative data that can be used to guide soil sampling activities.

\section{A.1.4.3.2 Soil Sampling}

Auguring, direct-push, excavation, drilling, or other appropriate sampling methods will be used to collect soil samples for laboratory analysis. Sample collection and handling activities will be conducted in accordance with the approved procedures. 


\section{A.1.4.3.3 Radiological Walk-Overs and Scanning/Swipe Sampling}

A radiological survey will be conducted for alpha, and beta/gamma-emitting radionuclides at CAS 06-07-01 on the surface soil within the fenced perimeter of the Area 6 Decontamination Facility. The radiological survey will identify locations potentially contaminated with radionuclides that may require sampling.

Radiological scanning and swipe sampling may be conducted on drain pipes, tanks, etc. for purposes of waste management and future release status. A handheld detector such as an NE Technologies Electra or equivalent instrument, will be used to scan the item of interest. If contamination is indicated, swipe samples will be collected and counted.

\section{A.1.4.3.4 Video Survey}

Video surveys will be conducted using a commercial camera system to locate and inspect septic system piping. The video survey will allow a visual assessment of the integrity of the septic system and piping by identifying obvious breaches, unexpected branchings (i.e., tie-ins or off-shoots), open joints, and the presence of material. The septic system piping can be inspected and physically verified to the extent practicable by tracking the camera head inside the piping network. The video survey will not be possible on piping with inside diameters less than $3 \mathrm{in}$. and may not be possible if there is limited access, pipe damage, blockage, or other factors. Material found in the piping that is representative of the former operations conducted at the CAS will be sampled.

\section{A.1.4.3.5 Concrete Sampling}

Samples of concrete will be collected from the concrete decontamination pads located inside and outside of Building 6-605 at CAS 06-07-01. Additional concrete samples may be collected from other pads and/or sumps if biasing factors suggest the need. Samples will be collected from areas of suspected or known contamination identified by the radiological survey and from processes knowledge and field observations (e.g., staining). 


\section{A.1.4.3.6 Analytical Program}

The analytical program for CAU 543 shown in Table A.1-4 was developed based on the suspected-contaminant information presented in Section A.1.1. The critical and noncritical COPCs identified for CAU 543 vary with each CAS and/or component and are listed in Table A.1-1.

The critical COPCs are given greater importance in the decision-making process relative to other COPCs. For this reason, more stringent performance criteria are specified for critical analyte data quality indicators (Section 6.0). Noncritical COPCs are defined as classes of contaminants that include all the analytes reported from the respective analytical methods that have PALs; those analytes are listed in Table A.1-5 for the various analytical methods proposed for this CAI. The noncritical COPCs also aid in reducing the uncertainty concerning the history and potential releases from the CASs and help in the accurate evaluation of potential contamination. If a COPC, either critical or noncritical, is detected in any sample at a concentration above the respective PAL, the COPC will be identified as a COC. During Decision II sampling and analysis, all COCs are considered critical parameters. Section 3.0 and Section 6.0 of the CAIP provide the analytical methods and laboratory performance requirements (e.g., detection limits, precision, and accuracy) to be followed during this CAI. Sample volumes are laboratory- and method-specific and will be determined in accordance with laboratory requirements. Specific analyses required for the disposal of IDW are identified in Section 5.0 of this CAIP. Analytical requirements (e.g., methods, detection limits, precision, and accuracy) are specified in the Industrial Sites QAPP (NNSA/NV, 2002), unless superseded by the CAIP. These requirements will ensure that laboratory analyses are sufficient to detect contamination in samples at concentrations exceeding the MRL. Specific analyses, if any, required for the disposal of IDW are identified in Section 5.0 of the CAIP.

For sampling performed to define the extent of contamination (Decision II), samples will be collected and analyzed only for those COCs identified in samples collected to resolve Decision I. However, if samples are collected to define the extent of contamination prior to nature of contamination data becoming available, the extent samples will be analyzed for the full list parameters given for that CAS. For samples collected to define the extent of contamination, critical analytes are the COCs identified during the Decision I activities that exceed PALs. 


\section{Table A.1-4 \\ Analytical Methods for CAU 543 \\ (Includes Environmental and Waste Characterization Analyses)}

\begin{tabular}{|c|c|c|}
\hline \multirow{2}{*}{ Analytical Parameter ${ }^{a}$} & \multicolumn{2}{|c|}{ Analytical Method } \\
\hline & Liquid & Solid/Sludge \\
\hline Total Volatile Organic Compounds & SW-846 8260B ${ }^{\mathrm{C}}$ & SW-846 $8260 \mathrm{~B}^{\mathrm{C}}$ \\
\hline TCLP Volatile Organic Compounds & SW-846 8260B & SW-846 8260B \\
\hline Total Semivolatile Organic Compounds & SW-846 $8270 C^{c}$ & SW-846 $8270 C^{c}$ \\
\hline TCLP Semivolatile Organic Compounds & SW-846 8270C & SW-846 8270C \\
\hline Total Metals & $\begin{array}{l}\text { SW-846 6010B } \\
(\text { mercury - 7470A }\end{array}$ & $\begin{array}{l}\text { SW-846 6010B } \\
\left(\text { mercury - 7471 } A^{c}\right)\end{array}$ \\
\hline TCLP Metals & SW-846 6010B/7470A & SW-846 6010B/7471A \\
\hline Polychlorinated Biphenyls & SW-846 $8082^{\mathrm{C}}$ & SW-846 $8082^{C}$ \\
\hline Total Petroleum Hydrocarbons $\left(\mathrm{C}_{6}-\mathrm{C}_{38}\right)$ & SW-846 8015B ${ }^{\mathrm{C}}$ (modified) & SW-846 8015B ${ }^{\mathrm{C}}$ (modified) \\
\hline Total Pesticides & SW $8468081^{\mathrm{C}}$ & SW $8468081^{c}$ \\
\hline Total Herbicides & SW $8468151 A^{c}$ & SW $8468151 A^{c}$ \\
\hline $\begin{array}{l}\text { Gamma Spectroscopy (to include Cesium-137, Cobalt-60, } \\
\text { and Americium-241 }{ }^{b} \text { ) }\end{array}$ & EPA Procedure $901.1^{\mathrm{d}}$ & HASL- $300^{\mathrm{e}}$ \\
\hline Strontium-90 & ASTM D5811-00 & HASL- $300^{\mathrm{e}}$ \\
\hline Isotopic Uranium & ASTM D3972-02 ${ }^{g}$ & ASTM E1000-02 \\
\hline Isotopic Plutonium & ASTM D3865-02 & ASTM C1001-00 \\
\hline
\end{tabular}

${ }^{a}$ If the volume of material is limited, prioritization of the analyses will be necessary.

${ }^{b}$ If americium-241 is detected above the minimum detectable activity, isotopic americium-241 analysis may also be performed on sample.

${ }^{\mathrm{c}}$ EPA Test Methods for Evaluating Solid Waste, Physical/Chemical Methods, 3rd Edition, Parts 1-4, SW-846 (EPA, 1996)

${ }^{\mathrm{d}}$ Prescribed Procedure for Measurements of Radioactivity in Drinking Water (EPA, 1980)

${ }^{\mathrm{e}}$ The Procedures Manual of the Environmental Measurements Laboratory, HASL-300 (DOE, 1997)

${ }^{f}$ Standard Test Method for Strontium-90 in Water (ASTM, 2000a)

${ }^{9}$ Standard Test Method for Isotopic Uranium in Water by Radiochemistry (ASTM, 2002b)

${ }^{\mathrm{h}}$ Standard Test Method for Radiochemical Determination of Uranium Isotopes in Soil by Alpha Spectroscopy (ASTM, 2002c)

'Standard Test Method for Plutonium in Water (ASTM, 2002a)

${ }^{j}$ Standard Test Method for Radiochemical Determination of Plutonium in Soil by Alpha Spectroscopy (ASTM, 2000b)

ASTM $=$ American Society of Testing and Materials

SW $=$ Solid Waste

TCLP = Toxicity Characteristic Leaching Procedure 
Table A.1-5

Laboratory Target Analytes for Nature of Contamination (Decision I) Sampling

\begin{tabular}{|c|c|c|c|c|c|}
\hline VOC & SVOC & TPH & РCB & Metals & Radionuclides \\
\hline $\begin{array}{l}\text { 1,1,1-Trichloroethane } \\
\text { 1,1,1,2-Tetrachloroethane } \\
\text { 1,1,2,2-Tetrachloroethane } \\
\text { 1,1,2-Trichloroethane } \\
\text { 1,1-Dichloroethane } \\
\text { 1,1-Dichloroethene } \\
\text { cis-1,2-Dichloroethene } \\
\text { trans-1,2-Dichloroethene } \\
\text { 1,2-Dichloroethane } \\
\text { 1,2-Dichloropropane } \\
\text { 1,2,3-Trichloropropane } \\
\text { 1,2,4-Trimethylbenzene } \\
\text { 1,2-Dibromo-3-chloropropane } \\
\text { 1,2-Dibromoethane } \\
\text { 1,3,5-Trimethylbenzene } \\
\text { cis-1,3-Dichloropropene } \\
\text { trans-1,3-Dichloropropene } \\
\text { 2-Butanone } \\
\text { 2-Chlorotoluene } \\
\text { 4-Methyl-2-pentanone } \\
\text { Acetone } \\
\text { Benzene } \\
\text { Bromobenzene } \\
\text { Bromochloromethane } \\
\text { Bromodichloromethane } \\
\text { Bromoform } \\
\text { Bromomethane } \\
\text { Carbon disulfide } \\
\text { Carbon tetrachloride } \\
\text { Chlorobenzene } \\
\text { Chloroethane } \\
\text { Chloroform } \\
\text { Chloromethane } \\
\text { Dibromochloromethane } \\
\text { Dibromomethane } \\
\text { Dichlorodifluoromethane } \\
\text { Ethylbenzene } \\
\text { Isopropylbenzene } \\
\text { lodomethane } \\
\text { Methyl tertiary butyl ether } \\
\text { Methylene chloride } \\
\text { N-Butylbenzene } \\
\text { N-Propylbenzene } \\
\text { sec-Butylbenzene } \\
\text { Styrene } \\
\text { tert-Butylbenzene } \\
\text { Tetrachloroethene } \\
\text { Toluene } \\
\text { Trichloroethene } \\
\text { Trichlorofluoromethane } \\
\text { Trichlorotrifluoroethane } \\
\text { Vinyl acetate } \\
\text { Vinyl chloride } \\
\text { Xylene }\end{array}$ & $\begin{array}{l}\text { 1,2,4-Trichlorobenzene }{ }^{a} \\
\text { 1,2-Dichlorobenzene } \\
\text { 1,3-Dichlorobenzene } \\
\text { 1,4-Dichlorobenzene } \\
\text { 2,4,5-Trichlorophenol } \\
\text { 2,4,6-Trichlorophenol } \\
\text { 2,4-Dichlorophenol } \\
\text { 2,4-Dimethylphenol } \\
\text { 2,4-Dinitrophenol } \\
\text { 2,4-Dinitrotoluene } \\
\text { 2,6-Dinitrotoluene } \\
\text { 2-Chloronaphthalene } \\
\text { 2-Chlorophenol } \\
\text { 2-Methylphenol } \\
\text { 2-Nitroaniline } \\
\text { 3,3'-Dichlorobenzidine } \\
\text { 4-Bromophenyl phenyl ether } \\
\text { 4-Chloroaniline } \\
\text { 4-Methylphenol } \\
\text { 4-Nitrophenol } \\
\text { Acenaphthene } \\
\text { Acenaphthylene } \\
\text { Aniline } \\
\text { Anthracene } \\
\text { Benzo(a)anthracene } \\
\text { Benzo(a)pyrene } \\
\text { Benzo(b)fluoranthene } \\
\text { Benzo(g,h,i)perylene } \\
\text { Benzo(k)fluoranthene } \\
\text { Benzoic Acid } \\
\text { Benzyl Alcohol } \\
\text { Bis(2-chloroethoxy) methane } \\
\text { Bis(2-chloroethyl)ether } \\
\text { Bis(2-chloroisopropyl)ether } \\
\text { Bis(2-ethylhexyl) phthalate } \\
\text { Butyl benzyl phthalate } \\
\text { Carbazole } \\
\text { Chrysene } \\
\text { Dibenzo(a,h)anthracene } \\
\text { Dibenzofuran } \\
\text { Diethyl Phthalate } \\
\text { Dimethyl Phthalate } \\
\text { Di-n-butyl Phthalate } \\
\text { Di-n-octyl Phthalate } \\
\text { Fluoranthene } \\
\text { Fluorene } \\
\text { Hexachlorobenzene } \\
\text { Hexachlorobutadiene } \\
\text { Hexachlorocyclopentadiene } \\
\text { Hexachloroethane } \\
\text { Indeno(1,2,3-cd)pyrene } \\
\text { Isophorone } \\
\text { Naphthalene } \\
\text { Nitrobenzene } \\
\text { N-Nitroso-di-n-propylamine } \\
\text { N-Nitrosodimethylamine } \\
\text { N-Nitrosodiphenylamine } \\
\text { Pentachlorophenol } \\
\text { Phenanthrene } \\
\text { Phenol } \\
\text { Pyrene } \\
\text { Pyridine }\end{array}$ & $\begin{array}{l}\text { Total Petroleum } \\
\text { Hydrocarbons } \\
\left(C^{6}-C^{38}\right) \\
\text { DRO, GRO }\end{array}$ & $\begin{array}{l}\text { Aroclor-1016 } \\
\text { Aroclor-1221 } \\
\text { Aroclor-1232 } \\
\text { Aroclor-1242 } \\
\text { Aroclor-1248 } \\
\text { Aroclor-1254 } \\
\text { Aroclor-1260 }\end{array}$ & $\begin{array}{l}\text { Arsenic } \\
\text { Barium } \\
\text { Beryllium } \\
\text { Cadmium } \\
\text { Chromium } \\
\text { Lead } \\
\text { Mercury } \\
\text { Selenium } \\
\text { Silver }\end{array}$ & $\begin{array}{l}\text { Americium-241 } \\
\text { Cesium-137 } \\
\text { Cobalt-60 } \\
\text { Eu-152 } \\
\text { Nb-94 } \\
\text { Radium } \\
\text { Thorium } \\
\text { Plutonium-238 } \\
\text { Plutonium-239/240 } \\
\text { Strontium-90 } \\
\text { Uranium-234 } \\
\text { Uranium-235 } \\
\text { Uranium-238 } \\
\text { Other parameters: } \\
\text { Gamma-emitting } \\
\text { radionuclides }\end{array}$ \\
\hline
\end{tabular}

${ }^{\mathrm{a}}$ May be reported with VOCs 


\section{A.1.5 Step 4 - Define the Boundaries of the Study}

The purpose of this step is to define the target population of interest, specify the spatial and temporal features of the population that are pertinent for decision making, determine practical constraints on data collection, and define the scale of decision making relevant to target populations for Decision I and Decision II decisions.

\section{A.1.5.1 Define the Target Population}

Decision I target populations represent locations within the CAS that contain COCs, if present. Decision II target populations are locations adjacent to the $\mathrm{COC}$ plume where $\mathrm{COC}$ concentrations are less than PALs.

\section{A.1.5.2 Identify the Spatial and Temporal Boundaries}

The spatial boundaries for each CAS are defined as the vertical or horizontal boundaries beyond which the CSM and/or the scope of the investigation will require reevaluation.

The spatial boundaries that apply to Decision I (determine the presence of a COC) are the sample locations selected to satisfy the criteria for Decision I samples. In general, geographic boundaries are defined by the area impacted from releases attributed to each CAS. Intrusive activities are not intended to extend into the boundaries of neighboring areas of environmental concern (e.g., other CASs). The spatial boundaries for the components each CAS are listed in Table A.1-6.

Temporal boundaries are those time constraints set up by weather conditions and project schedules. Significant temporal constraints due to weather conditions are not expected. Moist weather may place constraints on sampling and field screening contaminated soils because of the attenuating effect of moisture in samples (e.g., alpha-emitting radionuclides). There are no time constraints on collected samples as environmental conditions at all sites will not significantly change in the near future and conditions would have stabilized over the years since the sites were last used.

\section{A.1.5.3 Identify Practical Constraints}

Practical constraints include underground and overhead utilities, rough terrain, access restrictions such as scheduling conflicts at the NTS, posted contamination area requirements, physical barriers 
Table A.1-6

\section{CAU 543 Spatial Boundaries}

\begin{tabular}{|c|c|c|}
\hline \multirow{2}{*}{ CAS/Component } & \multicolumn{2}{|l|}{ Spatial Boundary } \\
\hline & Horizontal & Vertical \\
\hline Area 6 Decontamination Facility & $\begin{array}{l}\text { 50-ft buffer around perimeter fence for general CAS; } \\
\text { The TPH Use Restriction on northwest corner of Building 6-605 will not be entered. }\end{array}$ & A maximum of $20 \mathrm{ft}$ bgs \\
\hline Septic and Process waste line piping at all CASs & $20 \mathrm{ft}$ laterally from piping & A maximum of $20 \mathrm{ft} \mathrm{bgs}$ \\
\hline Septic Tanks and Sumps at Area 6 & $20 \mathrm{ft}$ laterally from edges of tank features and all junctions & A maximum of $20 \mathrm{ft} \mathrm{bgs}$ \\
\hline Aboveground Storage Tank & $\begin{array}{l}\text { Includes a } 20 \text {-ft lateral buffer from sides of the AST berm; length of piping to holding pen } \\
\text { and Building } 15-06 \text {; drain box at holding pen; distribution box; } 20 \text {-ft lateral boundary from } \\
\text { all these components }\end{array}$ & A maximum of $20 \mathrm{ft}$ bgs \\
\hline Liquid Manure Tank & $\begin{array}{l}20-\mathrm{ft} \text { lateral buffer around edges of tank; } 20-\mathrm{ft} \text { lateral buffer around concrete pad; } 20-\mathrm{ft} \\
\text { lateral from any piping }\end{array}$ & A maximum of $20 \mathrm{ft} \mathrm{bgs}$ \\
\hline Contaminated Sump & $20-\mathrm{ft}$ lateral buffer around edges of the sump & A maximum of $30 \mathrm{ft}$ bgs \\
\hline Clean-Out Boxes; Drain Boxes; Collection Boxes & 15 -ft lateral buffer from the sides of features & A maximum of $20 \mathrm{ft} \mathrm{bgs}$ \\
\hline Leachfields & 50-ft lateral buffer from leach lines & $\begin{array}{l}\text { A maximum of } 30 \mathrm{ft} \text { bgs from } \\
\text { base of piping }\end{array}$ \\
\hline Contaminated Surface Soil Areas & 50-ft lateral buffer from designated boundaries (e.g., fence, rope, posted area) & A maximum of $20 \mathrm{ft} \mathrm{bgs}$ \\
\hline
\end{tabular}


(e.g., fences, steep slopes), and areas requiring authorized access. Underground utilities surveys will be conducted at each CAS prior to the start of investigation activities to determine if utilities exist, and, if so, determine the limit of spatial boundaries for intrusive activities. No other practical constraints have been identified.

\section{A.1.5.4 Define the Scale of Decision Making}

The scale of decision making in Decision I is defined as each CAS. The scale of decision making for Decision II is defined as a contiguous area contaminated with any COC originating from the CAS.

\section{A.1.6 Step 5 - Develop a Decision Rule}

This step integrates outputs from the previous step with the inputs developed in this step into a decision rule ("If..., then...") statement. This rule describes the conditions under which possible alternative actions would be chosen.

\section{A.1.6.1 Specify the Population Parameter}

The population parameter for Decision I data collected from biased sample locations is the maximum observed concentration of each COC within the target population.

The population parameter for Decision II will be the observed concentration of each unbounded COC in any sample.

\section{A.1.6.2 Choose an Action Level}

Action levels are defined as the PALs and discussed in Section A.1.4.2. As appropriate, action levels may also be the unrestricted release criteria given in the NV/YMP RadCon Manual (DOE/NV, 2000c).

\section{A.1.6.3 Decision Rule}

If the concentration of any COPC in a target population exceeds the PAL for the COPC in a Decision I sample, then that COPC is identified as a COC and sampling to define the extent of contamination (Decision II) will be conducted. If the Site Supervisor determines that an indicator 
(e.g., staining) is present, then Decision II sampling may be conducted. If all COPC concentrations are less than the corresponding PALs, then the decision will be no further action.

Sample analyses conducted during this investigation will be sufficient to characterize the contents, if any, of a septic tank for clean closure according to the NAC.

If the observed population parameter of any COC in a Decision II sample exceeds the PALs, then additional samples will be collected. If all observed COC population parameters are less than PALs, then the decision will be that the extent of contamination has been defined in the lateral and/or vertical direction(s).

If contamination is inconsistent with the CSM or extends beyond the spatial boundaries, then work will be suspended and the investigation strategy reevaluated. If contamination is consistent with the CSM and is within spatial boundaries, then the decision will be made to continue sampling to define the extent.

\section{A.1.7 Step 6 - Specify the Tolerable Limits on Decision Errors}

The approach for Decision I and II sampling for all CASs, with the exception of CAS 15-23-01 and the Contamination Area component of CAS 06-07-01, relies on biased sampling locations. Only validated analytical results (quantitative data) will be used to determine if COCs are present (Decision I) or the extent of a COC (Decision II), unless otherwise stated. The baseline condition (i.e., null hypothesis) and alternative condition for Decision I are:

- Baseline condition - A COC is present

- Alternative condition - A COC is not present

The baseline condition (i.e., null hypothesis) and alternative condition for Decision II are:

- Baseline condition - The extent of a COC has not been defined

- Alternative condition - The extent of a COC has been defined

Decisions and/or criteria have an alpha (false rejection) or beta (false acceptance) error associated with their determination (discussed in the following subsections). Since quantitative data are individually compared to action levels, statistical evaluations of the data such as averages or confidence intervals are not appropriate. 
Statistical analysis is will be used in addition to bias sampling to determine the number Decision I sample locations at CAS 15-23-01 and the storage yard at CAS 06-07-01. Inputting parameters into standard statistical equations for calculating the required number of sample locations at these CASs resulted in 9 sample locations at CAS 15-23-01 and 16 sample locations at CAS 06-07-01.

\section{A.1.7.1 False Rejection Decision Error}

The false rejection (alpha) decision error would mean:

- Deciding that a COC is not present when it actually is (Decision I)

- Deciding that the extent of a COC has been defined when it has not (Decision II)

In both cases, the consequence is the increased risk to human health and the environment.

In Decision I, a false rejection decision error (where consequences are more severe) is controlled by meeting these criteria: (1) having a high degree of confidence that the sample locations selected will identify COCs if present anywhere within the CAS, and (2) having a high degree of confidence that analyses conducted will be sufficient to detect any COCs present in the samples. For Decision II, this error is reduced by: (1) having a high degree of confidence that the sample locations selected will identify the extent of COCs; (2) having a high degree of confidence that analyses conducted will be sufficient to detect any COCs present in the samples; and (3) having a high degree of confidence that the dataset is of sufficient quality and completeness.

To satisfy the first criterion, Decision I data and samples will be collected in areas most likely to be contaminated by any COCs. In Decision II, data collection will sample areas that represent the lateral and vertical extent of contamination. The following characteristics are considered during both Decisions to accomplish the first criterion:

- Source and location of release

- Chemical nature and fate properties

- Physical properties and migration pathways

- Hydrologic drivers

These characteristics were considered during the development of the CSMs and selection of sampling locations. The biasing factors listed in Section A.1.6.1 will be used to further ensure that these criteria are met. 
To satisfy the second criterion, all Decision I samples will be analyzed for the chemical and radiological parameters listed in Table A.1-4. Decision II samples will be analyzed for those chemical and radiological parameters that identified unbounded COCs.

To satisfy the third criterion, the entire dataset, as well as individual sample results, will be assessed against the DQIs of precision, accuracy, comparability, completeness, and representativeness defined in the Industrial Sites QAPP (NNSA/NV, 2002). The goal for the DQI of completeness is that 90 percent of the critical COPC results are valid for every sample. Critical COPCs are defined as those contaminants that are known or expected to be present within a CAS. Critical parameters/analytes identified as COPCs are discussed in Section A.1.1. In addition, sensitivity has been included as a DQI for laboratory analyses. Site-specific DQIs are discussed in more detail in Section 6.0 of the CAIP. Strict adherence to established procedures and QA/QC protocol also protects against false negatives.

\section{A.1.7.2 False Positive Decision Error}

The false positive (acceptance of the null or beta) decision error would mean one of the following:

- Deciding that a COC is present when it is not (Decision I)

- Accepting that the extent of a COC has not been defined when it really has (Decision II)

These errors result in increased costs for unnecessary characterization or corrective actions.

The false positive decision error is controlled by protecting against false positive analytical results. False positive results are typically attributed to laboratory and/or sampling/handling errors. Quality control samples such as field blanks, trip blanks, laboratory control samples, and method blanks minimize the risk of a false positive analytical result. Other measures include proper decontamination of sampling equipment and using certified clean sample containers to avoid crosscontamination.

\section{A.1.7.3 Statistical Model}

In the absence of biasing factors for surface contamination, sampling locations need to determined with the use of a randomization technique. Chapter 9 of EPA SW-846 defines the methodology suggested to determine the sufficient number of samples to be taken to ensure a 90 percent confidence 
level in the COPC concentration. This method is used here to determine the number of random sampling locations required at CAS 15-23-01 and the Contamination Area component of CAS 06-07-01. SW-846 makes the following assumptions:

- A regulatory threshold for the contaminant of concern has been defined.

- The COPC is uniformly distributed throughout the waste form.

- The concentration of the COPC is normally distributed.

- There is a positive analytical result for the contaminant of concern in each sample.

- The regulatory threshold exceeds the mean concentration of the contaminant.

Although some of these assumptions may not hold true for the radiological contaminants, the EPA SW-846 method can still be used to predict the number of samples required to reach the 90 percent confidence level. If the 90 percent confidence level of the mean concentration of the contaminant exceeds the regulatory threshold, the solid waste is assumed to contain the contaminant of concern at a hazardous level. Appendix A.3 provides a discussion of assumptions and the calculations used to determine the number of samples required at CAS 06-07-01, Contaminated Area and CAS 15-23-01.

\section{A.1.7.4 Quality Assurance/Quality Control}

Radiological survey instruments and field-screening equipment will be calibrated and checked in accordance with the manufacturer's instructions or approved procedures.

Quality control samples will be collected as required by the Industrial Sites QAPP (NNSA/NV, 2002) and in accordance with established procedures. The required QC samples include:

- Trip blanks (1 per sample cooler containing VOC environmental samples)

- Equipment blanks (1 per sampling event for each type of decontamination procedure)

- Source blanks (1 per source lot per sampling event)

- Field duplicates (minimum of 1 per matrix per 20 environmental samples, or 1 per CAS if less than 20 are collected)

- Field blanks (minimum of 1 per 20 environmental samples, or 1 per CAS if less than 20 are collected per sampling day)

- MS/MSD (minimum of 1 per matrix per 20 environmental samples or 1 per CAS if less than 20 are collected; not required for all radionuclide measurements) 
Additional QC samples may be submitted based on site conditions.

\section{A.1.8 Step 7 - Optimize the Design for Obtaining Data}

This section presents an overview of the resource-effective strategy planned to obtain the data required to meet the project DQOs developed in previous six steps. Section A.1.8.1 provides general investigation strategy, and Section A.1.8.2 provides the detailed sampling approach to resolve the decision statement for CAU 543. As additional data or information is obtained, this step will be reevaluated and refined, if necessary, to reduce uncertainty and increase the confidence that the nature and extent of contamination is accurately defined.

\section{A.1.8.1 General Investigation Strategy}

The initial activities to be conducted will be a visual inspection and photodocumentation of the area of all CASs and CAS components. A judgmental or biased sampling design (a nonprobabilistic approach) has been developed for the general investigation strategy for CAU 543 with the exception of CAS 15-23-01 and the Contamination Area component of CAS 06-07-01 in which a combination of judgmental and random (probabilistic) sampling will be implemented. This sampling approach focuses on specific sampling locations to support the decision statements presented in Section A.1.3 and the migration and release pathways identified in the CSMs. Chapter 7 of the EPA QA/G-4HW guidance document (EPA, 2000a) allows for judgmental (biased) sampling when chosen locations are based on expert knowledge of contamination sources and history of the sites.

For the CASs or CAS components that include septic tanks, distribution boxes, USTs, and ASTs, the initial visual inspection will also include accessing and opening tanks to document details on the tank contents. Additional liquid and solid samples will be collected for waste characterization purposes from these components if present and accessible. Based on the results of the radiological survey of the concrete surfaces, swipes may be collected and analyzed on site for removable radiological contaminants. Based on biasing factors, scabbling of the concrete may be conducted to collect samples for off-site analysis of chemical and radiological contaminants.

Most of the CASs and components of CASs have elements of an effluent collection and distribution system that involves subsurface piping. At these areas a video survey will be conducted from within the associated piping to identify residual material, breaches, or unknown tie-ins. Site conditions and 
conditions of the piping may not allow a 100 percent video survey. If the video survey identifies breaches and/or conditions that may have provided a means for effluent reach to the surrounding soils, then Decision I samples may be collected at those locations for laboratory analysis. If residual material is present and of an adequate volume, a sample will be collected for analysis. If no breaches or residual effluent is identified during the survey, than Decision I sampling adjacent to and within the buried portions of the pipelines will not be necessary.

Following the initial visual inspection and/or video surveys, Decision I soil sample locations will be identified and collected for laboratory analysis. The selection of theses locations considers the biasing factors listed in Section A.1.4.1 and features of the CSM. If site conditions are encountered during the Decision I surface sampling or the video survey results suggest shallow subsurface contamination exists, then subsurface Decision I samples may be collected immediately. Decision I surface and shallow subsurface soil samples will be collected for laboratory analysis of the parameters identified in Section A.1.4.3.6.

Decision II (step-out) sampling locations at each CAS will be selected based on the outer boundary sample locations where COCs were detected in the Decision I samples. Decision II locations will also be selected based on the elements of the CSM and other biasing factors. If biasing factors indicate a COC extends beyond the planned step-outs (i.e, field screening), locations may be modified or additional Decision II samples may be collected from incremental step-out locations as determined by the project staff. Initial step-outs will be at least as deep as the vertical extent of contamination defined at the Decision I location and the depth of the incremental step-outs will be based on the deepest contamination observed at all locations. For subsurface sampling locations, generally two consecutive soil samples with results below field-screening action levels are required to define the vertical extent of contamination. Generally, the uppermost "clean" sample from each location will be submitted for laboratory analysis. Contaminants determined not to be present in Decision I samples may be eliminated from Decision II analytical suites.

Due to the nature of buried features possibly present (e.g., structures and utilities), sample locations may be relocated, based upon actual field conditions, review of engineering drawings, and information obtained during the site visit. However, the new locations will meet the decision needs and criteria stipulated in Section A.1.4.1. 


\section{A.1.8.2 Detailed Investigation Strategy}

The following sections discuss the more detailed CAS- and CAS component-specific investigation activities, including proposed sample locations.

\section{A.1.8.2.1 CAS 06-07-01, Area 6 Decontamination Facility}

The detailed investigation strategy for the Area 6 Decontamination Facility will be discussed based on the various components of the CAS including effluent collection system, decontamination pads, Building 6-605, and the Contamination Area.

Effluent Collection/Distribution System - Prior to Decision I sampling, a video mole survey will be performed on as much of the subsurface piping as practical to identify breaks, residual materials, and location of sumps/tanks. Excavation may be performed to locate the subsurface sumps and septic tanks. If any breaches are identified within the piping, excavation and Decision I subsurface soil sampling will be implemented. Additional Decision I soil sampling will be performed at the junctions of subsurface piping at Sump 1, Sump 2, and the two septic tanks associated with Buildings 6-605 and 6-607 assuming all these components are still present. Decision I soil samples will be collected near the base of the sumps and septic tanks to capture potential leaks. Decision I samples will be collected on any residual sediments or liquids identified in the piping, sumps, and septic tanks for waste management purposes. See Figure A.1-7 for proposed sample locations.

Decision II step-out samples may be collected, as described in Section A.1.8.1. The Site Supervisor will determine if Decision II sampling is appropriate based on biasing factors, primarily field screening of Decision I samples.

Decontamination Pads - Decision I soil samples will be collected from the surface soils surrounding the edges of the outdoor concrete pads adjacent to Buildings 6-605 and 6-606 to capture potential contaminated run-off. The concrete will be scabbled at visibly stained areas and concrete samples will be collected for Decision I analysis. Decision I samples will be collected from any residual sediment still remaining within the pad trench or floor drains. Figure A.1-7 shows the proposed sample locations. 


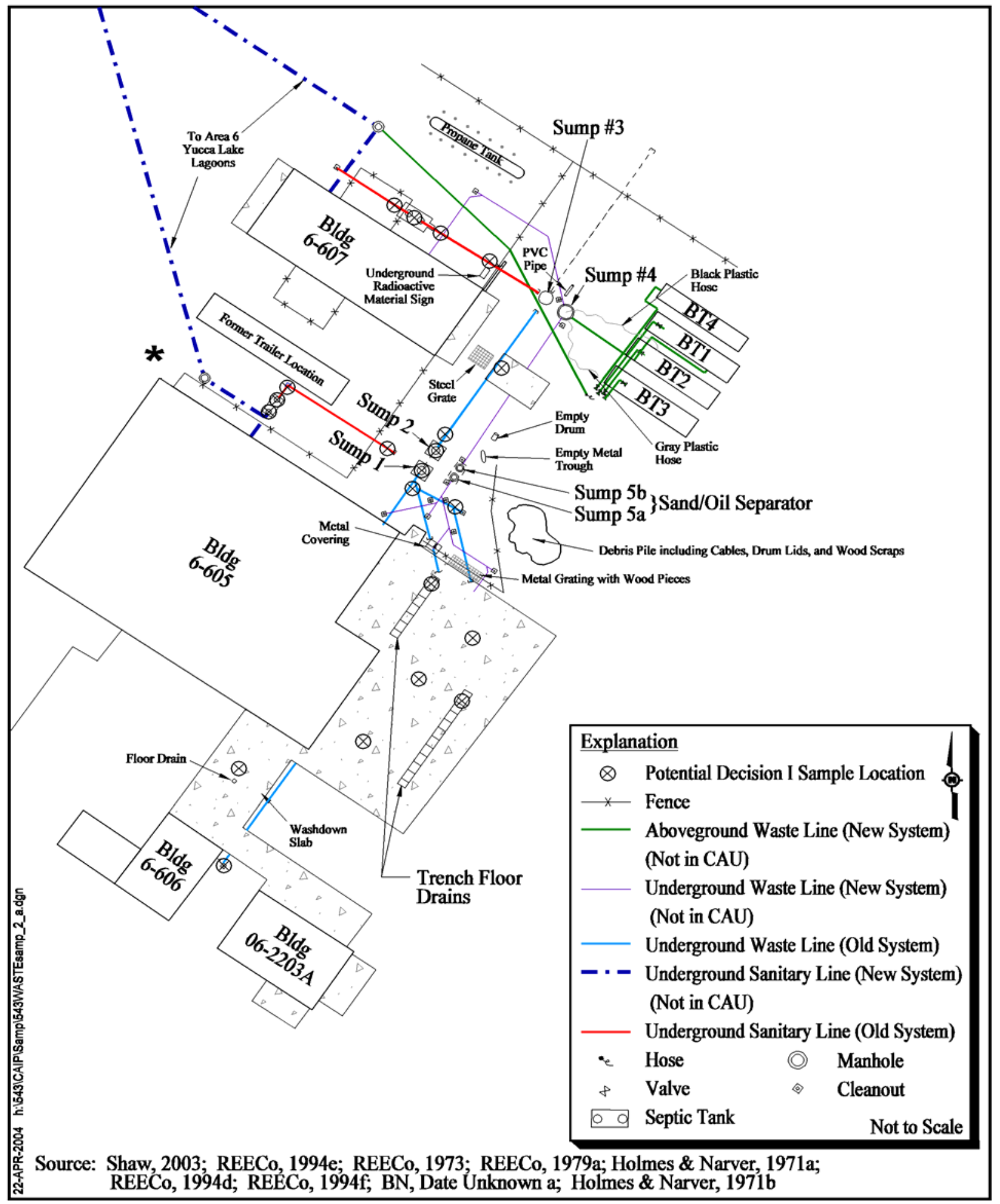

Figure A.1-7

CAU 543, CAS 06-07-01, Decon Pad, Septic System, and Piping Proposed Decision I Sample Locations 
Decision II step-out samples may be collected, as described in Section A.1.8.1. The Site Supervisor will determine if Decision II sampling is appropriate based on biasing factors, primarily field screening of Decision I samples.

Building 6-605 - Decision I sample collection will be implemented for components within Building 6-605 to determine future waste disposal actions of building materials. All drains, trenches, and piping within the building will be inspected for remaining residual sediments/materials. If residual material is present, Decision I samples will be collected. If biasing factors indicate the need, concrete within the building floors may be scabbled and sampled for analysis. The remaining caustic dip tanks will be accessed and inspected for residual materials. Any remaining liquids and/or solids present will be collected for Decision I sample analysis. Radiological scanning and swipe collection will be conducted during Decision I sampling to determine the status of building materials and equipment for free release criteria. It is expected that the nature of Decision I sampling will most likely provide sufficient information on the extent of contamination for Building 6-605 so that Decision II sampling may not be necessary. See Figure A.1-8 for proposed sample locations.

Contamination Area - A statistically based and biased sampling approach will be implemented during Decision I sampling of the surface soils within the area designated as the Contamination Area. A total of 16 random surface samples has been determined sufficient to satisfy the criteria of a 90 percent confidence level in the COPC concentration as determined by the methodology defined in Chapter 9 of EPA SW-846. The 16 sample locations have been randomly generated using the VSP program and will be within the boundary of the Contamination Area. Figure A.1-9 shows the proposed surface soil sample locations. Additional biased samples may be collected where deemed appropriate.

Decision II step-out samples may be collected, as described in Section A.1.8.1. The Site Supervisor will determine if Decision II sampling is appropriate based on biasing factors, primarily field screening of Decision I samples.

\section{A.1.8.2.2 Area 15 EPA Farm}

Discussions of the detailed investigation strategy for the Area 15 EPA Farm will be grouped based on related or similar CASs. The groups will be the septic system and leachfield (CASs 15-04-01 and 


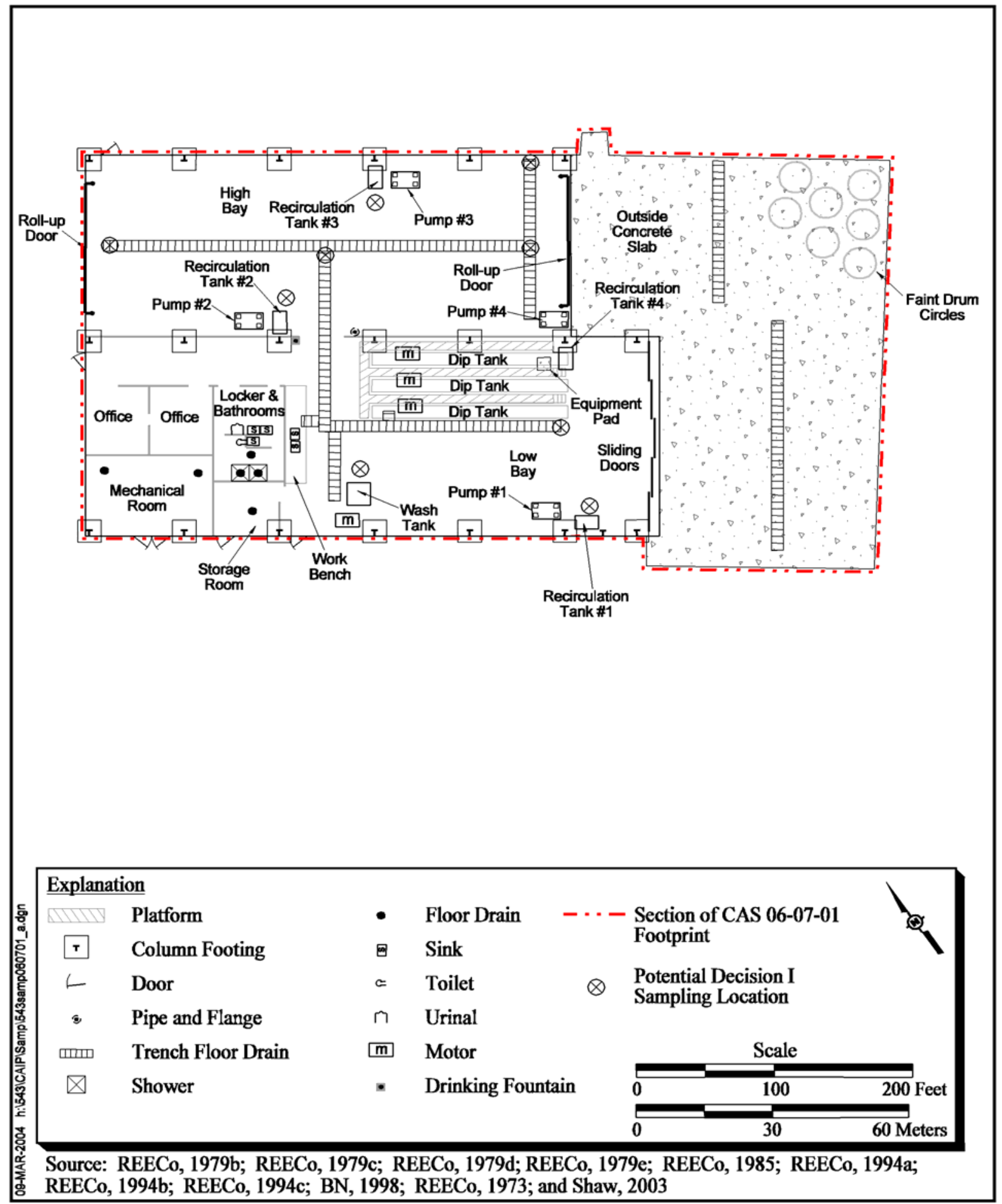

Figure A.1-8

CAU 543, CAS 06-07-01, Potential Decision I Sample Locations 


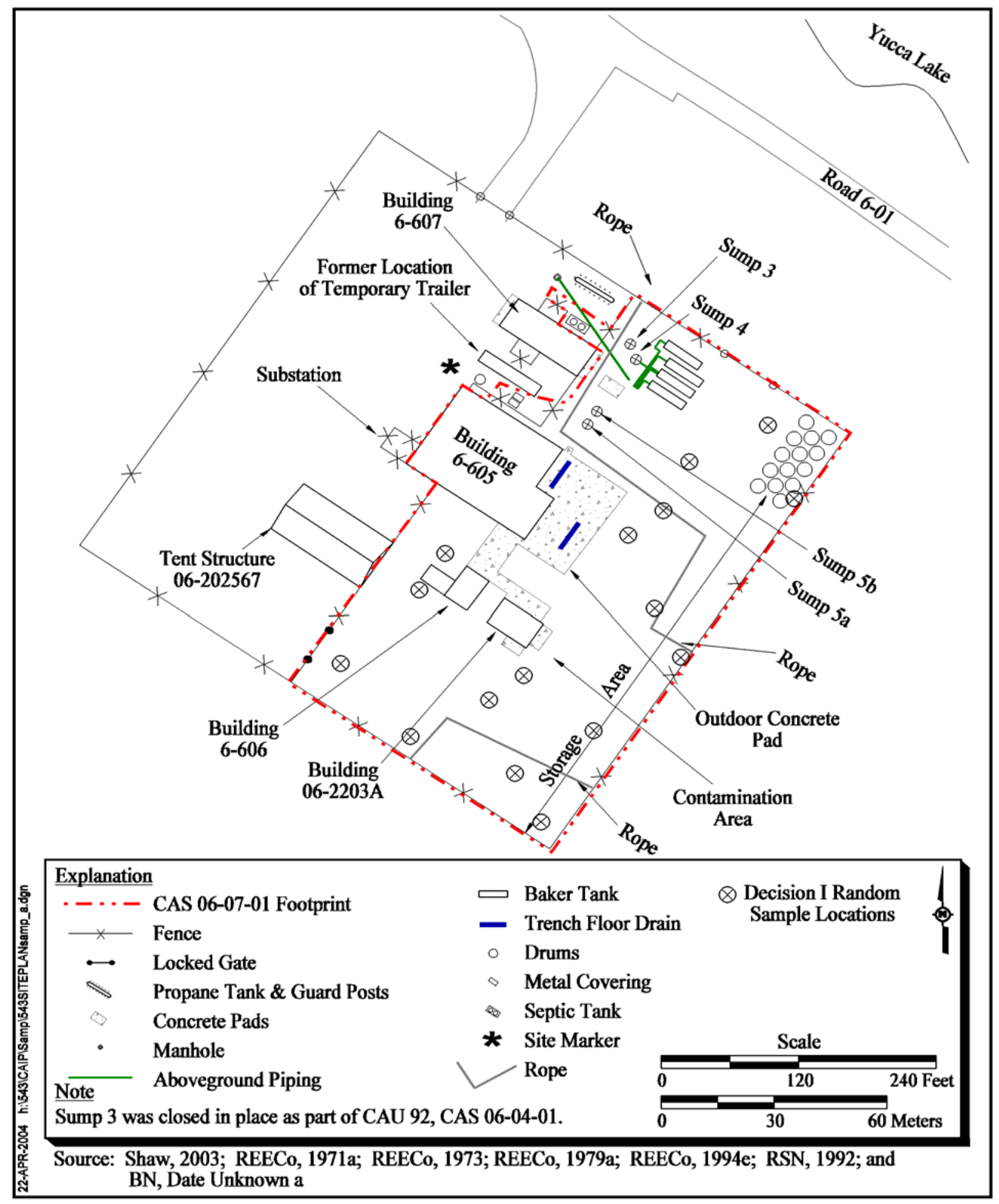

Figure A.1-9

CAU 543, CAS 06-07-01, Decon Pad, Proposed Decision I Random Sampling Locations 
15-05-01); liquid manure underground storage tank and concrete pad (15-08-01); the contaminated sump and AST (CASs 15-23-03 and 15-01-03); and the decontamination area (CAS 15-23-01).

\section{Septic Tank and Leachfield System, CASs 15-04-01 and 15-05-01}

Prior to Decision I sampling, a video mole survey will be performed to identify residual materials, breaches, location of the septic tank if still present, and the end of distribution lines. Excavation will be performed to access and inspect the septic tank and distribution box for integrity. Decision I soil sampling will be conducted below the septic tank inlet and outlet, the outlet from Building 15-06, the distribution box inlet/outlet, below the tank and box, and locations of identified breaches within any part of the system. Decision I activities at the Leachfield will consist of excavating to locate the boundaries of the leachfield, exposing the midpoint, and the proximal and distal ends of the associated perforated distribution pipes, and collecting biased samples from soil beneath the leachrock/native soil interface at the midpoint, and proximal and distal ends of the distribution pipes. If the interface cannot be identified, then samples will be collected directly beneath the distribution pipes.

The contents of the septic tank and distribution box will be sampled during Decision I for waste management purposes. Any remaining residual materials within piping or the clean out will also be sampled provided enough volume is present. Figure A.1-10 and Figure A.1-11 show the proposed sampling locations for the septic tank and leachfield systems, respectively.

Decision II step-out samples may be collected, as described in Section A.1.8.1. The Site Supervisor will determine if Decision II sampling is appropriate based on biasing factors, primarily field screening of Decision I samples.

\section{CAS 15-08-01, Liquid Manure Tank}

Prior to collecting Decision I samples, a video mole survey will be performed to identify if piping connects to the tank or is broken and if residual materials are present. Decision I subsurface soil samples will be collected from below the manure tank inlet and outlet and base of tank and at identified breaches within the piping. Surface soil samples will be collected at the liquid waste transfer point. Decision I surface soil samples will be collected at the outfall located to the south of 


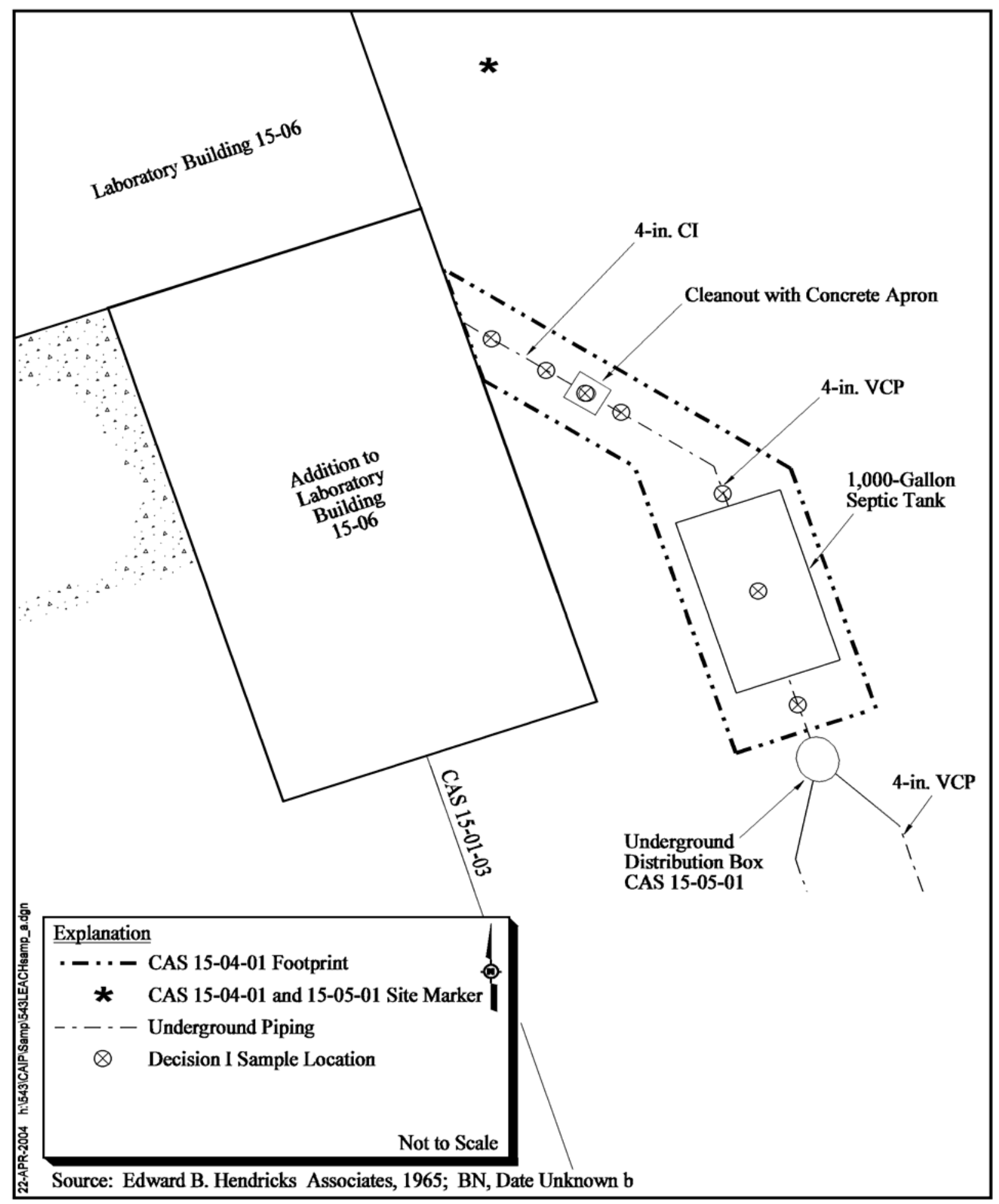

Figure A.1-10

CAU 543, CAS 15-04-01, Septic Tank

Proposed Decision I Sample Locations 


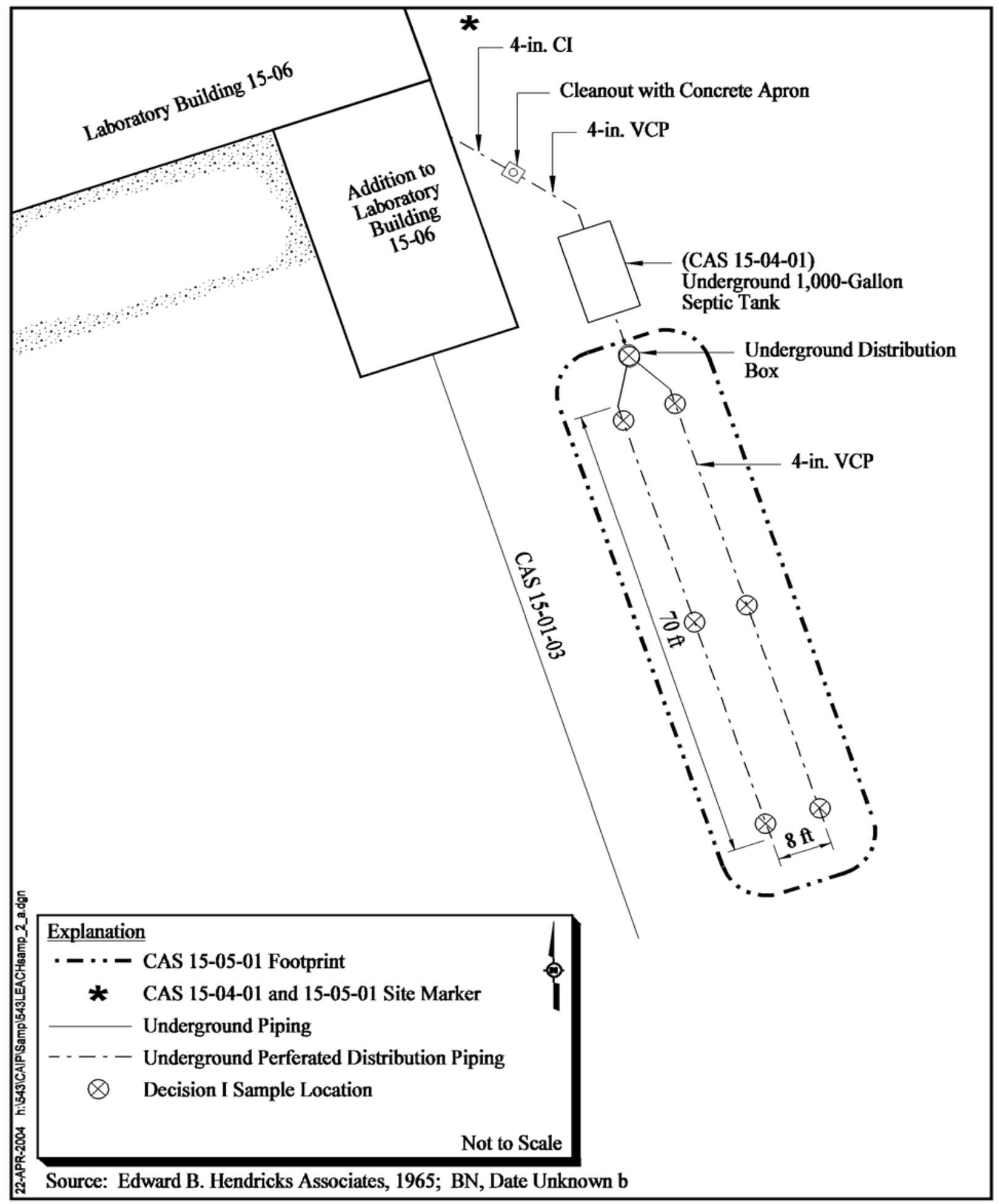

Figure A.1-11

CAU 543, CAS 15-05-01, Leachfield

Proposed Decision I Sample Locations 
the tank. Tank contents will be sampled if present. Figure A.1-12 shows the proposed sample locations.

Decision II step-out samples may be collected, as described in Section A.1.8.1. The Site Supervisor will determine if Decision II sampling is appropriate based on biasing factors, primarily field screening of Decision I samples.

\section{CAS 15-23-03, Contaminated Sump}

Prior to Decision I sampling, a video mole will be performed along the piping from the sump outfall to the distribution box to identify breaches and residual material. Decision I subsurface soil samples will be collected below the distribution box at the effluent end and breaches in the piping. The piping will be sampled to determine if transite. Decision I soil samples will be collected below the outfall pipe and within the sump.

Decision II step-out samples may be collected, as described in Section A.1.8.1. The Site Supervisor will determine if Decision II sampling is appropriate based on biasing factors, primarily field screening of Decision I samples. Figure A.1-13 shows the proposed sample locations for Decision I.

\section{CAS 15-01-03, Aboveground Storage Tank}

Decision I investigation at this CAS includes the soils at the AST, the AST, and piping that extends from the AST to the distribution box to Building 15-06 and the holding pen concrete drain box. Prior to sampling, a video mole survey will be performed to identify breaches or residual materials. Decision subsurface soil samples will be collected at identified breaks and the distribution box inlet and outlet. Surface soil samples will be collected from the base of the AST near the tank staining and at the transfer point of liquid waste. The piping at the transfer point will be sampled for potential ACM. Soil beneath the junctions at the concrete drain box and Building 15-06 will also be sampled during Decision I investigation.

Decision II step-out samples may be collected, as described in Section A.1.8.1. The Site Supervisor will determine if Decision II sampling is appropriate based on biasing factors, primarily field screening of Decision I samples. Figure A.1-14 shows the proposed sample locations for Decision I. 


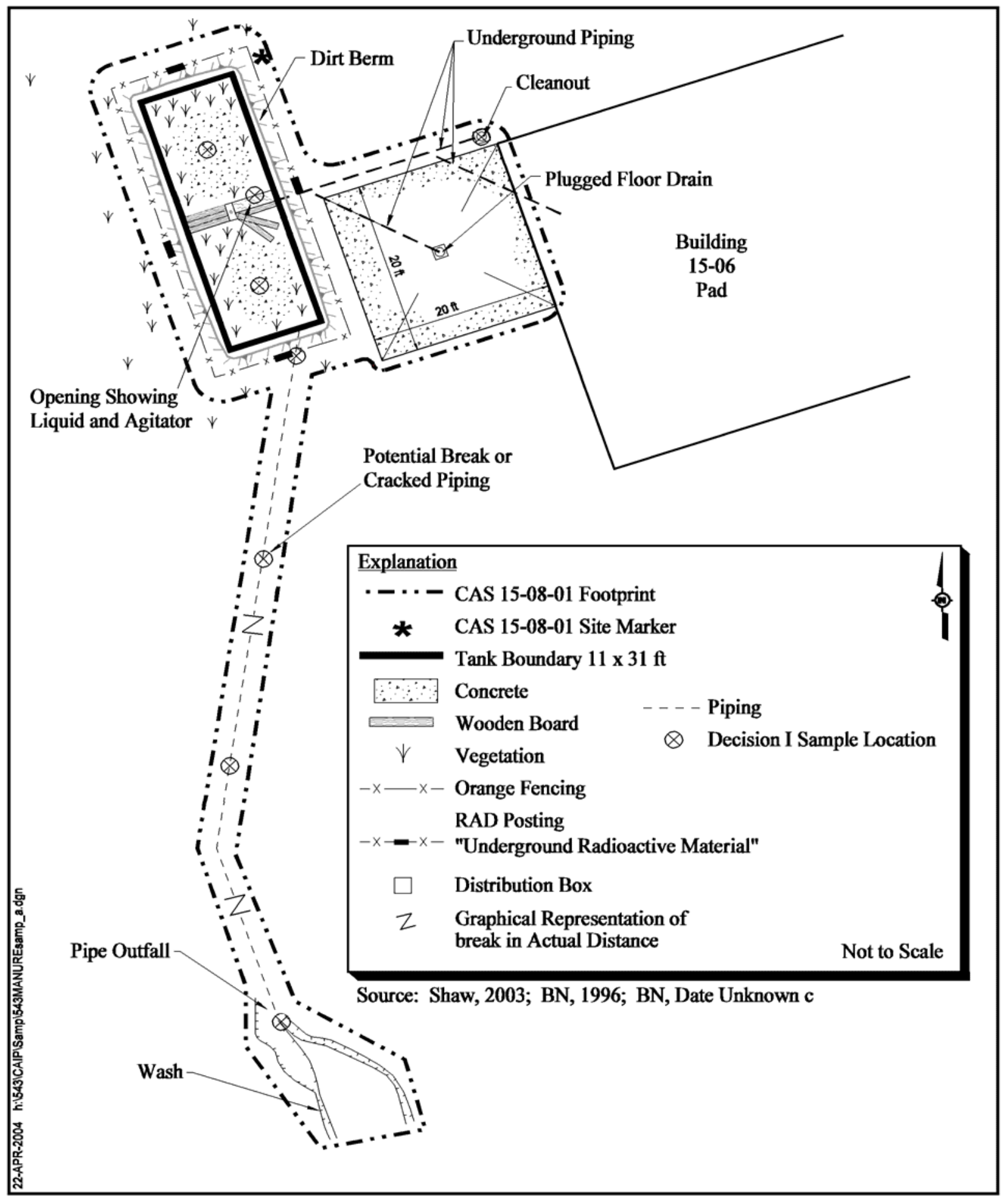

Figure A.1-12

CAU 543, CAS 15-08-01, Liquid Manure Tank Proposed Decision I Sample Locations 


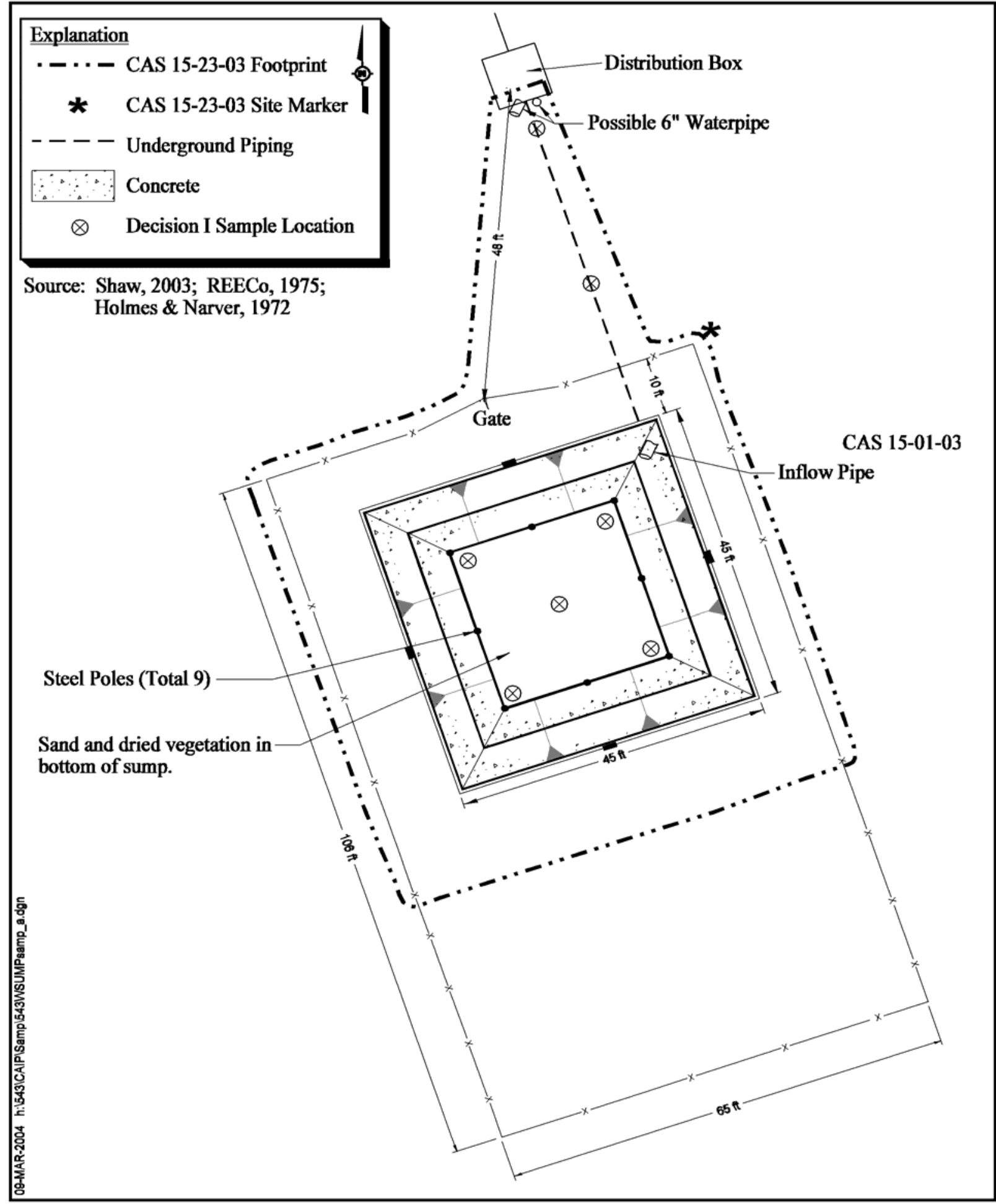

Figure A.1-13

CAU 543, CAS 15-23-03, Contaminated Sump, Piping Proposed Decision I Sample Locations 


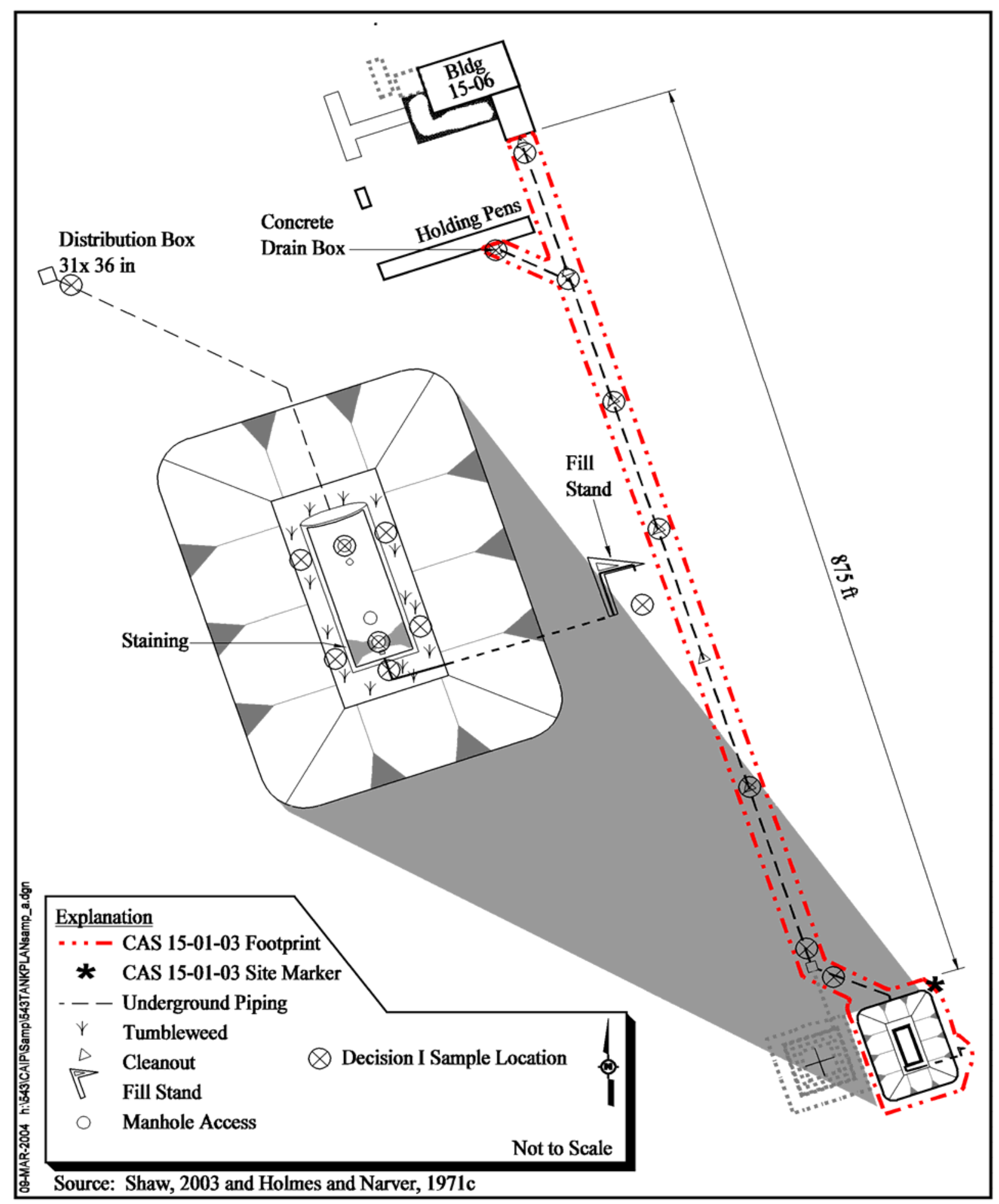

Figure A.1-14

CAU 543, CAS 15-01-03, Aboveground Storage Tank Proposed Decision I Sample Locations 


\section{CAS 15-23-01, Decontamination Pad}

The Decision I investigation involves the surface soils located beneath and surrounding the PSP located on the ground. A radiological survey will be performed to determine if elevated radiological conditions exist. A shallow excavation may be performed to determine if a sump is present below the PSP. If biased sample locations are observed, Decision I soil samples will be collected. A statistical sampling approach is being implemented for the surface soils at this CAS. A total of 9 surface samples will be collected within the area of the PSP to meet the 90 percent confidence level in the COPC concentration as determined by the methodology defined in Chapter 9 of EPA SW-846.

Decision II step-out samples may be collected, as described in Section A.1.8.1. The Site Supervisor will determine if Decision II sampling is appropriate based on biasing factors, primarily field screening of Decision I samples. Figure A.1-15 shows the proposed random sampling locations. 


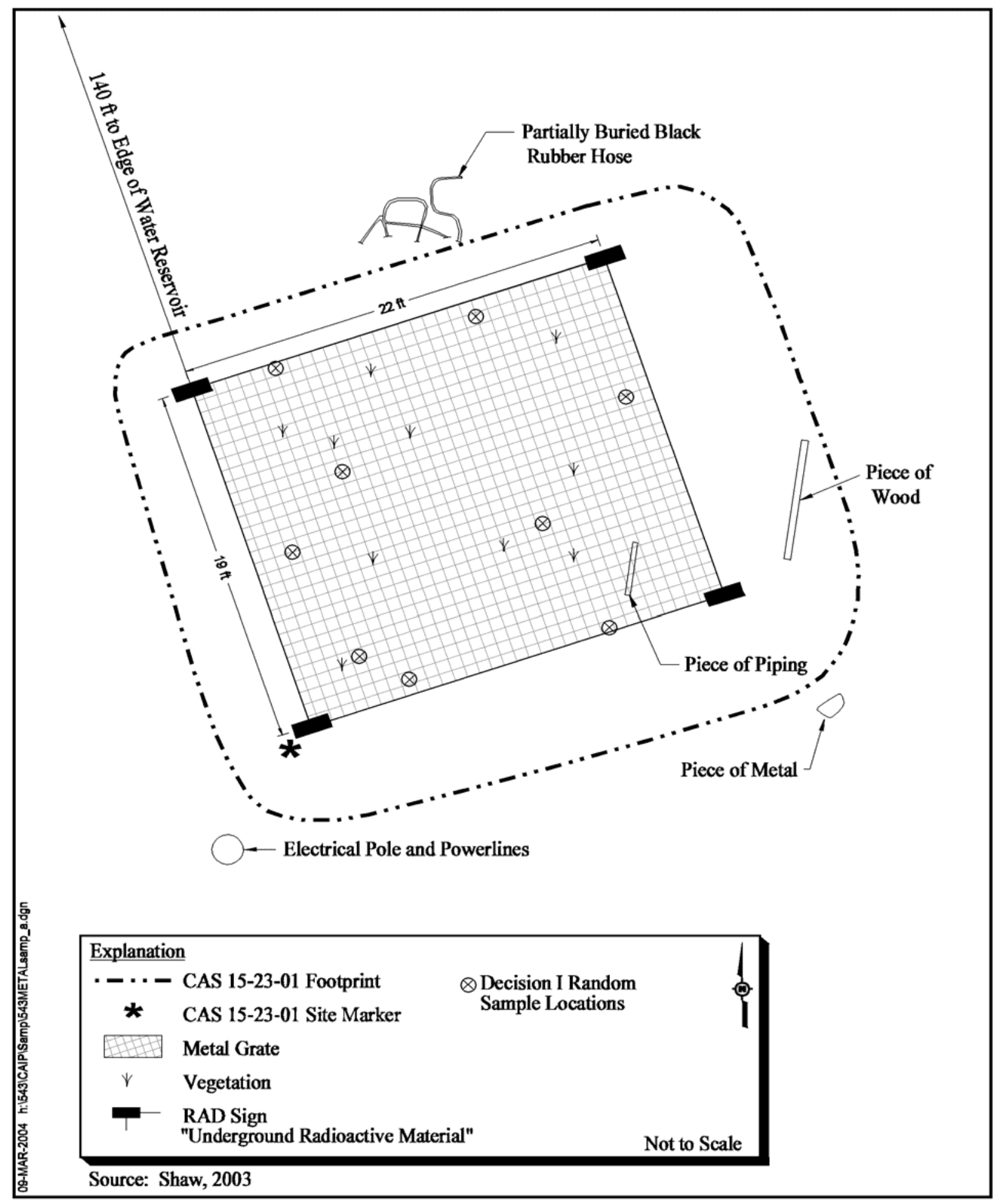

Figure A.1-15

CAU 543, CAS 15-23-01, Underground Radioactive Material Area Proposed Decision I Random Sample Locations 


\section{A.1.9 References}

ASTM, see American Society for Testing and Materials.

Adams, S., IT Corporation. 1998. Memorandum to R. McCall (Science Applications International Corporation) regarding methodology for determining action levels for CAU 407, the Roller Coaster RADSAFE Area, 16 June. Las Vegas, NV.

Adams, S., IT Corporation. 2002. Memorandum to B. Iverson (GeoTrans) entitled, "Radiological Contaminants of Potential Concern (COPC) at the Bunkers of Corrective Action Unit (CAU) 204,” 29 March. Las Vegas, NV.

American Society for Testing and Materials. 2000a. Standard Test Method for Strontium-90 in Water, D5811-2000. Philadelphia, PA.

American Society for Testing and Materials. 2000b. Standard Test Method for Radiochemical Determination of Plutonium in Soil by Alpha Spectroscopy, C1001-2000. Philadelphia, PA.

American Society for Testing and Materials. 2002a. Standard Test Method for Plutonium in Water, D3865-02. Philadelphia, PA.

American Society for Testing and Materials. 2002b. Standard Test Method for Isotopic Uranium in Water by Radiochemistry, D3972-2002. Philadelphia, PA.

American Society for Testing and Materials. 2002c. Standard Test Method for Radiochemical Determination of Uranium Isotopes in Soil by Alpha Spectroscopy, E1000-2002.

Philadelphia, PA.

BN, see Bechtel Nevada.

Barth, D., U.S. Environmental Protection Agency (Retired). 2003. Telecon with A. Steed (SAIC) and B. Iverson (GeoTrans) regarding the EPA Farm, 13 February. Las Vegas, NV.

Bechtel Nevada. Date Unknown a. Engineering drawing SK-006-03-C11 entitled, "CP and Yucca Lake Area Existing Sewage Systems Site Plan.” Las Vegas, NV.

Bechtel Nevada. Date Unknown b. Engineering drawing JS-015-06-M4 entitled, "Nevada Test Site Area 15 Demolition Plans CAU 95 EPA Farm Building 15-06 Soil, Waste and Vent Plan." Mercury, NV: Archives \& Records Center.

Bechtel Nevada. Date Unknown c. Engineering drawing JS-015-06-C1 entitled, "Nevada Test Site Area 15, Demolition Plans CAU 95 EPA Farm Building 15-06 Site Plan,” Las Vegas, NV. 
Bechtel Nevada. 1996. Engineering drawing JS-015-139-E1 entitled, "Nevada Test Site - Area 15, NTS Retrofit Power Metering System In-House Energy Management Systems (Phase 1B) Plans, Elevation \& Diagram," Las Vegas, NV.

Bechtel Nevada. 1998. Engineering drawing FWR-98223-A06-M1 entitled, "Decon Shower Decontamination Facility Bldg 605 Demolition and Floor Plan," 3 November. Las Vegas, NV.

Betrand, K., Bechtel Nevada. 2003. Record of Telecon with B. Bailey (Shaw) regarding CAS 06-07-01, 2 June. Las Vegas, NV.

Bicker, A.E., Reynolds Electrical \& Engineering Co., Inc. 1988. Memorandum to B.P. Smith (REECo) entitled, "Control of Effluent from Building 650 and the Area 6 Decontamination Facility," 17 November. Las Vegas, NV.

Bielawski, J.P., Reynolds Electrical \& Engineering Co., Inc. 1994. Memorandum to D.S. Gilmore (REECo) entitled, "Decontamination Facility Upper Wastewater System Construction Approval and Additional Sampling," 23 March. Las Vegas, NV.

Bingham, F.E., Reynolds Electrical \& Engineering Co., Inc. 1990. Memorandum to the Files entitled, "Telephone Call from David McNelis on Area 6 Decontamination (Decon) Pond Problem," 3 January. Las Vegas, NV.

Bingham, F.E., Reynolds Electrical \& Engineering Co., Inc. 1992. Letter to J.D. Stewart (DOE/NTSO) entitled, "Survey of Nevada Test Site (NTS) Abandoned Septic Tank Systems Tiger Team Finding SW/CF-3," 2 January. Las Vegas, NV.

Bingham, F.E., Reynolds Electrical \& Engineering Co., Inc. 1993a. Letter to D.R. Elle (DOE/NV) entitled, "Closure of Tiger Team Finding SW/CF-06," 7 July. Las Vegas, NV.

Bingham, F.E., Reynolds Electrical \& Engineering Co., Inc. 1993b. Letter to D.R. Elle (DOE/NV) entitled, "Decontamination Facility Sampling Plan," 22 September. Las Vegas, NV.

Boehlecke, R.F., Science Applications International Corporation. 1997. Electronic transmittal to E. Shupp (IT) entitled, "MSDS's." Las Vegas, NV.

Boyd, G., Bechtel Nevada. 2003. Record of Telecon with A. Steed (SAIC) regarding CAS 06-07-01, 17 March. Las Vegas, NV.

DOE, see U.S. Department of Energy.

DOE/NV, see U.S. Department of Energy, Nevada Operations Office.

DRI, see Desert Research Institute. 
Desert Research Institute. 1988. CERCLA Preliminary Assessment of DOE's Nevada Operations Office Nuclear Weapons Testing Areas, Volume I. Prepared for the U.S. Department of Energy, Nevada Operations Office. Las Vegas, NV: Water Resources Center.

Desert Research Institute. 1993. Tritium Activities in Selected Wells on the Nevada Test Site, DOE/NV/10845-20. Publication Number 45104. Prepared by B.F Lyles. Las Vegas, NV: Water Resources Center.

Desert Research Institute. 1994. A Class III Cultural Resource Reconnaissance of a Proposed Soil Treatability Pilot Plant Site at the EPA Farm, Area 15, Nevada Test Site, Nye County, Nevada, SR090893-1. Prepared by N.G. Goldenberg, W.G. Johnson, and A.R. McLane. Las Vegas, NV.

EG\&G/EM, see EG\&E Energy Measurements.

EPA, see U.S. Environmental Protection Agency.

EG\&G Energy Measurements. 1986. An Aerial Radiological Survey of Areas 12, 15, 17 and 19 Nevada Test Site, EGG-10282-1113. Prepared by J.E. Jobst. Las Vegas, NV.

ERDA, see U.S. Energy Research and Development Administration.

Edward B. Hendricks Associates. 1965a. Engineering drawing NV-35-08-01.2 entitled, “Area 15 U.S.P.H.S. Field Research Complex Laboratory Mech-Elect. Plot Plan,” 29 November. Mercury, NV: Archives \& Records Center.

Edward B. Hendricks Associates. 1965b. As-built engineering drawing NV-35-08-01.2 Sheet M-2 entitled, “Area 15 N.T.S. U.S.P.H.S. Field Research Complex Laboratory Plumbing Plan,” 30 November. Las Vegas, NV.

Edward B. Hendricks Associates. 1965c. As-built engineering drawing NV-35-08-01.1 Sheet A-1 entitled, "Area 15 N.T.S. U.S.P.H.S. Field Research Complex Plan,” 2 December. Las Vegas, NV.

Elle, D.R., U.S. Department of Energy, Nevada Operations Office. 1994. Letter to P.J. Liebendorfer (NDEP) entitled, "Summary of Activities at the Area 6 Decontamination (A-6 Decon) Laundry Facility," 19 April. Las Vegas, NV.

Frazier, A.R., Reynolds Electrical \& Engineering Co., Inc. 1987. Letter to W. McCurry (NDEP) entitled, "Description of NTS and TTR Septic Tank and Leachfield Systems," 21 December. Las Vegas, NV.

Giles, K., Desert Research Institute. 2003. Telecon with A. Steed (SAIC) and B. Iverson (GeoTrans) regarding the EPA Farm, 6 February. Las Vegas, NV. 
Holmes \& Narver, Inc. 1971a. Engineering drawing 006-029-C2 entitled, "Rad-Safe Decontamination Laundry Plot Plan," 23 December. Las Vegas, NV.

Holmes \& Narver, Inc. 1971b. Engineering drawing 006-029-M10 entitled, "Rad-Safe Decontamination Laundry Sanitation \& Waste Drainage Plan,” 23 December. Las Vegas, NV.

Holmes \& Narver, Inc. 1971c. Engineering drawing, 015-094-C3.7 Sheet 6 of 10, entitled "Nevada Test Site - Area 15, Modifications to Bldg. 15-06 - USPHS Farm Plan, Profile, and Details," 17 June. Las Vegas, NV.

Holmes \& Narver, Inc. 1972a. Engineering drawing, 015-094-C3.2, entitled "Nevada Test Site Area 15, Modifications to Bldg. 15-06 - USPHS Farm, Plan, Profile \& Details,” 2 January. Las Vegas, NV

Holmes \& Narver, Inc. 1972b. Engineering drawing, 015-06-M1.1 Sheet 5, entitled, "Nevada Test Site - Area 15, Modifications to Bldg. 15-06 - USPHS Farm Plans - Water \& Drainage Piping,” 2 January. Las Vegas, NV.

Holmes \& Narver, Inc. 1973a. Engineering drawing, 015-06-C1 entitled, "Nevada Test Site Area 15 New EPA Slaughter Facility Grading Plan,” 24 August. Mercury, NV.

Holmes \& Narver, Inc. 1973b. Engineering drawing, 015-06-M2.1 entitled, "Nevada Test Site Area 15 New EPA Slaughter Facility Plumbing Plan \& Sections," 24 August. Mercury, NV.

Holmes \& Narver, Inc. 1974. Engineering drawing, 015-06-M2.1, entitled "Nevada Test Site-Area 15, New EPA Slaughter Facility, Plumbing Plan \& Sections," 6 September. Las Vegas, NV.

Holmes \& Narver, Inc. 1979a. Engineering drawing, Page No. 21, entitled "Area 15 Environmental Protection Agency," 1 April. Las Vegas, NV.

Holmes \& Narver, Inc. 1979b. Engineering drawing, JS-015-06-M2, entitled "Title II EPA Farm Slaughter Facility Mods Water Piping Plan \& Details," 1 March. Las Vegas, NV.

Holmes \& Narver, Inc. 1981. Engineering drawing 006-029-M10.1 entitled, "Rad-Safe Decontamination Laundry Sanitation \& Waste Drainage Plan," 3 May. Las Vegas, NV.

Hopper, R., U.S. Environmental Protection Agency and S. Helleman, D.B. Stephens. 1995. Record of Telecon with L. Tryboski (IT Corporation) regarding the EPA Farm, 3 August. Las Vegas, NV.

Hopper, D., U.S. Environmental Protection Agency. 2003. Meeting with A. Steed (SAIC) and B. Iverson (Geo Trans) regarding the EPA Farm, 4 February. Las Vegas, NV. 
Moore, J., Science Applications International Corporation. 1999. Memorandum to M. Todd (SAIC) entitled, "Background Concentrations for NTS and TTR Soil Samples," 3 February. Las Vegas, NV.

NAC, see Nevada Administrative Code.

NBMG, see Nevada Bureau of Mines and Geology.

NCRP, see National Council on Radiation Protection and Measurements.

NNSA/NV, see U.S. Department of Energy, National Nuclear Security Administration Nevada Operations Office.

National Council on Radiation Protection and Measurements. 1999. Recommended Screening Limits for Contaminated Surface Soil and Review of Factors Relevant to Site-Specific Studies, NCRP Report No. 129. Washington, DC.

Nevada Administrative Code. 2002. NAC 445A, "Water Controls.” Carson City, NV.

Nevada Bureau of Mines and Geology. 1998. Mineral and Energy Resource Assessment of the Nellis Air Force Range, Open-File Report 98-1. Reno, NV.

Nicosia, W.C., Shaw Environmental, Inc. 2003. Memorandum to M. England (SAIC) entitled, "Radiological Land Area Surveys of Various Locations at the Nevada Test Site for Preliminary Assessments," 3 March. Las Vegas, NV.

Olsen, A. Bechtel Nevada. 1997. Correspondence to L. Tryboski (IT Corporation) regarding CAUs at the EPA Farm Facility, 5 August. Las Vegas, NV.

Paradis, L., Company Unknown. 1998. Record of Telecon with L.M. Mercado (SAIC) regarding the status of the Area 6 decon pad, 4 August. Las Vegas, NV.

REECo - See Reynolds Electrical \& Engineering Co., Inc.

RSN, see Raytheon Services Nevada.

Radack, P.M., Reynolds Electrical \& Engineering Co., Inc. 1992. Memorandum to M.B. Brown (REECo) entitled, "Decontamination Facility Septic Tank," 2 June. Las Vegas, NV.

Raytheon Services Nevada. 1992. Engineering drawing JS-006-083-C2 entitled, “Area 6 Yucca Lake Utilities - Water Map,” 29 December. Las Vegas, NV.

Reynolds Electrical \& Engineering Co., Inc. 1971a. Environmental Sciences Decontamination Facility Operations Guide, September. Mercury, NV. 
Reynolds Electrical \& Engineering Co., Inc. 1971b. Ground-level photograph 3296-06 showing Building 6-605, 4 February. Nellis Air Force Base, NV: Remote Sensing Laboratory Photo Library.

Reynolds Electrical \& Engineering Co., Inc. 1973. Engineering drawing SK-6-183 entitled, "Decon Facility Drainage Control Grading Plan," 15 February. Las Vegas, NV.

Reynolds Electrical \& Engineering Co., Inc. 1975a. Engineering Drawing, 15-E.P.A.-C1, entitled "Nevada Test Site - Area 15, E.P.A. Farm Contaminated Waste Disposal System Modification Plan \& Profile - Sections - Details," 10 June. Las Vegas, NV.

Reynolds Electrical \& Engineering Co., Inc. 1975b. Engineering drawing, 15-E.P.A.-E1, entitled, "Nevada Test Site - Area 15, E.P.A. Farm Contaminated Waste Disposal System Elect. Plan Diagram \& Details," 11 June. Las Vegas, NV.

Reynolds Electrical \& Engineering Co., Inc. 1979a. Engineering drawing 6-DD-C1 entitled, "Dyna-Drill Maintenance Shop Plot \& Utility Plan," 29 September. Las Vegas, NV.

Reynolds Electrical \& Engineering Co., Inc. 1979b. Engineering drawing 6-D-A1 entitled, "Rad-Safe Decontamination Facility Architectural - Floor Plan," 5 July. Las Vegas, NV.

Reynolds Electrical \& Engineering Co., Inc. 1979c. Engineering drawing 6-D-S2 entitled, "Rad-Safe Decontamination Facility Floor Slab Drainage Plan \& Sections," 5 July. Las Vegas, NV.

Reynolds Electrical \& Engineering Co., Inc. 1979d. Engineering drawing 6-D-A2 entitled, "Rad-Safe Decontamination Facility Partial Floor Plan, Sect. \& Det's," 5 July. Las Vegas, NV.

Reynolds Electrical \& Engineering Co., Inc. 1979e. Engineering drawing 6-D-M3 entitled, "Rad-Safe Decontamination Facility Plumbing Layout \& Schedule," 5 July. Las Vegas, NV.

Reynolds Electrical \& Engineering Co., Inc. 1979f. Engineering drawing 6-D-M1 entitled, "Rad-Safe Decontamination Facility Piping Layout \& Legend," 2 July. Las Vegas, NV.

Reynolds Electrical \& Engineering Co., Inc. 1985. Engineering drawing 6-605-C1 entitled, "Reline Concrete Drains Decon Facility Bldg 6-605,” 16 April. Las Vegas, NV.

Reynolds Electrical \& Engineering Co., Inc. 1994a. Engineering drawing 6-605-556-S5.1 entitled, "Concrete Floor Repair Decon Facility, Building 6-605 Existing Floor Plan," 10 November. Las Vegas, NV.

Reynolds Electrical \& Engineering Co., Inc. 1994b. Engineering drawing 6-605-556-S6.1 entitled, "Concrete Floor Repair Decon Facility, Building 6-605 Floor Plan," 7 September. Las Vegas, NV. 
Reynolds Electrical \& Engineering Co., Inc. 1994c. Engineering drawing 6-605-556-S9.1 entitled, "Recirculation Tank System Decon Facility, Building 6-605 Floor Plan," 11 July. Las Vegas, NV.

Reynolds Electrical \& Engineering Co., Inc. 1994d. Engineering drawing 6-DF-556-C11.1 entitled, "Upper Wastewater Disposal System Decon Facility, Area 6 Site Plan," 29 October.

Las Vegas, NV.

Reynolds Electrical \& Engineering Co., Inc. 1994e. Engineering drawing 6-DF-556-C3.2 entitled, "Sanitary Sewerage System Decon Facility, Area 6 Site Plan," 27 October. Las Vegas, NV.

Reynolds Electrical \& Engineering Co., Inc. 1994f. Engineering drawing 6-DF-556-10.1 entitled, "Upper Wastewater Disposal System Decon Facility, Area 6 existing/Demolition Plan," 5 October. Las Vegas, NV.

SAIC, see Science Applications International Corporation.

Shaw, see Shaw Environmental, Inc.

SWRHL, see Southwestern Radiological Health Laboratory.

Science Applications International Corporation. 2003. Surface Geophysical Survey Final Report Corrective Action Units Nevada Test Site, May. Prepared for Shaw Environmental, Inc. Harrisburg, PA.

Shaw Environmental, Inc. 2003. CAU 543 Project Files. Las Vegas, NV.

Smith, M. 1991. Site Monitoring/Site Demarcation Checklist: Area 15 Site Dry Well - Feed Storage Bin, 29 May. Las Vegas, NV.

Soong, C., Bechtel Nevada. 2003. Record of Telecon with B. Bailey (Shaw) regarding CAS 06-07-01, 9 June. Las Vegas, NV.

Sorom, E., Reynolds Electrical \& Engineering Co., Inc. 1995. Telecon with L. Tryboski (IT Corporation) regarding the tank at the EPA Farm, 13 July. Las Vegas, NV.

Southwestern Radiological Health Laboratory. 1967. Status of the Nevada Test Site Experimental Farm Summary Report for July 1964-December 1965, SWRHL-36r. Prepared by R.L. Douglas for the U.S. Atomic Energy Commission. Las Vegas, NV: U.S. Public Health Service

USGS, see U.S. Geological Survey.

U.S. Department of Energy. 1988. Environmental Survey Preliminary Report, DOE/EH/OEV-15P, April. Washington, DC: Environment, Safety, and Health Office of Environmental Audit. 
U.S. Department of Energy. 1993. DOE Order 5440.5, Change 2, Radiation Protection of the Public and the Environment. Washington, DC: U.S. Government Printing Office.

U.S. Department of Energy. 1997. Procedures Manual of Environmental Measurements Laboratory, HASL-300, 28th Ed., Vol. I. New York, NY.

U.S. Department of Energy, National Nuclear Security Administration Nevada Operations Office. 2002. Industrial Sites Quality Assurance Project Plan, Nevada Test Site, Nevada, DOE/NV--372-Rev. 3. Las Vegas, NV.

U.S. Department of Energy, Nevada Operations Office. 1984. Safety Assessment of the Area 6 Decontamination Pad and Laundry, DOE/NV/10327-12. Prepared by M.W. Chilton and J.A. Orcutt. Las Vegas, NV.

U.S. Department of Energy, Nevada Operations Office. 1992. RCRA Part B Permit Application for Waste Management Activities at the Nevada Test Site: Section L Potential Solid Waste Management Units, Volume IV. Las Vegas, NV.

U.S. Department of Energy, Nevada Operations Office. 1993. Nevada Test Site Conceptual Site Treatment Plan, October. Las Vegas, NV.

U.S. Department of Energy, Nevada Operations Office. 1995. Preliminary Characterization of Abandoned Septic Tank Systems, Volumes I and II, DOE/NV-414 UC-700. Prepared by Reynolds Electrical \& Engineering Co., Inc. Las Vegas, NV.

U.S. Department of Energy, Nevada Operations Office. 1996. Final Environmental Impact Statement for the Nevada Test Site and Off-Site Locations in the State of Nevada, DOE/EIS 0243. Las Vegas, NV.

U.S. Department of Energy, Nevada Operations Office. 1998a. Closure Report for Decontamination \& Decommissioning (D\&D) Category, Corrective Action Unit 95, EPA Farm Laboratory Building 15-06, Nevada Test Site, DOE/NV-11718-178. Las Vegas, NV.

U.S. Department of Energy, Nevada Operations Office. 1998b. Nevada Test Site Resource Management Plan, DOE/NV--518. Las Vegas, NV.

U.S. Department of Energy, Nevada Operations Office. 1999. Closure Report for Corrective Action Unit 92: Area 6 Decontamination Pond Nevada Test Site, Nevada, DOE/NV/11718-306. Las Vegas, NV.

U.S. Department of Energy, Nevada Operations Office. 2000a. Closure Report for Petroleum Hydrocarbon Release at the Area 6 Decontamination Facility at the Nevada Test Site: Tank 6-605-1 (NDEM \#990204-3304), February. Las Vegas, NV. 
U.S. Department of Energy, Nevada Operations Office. 2000b. Nevada Test Site Contaminated Land Areas Report, Volume I, DOE/NV/11718-481-VOL 1. Las Vegas, NV.

U.S. Department of Energy, Nevada Operations Office. 2000c. NV/YMP Radiological Control Manual, Rev. 4, DOE/NV/11718-079, UC-702. Prepared by A.L. Gile of Bechtel Nevada. Las Vegas, NV.

U.S. Energy Research and Development Administration. 1976. Letter to H.D. Cunningham transmitting the attachment "Disposal Procedures for Contaminated Liquid Waste EPA Farm," Accession numbers NVO173551 and NVO173552, September. Las Vegas, NV: NNSA/NSO Public Reading Facility.

U.S. Environmental Protection Agency. 1973. Status of the Environmental Protection Agency's Nevada Test Site Experimental Dairy Herd January 1, 1969 - December 31, 1970, NERC-LV-539-22. Prepared by D. D. Smith for the U.S. Atomic Energy Commission. Las Vegas, NV.

U.S. Environmental Protection Agency. 1977. Five-Year Summary Report of an Experimental Dairy Herd Maintained on the Nevada Test Site 1971 Through 1975, EMSL-LV-0539-9. Prepared for the U.S. Energy Research and Development Administration. Las Vegas, NV.

U.S. Environmental Protection Agency. 1980. Prescribed Procedures for Measurement of Radioactivity in Drinking Water, EPA 600/4-80-032. Washington, DC.

U.S. Environmental Protection Agency. 1983. Standards for Remedial Actions of Inactive Uranium Processing Sites, Title 40 Code of Federal Regulations, Part 192. Washington, DC.

U.S. Environmental Protection Agency. 1996. Test Methods for Evaluating Solid Waste, Physical/Chemical Methods, SW-846, $3^{\text {rd }}$ Edition, CD-ROM PB97-501928GEI.

Washington, DC.

U.S. Environmental Protection Agency. 2000a. Data Quality Objectives Process for Hazardous Waste Site Investigations, EPA QA/G-4HW. Washington, DC.

U.S. Environmental Protection Agency. 2000b. Guidance on Choosing a Sampling Design for Environmental Data Collection, EPA QA/G-5S. Washington, DC.

U.S. Environmental Protection Agency. 2002a. Guidance for Quality Assurance Project Plans, EPA QA/G-5, EPA/240/R-02/009. Washington, DC.

U.S. Environmental Protection Agency. 2002b. Region IX Preliminary Remediation Goals (PRGs). Prepared by S.J. Smucker. San Francisco, CA.

U.S. Environmental Protection Agency. 2002c. Integrated Risk Information System (IRIS) Database, as accessed at http://www.epa.gov/iris/index.html on 16 October. 
U.S. Geological Survey. 2003. "USGS/DOE Nevada Water Use Wells.” As accessed at http://waterdata.usgs.gov/nwis/inventory/?site_no=371106116110401 on 13 November.

Western, A.W., Reynolds Electrical \& Engineering Co., Inc. 1977. Memorandum to A.E. Bicker (REECo) entitled, "Concrete Floor - Decon Facility," 28 March. Las Vegas, NV.

Wuellner, J.W., Reynolds Electrical \& Engineering Co., Inc. 1994. Memorandum to E.W. Kendall (REECo) entitled, "Inspection of Buildings 605 and 607," 23 June. Las Vegas, NV. 
Date: January 2008

\section{APPENDIX B}

\section{SAMPLE ANALYTICAL RESULTS}


Closure Report - CAU 543

Section: Appendix B

Revision: 0

Date: January 2008

PAGE INTENTIONALLY LEFT BLANK 


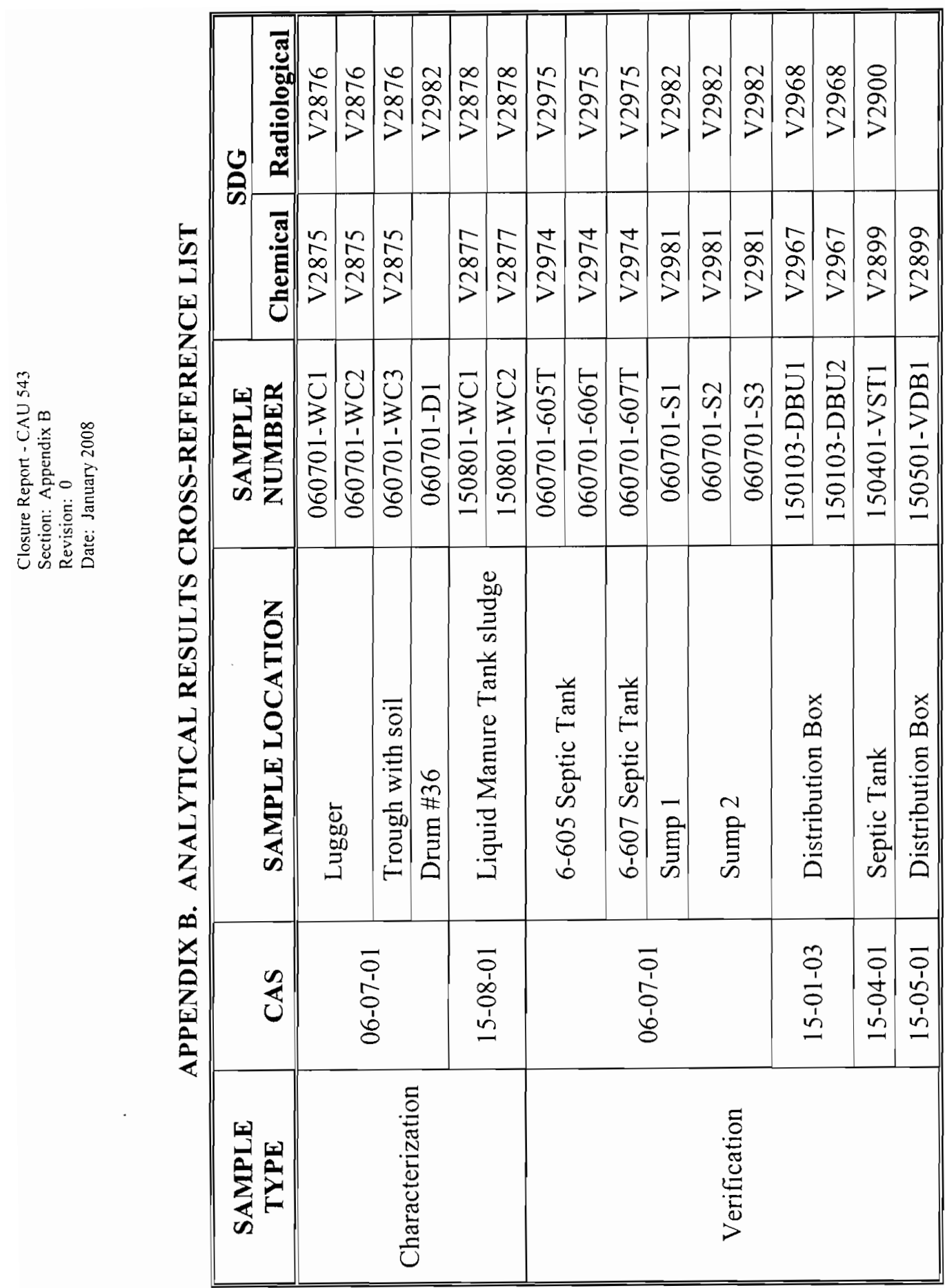


Ciosure Report - CAU 543

Section: Appendix B

Revision: 0

Date: January 2008

THIS PAGE INTENTIONALLY LEFT BLANK 
Closure Report - CAU 543

Section: Appendix B

Revision: 0

Date: January 2008

\section{Sample Delivery Group V2875}


Closure Report - CAU 543

Section: Appendix B

Revision: 0

Date: January 2008

THIS PAGE INTENTIONALLY LEFT BLANK 


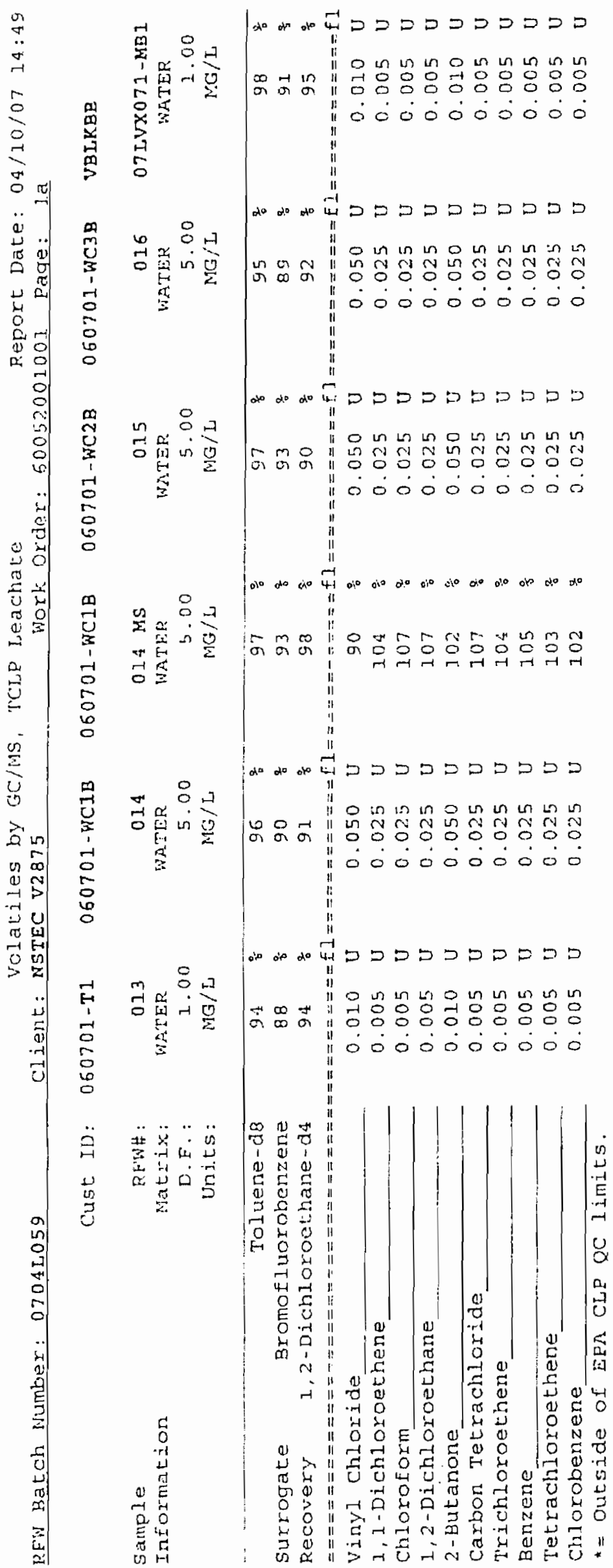




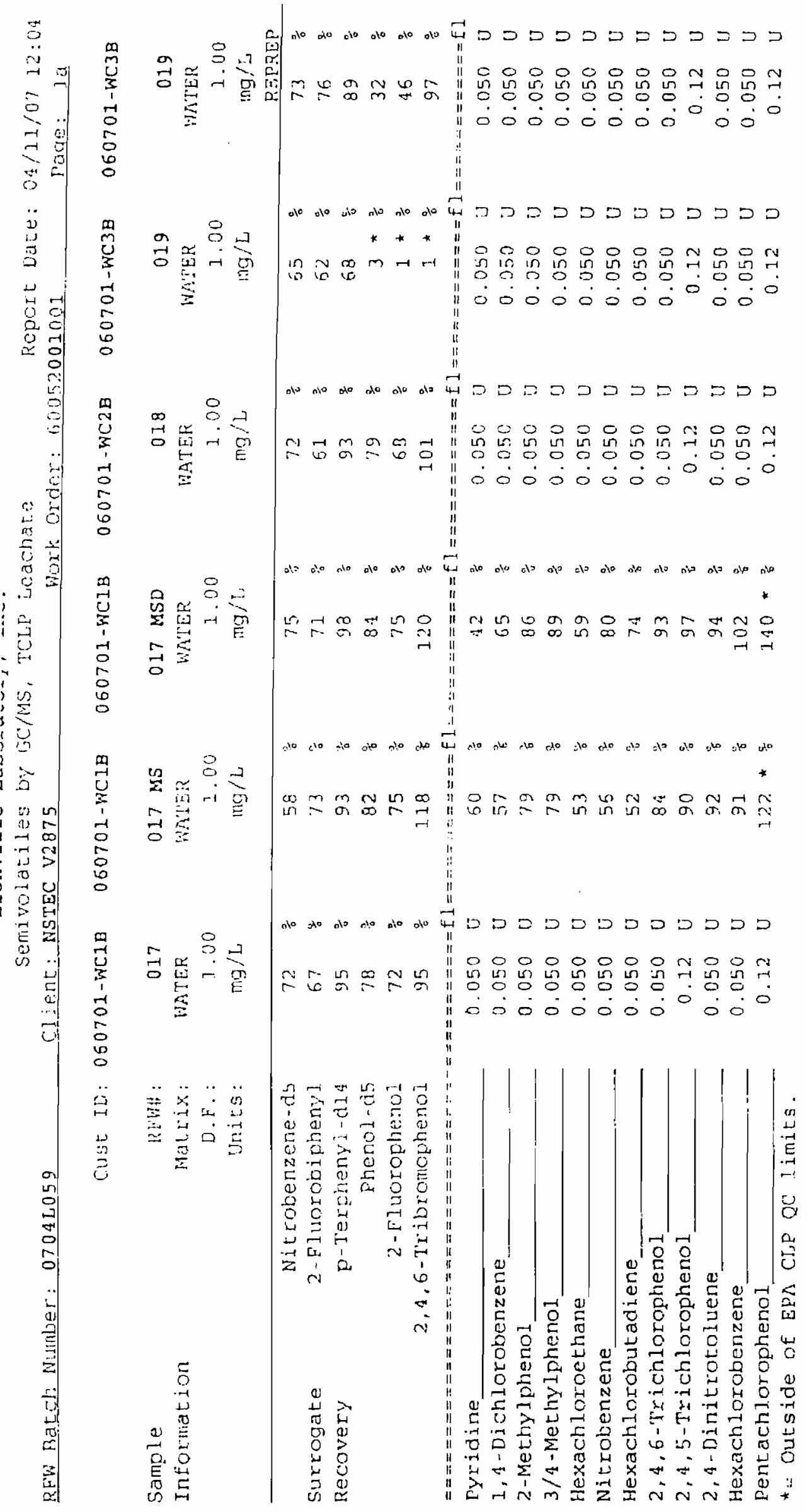




\section{U.S. EPA}

\section{INORGANIC ANALYSES DATA SHEET}

EPA SAMPLE NO.

WC1C

Lab Name: LIONVILIE_LABORATORY

Lab Code: LVLI

Matrix (soil/water): WATER

Ievel (low/med): LOW

o solids:
Contract: 60052

SAS NO.:

Lab Sample ID: 07045059-0̄20

Date Received: 04/03/07

Concentration Units (ug/L or mg/kg ory weight): UG/L_

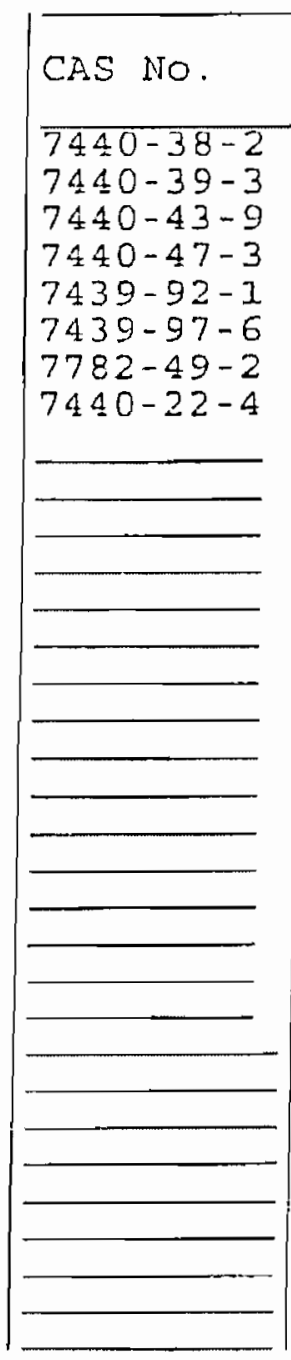

Color Before:

Color After:

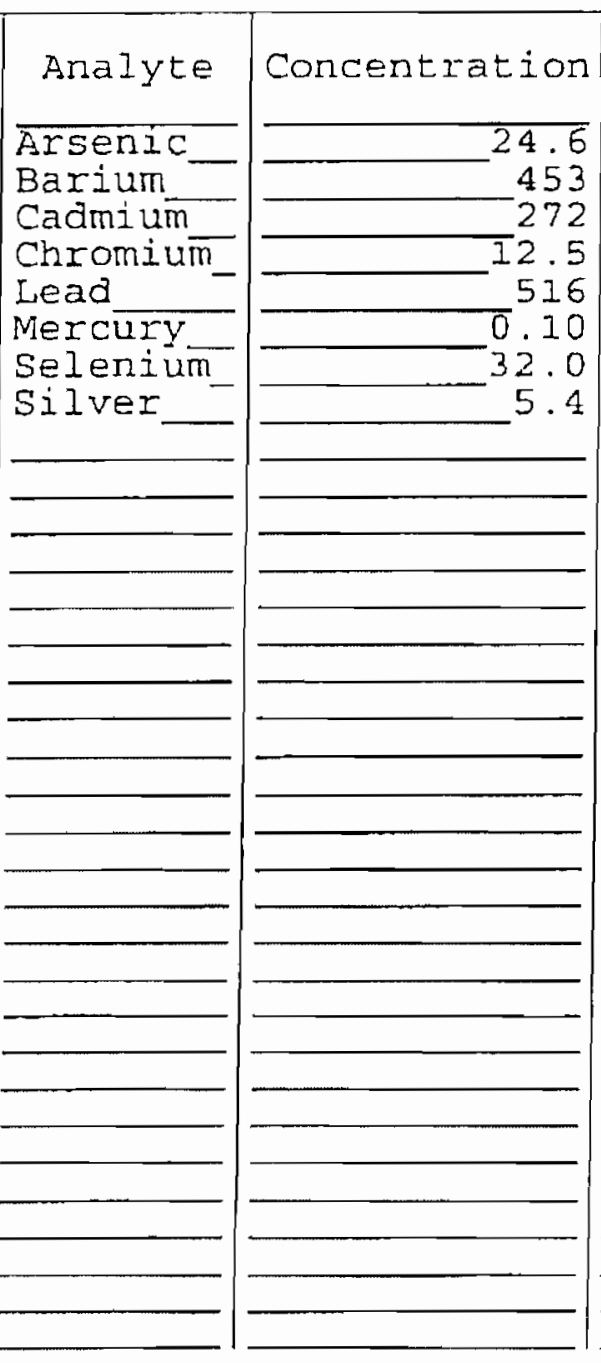

Clarity Before:

Clarity fifter:

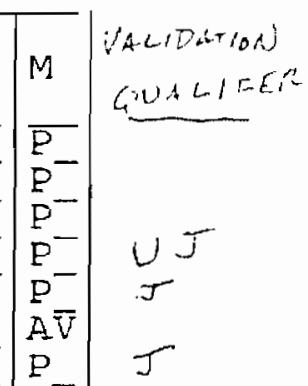

Comments:

$060701-W C 1 C$

TCLP_OF_003 


\section{INORGANIC ANAI ÝSES DATA SHEET}

Lab Name: LIONVILLE_LABORATORY

Lab Code: LVLI

Matrix (soil/water): WATER

Level (low/med):

号 Solids :
Case No.: NSTEC SAS No.:

LOW

$0 \overline{0}$
EPA SAMPLE NO.

WC 2 C

SDG NO.: V2875

Lab Sample ID: $0704 \mathrm{LO59- \overline {0 }}$

Date Received: 04/03/07

Concentration Units (ug/L or $\mathrm{mg} / \mathrm{kg}$ dry weight): UG/L_

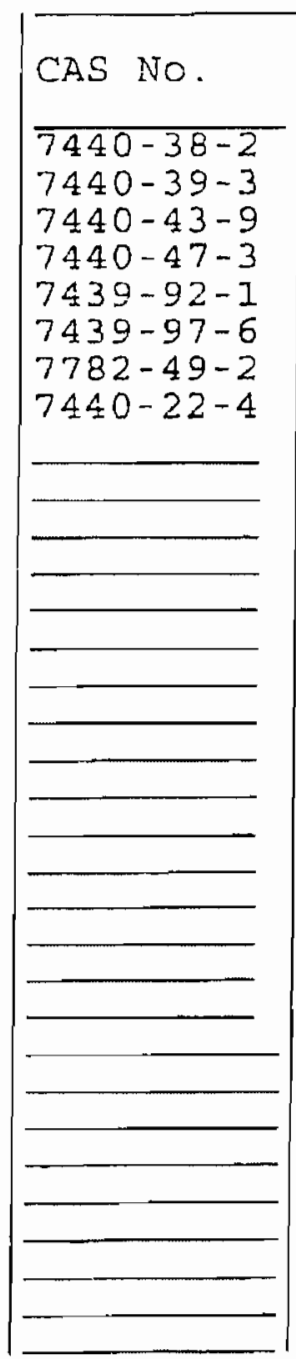

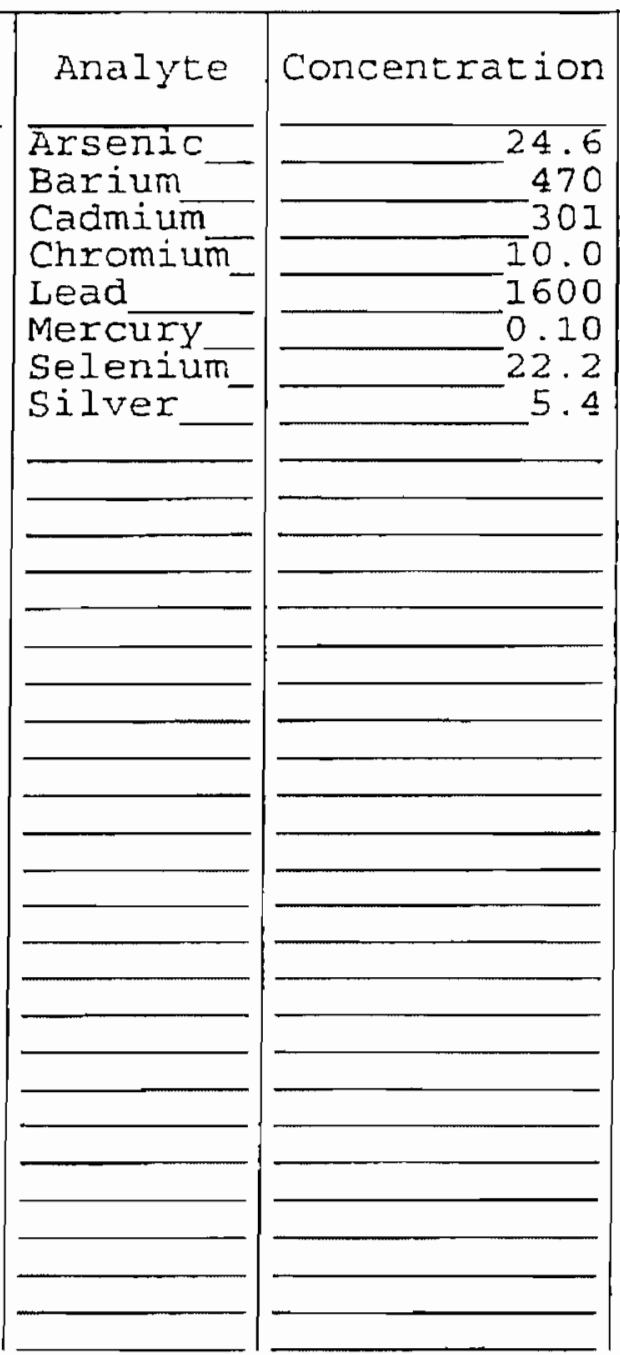

$\mathrm{C}$
$\overline{\mathrm{U}}$
$-\overline{\mathrm{Q}}$
$-\overline{\mathrm{U}}$
$\overline{\mathrm{U}}$
$\overline{-}$
-
-
-

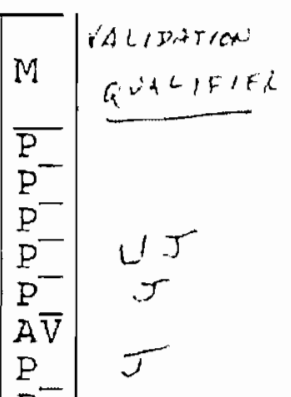

Color Before:

Color After:
Clarity Before:

Clarity fifter:
Texture:

Artifacts:

Comments :

$060701-W C 2 C$

TCI.P_OF_007 
U.S. EPA

1

INORGANIC ANALYSES DATA SHEET
Matrix (soil/water): WATER

Level (low/med): LOW

o Solids :
EPA SAMPLE NO.

Contract: 60052

SAS No.:

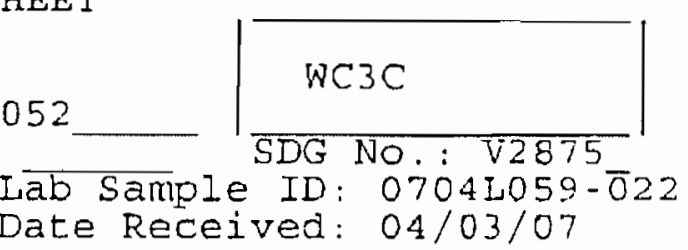
Date Received: 04/03/07
$-0 . \overline{0}$

\section{\begin{tabular}{l}
$\mid$ WC3C \\
\hline SDG No-: V2875 \\
ID: $07041059-022$ \\
ived: $04 / 03 / 07$
\end{tabular}}

Concentration Units (ug/L or $\mathrm{mg} / \mathrm{kg} \mathrm{dry}$ weight): UG/L_

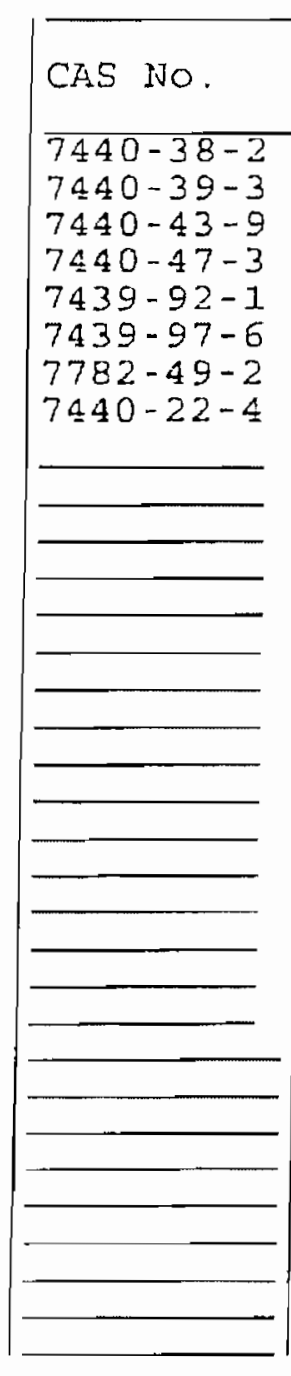

Color Before:

Color After:

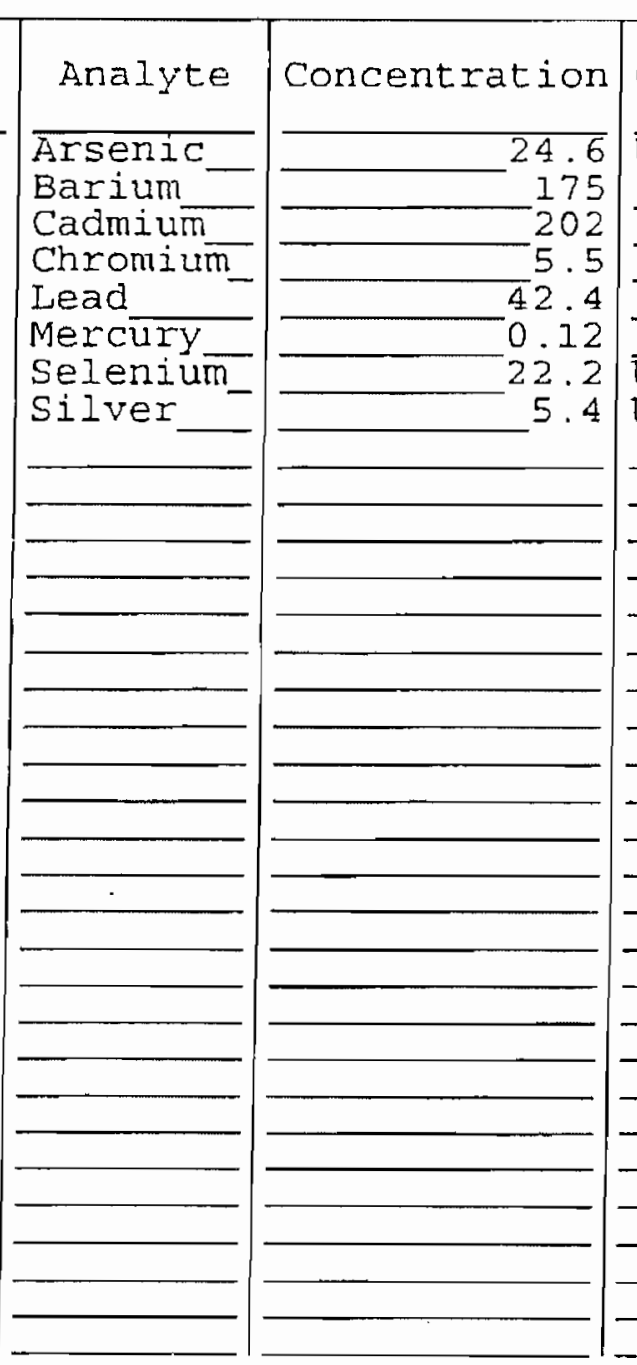

Clarity Before: Clarity After:

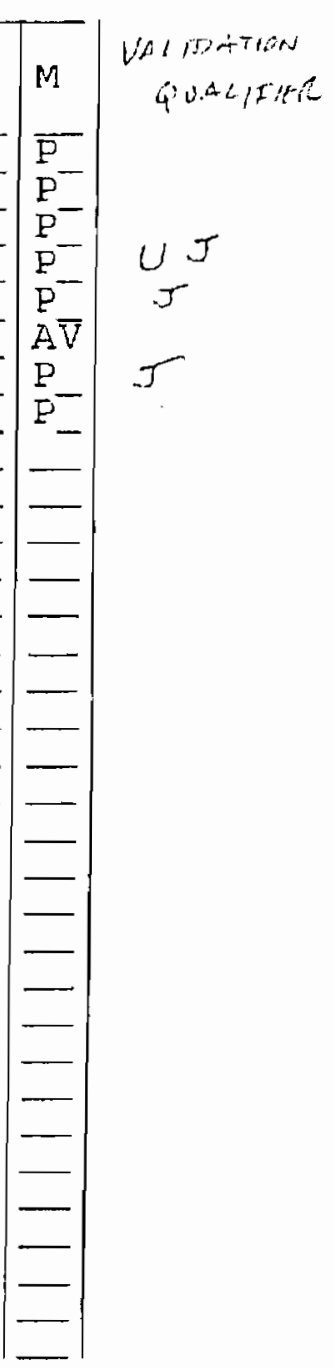

Texture: Artifacts:

\section{Comments :}

$050701-W C 3 C$

TCLP_OF_O11 


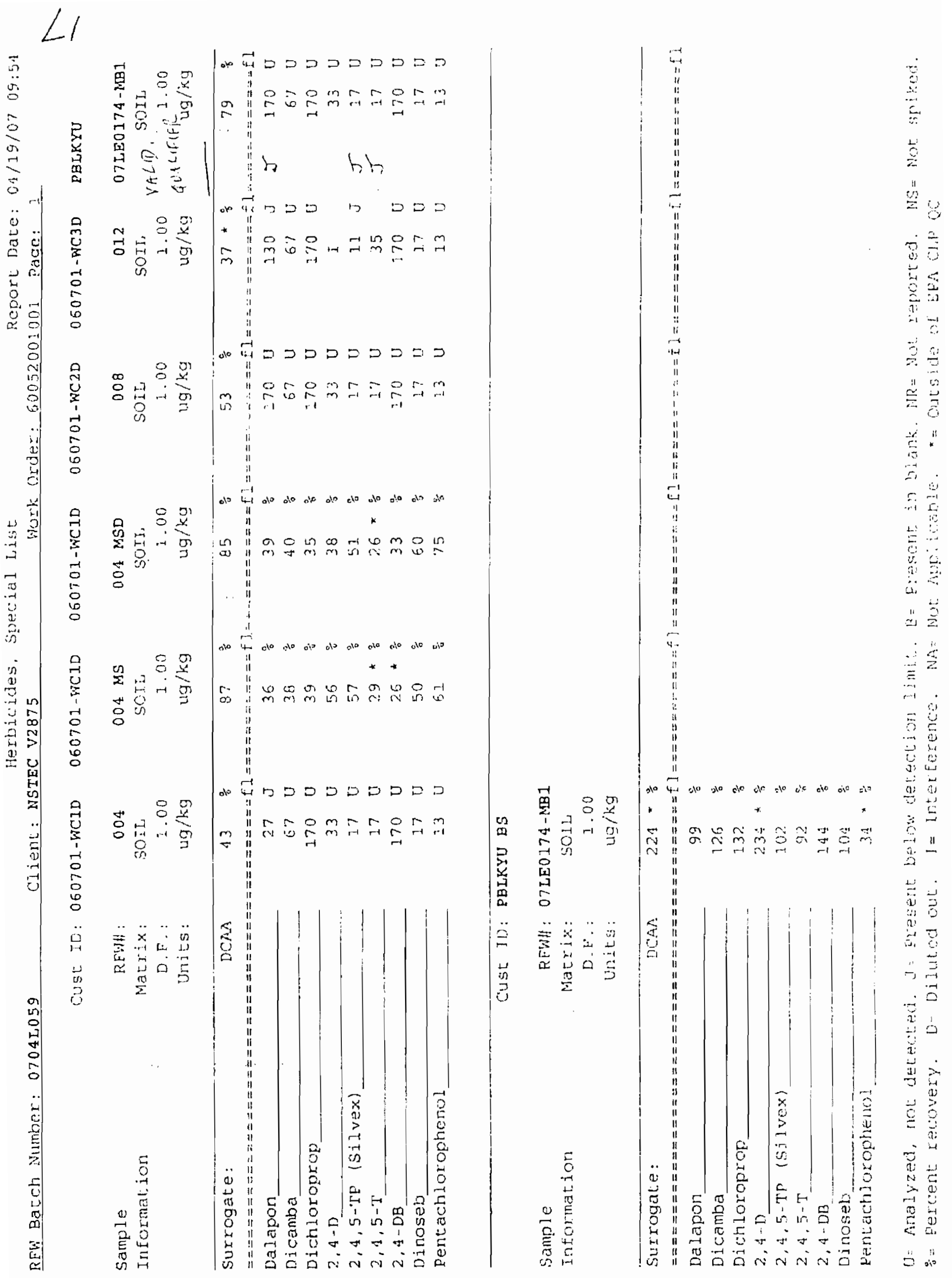




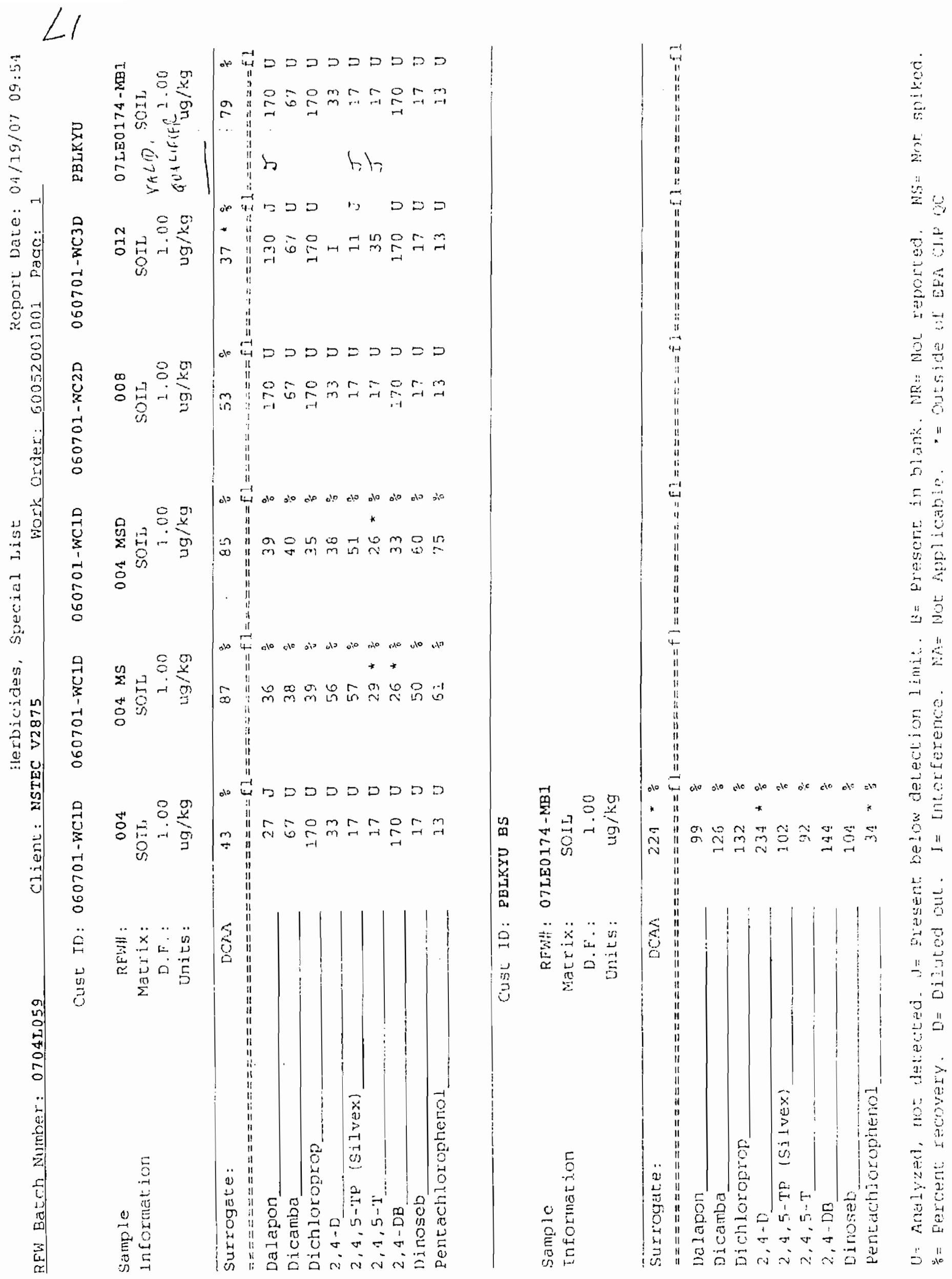




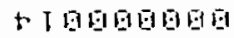

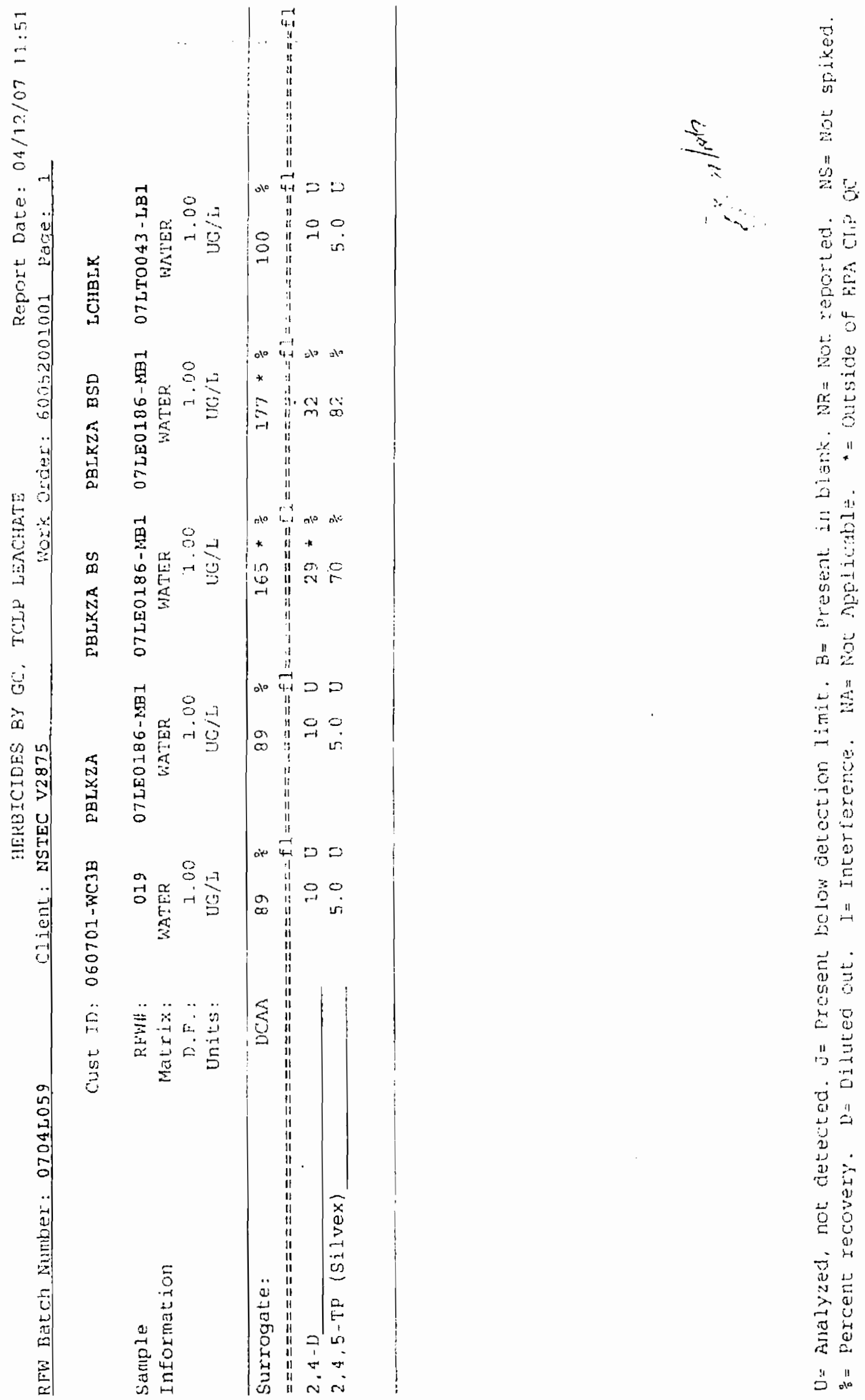




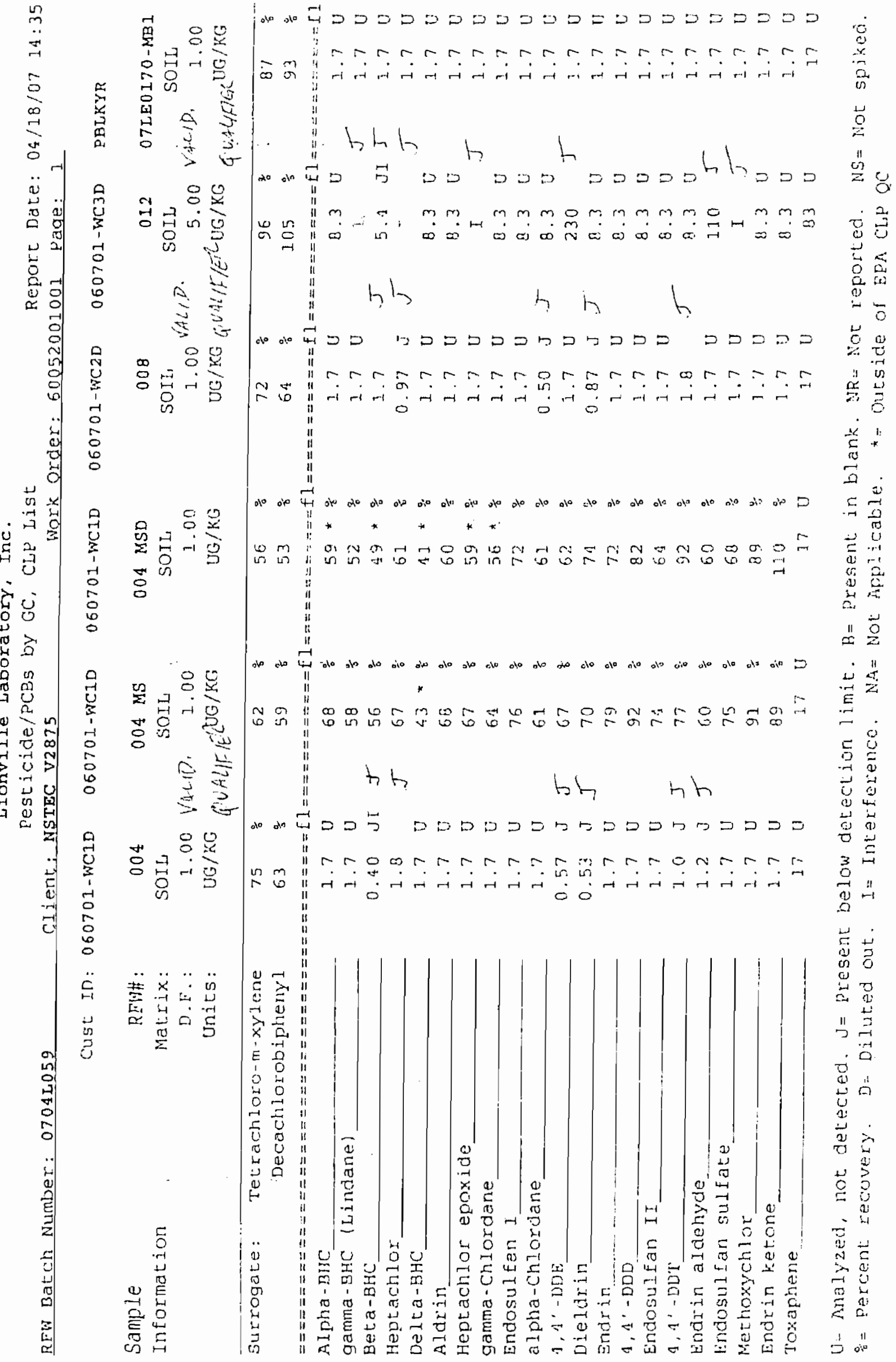




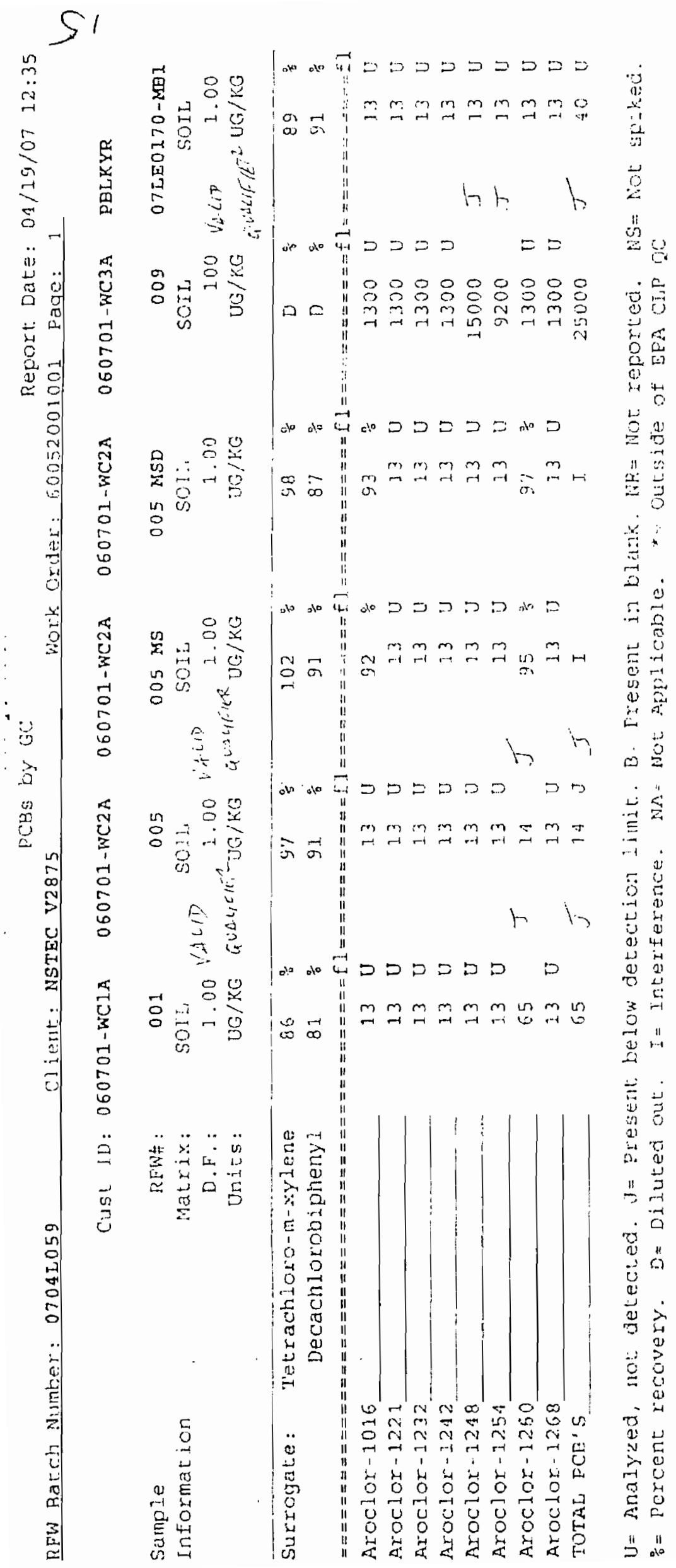


=
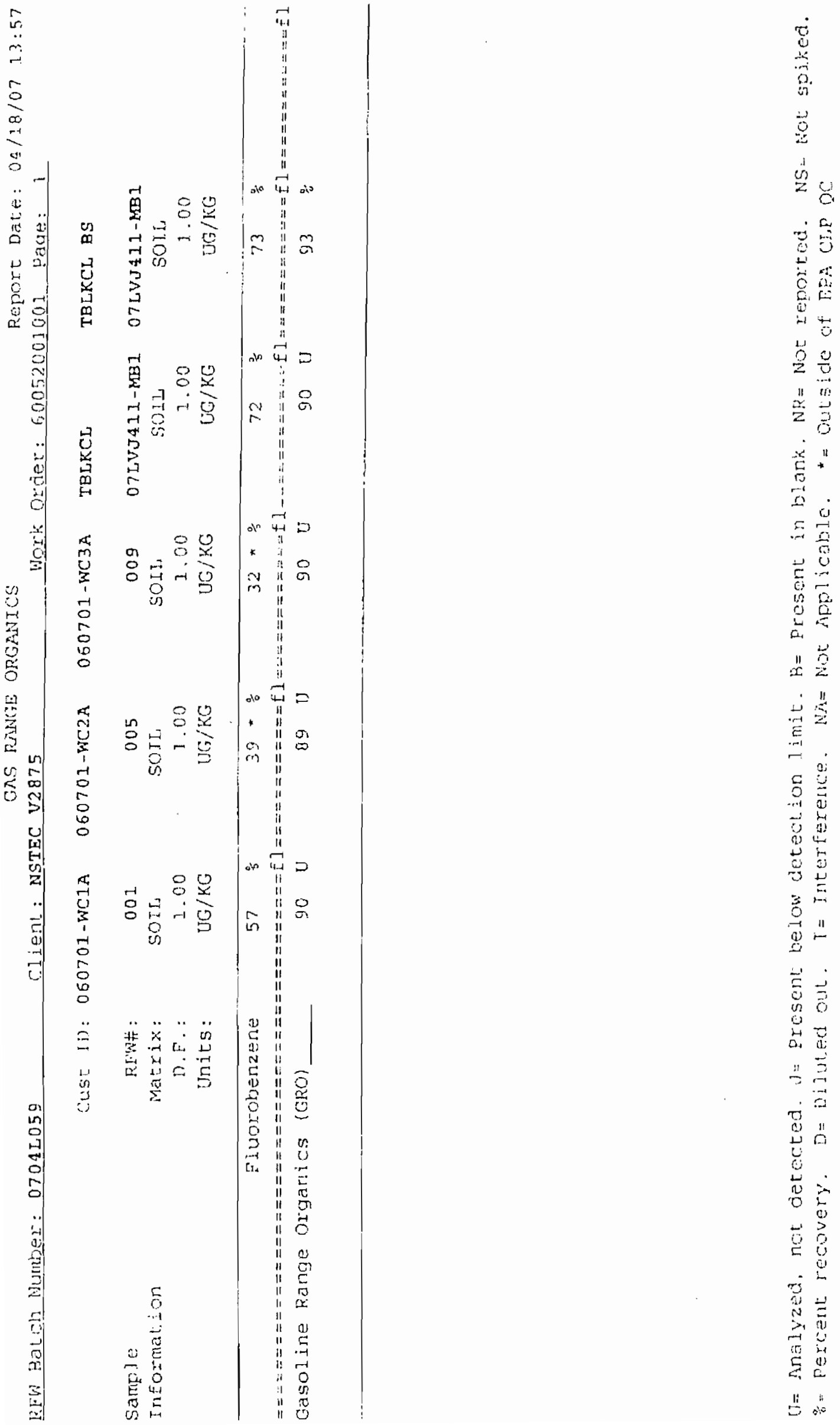


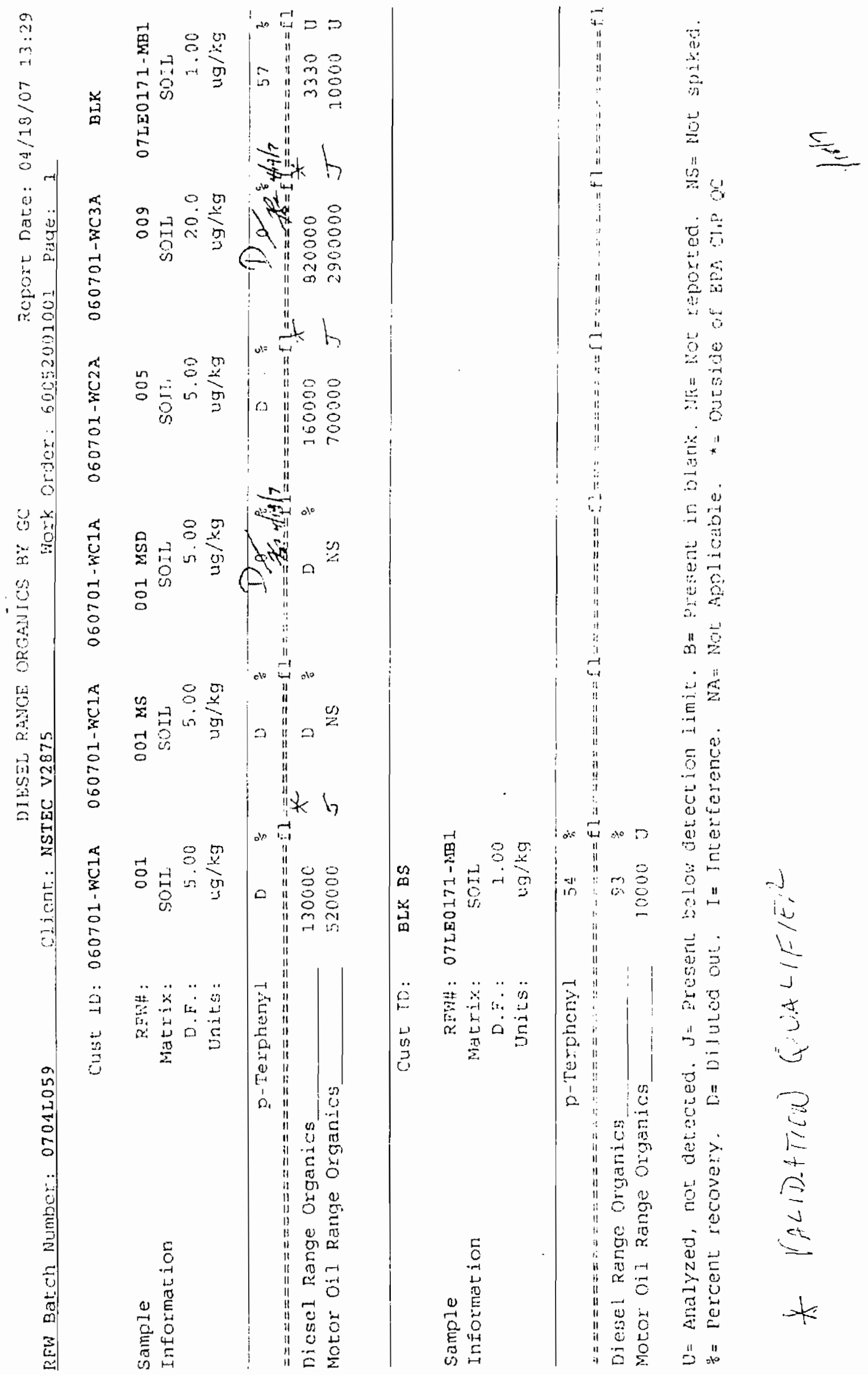




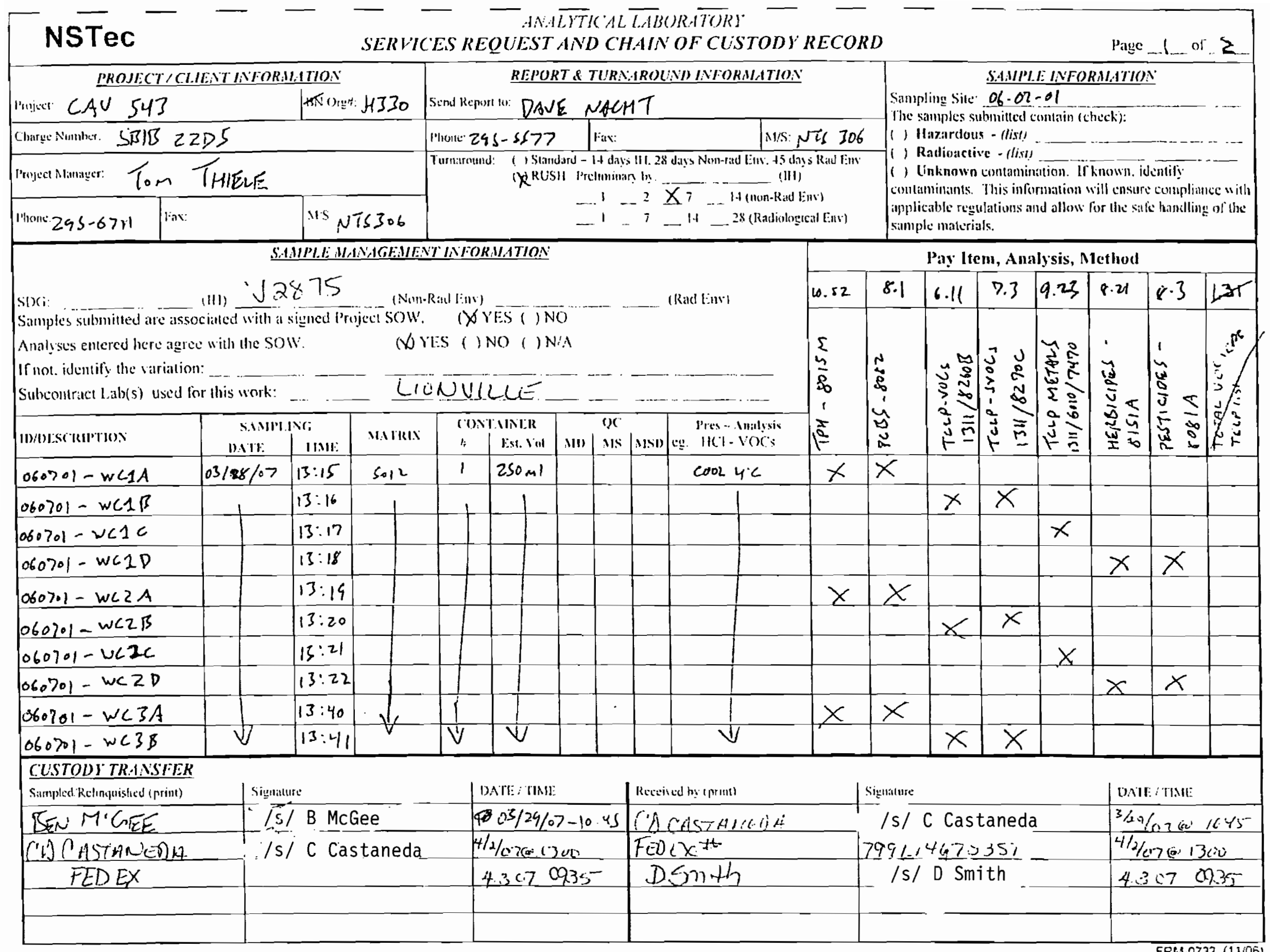




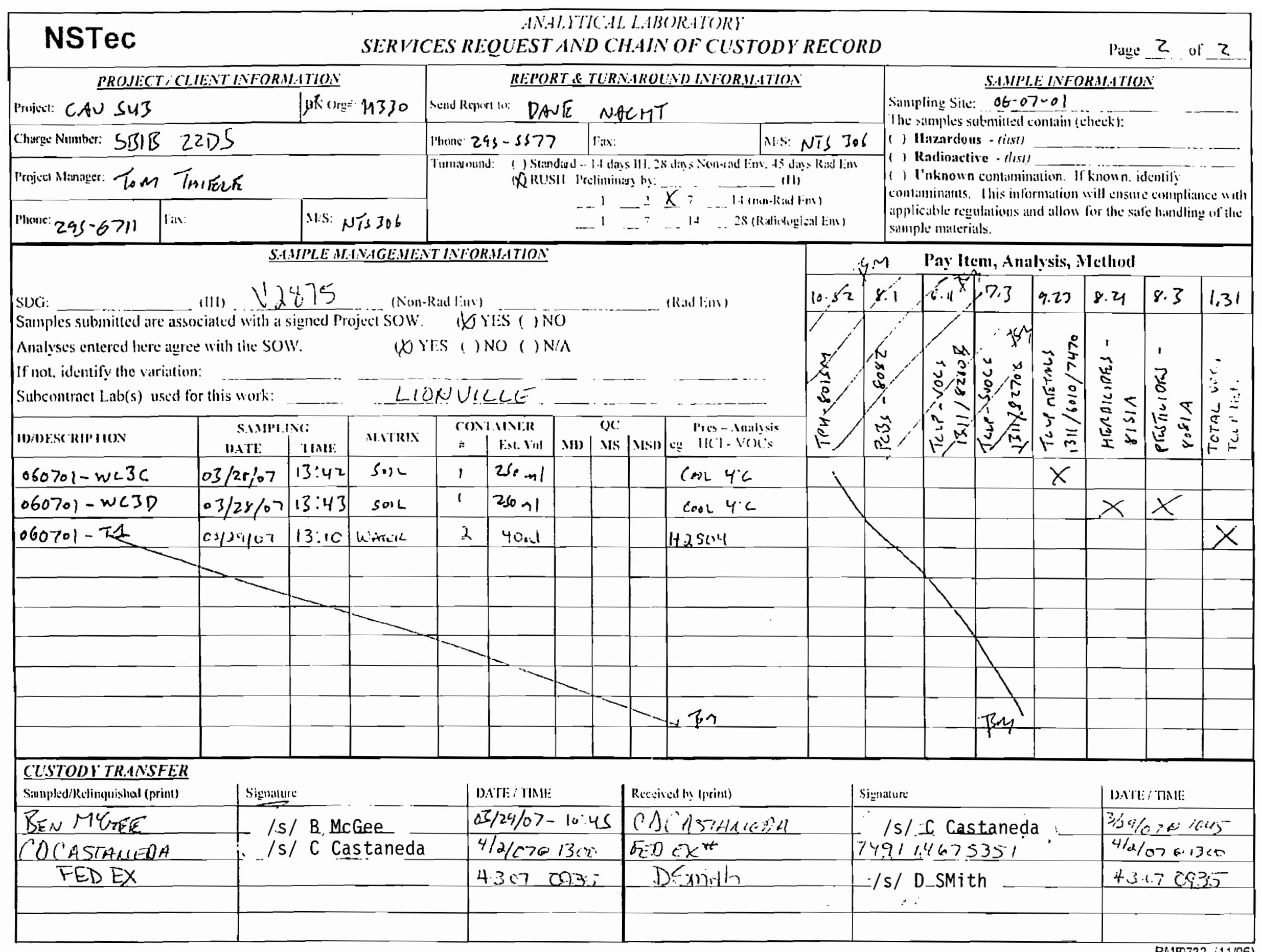


Closure Report - CAU 543

Section: Appendix B

Revision: 0

Date: January 2008

\section{Sample Delivery Group V2876}


Closure Report - CAU 543

Section: Appendix B

Revision: 0

Date: January 2008

\section{THIS PAGE INTENTIONALLY LEFT BLANK}



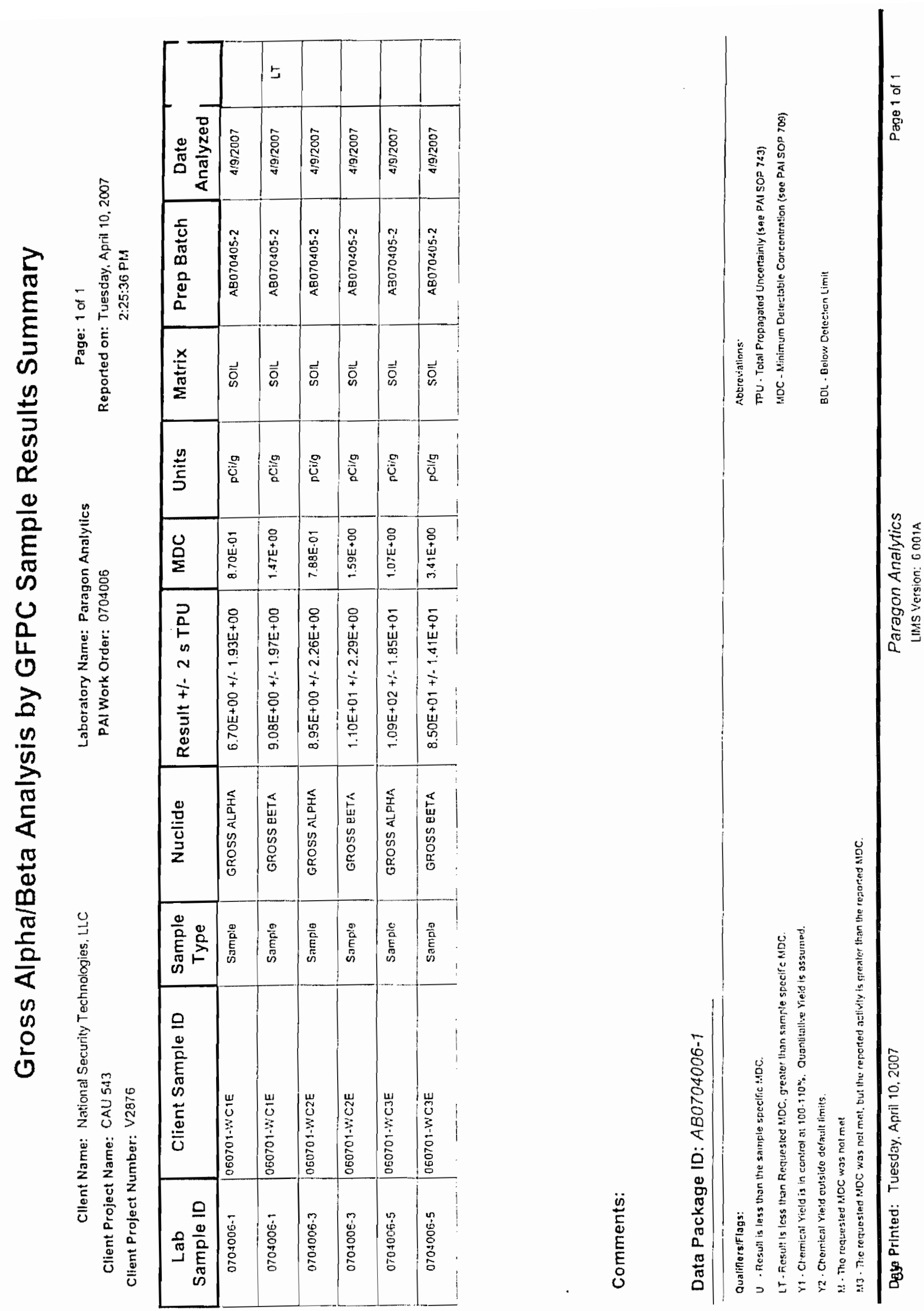


\title{
Gamma Spectroscopy Results
}

\author{
PAl 713 Rev 9 \\ Sample Results
}

Lab Name: Paragon Analytics

Work Order Number: 0704006

Client Name: National Security Technologies, LLC

ClientProject ID: CAU 543 V2876

Field ID: 060701-WC1E

Lab ID: $0704006-1$

LIbrary: LNG_GAM-A.00

Analysis ReqCode: NGS.A.002
Sample Matrix: SOLL

Prep SOP: PAI 739 Rev 8

Date Collected: 28-Mar-07

Date Prepared: 05-Apr-07

Date Analyzed: 09-Apr-07
Prep Batch: GS070405-1

QCBatchID: GS070405-1-1

Run ID: GS070405-1A

Count Time: 30 minutes

Report Basis: Dry Weight
Final Aliquot: $342 \mathrm{~g}$

Prep Basis: Dry Weight

Moisture(\%): NA

Result Units: pCi/g

File Name: $070538 d 06$

\begin{tabular}{|c|c|c|c|c|}
\hline CASNO & Target Nuclide & Result +/- 2 s TPU & MDC & Lab Qualifier \\
\hline $14331-63-0$ & AC- 228 & $2.08 E+00+1-4.82 E-01$ & $5.70 \mathrm{E}-01$ & G \\
\hline $14596-10-2$ & Am-241 & $-8.34 E-01+1-2.22 E+00$ & $3.86 \mathrm{E}+00$ & U.G \\
\hline $14913-49-6$ & $\mathrm{Bi}-212$ & $2.53 \mathrm{E}+00+/-1.60 \mathrm{E}+00$ & $2.31 E+00$ & G.TI \\
\hline $14733-03-0$ & Bi-214 & $1.24 E+00+/-3.45 E-01$ & $3.80 E-01$ & $G, J$ \\
\hline $14762-78-8$ & $\mathrm{Ce}-144$ & $-9.54 \mathrm{E}-02+1-8.93 \mathrm{E}-01$ & $1.53 E+00$ & $U, G$ \\
\hline $10198-40-0$ & Co.60 & $4.73 \mathrm{E}-02+1.9 .66 \mathrm{E}-02$ & $1.68 \mathrm{E} \cdot 01$ & $U, G$ \\
\hline $13967-70-9$ & Cs-134 & $-1.07 \mathrm{E}-01+1-1.74 \mathrm{E}-01$ & $3.19 E-01$ & $U, G$ \\
\hline $10045 \times 97.3$ & $C s-137$ & $1.60 E+01+1-1.98 E+00$ & 2.11E-01 & $G$ \\
\hline $14683-23-9$ & Eu-152 & $5.67 E-02+1-4.21 E-01$ & $7.96 \mathrm{E}-01$ & $U, G$ \\
\hline $15585-10-1$ & Eu.154 & $1.63 E-01+1-9.49 E-01$ & $1.62 E+00$ & $U, G$ \\
\hline $14391-16-3$ & Eu-155 & $2.21 \mathrm{E}-01+/-5.78 \mathrm{E}-01$ & $9.68 \mathrm{E}-01$ & $U, G$ \\
\hline $13966-00-2$ & $K-40$ & $2.50 E+01+1-4.25 E+00$ & $1.63 E+00$ & G \\
\hline $15092-94-1$ & Pb-212 & $2.23 E+00+1-3.96 E-01$ & $341 E-01$ & $G$ \\
\hline $15067-28-4$ & $P b-214$ & $1.19 E+00+1-2.91 E-01$ & $4.08 E-01$ & G,J \\
\hline $14834-73-2$ & $P m-144$ & 5.67E-03+1-8.71E-02 & $1.57 \mathrm{E}-01$ & U.G \\
\hline
\end{tabular}

\section{Comments:}

\footnotetext{
Qualifiers/Flogs:

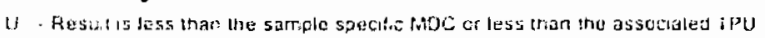

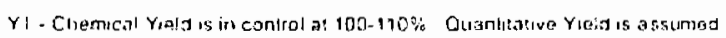

Ya - Cronucal Yielá outside delaull lum!s

LT - Resioli is iess than Requesled MnC greater than sanple sperilic MOC

1.13 - The tequesied MDC was not mel but the fupolted

aellinly is greater than the weotled HDC

M. Tht zquested MOC was nal me:
}

ADsreviations

TPU - Tolal Propagated Uncortanky (see PAI SOP 743)

MUC - Minimum Deteciabie Concentraion (see PAI SOP TOS;

BDL - Butow Deteztion Limit

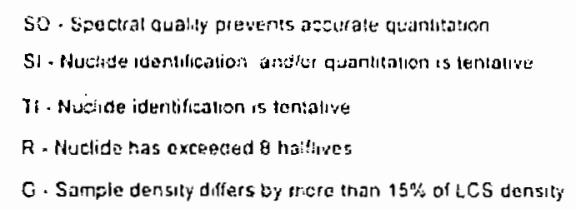

Data Package ID: GS50704006-1

Date Printed: Monday April 09, 2007
Page 1 of 6

LIMIS Version $6001 \mathrm{~A}$ 


\title{
Gamma Spectroscopy Results
}

\author{
PAl 713 Rev 9 \\ Sample Results
}

Lab Name: Paragon Analytics

Work Order Number: 0704006

Client Name: National Securily Technologies, LLC

ClientProject ID: CAU 543 V2876

Field ID: 060701.WC1E

Lab ID: $0704005 \cdot 1$

Library: LNG_GAM-A.0O

Analysis ReqCode: NGS-A-002
Sample Matrix: SOIL

Prep SOP: PAI 739 Rev 8

Date Collected: 28-Mar-07

Date Prepared: 05-Apr-07

Date Analyzed: 09-Apr-07
Prep Batch: GS070405-1

QCBatchID: GS070405-1.1

Run ID: GS070405-1A

Count Time: 30 minutes

Report Basis: Dry Weight
Final Aliquot: $342 \mathrm{~g}$

Prep Basis: Dry Weight

Moisture(\%): NA

Result Units: $p \mathrm{Ci} / \mathrm{g}$

File Name: 070538d06

\begin{tabular}{|c|c|c|c|c|}
\hline CASNO & Target Nuclide & Result +/- 2 s TPU & MDC & Lab Qualifier \\
\hline $14834-74-3$ & $P m-146$ & $1.89 E-01+/ .2 .09 E-01$ & $3.40 \mathrm{E}-01$ & U.G \\
\hline $13967-48-1$ & Ru-106 & $-9.94 \mathrm{E} \cdot 01+1 \cdot 1.02 \mathrm{E}+00$ & $1.96 E+00$ & $U, G$ \\
\hline $14234-35-6$ & Sb-125 & $6.04 E-01+/-3.34 E-01$ & $5.52 E-01$ & G.TI \\
\hline $15065-10-8$ & Th-234 & $1.69 E+01+/-3.84 E+00$ & $4.72 E+00$ & $G$ \\
\hline $14913-50-9$ & TI-208 & $7.37 E-01+/-1.88 E-01$ & $1.91 E-01$ & $G$ \\
\hline $15117-96-1$ & U-235 & $2.25 \mathrm{E}-01+1-8.84 \mathrm{E}-01$ & $1.49 E+00$ & $U, G$ \\
\hline $13982-36-0$ & $Y-88$ & $-6.12 \mathrm{E}-02+/-1.19 \mathrm{E}-01$ & $2.30 E-01$ & $U, G$ \\
\hline
\end{tabular}

\section{Comments:}

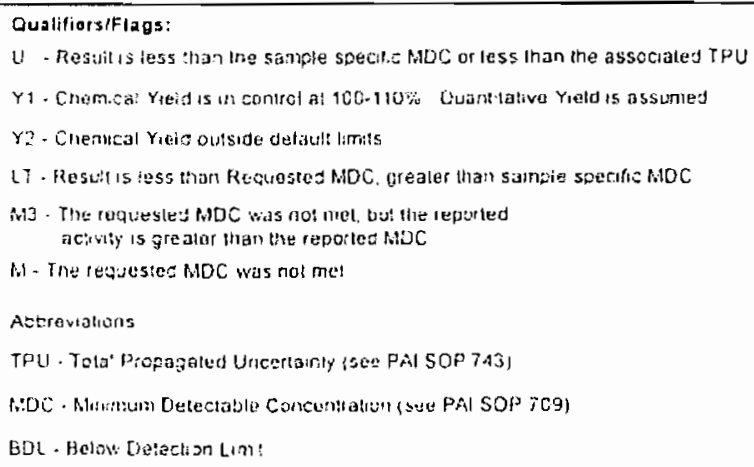

Data Package ID: GSS0704006-1 


\section{Gamma Spectroscopy Results}

\section{PAl 713 Rev 9 \\ Sample Results}

Lab Name: Paragon Analytics

Work Order Number: 0704006

Client Name: Natonal Security Technologies, LLC

ClientProject ID: CAU 543 V2876

Field ID: 050701-WC2E

Lab ID: $0704006-3$

Library: LNG_GAM-A-DO

Analysis ReqCode: NGS.A.002
Sample Matrix: SOIL

Prep SOP: PAI 739 Rev 8

Date Collected: 28-Mar-07

Date Prepared: 05-Apr-07

Date Analyzed: 09-Apr-07
Prep Batch: GS070405-1

QCBatchID: GS070405-1-1

Run ID: GS070405-1A

Count Time: 30 minutes

Report Basis; Dry Weight
Final Aliquot: $354 \mathrm{~g}$

Prep Basis: Dry Weight

Moisture(\%): NA

Result Units: pCing

File Name: 070507d08

\begin{tabular}{|c|c|c|c|c|}
\hline CASNO & Target Nuclide & Result +/- $2 \mathrm{~s}$ TPU & MDC & Lab Qualifier \\
\hline $14331-83-0$ & $A C-228$ & $2.50 E+O 0+1-4.78 E-01$ & $5.17 E \cdot 01$ & $\mathrm{G}$ \\
\hline $14682-66-7$ & A. -20 & 4.35E-02+/- 4.38E-02 & $2.94 \mathrm{E}-02$ & $G, T I$ \\
\hline $14596-10-2$ & $A m-241$ & $1.78 \mathrm{E}-02+/-1.79 \mathrm{E}-01$ & $3.06 \mathrm{E}-01$ & $U, G$ \\
\hline $14913-49-6$ & $\mathrm{Bi}-212$ & $1.85 \mathrm{E}+00+/ .1 .04 \mathrm{E}+00$ & $1.35 E+00$ & $G$ \\
\hline $14733.03-0$ & $\mathrm{Bi}-214$ & $1.18 \mathrm{E}+00+/ .2 .79 \mathrm{E}-01$ & $2.76 E-01$ & $G, J$ \\
\hline $14762-78-8$ & $\mathrm{Ce}-144$ & $-2.30 E-01+1-4.34 E-01$ & $7.80 E-01$ & $U, G$ \\
\hline $10198-40-0$ & Co-60 & $2.45 \mathrm{E}-02+i-7.92 \mathrm{E}-02$ & $1.44 E-01$ & U.G \\
\hline $13967-70-9$ & Cs-134 & $-1.62 E-02+i-6.25 E-02$ & $1.58 E-01$ & $\cup, G$ \\
\hline $10045-97-3$ & Cs-137 & $5.09 \mathrm{E}+00+1-6.87 \mathrm{E}-01$ & $1.49 \mathrm{E}-01$ & $G$ \\
\hline $14683-23-9$ & Eu-152 & $2.51 E-01++/-4.27 E-01$ & $7.28 \mathrm{E}-01$ & $\cup . G$ \\
\hline $15585-10-1$ & $E_{u-15}$ & $-4.03 E-01+1-4.48 E-01$ & $9.34 E-01$ & $U, G$ \\
\hline $14391-16-3$ & Eu-155 & $1.20 E-01+1-2.34 E-01$ & $3.91 E-01$ & $U, G$ \\
\hline $13966-00-2$ & $K-40$ & $2.73 E+01+1-4.42 E+00$ & $1.33 E+00$ & $G$ \\
\hline $15092-94-1$ & $\mathrm{~Pb}-212$ & $2.23 \mathrm{E}+00+1-3.65 \mathrm{E}-01$ & $2.54 E-01$ & G \\
\hline $15067-28-4$ & $\mathrm{~Pb}-214$ & $1.38 E+00+/-2.81 E-01$ & $3.52 E-01$ & G.J \\
\hline
\end{tabular}

\section{Comments:}

\footnotetext{
Oualifiersiflags:

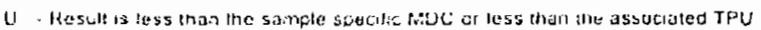

$Y$ : - Cnerrical rield is in contral at $100.110 \%$ Ouantilatwe Yals is assumed

Y2. Chemical Yelu ousido default lumis

$L T$. Hesult is less iran Requested MOC, greater than sample speralic MDC

M3. The tequespled BDC was not mul. Uu' the reported activicy is gee ater than inc reported $\$ D C$

A. The requested MOC was nol mei
}

SO - SDectral gualily prevenls accurate guantitalion

Aztreviations

IFU - Total Propagated Uncertanty (sce PAI SOP 749)

MOC - Ainumum Dolectabie Concentration (ser PAl SOP 709)

BOL - Berow Detection LImit

Data Package ID: GSS0704006-1 


\section{Gamma Spectroscopy Results}

\section{PAl 713 Rev 9 \\ Sample Results}

Lab Name: Paragon Analytics

Work Order Number: 0704006

Client Name: National Security Technologies, LLC

ClientProject ID: CAU 543 V2876

\begin{tabular}{|ll|}
\hline Field ID: & $060701-$ WC2E \\
Lab ID: & $0704006-3$ \\
\hline
\end{tabular}

Library: LNG_GAM-A-OO Analysis ReqCode: NGS.A.002
Sample Matrix: SOIL

Prep SOP: PAI 739 Rev 8

Date Collected: $28 \cdot$ Mar-07

Date Prepared: 05-Apr-07

Date Analyzed: 09-Apr-07
Prep Batch: GS070405-1

QCBatchID: GS070405-1-1

Run ID: GS070405-1A

Count Time: 30 minules

Report Basis: Dry Weight
Final Aliquot: $354 \mathrm{~g}$

Prep Basis: Dry Weight

Moisture $(\%)$ : NA

Result Units: $\mathrm{pCi} / \mathrm{g}$

File Name: $070507 \mathrm{d08}$

\begin{tabular}{|c|c|c|c|c|}
\hline CASNO & Target Nuclide & Result +/- $2 \mathrm{~s}$ TPU & MDC & Lab Qualifier \\
\hline $14834-73-2$ & $P m-144$ & $-2.00 E-02+1 \cdot 7.63 E-02$ & $1.43 E-01$ & $U, G$ \\
\hline $14834-74-3$ & Pm-146 & $-4.76 E-02+1-1.11 E-01$ & $2.04 \mathrm{E}-01$ & U.G \\
\hline $13967-48.1$ & Ru-106 & $0 \mathrm{E}+00+1.6 .76 \mathrm{E}-01$ & $1.24 E+00$ & $U, G$ \\
\hline $14234-35-6$ & Sb-125 & 4.27E-01+/-2.65E-01 & 4.60E-01 & $\cup, G$ \\
\hline $15065-10 \cdot 8$ & Th-234 & $4.45 E+00+1 \cdot 1.11 E+00$ & $1.77 E+00$ & $G$ \\
\hline $14913-50-9$ & $\mathrm{~T} 1.208$ & $7.08 E-01+/-1.62 E-01$ & $1.42 \mathrm{E}-01$ & $G$ \\
\hline $15117-96-1$ & U-235 & $-1.25 \mathrm{E}-01+1.4,44 \mathrm{E}-01$ & $7.85 \mathrm{E}-01$ & $U, G$ \\
\hline $13982 \cdot 36-0$ & $Y .88$ & $1.01 \mathrm{E}-01+1.9 .05 \mathrm{E}-02$ & $1.38 E-01$ & $U, G$ \\
\hline
\end{tabular}

\section{Comments:}

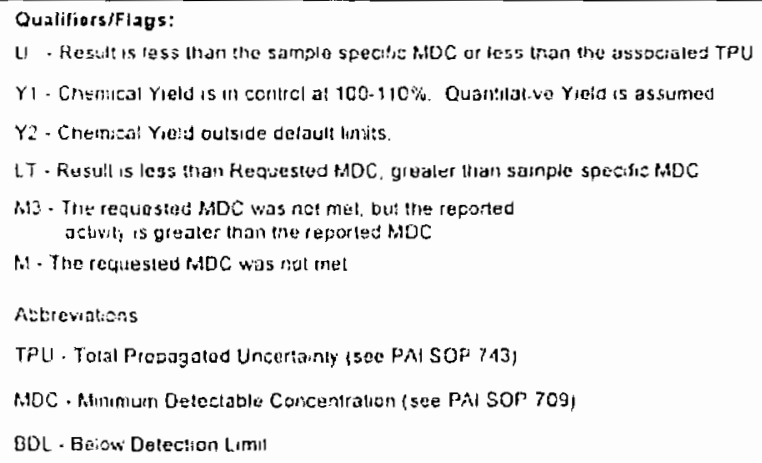

Data Package ID: GSS0704006-1 


\title{
Gamma Spectroscopy Results
}

\author{
PAl 713 Rev 9 \\ Sample Results
}

Lab Name: Paragon Analytics

Work Order Number: 0704006

Client Name: National Security Technologies, LLC

ClientProject ID: CAU 543 V2876

Field ID: 060709-WC3E

Lab ID: $0704005-5$

Library: LNG_GAM-A-OO

Analysis ReqCode: NGS-A.002
Sample Matrix: SOIL

Prep SOP: PAI 739 Rev 8

Date Collected: 28-Mar.07

Date Prepared: 05-Apr-07

Date Analyzed: 09-Apr-07
Prop Batch: GS070405-1

QCBatchID: GS070405-1-1

Run 1D: GS070405-1A

Count Time: 30 minutes

Report Basis: Dry Weight
Final Aliquot: $266 \mathrm{~g}$

Prep Basis: Dry Weight

Moisture(\%): NA

Result Units: $p \mathrm{Ci} / 9$

File Name: $070563 \mathrm{~d} 09$

\begin{tabular}{|c|c|c|c|c|}
\hline CASNO & Target Nuclide & Result +1- 2 s TPU & MDC & Lab Qualifier \\
\hline $14331-83-0$ & $A C-228$ & $1.44 \mathrm{E}+00+1-4.99 \mathrm{E}-01$ & $9.01 E-01$ & $G$ \\
\hline $14595-10-2$ & $A m-241$ & $2.66 E+01+/-3.92 E+00$ & $2.62 E+00$ & $G$ \\
\hline $14733-03-0$ & $B-214$ & $1.40 \mathrm{E}+00+1-3.96 \mathrm{E}-01$ & $5.17 \mathrm{E}-01$ & G.J \\
\hline $14762-78-8$ & $\mathrm{Ce}-144$ & $-6.10 \mathrm{E}-01+1-8.54 \mathrm{E}-01$ & $1.51 E+00$ & $U, G$ \\
\hline $10198-40-0$ & Co-60 & $1.32 \mathrm{E}+00+1-2.48 \mathrm{E}-01$ & $2.29 \mathrm{E}-01$ & G \\
\hline $13967.70-9$ & Cs-134 & $-4.50 \mathrm{E}-02+/-1.31 \mathrm{E}-01$ & $2.38 \mathrm{E}-01$ & $U, G$ \\
\hline $10045-97-3$ & Cs -137 & $2.12 \mathrm{E}+01+/ .2 .60 \mathrm{E}+00$ & $2.84 E-01$ & G \\
\hline $14683-23-9$ & Eu-152 & $2.62 \mathrm{E}-01+/-533 \mathrm{E}-01$ & $9.35 E-01$ & $U, G$ \\
\hline $15585-10-1$ & Eu-154 & $-9.28 \mathrm{E}-01+/ .1 .29 \mathrm{E}+00$ & $2.48 E+00$ & $U, G$ \\
\hline $14391-16-3$ & Eu-155 & $2.29 \mathrm{E}-01+/-5.60 \mathrm{E}-01$ & $9.38 E-01$ & $U, G$ \\
\hline $13966-00-2$ & $K-40$ & $215 E+01+/-4.25 E+00$ & $2.41 E+00$ & $G$ \\
\hline $15100-28-4$ & $\mathrm{~Pa}-234 \mathrm{~m}$ & $1.11 E+02+1-3.67 E+01$ & 4. $13 E+01$ & $\mathrm{G}$ \\
\hline $15092-94-1$ & $\mathrm{~Pb}-212$ & $1.56 E+00+1 \cdot 3.66 E-01$ & $4.22 E-01$ & $G$ \\
\hline $15067-28-4$ & Pb-214 & $1.20 \mathrm{E}+00+/-3.78 \mathrm{E}-01$ & $5.85 E-01$ & $G, J$ \\
\hline $14834-73-2$ & $\mathrm{Pm}-144$ & $2.62 \mathrm{E}-02+/ \cdot 1.23 \mathrm{E}-01$ & 2.16E-01 & U,G \\
\hline
\end{tabular}

\section{Comments:}

\footnotetext{
Qualifiers/Flags:

$U$. Result is toss tran the sariple spectl.c p.10C or loss than tha as sosinea TPu

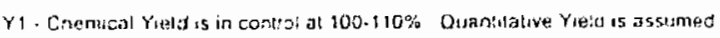

Y2. Chem:al Yield outside dotaull litrils

L7 - Resull us less than Roquested MDC. greater than sampie sperific MDC

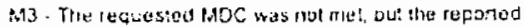

activity is greater than the reporice MDC

in. The requesied MDC was nei me:

Avorevaltens

TPU - Tolel Propagated Uncenarity (see PAI SOP 743)

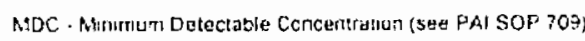

BuL - Betow betectien Limt
}

SO - Spiecris! gually' prevents occurate quan!tution

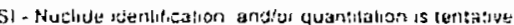

Data Package ID: GSS0704006-1 


\title{
Gamma Spectroscopy Results
}

\author{
PAl 713 Rev 9 \\ Sample Results
}

Lab Name: Paragon Analytics

Work Order Number: 0704006

Client Name: National Security Technologies, LLC

ClientProject ID: CAU 543 V2876

Field ID: 060701-WC3E

Lab ID: $0704006-5$

Library: LNG_GAM-A.00 Analysis ReqCode: NGS-A.002
Sample Matrix: SOIL Prep SOP: PAI 739 Rev 8

Date Collected: 28-Mar-07

Date Prepared: 05-Apr-07 Date Analyzed: 09-Apr-07
Prep Batch: GS070405-1

QCBatchID: GS070405-1-1

Run ID: GS070405-1A

Count Time: 30 minutes

Report Basis: Dry Weighl
Final Aliquot: $266 \mathrm{~g}$

Prep Basis: Dry Weight

Moisture(\%): NA

Result Units: pCi/g

File Name: $070563 d 09$

\begin{tabular}{|c|c|c|c|c|}
\hline CASNO & Target Nuclide & Result +/- 2 s TPU & MDC & Lab Qualifier \\
\hline $14834-74-3$ & $P \pi 1-146$ & $-9.54 E-02+1-2.45 E-01$ & 4.31E-01 & $\cup, G$ \\
\hline $13967-48-1$ & Ru-106 & $-2.66 \mathrm{E}-01+/-1.23 \mathrm{E}+00$ & $2.24 E+00$ & $U, G$ \\
\hline $14234-35-6$ & Sb-125 & $3.06 \mathrm{E}-02+/ .5 .06 \mathrm{E}-01$ & $8.70 E-01$ & $U, G$ \\
\hline $15065-10-8$ & Th-234 & $6.83 E+01+1-9.34 E+00$ & $5.67 E+00$ & $G$ \\
\hline $14913-50-9$ & $\mathrm{Tl}-208$ & $4.11 E-01+/-1.89 E-01$ & $2.65 \mathrm{E}-01$ & $G$ \\
\hline $15117-96-1$ & U.235 & $9.11 \mathrm{E}-01+/-8.85 \mathrm{E}-01$ & $1.43 E+00$ & U.G \\
\hline $13982-36-0$ & $Y-88$ & $4.65 E-02+i-1.36 E-01$ & $2.37 E-01$ & $U, G$ \\
\hline
\end{tabular}

\section{Comments:}

Qualifiors/Flags:

$U$. Resuli is less llian trit satrele siocitio MDC or less than the assosiatcd TPU

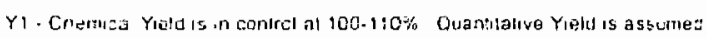

$Y 2$. Chemica: Yind nutside detaul? lim:ts

LT . Resull is less Inall Requested MOC. grealer Ihan sample specific MOC

M3. Ine requesied MDC was not enet the the reportud aclivily is groaier Mari the reperted kibic

A. The requested ADC was not mel

Aubraviations

TPU . Toto! Propagated Uncertarnty \{see PAI SOP 743 !

MOC - Minimum Detectatlu Concentratien (see PAI SOP 709)

$B D L+B a$ ses Delection LImı

\section{Data Package ID: GSS0704006-1}

$$
\begin{aligned}
& \text { Paragon Analytics } \\
& \text { LIMS Version } 6001 \mathrm{~A}
\end{aligned}
$$



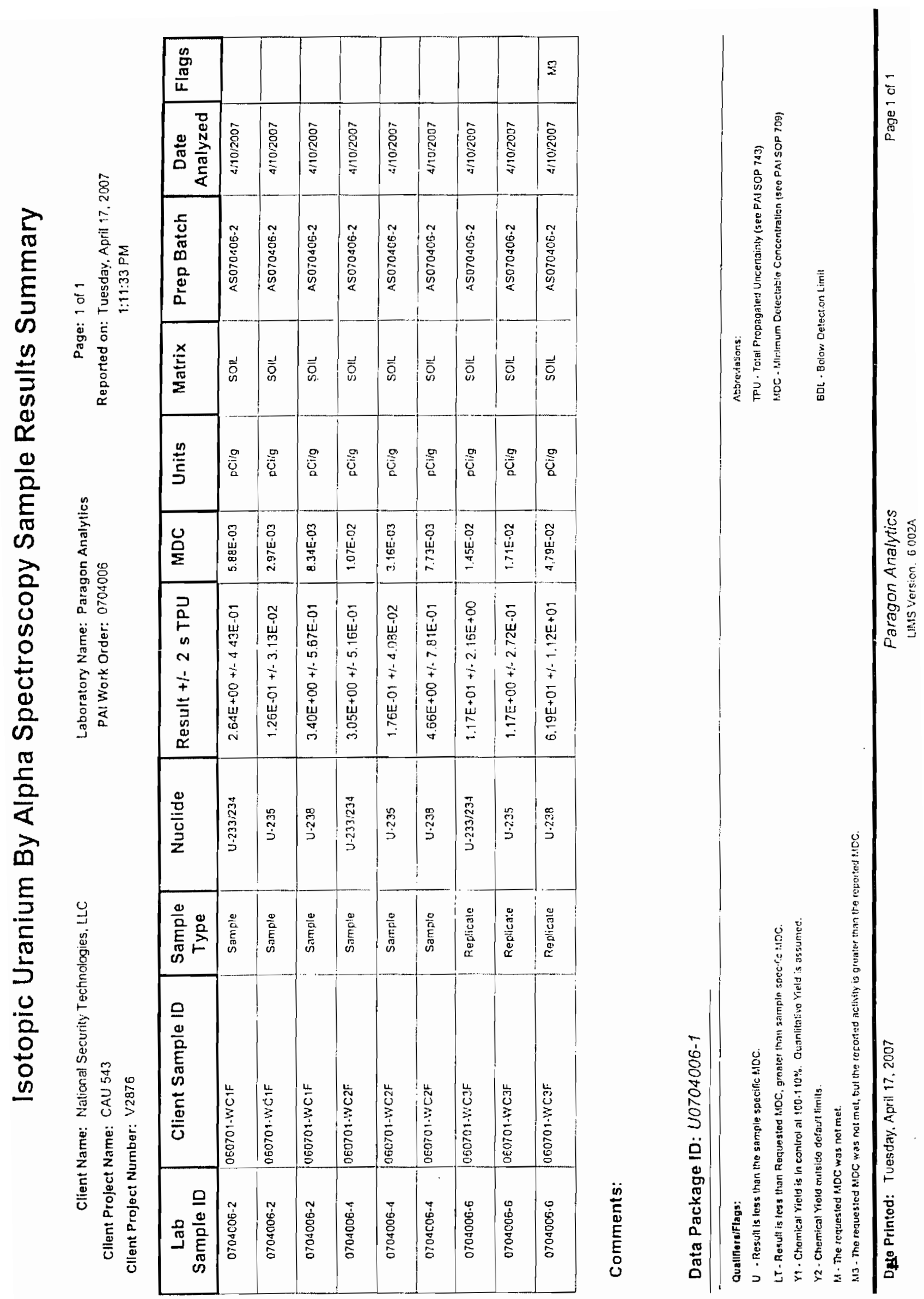

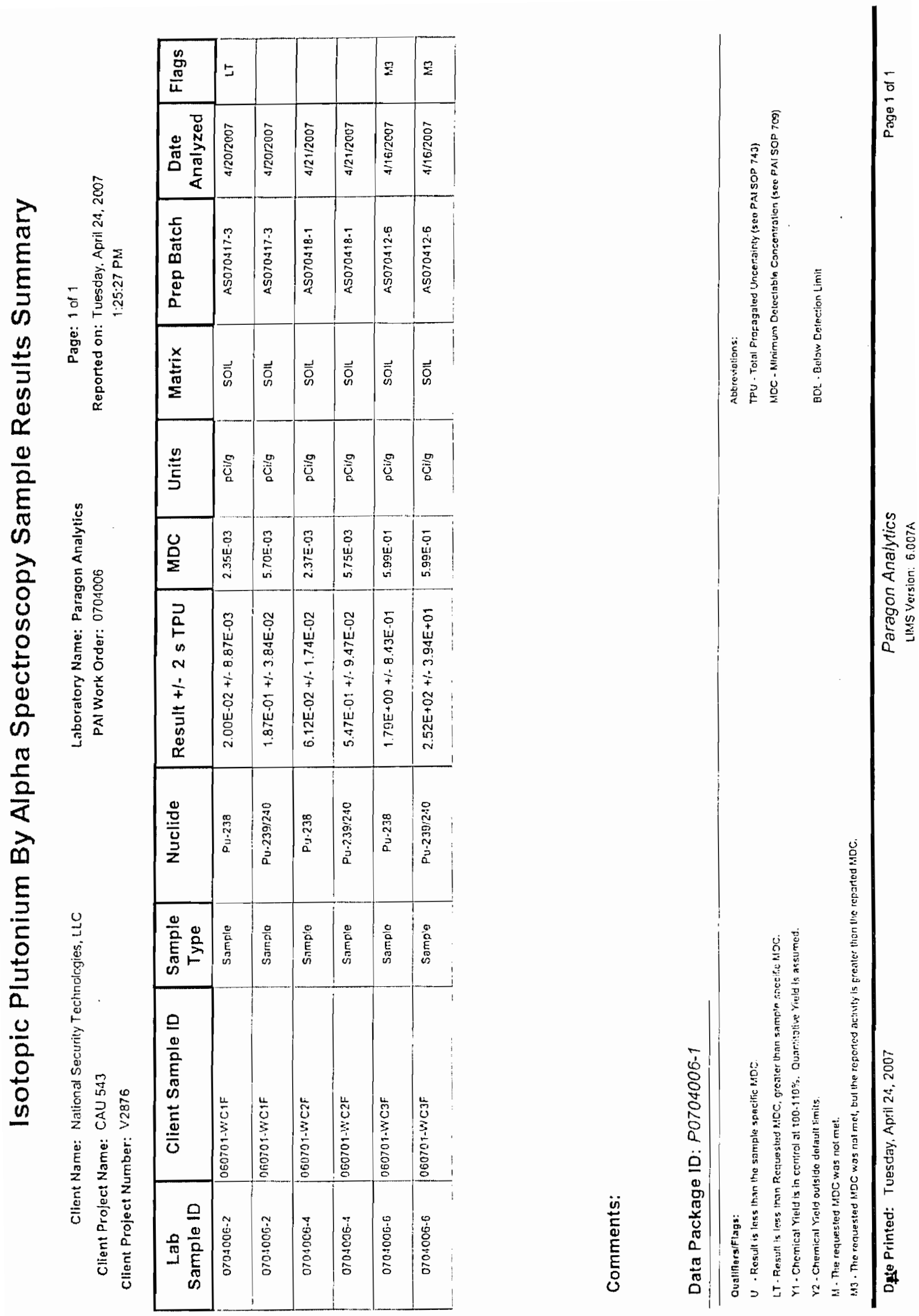


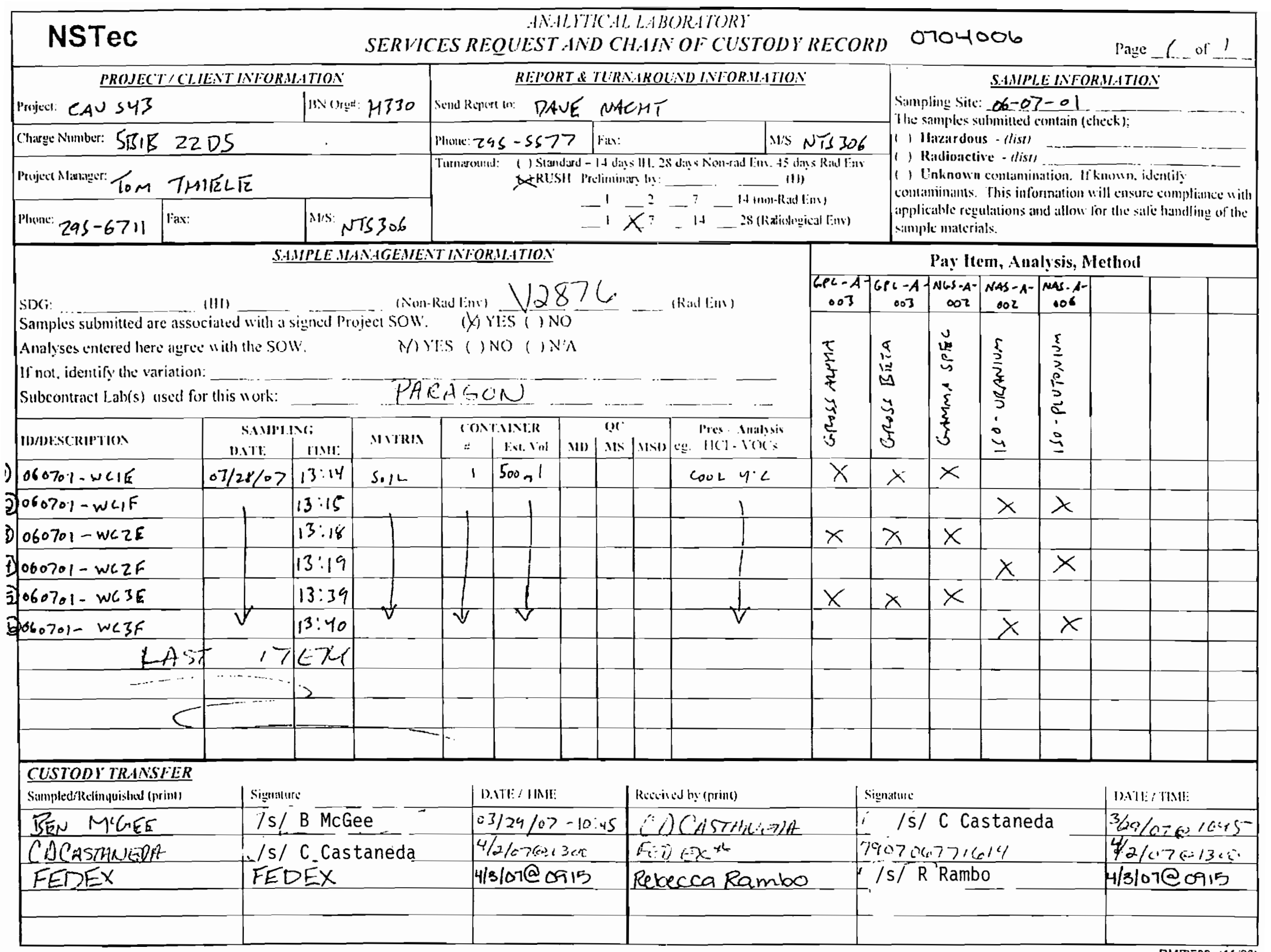


Closure Report - CAU 543

Section: Appendix B

Revision: 0

Date: January 2008

Sample Delivery Group V2877 
Closure Report - CAU 543

Section: Appendix $B$

Revision: 0

Date: January 2008

THIS PAGE INTENTIONALLY LEFT BLANK 


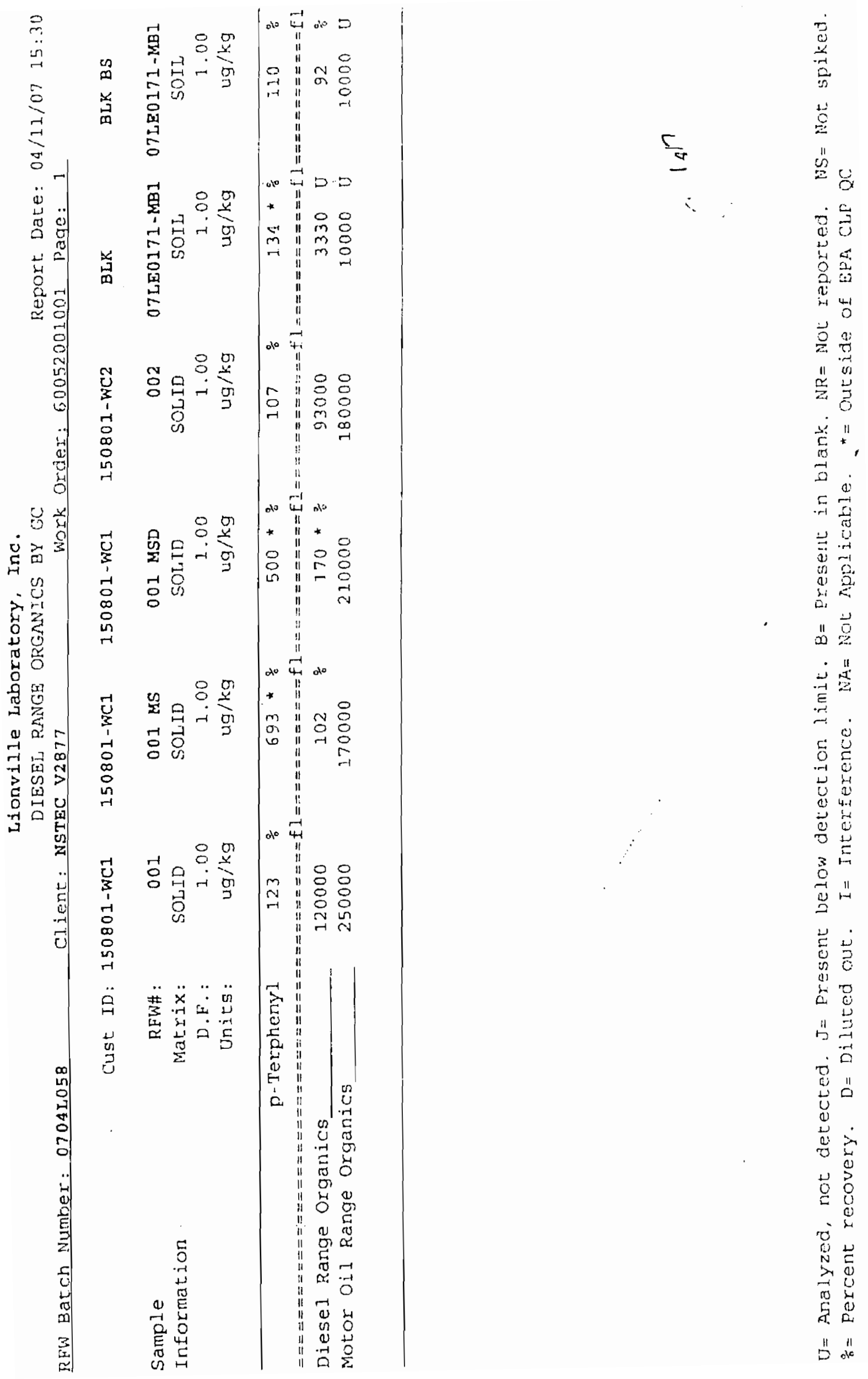




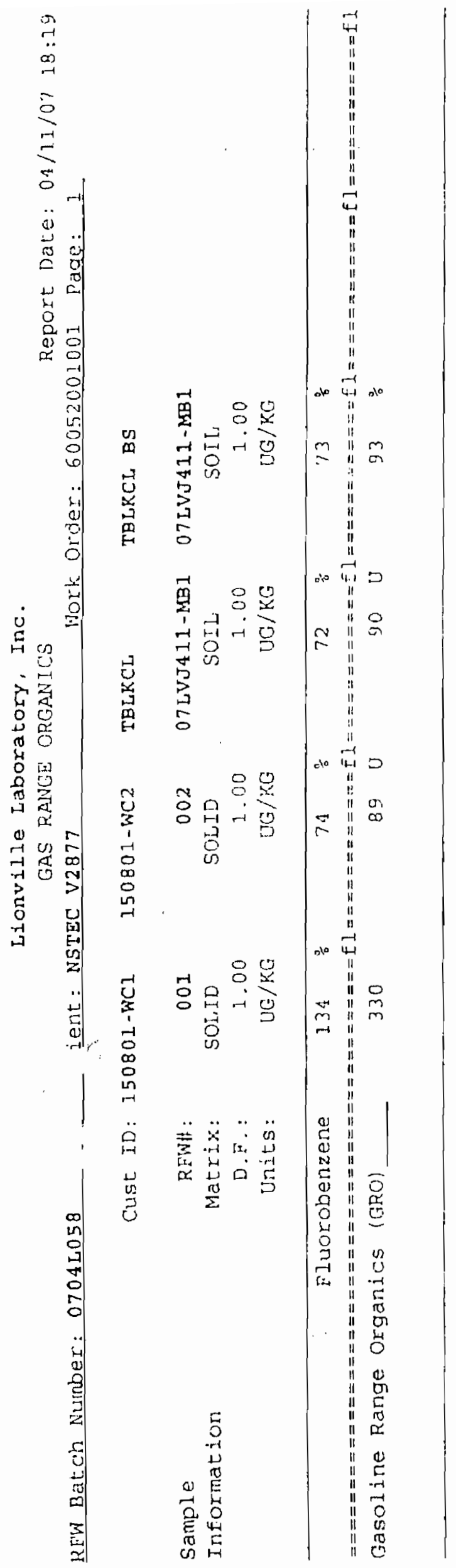

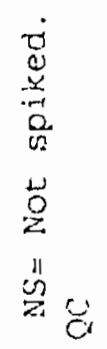

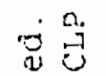

点告

क्ष

Dे

2.

资

资

드."

$\rightarrow$

S.

동

ᄂ

要

\%

近

苍:

is

-

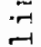

$5 \stackrel{0}{0}$

-

य)

11

C

3

i:

2

苛哇

a

is 0

1)

25

or

몀

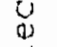

崩它

岂总

5

d

$N$

त्ञ

II) 


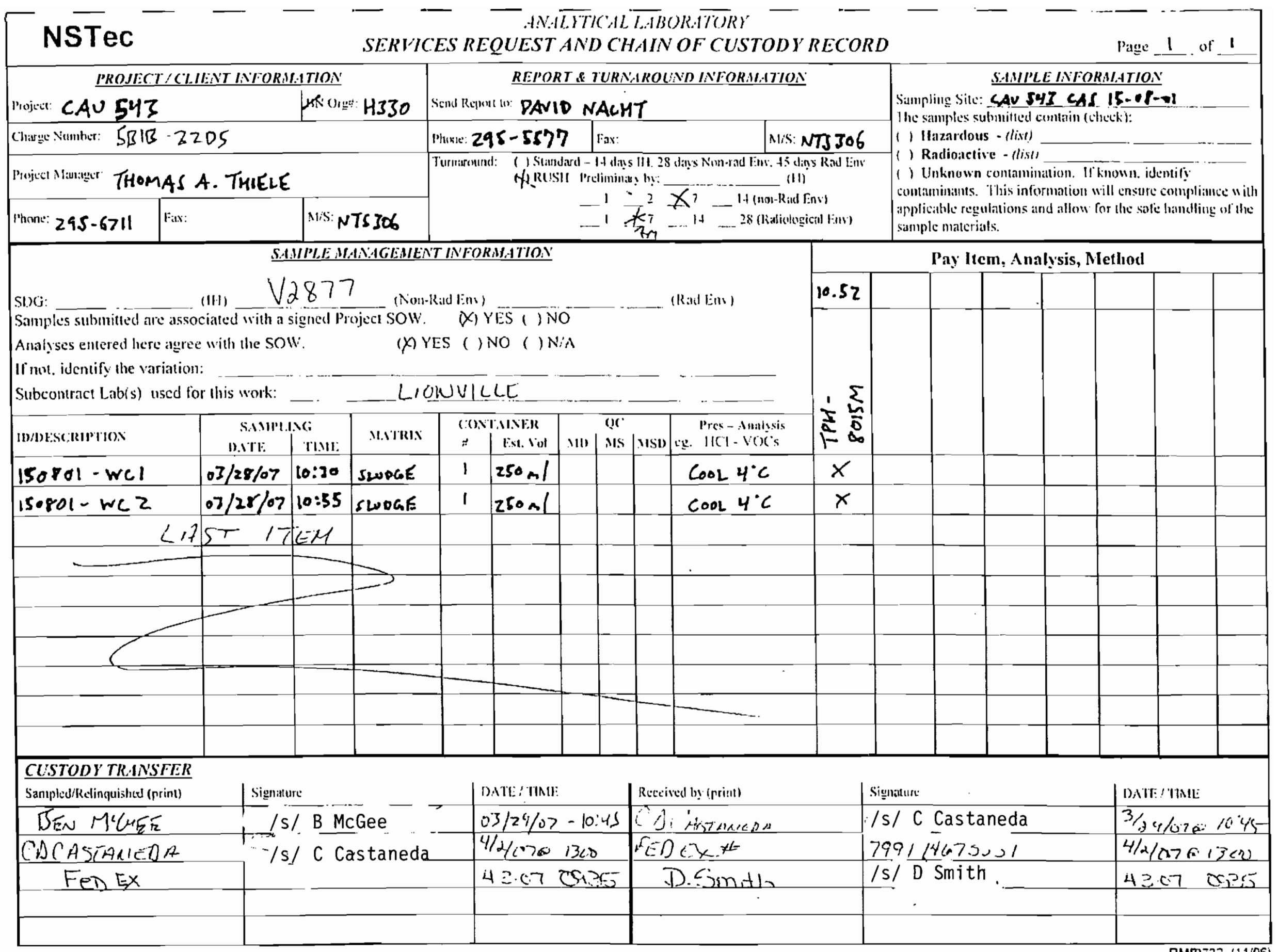


Closure Report - CAU 543

Section: Appendix B

Revision: 0

Date: Jimuary 2008

THIS PAGE INTENTIONALLY LEFT BLANK 
Closure Report - CAU 543

Section: Appendix B

Revision: 0

Date: January 2008

\section{Sample Delivery Group V2878}


Closure Report - CAU 543

Section: Appendix B

Revision: 0

Date: Jinnuary 2008

THIS PAGE INTENTIONALLY LEFT BLANK 


\title{
Gamma Spectroscopy Results
}

\author{
PAl 713 Rev 9 \\ Sample Results
}

Lab Name: Paragon Analytics

Work Order Number: 0704007

Client Name: National Security Technologies, LLC

ClientProject ID: CAU 543 V2878

Field ID: 150801-WC1

Lab ID: $0704007-1$

Library: LNG_GAM-A-00

Analysis ReqCode: NGS-A-002
Sample Matrix: SLUDGE

Prep SOP: PAI 739 Rev 8

Date Collected: 28-Mar-07

Date Prepared: 06-Apr-07

Date Analyzed: 09-Apr-07
Prep Batch: GS070406-1

QCBatchID: GS070406-1-1

Run 10: GS070406-1A

Count Time: 30 minutes

Report Basis: As Received
Final Aliquat: $57.7 \mathrm{~g}$

Prep Basis: As Received

Moisture(\%): NA

Result Units: $\mathrm{pCi} / \mathrm{g}$

File Name: $070481 \mathrm{~d} 01$

\begin{tabular}{|c|c|c|c|c|}
\hline CASNO & Target Nuclide & Result +/- $2 \mathrm{~s}$ TPU & MDC & Lab Qualifier \\
\hline $14331-83-0$ & $A C-228$ & $4.38 \mathrm{E}-01+/-6.39 \mathrm{E}-01$ & $1.06 E+00$ & $\cup, G$ \\
\hline $14596-10-2$ & Am-241 & $-1.12 E-01+/-6.32 E-01$ & $1.10 \mathrm{E}+00$ & $\cup, G$ \\
\hline $14762-78-8$ & $\mathrm{Ce}-144$ & $1.43 E-01+/-5.67 E-01$ & $9.72 E-01$ & $\cup, G$ \\
\hline $10198-40-0$ & $\mathrm{C} 0.60$ & $-2.91 \mathrm{E}-02+/-1.70 \mathrm{E}-01$ & $3.11 \mathrm{E}-01$ & $U, G$ \\
\hline $13967-70-9$ & Cs-134 & $-7.91 \mathrm{E}-02+1-1.65 \mathrm{E}-01$ & $2.93 \mathrm{E}-01$ & $U, G$ \\
\hline $10045-97 \cdot 3$ & Cs -137 & $4.82 \mathrm{E}-02+/-1.31 \mathrm{E}-01$ & $2.24 \mathrm{E}-01$ & U.G \\
\hline $14683-23-9$ & Eu-152 & $-2.40 \mathrm{E}-02+1-7.84 \mathrm{E}-01$ & $1.42 E+00$ & U.G \\
\hline $15585-10-1$ & Eu-154 & $4.30 \mathrm{E}-02+/-8.21 \mathrm{E}-01$ & $1.46 E+00$ & $U, G$ \\
\hline $14391-16-3$ & Eu-155 & $-1.74 \mathrm{E}-01+1-3.25 \mathrm{E}-01$ & $5.86 \mathrm{E}-01$ & U.G \\
\hline $13966-00-2$ & $k-40$ & $1.29 \mathrm{E}+00+1-1.56 \mathrm{E}+00$ & $2.55 E+00$ & $U, G$ \\
\hline $15092-94 \cdot 1$ & $\mathrm{~Pb}-212$ & $-7.32 \mathrm{E}-02+/-2.21 \mathrm{E}-01$ & $3.90 \mathrm{E}-01$ & $U, G$ \\
\hline $14834-73-2$ & $\mathrm{Pm}-144$ & $-5.01 \mathrm{E}-02+1-1.41 \mathrm{E}-01$ & $2,55 \mathrm{E}-01$ & $U, G$ \\
\hline $14834-74-3$ & Pm-146 & $7.20 \mathrm{E}-02+/-1.34 \mathrm{E}-01$ & $2.26 \mathrm{E}-01$ & $U, G$ \\
\hline $13967-48-1$ & Ru-106 & $-1.27 \mathrm{E}-01+1-1.21 \mathrm{E}+00$ & $2.15 E+00$ & $U, G$ \\
\hline $14234-35-6$ & Sb-125 & $1.84 \mathrm{E}-01+/-2.66 \mathrm{E}-01$ & $4.41 E-01$ & $U, G$ \\
\hline
\end{tabular}

:omments:

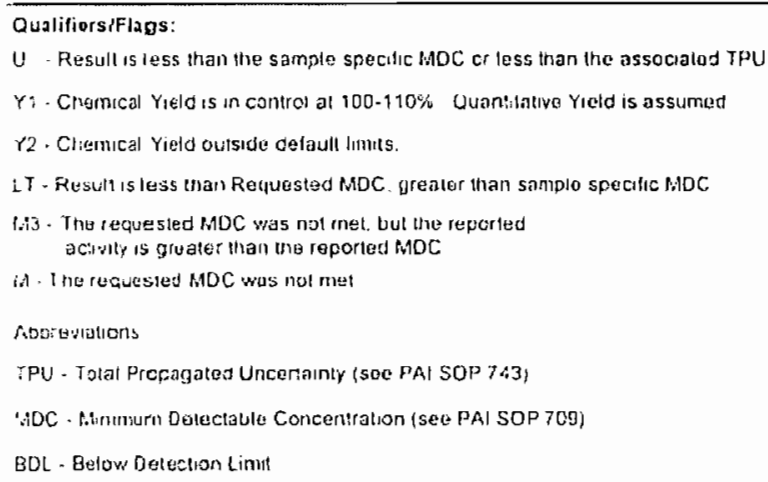

Data Package ID: GSS0704007-1

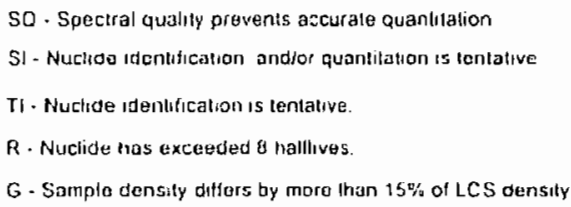




\section{Gamma Spectroscopy Results \\ PAl 713 Rev 9 \\ Sample Results}

Lab Name: Paragon Analytics

Work Order Number: 0704007

Client Name: National Security Technologies, LLC

ClientProject ID: CAU 543 V2878

Field ID: 150801-WC1

Lab ID: $0704007-1$

Library: LNG_GAM-A-CO

Analysis ReqCode: NGS-A-002
Sample Matrix: SLUDGE

Prep SOP: PAl 739 Rev 8

Date Collected: 28-Mar-07

Date Prepared: 06-Apr-07

Date Analyzed: 09-Apr-07
Prep Batch: GS070406-1

QCBatchID: GS070406-1-1

Run ID: GS070406-1A

Count Time: 30 minutes

Report Basis: As Received
Final Aliquot: $57.7 \mathrm{~g}$

Prep Basis: As Received

Moisture(\%): NA

Result Units: $p C i / g$

File Name: $070481 \mathrm{~d} 01$

\begin{tabular}{|c|c|c|c|c|}
\hline CASNO & Target Nuclide & Result $+/-2$ S TPU & MDC & Lab Qualifier \\
\hline $15065-10-8$ & Th-234 & $5.67 E-01+/-1.83 E+00$ & $3.10 E+00$ & U.G \\
\hline $15117-96-1$ & U-235 & $-2.44 E-01+/-6.12 E-01$ & $1.09 E+00$ & U.G \\
\hline $13982-36-0$ & Y-88 & $-7.25 E-02+/-1.53 E-01$ & $2.86 E-01$ & U,G \\
\hline
\end{tabular}

\section{Comments:}

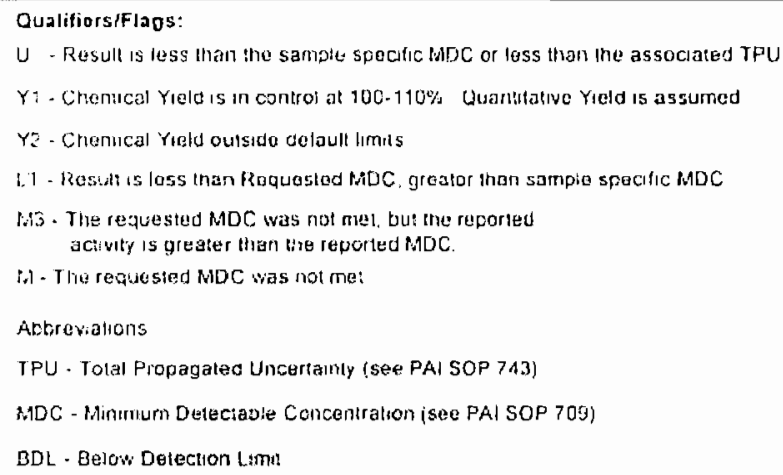

Data Package ID: GSS0704007-1 


\title{
Gamma Spectroscopy Results
}

\author{
PAI 713 Rev 9 \\ Sample Results
}

Lab Name: Paragon Analytics

Work Order Number: 0704007

Client Name: National Security Technologies. LLC

ClientProject ID: CAU 543 V2878

Field ID: 150801-WC2

Lab ID: $0704007-2$

Library: LNG_GAM-A.00

Analysis ReqCode: NGS-A.002
Sample Matrix: SLUDGE

Prep SOP: PAI 739 Rev 8

Date Collected: 28-Mar-07

Date Prepared: 06-Apr-07

Date Analyzed: 09-Apr-07
Prep Batch: GS070406-3

QCBatchID: GS070406-3-1

Run ID: GS070406-1A

Count Time: 30 minutes

Report Basis: Dry Weigh!
Final Aliquot: $52.5 \mathrm{~g}$

Prep Basis: Dry Weight

Moisture(\%): NA

Result Units: $p \mathrm{Ci} / \mathrm{g}$

File Name: $070434 d 03$

\begin{tabular}{|c|c|c|c|c|}
\hline CASNO & Target Nuclide & Result $+1-2 \mathrm{~s}$ TPU & MDC & Lab Qualifier \\
\hline $14331-83-0$ & $A C-228$ & $8.01 \mathrm{E}-01+/-1.10 \mathrm{E}+00$ & $1.82 E+00$ & U,G \\
\hline $14596-10-2$ & $A m-241$ & $6.13 \mathrm{E}-01+/-1.21 \mathrm{E}+00$ & $2.06 E+00$ & $U, G$ \\
\hline $14762-78-8$ & Ce-144 & 2.37E-01+/-7.15E-01 & $1.25 E+00$ & U,G \\
\hline $10198-40-0$ & Co-60 & $-8.16 \mathrm{E}-02+/-1.81 \mathrm{E}-01$ & $4.15 \mathrm{E}-01$ & $U, G$ \\
\hline $13967-70-9$ & $C_{s-134}$ & $1.49 \mathrm{E}-02+/-2.13 \mathrm{E}-01$ & $3.86 \mathrm{E}-01$ & U.G \\
\hline $10045-97-3$ & Cs.137 & $7.41 \mathrm{E}-01+/-3.30 \mathrm{E}-01$ & 4.10E-01 & L.T.G \\
\hline $14683-23-9$ & Eu-152 & $0 \mathrm{E}+00+/-9.63 \mathrm{E}-01$ & $1.97 \mathrm{E}+00$ & $U, G$ \\
\hline $15585-10-1$ & Eu-154 & $-3.74 \mathrm{E}-01+/-1.09 \mathrm{E}+00$ & $2.26 \mathrm{E}+00$ & U.G \\
\hline $14391-16-3$ & Eu-155 & $1.46 E-01+/-5.12 E-01$ & $8.93 E-01$ & U.G \\
\hline $13966-00-2$ & $K-40$ & $2.76 \mathrm{E}+01+1-6.92 \mathrm{E}+00$ & $4.98 E+00$ & $G$ \\
\hline $15092-94-1$ & $\mathrm{~Pb}-212$ & $6.45 \mathrm{E}-01+/-3.49 \mathrm{E}-01$ & $5.00 \mathrm{E}-01$ & $G$ \\
\hline $15067-28-4$ & $\mathrm{~Pb}-214$ & $6.79 \mathrm{E}-01+/-3.31 \mathrm{E}-01$ & 5.48E-01 & G.J \\
\hline $14834-73-2$ & Pm-144 & $5.04 \mathrm{E}-02+/-1.99 \mathrm{E}-01$ & $3.58 \mathrm{E}-01$ & $U, G$ \\
\hline $14834-74-3$ & Pm-146 & 1.97E-01+/-2.26E-01 & $3.64 E-01$ & U.G \\
\hline $13967-48-1$ & $R u-106$ & $-1.69 \mathrm{E}+00+1-1.66 \mathrm{E}+00$ & $3.61 E+00$ & U.G \\
\hline
\end{tabular}

\section{iomments:}

\section{Qualifiors/fiogs:}

$U$ - Result is less than the sample specihe MOC or loss than tho assoctated TPU

$r:$ - Chemical Yield is in control al 100-110\% Quantitalive Yiold is assumod

r2 - Chemical Yiold cuisida defaull limits

LT - Restile Is less than Requested MDC. guealer than sample specitio MDC

1.93 - The requested MOC was not met, but the reported

activity is gruater than whe reported f.ADC.

M- The roguesled MOC was not ma:

Aovrewalions

TPU - Tolal Propagnted Uncerlainly (see PAI SOP 743)

ADC - Munlinum Deteciable Concentration (see PAI SOP 709)

BCL - Below Detezion Linn

\section{Data Package ID: GSS0704007-1}

SQ - Spectral quality prevents accurale quantitation

St - Nueliae idenlification andjor quantititien rs tentative.

Tl - Nuclido identitueation is lentative

$R$ - Nuclido hos exteedod a hallives.

G. Sample densıty ditfers by more than $15 \%$ of LCS densily 


\title{
Gamma Spectroscopy Results
}

\author{
PAl 713 Rev 9 \\ Sample Results
}

Lab Name: Paragon Analytics

Work Order Number: 0704007

Client Name: National Security Technologies, LLC

ClientProject ID: CAU 543 V2878

\begin{tabular}{|ll|}
\hline Field ID: & $150801-W C 2$ \\
Lab ID: & 0704007.2 \\
\hline
\end{tabular}

Library: LNG_GAM-A-OO

Analysis ReqCode: NGS-A-002
Sample Matrix: SLUDGE

Prep SOP: PAl 739 Rev 8

Date Collected: 28-Mar-07

Date Prepared: 06-Apr-07

Date Analyzed: 09-Apr-07
Prep Batch: GS070406-3

QCBatchID: GS070406-3-1

Run ID: GS070406-1A

Count Time: 30 minutes

Report Basis: Dry Weight
Final Aliquot: $52.5 \mathrm{~g}$

Prep Basis: Dry Weight

Moisture(\%): NA

Result Units: $\mathrm{pCi} / \mathrm{g}$

File Name: $070434 d 03$

\begin{tabular}{|c|c|c|c|c|}
\hline CASNO & Target Nuclide & Result +/- 2 s TPU & MDC & Lab Qualifier \\
\hline $14234-35-6$ & Sb-125 & $5.36 E-02+/-5.02 E-01$ & $9.09 E-01$ & U,G \\
\hline $15065-10-8$ & Th-234 & $-1.16 E+00+/-2.84 E+00$ & $5.23 E+00$ & U,G \\
\hline $14913-50-9$ & Tl-208 & $4.63 E-01+/-2.41 E-01$ & $3.06 E-01$ & G \\
\hline $15117-96-1$ & U-235 & $-5.04 E-01+/-7.44 E-01$ & $1.44 E+00$ & U,G \\
\hline $13982-36-0$ & Y-88 & $8.76 E-02+1-2.09 E-01$ & $3.73 E-01$ & U.G \\
\hline
\end{tabular}

\section{Comments:}

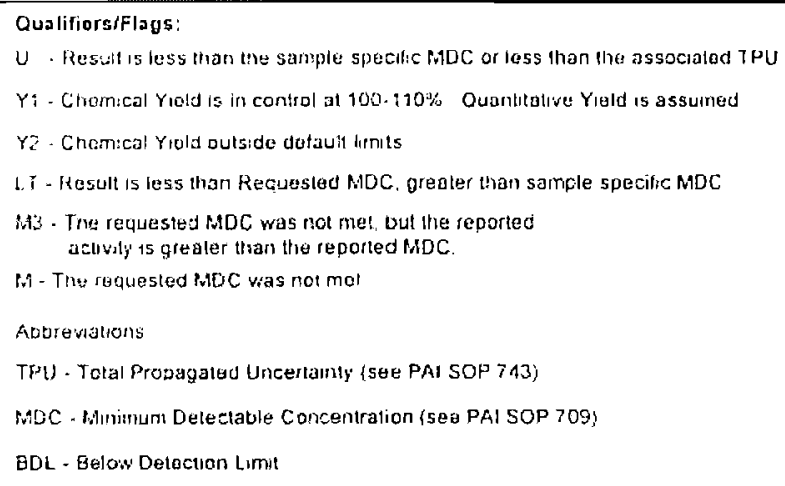

Data Package ID: GSS0704007-1

\author{
So - Speciral qualily prevents accurate quantulation \\ S1 - Nuclide identification andor quanutation is tentolive \\ $\mathrm{TI}$ - Nustide ioentlicalion is tentative \\ $R$. Nuclide has exceeded $B$ halfives \\ G - Sample Jensity diflers by more than $15 \%$ of LCS donsity
}



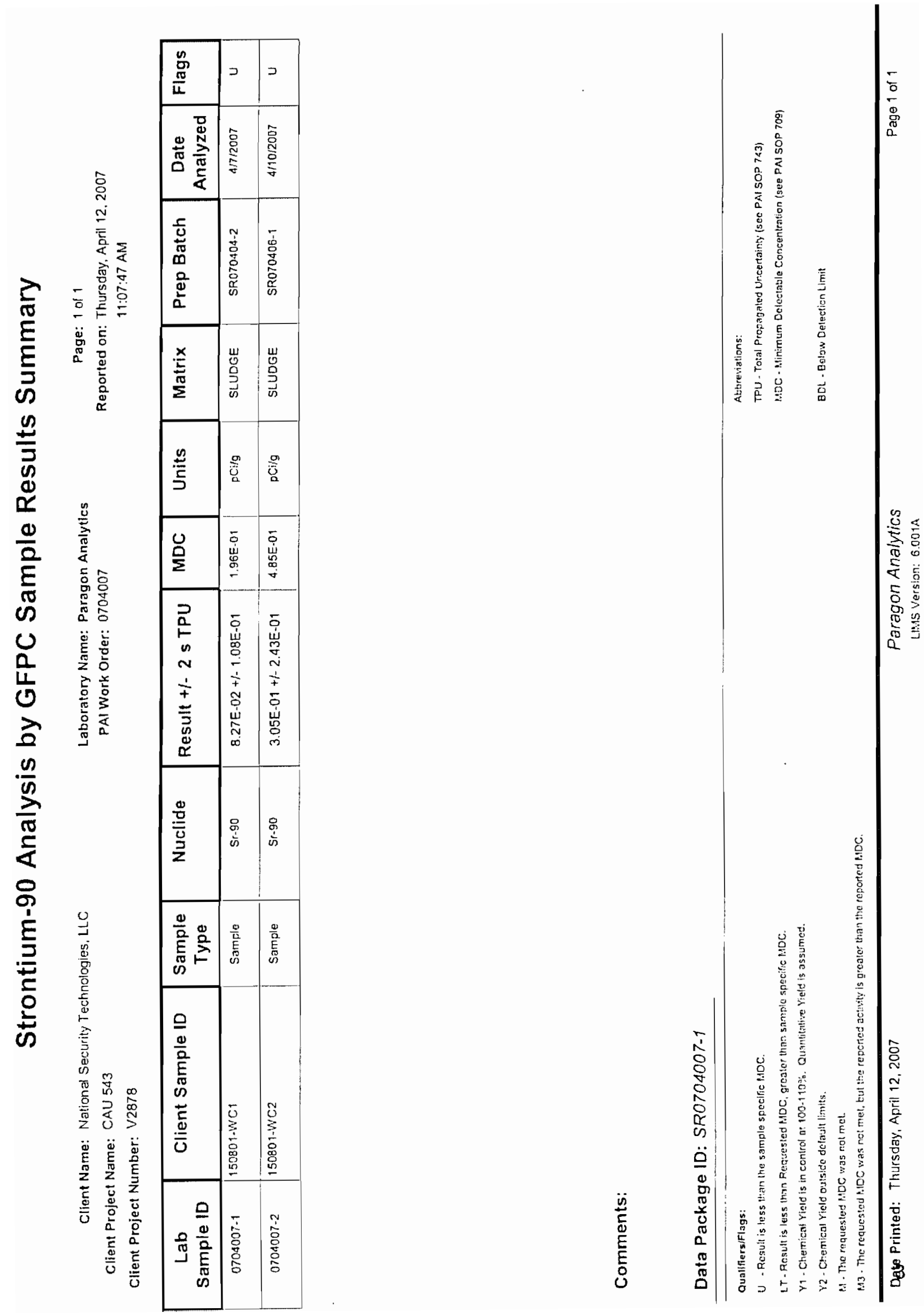


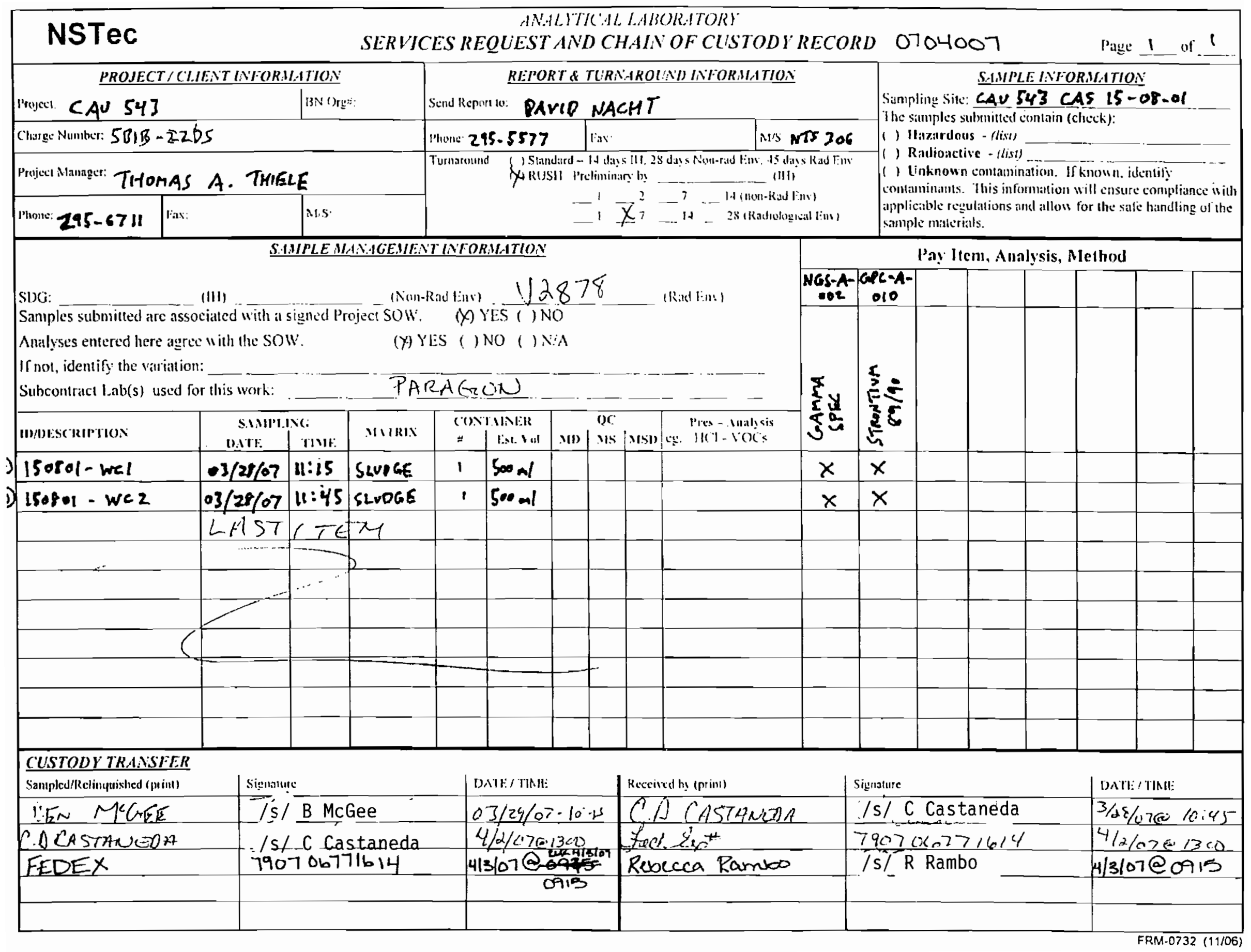


Closure Report - CAU 543

Section: Appendix B

Revision: 0

Date: January 2008

Sample Delivery Group V2899 
Closure Report - CAU 543

Section: Appendix B

Revision: 0

Datc: January 2008

THIS PAGE INTENTIONALLY LEFT BLANK 
เ เดอดอยดด

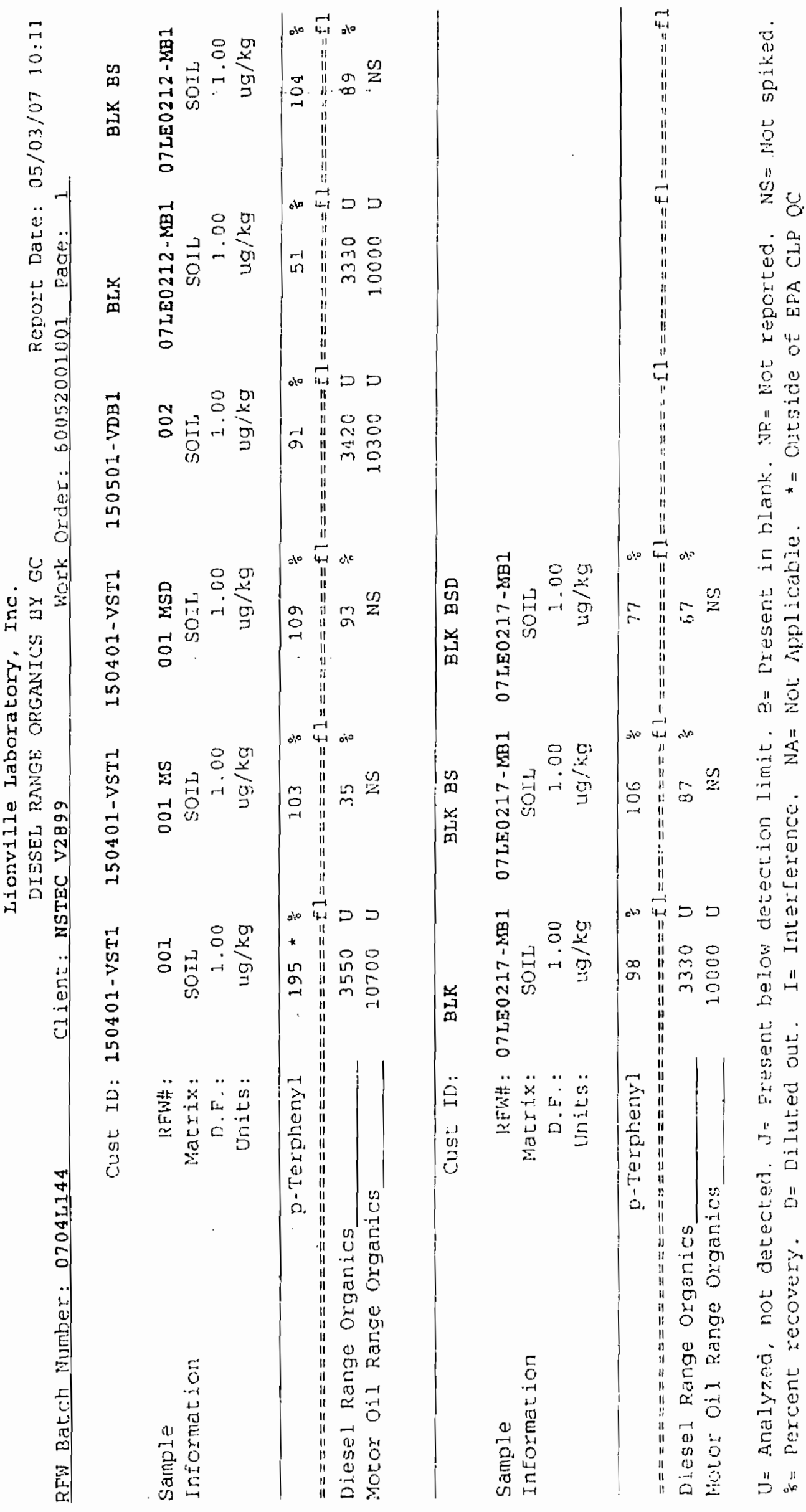




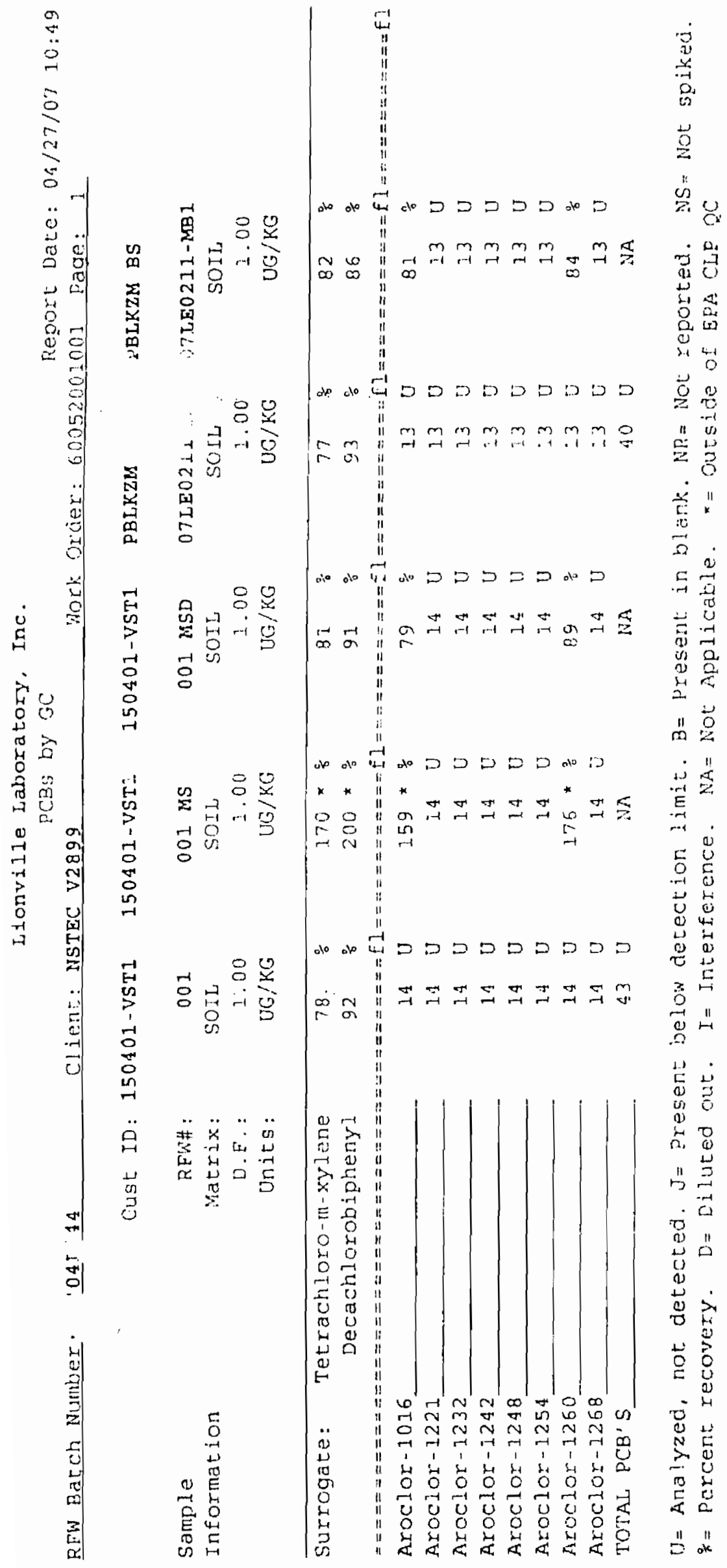




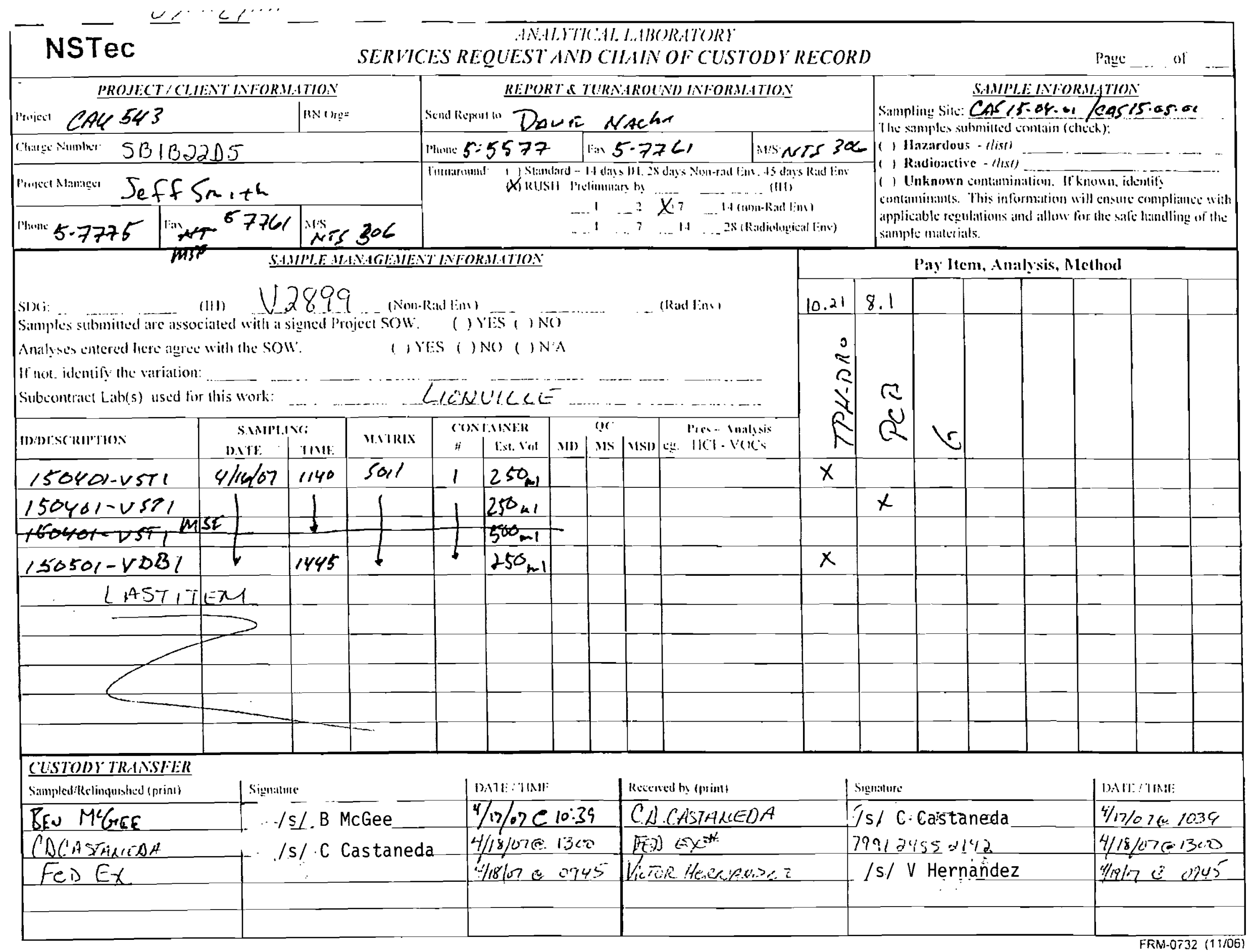


Closure Report - CAU 543

Section: Appendix B

Revision: 0

Date: January 2008

THIS PAGE INTENTIONALLY LEFT BLANK 
Closure Report - CAU 543

Section: Appendix B

Revision: 0

Date: January 2008

\section{Sample Delivery Group V2900}


Closure Report - CAU 543

Section: Appendix B

Revision: 0

Datc: January 2008

THIS PAGE INTENTIONALLY LEFT BLANK 


\section{Gamma Spectroscopy Results}

\section{PAl 713 Rev 9 \\ Sample Results}

Lab Name: Paragon Analytics

Work Order Number: 0704141

Cllent Name: National Security Technologies, LLC

ClientProject ID: CAU 543 V 2900

\begin{tabular}{|c|c|c|c|}
\hline $\begin{array}{l}\text { Field ID: } 150401 . \text { UST1 } \\
\text { Lab ID: } 0704141-1\end{array}$ & $\begin{array}{l}\text { Sample Matrix: SOIL } \\
\text { Prep SOP: PAI } 739 \text { Rev } 8 \\
\text { Date Collectod: } 16-A p r-07\end{array}$ & $\begin{array}{l}\text { Prep Batch: GS070420-2 } \\
\text { QCBatchID: GS070420-2-1 } \\
\text { Run ID: GS070420-2A }\end{array}$ & $\begin{array}{l}\text { Final Aliquot: } 459 \mathrm{~g} \\
\text { Prep Basis: Dry Weight } \\
\text { Moisture(\%): NA }\end{array}$ \\
\hline $\begin{array}{l}\text { Library: LNG_GAMPA-OOI } \\
\text { Malytis RoqCodo: NGS-A-002 }\end{array}$ & $\begin{array}{l}\text { Date Prepared: } 20-A p r-07 \\
\text { Dale Analyzed: } 26-A p r-07\end{array}$ & $\begin{array}{l}\text { Count Time: } 30 \text { minutes } \\
\text { Report Basis: Dry Weight }\end{array}$ & $\begin{array}{l}\text { Result Units: pCikg } \\
\text { Filc Name:070647d02 }\end{array}$ \\
\hline
\end{tabular}

\begin{tabular}{|c|c|c|c|c|}
\hline CASNO & Target Nuclide & Result $+1-2 \mathrm{~s}$ TPU & MDC & Lab Qualifier \\
\hline $13967 \cdot 48-1$ & Ru-106 & $2.25 E-01+/-5.11 E-01$ & B.78E-01 & $U$ \\
\hline $14234-35-6$ & Sb-125 & $-3.33 E-02+\gamma-1.46 E-01$ & $2.77 E-01$ & $\mathrm{U}$ \\
\hline $15065-10-8$ & $T h-234$ & $1.30 E+00+/-1.39 E+00$ & $2.26 E+00$ & $\mathbf{U}$ \\
\hline $14913-50-9$ & $\mathrm{~T} 1.208$ & $3.54 \mathrm{E}-01+i-1.04 \mathrm{E} \cdot 01$ & 1.15E-01 & \\
\hline $15117-96-1$ & U.235 & $3.03 \mathrm{E} \cdot 01+1-3.72 \mathrm{E}-01$ & $6.08 \mathrm{E}-01$ & $u$ \\
\hline $13982-36 \cdot 0$ & Y. 88 & $.4 .73 \mathrm{E}-03+1.7 .02 \mathrm{E} \cdot 02$ & $1.29 \mathrm{E} \cdot 01$ & $u$ \\
\hline
\end{tabular}

\section{Comments:}

\section{Quallnersifiags:}

$U$ - Resuil is less than the sample specifie MOC or less vian libe associaled TRU.

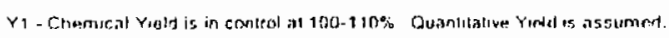

Y2. Chermeal Yeedo bulsida detaull limals

LT - Resull is less than Requested MDC, givathe Il:an sampli specufic MDC.

1.13. The ruquesled MDC was nat mat, but the reperent actinly is geater than tho reporled kalse.

M- The requesled A.tDe was no: met.

Aberewasions:

IFU - To:al Propapated Uncontinty (see PAI SOP 7.3 J)

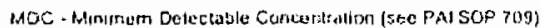

BDL-Eatow Detection Lim!1

Data Package ID: GSS0704141-1
SO - Spectal qualify prewents accarale quantitiacu

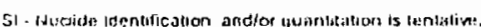
II. Huehde idembitisalion is ienta?tre.

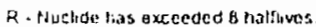
G. Sumpic densiy dillers by more than 15\% of LCS Juristy. 


\section{1}

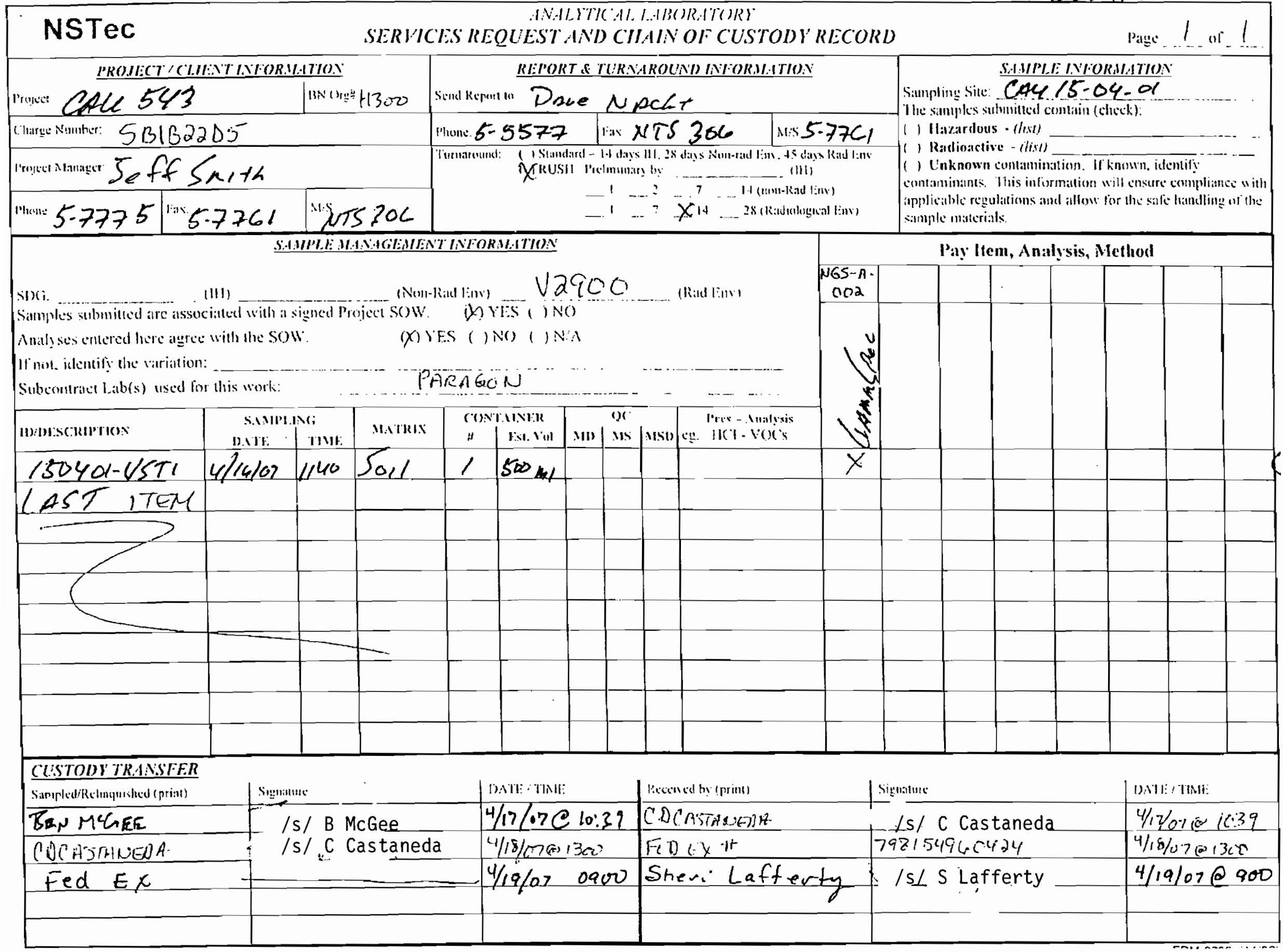


Closure Report - CAU 543

Section: Appendix B

Revision: 0

Date: January 2008

THIS PAGE INTENTIONALLY LEFT BLANK 
Closure Report - CAU 543

Section: Appendix B

Revision: 0

Date: January 2008

Sample Delivery Group V2967 
Closure Report - CAU 543

Section: Appendix B

Revision: 0

Datc: January 2008

THIS PAGE INTENTIONALLY LEFT BLANK 


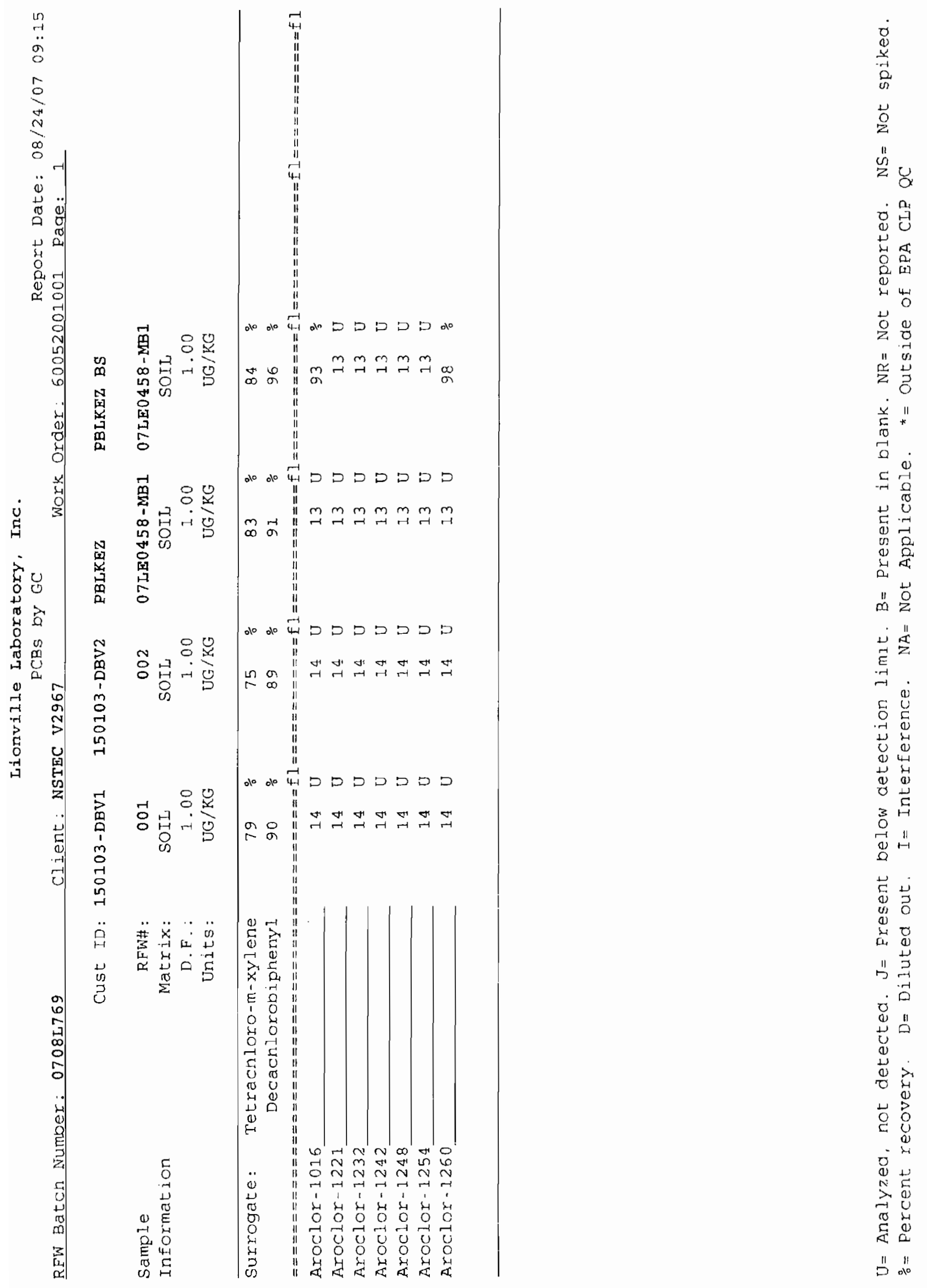




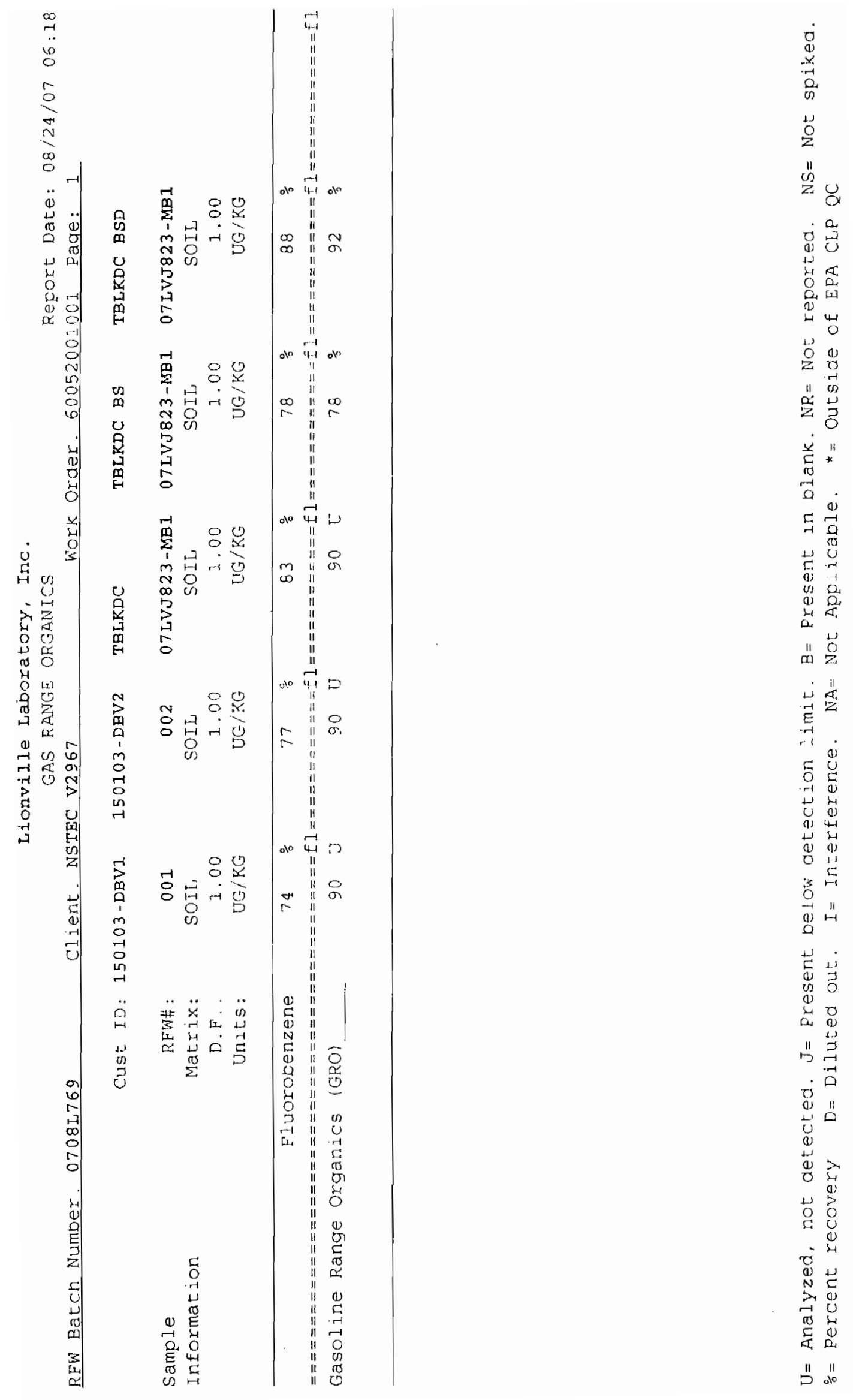




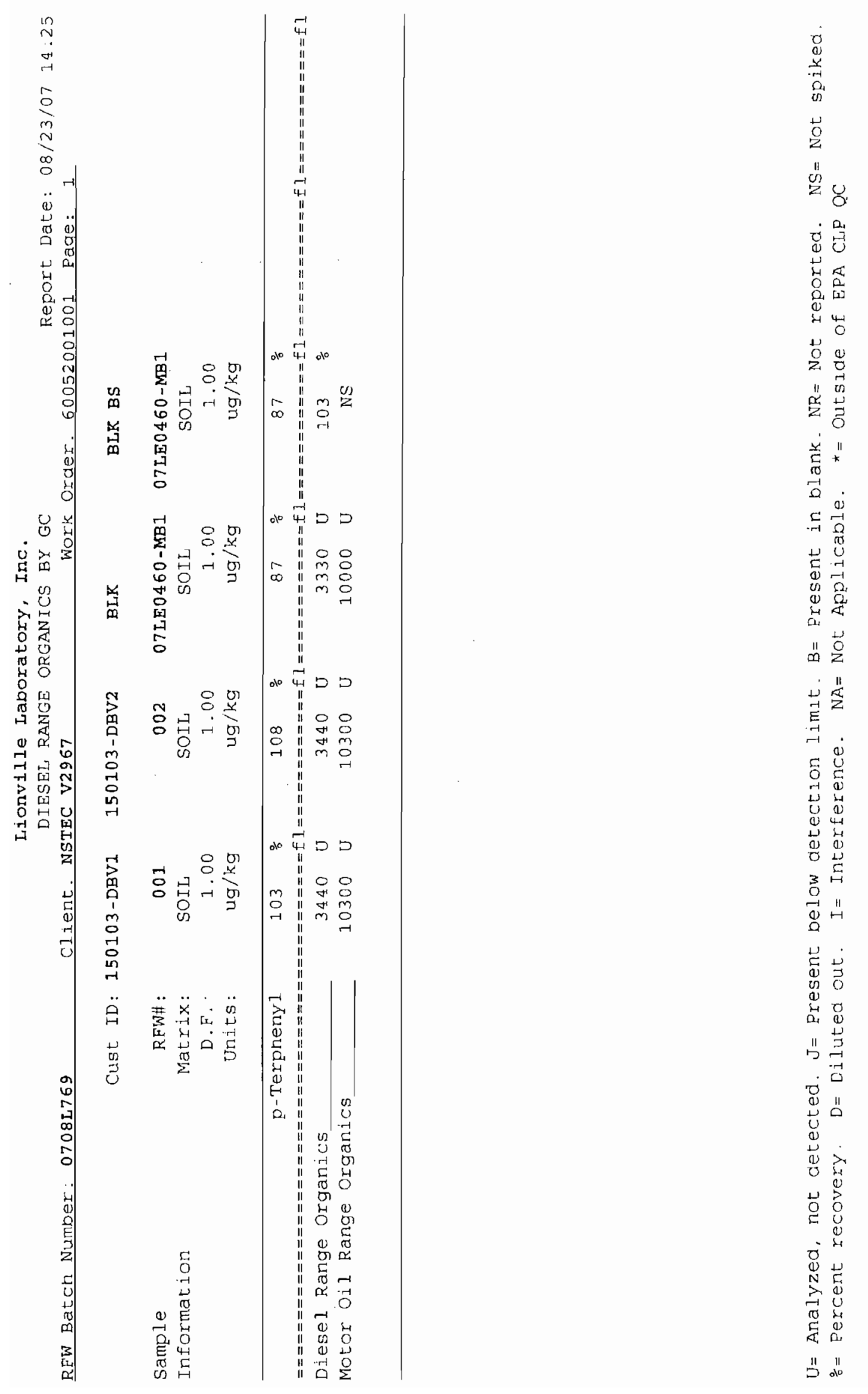




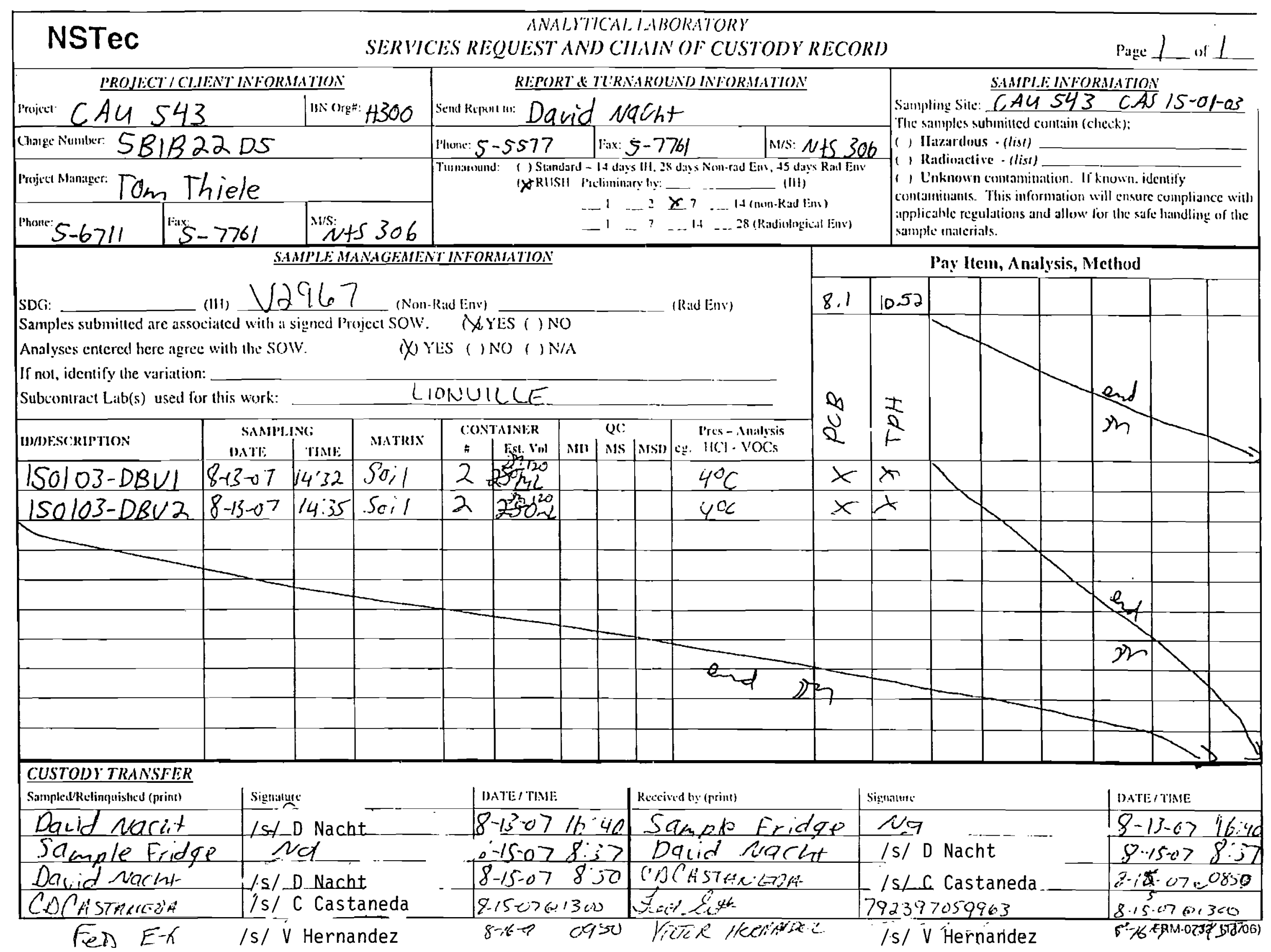


Closure Report - CAU 543

Section: Appendix B

Revision: 0

Date: January 2008

\section{Sample Delivery Group V2968}


Closure Report - CAU 543

Section: Appendix B

Revision: 0

Date: Jamuary 2008

THIS PAGE INTENTIONALLY LEFT BLANK 


\title{
Gamma Spectroscopy Results
}

\author{
PAl 713 Rev 9 \\ Sample Results
}

Lab Name: Paragon Analytics

Work Order Number: 0708142

Client Name: National Security Technologies, LLC

ClientProject ID: CAU 543 V2968

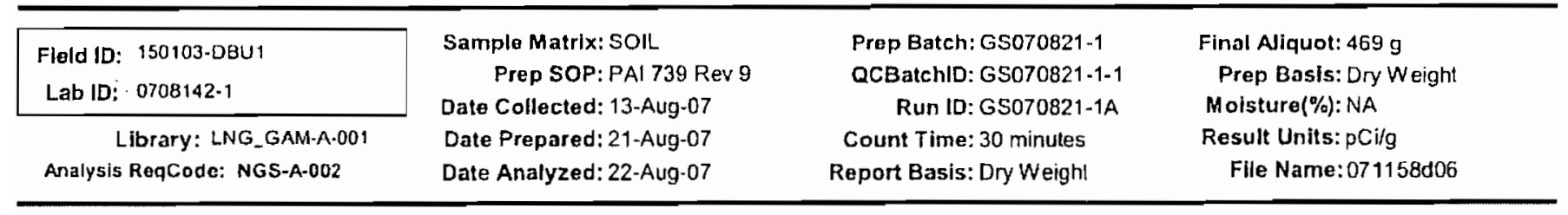

\begin{tabular}{|c|c|c|c|c|}
\hline CASNO & Target Nuclide & Result $+1-2 \mathrm{~s}$ TPU & MDC & Lab Qualifier \\
\hline $14331-83-0$ & $A c-228$ & $7.67 \mathrm{E}-01+/-2.77 \mathrm{E}-01$ & 4.17E-01 & TI \\
\hline $14596-10-2$ & $A m-241$ & $1.28 \mathrm{E}+00+/-9.87 \mathrm{E}-01$ & $1.54 \mathrm{E}+00$ & $\mathrm{U}$ \\
\hline $14733-03-0$ & Bi.214 & $6.40 \mathrm{E}-01+/-1.98 \mathrm{E}-01$ & $2.40 \mathrm{E}-01$ & J \\
\hline $14762-78-8$ & Ce. 144 & $O E+00+/-3.38 E-01$ & $5.94 E-01$ & $\mathrm{U}$ \\
\hline $10198-40-0$ & $\mathrm{Co}-60$ & $2.00 E-02+1-5.49 E-02$ & 9.99E-02 & $\mathrm{U}$ \\
\hline $13967-70-9$ & Cs-134 & $-2.22 \mathrm{E}-02+/-6.20 \mathrm{E}-02$ & 1.16E-01 & $u$ \\
\hline $10045-97-3$ & Cs-137 & $-1.11 \mathrm{E}-02+/-5.98 \mathrm{E}-02$ & 1.13E-01 & $\mathrm{U}$ \\
\hline $14683-23-9$ & Eu-152 & $6.60 \mathrm{E}-02+/-2.64 \mathrm{E}-01$ & 4.95E-01 & $\mathbf{U}$ \\
\hline $15585-10-1$ & Eu-154 & $9.45 E-02+/-3.95 E-01$ & $7.06 \mathrm{E}-01$ & $\mathbf{u}$ \\
\hline $14391-16-3$ & Eu-155 & $-5.53 E-03+/-2.55 E-01$ & $4,45 E-01$ & $\mathrm{u}$ \\
\hline $13966-00-2$ & $K-40$ & $2.02 E+01+i-3.37 E+\infty 0$ & $1.41 E+00$ & \\
\hline $15092.94-1$ & $\mathrm{~Pb} \cdot 212$ & $8.85 \mathrm{E} \cdot 01+/ .1 .82 \mathrm{E}-01$ & $1.55 \mathrm{E}-01$ & \\
\hline $15067-28-4$ & $\mathrm{~Pb}-214$ & $5.89 \mathrm{E} \cdot 01+1-1.52 \mathrm{E}-01$ & $2.13 E-01$ & J \\
\hline $14834-73-2$ & $P m-144$ & $9.62 \mathrm{E} \cdot 03+1-5.87 \mathrm{E}-02$ & $1.05 E-01$ & $\mathrm{u}$ \\
\hline $14834-74-3$ & $P m-146$ & $-1.30 \mathrm{E}-02+1-6.41 \mathrm{E}-02$ & $1,20 E-01$ & $\mathrm{U}$ \\
\hline
\end{tabular}

Comments:

\begin{tabular}{|c|c|}
\hline \multicolumn{2}{|l|}{ Qualifiers/flags: } \\
\hline$U$ - Result is loss than the sample specific MDC or less than the associated TPU & SO-Spretral qually prevents accurate quinltialion. \\
\hline Y1 - Chemical Yield os in control at 100. $110 \%$. Ouanlitalive Yield is assumed. & Si - Nuclide idtontificalion andior quantiation is tentalive, \\
\hline Y2 - Cleermical Yietd dutside delault lirnts. & TI-Nuclida istontrication is tuntative, \\
\hline LT - Result is less than Requesied MDC. Greater than simple specilic MOC. & R - Nuclite has exceedod 8 hallives. \\
\hline 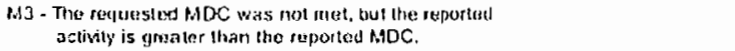 & G. Sample densily diffors by mare than $15 \%$ of of LCS densily \\
\hline
\end{tabular}

.

Abhrévialions:

TPU - Tolal Propagated Uncertainly (sec PA| SOP 749)

HOC - Minimum Detactable Concentration (see PNI SOP 709)

BDL - Below Delcction Limit

Data Package ID: GS0708142-1 


\section{Gamma Spectroscopy Results}

PAl 713 Rev 9

Sample Results

Lab Name: Paragon Analytics

Work Order Number: 0708142

Client Name: National Security Technologies. LLC

ClientProject ID: CAU 543 V2968

\begin{tabular}{|c|c|c|c|}
\hline $\begin{array}{l}\text { Fleld ID: } 150103-0841 \\
\text { Lab ID: } 0708142-1\end{array}$ & $\begin{array}{l}\text { Sample Matrix: SOLL } \\
\text { Prep SOP: PAI } 739 \text { Rev } 9 \\
\text { Date Collected: } 13-\text { Aug-07 }\end{array}$ & $\begin{array}{c}\text { Prep Batch: GS070821-1 } \\
\text { QCBatchID: GS070821-1-1 } \\
\text { Run ID: GS070821-1A }\end{array}$ & $\begin{array}{l}\text { Final Aliquot: } 469 \mathrm{~g} \\
\text { Prep Basis: Dry Weight } \\
\text { Moisture(\%): NA }\end{array}$ \\
\hline Library: LNG_GAM-A.001 & Date Prepared: 21-Aug-07 & Count Time: 30 minutes & Result Units: pCi/g \\
\hline Analysis ReqCode: NGS-A-002 & Date Analyzed: 22-Aug-07 & Report Basis: DryWeighl & File Name: $071158 \mathrm{~d} 06$ \\
\hline
\end{tabular}

\begin{tabular}{|c|c|c|c|c|}
\hline CASNO & Target Nuclide & Result +/- 2 s TPU & MDC & Lab Qualifier \\
\hline $15623-45-7$ & $\mathrm{Ra}-223$ & $1.31 E+00+i-6.77 E-01$ & $9.62 E-01$ & TI \\
\hline $13967-48-1$ & Ru-106 & $-2.70 E-01+/-5.53 E-01$ & $1.07 E+00$ & $\mathrm{U}$ \\
\hline $14234-35-6$ & $\mathrm{Sb}-125$ & $-8.97 E-03+/-1.28 E-01$ & $2.37 \mathrm{E}-01$ & $U$ \\
\hline $15065 \cdot 10-8$ & $T h-234$ & $-6.77 E-01+/-1.31 E+00$ & $2.36 E+00$ & $U$ \\
\hline $14913-50-9$ & TI-208 & 2.29E-01+j-9.11E-02 & $1.14 \mathrm{E}-01$ & \\
\hline $15117-96-1$ & U-235 & $1.38 E-02+1-3.29 E-01$ & $5.76 \mathrm{E}-01$ & $\bar{u}$ \\
\hline $13982-36-0$ & $Y-88$ & $1.3+E-02+1-7.45 E-02$ & $1.34 \mathrm{E}-01$ & $\mathrm{U}$ \\
\hline
\end{tabular}

\section{Comments:}

Quallfiers/Flags:

$U$ - Result is less than the simne socciln: MOC or less than the as socialted TPU

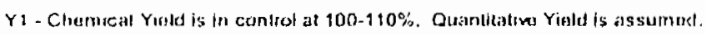

Y2 - Chomical Ylold outside detaull limits

$L T$. Resull is less than Reques ted HDC, greater than sample spocilic MDC.

M3 - The requested MDC was nol mer, but the reporter activly is greater thats the ieportert MDC.

B.1 - The reques led M.MC was nel mel.

Abbresialtorls:

TPU - Tolial Propagaled Uncerlamty (se! PAI SOP 7:3)

MDC - Alinimum Delectahle Concentration (sev PAI SOP 709)

HOL - Belaw Dezection Lim!

Data Package ID: GS0708142-1
So - Spectral quality provents accura1e quantuavon
Si - Nuchdes identification and/or quantilation is tentativa.
Th- Nuclate identidication is ten:ation.
R - Nuclisle has oxecoded t a hives
G - Sampie density differs by more than $15 \%$ of LCS density 


\title{
Gamma Spectroscopy Results
}

\author{
PAl 713 Rev 9
}

Sample Results

Lab Name: Paragon Analytics

Work Order Number: 0708142

Client Name: National Security Technologies. LLC

ClientProject ID: CAU 543 V2968

\begin{tabular}{ll} 
Fleid ID: & $150103-$ DBU2 \\
Lab ID: & 0r08142-2 \\
\hline
\end{tabular}

Library: LNG_GAM-A-001

Analysis ReqCode: NGS-A-002
Sample Matrix: SOIL

Prep SOP: PAI 739 Rev 9

Date Collected: 13-Aug-07

Date Prepared: 21-Aug-07

Date Analyzed: 22-Aug-07
Prep Batch: GS070821-1 QCBatchID: GS070821-1-1

Run ID: GS070821-1A

Count Time: 30 minutes

Report Basis: Dry Weight
Final Aliquot: $462 \mathrm{~g}$

Prep Basis: Dry Weight

Molsture(\%):NA

Result Units: pCilg

File Name:07 1159d06

\begin{tabular}{|c|c|c|c|c|}
\hline CASNO & Target Nuclide & Result +/- 2 s TPU & MDC & Lab Qualifier \\
\hline $14331-83-0$ & Ac-228 & $8.60 \mathrm{E}-01+/-2.48 \mathrm{E}-01$ & $4.16 E-01$ & \\
\hline $14596-10-2$ & Amr-241 & $-2.47 \mathrm{E}-01+1-9.94 \mathrm{E}-01$ & $1.78 E+00$ & $U$ \\
\hline $14733-03-0$ & $B i-214$ & $5.26 \mathrm{E}-01+/-1.77 \mathrm{E}-01$ & $1.96 E-01$ & $J$ \\
\hline $14762-78-8$ & Ce.144 & $-3.14 \mathrm{E}-01+1.3 .70 \mathrm{E}-01$ & $6.83 E-01$ & $U$ \\
\hline $10198 \cdot 40-0$ & $\mathrm{Co}-60$ & $0 \mathrm{E}+00+/-4.27 \mathrm{E}-02$ & $8.86 E-02$ & $U$ \\
\hline $13967-70-9$ & Cs-134 & $1.43 \mathrm{E} \cdot 02+/-5.88 \mathrm{E}-02$ & $1.04 \mathrm{E}-01$ & $\mathrm{U}$ \\
\hline $10045-97-3$ & Cs-137 & $3.21 E-02+1-5.92 E-02$ & $1.01 E-01$ & $U$ \\
\hline $14683-23-9$ & Eu-152 & $2.01 \mathrm{E}-01+1-2.52 \mathrm{E}-01$ & $4.02 E-01$ & $U$ \\
\hline $15585-10-1$ & Eu-154 & $7.79 E-02+/-3.54 E-01$ & $6.42 \mathrm{E}-01$ & $U$ \\
\hline $14391-16-3$ & Eu-155 & $1.28 \mathrm{E}-01+/-2.50 \mathrm{E}-01$ & $4.21 E-01$ & $U$ \\
\hline $13966-00-2$ & $k-40$ & $2.29 E+01+1-3.69 E+00$ & $1.27 \mathrm{E}+00$ & \\
\hline $15092-94-1$ & $\mathrm{~Pb}-212$ & $8.75 \mathrm{E}-01+/-1.81 \mathrm{E}-01$ & $1.56 \mathrm{E}-01$ & \\
\hline $15067-28-4$ & $\mathrm{~Pb}-214$ & $6.61 \mathrm{E}-01+/ .1 .59 \mathrm{E}-01$ & $1.96 \mathrm{E}-01$ & $J$ \\
\hline $14834-73-2$ & $\mathrm{Pm} \cdot 144$ & $-4.68 E-02+1-6.02 E-02$ & $1.20 \mathrm{E}-01$ & $\mathrm{U}$ \\
\hline $14834-74-3$ & $\mathrm{Pm} \cdot 146$ & $2.19 \mathrm{E}-02+1-6.96 \mathrm{E}-02$ & $1.22 \mathrm{E}-01$ & $u$ \\
\hline
\end{tabular}

\section{Comments:}

\footnotetext{
QuallfiersfFlags:

$U$ - Result is less than the samplo specific MDC or loss than the associated TPU

$Y 1$ - Chomical Yold is 11 control at $100-110 \%$, Quantitative Yiekd is assumed.

$Y 2$ - Chernical Yicld outsido dolault lımits.

LT - Resull is less than Requestod MDC. greater than samplo specilic MDC.

M.13 - The reciucsted MOC was not met, but tho reportad

activly is greater than the reported MADC.

M - The requested MDC was not met.

Atureviatipns:

TPU - Total Propagated Uncertainly (See PAI SOP 743)

MOC - Minimum Dotectable Concentration (see PAI SOP 708)

BOL - Betow Delecton Limit
}

So. Spectral quality prevents accurato quantiation.

SI - Nuclido idontilicalion andjor quantitalion is tontative.

$\mathrm{Tl}$. Nuclide idenlification is tontative.

R - Nuclido has excecoed 8 halfives.

G-Sample densuy diflers by more than $15 \%$ of LCS densily.

Data Package ID: GS0708142-1 


\section{Gamma Spectroscopy Results \\ PAI 713 Rev 9 \\ Sampie Results}

Lab Name: Paragon Analytics

Work Order Number: 0708142

Client Name: National Security Technologıes, LLC

ClientProject ID: CAU 543 V2968

\begin{tabular}{l} 
Fleld ID: $150103-0842$ \\
Lab ID: $0709142-2$ \\
\hline
\end{tabular}

LIbrary: LNG_GAM-A-001 Analysis RoqCode: NGS.A-002
Sample Matrix: SOIL Prep SOP: PAI 739 Rev 9

Date Collected: 13-Aug-07

Date Prepared: 21-Aug-07

Date Analyzed: 22-Aug-07
Prep Batch: GS070821-1

QCBatchID: GS070821-1-1

Run ID: GS070821-1A

Count Time: 30 minutes

Report Basts: Dry Weight
Final Aliquot: $462 \mathrm{~g}$

Prep Basis: Dry Weight

Moisture(\%): NA

Result Unlts: $\mathrm{pC} / \mathrm{g}$

File Name: $071159 d 06$

\begin{tabular}{|l|c|c|c|}
\hline \multicolumn{1}{|c|}{ CASNO } & Target Nuclide & Result $+/-2$ s TPU & MDC Qualifier \\
\hline $13967-48-1$ & Ru-106 & $-9.46 \mathrm{E}-02+1-5.09 \mathrm{E}-01$ & $9.63 \mathrm{E}-01$ \\
\hline $14234-35-6$ & $\mathrm{Sb}-125$ & $-7.28 \mathrm{E}-02+/-1.48 \mathrm{E}-01$ & $2.82 \mathrm{E}-01$ \\
\hline $15065-10-8$ & Th-234 & $3.87 \mathrm{E}-01+1 \cdot 1.34 \mathrm{E}+00$ & $2.29 \mathrm{E}+00$ \\
\hline $14913-50.9$ & Tl-208 & $2.48 \mathrm{E}-01+1-9.03 \mathrm{E}-02$ & $1.06 \mathrm{E}-01$ \\
\hline $15117-96-1$ & $\mathrm{U}-235$ & $-8.38 \mathrm{E}-02+1-3.42 \mathrm{E}-01$ & $6.11 \mathrm{E}-01$ \\
\hline $13982-36-0$ & Y-88 & $-1.46 \mathrm{E}-02+1-6.60 \mathrm{E}-02$ & $1.28 \mathrm{E}-01$ \\
\hline
\end{tabular}

\section{Comments:}

\footnotetext{
Quallfiers/Fings:

$U$-Rosult is less than the samplo spocitic MOC or less man the associatorl TPU

Y1. Chemieat Yield is in controd at 100-110\%. Qunntitative Yield is assumed.

Y2 - Chomical Yold outsido dofaull limils

LT - Rosult is Iess t!lan Requested MDC, groater than sample ssocific tiDC.

M3. The requested MoC was ind met, but the nuportud

aetivly is groater than the roponed $M 0 C$

M. The requested MOC was not met.
}

SO - Speciral qutaluy prewents accutata quartitation.

St - Nuclide idontification ond/or guanitation is tentisive

T) - Nuclide identifieation is ten1ative.

$R$. Nucide has uxesenten o hallises.

G - Sarnplu donsity diffors by more than $15 \%$ of LCS donsity.

Abbreviations:

TPU - Tonal Pronagated Uncertainly (sten PAI SOP 743)

MDC - Minimum Dotoctable Concentration (soe PAI SOP 709)

BDL - Bolow Detection timit

Data Package ID: GS0708142-1 

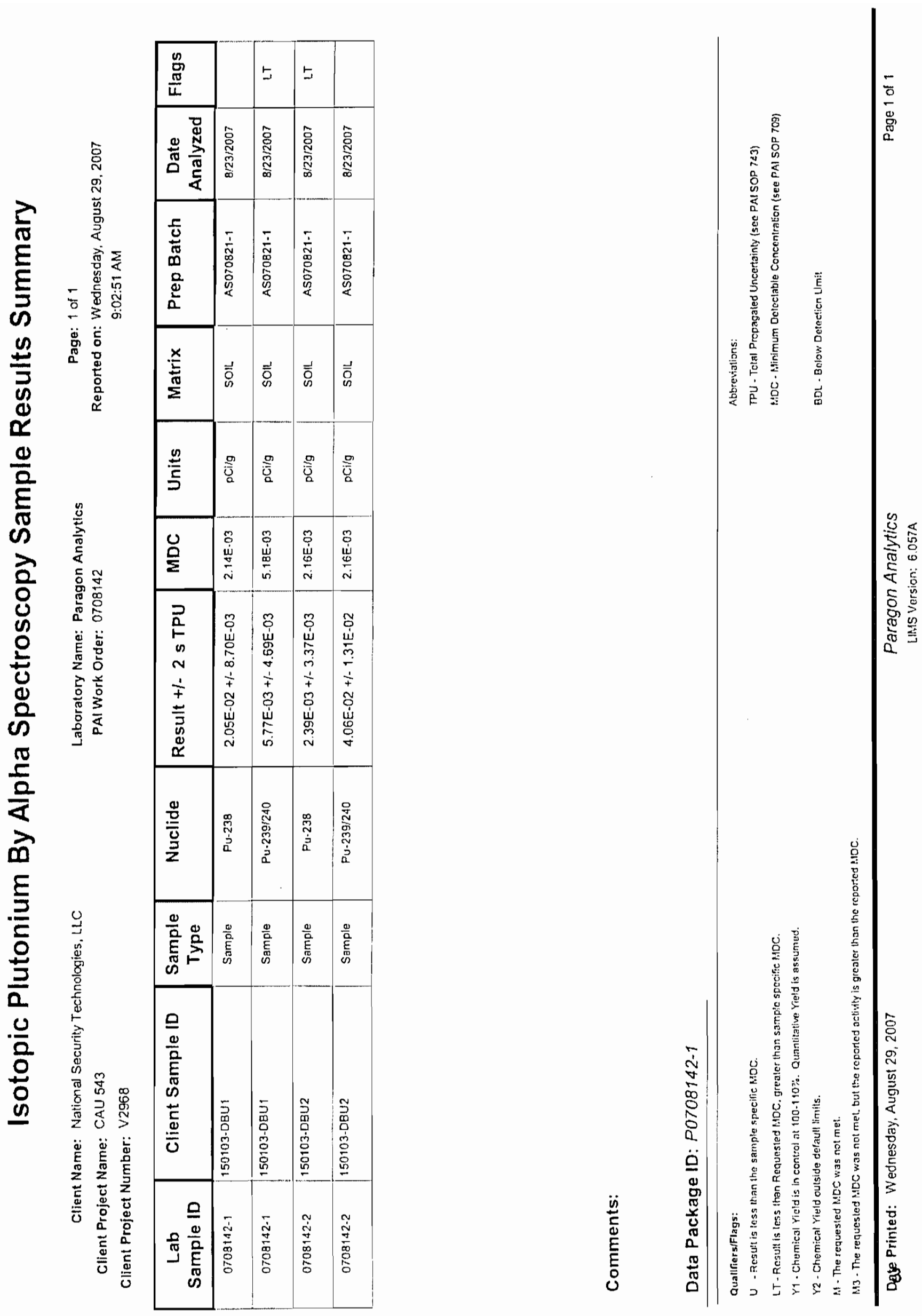
NSTec

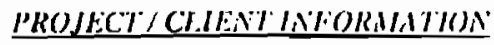

M.

harrge Numter: $5 B 1 B 22 D 5$

Pruict Matrager: TOm Thiele

\begin{tabular}{|l|l|l|}
\hline Phome: $5-6711$ & Fax $5-7761$ & Nis: \\
\hline
\end{tabular}

Hsing 14300
ANALTTCALIABORATOR!

SERVICES REQUEST ANI CHAN OF CUSTODY RECORD

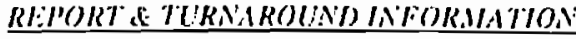

$$
\begin{aligned}
& \text { sinu kipknt 10: David Nacht }
\end{aligned}
$$

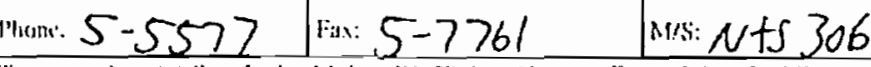

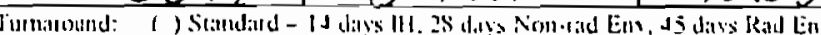

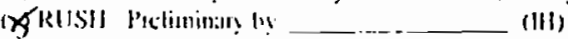

$$
\begin{aligned}
& \text { - } 1 \text { - } 2-7 \quad-1+\text { (nom-kid Env) } \\
& \text { _. } 1 \text { __ X }
\end{aligned}
$$

SDC (Iit)

Nomliad Em) $\operatorname{Van} 968$ (Rid E (W) Simples submilled are associated wilh a signed Project SOW. (X YES $($ ) NO Analyses enlered here angee with the SOW

If not, identify the variation:

Subcontract L_ab(s) used for this work:

(X) YES ( INO ( ) N/A

SAMIIIENIOKMATION Simpling sile: $C A 4543$ CAS 15-01-03 The samples sulmilled comlim (chect)

( ) Ilarzardous - (lisu)

1) Unknown contaminition. If kmown, ielentify

contaninans. This information will ensure compliance will applicable regulations and alluw for the sale flandling or the bitmple materials.

Pay Itcm, Analysis, Method

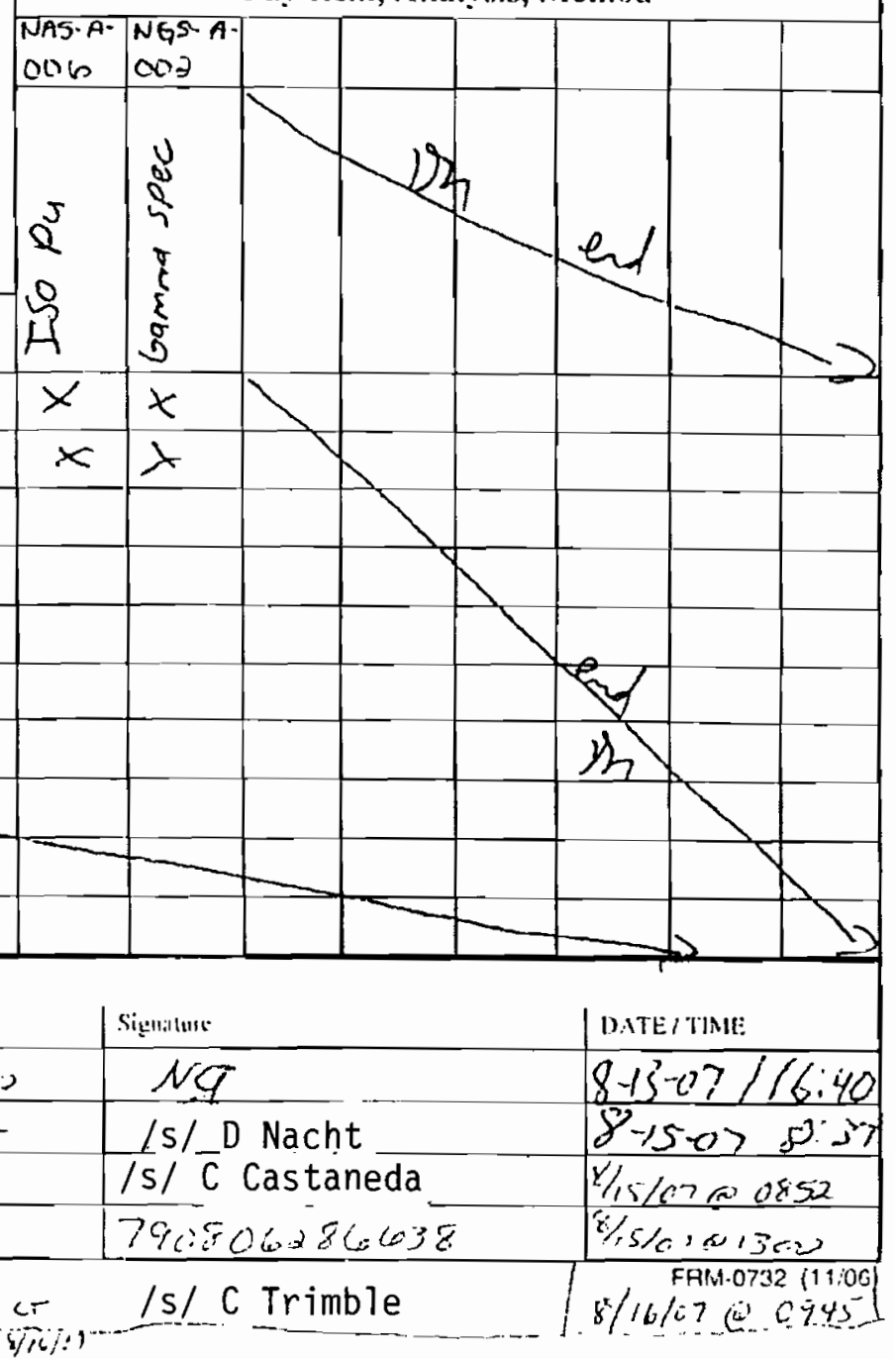


Closure Report - CAU 543

Section: Appendix B

Revision: 0

Date: January 2008

Sample Delivery Group V2974 
Closurc Report - CAU 543

Seclion: Appendix B

Revision: 0

Date: January 2008

TIIIS PAGE INTENTIONALLY LEFT BLANK 


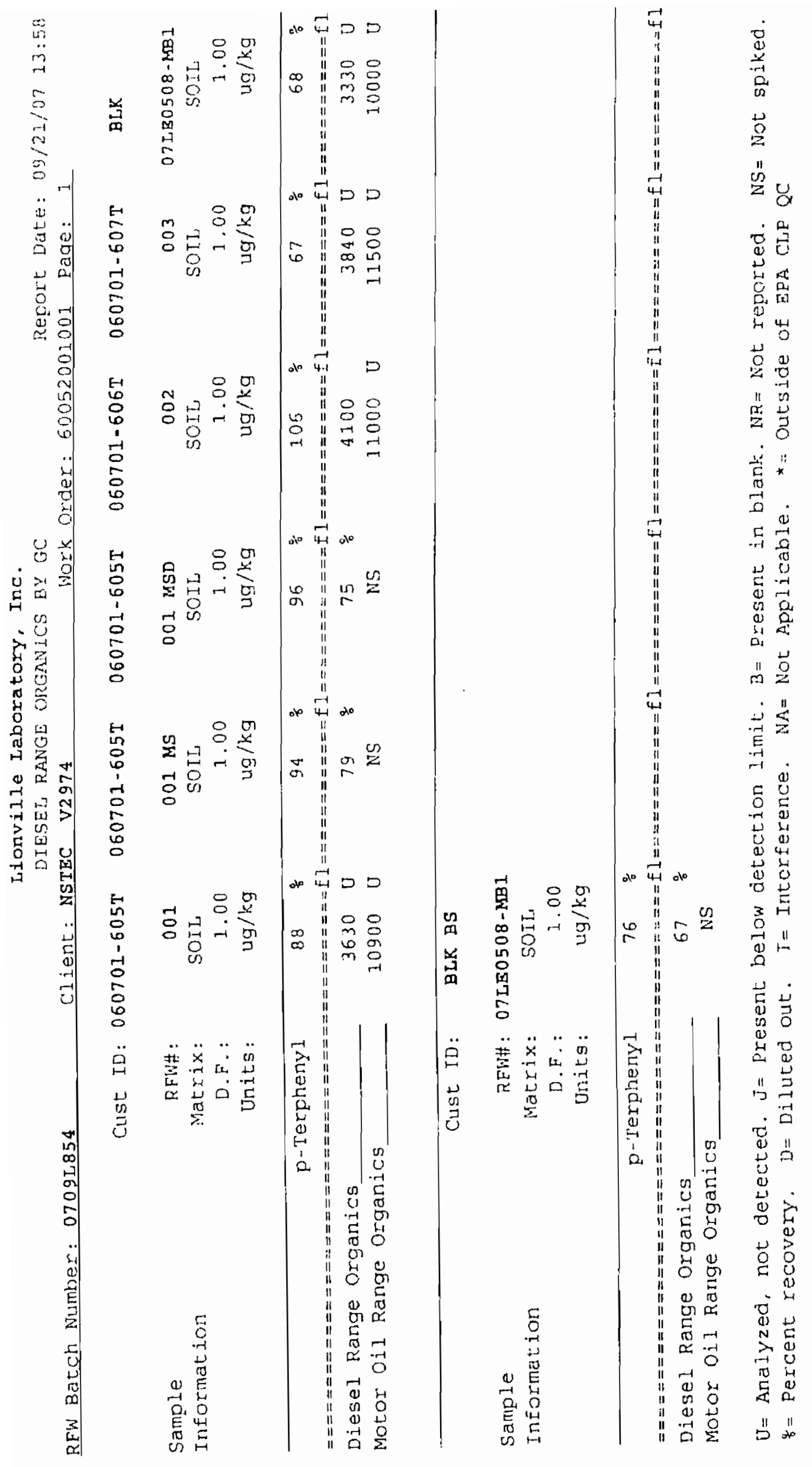




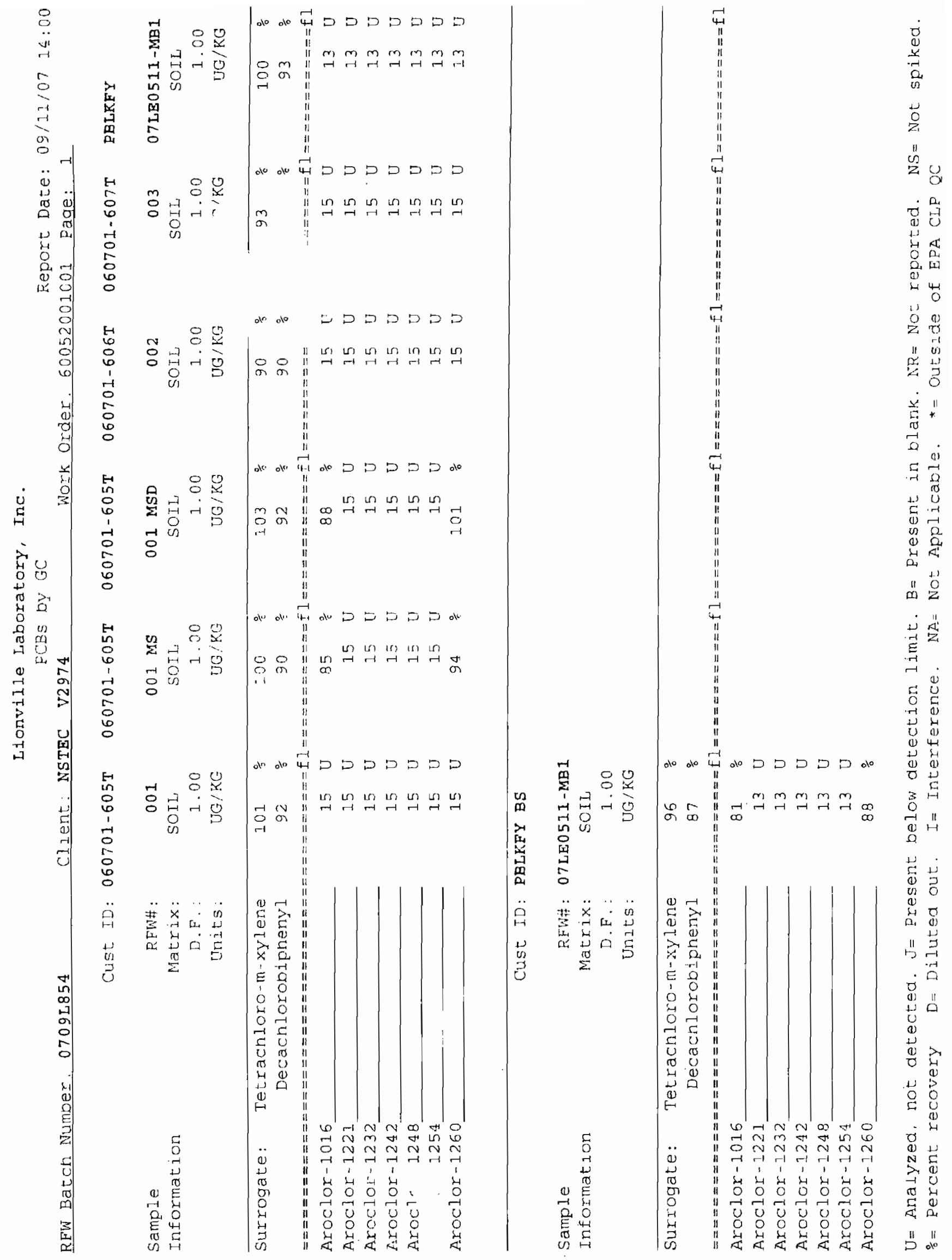


NSTec

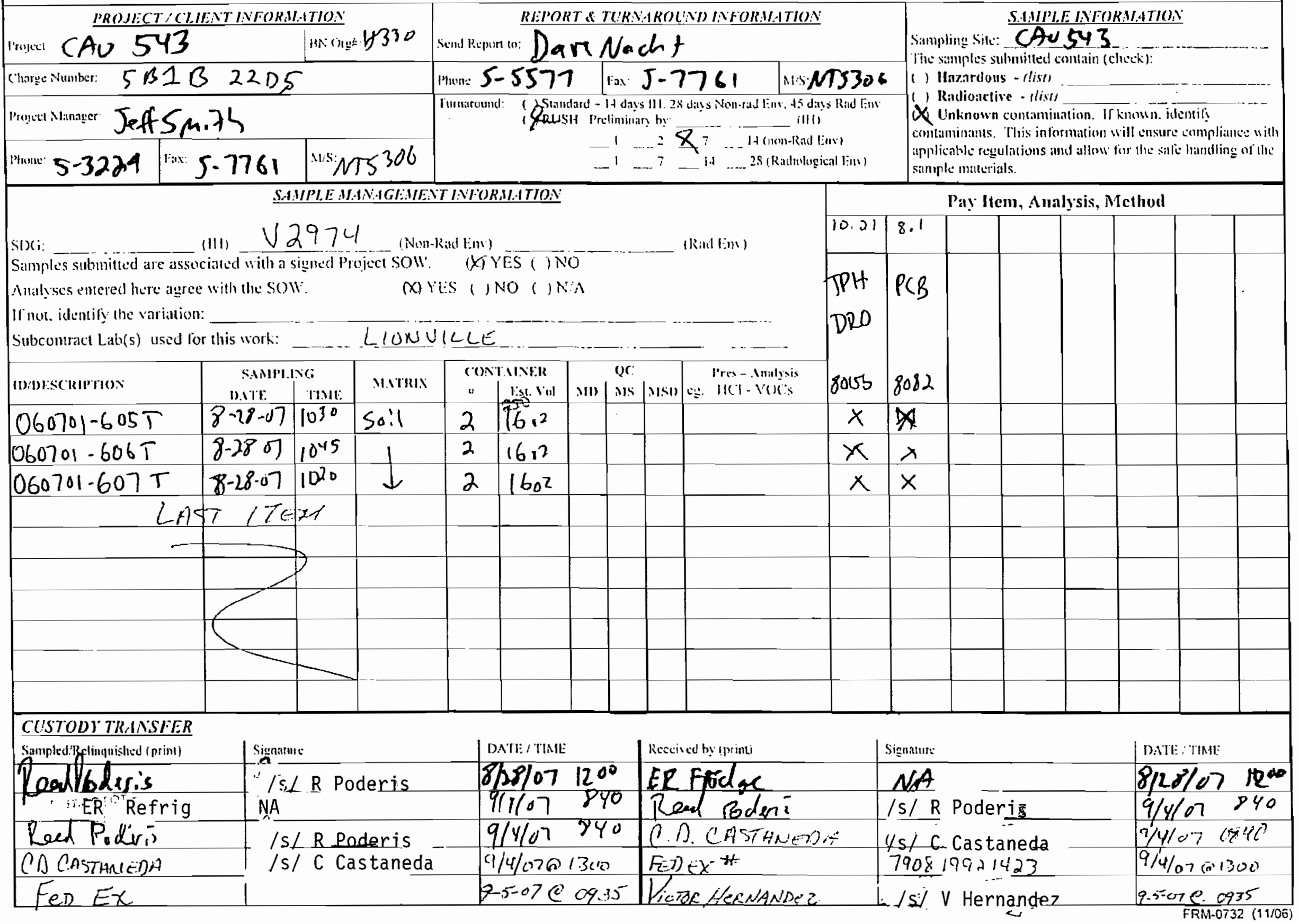


Closure Report - CAU 543

Section: Appendix B

Revision: 0

Date: Jamuary 2008

THIS PAGE INTENTIONALLY LEFT BLANK 
Closure Report - CAU 543

Section: Appendix B

Revision: 0

Date: January 2008

\section{Sample Delivery Group V2975}


Closure Report - CAU 543

Section: Appendix B

Revision: 0

Date: January 2008

THIS PAGE INTENTIONALLY LEFT BLANK 

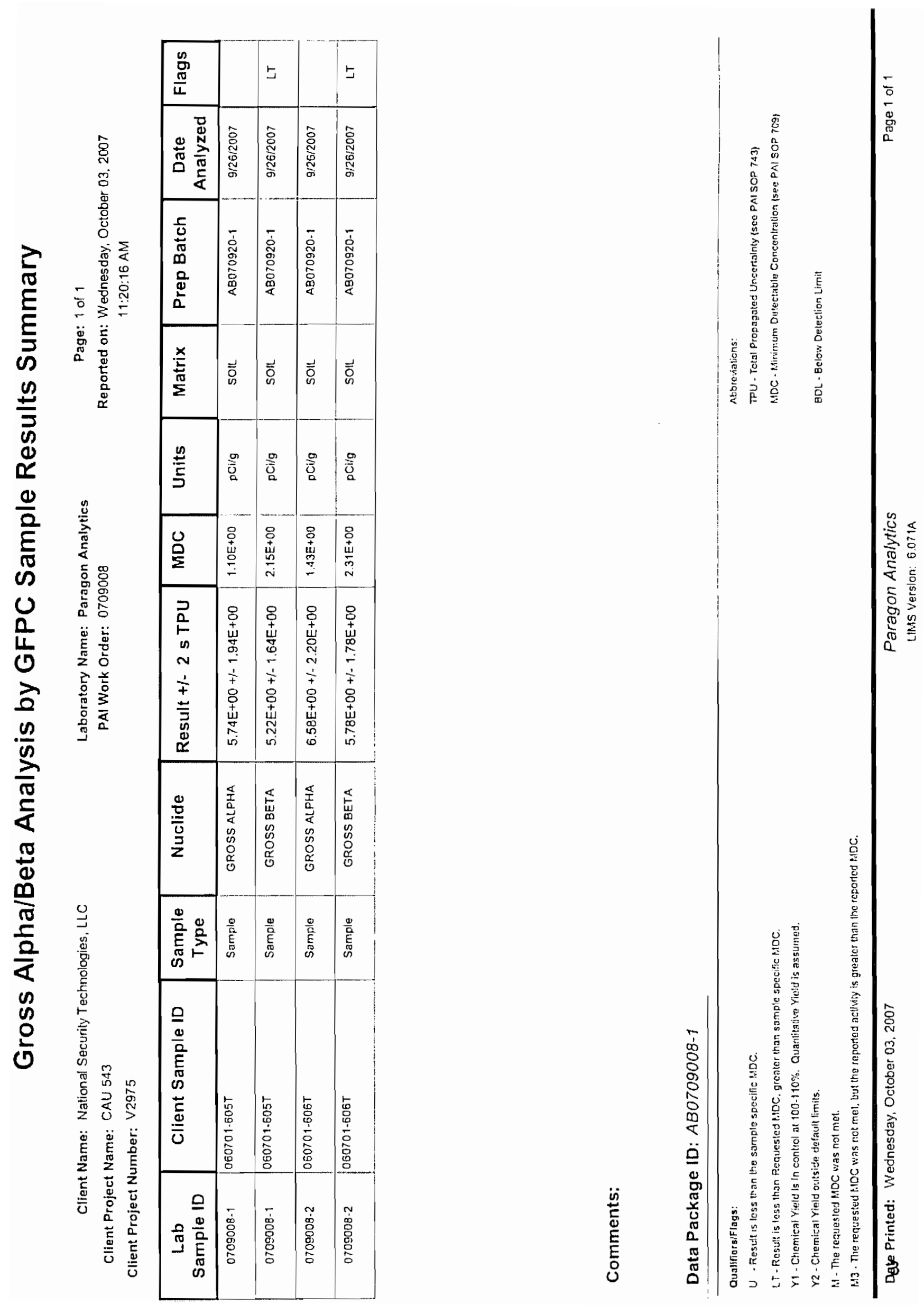


\section{Gamma Spectroscopy Results \\ PAI 713 Rev 9 \\ Sample Results}

Lab Name: Paragon Analytics

Work Order Number: 0709008

Client Name: National Security Technologies, LLC

ClientProject ID: CAU 543 V2975

\begin{tabular}{|c|c|c|c|c|c|}
\hline \multicolumn{2}{|c|}{$\begin{array}{l}\text { Field ID: } 060701-607 T \\
\text { Lab ID: } 0709008-3\end{array}$} & $\begin{array}{l}\text { Sample Matrix: SOIL } \\
\quad \text { Prep SOP: PAI } 739 \text { Rev } 9 \\
\text { Date Collected: } 28-\text { Aug-07 } \\
\text { Date Prepared: } 11 \text {-Sep-07 } \\
\text { Date Analyzed: } 14-\text { Sep- } 07\end{array}$ & $\begin{array}{l}\text { Prep Batch: GS070910-1 } \\
\text { QCBatchID: GS070910-1-1 } \\
\text { Run ID: GS070910-1A } \\
\text { Count Time: } 30 \text { minutes } \\
\text { Report Basis: Dry Weight }\end{array}$ & \multicolumn{2}{|c|}{$\begin{array}{l}\text { Final Aliquot: } 295 \mathrm{~g} \\
\text { Prep Basis: Dry Weight } \\
\text { Moisture(\%): NA } \\
\text { Result Units: } p \text { Cirg } \\
\text { File Name: } 071263 \mathrm{~d} 01\end{array}$} \\
\hline CASNO & Target Nuclide & Result $+1-2 \mathrm{~s}$ TPU & MDC & $\begin{array}{c}\text { Requested } \\
\text { MDC }\end{array}$ & Lab Qualifier \\
\hline $14596-10-2$ & Am-241 & $-3.14 \mathrm{E}-02+1-4.71 \mathrm{E}-01$ & $8.06 \mathrm{E}-01$ & & $U, G$ \\
\hline $10198-40 \cdot 0$ & $\operatorname{Co}-60$ & $4.69 \mathrm{E}-02+1-6.79 \mathrm{E}-02$ & 1.12E-01 & & U,G \\
\hline
\end{tabular}

\section{Comments:}

\section{Qualifiers/Fings:}

$U$ - Rnsuit is less than the samelo specific moC ar less than the associated TPU

$Y 1$ - Chumical Yold is in control at 100-110"ic. Quantitative Yretd is assumed.

Y2. Chemeal Yold outside defauld lunits.

LT - Resull is, less than Reguested HADC, groater than sample specific MDC.

3.ts - Thes rethesters HOC was nul net, but the roported activaly is greas bre than the reported MOC

M. The roluested Moc; was not met

\section{fubtituallens:}

TPU - Tolisl Propagated Uncerainty (sec PAl SOP 743)

MDC - AMnimum Detectabte Concertration (see PAI SOP 709)

EDL - Deslow Detertian Lunit

Data Package ID: GSSO709008-1
SQ - Spertral qualıy provents sccusals quantibilon.

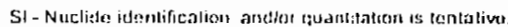

71 - Nuclies identificolion is tentative.

$R$ - Nuchido has excecded 8 nalltwes.

G. Sample density disfors by mate than $15 \%$ of LCS density 

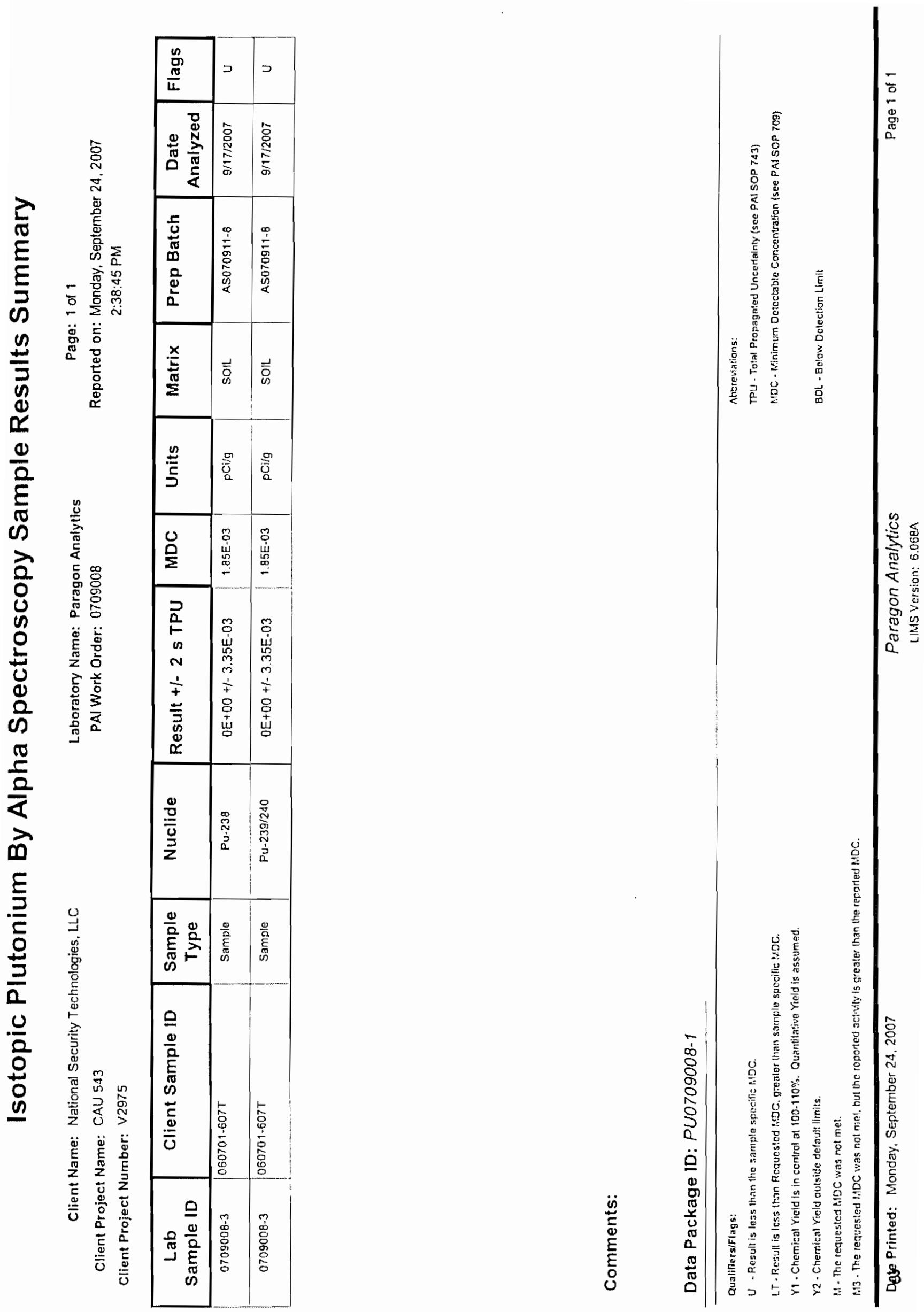

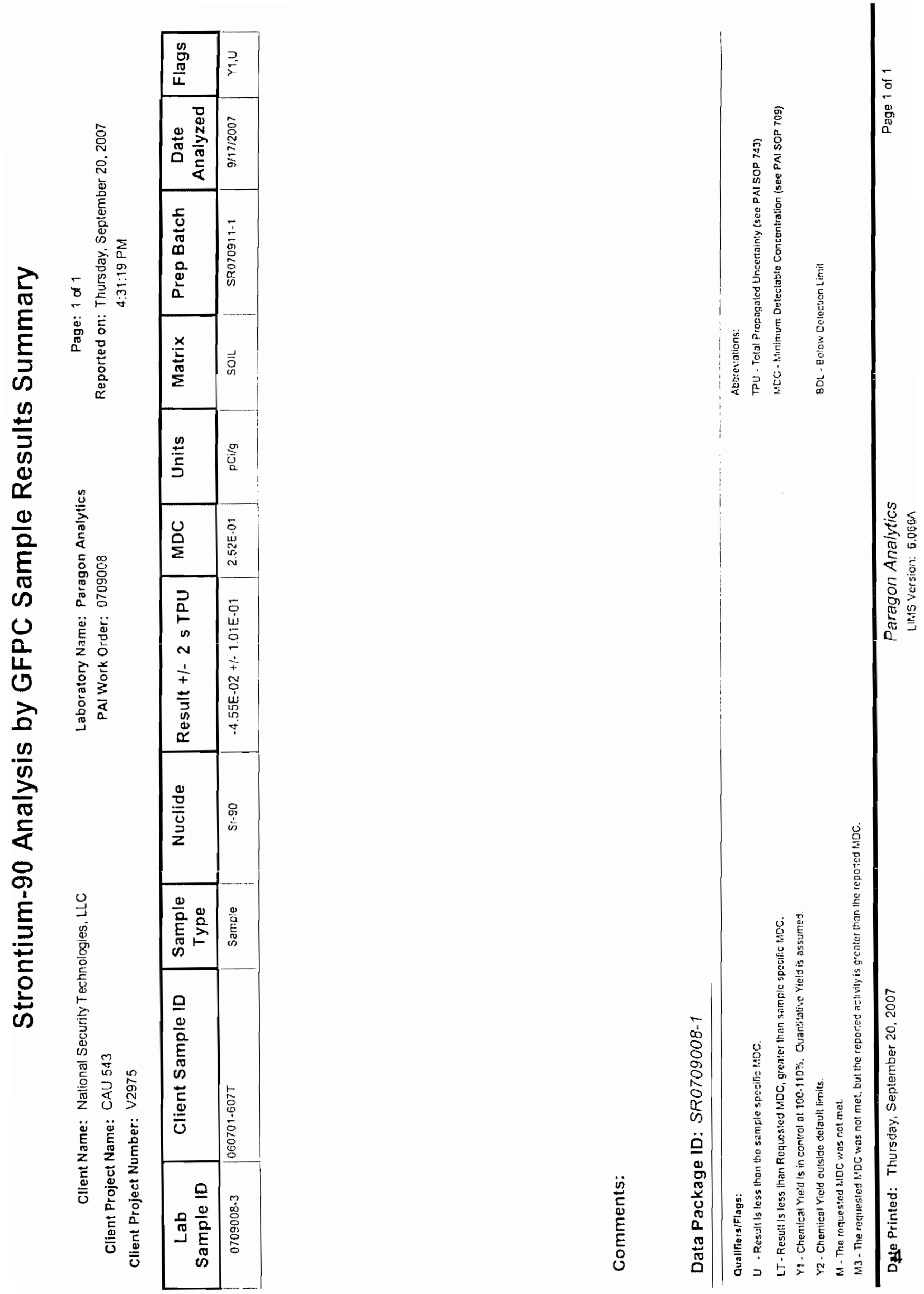


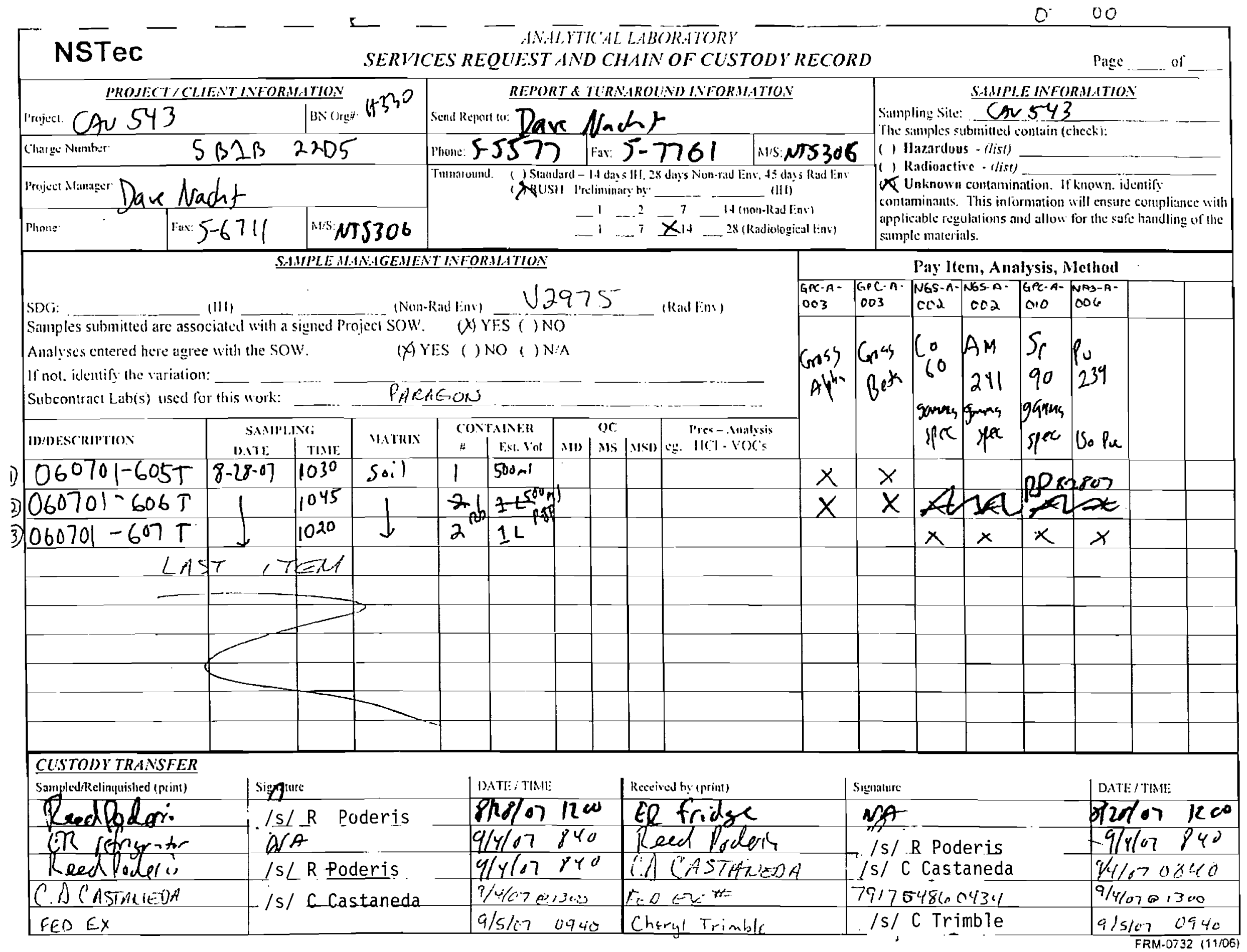


Closure Reporl - CAU 543

Section: Appendix $B$

Revision: 0

Date: January 2008

TIIS PAGE INTENTIONALLY LEFT BLANK 
Closure Report - CAU 543

Section: Appendix B

Revision: 0

Date: January 2008

\section{Sample Delivery Group V2981}


Closure Report - CAU 543

Section: Appendix B

Revision: 0

Date: January 2008

THIS PAGE INTENTIONALLY LEFT BLANK 


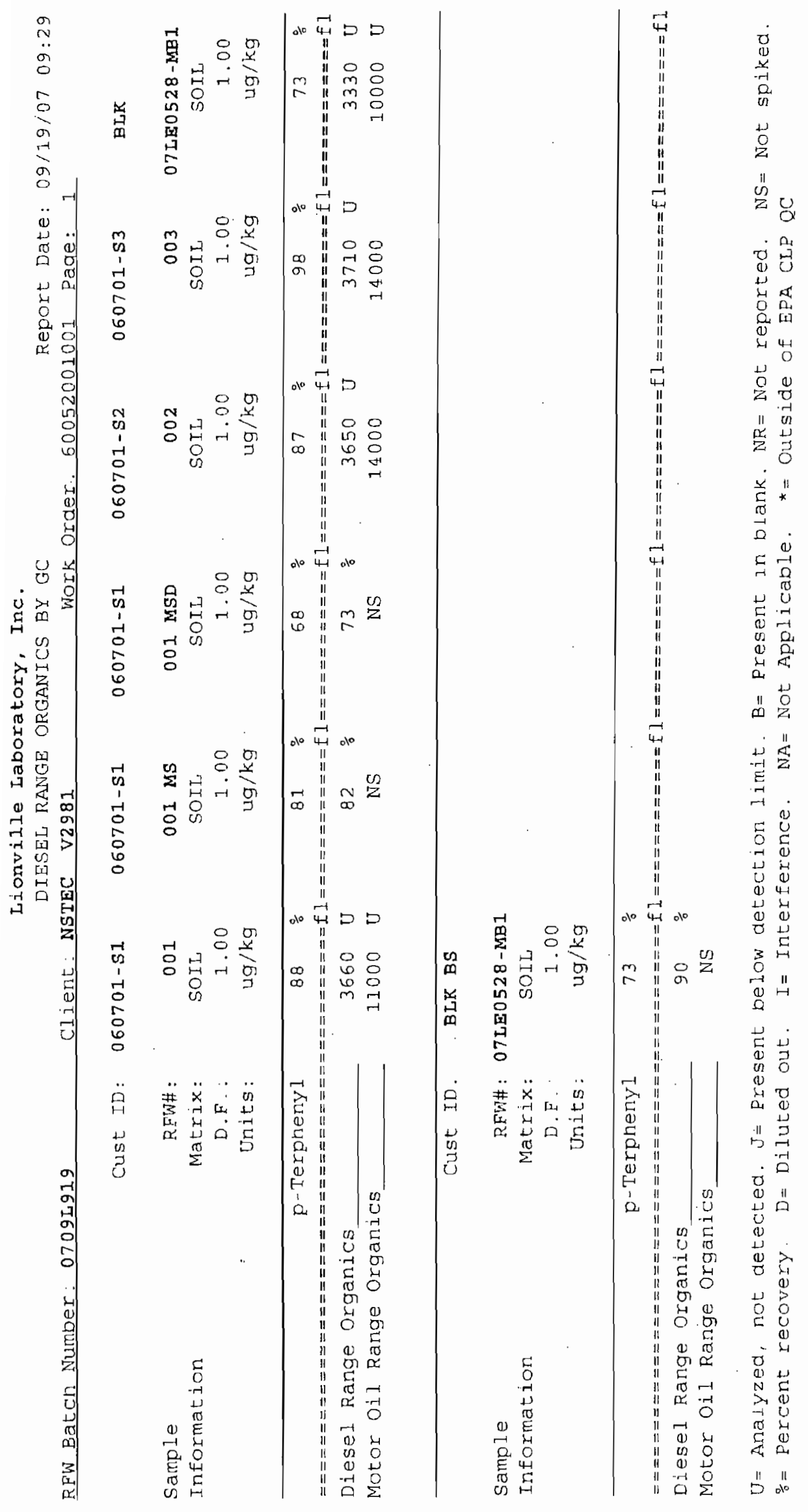




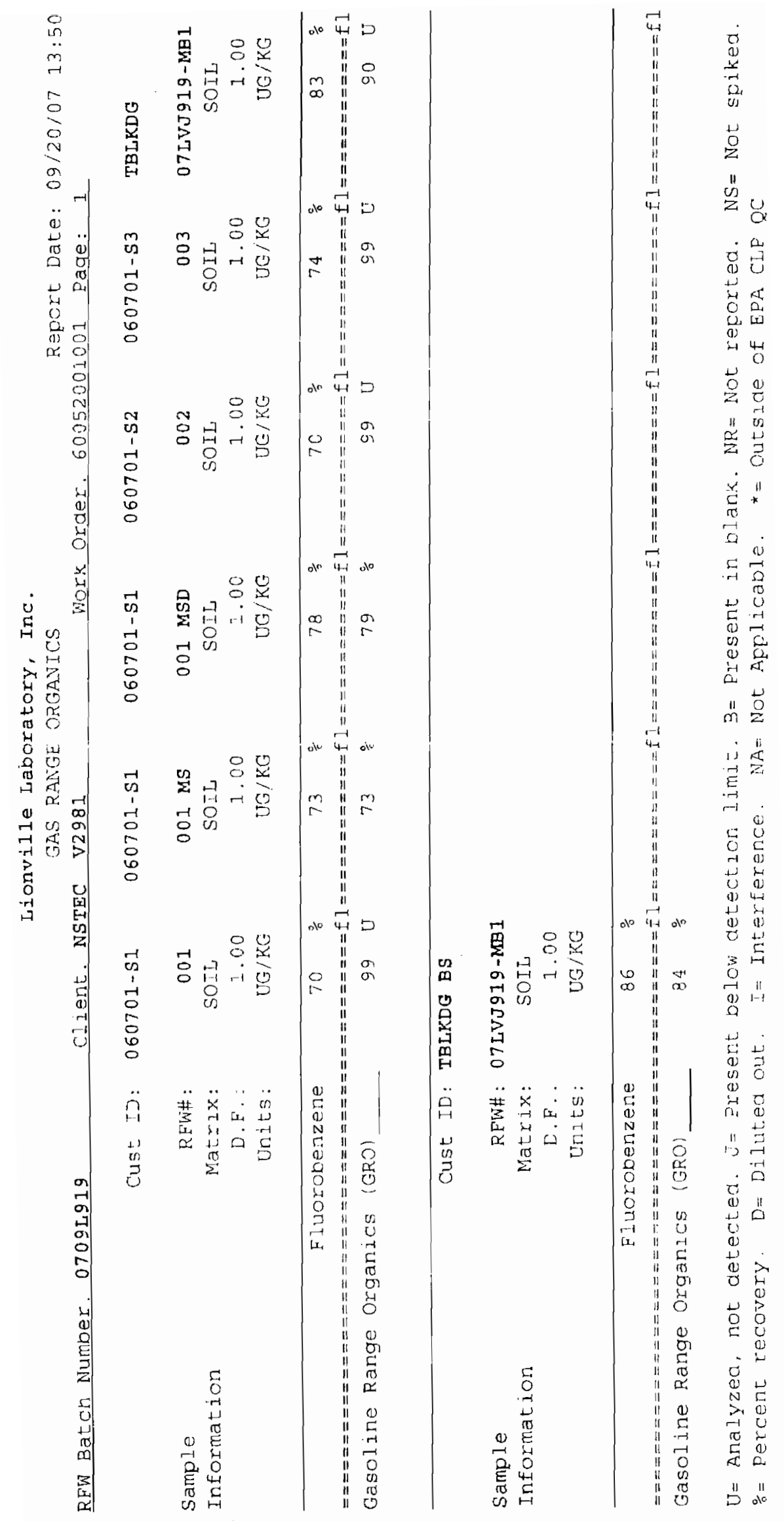




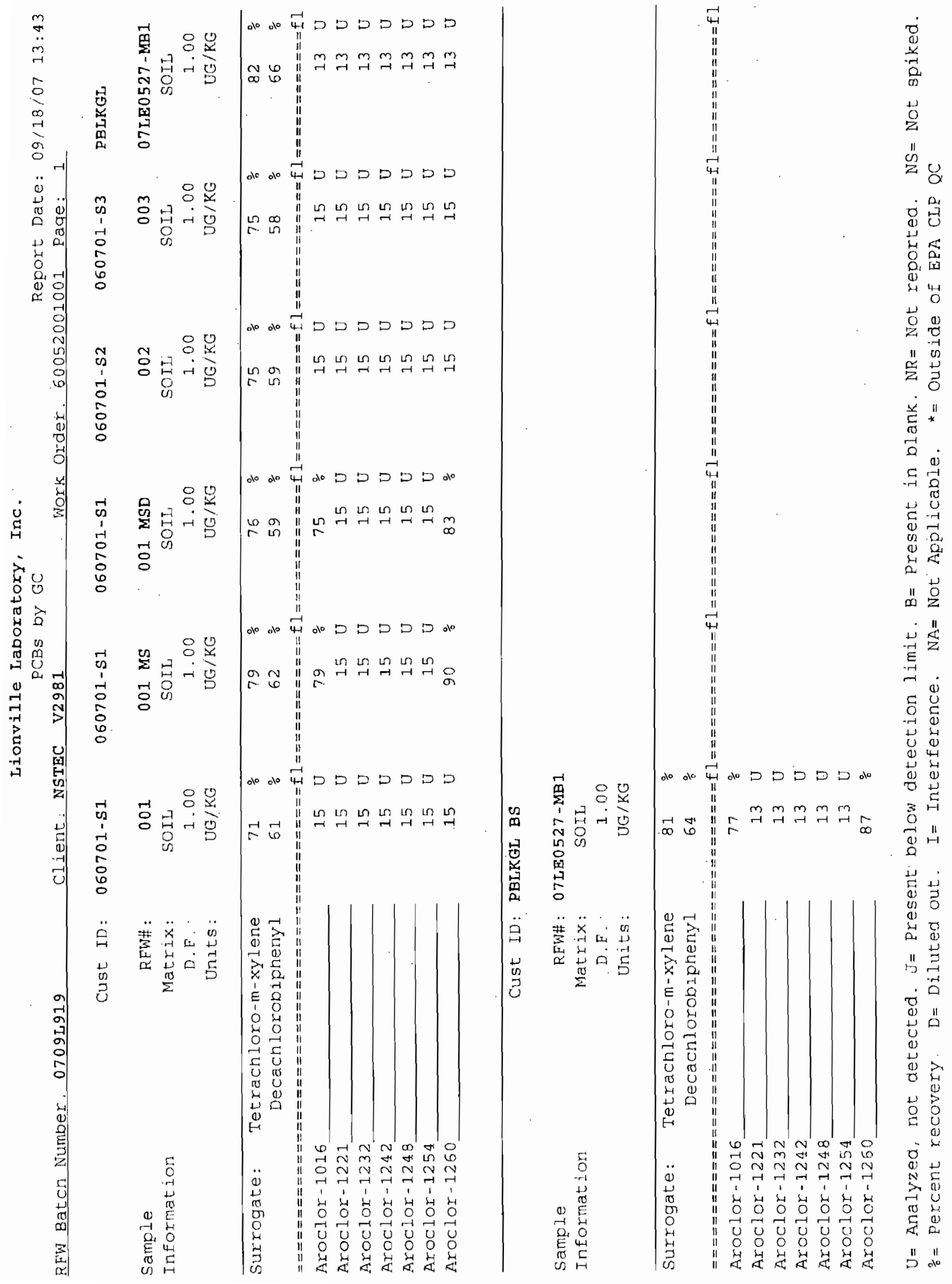




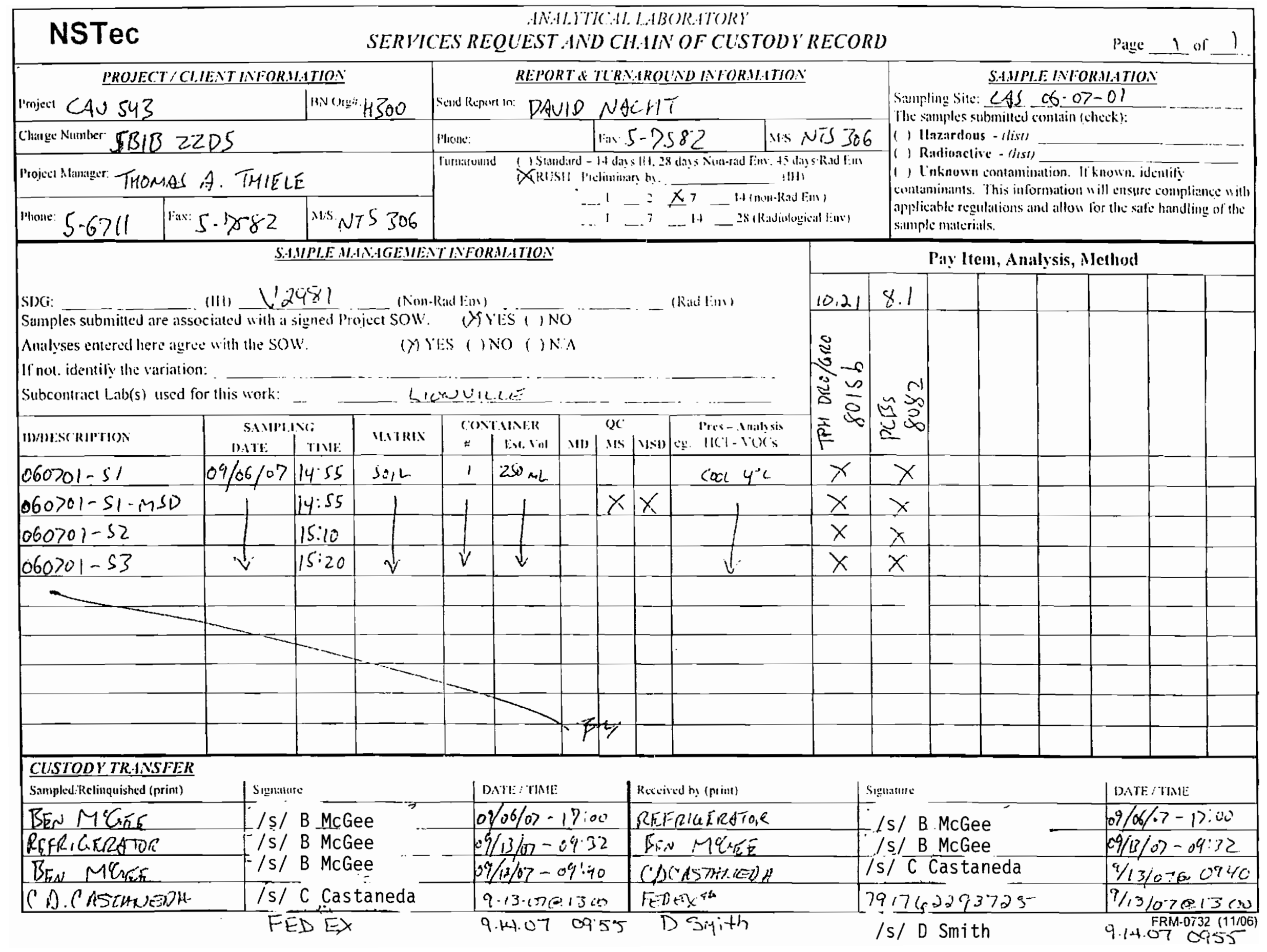


Closure Report - CAU 543

Section: Appendix B

Revision: 0

Date: January 2008

\section{Sample Delivery Group V2982}


Closure Report - CAU 543

Section: Appendix B

Revision: 0

Date: January 2008

THIS PAGE INTENTIONALLY LEFT BLANK 

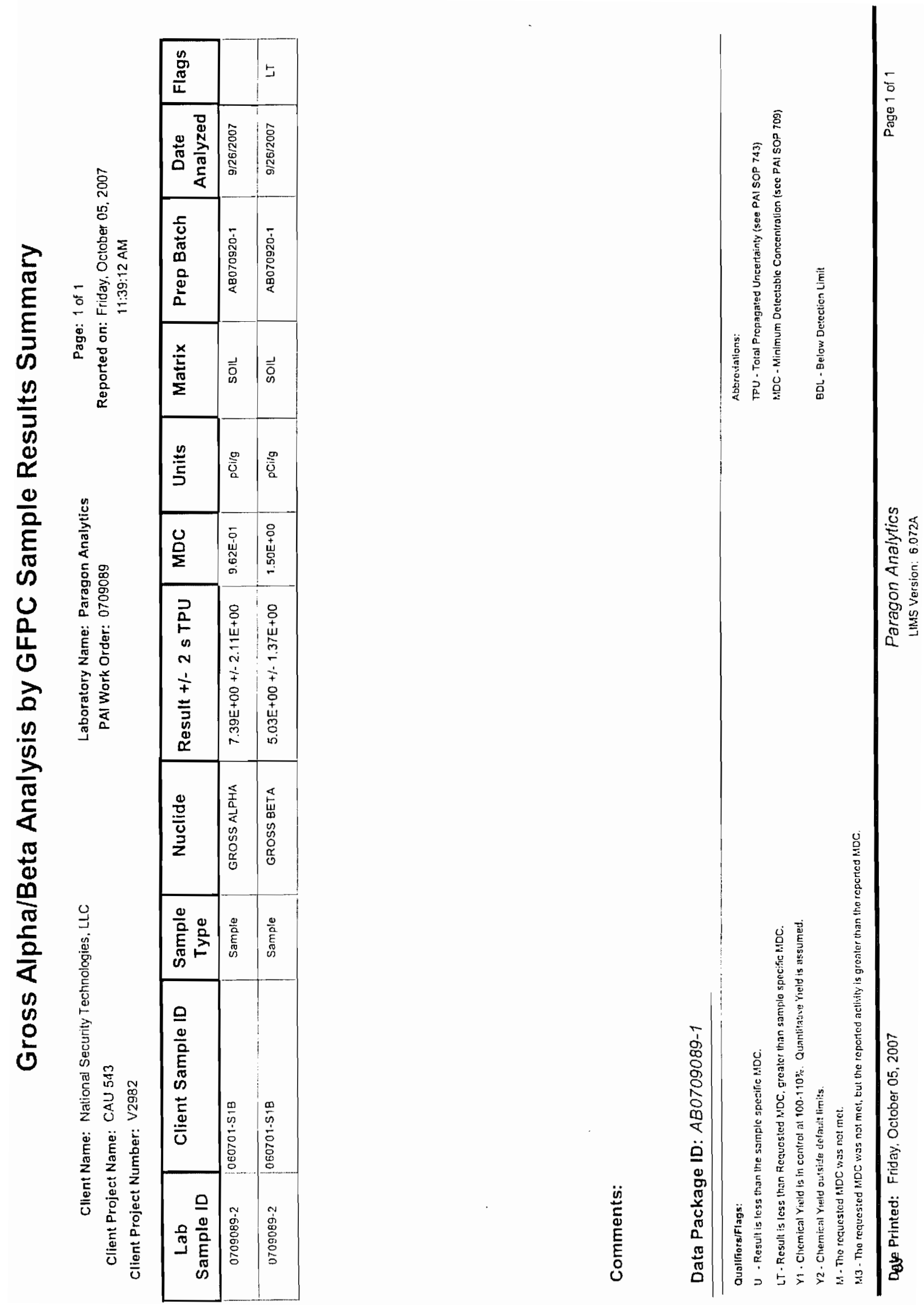


\section{Gamma Spectroscopy Results}

\section{PAl 713 Rev 9 \\ Sample Results}

Lab Name: Paragon Analytics

Work Order Number: 0709089

Client Name: National Security Technologies, LLC

ClientProject ID: CAU 543 V2982

\begin{tabular}{l} 
Fleld ID: $060701-52$ \\
Lab ID: $0709089-3$ \\
\hline
\end{tabular}

Library: LNG..GMM.A.DO Analysis RoqCode: NG5.A.002
Sample Matrix: SOIL

Prep SOP: PAI 739 Rov 9

Date Collected: 06-5ep-07

Date Prepared: 20-Sep-07

Date Analyzed: 23-Sep-07
Prep Batch: GS070920-1

QCBatchID: GSO70920-1-1

Run ID: GS070920.1A

Count Time: 30 minutes

Report Basis: Dry Weight
Final Alquot: $347 \mathrm{~g}$

Prep Basis: Dry Weight

Molsture(\%): NA

Result Units: pCilg

File Name:07 1325d01

\begin{tabular}{|c|c|c|c|c|c|}
\hline CASNO & Target Nuclide & Result +/- 2 s TPU & MDC & $\begin{array}{c}\text { Requested } \\
\text { MDC }\end{array}$ & Lab Qualifier \\
\hline 14331.83 .0 & $\mathrm{Ac}-228$ & $2.20 E+00+1-3.70 E-01$ & $4.21 E-01$ & & $G$ \\
\hline $14596-10-2$ & Am-241 & $-4.27 E-01+/-4.33 E-01$ & $7.61 E-01$ & & U.G \\
\hline $14913 \cdot 49 \cdot 6$ & $\mathrm{Bi} \cdot 212$ & $1.34 E+00+1-7.03 E-01$ & $9.97 E-01$ & & $G$ \\
\hline $14733-03 \cdot 0$ & $B i-214$ & $1.06 E+00+/-2.07 E-01$ & $2.11 E-01$ & & $G, J$ \\
\hline $14762-78-8$ & Ce. 144 & $-2.74 E-02+/-6.65 E-01$ & $1.12 E+00$ & & U.G \\
\hline $10103 \cdot 40 \cdot 0$ & $\operatorname{Cos} 50$ & $2.13 E-01,1,6.29[-02$ & $9.90[-02$ & & $G$ \\
\hline 13967.70 .9 & $\mathrm{Cs}-134$ & $1.16 E-01+1.7 .11 E \cdot 02$ & $1.08 E-01$ & & G.Ti \\
\hline $10045-97-3$ & Cs-137 & $-1.82 \mathrm{E}-02+1-607 \mathrm{E}-02$ & 1.08E-01 & $1.00 E+00$ & $U . G$ \\
\hline $14683.23-9$ & Eu-152 & $-2.26 \mathrm{E}-02+/-3.33 \mathrm{E}-01$ & $5.92 E-01$ & & U.G \\
\hline $15585-10-1$ & $E_{u-15 d}$ & $-1.6 \mathrm{BE}-01+/-3.60 \mathrm{E}-01$ & $6.50 E-01$ & & $\cup, \mathrm{G}$ \\
\hline $14391-16-3$ & Eu-155 & $9.95 E-02+/-2.39 E-01$ & 4.00E-01 & & U.G \\
\hline $13966-00-2$ & $K-40$ & $2.98 E+01+/-4.03 E+00$ & $1.30 E+00$ & & $G$ \\
\hline $15092-94-1$ & Pb-212 & $2.38 E+00+1-3.40 E-01$ & 2.01E-01 & & $G$ \\
\hline $15067-28-4$ & Pb-214 & $1.13 E+00+1-1.96 E-01$ & $2.08 E-01$ & & $G, \downarrow$ \\
\hline $14834-73-2$ & $\mathrm{Pm}-144$ & $1.86 \mathrm{E}-03+/-6.02 \mathrm{E}-02$ & $1.04 E-01$ & & U.G \\
\hline
\end{tabular}

\section{Comments:}

\section{Oualliorsiflags:}

U - Result is lass than the sample specife HAC or kiss than the associaton! TPU

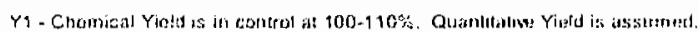

Y2. Chomical Yicla ou'sido dofaul! limits.

LT . Rosun is less than Requestod MDC, grontor than sample spocile MOC

MJ - The infulested MOC was not net, but twe reportos

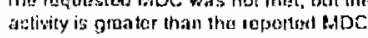

H.t - Tho requeslod MDC was not ne:

Aubremal:ons:

TPU - iolal Propagated Uncenainty loce PNI SOP 743)

ADC - Asinimum Deleciable Concentration (SeC PNI SOP 709)

BOL - Below Dolection Lirsit

Data Package ID: GSS0709089-1
SO- Spectral quality prevents accurdite quarntitation.

S1- Nuclde tetemidcation ardial quantuation is lentative.

TI. Nuclide isentificinion is tenlative.

R. Nuclute has raxceoned is hialliwes.

G - Sample denshly elifters by renet than 15 is of LCS densily. 


\section{Gamma Spectroscopy Results \\ PAI 713 Rev 9 \\ Sample Results}

Lab Name: Paragon Analytics

Work Order Number: 0709089

Client Name: National Security Technologies, LLC

ClientProject ID: CAU 543 V2982

\begin{tabular}{|c|c|c|c|c|c|}
\hline \multicolumn{2}{|c|}{$\begin{aligned} \text { Field ID: } 050701-S 2 \\
\text { Lab ID: } 0709089.3\end{aligned}$} & \multirow{2}{*}{$\begin{array}{l}\text { Sample Matrix: SOIL } \\
\quad \text { Prep SOP: PAI } 739 \text { Rev } 9 \\
\text { Date Collected: 06-Sep-07 } \\
\text { Date Prepared: } 20-\text { Sep-07 } \\
\text { Date Analyzed: } 23 \cdot \text { Sep-07 }\end{array}$} & \multirow{2}{*}{$\begin{array}{l}\text { Prep Batch: GS070920-1 } \\
\text { QCBatchlO: GS070920-1-1 } \\
\text { Run ID: GS070920-1A } \\
\text { Count Time: } 30 \text { minutes } \\
\text { Report Basis: Dry Weight }\end{array}$} & \multirow{2}{*}{\multicolumn{2}{|c|}{$\begin{array}{l}\text { Final Aliquot: } 347 \mathrm{~g} \\
\text { Prep Basis: Dry Weight } \\
\text { Molsture(\%): NA } \\
\text { Result Units: pCi/g } \\
\text { File Name: } 071325 \mathrm{~d} 01\end{array}$}} \\
\hline $\begin{array}{r}\text { Libra } \\
\text { Analysis Requ }\end{array}$ & $\begin{array}{l}\text { LNG_GAM-A-DO1 } \\
\text { c: NGS-A-002 }\end{array}$ & & & & \\
\hline CASNO & Target Nuclide & Result +/- 2 s TPU & MDC & $\begin{array}{l}\text { Requested } \\
\text { MDC }\end{array}$ & Lab Qualifier \\
\hline $14834-74-3$ & $P m-146$ & $4.98 \mathrm{E}-02+1-6.60 \mathrm{E}-02$ & $1.08 \mathrm{E}-01$ & & U.G \\
\hline $13967.48-1$ & Ru-106 & $-3.42 E-01+1-5.72 E-01$ & $1.03 E+00$ & & $U, G$ \\
\hline $14234-35-6$ & Sb-125 & $1.12 E-01+/-1.27 E-01$ & $2.27 E-01$ & & U.G \\
\hline $15065-10-8$ & Th-234 & $1.66 E+00+1.1 .37 E+00$ & $2.19 E+00$ & & U,G \\
\hline $14913-50-9$ & $T 1-208$ & $6.56 \mathrm{E}-01+1-1.20 \mathrm{E}-01$ & 9.79E-02 & & G \\
\hline $15177-96-1$ & $\mathrm{U}-235$ & $1.88 E-01+/-4.38 E-01$ & 7.31E-01 & & U.G \\
\hline $13982-36-0$ & $Y-88$ & $-1.43 E-02+1-7.64 E-02$ & $1.35 \mathrm{E}-01$ & & $U, G$ \\
\hline
\end{tabular}

\section{Comments:}

\section{Qualiflersiflags:}

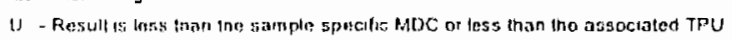

SO. Speciral quality prever:ts accuratu quonitation.

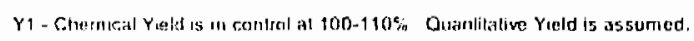

St - Nuchde idenificaion andior quantitation is tentative

$Y 2$. Chemical Yiglus cutside delaun limnts.

11 - Nuclide idenlihization is lentetiwe:

LT - Rusult us less than Requesterd HDC, grealor than sample snocific MDC.

R - Nuelade las excendou B halliwes.

Mi - The requesled MDC was not mel, but the reportod activily is greater thian the reperted MDC.

G - Sample dene ty dilfars by more than $15 \%$ of LCS densily

A. - The requesled RrDC was not met.

\section{A!ture: tations:}

TPU - Total Propanated Uncorianiy (5ec PAl SOP 743)

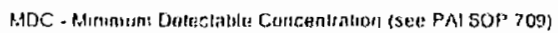

BDA. Bciaw Latestion Lumi?

Data Package ID: GSSO709089-1 


\section{Gamma Spectroscopy Results}

\section{PAl 713 Rev 9 \\ Sample Results}

Lab Name: Paragon Analytics

Work Order Number: 0709089

Client Name: National Securily Technologies, LLC

ClientProject ID: CAU 543 V2982

Fiold ID: $060701-53$
Lab ID: 0709089-4

Library: LNG_GAM-A-DO1

Anulysis ReqCode: NGS-A.002
Samplo Matrix: SOlL

Prep SOP: PAl 739 Rev 9

Date Collected: 06-Sep-07

Date Prepared: 20. Sep-07

Date Analyzed: $23-5 e p-07$
Prep Batch: GS070920-1

QCBatchlD: GSO70920-1-1

Run ID: GS070920-1A

Count Time: 30 minutes

Report Basis: Dry Weight
Final Aliquot: $357 \mathrm{~g}$

Prep Basis: Dry Weight

Moisture(\%): NA

Result Units: $p \mathrm{Ci} / \mathrm{g}$

File Name: 071326d01

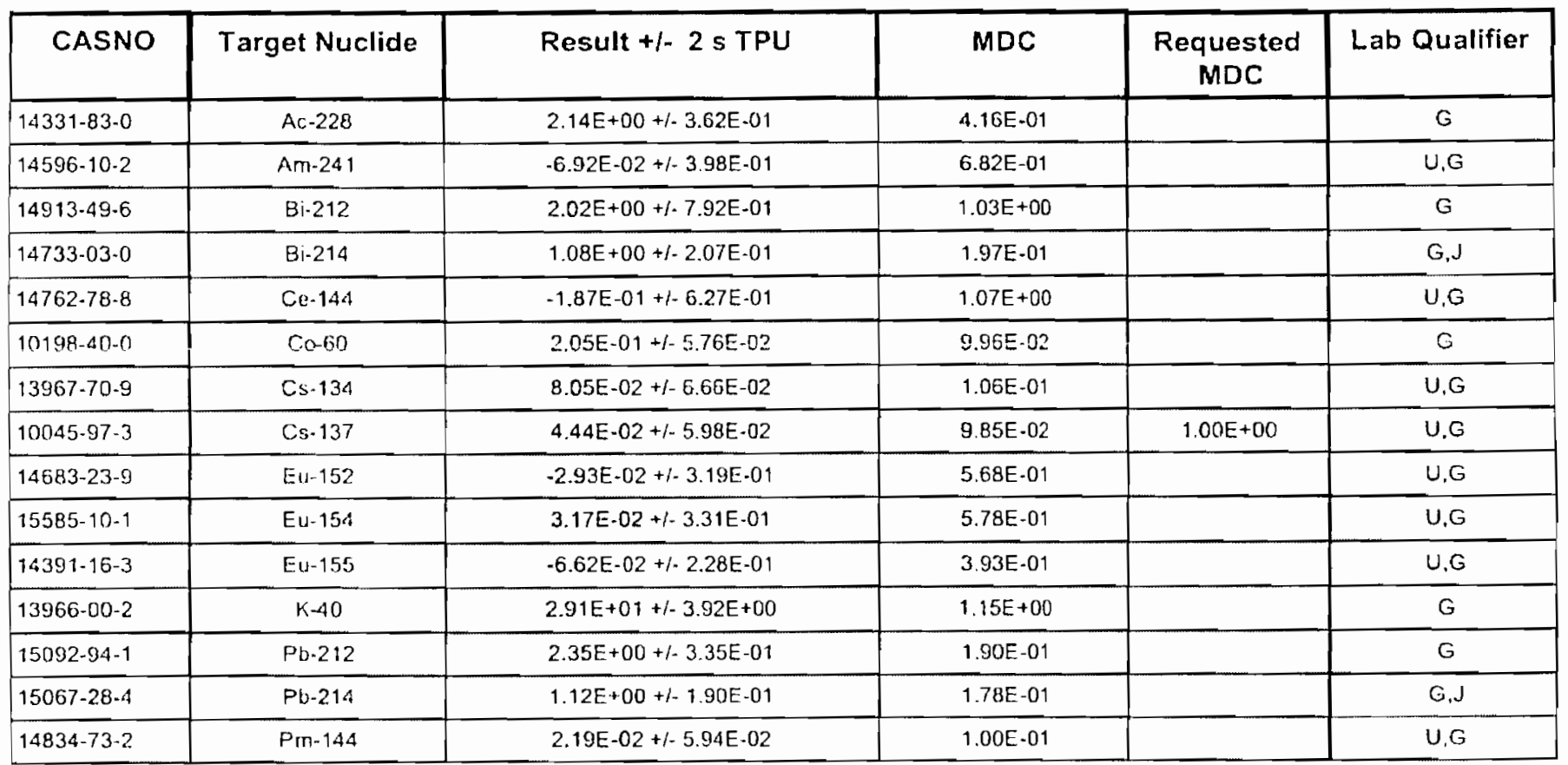

\section{Comments:}

\section{Quallfersiflags:}

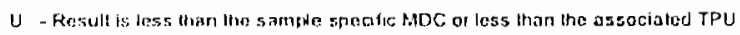

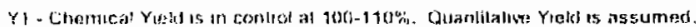

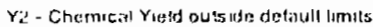

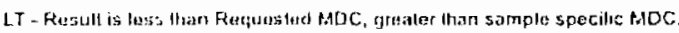

M.3. The recinested MOC was nol mol, but the reporied

achinly is granter thath the reported mos

A. The reclucested MDC was not the

Albtrewaliorrs:

TPU - Tolal Propagated Uncortainty \{son PAI SOP 743\}

MDC - Minamum Delectable Comegrittatian (see FAI SOP 709)

BDL - Below Dotection Limit

Data Package ID: GSS0709089-1
SO - Spucatral quality prevents accurata givantitation.
Sl - Nuclide identification andior quanthation is tentative.
$\mathrm{TI}$ - Nuehds identification is tentative.
$R$ - Pucì te has exceeded to hatlivins.
C - Samnle densily diflers by more 11 an $15 \%$ of LCS densilty. 


\title{
Gamma Spectroscopy Results
}

\author{
PAI 713 Rev 9
}

\section{Sample Results}

Lab Name: Paragon Analytics

Work Order Number: 0709089

Client Name: Nalional Security Technologies, LLC

ClientProject ID: CAU 543 V2982

\begin{tabular}{|c|c|c|c|c|c|}
\hline \multicolumn{2}{|c|}{$\begin{array}{l}\text { Field ID: } 060701-S 3 \\
\text { Lab ID: } 0709089 \times 4\end{array}$} & $\begin{array}{l}\text { Sample Matrix: SOIL } \\
\quad \text { Prep SOP: PAI } 739 \text { Rev } 9 \\
\text { Date Collected: } 06-\text { Sep- } 07 \\
\text { Date Prepared: } 20-\text { Sep- } 07 \\
\text { Date Analyzed: } 23-\text { Sep- } 07\end{array}$ & $\begin{array}{l}\text { Prep Batch: GS070920-1 } \\
\text { QCBatchID: GS070920-1-1 } \\
\text { Run ID: GS070920-1A } \\
\text { Count Time: } 30 \text { minutes } \\
\text { Report Basis: Dry Weight }\end{array}$ & \multicolumn{2}{|c|}{$\begin{array}{l}\text { Final Aliquot: } 357 \mathrm{~g} \\
\text { Prep Basis: Dry W eight } \\
\text { Moisture(\%): NA } \\
\text { Result Unlts: pCi/g } \\
\text { File Name: } 071326 \text { d01 }\end{array}$} \\
\hline CASNO & Target Nuclide & Result $+/-2$ s TPU & MDC & $\begin{array}{c}\text { Requested } \\
\text { MDC }\end{array}$ & Lab Qualifier \\
\hline $14834-74-3$ & $\mathrm{Pm}-146$ & $4,06 \mathrm{E}-02+1-6.19 \mathrm{E}-02$ & $1.03 E-01$ & & U,G \\
\hline $13967-48-1$ & Ru-106 & $1.91 \mathrm{E}-01+/-5.79 \mathrm{E}-01$ & $9.81 E-01$ & & U.G \\
\hline $14234-35-6$ & Sb-125 & $1.52 E-01+/-1.44 E-01$ & $2.64 \mathrm{E}-01$ & & $\mathrm{U}, \mathrm{G}$ \\
\hline $15623-47-9$ & Th-227 & $7.68 \mathrm{E}-01+/-4.38 \mathrm{E}-01$ & $6.14 \mathrm{E}-01$ & & $\mathrm{G}, \mathrm{TI}$ \\
\hline $15065 \cdot 10-8$ & Th-234 & $2.16 E+00+/-1.21 E+00$ & $2.02 E+00$ & & $G$ \\
\hline $14913-50-9$ & $\mathrm{Tl}-208$ & $6.87 E=01+1 \cdot 1.21 E-01$ & $9.67 E-02$ & & $G$ \\
\hline $15117-96-1$ & U-235 & $-2,60 E-01+/-4.25 E-01$ & 7.38E-01 & & $U, G$ \\
\hline $13982-36-0$ & $Y=88$ & $9.25 \mathrm{E}-02+/-6.83 \mathrm{E}-02$ & $1.05 \mathrm{E}-01$ & & U.G \\
\hline
\end{tabular}

\section{Comments:}

Data Package ID: GSS0709089-1 

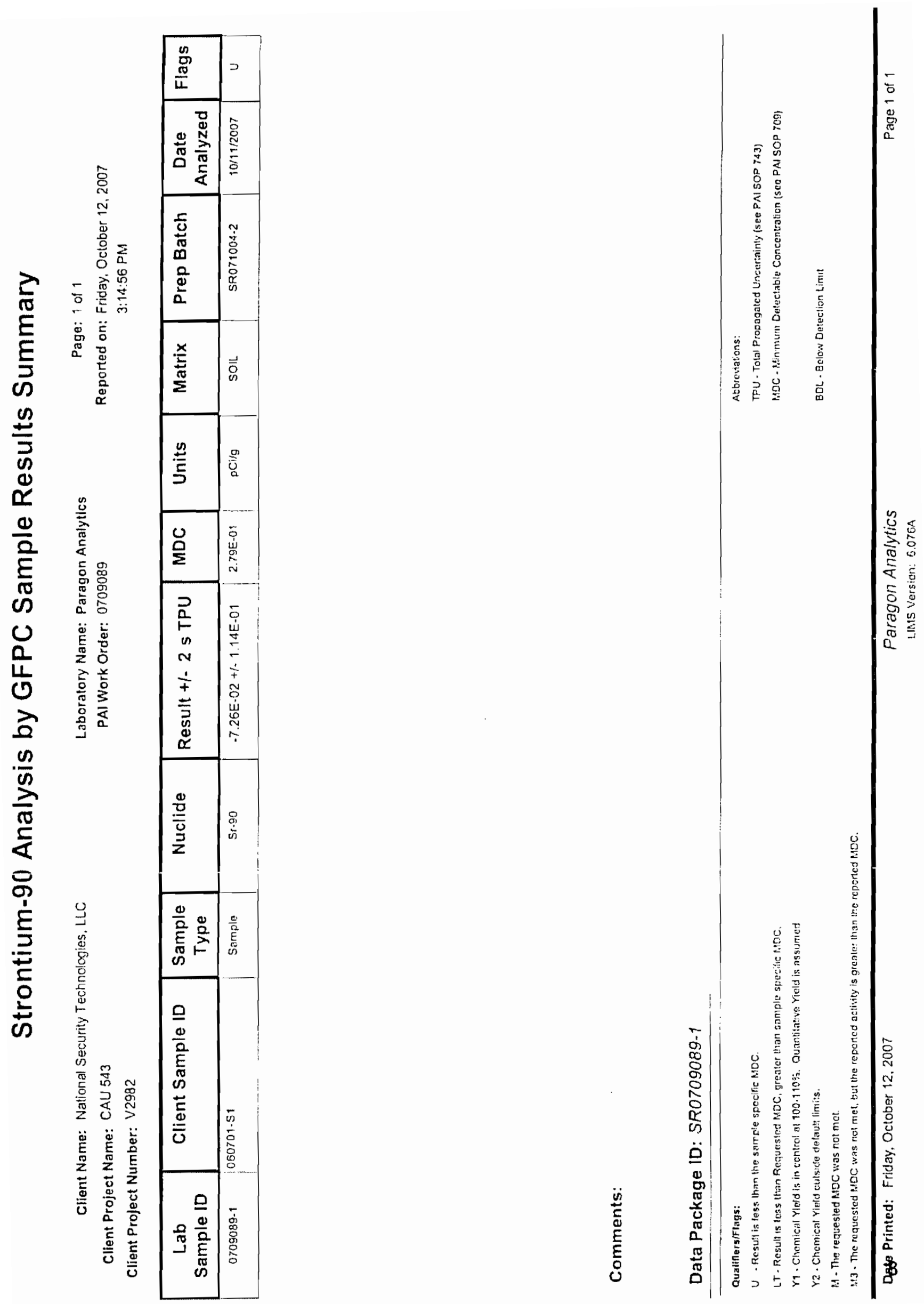

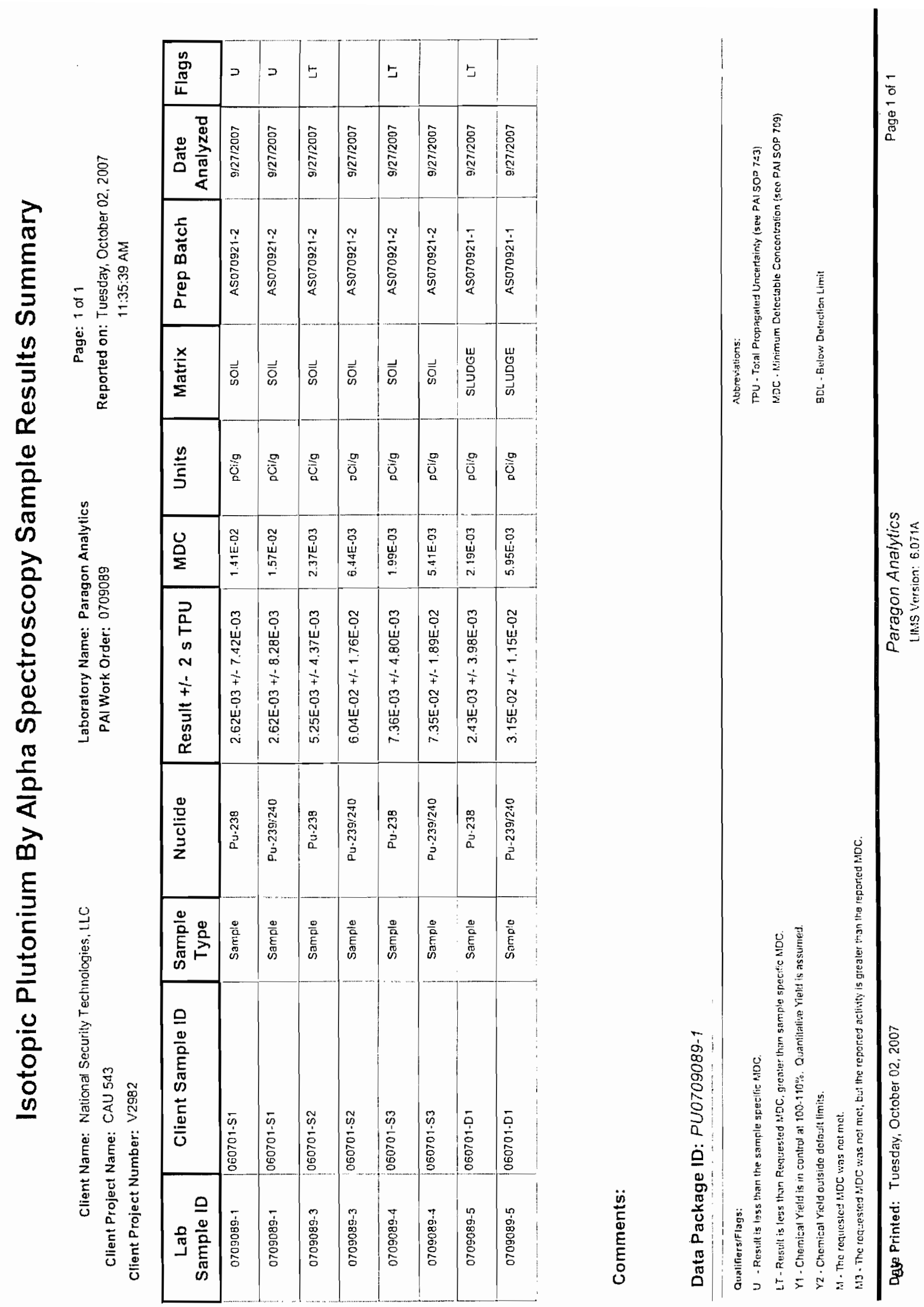


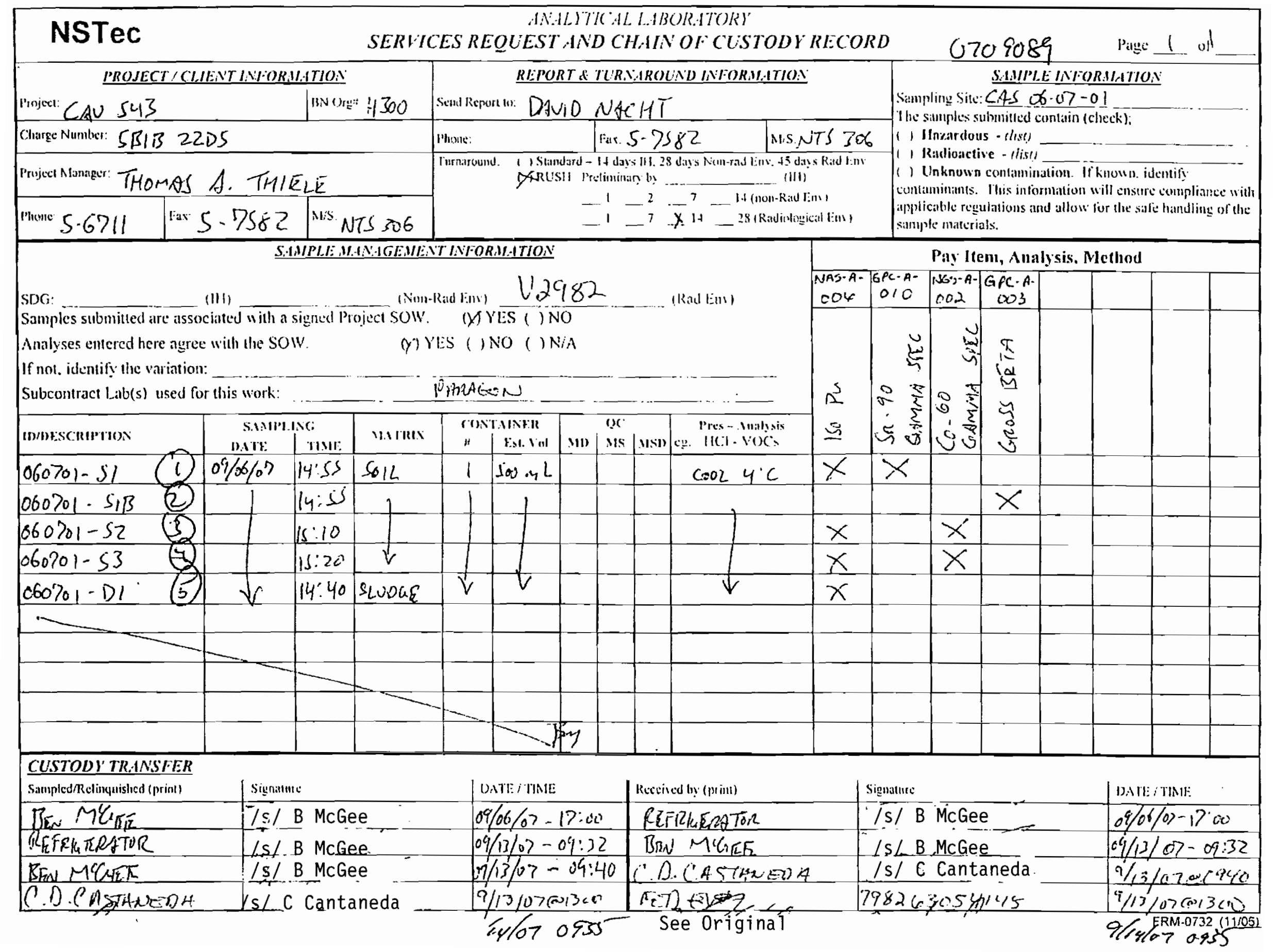


Date: January 2008

\section{APPENDIX C}

\section{WASTE DISPOSITION DOCUMENTATION}


Closure Report - CAU 543

Section: Appendix C

Revision: 0

Datc: January 2008

THIS PAGE INTENTIONALLY LEFT BLANK 
Closure Report - CAU 543

Section: Appendix C

Revision: 0

Date: January 2008

Corrective Action Site 06-07-01

Decon Pad 
Closure Report - CAU 543

Section: Appendix C

Revision: 0

Date: January 2008

THIS PAGE INTENTIONALLY LEFT BLANK 


\section{Certificate of Disposal}

This is to cerlify that the Waste Stream No. LRY5MWFY07002 package numbers 07M037 and 07M038 were shijped and received at the Nevada Test Site Radioactive Waste Management Site in Area 5 for disposal as stared below.

Theresa Hale

Shipped by
NSTec Waste Generator: Services

Organization
Senior Scientist

Title

/s/ Theresa Hale Signature

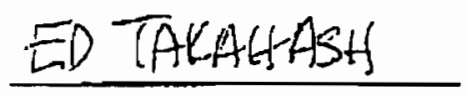

Received by

Notec Riome

Organization
Date $9-28-07$

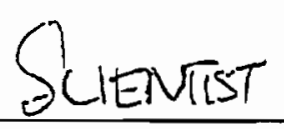

Tille

/St E Takahashi

Signature

Date 28 SEP- -447 


\section{Certificate of Disposal}

This is to certify that the Waste Stream No. LRYSMWFY07002, packages number 07M039 and $07 \mathrm{M} 040$ were shipped and received at the Nevada Test Site Radioactive Waste Management Site in Area 5 for disposal as stated below.

Theresa Yale

Shipped by

Signature

ED TAKANIASIII Received by
NSTec Waste Generator Services

Organization
Senior Scientist

Title
Date $9-28-07$

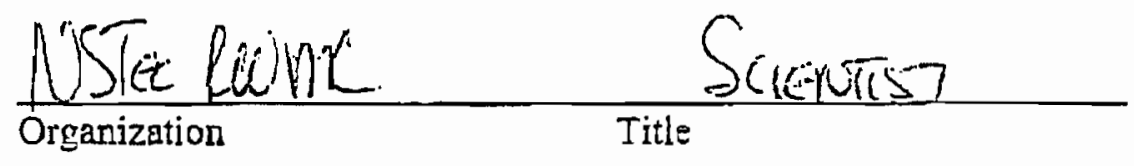

/s/ E Takahashi

stgnature
Date.28-Sep. 0447 


\section{Certificate of Disposal}

This is to certify that the Waste Stream No. LRY5MWFY07002, packages number 07M04 1 and 07M042 were shipped and received at the Nevada Test Site Radioactive Waste Management Site in Area 5 for disposal as stated below.

Theresa Hale

Shipped by

/s/ Theresa Hale

Signature

ID TAKAEECSEHT

Received by

/s/ E Takahashi

Signature
NSTec Waste Generator Services

Senior Scicntist

Tisle

Dare $9-28-07$

NStec Ruimo

Organization

Sciontst

Title

Date $25-5 e^{2}-\partial \phi \phi z$ 
$702-295-4815$

$T-281 P .005 / 011 \quad F-649$

Certificate of Disposal

This is to certify that the Waste Stream No. LRY5MWFY07002, packages number 07M043 and $07 \mathrm{M} 044$ were slipped and received at the Nevada Test Site Radioactive Waste Management Site in Area 5 For disposal as stated below.

Theresa Hale

Shipped by

Is/ Theresa Hale

Signature

DD TAKA-HASIT

Received by

/S/E Takahashi
NSTec Waste Generator: Services

Organization

NSTerilinn

Organization
Senior Scientist

Title

Date $9-2.8-07$

Serehtist

Title

Date. 


\section{Certificate of Disposal}

This is to certify that the Waste Stream No. LRY5MWFY07002, packages number 07M045 and 07M046 were shipped and received at the Nevada Test Site Radioactive Waste Management Site in Area 5 for disposal as stated below.

Theresa Hale

Shipped by

Ls/ Theresa Hale

Signature

$\underset{\text { Received by }}{\text { Laverectff }}$

LSL Nancy Etheridge Signature
NSTec Waste Generator Services

Senior Scientist

Organization Title
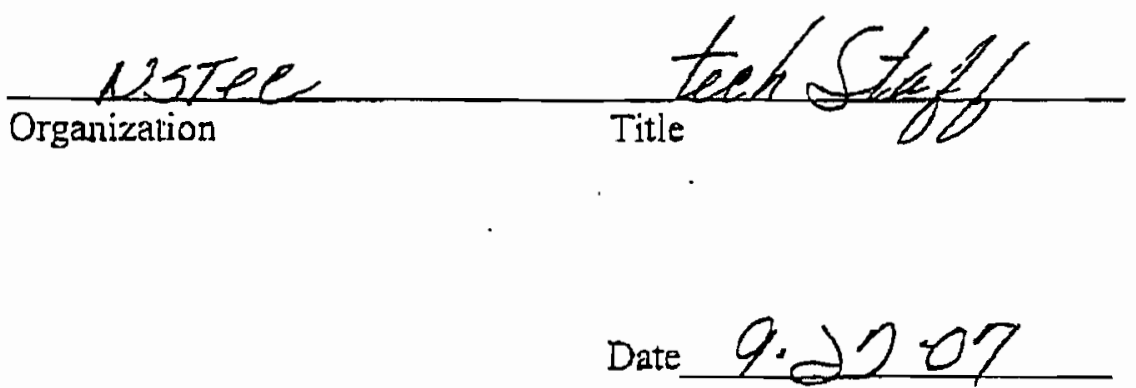


\section{Certificate of Disposal}

This is to certify that the Waste Stream No. LRY5MWFY07002, pacliages number 07M047 and 07M048 were shipped and received at the Nevada Test Site Radioactive Waste Managcment Site in Area 5 for disposal as stated below.

Theresa Hale

Shipped by

/s/ Theresa Hale Signature

$\frac{\text { Nanew Entereaget }}{\text { Received by }}$ /s/ Nancy Etheridge Signature
NSTec Waste Generator Seivices

Senior Scientist

Tille

Date $9-2>-07$

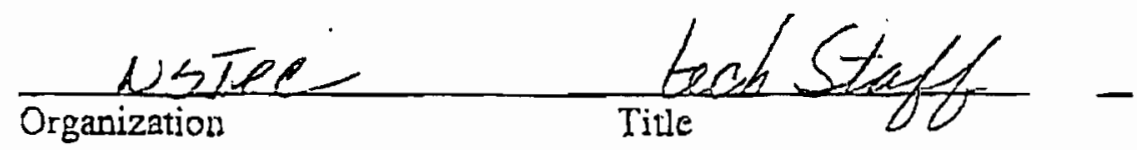

Date $9 \cdot 27 \cdot 02$ 
Oct -0)-2007 03:05 pm

FrOM-WASTE OPERATIONS

$702-295-4815$

T-2B1 P.008/011

$F-649$

Certificate of Disposal

This is to certify that the Waste Stream No. LRY5MWFY07002, packages number 07M1049 and 07M050 were shipped and received at the Nevada Test Site Radioactive Waste Management Site in Area 5 for disposal as stated below.

Theresa Ingle

Slipped by

/s/ Theresa Hale

Signature

$\frac{\text { Naneyfothereege }}{\text { Received by }}$

/s/ Nancy Etheridge

Signature
NSTec Waste Generator Services

Organization

Date $\quad 9-27-07$

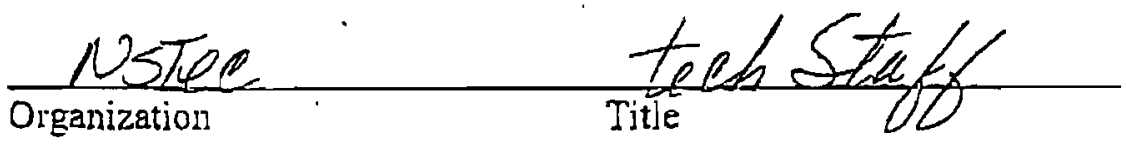

Dare $9 \cdot 2007$ 


\section{Certificate of Disposal}

This is to certify that the Waste Stream No. LRY5MWFYY07002, packages number 07M051 and 07M052 were shipped and received at the Nevada Test Site Radioactive Waste Management Site in Area 5 for clisposal as stated below.

Theresa Hale

Shipped by

/s/ Theresa Hale

Signature

Uaned ETheridae
Received by

/s/ Nancy Etheridge

Signature
NSTec Waste Generator Services

Organization
Senior Scientist

Title
Date $9.27-07$

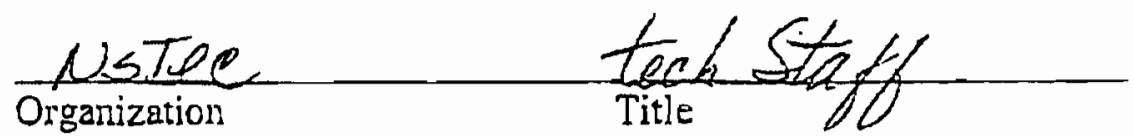

Date $9 \cdot 2202$ 


\section{Certificate of Disposal}

This is to certify that the Waste Stream No. LRYjLIFY07002 package numbers 072296 and 07L297 were shipped and received at the Nevada Test Site Radioactive Waste Management Site in Area 5 for disposal as stated below.

Theresa Hale

Shipped by

$\frac{|s| \text { Theresa Hale }}{\text { Signature }}$
NSTec Waste Generator Scnvices

Organization

$\frac{10-10-0 ?}{\text { Date }}$

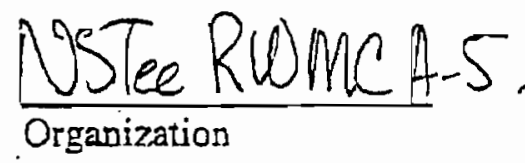

Senior Technical Slaff:

Title

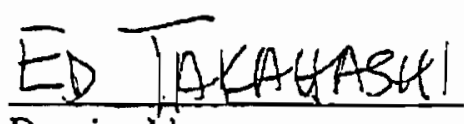

Received by

(1)

Bhgidature

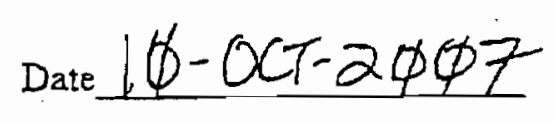


$0 c t-16-2007 \quad 07: 48 a m$

FrOM-WASTE OPERATIONS

$702-295-4815$

$T-301 \quad P .003 / 005 \quad F-731$

Certificate of Disposal

This is to certify that the Waste Strain No. LRY5LLFY07002 package numbers 07L298 and 07L299 were shipped and received at the Nevada Test Site Radioactive Waste Management Site in Area 5 for disposal as stated below.

Theresa Hale

Shipped by

/s/ Theresa Hale

Signature

ED TARASASHH

Received by

/s/ E Takahashi

SIgnature
NSTec Waste Generator Services

Organization

NoTe Rum A-5

Organization
Senior Technical Staff

Title

$10-10-07$

Date

ScIENTIST

Title

Dare $14 \hat{4}-0 G T-2 \phi \phi 7$ 


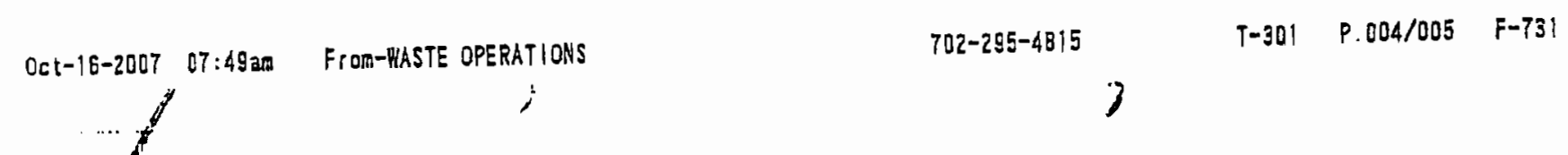

\section{Certificate of Disposal}

This is to certify that the Waste Stream No. LRY5LLFY07002 package numbers 07 L310 and 07L 31 \& were shipped and received at the Nevada 'lest Site Radioactive Waste Management Site in Area 5 for disposal as stated below.

Theresa Hale

Shipped by

$\rightarrow$ Is/ Theresa Hale

Signature

ED TAKAHASHY

Received by
NSTec Waste Generator Services

Organization

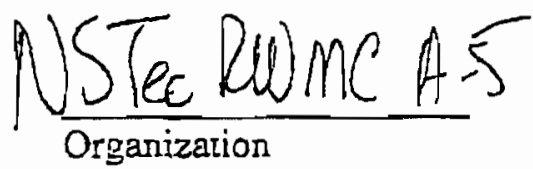

Senior Technical Staff

Title

$\frac{10-10-07}{\text { Date }}$

/s/ E Takahashi

Sisnature 


\section{Certificate of Disposal}

This is to certify that the Waste Stream No. LRY5LLFY07002 package number 07L312 was shipped and received at the Nevada Test Site Radioactive Waste Management Site in Area 5 for disposal as stated below.

Theresa Hale

Shipped by

Signature

ED THKAHASHI Received by

Sigharue
NSTec Waste Generator Services

Organization

$\frac{10-10-07}{\text { Date }}$

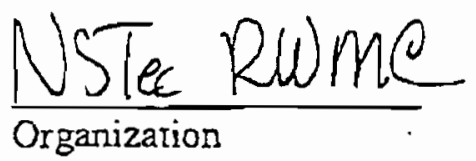

Date $16-04-2067$ 


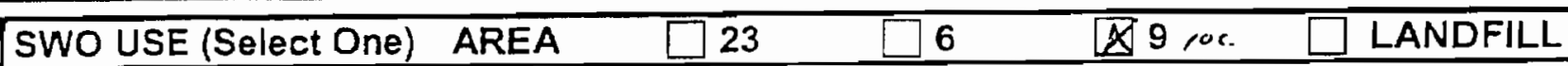

For waste characlerization, approval, and/or assislance, contact Solid Waste Operation (SWO) al 5-7898. REQUIRED: WASTE GERERATOR INFORMATION

(This form is for rollofls, dump trucks, and other onsite disposal of malerials.)

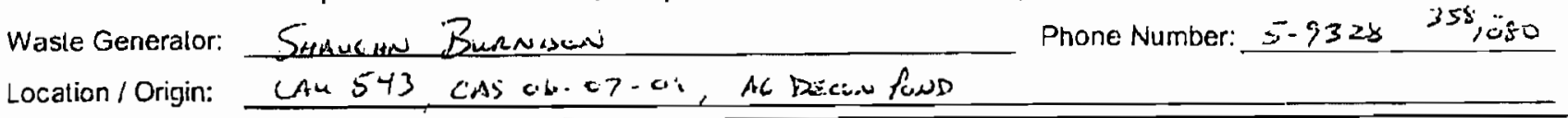

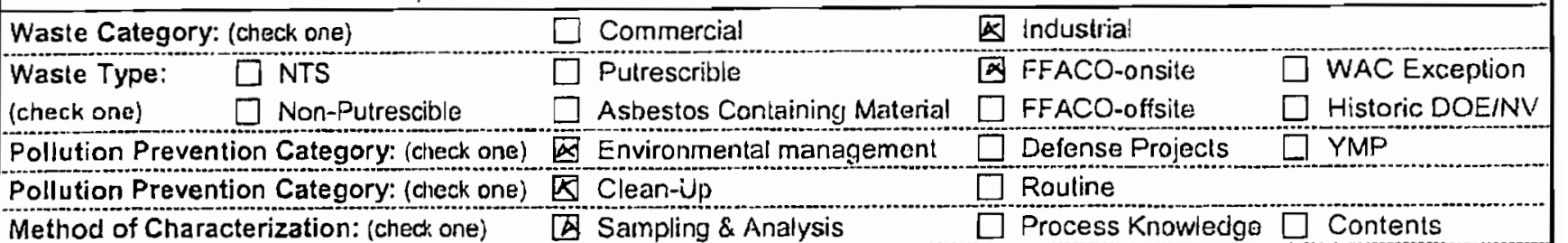

Prohibited Waste at all three Radioactive waste; RCRA waste; Hazardous wasle; Free liquids, PCBs above TSCA regulatory NTS landfills:

Additional Proluibited Waste at the Area 9 U10C Landfill:

levels, and Medical wasles (needles, sharps, bloody clothing).

Sewage Sludge. Animal carcasses, Wet garbage (food waste); and Friable asbestos

REQUIRED: WASTE CONTENTS ALLOWABLE WASTES

Check all allowable wasles that are contained within this load:

NOTE: Waste disposal at the Area 6 Hydrocarbon Landfill must have come into contact with petroleum hydrocarbons or coolants, such as: gasoline (no benzene, lead); jet fuel: diesel fuel; lubricants and hydraulics; kerosene; asphaltic petroleum hydrocarbon; and ethylene glycol.
Acceptable waste at any NTS landfill:
$\square$ Paper
$\square$ Rocks / unaltered geologic materials
E Empty containers
$\square$ Asphall $\square$ Mela!
$\square$ Wood
$\square$ Soil
$\square$ Rubber (excluding tires)
$\square$ Demolition debris
Plastic $\square$ Wire
Cable
$\square$ Cloth
$\square$ insulation (non-Asbestosform)
$\square$ Cement \& concrete

四 Manufactured items: (swamp coolers, furniture, rugs, carpet, electronic components, PPE, etc.) is'BuLk icn-AwER Additional waste accepted at the Area 23 Mercury Landfill: $\square$ Office Waste $\square$ Food Waste $\square$ Animal Carcasses
$\square$ Asbestos
$\square$ Friable
Non-Friable (conlact SwO if regulated load)
Quantity:

\section{Additional waste accepted at the Area 9 U10c Landfill:}
$\square$ Non-friable asbestos
Drained automobiles and military vehicles
Solid fractions from sand/oil/water
Light ballasts (contact Swo)
Drained fuel filters (gas \& diesel) Hydrocarbons (contact swo) $\square$ Other
$\square$ Deconned Underground and Above Ground Tanks

Additional waste accepted at the Area 6 Hydrocarbon Landfill:
$\square$ Septic sludge
$\square$ Rags
$\square$ Drained fuel filters (gas \& diesen)
Plants
Soi'
$\square$ Sludge from sand/oil/water separators
Crushed non-teme plated oil filters REQUIRED: WASTE GENERATOR SIGNATURE

Initiais: (if initialed, no radiological clearance is necessary.)

The above mentioned waste was generated outside of a Controlled Was knowledge, does not contain radiological materials.

To the best of my knowledge, the waste described above contains only 1 site. I have verified this through the waste characterization method ider prohibited and allowable waste items. I have contacted Property Manag is approved for disposal in the landfill.

Print Name: Simuiun Burensuni

Signature: _L / Shaughn Burnison

Date: $\because / 2 / 7$

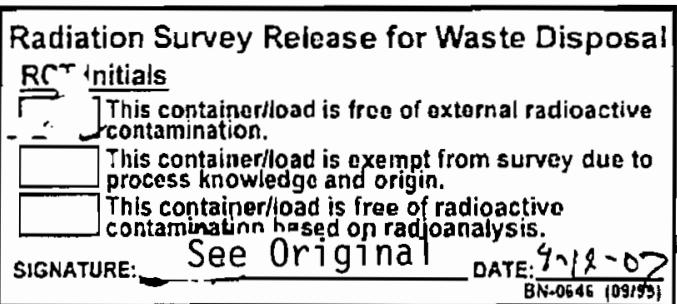
adiological Release Sticker" here. Onsite use only.

Note: "Food waste, office trash and animal carcasses do not require a radiological clearance. Freon-containing appliances must have signed removal certification statement with Load Verificalion."

SWO USE ONLY

t.Dad Weight (net from scale or estimate):

$4-12-6.7$

Signature of Certifier /s/ Steven C 
Form

\begin{tabular}{|llllll}
\hline SWO USE (Select One) & AREA \\
\hline
\end{tabular}

For waste characterization, approval, and/or assistance, contacl Solid Waste Operation (SWO) al 5-7898.

\section{REQUIRED: WASTE GERERATOR INFORMATION}

(This form is for rollofits, dump trucks, and other onsite disposa/ of materials.)

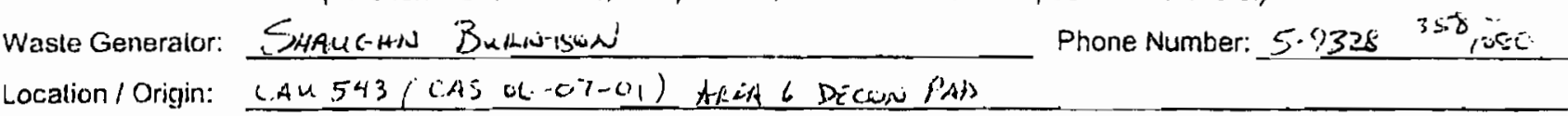

Waste Category: (check one)

Waste Type: $\square$ NTS

Commorcial

Industrial

(check one) $\square$ Non-Putrescible $\square$ Asbestos Containing Material

Pollution Prevention Category: (check one) $\Delta$ Environmental management

Pollution Prevention Category: (check one) $Q$ Clean-Up

Method of Characterization: (check onc) $\forall$ Sampling \& Analysis

(1) FFACO-onsite

$\square$ FFACO-ofisile

Defenso Projects

$\square$ WAC Exception
Prohibited Waste at all three Radioactive waste; RCRA waste: Hazardous waste; Free liquids, PCBS above TSCA regulatory NTS landfills: levels, and Medical wasles (needles, sharps, bloody clothing).

Additional Prohibited Waste at the Area 9 U10C Landfill:

Sewage Sludge, Animal carcasses, Wet garbage (food waste); and Friable asbestos

\section{REQUIRED: WASTE CONTENTS ALLOWABLE WASTES}

Check all allowable wastes that are contained within this load:

NOTE: Waste disposal at the Area 6 Hydrocarbon Landfill must have come into contact with petroleum hydrocarbons or coolants, such as: gasoline (no benzene, lead); jel fuel; diesel fuel; lubricants and hydraulics; kerosene; asphaltic petroleum hydrocarbon; and olhylene glycol.

Acceptable waste at any NTS tandfill: $\square$ Paper $\square$ Rocks/ unaltered geologic materials
$\square$ Asphalt
Metal
$\square$ Wood
$\square$ Soil
$\square$ Rubber (excluding tires)
$\square$ insulation (non-Asbestosform)
$\square$ Plastic $\square$ Wire $\square$ Cable $\square$ Cloth

$\square$ Empty containers
$\square$ Demolition debris
$\square$ Cement \& concrete

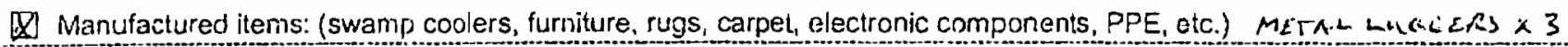
Additional waste accepted at the Area 23 Mercury Landfill: $\square$ Office Waste $\square$ Food Waste $\square$ Animal Carcasses
$\square$ Asbestos
Friable
Non-Friable (contacl SWO if regulated load)
Quantity:

Additional waste accepted at the Area 9 U10c Landfill:
$\square$ Non-iriable asbestos
Drained automobiles and military vohicles
$\square$ Light ballasts (contacl Swo)
Drained fuel filters (gas \& diesel)
Solid fractions from sand/oil/water
$\square$ Hydrocarbons (contact SWO)
Other
$\square$ Deconned Underground and Above Ground Tanks

Additional waste accepted at the Area 6 Hydrocarbon Landfill:
$\square$ Septic sludge
$\square$ Rags
$\square$ Drained fuel filters (gas \& diesel)
$\square$ Sludge from sand/oil/water separators
Crushed non-teme plated oil filters
Plants REQUIRED: WASTE GENERATOR SIGNATURE PCBs below 50 parts per million

Initials: (if initialed, no radiological clearance is necessary.)

The above mentioned waste was generated outside of a Controlled Wa! knowledge, does not contain radiological materials.

To the best of my knowledge, the waste described above contains only site. I have verified this through the waste characterization method ide prohibited and allowable waste items. I have contacted Property Mana is approved for disposal in the landfill.

Print Name: SunuGañ Branisud

Signalure: /s/. Shaughn Burnison

Date: $i / 12 / 07$

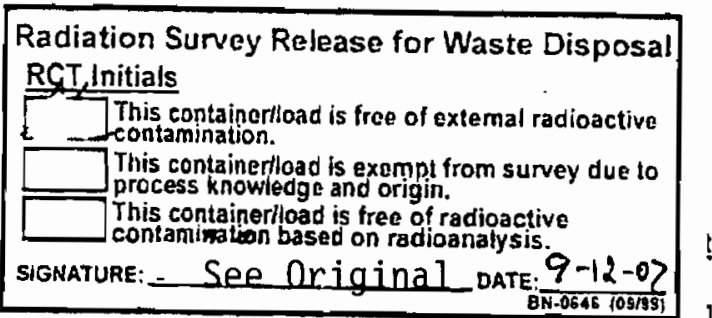

Note: "Food waste, office trash and animal carcasses do not require a radiological clearance. Freon-containing appliances must have signed removal certification statement with Load Verification."

SWO USE ONLY

Load Weight (nel from scale or estimate): 4000

$\zeta, 12-07$

Signature of Certifier: _._S/ Richard Everett 


\begin{tabular}{lllllll}
\hline SWO USE (Select One) & AREA & $\square 23$ & $\square 6$ & $\bar{\alpha} 9$ & $10 \mathrm{C}$ & $\square$ LANDFILL
\end{tabular}

For waste characterization, approval, and/or assistance, contact Solid Wasie Operation (SWO) at 5-7898. REQUIRED: WASTE GERERATOR INFORMATION

(This form is for rolloffs, dump Irucks, and other onsile disposal of malerials.)

Waste Generator: SthuGuin BuRNiss,N

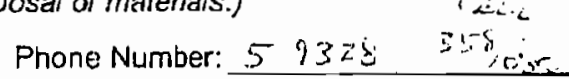

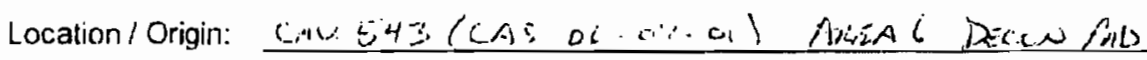

Waste Category: (check one)

Waste Type: $\square$ NTS $\square$ Commercial $\triangle$ Industrial

(check one)

$\square$ Non-Putrescible

$\square$ Putrescrible

区 FFACO-onsite

$\square$ Asbestos Containing Material

$\square$ FFACO-offsite WAC Exception

Pollution Prevention Category: (check one) $\triangle$ Environmental managemen!

Pollution Prevention Category: (check one) $\triangle$ Clean-Up

Method of Characterization: (check one) a Sampling \& Analysis

Delense Projects

$\square$ Routine

Process Knowledge

Page 1 of 2

NTS landfills:

Additional Prohibited Waste

at the Area 9 U10C Landfill:

Sewage Sludige, Animal carcasses, Wel garbage (food waste); and F riable asbestos

REQUIRED: WASTE CONTENTS ALLOWABLE WASTES

Check all allowable wastes that are contained within this toad:

NOTE: Waste disposal a! the Area 6 Hydrocarbon Landfill must have come into contact with petroleum hydrocarbons or coolants, such as: gasoline (no benzene, lead); jel fuel; diesel fuel; lubricants and hydraulics; kerosene; asphaltic petroleum hydrocarbon; and ethylene glycol.
Acceptabie waste at any NTS landfill:
$\square$ Asphalt
Metal
(X) Wood
$\square$ Paper
$\square$ Rocks / unaltered geologic materials
$\triangle 1$ Empty containers
$\square$ Plastic $\square$ Wire
Cable
$\square$ Soil
$\square$ Rubber (excluding tires)
$\square$ insulalion (non-Asbestosform)
D. Demolition debris
$\square$ Cement \& concrete

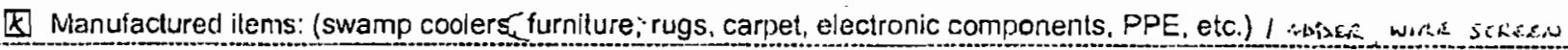
Additional waste accepted at the Area 23 Mercury Landfill: $\square$ Office Waste $\square$ Food Waste $\square$ Animal Carcasses $\square$ Asbestos $\square$ Friable $\square$ Non-Friable (contacl SWO if regulated load) Quantity:

Additional waste accepted at the Area 9 u10c Landfill:
$\square$ Non-friable asbestos
$\square$ Drained automobiles and military vehicles
Light ballasts (contact SWO)
Drained fuel filters (gas \& diesel)
Hydrocarbons (contact SWO)
Other
Solid fractions from sand/oil/water
Deconned Underground and Above Ground Tanks

Additional waste accepted at the Area 6 Hydrocarbon Landfil:
$\square$ Septic sludge $\square$ Rags
$\square$ Drained fuel fillers (gas \& diesel)
$\square$ Sludge from sand/oil/water separators
Crushed non-teme plated oil filters
Plants
Soil

REQUIRED: WASTE GENERATOR SIGNATURE

Initials: (if initialed, no radiological clearance is necessary.)

The above mentioned waste was generated outside of a Controlled Waste knowledge, does not contain radiological materials.

To the best of my knowledge, the waste described above contains only the site. I have verified this through the waste characterization method identif prohibited and allowable waste items. I have contacted Property Managen is approved for disposal in the landfill.

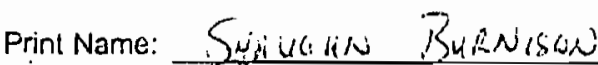
Signature: / $/ \mathrm{s} /$ Shaughn Burnison Date: $i / 13 / 0>2 \begin{gathered}\text { "Radiological Release Sticker" } \\ \text { here. Onsite use only. }\end{gathered}$

Note: "Food waste, office trash and animal carcasses do not require a radiological clearance. Freon-containing appliances must have signed removal certification stalement with Load Verification."

SWO USE ONLY

Load Weight (nel from scale or estinate): 3502

$9 \cdot 13-0,7$

Signature of Certura.

/s/ Steven Curtis

Radiation Survey Release for Waste Disposal RCT Initials

RThis container/load is free of external radioactive Icontamination.

This containerload is exempt from survey due to process knowlodge and origin.

This containerload is tree of radioactive contamination hasad on radioanalys is.

SIGNATURE: See Oriqinal! DATE: $9-12-07$ 
NSTec

fistusics

Form 2 s.tilite Disher Sw SN Jw

FRM-0918

NTS LANDFILL LOAD VERIFICATION

08/23/06

Rev. 0

Page 1 of 2

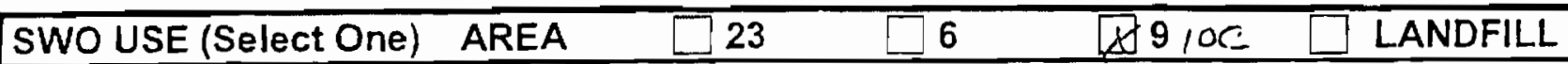

For waste characterization, approval, and/or assislance, contacl Solid Waste Operalion (SWO) al 5-7898.

REQUIRED: WASTE GERERATOR INFORMATION

(This form is for rolloffs, dump trucks, and other onsite disposal of malerials.)

Waste Generator: SHAvich Buenis=n

Phone Number:

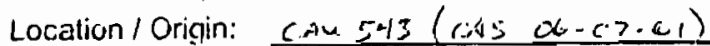

\begin{tabular}{|c|c|c|c|c|}
\hline \multicolumn{2}{|c|}{ Waste Category: (check one) } & \multirow{2}{*}{$\begin{array}{l}\square \text { Commercial } \\
\square \text { Putrescrible }\end{array}$} & \multicolumn{2}{|l|}{ [Q] Industrial } \\
\hline Waste Type: & $\square$ NTS & & [X] FFACO-onsite & $\square$ WAC Exception \\
\hline (check one) & $\square$ Non-Putrescible & Asvestos Containing Material & $\bar{\square}$ FFACO-offsite & $\square$ Historic DOEINV \\
\hline \multicolumn{2}{|c|}{ Pollution Prevention Category: (check one) } & [X] Environmental management & Defiense Frojects & $\square$ YMP \\
\hline \multicolumn{2}{|c|}{ Pollution Prevention Category: (check one) } & Clean-Up & Routine & \\
\hline
\end{tabular}

Prohibited Waste at all three Radioactive waste; RCRA waste; Hazardous waste; Free liquids, PCBs above TSCA regulatory NTS landfills:

Additional Prohibited Waste at the Area 9 U10C Landfill:

ievels, and Medical wastes (needles, sharps, bloody clothing).

Sewage Sludge, Animal carcasses, Wet garbage (food waste); and Friable asbestos

REQUIRED: WASTE CONTENTS ALLOWABLE WASTES

Check all allowable wasles that are conlained within this load:

NOTE: Waste disposal at the Area 6 Hydrocarbon Landfill must have come into contact with pelroleum hydrocarbons or coolants, such as: gasoline (no benzene, lead); jet fuel; diesel fuel; lubricants and hydraulics; kerosene; asphaltic petroleum hydrocarbon; and ethylene glycol.

Acceptable waste at any NTS landfil

(x) Paper

$\square$ Rocks / unaltered geologic materials

$\square$ Emply conlidiners

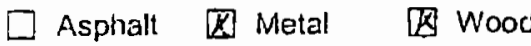

[X] Soil

$\square$ Rubber (excluding tires)

[K] Demolition debris

$\square$ Plastic $\square$ Wire

Cable

$\square$ Insulation (non-Asbestosform)

$\square$ Cement \& concrete

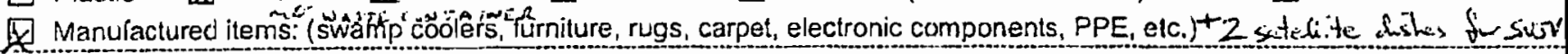
Additional waste accepted at the Area 23 Mercury Landfill: $\square$ Office Wasle $\square$ Food Waste $\square$ Animal Carcasses $\square$ Asbestos $\square$ Friable $\square$ Non-Friable (contact SWO if regulated load) Quantity:

Additional waste accepted at the Area 9 U10c Landfill:
$\square$ Non-friable asbestos
Drained automobiles and military vehicles
L Light ballasis (contact SwO)
Drained fuel filters (gas \& diesel)
Solid fractions from sand/oil/water
Hydrocarbons (contact SWO)
Other
Deconned Underground and Above Ground Tanks

Additional waste accepted at the Area 6 Hydrocarbon Landfill:
$\square$ Septic sludge
$\square$ Rags
$\square$ Drained fuel filters (gas \& diesel)
Plants

$\square$ Soil
$\square$ Sludge from sand/oil/water separalors

Crushed non-teme plated oil filters REQUIRED: WASTE GENERA

Initials: (if initialed, no radiological clearance is necessary.)

The above mentioned waste was generated outside of a Controlled Wa knowledge, does not contain radiological materials.

To the best of my knowledge, the waste described above contains onls site. I have verified this through the waste characterization method ide prohibited and allowable waste items. I have contacted Property Mana is approved for disposal in the landfill.

Print Name: _ Shatacirni Bureviswer

Signature: Ls/ Shaughn Burnison

Date: $i / / 8 / 0>$

Radiation Survey Release for Waste Disposal RCT Initials

This contalner/load is free of external radioaclive contamination.

This containeriload is exempt from survay due to 1 process knowledge and origin.

This containerl pad is free of radioactive SIGNatuRE: See Originat DATE: $1 / 18 / 67$

Nole: "Food waste, office trash and animal carcasses do not require a radiologicai clearance. Freon-containing appliances must have signed removal certification statement with Load Verification."

SWO USE ONLY

Load Weight (net frop scale or estimate) Signature of Certifier: /s/Don. Bicford

If applicable, place FRM-0646,

"Radiological Release Sticker" here. Onsite use only. 
Closure Report - CAU 543

Section: Appendix C

Revision: 0

Date: January 2008

Corrective Action Site 15-01-03 Aboveground Storage Tank 
Closure Report - CAU 543

Section: Appenclix C

Revision: 0

Datc: Jamuary 2008

THIS PAGE INTENTIONALLY LEFT BLANK 


\section{Certificate of Disposal}

This is to certify that the Waste Stream No. LRY5LLFY07002 package number 07L295 was shipped and received at the Nevada Test Site Radioactive Waste Management Site in Area 5 for disposal as stated below.

Theresa Hale

Shipped by

/s/ Theresa Haie

Signature

Nancy Etherselge
Received by

Is Nancy Etheridge
NSTec Waste Generator Services

Organization

Senior Technical Staff

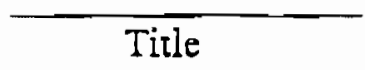

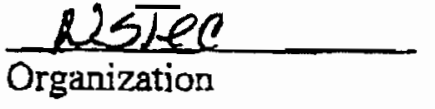

Organization
$9-20-07$

Date
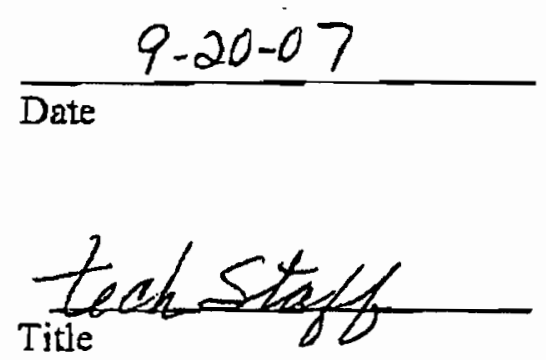

Iitle

Date

9.20 .07

Package $\frac{7}{\pi} 072295$ is a 25,000 gallon above ground storage tank from CAU543 area 15. 2018243 is the NTS property control number for the tank. 


\section{Certificate of Disposal}

This is 10 cerlify that Waste Sueam No, I.RY5LLFY07002 package number 07L294 was shipped and received al the Nevada Test Site Radioactive Waste Management Sile in Area 5 for clisposal as stared below.

Theresia Hale

Shipped by

$\underbrace{/ s / \text { Theresa Hâle }}_{\text {Signacure }}$ Naney Esteridge

$\frac{\text { Nsjee }}{\text { Organization }}$

Senior Technical Staff

Title

$\frac{9-20-07}{\text { Date }}$

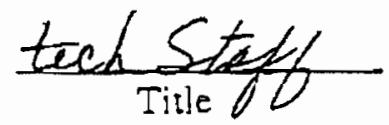

$\frac{9 \cdot 20 \cdot 02}{\text { Dare }}$ 


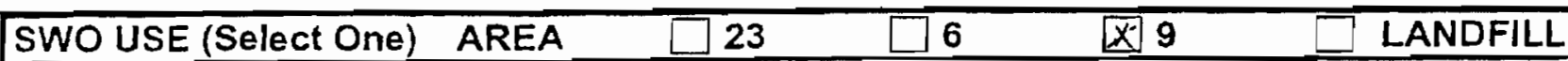

For waste characterizalion, approval, and/or assistance, contact Solid Waste Operation (SWO) at 5-7898.

REQUIRED: WASTE GERERATOR INFORMATION

(This form is for rolloffs, dump trucks, and other onsite disposal of materials.)

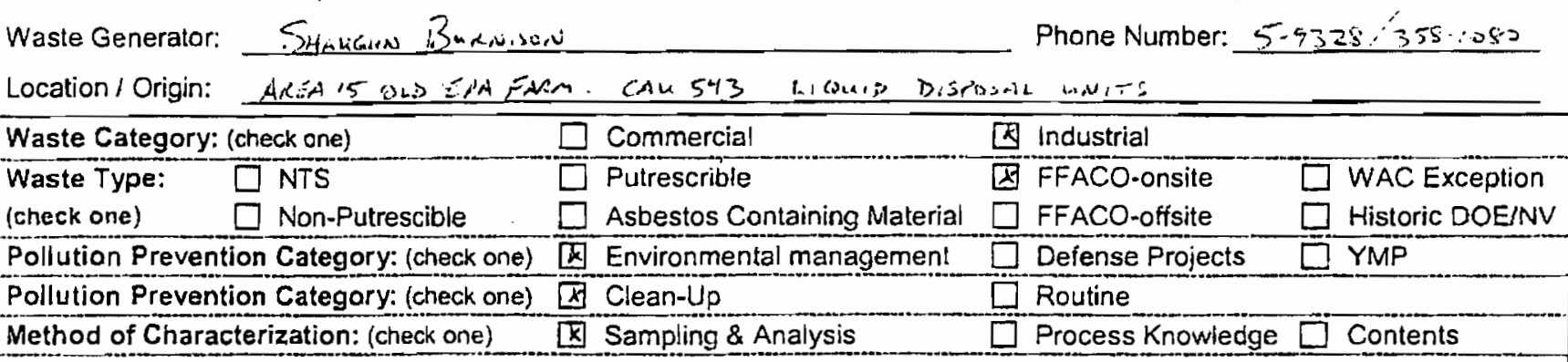

Prohibited Waste at all three Radioactive waste; RCRA wasle; Hazardous waste; Free liquids, PCBs above TSCA regulatory NTS landfills:

Additional Prohibited Waste

at the Area 9 U10C Landfill:

levels, and Medical wastes (needles, sharps, bloody clothing).

Sewage Sludge, Animal carcasses, Wet garbage (food waste); and Friabie asbestos

REQUIRED: WASTE CONTENTS ALLOWABLE WASTES

Check all allowable wastes that are contained within this load:

NOTE: Waste disposal at the Area 6 Hydrocarbon Landfill must have come into contact with petroleum hydrocarbons or coolants, such as: gasoline (no benzene, lead); jet fuel; diesel fuel; lubricants and hydraulics; kerosene; asphaltic petroleum hydrocarbor: and ethylene glycol.
Acceptable waste at any NTS landfill:
$\square$ Asphalt $₫$ Metal $\square$ Wood
$\square$ Paper
$\square$ Soil
$\square$ Rocks / unaltered geologic materials
Empty containers
$\square$ Plastic $\square$ Wire
Cable
$\square$ Rubber (excluding tires)
Demolition debris
$\square$ Cloth
$\square$ Insulation (non-Asbestosform)
Cement \& concrete
$\square$ Manufactured items: (swamp coolers, furniture, rugs, carpet, electronic components, PPE, etc.)

Additional waste accepted at the Area 23 Mercury Landfill: $\square$ Office Waste $\square$ Food Waste $\square$ Animal Carcasses
$\square$ Asbestos $\square$ Friable $\square$ Non-Friable (contact SWO if regulated load) Quantity:

$\square$ Asbestos $\square$ Friable $\square$ Non-Friable (contact
$\square$ Non-friable asbestos
Drained automobiles and military vehicles
$\square$ Light ballasts (contact Swo)
Drained fuel filters (gas \& diesel)
Solid fractions from sand/oil/water
$\square$ Hydrocarbons (contact SWO) Other
Deconned Underground and Above Ground Tanks

Additional waste accepted at the Area 6 Hydrocarbon Landfill:
$\square$ Septic sludge
$\square$ Rags
$\square$ Drained fue fillers (gas \& diesel)
$\square$ Crushed non-teme plated oil filters
Plants
$\square$ Soil
$\square$ Sludge from sand/oil/water separators
$\square$ PCBs below 50 parts per million REQUIRED: WASTE GENERATOR SIGNATURE

Initials: ___ (if initialed, no radiological clearance is necessary.)

The above mentioned waste was generated outside of a Controlled Wastc Manag

knowledge, does not contain radiological materials.

To the best of my knowledge, the waste described above contains only those ma site. I have verified this through the waste characterization method identified $a b$, prohibited and allowable waste items. I have contacted Property Management ar is approved for disposal in the landfill.

Print Name: Sratugru Bu-itw bon

Signature: __L Shaughn Burnjison ___ Date: $4 / 3 / 37$

\begin{tabular}{l} 
Radiation Survey Release for Waste Disposal \\
RCT initials \\
\hline This containerload is free of external radioactive \\
contamination. \\
This container/load is exempt from survey due to \\
process knowledge and origin. \\
This containeriload is free of radioactive \\
contanunation based on radioanalysis. \\
signaTURE: See Or ig ina 7
\end{tabular}

Note: "Food waste, office trash and animal carcasses do not require a radiological clearance. Freon-containing appliances must have signed removal certification statement with Load Verification."

SWO USE ONLY

Load Weight (net from scale or estimate):

$4 \cdot 3 \cdot 47$

Signature of Certifier: /s / Don Bjckford 
NSTEC

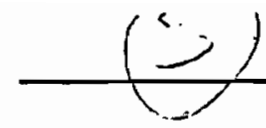

Form

\begin{tabular}{|llllll}
\hline SWO USE (Select One) AREA & $\square 23$ & $\square 6$ & $\times 9$ & 10c
\end{tabular}$\square$ LANDFILL

For waste characlerizalion, approval, and/or assislance, contact Solid Waste Operation (SWO) at 5-7898.

\section{REQUIRED: WASTE GERERATOR INFORMATION}

(This form is for rolloffs, dump trucks. and other onsite disposal of materials.)

Waste Generator: SHAught) Bu(RNison Phone Number: 5.9328

Location / Origin CAM 913 (CAS 15-01-03) OLD EPA FACM

Waste Category: (check one)

Waste Type: $\quad \square$ NTS

[ Commercial

Industrial

(check ons)

$\square$ Non-Puirescible

$\square$ Pulrescrible

D FFACO-onsite

[] Asbestos Containing Material

$\square$ FFACO-offsite

Pollution Prevention Category: (check one) $\mathbb{Q}$ Environmental management

Pollution Prevention Category: (check ane) $\triangle$ Clean-Up

Method of Characterization: (check one) X Sampling \& Analysis Q Process Knowledge $\square$ Contents

$\square$ Defense

Prohibited Waste at all three Radioactive waste; RCRA waste; Hazardous waste; Free liquids, PCBs above TSCA regulatory NTS landfills:

levels, and Medical wastes (needies, sharps, bloody clothing).

Additional Prohibited Waste Sewage Sludge. Animal carcasses, Wet garbage (food waste); and Friable asbestos

at the Area 9 un

\section{REQUIRED: WASTE CONTENTS ALLOWABLE WASTES}

Check all allowable wastes that are contained within this load:

NOTE: Waste disposal at the Area 6 Hydrocarbon Landfill must have come into contact with petroleum hydrocarbons or coolants, such as: gasoline (no benzene, lead); jet fuel; diesel fuel; lubricants and hydraulics; kerosene; asphaltic petroleum hydrocarbon; and ethylene glycol.
Acceptable waste at any NTS landfill:
$\square$ Paper
Rocks / unaltered geologic materials
$\square$ Empty containers
$\square$ Asphal!
区 Metal
$\square$ wood
$\square$ Soil
$\square$ Rubber (excluding tires)
$\square$ Plastic [X] Wire
Cable
$\square$ Clolh
(Insulation (non-Asbeslosform)
Demolition debris
Cement \& concrete

Manufaclured items: (swamp coolers, furniture, rugs, carpet, electronic components, PPE, etc.)

Additional waste accepted at the Area 9 U10 c Landfill:
$\square$ Non-friable asbestos
$\square$ Drained automobiles and military vehicies
$\square$ Light ballasts (contact Swo)
Drained fuel filters (gas \& diesel)
Solid fractions from sand/oil/water
$\square$ Hydrocarbons (contact SWO
Other
Deconned Underground and Above Ground Tanks

Additional waste accepted at the Area 6 Hydrocarbon Landfill:
$\square$ Septic sludge
$\square$ Rags
$\square$ Drained fuel filters (gas \& diesel)
Crushed non-teme plated oil filters
Plants
Soil
$\square$ Sludge from sand/oil/water separators
$\square$ PCBs below 50 parts per million REQUIRED: WASTE GENERATOR SIGNATURE

Initials

(if initialed, no radiological clearance is necessary.)

The above mentioned waste was generated outside of a Controlied Waste Ma

knowledge, does not contain radiological materials.

To the best of my knowledge, the waste described above contains only those site. I have verified this through the waste characterization method identified prohibited and allowable waste items. I have contacted Property Managemen is approved for disposal in the landfill.

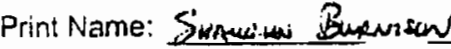

Signature: fs/. Shaughn Burnison Date: $\delta / 14 / 27$

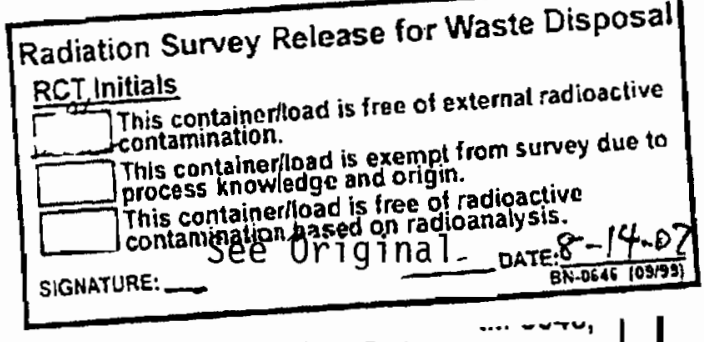

-. - - ru,

"Radiological Release Sticker" here. Onsite use only.

Note: "Food waste, office trash and animal carcasses do not require a radiological clearance. Freon-containing appliances must have signed removal certification statement with Load Verification."

Load Weight (net from'scale or ostimate): 3 s ov $5-14-07$ Signature of Certifier: /s/ Don Bickford

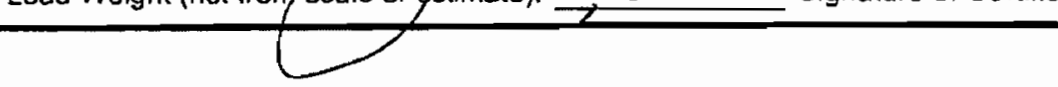

\section{cremon}


Date: January 2008

Corrective Action Site 15-04-01 Septic Tank 
Closure Report - CAU 543

Section: $\Lambda$ ppendix $C$

Revision: 0

Date: January 2008

THIS PAGE INTENTIONALLY LEFT BLANK 


\begin{tabular}{|llllll}
\hline SWO USE (Select One) & AREA & $\square 23$ & 76 & X 9 & $\square$ LANDFILL
\end{tabular}

For wasle characterization, approval, and/or assisiance, contact Solid Waste Operation (SWO) al 5-7898. REQUIRED: WASTE GERERATOR INFORMATION

(This form is for rotloffs, dump trucks, and other onsite disposal of materials.)

Waste Generator: Srmugin Burnusan Phone Number: $5.9328,3581080$ Localion / Origin:

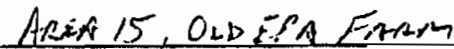
$\cos 243$ Liour D Disposat Uni,

Waste Category: (check one)

$\square$ Commercial

Q Industria!

Waste Type:

$\square$ NTS

$\square$ Putrescrible

$\triangle$ FFACO-onsite

(check one) $\square$ Non-Putrescible $\square$ Asbestos Containing Material
Pollution Prevention Category: (check one) $\square$ Environmental management

$\square$ FFACO-ofisite

Pollution Prevention Category: (check one) 18 Clean-Up

Method of Characterization: (check one) De Sampling \& Analysis

$\square$ Deiense Projects

$\square$ WAC Exception

Prohibited Waste at all three Radioactive waste: RCRA wasle; Hazardous waste: Free liquids, PCBs above TSCA regulatory NTS landifils:

Additional Pronibited Waste at the Area 9 U10C Landfill:

\section{levels, and Medical wastes (needies, sharps, bloody clothing).}

Sewage Sludge, Animal carcasses, Wet garbage (food waste); and Friable asbestos

REQUIRED: WASTE CONTENTS ALLOWABLE WASTES

Check all allowable wastes thal are contained within this load:

NOTE: Waste disposal at the Area 6 Hydrocarbon Landfill must have come into contact with petroleum hydrocarbons or coolants, such as: gasoline (no benzene. lead); jet fuel; diesel fuel; lubricants and hydraulics; ke rosene; asphaltic petroleum hydrocarbon; and ethylene glycol.
Acceptable waste at any NTS landfill:
$\square$ Paper
$\square$ Rocks / unaltered geologic materials
Empty containers
$\square$ Asphalt $\square$ Metal $\square$ Wood
Q Soil
$\square$ Rubber (excluding tires)
Tlastic $\square$ Wire
$\square$ Cable
$\square$ Cloth
$\square$ Insulation (non-Asbestosform)
Demolition debris
$\square$ Manufactured items: (swamp coolers, fumiture, rugs, carpet, electronic componenis, PPE, etc.)
Additional waste accepted at the Area 23 Mercury Landfill: $\square$ Office Waste
$\square$ Food Waste
Animal Carcasses

$\square$ Asbestos

$\square$ Non-Friable (contacl SWO if regulated load)

Quantity:

Additional waste accepted at the Area 9 U10 Landfill:
Q Non-friable asbestos
$\square$ Drained automobiles and military vehicies
Solid fractions from sand/oil/water
$\square$ Light ballasts (contact SWO) $\square$ Drained fuel filters (gas \& cliesel)
Deconned Underground and Above
Other Ground Tanks

Hydrocarbons (contact SWO)

Additional waste accepted at the Area 6 Hydrocarbon Landfill:

$\begin{array}{llll}\square \text { Septic sludge } \square \text { Rags } & \square \text { Drained fuel filters (gas \& diesel) } & \square \text { Crushed non-teme plated oil filters } \\ \square \text { Plants } & \square \text { Soil } & \square \text { Sludge from sand/oil/water separators } \square \text { PCBs below } 50 \text { parts per million }\end{array}$

initials: (if initialed, no radiological clearance is necessary.)

The above mentioned waste was generated outside of a Controlled Waste Manageme knowledge, does not contain radiological materials.

To the best of my knowledge, the waste described above contains only those materic site. I have verified this through the waste characterization method identified above : prohibited and allowable waste items. I have contacted Property Management and hi is approved for disposal in the landfill.

Print Name: Sirmearren Buin wiom

Signature: _ _s/ Shaughn Burnison Date: $12 \mathrm{ArL} \times \mathrm{Z}$

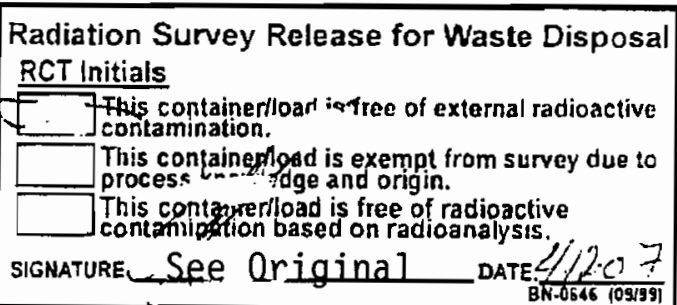

Note: Food waste. office trash and animal carcasses do not require a radjological clearance. Freon-containing appliances must have signed removal certification statement with Load Verification." SWO USE ONLY Load Weight (net from scale or estimate): $15 \% 6 \begin{gathered}4-12-0.7 \\ \text { Signature of Certifier }\end{gathered}$ /s/ Don Bickford 


\begin{tabular}{|c|c|c|}
\hline $\begin{array}{l}\text { NSTec } \\
\text { Form }\end{array}$ & & $\begin{array}{r}08 / 23 / 06 \\
\text { Rev. } 0\end{array}$ \\
\hline FRM-0918 & NTS LANDFILL LOAD VERIFICATION & Page 1 of 2 \\
\hline
\end{tabular}

\begin{tabular}{|llllll}
\hline SWO USE (Select One) & AREA & $\square 23$ & $\square 6$ & $\square 9$ & $\square$ LANDFILL
\end{tabular}

For waste characterization, approval, and/or assisfance, contact Solid Waste Operation (SWO) at 5-7898.

$$
\text { REQUIRED: WASTE GERERATOR INFORMATION }
$$

(This form is for rolloffs, dump trucks, and other onsite disposal of materials.)

Waste Generator: Sinucmi A. Surnison, Phone Number: 5-9328/358-1080

$\begin{array}{lll}\text { Waste Category: (check one) } & \square \text { Commercial } & \square \text { Industrial } \\ \text { Waste Type: } \quad \square \text { NTS } & \square \text { Putrescrible } & \square \text { FFACO-onsite } \\ \text { W } & \square \text { WAC Exception }\end{array}$

(check one) $\square$ Non-Putrescible $\square$ Asbestos Containing Matcrial $\square$ FFACO-offsite $\square$ Historic DOE/NV

Pollution Prevention Category: (check one) D Environmental management $\square$ Defense Projects $\square$ YMP

Pollution Prevention Category: (check one) Q Clean-Up $\square$ Routine

Method of Characterization: (check one) $\quad$ Q Sampling \& Analysis $\quad \square$ Process Knowledge $\square$ Contents

Prohibited Waste at all three Radioactive waste; RCRA wasle; Hazardous wasle; Free liquids. PCBs above TSCA regulatory NTS landfills:

Additional Prohibited Waste Sewage Sludge, Animal carcasses, Wet garbage (food wasle); and Friable asbeslos
at the Area 9 U10C Landfill:

\section{REQUIRED: WASTE CONTENTS ALLOWABLE WASTES}

Check all allowable wastes that are coniained within this load:

NOTE: Waste disposal al the Area 6 Hydrocarbon Landfill must have come into contact with petroleum hydrocarbons or coolants, such as: gasoline (no benzene, lead); jet fuel; diesel fuel; lubricanls and hydraulics; kerosene; asphaltic petroleum hydrocarbon; and ethylene glycol.

Acceptable waste at any NTS landfill: $\square$ Paper $\square$ Rocks / unallered geologic materials

$\begin{array}{llll}\square \text { Asphalt } \quad \square \text { Metal } & \square \text { Wood } & \square \text { Soil } & \square \text { Rubber (excluding tires) } \\ \square \text { Plastic } & \square \text { Wire } & \square \text { Cable } & \square \text { Cloth }\end{array}$

$\square$ Manufactured items: (swamp coolers, furniture, rugs, carpet, electronic components, PPE, etc.)

Additional waste accepted at the Area 23 Mercury Landfill: $\square$ Office Waste $\square$ Food Waste $\square$ Animal Carcasses

$\square$ Asbestos $\square$ Friable $\square$ Non-Friable (contact SWO if regulated load) Quantity:

Additional waste accepted at the Area 9 U10c Landfilt:

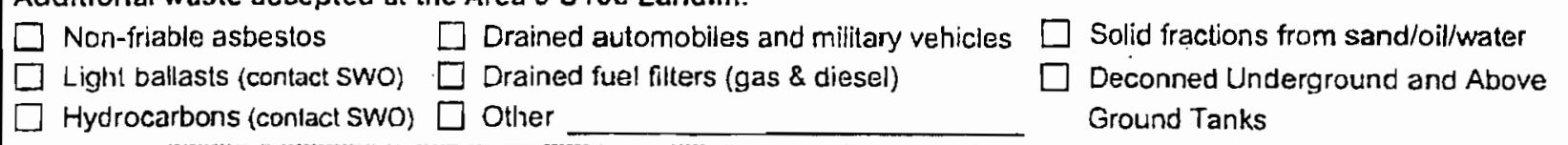

Additional waste accepted at the Area 6 Hydrocarbon Landfill: $\square$ - $\square$ Crushed non-teme plated oil filters

因 Septic sludge $\square$ Rags $\square$ Drained fuel filters (gas \& diesel) $\quad \square$ Crushed non-leme plated oil filters

$\square$ Plants $\quad \square$ Soil $\square$ Sludge from sand/oil/water separators $\square$ PCBs below 50 parts per million

Initials: ___ (if initialed, no radiological clearance is necessary.)

The above mentioned waste was generated outside of a Controlled Waste Management Area (CWMA) and to the best of my knowledge, does not contain radiological materials.

To the best of my knowledge, the waste described above contains only those mate site. I have verified this through the waste characterization method identified abo prohibited and allowable waste items. I have contacted Property Management and is approved for disposal in the landfill.

Print Name: Sinucion Bumsurew

Signalure: Ls/ Shaughn Burnison Date: $4 / 6 / c 7$

Note: "Food waste, office trash and animal carcasses do not require a radiological ! must have signed removal certification statement with Load Verification "

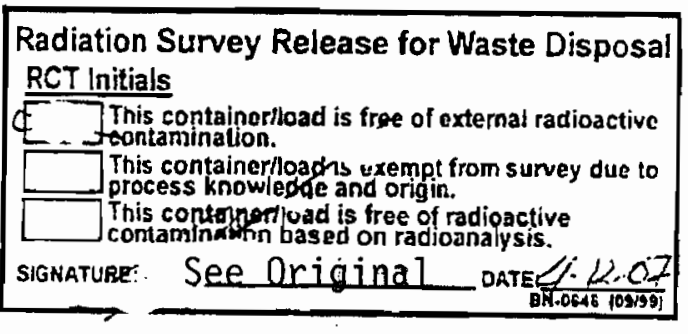

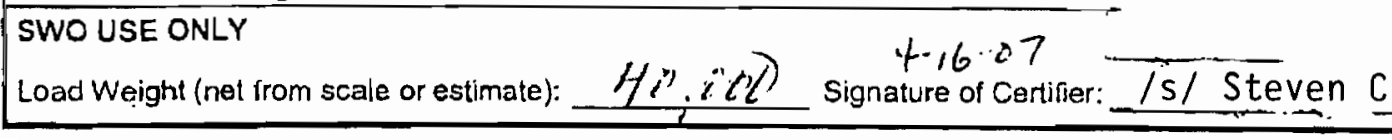


NSTec

Form

FRM-0918

NTS LANDFILL LOAD VERIFIEATION

08/23/06

Rev. 0

Page 1 of 2

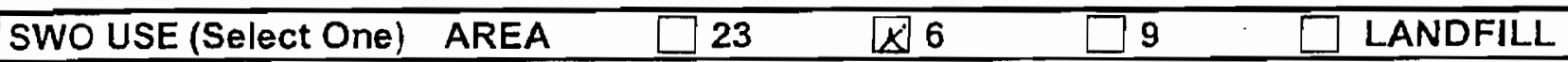

For waste characterization, approval, and/or assislance, contact Solid Waste Operation (SWO) at 5-7898.

REQUIRED: WASTE GERERATOR INFORMATION

(This form is for rollofis, dump trucks, and other onsile disposal of materials.)

Waste Generalor: Shiught Burnivin

Location / Origin: ARE 15, EPA FARM, CAU 543 SEATC LA15TE

Phone Number: $5-9328 / 3,78 \cdot 1080$

Waste Category: (check one)

Waste Type: $\square$ NTS

(check one) $\square$ Non-Putrescible $\square$ Asbestos Conlaining Material

Industrial

Pollution Prevention Category: (check one

Pollution Prevention Category: (check one)

Method of Characterization: (check one)

$\triangle$ Environmental management

X] FFACO-onsite

$\square$ FFACO-offisite

Clean-Up

$\square$ Defense Projects

[x Sampling \& Analysis

Routine

Prohibited Waste at all three Radioaclive waste; RCRA waste; Hazardous waste; Free liquids, PCBs above TSCA regulatory NTS landfills:

levels, and Medical wastes (needles, sharps, bloody clothing).

Additional Prohlbited Waste

at the Area 9 U1DC Landfill:

Sewage Sludge, Animal carcasses, Wet garbage (food waste); and Friable asbestos

REQUIRED: WASTE CONTENTS ALLOWABLE WASTES

Check all allowable wastes that are contained within this load:

NOTE: Waste disposal at the Area 6 Hydrocarbon Landill must have come into conlact with petroleum hydrocarbons or coolanls, such as: gasoline (no benzene, lead); jet fuel; diesel fuel; lubricants and hydraulics; kerosene; asphaltic petroleum hydrocarbon; and elhylene glycol.

Acceptable waste at any NTS landfill: $\square$ Paper $\square$ Rocks / unaltered geologic malerials
$\square$ Asphalt
$\square$ Metal
$\square$ Wood
[X] Soil
$\square$ Rubber (excluding tires)
D Plastic $\square$ Wire
$\square$ Cable
$\square$ Cloth
$\square$ insulation (non-Asbestosform)

Empty containers

$\square$ Demolition debris

$\square$ Manufactured items: (swamp coolers, furniture, rugs, carpet, electronic components, PPE, etc.)
Additional waste accepted at the Area 23 Mercury Landfill: $\square$ Office Waste
$\square$ Food Waste
Animal Carcasses

$\square$ Cement \& concrete
$\square$ Asbeslos
Friable
$\square$ Non-Friable (contact SWO if regulated load)
Quantity:

Additional waste accepted at the Area 9 U10 Landfill:
$\square$ Non-friable asbestos
$\square$ Drained automobiles and military vehicles
$\square$ Light ballasls (contact SwO)
Drained fuel filters (gas \& diesel)
Solid fractions from sand/oil/water
Hydrocarbons (contact SWO)
Other
Deconned Underground and Above Ground Tanks

Additional waste accepted at the Area 6 Hydrocarbon Landfill:
DI Septic sludge
$\square$ Rags
$\square$ Drained fuel filters (gas \& diesel)
$\square$ Sluriae from sand/oil/water separators
$\square$ Crushed non-teme plated oil filters
2 PCBs below 50 parts per million

$\square$ Plants $\square$ Soil $\quad \square$ Slu

Initjals: (if initialed, no radiological $\mathrm{cl}$

The above mentioned waste was generated of knowledge, does not contain radiological mat.

To the best of my knowledge, the waste descr site. I have verified this through the waste ch prohibited and allowable waste items. I have is approved for disposal in the landfill.

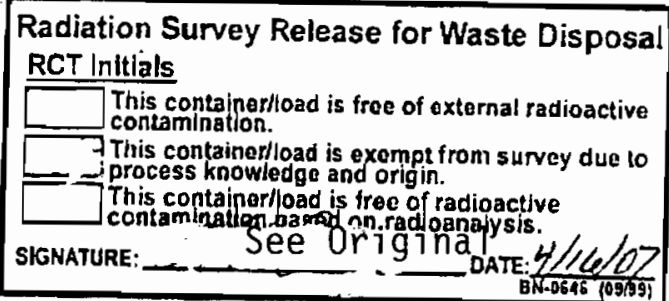

Print Name: SHawain BuRNASUN

Signature: Isf Shaughn Burnison
Date: $9 / 16 / 07$
A) and to the best of my

swed for disposal at this

if the above-mentioned at this materiallequipment

Note: "Food waste, office trash and animal carcasses do not require a radiological clearance. Freon-containing appliances must have signed removal cerlification statement with Load Verification."

SWO USE ONLY
Load Weight (net from scale or estimate):

$4 \hat{c} ; 0 x ; \quad 4-16.07$

Signature of Certifier: /s/ Steven C

If applicable, place FRM-0646,

"Radiological Release Sticker"

here. Onsite use only. 


\begin{tabular}{|llllll}
\hline SWO USE (Select One) & AREA & $\square 23$ & $\not \mathbf{6}$ & $\square 9$ & $\square$ LANDFILL
\end{tabular}

For waste characterizalion, approval, and/or assistance, conlact Solid Wasle Operation (SWO) at 5-7898. REQUIRED: WASTE GERERATOR INFORMATION

(This form is for rolloffs, dump trucks, and other onsite disposal of materials.)

Waste Generator: SHaucini Rufurion

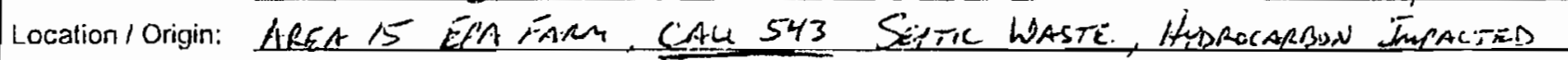
Waste Category: (check one) Waste Type: $\square$ NTS (check one) $\square$ Non-Putrescible $\square$ Asbestos Containing Material $\square$ Commercial
$\square$ Putrescriblc
$\square$ Asbestos Containing Material
$\square$ Environmental management Pollution Prevention Category: (check one) (Clean-1up Pollution Prevention Category: (check one)

Method of Characterization: (check one

$x$ Sampling \& Analysis Phone Number: $5-9328 / 358 \cdot 10.50$ Prohibited Waste at all three Radioactive waste; RCRA waste; Hazardous waste; Free liquids, PCBs above TSCA regulatory NTS landfills: levels, and Medical wastes (needles, sharps, bloody clothing).

Additional Prohibited Waste at the Area 9 U10C Landfill:

Sewage Sludge, Animal carcasses, Wet garbage (food waste): and Friable asbestos

\section{REQUIRED: WASTE CONTENTS ALLOWABLE WASTES}

Check all allowable wastes that are conlained within this load:

NOTE: Waste disposal at the Area 6 Hydrocarbon Landfill must have come inlo contact wilh petroleum hydrocarbons or coolants, such as: gasoline (no benzene, lead); jet fuel; diesel fuel; lubricants and hydraulics; kerosene; asphaltic petroleum hydrocarbon; and ethylene glycol.

Acceptable waste at any NTS landfill: $\square$ Paper $\square$ Rocks / unaltered geologic materials

$\square$ Asphali $\square$ Metal $\square$ Wood $\quad \square$ Soil $\square$ Rubber (excluding lires)

[ Plastic $\square$ Wire $\square$ Cable $\square$ Cloth

$\square$ Insulation (non-Asbestosform)

Empty containers

$\square$ Manufactured items: (swamp coolers, furniture, rugs, carpet, electronic components, PPE, etc.)

Additional waste accepted at the Area 23 Mercury Landfill: $\square$ Office Waste $\square$ Food Waste $\square$ Animal Carcasses
$\square$ Asbestos
Friable
Non-Friable (contact SWO if regulated load)
Quantity:

Additional waste accepted at the Area 9 U10c Landfill:
$\square$ Non-friable asbestos
$\square$ Drained automobiles and military vehicles
$\square$ Light ballasts (contact swo)
$\square$ Drained fuel filters (gas \& diesel)

Hydrocarbons (contact Swo) $\square$ Other

Solid fractions from sand/oil/water

$\square$ Deconned Underground and Above Ground Tanks

Adcitional waste accepted at the Area 6 Hydrocarbon Landfill:
$₫$ Septic sludge
$\square$ Rags
$\square$ Drained fuel fillers (gas \& diesel)
$\square$ Sludge from sand/oil/water separalors
REQUIRED: WASTE GENERATOR SIGNATURE
Crushed non-teme plated oil fillers
Planis
Soil

REQUIRED: WASTE GENERA

Initials: (if initialed, no radiological clearance is necessary.)

The above mentioned waste was generated outside of a Controlled Waste Management Area (CWMA) and to the best of my knowledge, does not contain radiological materials.

To the best of my knowledge, the waste described above contains only those ma site. I have verified this through the waste characterization method identified abe prohibited and allowable waste items. I have contacted Property Management an is approved for disposal in the landfill.

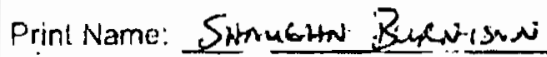

Signature: /s/ Shaughn Burnison Date: $1 / 17 \%$

Note: "Food waste, office trash and animal carcasses do not require a radiological must have signed removal certification statement with Load Verification."

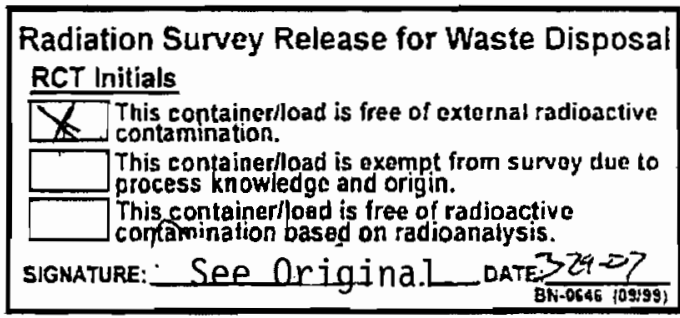
SWO USE ONLY

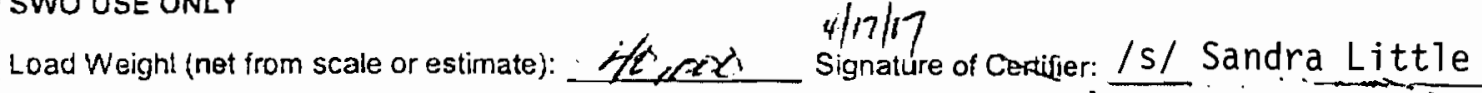


Closure Report - CAU 543

Section: Appendix C

Revision: 0

Date: January 2008

Corrective Action Site 15-05-01

Leachfield 
Closure Report - CAU 543

Section: Appendix C

Revision: 0

Date: January 2008

THIS PAGE INTENTIONALLY LEFT BLANK 


\begin{tabular}{llllll}
\hline SWO USE (Select One) & AREA & $\square 23$ & $\square 6$ & $\square 9$ & $\square$ LANDFILL
\end{tabular}

For waste characterizalion, approval, and/or assistance, contact Solid Wasle Operation (SWO) a! 5-7898.

$$
\text { REQUIRED: WASTE GERERATOR INFORMATION }
$$

(This form is for rolloffs, dump irucks, and other onsite disposal of materials.)

Waste Generalor: Sutaucitan Burnisun Phone Number: $5.932 .8 / 58 \cdot 3080$

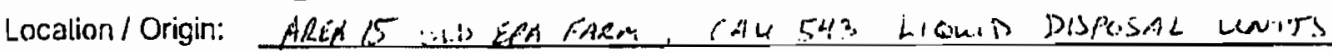

Waste Category: (check one)

Waste Type: $\square$ NTS

$\square$ Commercial

A Industrial

(check one)

$\square$ Putrescrible

id FFACO-onsite

$\square$ Asbestos Containing Material

Pollution Prevention Category: (check one) [A Environmental management

Pollution Prevention Category: (check one) $\alpha$ Clean-Up

Method of Characterization: (check one)

$\square$ Sampling \& Analysis

FFACO-ofísite

$\square$ WAC Exception

$\square$ Defense Projects

$\square$ Historic DOE/NV

Q $\square$ Process Knowledge $\square$ Contents

NTS landfills:

Additional Prohibited Waste

at the Area 9 U10C Landfill: levels, and Medical wasles (needles, sharps, bloody clothing).

Sewage Sludge, Animal carcasses, Wet garbage (food waste); and Friable asbestos

\section{REQUIRED: WASTE CONTENTS ALLOWABLE WASTES}

Check all allowable wasles that are contained within this load:

NOTE: Waste disposal at the Area 6 Hydrocarbon Landfill must have come inlo contact with petroleum hydrocarbons or coolants, such as: gasoline (no benzene, lead); jet fuel; diesel fuel; lubricants and hydraulics; kerosene; asphaltic petroleum hydrocarbon; and ethylene glycol.
Acceptable waste at any NTS landfill: $\square$ Paper
$\square$ Asphalt $\square$ Metal
$\square$ Wood
[a] Soil
$\square$ Rocks / unaltered geologic materials
$\square$ Plastic $\square$ Wire $\quad \square$ Cable
$\square$ Cloth
$\square$ Rubber (excluding tires)
$\square$ insulation (non-Asbestosform)

$\square$ Emply containers

(7) Demolition debris

Manufactured items: (swamp coolers, furniture, rugs, carpet, electronic components, PPE, etc.)
Additional waste accepted at the Area 23 Mercury Landfill: $\square$ Office Waste
$\square$ Food Wasle
$\square$ Asbestos $\square$ Friable $\square$ Non-Friable (contact SwO if regulated load) Quantily:

A Cement \& concrete

Additional waste accepted at the Area 9 U10 L Landfill:
$\square$. Non-friable asbestos
$\square$ Drained automobiles and military vehicles
$\square$ Light ballasts (contact SwO)
Drained fuel filters (gas \& diesel)
Solid fractions from sand/oil/water
$\square$ Hydrocarbons (contac: SwO)
Other
Deconned Underground and Above Ground Tanks

Additional waste accepted at the Area 6 Hydrocarbon Landfill:
$\square$ Septic sludge
$\square$ Rags
$\square$ Drained fue! filters (gas \& diesel)
$\square$ Crushed non-teme plated oil filters
Plants
$\square$ Soil
$\square$ Sludge from sand/oil/water separalors
$\square$ PCBs bolow 50 parts per million
REQUIRED: WASTE GENERATOR SIGNATURE

Initials: (if initialed, no radiological clearance is necessary.)

The above mentioned waste was generated outside of a Controlled Waste Mat knowledge, does not contain radiological materials.

To the best of my knowledge, the waste described above contains only those site. I have verified this through the waste characterization method identified prohibited and allowable waste items. I have contacted Property Managomen is approved for disposal in the landfill.

Print Name: Syinukit Reperison

Signature: /s/ Shaughn. Burnison

Date: $4 / 5 / 0>$

Radiation Survey Release for Waste Disposal RCT Initials This containerload is free of external radioactive
contamination.

This containerlload Is exempt from survey due to process knowledge and orlgin.

This container/load is free of radioactive

contanination based on radioanalysis.

signature: See Original oate. $4 / 5 / 07$

Note: "Food waste, office trash and animal carcasses do not require a radiological clearance. Freon-containing appliances must have signed removal certification statement with Load Verification."

SWO USE ONLY

Load Weight (net frop scaledor estimate): 530
$4-3=\Delta 7$

Signature of Cerlifier: _ $1 \mathrm{~s} /$ Don Bickford 
Closure Rcport - CAU 543

Section: Appendix C

Revision: 0

Date: January 2008

THIS PAGE INTENTIONALLY LEFT BLANK 
Closure Report - CAU 543

Section: Appendix C

Revision: 0

Date: January 2008

Corrective Action Site 15-08-01

Liquid Manure Tank 
Closure Report - CAU 543

Section: Appendix C

Revision: 0

Date: January 2008

THIS PAGE INTENTIONALLY LEFT BLANK 


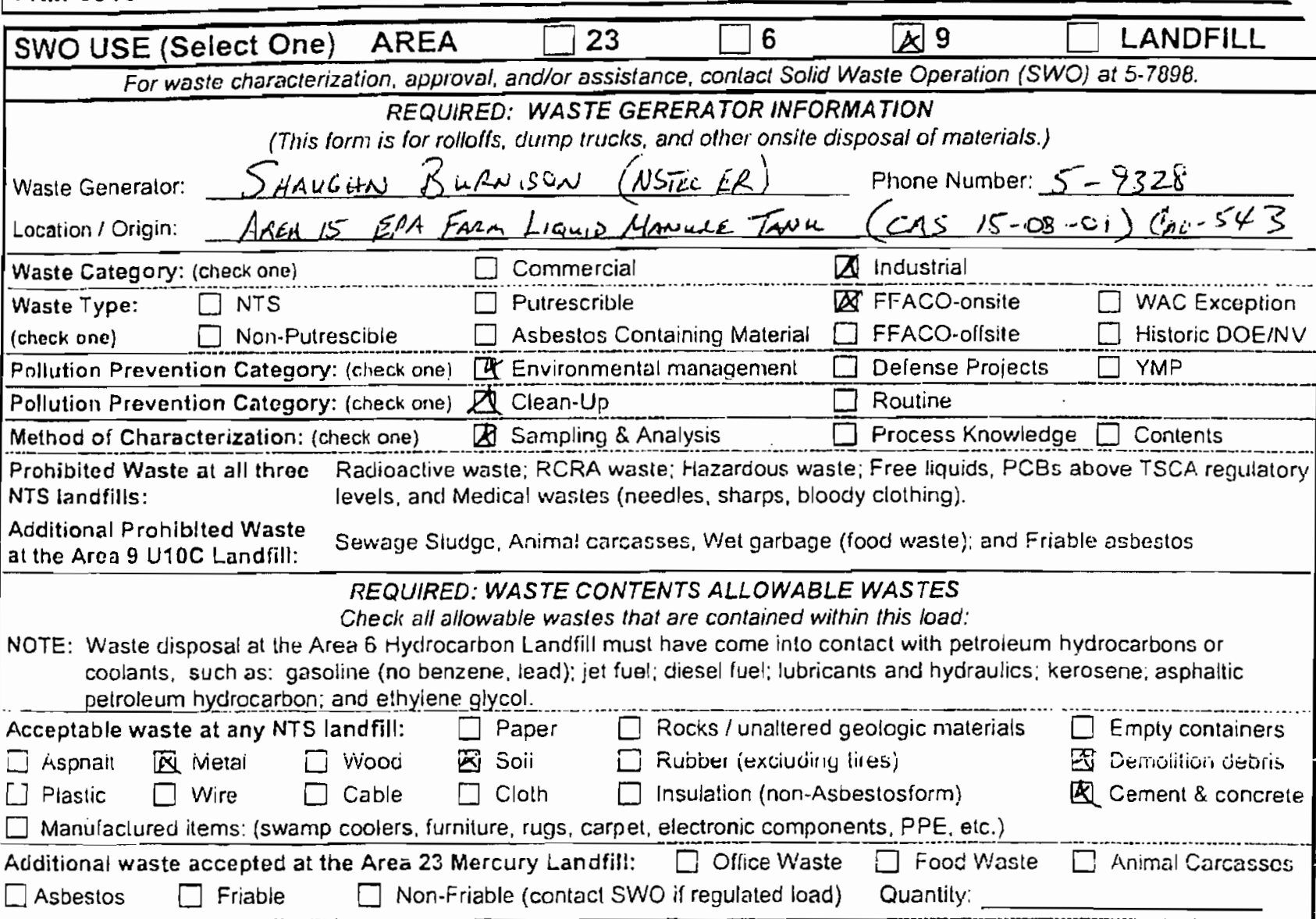

Additional waste accepted at the Area 9 U10c Landfill:
$\square$ Non-friable asbestos
$\square$ Drained automobiles and military vehicles
Light ballasts (contact Swo)
Drained fuel filters (gas \& diesel)
Solid Iractions from sand/oil/water
Hydrocarbons (contac: SwO)
Other
Deconned Underground and Above Ground Tanks

Additiona! waste accepted at the Area 6 Hydrocarbon Landfill:
$\square$ Septic sluage
$\square$ Rags
$\square$ Drained fuel fillers (gas \& diesel)
Sludge from sand/oil/water separators
Crushed non-teme plated oil filters
Plants
Soil

REQUIRED: WASTE GENERA

Initials: (if initialed, no radiological clearance is necessary.)

The above mentioned waste was generated outside of a Controlled $W_{c}$ knowledge, does not contain radiological materials.

To the best of my knowledge, the waste described above contains onl: site. I have verified this through the waste characterization method id. prohibited and allowable waste items. I have contacted Property Man: is approved for disposal in the landfill

Radiation Survey Release for Wasle Disposal RCJ Initials

This contalnerilood is free of extornal radioactive contamination.

This containerlload is exempt from survey due to process knowledge and origin.

This container/load is free of radioactive This container/had is tree of radioactive
contamination based on cadioanalysis. SIGNATURE: See Óriginaf coanalysis. Q1-05.

Print Name: SHaughn BurNis'a Signature: _/s/ Shaughn Burnison Date: $2 / 3, / 27$
If applicable, place FRM-0646 "Radiological Release Sticker" here. Onsite use only.

Nole: "Food waste. office trash and animal carcasses do not require a radiological clearance. Freon-containing appliances must have signed removal certification statement with Load Verification."

SWO USE ONLY

Loaes Weight (net trom scale of estinate) 40,000

$7-31-6.7$

Signature of Certifier: / / / Don Bickford 
Form

\begin{tabular}{|llllll} 
SWO USE (Select One) & AREA & {$[23$} & $\square 6$ & $\mathbb{2} 9$ & ब LANDFILL
\end{tabular}

For waste characterization, approval, and/or assistance, contact Solid Waste Operation (SWO) al 5-7898. REQUIRED: WASTE GERERATOR INFORMATION

(This form is for rollofis, dump trucks, and other onsile disposal of maleria/s.)

Waste Generator: Stheititivi BuENSON

Phone Number: $265-7328$

Localion / Origin:

Waste Category: (check one)

Waste Type: $\square$ NTS

$\square$ Commercial

C CAS

15-08-0!1

(chock one) $\square$ Non-Putrescible $\square$ Asbestos Containing Material

Pollution Prevention Category: (check one) $\$$ Environmenta! management

Pollution Prevention Category: (check one) D Clean-Up

Industrial

Method of Characterization: (check one) $\triangle$ Sampling \& Analysis $\square$ Process Knowledge $\square$ Contents

Prohibited Waste at all three Radioactive wasle; RCRA waste; Hazardous waste; Free liquids, PCBs above TSCA regulatory

NTS landfills:

Additional Prohibited Waste Sewage Sludge. Animal Carcasses, Wel garbage (food waste); and Friable asbestos

at the Arca 9 U10C Landfill: levels, and Medical wastes (needles, sharps, bloody clothing).

\section{REQUIRED: WASTE CONTENTS ALLOWABLE WASTES}

Check all allowable wastes that are conlained wilhin this load:

NOTE: Waste disposal at the Area 6 Hydrocarbon Landfill must have come into contact with petroleum hydrocarbons or coolants, such as: gasoline (no benzene, lead); jet fuel; diesel fuel; lubricants and hydraulics; kerosene; asphaltic petroleum hydrocarbon: and ethylene glycol.

Acceptable waste at any NTS landfill: $\square$ Paper

$\square$ Asphall $\quad$ Metal W Wood

$\square$ Paper

Soil

$\square$ Cable

Cloth
$\square$ Rocks / unaltered geologic materials
$\square$ Rubber (excluding lires)
$\square$ Insulation (rion-Asbestosform)

Plastic $\square$ Wire

Manuf́aclured itens: (swamp coolers, furniture, rugs, carpel. electronic components, PPE, etc.)

(2) Demolition debris

Additional waste accepted at the Area 23 Mercury Landfill: $\square$ Office Waste $\square$ Food Waste

Cement \& concrete
$\square$ Asbestos
$\square$ Friable
$\square$ Non-Friable (contact SWO if regulated load)
Quantity:

Additional waste accepted at the Area 9 U10c Landfill:
$\square$ Non-friable asbestos
$\square$ Drained automobiles and military vehicles
$\square$ Solid fractions from sand/oil/water
Light ballasts (contac! SwO)
Drained fuel filters (gas \& diesel)
Deconned Underground and Above Other
Wydrocarbons (contaci sWO) Ground Tanks
Ground Tanks

Additional waste accepted at the Area 6 Hydrocarbon Landfill:
$\square$ Seplic sludge
$\square$ Rags
Drained fuel filters (gas \& diesel)
Plants
$\square$ Soil
$\square$ Sludge from sand/oil/water separalors
$\square$ Crushed non-teme plated sil filters
$\square$ PCBs below 50 parts per million

Animal Carcasses

Initials:

(if initialed, no radiological clearance is necessary.)

The above mentioned waste was generated outside of a Controlled Waste $\mathrm{N}$ knowledge, does not contain radiological materials.

To the best of my knowledge, the waste described above contains only tho: site. I have verified this through the waste characterization method identific prohibited and allowable waste items. I have contacted Property Managem. is approved for disposal in the landfill.

Print Name: Shaughn Burnison

Radiation Survey Release for Waste Disposal RCT Initials

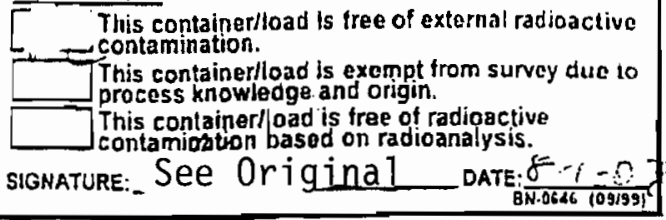

Signature: _. /s/ Shaughn Burnison __ Date: $8 / 1 / 07$

here. Onsite use only.

Note: "Food waste, office trash and animal carcasses do not require a radiological clearance. Freon-containing appliances must have signed removal certification statement with Load Verilication."

SWO USE ONLY 770058.7

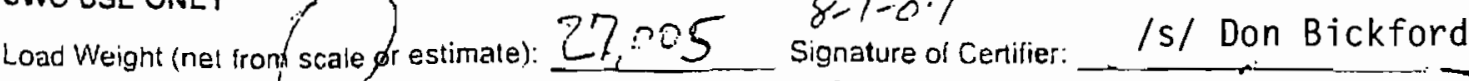




\begin{tabular}{|c|c|c|}
\hline NSTec & & $08 / 23 / 06$ \\
\hline Form & & Rev. 0 \\
\hline FPM-0918 & NTS LANDFILL LOAD VERIFICATION & Page 1 of 2 \\
\hline
\end{tabular}

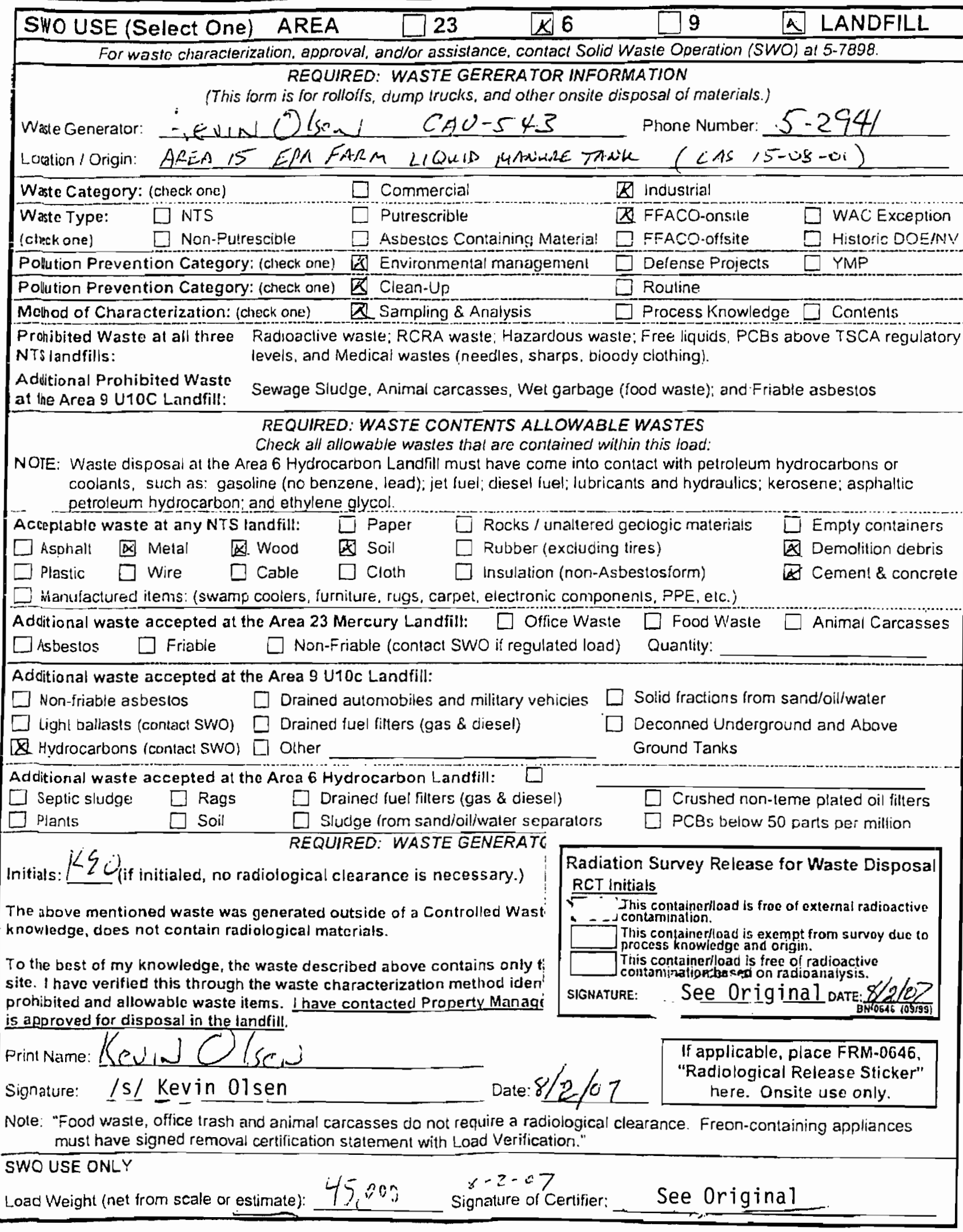


SWO USE (Select One) AREA

$\square 23$

6

K 9 10C $\quad$ CKLANDFILL

For waste characlerization, approval, and/or assistance, conlact Solid Waste Operalion (SWO) al 5-7898. REQUIRED: WASTE GERERATOR INFORMATION

(This form is for rollotfs, dump lrucks, and oller onsite disposal of materials.)

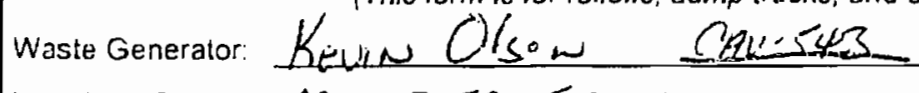

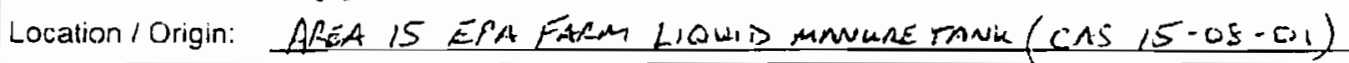

Waste Category: (check one)

Waste Type: $\square$ NTS

(check one)

$\square$ Non-Putrescible

$\square$ Commercial
$\square$ Putrescrible

$\triangle$ Industrial

DEFACO-onsite

$\square$ FFACO-offsite

$5-2541$

Defense Projects

WAC Exceplión

Pollution Prevention Category: (check orte) $Q$ Environmental management

Pollution Prevention Category: (check one) Clean-Up

D Rouline

Method of Characterization: (check one) $X$ Sampling \& Analysis

$\square$ Process Knowledge $\square$ Contents

Prohibited Waste at all three Radioactive waste; RCRA waste; Hazardous wasle; Free liquids, PCBS above TSCA regulatory

NTS landfills:

Additional Prohibited Waste

at the Area 9 U10C Landfill:

levels, and Medical wastes (needles, sharps, bloody clothing).

Sewage Sludge. Animal carcasses, Wet garbage (food waste), and Friable asbestos

REQUIRED: WASTE CONTENTS ALLOWABLE WASTES

Check all allowable wastes that are contained within this load:

NOTE: Waste disposal at the Area 6 Hydrocarbon Landfill must have come into contact with petroleun hydrocarons or coolants, such as: gasoline (no benzene, lead); jet fuel; diesel fuel; lubricants and hydraulics; kerosene; asphaltic petroleum hydrocarbon; and ethylene glycol.
Acceptable waste at any NTS landfill:
$\square$ Paper
$\square$ Rocks / unaltered geologic materials
因 Soil
$\square$ Rubber (excluding tires)
$\square$ Asphall $\square$ Metal
$\bowtie$ Wood
$\square$ Cloth
$\square$ Insulalion (non-Asbestosform)
Emoty containers
Demolition debris
$\square$ Plastic $\square$ Wire
$\square$ Cable
- Cloth

Det, e

- Manulactured items: (swamp coolers, furniture, rugs,

Additional waste accepted at the Area 23 Mercury Landfill: $\square$ Ofice Waste $\square$ Food Waste $\square$ Anmal Carcasses
$\square$ Asbestos
$\square$ Friable
$\square$ Non-Friable (contaci SWO if regulated load)
Quantity:

Additional waste accepted at the Area 9 U10c Landfill:

$\begin{array}{ll}\square \text { Non-friable asbestos } & \square \text { Drained automobiles and military vehicles } \\ \square \text { Light ballasts (contacl Swo) } \\ \square \text { Dolid fractions from sandioil/water } \\ \square \text { Hydrocarbons (contacl Swo) } \square \text { Other } & \square \text { Deconned Underground and Above }\end{array}$

Additional waste accepted at the Area 6 Hydrocarbon Landfill:

\begin{tabular}{llll}
$\square$ Seplic sludge $\square$ Rags & $\square$ Drained fuel filters (gas \& diesel) & $\square$ Crushed non-leme plated oil filters \\
$\square$ Plants & $\square$ Soil & $\square$ Sludge from sandoil/water separators & $\square$ PCBs below 50 parts per million \\
\hline
\end{tabular}

Initials: $E$ G (if initialed, no radiological clearance is necessary.)

The above mentioned waste was generated outside of a Controlled Waste Manas

knowledge, does not contain radiological materials.

To the best of my knowledge, the waste described above contains only those mi site. I have verified this through the waste characterization method identified ab prohibited and allowable waste items. I have contacted Property Management al is approved for disposal in the landfill.

Print Nane: Kej/yi $/$ Sung

Signature: $\quad / \mathrm{s} /$ Kevin $01 \mathrm{sen}$

Radiation Survey Release for Waste Disposal RCT Initials

This containerlload is free of external radioactive contamination.

This containerlload is exempt from survey due to process knowledge and origin.

This container/load is free of radioactive contamination based on radioanalysis.

Note: "Food waste, office trash and animal carcasses do not require a radiological clearance. Freon-containing appliances must have signed removal certification statement with Load Verification."

SWO USE ONLY

Load Weight (net from fale, os estimate) $4 ?: 6 ?$ ? $2 y-z-\cos 7$ Signature of Certifier:
/S/ Don Bickford 
NSTec

Form

FRM-0918

NTS LANDFILL LOAD VERIFICATION

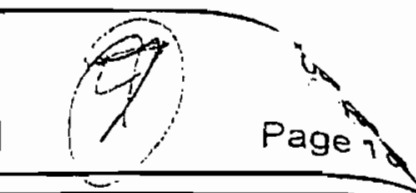

\begin{tabular}{|c|c|}
\hline SWO USE (Select One) & AREA \\
\hline
\end{tabular}

For wasle characterization, approval, and/or assislance, conlacl Solid Waste Operation (SWO) al 5-7898.

REQUIRED: WASTE GERERATOR INFORMATION

Waste Generator: (This form is for rolloffs, dump trucks, and other onsile disposal of materials.)

Location / Origin: Area 15 EPA Farm Liquid Manure Tank - CAS 15-08-01 -- Tank Properly Number 9997990

\begin{tabular}{|c|c|c|c|c|c|}
\hline \multicolumn{2}{|c|}{ Waste Category: (check one) } & \multirow{2}{*}{\multicolumn{2}{|c|}{$\begin{array}{l}\square \text { Commercial } \\
\square \text { Pulrescrible }\end{array}$}} & \multicolumn{2}{|l|}{ 区 Industrial } \\
\hline Waste Type: & $\square$ NTS & & & 区 FFACO-onsile & $\square$ WAC Exception \\
\hline (check one) & $\square$ Non-Putrescible & $\square$ & Asbestos Containing Malerial & $\square$ FFACO-offsite & $\square$ Historic DOE/NV \\
\hline \multicolumn{2}{|c|}{ Pollution Prevention Category: (cleck one) } & 逐 & Environmental manajement & Detense Projects & $\square$ YMP \\
\hline \multicolumn{2}{|c|}{ Pollution Prevention Category: (check one) } & . & Clean-Up & Routine & \\
\hline \multicolumn{2}{|c|}{ Method of Charagterization: (check one) } & 邓 & Sampling \& Analysis & $\square$ Process Knowledge & $\square$ Contents \\
\hline
\end{tabular}

Prohibited Waste at all three Radioactive wasle: RCRA waste; Hazardous waste; Free liquids, PCBs above TSCA reciulatory NTS landfills:

Additional Prohibited Waste

at the Area 9 U10C Landfill:

levels, and Medical wastes (needles, sharps, bloody clothing).

Sewage Sludge, Animal carcasses, Wet garbage (food waste); and Friable asbestos

REQUIRED: WASTE CONTENTS ALLOWABLE WASTES

Check all allowable wasles that are contained within this load:

NOTE: Waste disposal at the Area 6 Hydrocarbon Landfili must have come into contact with petroleum hydrocarbons or coolants, such as: gasoline (no benzene, lead); jet fuel; diesel fuel; lubricants and hydraulics; kerosene; asphaltic. petroleum hydrocarbon; and ethylene glycol.

Acceptable waste at any NTS landfill:

$\square$ Paper

$\square$ Rocks / unallered geologic naterials

$\square$ Rubber (excluding tires)

$\square$ Asphalt $\square$ Metal $\square$ Wood

$\square$ Soil

$\square$ Plastic $\square$ Wire . $\square$ Cable $\square$ Cloth $\square$ Insulation (non-Asbestosiom)
$\square$ Manufactured items: (swamp conlers, furniture, rugs, carpet, electronic components, PPE, etc.)

$\square$ Exply containers
$\square$ Cemtition debris
$\square$ Cement \& concrete

Additional waste accepted at the Area 23 Mercury Landfill: $\square$ Office Waste $\square$ Food Waste $\square$ Anima! Carcasses
$\square$ Asbestos $\square$ Friable $\square$ Non-Friable (contact SWO if regulated load) Quantity: Additional waste accepted at the Area 9 U10c Landfill:
$\square$ Non-friable asbestos
Drained automobiles and miltitary vehicles
Light ballasts (contact SwO)
Drained fuel filters (gas \& diesel)
Other
Solid fractions from sand/oil/water
Hydrocarbons (contact SWO)
Deconned Underground and Above Ground Tanks
Additional waste accepted at the Area 6 Hydrocarbon Landfill:
$\square$ Septic siucige $\square$ Rags
$\square$ Drained fuel filters (gas \& diesel)
Crushed non-leme plated oil fillers
Plants
$\square$ Sludge from sand/oil/water separators
PCBs below 50 parts per million

Initials: $K \mathcal{K}$ (if initialed, no radiological clearance is necessary.)

The above mentioned waste was generated outside of a Controlled Wast

knowledge, does not contain radiological materials.

To the best of my knowledge, the waste described above contains only th site. I have verified this through the waste characterization method ident proluibited and allowable waste items. I have contacted Property Manage is approved for disposal in the landfill.

Print Name: Kivin) Q/Sch

Signature: /s/ Kevin 01 sen

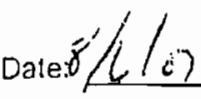

Radiation Survey Release for Waste Disposal RC历lgitials

This containcriload is trec of external radioactive Icomiamination.

= This containeriload is exempt from survey duc to process knowledgo and origin.

This containeriload is free of radioactive This conrainerload is ree of radioactive

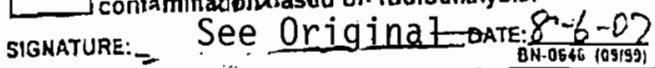

Note: "Food waste, office trash and animal carcasses do not require a radiological clearance. Freon-containing appliances must have signed removal certification statemenl wilh Load Verificalion."

SWO USE ONLY

Load Weight (net from scale or estimate):

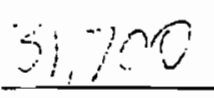

$3-6.27$

Signature of Certifier:

If applicable, place FRM-0646,

"Radiological Release Sticker" here. Onsite use only. 


\section{NSTec \\ Form \\ FRM-0918 \\ NTS LANDFILL LOAD VERIFICATION}

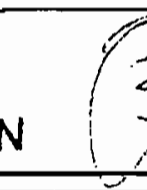

\begin{tabular}{|llllll|}
\hline SWO USE (Select One) & AREA & $\square 23$ & $\square 6$ & \23 & $\square$ LANDFILL \\
\hline
\end{tabular}

For wasle characlerization, approval, and/or assistance, confact Solid Waste Operation (SWO) al 5-7898.

REQUIRED: WASTE GERERATOR INFORMATION

Waste Generator:

$$
\text { TeviN form is for rollolfs, dump trucks, and }
$$

osal of materials.

Location / Origin:

Area 15 EPA Farm Liquid Manure Tank --- CAS 15-08-01

Phone Number: $5-2941$

Waste Category: (check one)

Waste Type: $\square$ NTS

(check one)

$\square$ Non-Putrescible

$\square$ Commercial

Dutrescrible

Tank Property Number 9997990

Pollution Prevention Category: (check one)

Pollution Prevention Category: (check one)

Method of Characterization: (check one)

$\square$ Asbesios Containing Materia!

区 Industrial

¿FFACO-onsile

$\otimes$ Environmental managemenl

Q Clean-Up

¿ Sampling \& Analysis

$\triangle$ FFACO-onsite
FFACO-offsite

WAC Exception

Defense Projects

Historic DOE/NV

Prohibited Waste at all three Radioactive waste; RCPA waste; Hazardous waste; Free liquids, PCBs above TSCA regulatory NTS landfills:

Additional Prohibited Waste

at the Area 9 U10C Landfill: leveis, and Medical wastes (needles, sharps, bioody clothing).

Sewage Sludge, Anirnal carcasses, Wet garbage (food wasie); and Friable asbestos

\section{REQUIRED: WASTE CONTENTS ALLOWABLE WASTES}

Check all allowable wasles that are contained within this load:

NOTE: Waste disposal at the Area 6 Hydrocarbon Landfill must have come into contact with petroleum hydrocarbons or coolants, such as: gasoline (no benzene, lead); jet fuel; diesel fuel; iubricants and hydraulics; kerosene; asphaltic petroleum hydrocarbon; and ethylene glycol.

Acceptable waste at any NTS landfill: $\square$ Paper $\square$ Rocks / unaltered geologic materials
$\square$ Asphalt
$\square$ Metal
$\square$ Wood
$\square$ Soil
Cable
$\square$ Cloth
$\square$ Rubber (excluding tires)
$\square$ insulation (non-Asbestosform)

Manufactured ilems: (swamp coolers, furniture, rugs. carpet, electronic components, PPE, etc.)

Additional waste accepted at the Area 23 Mercury Landfill: $\square$ Orfice Waste $\square$ Food Waste
$\square$ Asbestos
$\square$ Friable
$\square$ Non-Friable (contact swo if regulated load)
Quantity:

Additional waste accepled at the Area 9 U10 L Landfill:

$\square$ Non-friable asbestos $\quad \square$ Drained automobiles and military vehicles
$\square$ Light ballasts (contact swo) $\square$ Drained fuel filters (gas \& diesel)
$\square$ Hydrocarbons (contact swo) $\square$ Other

Solid fractions from sand/oil/water

Deconned Underground and Above Ground Tanks

Additional waste accepted at the Area 6 Hydrocarbon Landfill:
$\square$ Septic sludge
$\square$ Rags
$\square$ Drained fuel filters (gas \& diesel)
Crushed non-teme plated oil fillers
Plants
Soil
$\square$ Sludge from sand/oil/water separalors
REQUIRED: WASTE GENERATOR SIGNATURE

Initials: $\frac{K C O}{L}$ (if initialed, no radiological clearance is necessary.)

The above mentioned waste was generated outside of a Controlied Waste Managen knowledge, does not contain radiological materials.

To the best of my knowledge, the waste described above contains only those mate site. I have verified this through the waste characterization method identified abovi prohibited and allowable waste items. I have contacted Property Management and is approved for disposal in the landfill.

Print Name: KcJin: Olsen

Signature: $\quad / \mathrm{s} / \mathrm{Kev}$ in 01 sen
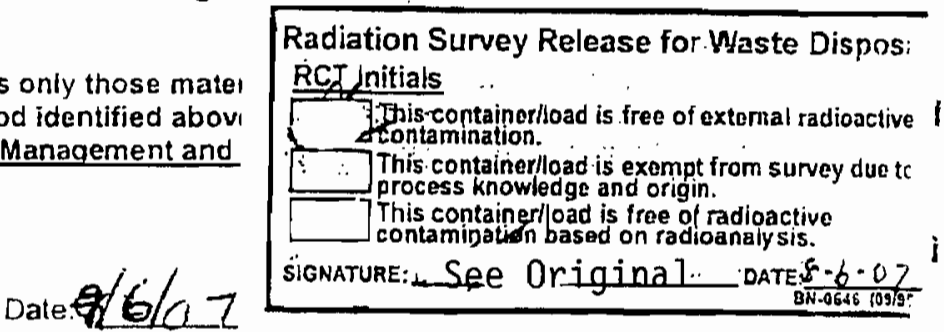

Note: "Food waste, office trash and animal carcasses do not require a racliological clearance. Freon-containing appliances must have signed removal certification statement with Load Verification."

SWO USE ONLY

Load Weight (net from scale or estimate)

$460 \mathrm{n}$

$3 \cdot 6 \cdot 6.9$

Signature of Certifier:

Ls/Don Bickford 


$\begin{array}{llllll}\text { SWO USE (Select One) } & \text { AREA } & \square 23 & \square 6 & \square 9 & \square \text { LANDFILL }\end{array}$

For waste characterizalion, approval, and/ol assistance, contact Solid Waste Operation (SWO) at 5-7898.

\section{REQUIRED: WASTE GERERATOR INFORMATION}

. (This form is for rolloffs, dump trucks, and other onsite disposal of malerials.)

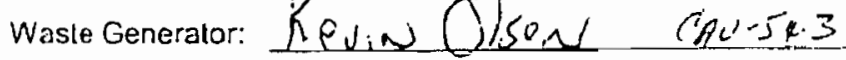

Phone Number: $5-2941$

Location / Origin: $\quad$ Area 15 EPA Farm Liquidi Manure Tank -- CAS 15-08-01 - Tank Property Number 9997990

Waste Category: (check one)

Waste Type: $\square$ NTS

$\square$ Commercial

区 Industrial

(check one)

$\square$ Non-Putrescible

$\square$ Putrescrible

区 FFACO-onsite.

$\square$ WAC Exception

Pollution Prevention Category: (check one) $\bigotimes$ Environmental managemenl

Pollution Prevention Category: (check one) $\triangle$ Clean-Up

Method of Characterization: (check one) $\backslash$ Sampling \& Analysis $\square$ Process Knowledge $\square$ Contents

D FFACO-offsile

$\square$ Historic DOE/NV

$\begin{array}{ll}\text { Prohibited Waste at all three Radioactive waste; RCRA waste; Hazardous waste; Free liquids, } \\ \text { NTS landfills: } & \text { levels, and Medical wastes (needles, sharps, bloody clothing). }\end{array}$

Additional Prohlbited Waste

at the Area 9 U10C Landfill:

Sewage Sludge. Animal carcasses, Wel garbage (food wasle); and Friable asbestos

\section{REQUIRED: WASTE CONTENTS ALLOWABLE WASTES}

Check all allowable wastes that are contained within this load:

NOTE: Waste disposal at the Area 6 Hydrocarbon Landfill must have come into contact with petroleum hydrocarbons or coolants, such as: gasoline (no benzene, lead); jet fuel; diesel fuel; lubricants and hydraulics; kerosene: asphallic petroleum hydrocarbon; and elhylene glycol.
Acceptable waste at any NTS landfill:
[D Paper
$\square$ Rocks / unaltered geologic materials
$\square$ Asphalt
$\square$ Metal
$\square$ wood
$\square$ Soil
$\square$ Rubber (excluding tires)
$\square$ Plastic
Wire
$\square$ Cable
$\square$ Clolh
Insulation (non-Asbestosform)

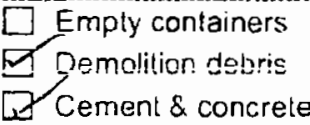

$\square$ Manufaclured items: (swamp coolers, furniture, rugs, carpel, electronic components, PPE, etc.)

Additional waste accepted at the Area 23 Mercury Landfill: $\square$ Office Waste $\square$ Food Waste
$\square$ Asbeslos
Friable
$\square$ Non-Friable (contact SwO if regulated load)
Quanlity:

Additional waste accepted at the Area 9 U10C Landfill:
$\square$ Non-Iriable asbestos
$\square$ Drained automobiles and military vehicles
$\square$ Solid fractions from sand/oil/water
$\square$ Light ballasis (contaci swo)
$\square$ Drained fuel filters (gas \& diesel)
$\square$ Deconned Underground and Above
Hydrocarbons (contacl SWO)
Other
Ground Tanks

Additional waste accepted at the Area 6 Hydrocarbon Landfill:
$\square$ Septic siudge
$\square$ Rags
Drained fuel filters (gas \& diesel)
Crushed non-teme plated oil fillers
Plants
$\square$ Soil
$\square$ Sludge from sand/oil/water separators
$\square$ PCBs below 50 parts per million

Initials: $\angle \mathcal{U} \mathcal{U}_{\text {(if initialed, no radiologica! clearance is necessary.) }}$

The above mentioned waste was generated outside of a Cuntrolled Waste Management Area (CWMA) and to the best of my knowledge, does not contain radiological materials.

To the best of my knowledge, the waste described above contains only those ma site. I have verified this through the waste characterization method identified abe prohibited and allowable waste items. I have contacted Property Manacement an is approved for disposal in the landfill.

Print Name: Koj」N Qlece

Signature: $/ \mathrm{s} / \mathrm{Kevin} 01 \mathrm{sen} \ldots$ _..__ Date: $\{1 / 6 / 07$

Note: "Food waste, office trash and animal carcasses do nol require a radiological must have signed removal certification statement with Load Verification."

SWO USE ONLY

Load Weight (net from scale or estimate): $\%$

$4 \cdot i-4 \cdot 7$

Signature of Certifier:
Radiation Survey Release for Waste Disposal RCJ Initials

This containeriload is free of external radioactive contamination.

This containerload is exempt:from survey due to process knowledgc and origin.

This container/load is free of radioactive

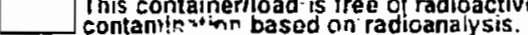

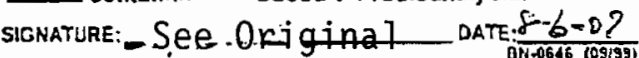




\begin{tabular}{|lrr|r|}
\hline NSTeC & & $\ddots$ & $08 / 23 / 06$ \\
Form & Rev. 0 \\
FRM-0918 & NTS LANDFILL LOAD VERIFICATION & $\ddots$ & Page 1 of 2 \\
\hline
\end{tabular}

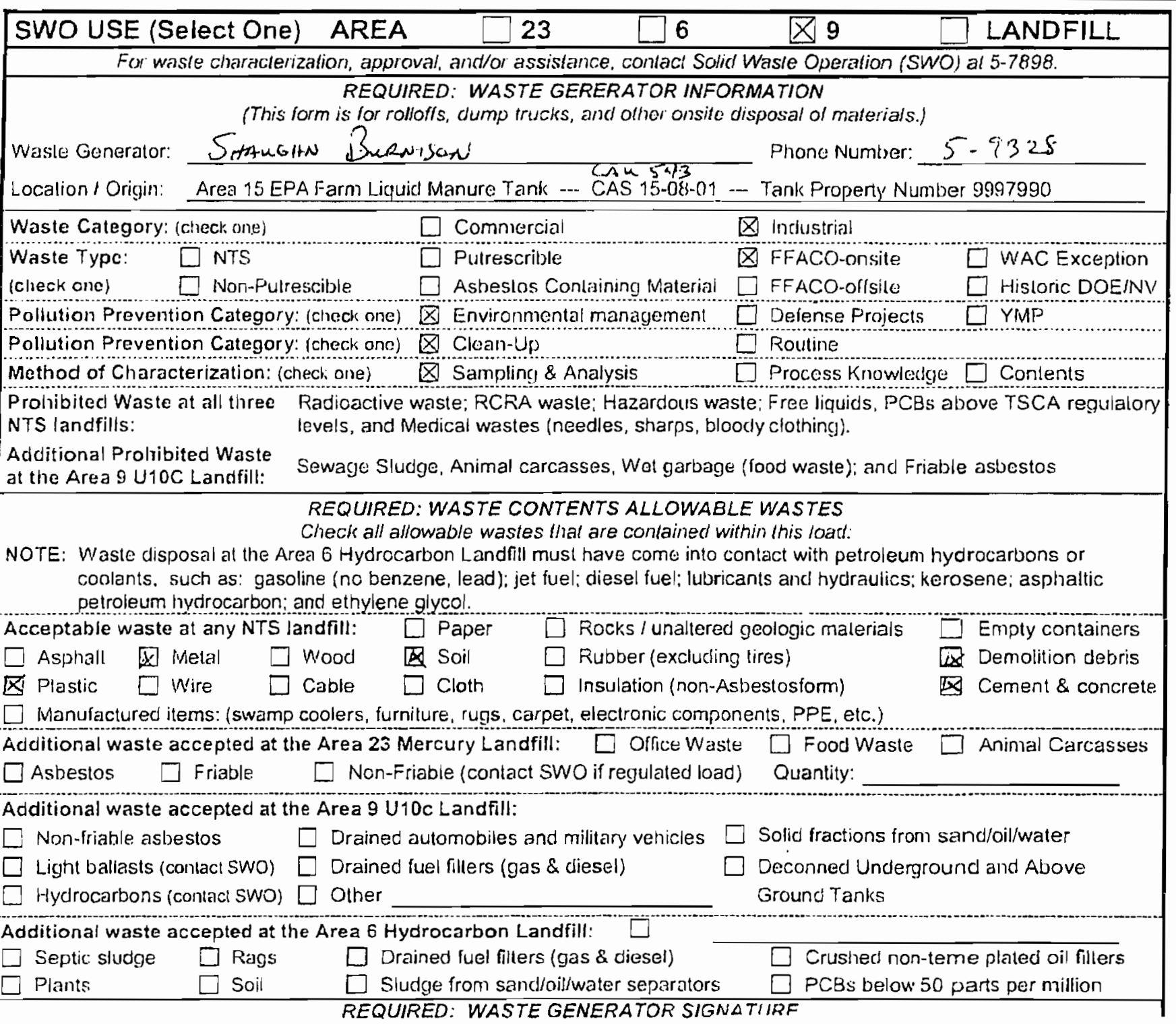

initials: ___ (if initialed, no radiological clearance is necessary.)

The above mentioned waste was generated cutside of a Controlled Waste Mar knowledge, does not contain radiological materials.

To the best of my knowledge, the waste described above contains only those site. I have verified this through the waste characterization method identified prohibited and allowable waste items. I have contacted Property Managemen is approved for disposal in the landfill.

Print Name: Sittuw-HN BufNisuN

Signalure: /s/ Shaughn Burnison

Nole: "Food waste, office trash and animal carcasses do not require a racliological clearance. Freon-containing appliances must have signed removal certification stalement with Load Verification."

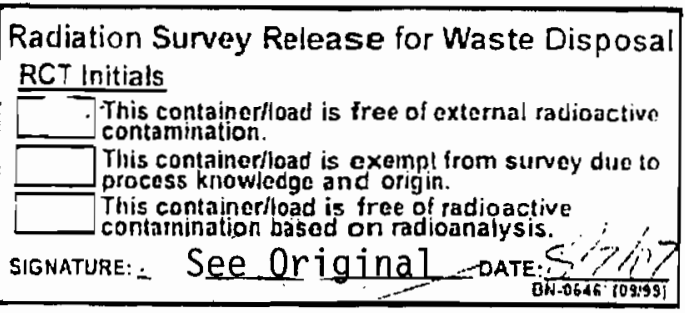

11 aptullavit, plale rnivi-uumo.

"Radiological Release Sticker" here. Onsite use only.
SWO USE ONLY
$?-7-0 ?$

Signature of Certiner: /s/ Don Bickford 
NSTec

Form

FRM-0918

NTS LANDFILL LOAD VERIFICATION

$08 / 23 / 06$

Rev. 0

Page 1 of 2

$\begin{array}{llllll}\text { SWO USE (Select One) } & \text { AREA } & \square 23 & \square 6 & \square 9 & \square \text { LANDFILL }\end{array}$

For waste characterization, approval, and/or assislance, contacl Solid Waste Operation (SWO) al 5-7898.

REQUIRED: WASTE GERERATOR INFORMATION

(This form is for rolloffs, dump lrucks, and other onsile disposal of materials.)

Waste Generator: Sinqugitti Bunisunisun

Phone Number: $5-9328$

Location / Origin: $\quad$ Area 15 EPA Farm Liquid Manure Tank --- CAS 15-08-01 -.- Tank Property Number 9997990

\begin{tabular}{|c|c|c|c|c|c|}
\hline \multicolumn{2}{|c|}{ Waste Category: (check one) } & $\square$ & Commercial & 凶 Industrial & \\
\hline Waste Type: & $\square$ NTS & $\square$ & Putrescrible & $\triangle$ FFACO-onsite & $\square$ WAC Exception \\
\hline (check one) & $\square$ Non-Putrescible & $\square$ & Asbestos Conlaining Material & $\square$ FFACO-olfsite & $\square$ Historic DOE/NV \\
\hline \multicolumn{2}{|c|}{ Pollution Prevention Category: (check one) } & $凶$ & Environmental management & Defense Projects & YIMP \\
\hline \multicolumn{2}{|c|}{ Pollution Prevention Category: (check one) } & 凶 & Clean-Up & Routine & \\
\hline \multicolumn{2}{|c|}{ Method of Characterization: (check one) } & Q & Sampling \& Analysis & $\square$ Process Knowleds & $\square$ Contents \\
\hline
\end{tabular}

Prohibited Waste at all three Radioactive waste; RCRA wasle; Hazardous waste; Free liquids, PCBs above TSCA regulatory NTS landfills:

Additional Prohibited Waste at the Area 9 U10C Landfill: levels, and Medical wastes (needles, sharps, bloody clothing).

Sewage Sludge, Animal carcasses, Wet garbage (food waste); and Friable asbestos

REQUIRED: WASTE CONTENTS ALLOWABLE WASTES

Check all allowable wastes that are contained within this load:

NOTE: Waste disposal at the Area 6 Hydrocarbon Landfill must have come into contact with petroleum hydrocarbons or coolants, such as: gasoline (no benzene, lead); jet fuel; diesel fuel; lubricants and hydraulics; kerosene; asphaltic petroleum hydrocarbon; and ethylene glycol.
Acceptable waste at any NTS landfill:
$\square$ Paper
$\square$ Rocks / unaltered geologic materials
$\square$ Empty containers
\& Asphall $\square$ Metal $\square$ wood
Soil
$\square$ Rubber (excluding tires)
Demolition debris
18. Plastic
$\square$ Cable
$\square$ Insulation (non-Asbestosform)
Cement \& concrete

$\square$ Manufactured items: (swamp coolers, furniture, rugs, carpet, electronic components, PPE, etc.)
Additional waste accepted at the Area 23 Mercury Landfill: $\square$ Office Waste
$\square$ Food Waste
Animal Carcasses

$\square$ Asbestos

Friable

$\square$ Non-Friable (contact SWO if regulated load)

Quantity:

Additional waste accepted at the Area 9 U10 Landfill:
$\square$ Non-iriable asbestos
$\square$ Drained automobiles and military vehicles
Light ballasts (contact swo)
$\square$ Drained fuel filters (gas \& diesel)
Solid fractions from sand/oil/water
Hydrocarbons (contact SWO
Other
$\square$ Deconned Underground and Above Ground Tanks

Additional waste accepted at the Area 6 Hydrocarbon Landfill:
$\square$ Septic siudge
$\square$ Rags
$\square$ Drained fuel filters (gas \& diesel)
Plants
Soil
$\square$ Sludge from sand/oil/water separalors
$\square$ Crushed non-teme plated oil filters REQUIRED: WASTE GENERATOR SIGNATURE

Initials: (if initialed, no radiological clearance is necessary.)

The above mentioned waste was generated outside of a Controlled Waste Management Area (CWMA) and to the best of $\mathrm{my}$ knowledge, does not contain radiological matorials.

To the best of my knowledge, the waste described above contains only those materials sitc. I have verified this through the waste characterization method identified above an prohibited and allowable waste items. I have contacted Property Management and havi is approved for disposal in the landfill.

Print Name: SHAuEHN BuRnisian

Signature: /S/ Shaughn Burnison

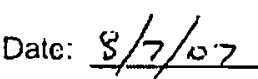

Note: "Food waste, office trash and animal carcasses do not require a radiological clear: must have signed removal certification statement with Load Verification."

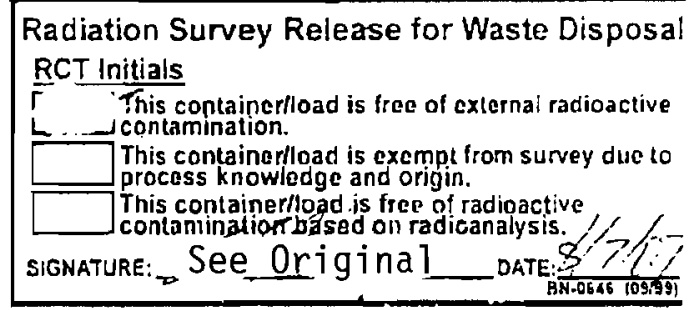

SWO USE ONLY
Load Weight (net from scale or estimate

$i-\pi-0.7$

Signature of Certifier: /s/. Den Bickford 
Closure Report - CAU 543

Section: Appendix C

Revision: 0

Date: January 2008

THIS PAGE INTENTIONALLY LEFT BLANK 
Closure Report - CAU 543

Section: Appendix C

Revision: 0

Date: January 2008

Corrective Action Site 15-23-01

Underground Radioactive Material Area 
Closure Report - CAU 543

Section: Appendix C

Revision: 0

Date: January 2008

THIS PAGE INTENTIONALLY LEFT BLANK 


NSTec
Form
FRM-0918

\begin{tabular}{|c|c|c|c|c|}
\hline \multicolumn{2}{|c|}{ SWO USE (Select One) AREA } & $\square 23 \quad \square 6$ & Q 9 & $\square$ LANDFILL \\
\hline \multicolumn{5}{|c|}{ For waste characterization, approval, and/or assistance, contact Solio Waste Operation (SWO) at 5-7898. } \\
\hline \multicolumn{5}{|c|}{$\begin{array}{c}\text { REQUIRED: WASTE GERERATOR INFORMATION } \\
\text { (This form is for rolloffs, dump irucks, and other onsite disposal of materials.) }\end{array}$} \\
\hline \multirow{2}{*}{$\begin{array}{l}\text { Waste Generator: } \\
\text { Location / Origin: }\end{array}$} & \multicolumn{2}{|c|}{ SHauginen Burnison } & \multicolumn{2}{|c|}{ _- Phone Number: $5:=528 / 330.80$} \\
\hline & \multicolumn{2}{|c|}{ 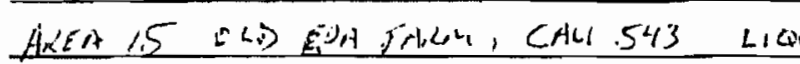 } & \multicolumn{2}{|c|}{ i) Dispostis Units } \\
\hline & Q Commercial & \multicolumn{2}{|c|}{ Industrial } \\
\hline \multicolumn{2}{|c|}{ Waste Type: $\square$ NTS } & $\square$ Putrescrible & E FFACO-onsite & $\square$ WAC Exception \\
\hline (check one) & $\square$ Non-Putrescible & Asbestos Containing Material & $\square$ FFACO-offsite & $\square$ Historic DOE/NV \\
\hline \multicolumn{3}{|c|}{ Pollution Prevention Category: (check one) Environmental management } & $\square$ Defense Projects & YMP \\
\hline \multicolumn{3}{|c|}{ Pollution Prevention Category: (check one) $\otimes$ Clean-Up } & $\square$ Routine & \\
\hline \multicolumn{3}{|c|}{ Method of Characterization: (check one) Sampling $\delta$} & 7 Process & \\
\hline
\end{tabular}

Prohibited Waste at all three Radioactive waste; RCRA waste; Hazardous waste; Free liquids, PCBs above TSCA regulatory NTS landfills:

Additional Prohibited Waste

at the Area 9 U10C Landfill:

levels, and Medical wastes (needles, sharps, bioody clothing).

REQUIRED: WASTE CONTENTS ALLOWABLE WASTES

Check all allowable wastes that are contained within this load:

NOTE: Waste disposal at the Area 6 Hydrocarbon Landfill must have come into contact with petroleum hydrocarbons or coolants, such as: gasoline (no benzene, lead); jet fuel; diesel fuel: lubricants and hydraulics; kerosene; asphaltic petroleum hydrocarbon; and ethylene glycol.
Acceptable waste at any NTS landfilt:
$\square$ Asphalt $\square$ Metal
Wood
$\square$ Paper
$\square$ Soil
$\square$ Rocks / unaltered geologic malerials
$\square$ Rubber (excluding tires)
$\square$ Plastic $\square$ Wire $\square$ Cable
$\square$ Cloth
$\square$ Insulation (non-Asbestosform)
$\square$ Manufactured items: (swamp coolers, furniture, rugs, carpet, electronic components, PPE, etc.)
Additional waste accepted at the Area 23 Mercury Landfill: $\square$ Officc Waste
$\square$ Asbestos
$\square$ Friable
$\square$ Non-Friable (contact $S W O$ if regulated load)
$\square$ Food Waste
Additional waste accepted at the Area 9 U10 C Landfill:
$\square$ Non-friable asbesios
$\square$ Drained automobiles and military vehicles
Light ballasts (contact SwO)
Drained fuel fillers (gas \& diesel)
Hydrocarbons (contact SWO)
Other
Quantity:
Solid fractions from sand/oil/water
Deconned Underground and Above Ground Tanks

$\square$ Empty containers

$\square$ Demolition debris

$\square$ Cement \& concrete

Animal Carcasses

Additional waste accepted at the Area 6 Hydrocarbon Landfill:
$\square$ Septic siudge
$\square$ Rags
$\square$ Drained fuel filters (gas \& diesel)
Soil
$\square$ Sludge from sand/oil/water separators
Plants REQUIRED: WASTE GENERATOR SIGNATURE

Initials: (if initialed, no radiological clearance is necessary.)

The above mentioned waste was generated outside of a Controlled Waste Management Area (CWMA) and to the best of my knowiedge, does not contain radiological materials.

To the best of my knowledge, the waste described above contains only those mate site. I have verified this through the waste characterization method identified abor prohibited and allowable waste items. I have contacted Property Management and is approved for disposal in the landfill.

Print Name: StamGan Bukinison

Signalure: / S/ Shaughn Burnison Date: $4 / 3 / 67$

Nole: "Food waste, office trash and animal carcasses do not require a radiological, must have signed removal certification statement with Load Verification."

SWO USE ONLY

Load Weight (net from scale or estimate):

$4 \cdot-3 \cdot 2 \cdot 7$ Signature of Certifier:

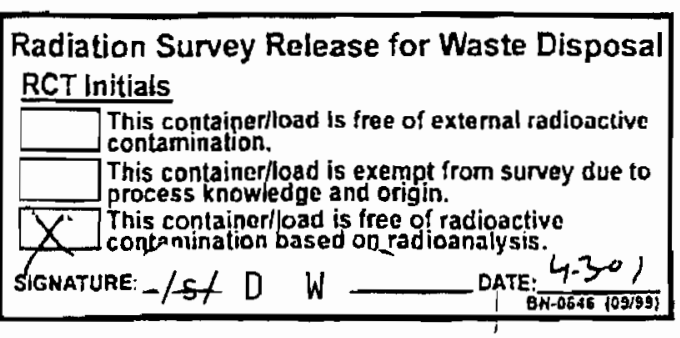

Radiation Survey Release for Waste Disposal itials Thtamination.

This cons knowledge and origin.

This containeriload is free ol radioactivo

4.301

Si Łs/. Don Bickford, 
Closure Report - CAU 543

Section: Appendix C

Revision: 0

Date: January 2008

THIS PAGE INTENTIONALLY LEFT BLANK 
Closure Report - CAU 543

Section: Appendix C

Revision: 0

Date: January 2008

Corrective Action Site 15-23-03

Contaminated Sump, Piping 
Closure Report - CAU 543

Section: Appendix C

Revision: 0

Date: January 2008

THIS PAGE INTENTIONALLY LEFT BLANK 
NSTeC

Form

FRM-0918

NTS LANDFILL LOAD VERIFICATION

$F_{2}$

Page 1 of

\begin{tabular}{|lllll}
\hline SWO USE (Select One) AREA & $\square 23$ & $\square 6$ & $\square 9$ & $\square$ LANDFILL
\end{tabular}

For wasto characterizalion, approval, and/or assislance, contact Solid Waste Operalion (SWO) at 5-7898.

REQUIRED: WASTE GERERATOR INFORMATION

(This iorm is for rolloffs, dump trucks, and other onsite disposal of materials.)

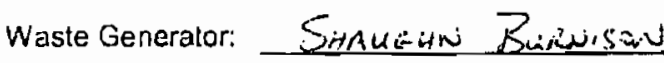

Phone Number: 5 -9325/358-1030

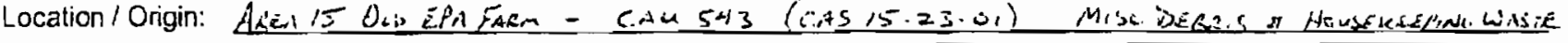

Waste Category: (check one)

Waste Type: $=$ NTS $\square$ Putrescrible

$\square$ Commercial

Industrial

FFACO-onsite

WAC Exception

(check one) $\square$ Non-Putrescible $\square$ Asbestos Containing Material

$\square$ FFACO-offsite

Pollution Prevention Category: (check one) $\forall$ Environmental management

Pollution Prevention Category: (check one) $\triangle$ Clean-Up

Method of Characterization: (check one) $\triangle$ Sampling \& Analysis $\square$ Process Knowledge $\square$ Conlents

Prohibited Waste at ail three Radioactive waste: RCRA waste; Hazardous waste; Free liquids, PCBs above TSCA regulatory

NTS landfilis:

levels, and Medical wastes (needles, sharps, bloody clothing).

Additional Prohibited Waste Sewage Sludge. Animal carcasses, Wel garbage (food waste): and Friable asbestos
at the Area 9 U10C Landfill:

REQUIRED: WASTE CONTENTS ALLOWABLE WASTES

Check all allowable wastes that are contained within this load:

NOTE: Waste disposal at the Area 6 Hydrocarbon Landill must have come into contact with petroleum hydrocarbons or coolants, such as: gasoline (no benzene, lead); jet fuel; diesel fuel; lubricants and hydraulics; kerosene; asphaltic petroleum hydrocarbon: and ethylene glycol.
Acceptable waste at any NTS landfill:
$\square$ Paper
$\square$ Rocks / unaltered geologic materials
Empty containers
$\square$ Asphalt $\square$ Metal
Q Wood
区 Soil
Rubber (excluding tires)
$\square$ insulation (non-Asbestosform)
$\mathbf{X}$ Demolition debris
$\square$ Plastic $\square$ Wire
$\square$ Cable
$\square$ Cloth
Cement \& concrete

X Manufactured items: (swamp coolers, fumiture, rugs, carpet, electronic components, PPE, etc.)
Additional waste accepted at the Area 23 Mercury Landfill: $\square$ Office Waste
Food Waste
Animal Carcasses

$\square$ Asbestos $\square$ Friable

Non-Friable (contact SWO if regulated load)

Additional waste accepted at the Area 9 U10c Landfill:
$\square$ Non-friable asbestos
$\square$ Drained automobiles and military vehicles
L Light ballasts (contac: SWO)
$\square$ Drained fuel filters (gas \& diesel)
Hydrocarbons (conlact SWO) $\square$ Other
Solid fractions from sand/oil/water
$\square$ Deconned Underground and Above Ground Tanks

Additional waste accepted at the Area 6 Hydrocarbon Landfill:
$\square$ Seplic sludge
$\square$ Rags
$\square$ Drained fuel filters (gas \& diesel)
$\square$ Sludge from sand/oil/water separators
Crushed non-teme plated oil filters
Plants
$\square$ Soil REQUIRED: WASTE GENERATOR SIGNATURE

Initials: (if initialed, no radiological clearance is necessary.)

The above mentioned waste was generated outside of a Controlled Waste Management Area (CWMA) and to the best of my knowledge, does not contain radiological materials.

To the best of my knowiedge, the waste described above contains only those materials that are allowed for disposai at this site. I have verified this through the waste characterization method identified abc prohibited and allowable waste Items. I have contacted Property Management an. is approved for disposal in the landfill.

Print Name: Siramben Burlwisan

Signature: Is/Shaughn Burnison___ Date: $4 / 2 / 0$ -

Note: "Food waste, office trash and animal carcasses do not require a radiological must have signed removal certification statement with Load Verification."

SWO USE ONLY

Load Weight (net from scalf or estimate) 2000
$\therefore-\Sigma-67$

Signature of Certifier:
Radiation Survey Release for Waste Disposal RCT Initials

This containerlload is free of extemal radioactive contamination.

This containerfload is oxempt from survey due to process knowledge and origin.

This container/oad is free of radioactive

GNATURE /S/ D W

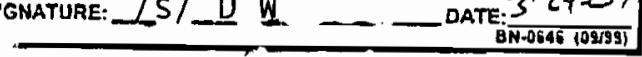

St Steven 


\section{REQUIRED: WASTE GERERATOR INFORMATION}

(This form is for rolloffs, dump trucks, and other onsite disposal of materials.)

\begin{tabular}{|c|c|c|c|c|}
\hline \multirow{2}{*}{$\begin{array}{l}\text { Waste Generator: } \\
\text { Location / Origin: }\end{array}$} & \multicolumn{2}{|l|}{ Sitaughan Rurulsons } & \multicolumn{2}{|c|}{ Phone Number: $5-9328$} \\
\hline & $\cos 543(\cos 15 \cdot 0.3 \cdot 01)$ & EAA FARM & ARSA 15 & - \\
\hline \multicolumn{2}{|c|}{ Waste Category: (check one) } & $\square$ Commercial & \multicolumn{2}{|l|}{ Ch Industrial } \\
\hline $\begin{array}{l}\text { Waste Type: } \\
\text { (check one) }\end{array}$ & $\begin{array}{l}\square \text { NTS } \\
\square \text { Non-Putrescible }\end{array}$ & $\square$ Putrescrible & $\begin{array}{l}\text { 2. FFACO-Onsite } \\
\text { FFACO-ollsite }\end{array}$ & $\begin{array}{l}\square \text { WAC Exceplion } \\
\square \text { Historic DOENN }\end{array}$ \\
\hline \multicolumn{2}{|c|}{ Pollution Prevention Category: (cleck one) } & $\begin{array}{l}\square \text { Asbestos Containing Material } \\
\square \text { Environmental management }\end{array}$ & $\square$ Defense Projects & $\square$ YMP \\
\hline \multicolumn{2}{|c|}{ Pollution Prevention Category: (check one) } & $\Delta$ Clean-Up & \multicolumn{2}{|l|}{$\square$ Roustine } \\
\hline \multicolumn{3}{|c|}{ Method of Characterization: (check one) } & \multicolumn{2}{|c|}{ D Process Knowledge $\mathbb{X}$ Contents } \\
\hline
\end{tabular}

Prohibited Waste at all three Radioactive waste; RCRA waste; Hazardous waste; Free liquids, PCBs above TSCA regulatory" NTS landfills:

Additional Prohibited Waste at the Area 9 U10C Landfill: levels, and Medical wastes (needles, sharps, bloody clothing).

Sewage Sludge, Animal carcasses, Wel garbage (food waste); and Friable asbestos

REQUIRED: WASTE CONTENTS ALLOWABLE WASTES

Check all allowable wastes that are contained within this load:

NOTE: Waste disposal at the Area 6 Hydrocarbon Landfil must have come into contact with petroleum hydrocarbons or coolants, such as: gasoline (no benzene, lead); jet fuel; diesel fuel; lubricants and hydraulics; kerosene; asphaltic petroleum hydrocarbon; and ethylene glycol.
Acceptable waste at any NTS landfill: I Paper
$\square$ Asphalt Metal
$\triangle$ Wood
Soil
[C Cable
$\square$ Cloth
$\square$ Rocks / unaltered geologic materials
$\square$ Rubber (excluding tires)
$\square$ Insulation (non-Asbestosform)
Emply containers
Plastic $\square$ Wire
wamp coolers,
furniture, rugs,

Carpet, electronic components, PPE, etc.)

Additional waste accepted at the Area 23 Mercury Landfilt: $\square$ Office Waste $\square$ Food Waste
$\square$ Asbestos
Friable
$\square$ Non-Friable (contact SWO if regulated load)
Quanlity:

Additional waste accepted at the Area 9 U10c Landfill:
$\square$ Non-friable asbestos
$\square$ Drained automobiles and military vehicles
Light ballasts (contact SWO)
Drained fuel filters (gas \& diesel)
Solid fractions from sand/oil/water
Hydrocarbons (contact SWO)
Other
$\square$ Deconned Underground and Above Ground Tanks

Additional waste accepted at the Area 6 Hydrocarbon Landfill:
¿ Septic sludge
$\square$ Drained fuel filters (gas \& diesel)
Plants
$\square$ Rags
$\square$ Sludge from sand/oil/waler separalors
Crushed non-leme plaled oil filters
REQUIRED: WASTE GENERATOR SIGNATURE
PCBs below 50 parts per million

Initials: $\mathbb{B}$ (if initialed, no radiological clearance is necessary.)

The above mentioned waste was generated outside of a Controlled Waste Management Area (CWMA) and to the best of my knowledge, does not contain radiological materials.

To the best of my knowledge, the waste described above contains only those materials that are allowed for disposal at this site. I have verified this through the waste characterization method identified above and a review of the above-mentioned prohibited and allowable waste items. I have contacted Property Management and have verified that this materiallequiprnent is approved for disposal in the landfill.

Prini Name: Snruconen Bures isuns

Signature: /s/ Shaughn Burnison

Date. $3 / 16 / 07$

If applicable, place FRn?:0646,

"Radiological Release Stickor" here. Onsite use only.

Note: "Food waste, office trash and animal carcasses do not require a radiological clearance. Freon-containing appliances must have signed removal certification statement with Load Verification"

SWO USE ONLY

Signature of Ceritiefe /s/ Dan Bifkford 


\begin{tabular}{|c|c|c|c|c|}
\hline SWO USE (Select One) & AREA & 23 & 6 & LANDFILL \\
\hline
\end{tabular}

For waste characterization, approval, and/or assistance, contact Solid Waste Operation (SWO) al 5-7898.

\section{REQUIRED: WASTE GERERATOR INFORMATION}

(This form is for rolloffs, dump trucks, and other onsite disposal of materials.)

\begin{tabular}{|c|c|c|c|c|}
\hline \multirow{2}{*}{$\begin{array}{l}\text { Waste Generalor: } \\
\text { Location / Origin: }\end{array}$} & \multicolumn{3}{|c|}{ SHaughen Burnisan } & \multirow{2}{*}{ 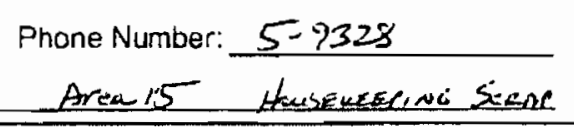 } \\
\hline & CAU 543 (CAS is & $(-03 \cdot 01)$ & OLD Eid Fotrin & \\
\hline \multicolumn{2}{|c|}{ Waste Category: (check ono) } & \multicolumn{2}{|c|}{$\square$ Commercial $\bar{\Sigma}$} & Industrial \\
\hline \multirow{2}{*}{$\begin{array}{l}\text { Waste Type: } \\
\text { (chock one) }\end{array}$} & $\square$ NTS & \multirow{2}{*}{\multicolumn{2}{|c|}{$\begin{array}{l}\square \text { Putrescrible } \\
\square \text { Asbestos Containing Material }\end{array}$}} & \\
\hline & $\square$ Non-Putrescible & & & FFACO-offsite \\
\hline \multicolumn{2}{|c|}{ Pollution Prevention Category: (check one) } & \multicolumn{2}{|c|}{ [Q] Environmental management } & Defense Projects \\
\hline \multicolumn{2}{|c|}{ Pollution Prevention Category: (check one) } & \multicolumn{2}{|c|}{ D Clean-Up } & Rouline \\
\hline \multicolumn{2}{|c|}{ Method of Characterization: (check one) } & Sampling & Analysis & Process Knowiedge $\square$ Contents \\
\hline \multicolumn{4}{|c|}{$\begin{array}{ll}\text { Prohibited Waste at all three } & \text { Radioact } \\
\text { NTS landfills: } & \text { levels, ar }\end{array}$} & $\begin{array}{l}\text { Free liquids, PCBs above TSCA res } \\
\text { clothing). }\end{array}$ \\
\hline
\end{tabular}

Additional Prohibited Waste Sewage Sludge, Animal carcasses, Wet garbage (food waste); and Friable asbestos at the Area 9 U10C Landfill:

\section{REQUIRED: WASTE CONTENTS ALLOWABLE WASTES \\ Check all allowable wastes that are contained within this load:}

NOTE: Waste disposal at the Area 6 Hydrocarbon Landfill mus! have come into contact with petroleum hydrocarbons or coolants, such as: gasoline (no benzene, lead): jet fuel; diesel fuel; lubricants and hydraulics; kerosene; asphaltic petroleum hydrocarbon; and ethylene glycol.
Acceptable waste at any NTS landfill:
$\square$ Paper
$\square$ Rocks / unaltered geologic materials
$\square$ Emply containers
$\square$ Asphalt $\quad \square$ Metal $\square$ Wood
[D Soil
$\square$ Rubber (excluding tires)
$\square$ Plastic 构 Wire
$\square$ Cable
$\square$ Cloth
$\square$ Insulation (non-Asbestosform)
$\square$ Demolition debris

ivianuiaciured items: (swamp coolers, iurniture, rugs, carpet, electronic components, PPE, etc.)

Additional waste accepted at the Area 23 Mercury Landfill: $\square$ Office Waste $\square$ Food Waste $\square$ Animal Carcasses
$\square$ Asbestos
$\square$ Friable
$\square$ Non-Friable (contact SWO if regulated load)
Quantity:

Additional waste accepted at the Arca 9 U10c Landfill: $\square$ Non-friable asbestos $\quad \square$ Drained automobiles and military vehicles
$\square$ Light ballasts (contact SwO) $\square$ Drained fuel filters (gas \& diesel)
$\square$ Hydrocarbons (contact SwO) $\square$ Other

Additional waste accepted at the Area 6 Hydrocarbon Landfill:
$\square$ Septic sludge $\square$ Rags
$\square$ Drained fuel filters (gas \& diesel)
$\square$ Sludge from sand/oil/water separators
$\square$ Plants Soil

Solid fractions from sand/oil/water

$\square$ Deconned Underground and Above Ground Tanks REQUIRED: WASTE GENERATOR SIGNATURE

lnitials: $S \mathcal{B}$ (if initialed, no radiological clearance is necessary.)

The above mentioned waste was generated outside of a Controlled Waste Management Area (CWMA) and to the best of my knowledge, does not contain radiological materials.

To the best of my knowledge, the waste described above contains only those materials that are allowed for disposal at this site. 1 have verified this through the waste characterization method identified above and a review of the above-mentioned prohibited and allowable waste items. I have contacted Property Management and have verified that this materiallequipment is approved for disposal in the landfill.

Print Name: Strnuchtä BuRNisoni

Signalure: _/s/. Shaughn Burnison Date: $8 / 1 / 2$

If applicablc, place FRM-0646, "Radiological Release Sticker" here. Onsite use only.

Nole: "Food waste, office trash and animal carcasses do not require a radiological clearance. Freon-containing appliances must have signed removal certification statement wilh Load Verification."

SWO USE ONLY

Load Weight (net from scale or estimate): $\ddot{b}-16 \cdot e^{27}$ Signature of Cerlifier: /s/ Don Bickford 
Closure Report - CAU 543

Section: Appendix C

Revision: 0

Datc: Janualy 2008

THIS PAGE INTENTIONALLY LEFT BLANK 
Closure Report - CAU 543

Section: Appendix D

Revision: 0

Date: January 2008

\section{APPENDIX D}

\section{SITE CLOSURE PHOTOGRAPHS}


Closure Report - CAU 543

Section: Appendix D

Revision: 0

Date: January 2008

THIS PAGE INTENTIONALLY LEFT BLANK 
PHOTOGRAPH LOG

\begin{tabular}{|c|c|c|c|c|}
\hline CAS & $\begin{array}{c}\text { Photo } \\
\text { Number }\end{array}$ & Date & Perspective & Description \\
\hline \multirow{19}{*}{ 06-07-01 } & 1 & $8 / 27 / 2007$ & to northwest & Septic tank 6-605 during excavation \\
\hline & 2 & 9/5/2007 & to northeast & Septic tank 6-605 excavation after tank removal \\
\hline & 3 & $10 / 10 / 2007$ & to northeast & Septic tank 6-605 excavation, backfilled \\
\hline & 4 & $10 / 25 / 2004$ & to north & Septic tank 6-607 before closure activities \\
\hline & 5 & 9/26/2007 & to northwest & Septic tank 6-607 excavation after tank removal \\
\hline & 6 & 10/10/2007 & to north & Septic tank 6-607 excavation, backfilled \\
\hline & 7 & 9/5/2007 & to east & Sump excavation, after sumps have been removed \\
\hline & 8 & 10/10/2007 & to northeast & Sump excavation, backfilled \\
\hline & 9 & $10 / 25 / 2004$ & to north & Debris and cleanouts, before closure activities \\
\hline & 10 & $9 / 24 / 2007$ & to northwest & Cleanout, grouted \\
\hline & 11 & $11 / 22 / 2006$ & to northeast & $\begin{array}{l}\text { Building 6-605 concrete pad, diversion box, trenches covered } \\
\text { with plywood, before closure activities }\end{array}$ \\
\hline & 12 & 9/24/2007 & to southeast & Building 6-605 diversion box, grouted \\
\hline & 13 & 9/24/2007 & to northwest & Building 6-605 floor drain trenches, trenches grouted \\
\hline & 14 & $9 / 26 / 2007$ & to southwest & $\begin{array}{l}\text { Building 6-605 Use Restriction (UR) and polychlorinated } \\
\text { biphenyl (PCB) signs }\end{array}$ \\
\hline & 15 & 9/26/2007 & to northwest & Building 6-605 Fencing and UR sign \\
\hline & 16 & 9/5/2007 & to south & Moving mixed waste into hazardous waste accumulation area \\
\hline & 17 & $11 / 22 / 2006$ & to north & Debris, luggers and drums, before closure activities \\
\hline & 18 & $11 / 22 / 2006$ & to south & Debris, luggers and drums, before closure activities \\
\hline & 19 & 9/26/2007 & to east & Lugger and drum debris area, after closure activities \\
\hline \multirow{13}{*}{$15-01-03$} & 20 & $1 / 31 / 2007$ & to southwest & $\begin{array}{l}\text { Aboveground Storage Tank (AST), showing piping coming in } \\
\text { from right (north) and going to fill stand (to east) }\end{array}$ \\
\hline & 21 & $1 / 31 / 2007$ & to southeast & Fill stand and associated piping to AST \\
\hline & 22 & $8 / 14 / 2007$ & to southeast & AST scaffolding, checking tank contents \\
\hline & 23 & $9 / 20 / 2007$ & to east & Rigging AST for removal \\
\hline & 24 & 9/20/2007 & to southeast & Placing AST on flatbed trailer \\
\hline & 25 & 9/20/2007 & to south & AST on flatbed trailer, prepared to transport \\
\hline & 26 & 9/20/2007 & to south & AST depression after AST has been removed \\
\hline & 27 & $1 / 31 / 2007$ & to southwest & Distribution box, before closure activities \\
\hline & 28 & $8 / 14 / 2007$ & to west & Distribution box excavation, after box removal \\
\hline & 29 & $10 / 2 / 2007$ & to northwest & Distribution box excavation, backfilled \\
\hline & 30 & 9/20/2007 & to southeast & $\begin{array}{l}\text { Distribution box low-level waste (LLW) being prepared for } \\
\text { lifting }\end{array}$ \\
\hline & 31 & $9 / 20 / 2007$ & to southeast & Distribution box LLW loading onto transportation vehicle \\
\hline & 32 & $1 / 31 / 2007$ & to west & Building 15-06 pad, before closure activities \\
\hline
\end{tabular}




\section{PHOTOGRAPH LOG}

\begin{tabular}{|c|c|c|c|c|}
\hline CAS & $\begin{array}{c}\text { Photo } \\
\text { Number }\end{array}$ & Date & Perspective & Description \\
\hline \multirow{8}{*}{$15-01-03$} & 33 & $1 / 31 / 2007$ & to southwest & $\begin{array}{l}\text { Building } 15-06 \text { floor drain trenches, with wood debris, before } \\
\text { closure activities }\end{array}$ \\
\hline & 34 & 9/20/2007 & to northwest & Building 15-06 pad with floor drain trenches grouted \\
\hline & 35 & $10 / 1 / 2007$ & to southeast & Building 15-06 UR and PCB signs on UR fencing \\
\hline & 36 & $10 / 1 / 2007$ & to south & $\begin{array}{l}\text { UR, PCB, and URMA [Underground Radioactive Material } \\
\text { Area] signs posted over underground piping }\end{array}$ \\
\hline & 37 & $12 / 8 / 2004$ & to east & $\begin{array}{l}\text { Piping debris northeast of CAS 15-01-03 Building 15-06 pad, } \\
\text { before closure activities }\end{array}$ \\
\hline & 38 & $10 / 1 / 2007$ & to northeast & $\begin{array}{l}\text { Piping debris area northeast of CAS 15-01-03 Building 15-06 } \\
\text { pad, after closure activities }\end{array}$ \\
\hline & 39 & $4 / 3 / 2007$ & to southeast & $\begin{array}{l}\text { Asphalt debris north of CAS 15-01-03 Building 15-06 pad, } \\
\text { before closure activities }\end{array}$ \\
\hline & 40 & 9/20/2007 & to west & $\begin{array}{l}\text { Asphalt debris area north of CAS 15-01-03 Building 15-06 } \\
\text { pad, after closure activities }\end{array}$ \\
\hline \multirow{2}{*}{$15-04-01$} & 41 & $4 / 9 / 2007$ & to northeast & Septic tank, exposed during closure activities \\
\hline & 42 & $4 / 9 / 2007$ & to north & Septic tank, excavated \\
\hline $\begin{array}{c}15-04-01 \\
\text { and } \\
15-05-01\end{array}$ & 43 & $10 / 1 / 2007$ & to southeast & Septic tank and distribution box excavations, backfilled \\
\hline \multirow[t]{2}{*}{$15-08-01$} & 44 & $1 / 31 / 2007$ & to south & $\begin{array}{l}\text { Liquid manure tank top, including debris, before closure } \\
\text { activities }\end{array}$ \\
\hline & 45 & $10 / 2 / 2007$ & to east & Liquid manure tank excavation, backfilled \\
\hline \multirow{2}{*}{$15-23-01$} & 46 & $1 / 31 / 2007$ & to west & Steel planking and other debris, before closure activities \\
\hline & 47 & $10 / 1 / 2007$ & to northeast & CAS 15-23-01 after debris removal \\
\hline \multirow{6}{*}{$15-23-03$} & 48 & $1 / 31 / 2007$ & to southwest & Sump, before closure activities \\
\hline & 49 & $4 / 3 / 2007$ & $\begin{array}{c}\text { to south- } \\
\text { southwest }\end{array}$ & $\begin{array}{l}\text { Sump, partially filled, with concrete perimeter partially } \\
\text { exposed }\end{array}$ \\
\hline & 50 & 9/20/2007 & $\begin{array}{l}\text { to south- } \\
\text { southwest }\end{array}$ & Sump, final backfilled area \\
\hline & 51 & $10 / 2 / 2007$ & to south & UR signs posted around perimeter of sump \\
\hline & 52 & $1 / 31 / 2007$ & $\begin{array}{l}\text { to south- } \\
\text { southwest }\end{array}$ & Cabinet debris, before closure activities \\
\hline & 53 & $10 / 2 / 2007$ & to southwest & Debris area, after closure activities \\
\hline
\end{tabular}




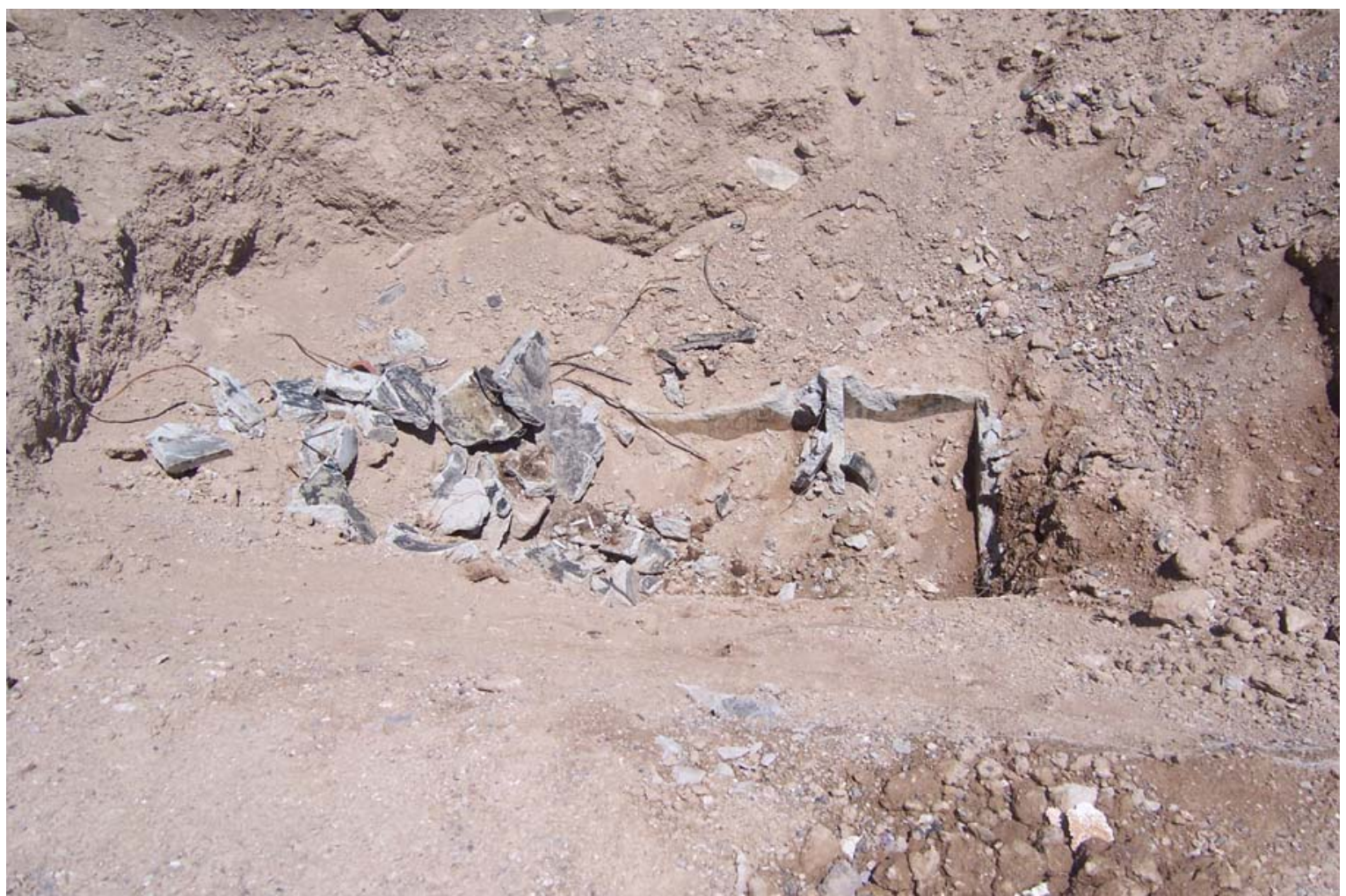

Photograph 1. CAS 06-07-01, Septic tank 6-605 during excavation

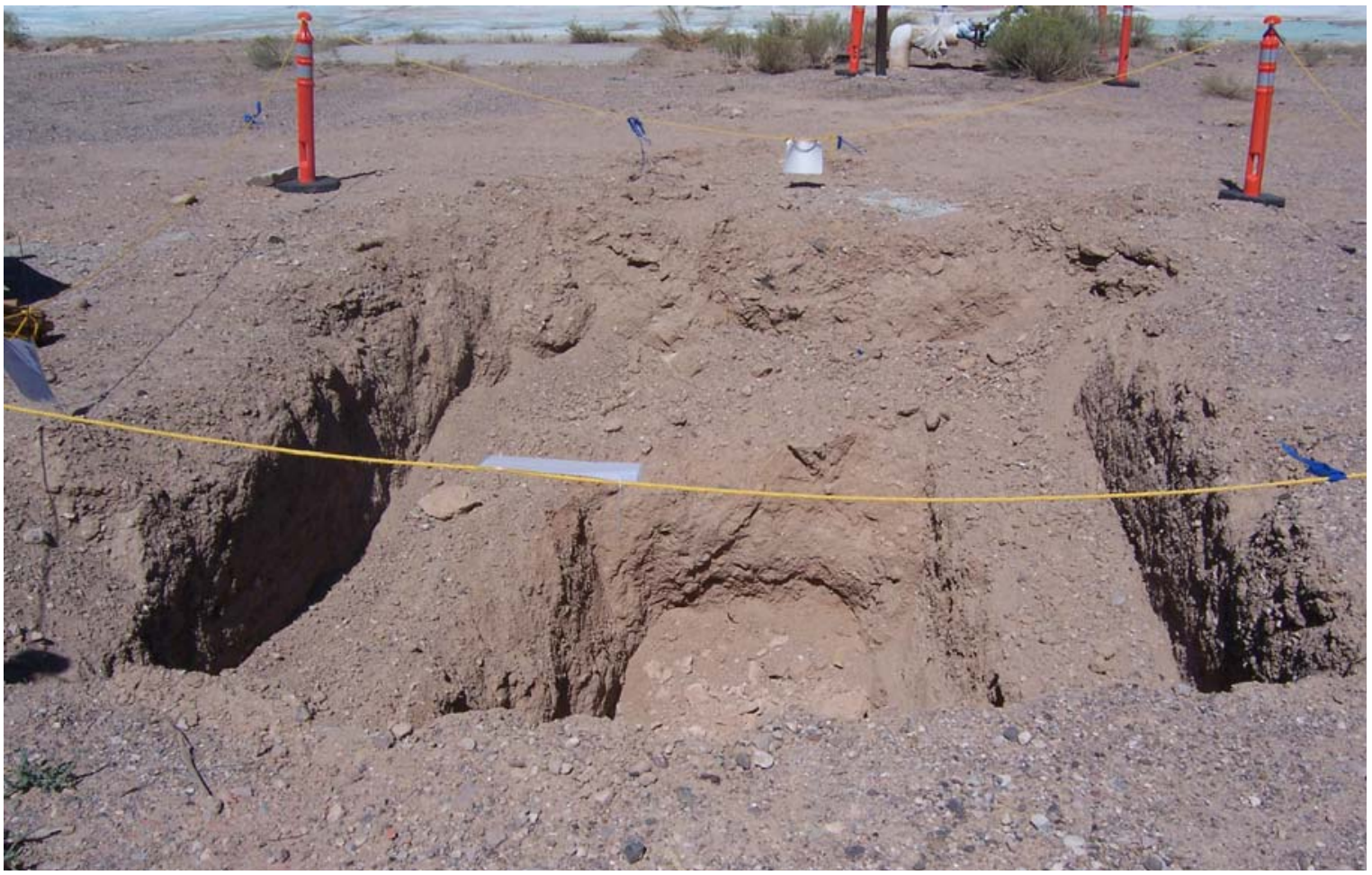

Photograph 2. CAS 06-07-01, Septic tank 6-605 excavation after tank removal 


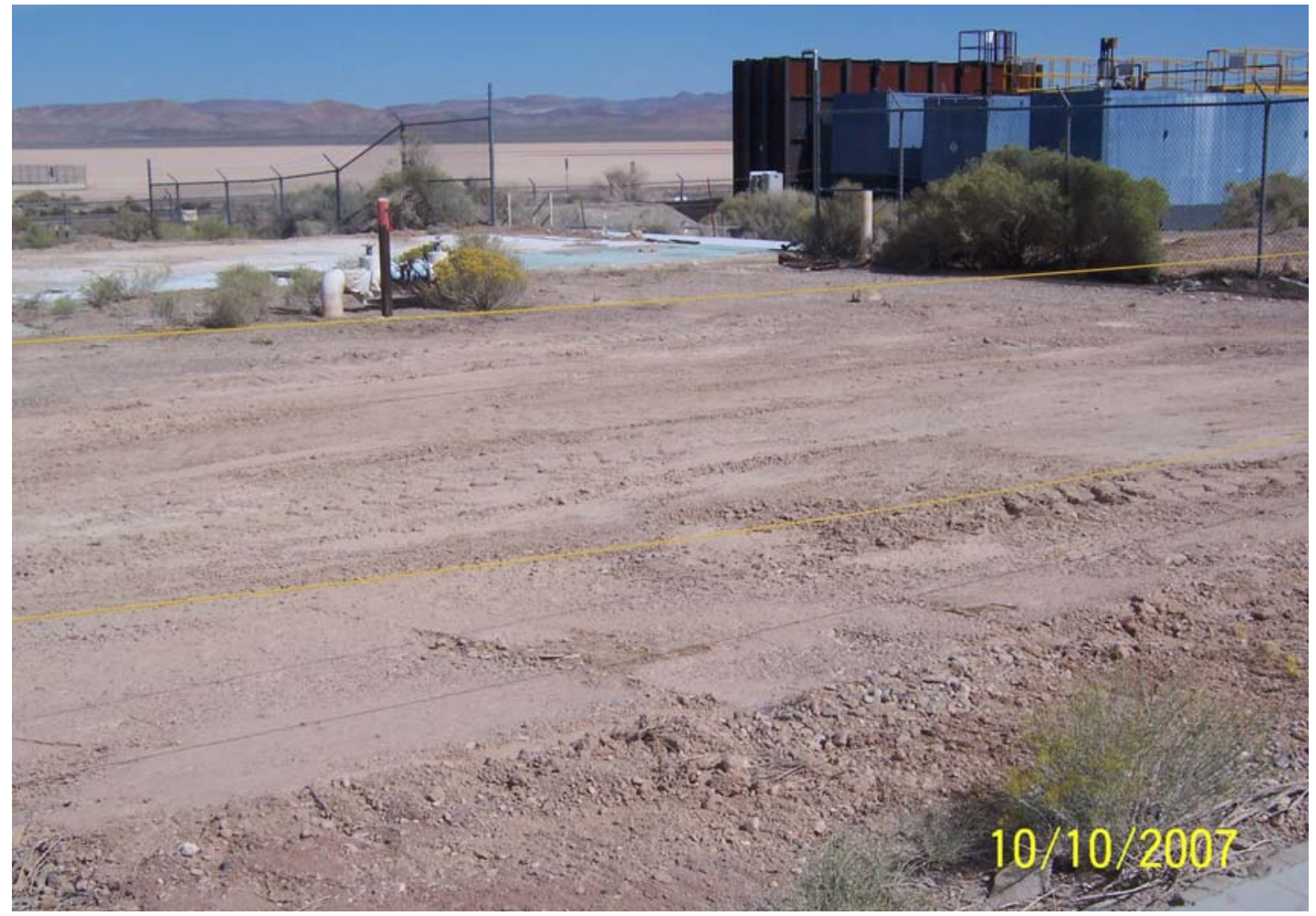

Photograph 3. CAS 06-07-01, Septic tank 6-605 excavation, backfilled

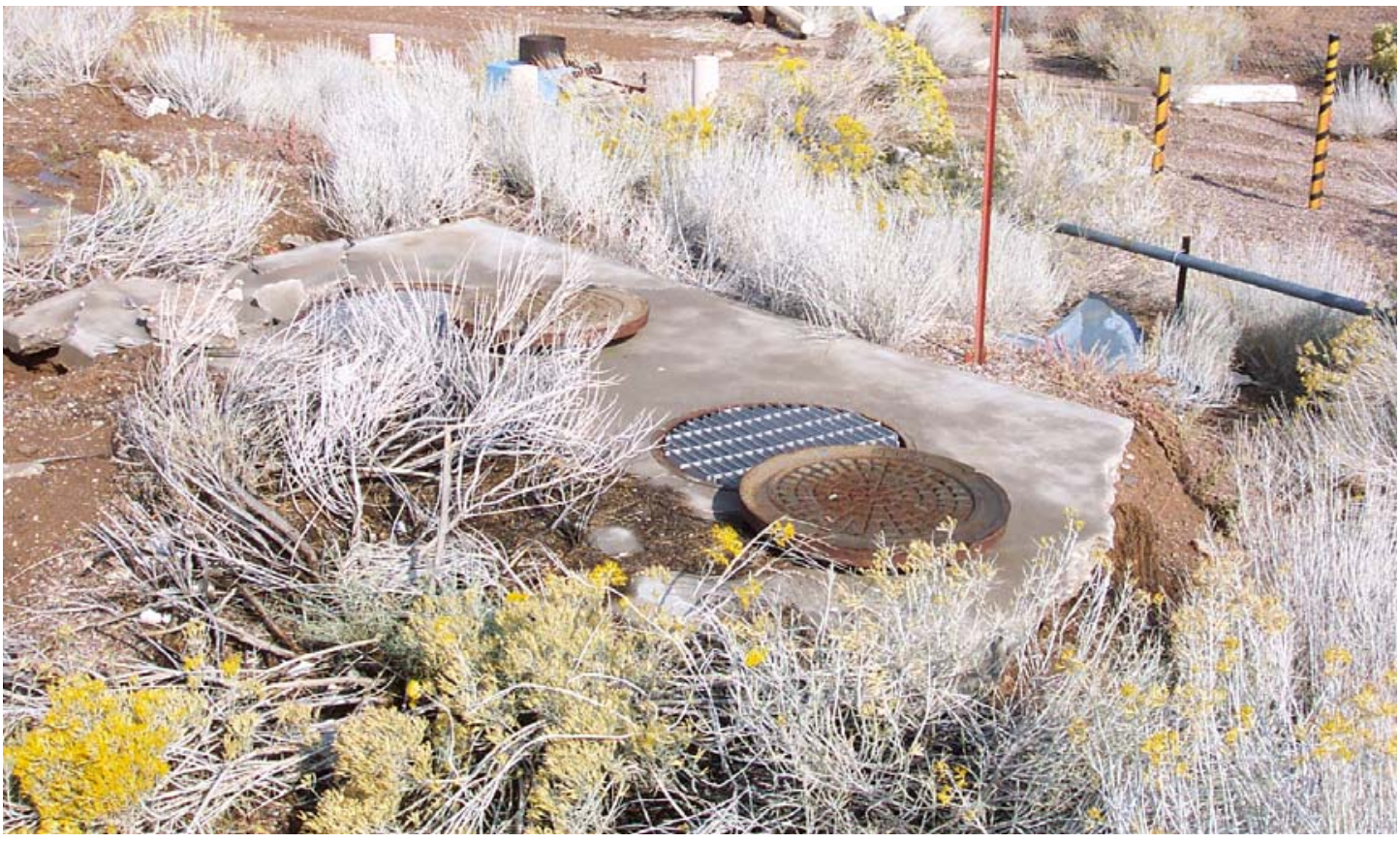

Photograph 4.: CAS 06-07-01, Septic tank 6-607 before closure activities 


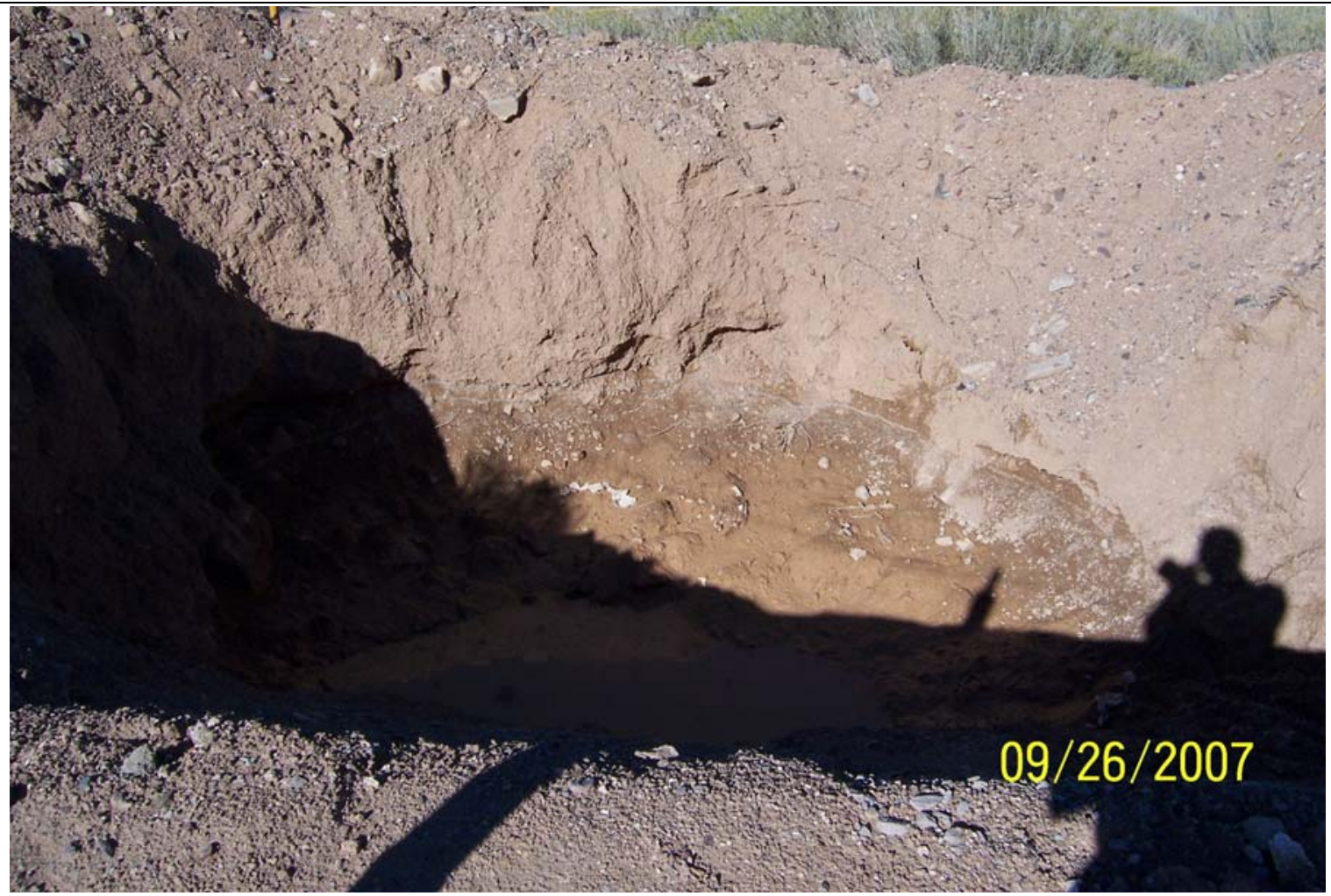

Photograph 5. CAS 06-07-01, Septic tank 6-607 excavation after tank removal

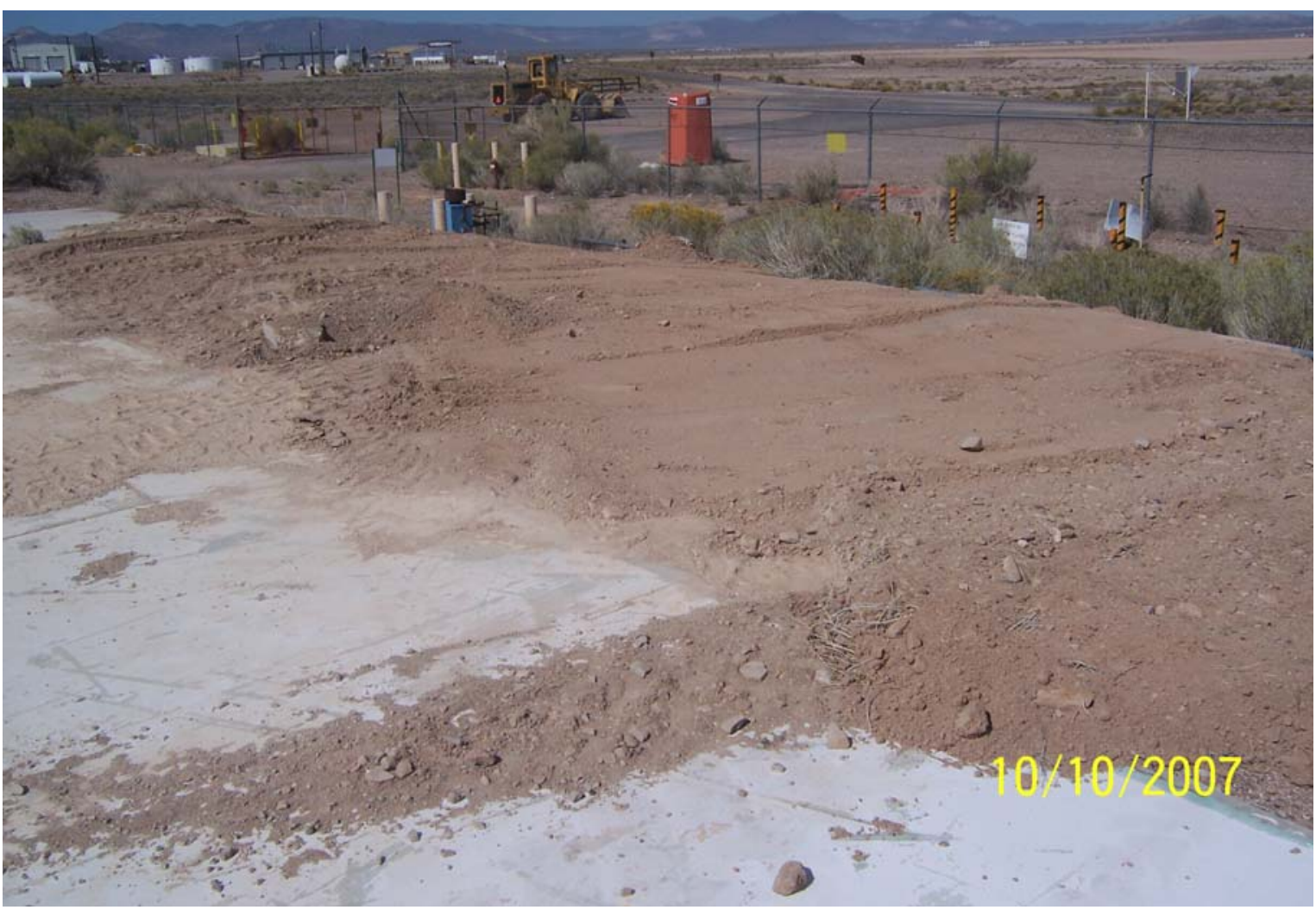

Photograph 6. CAS 06-07-01, Septic tank 6-607 excavation, backfilled 


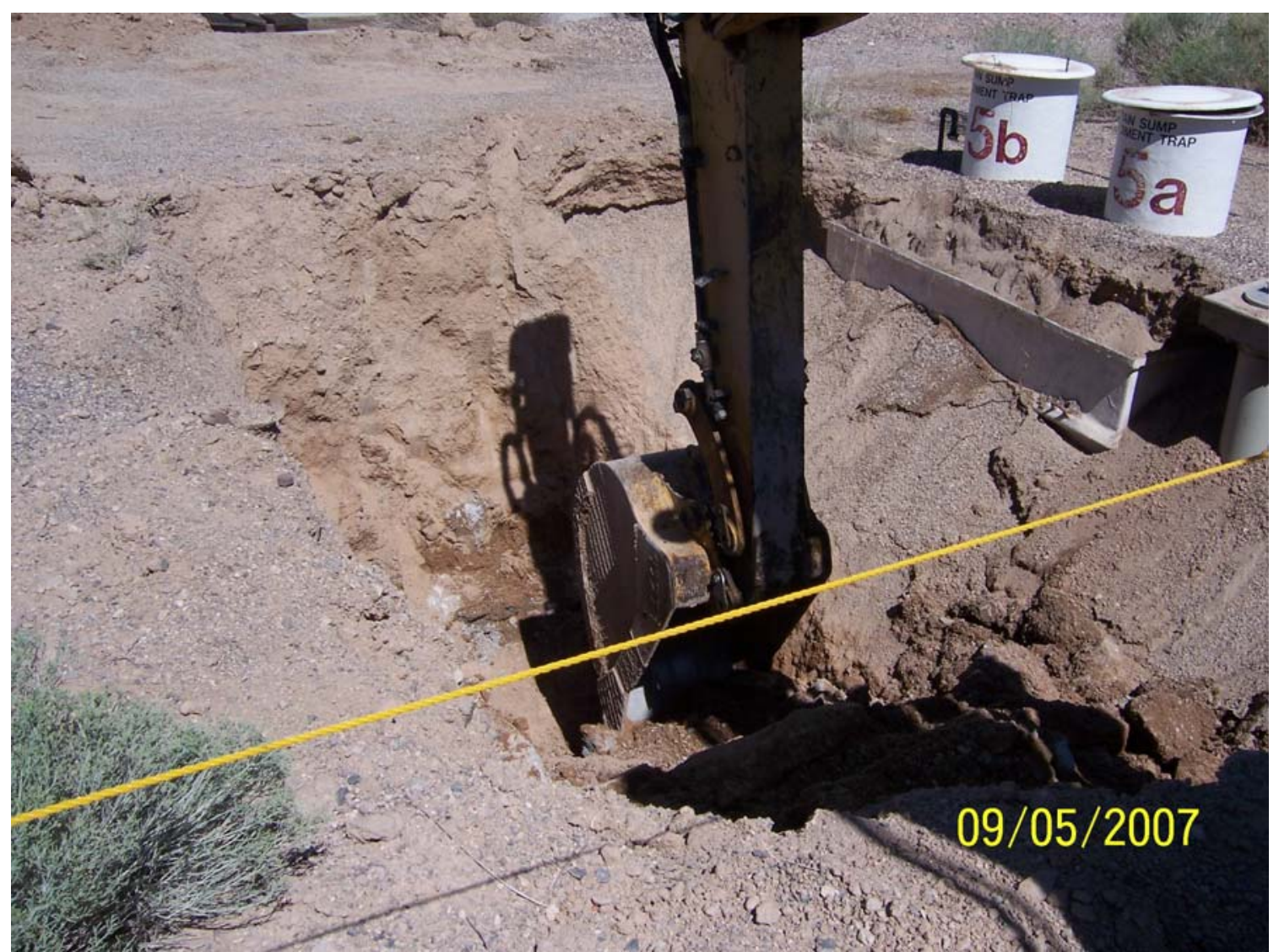

Photograph 7. CAS 06-07-01, Sump excavation, after sumps have been removed

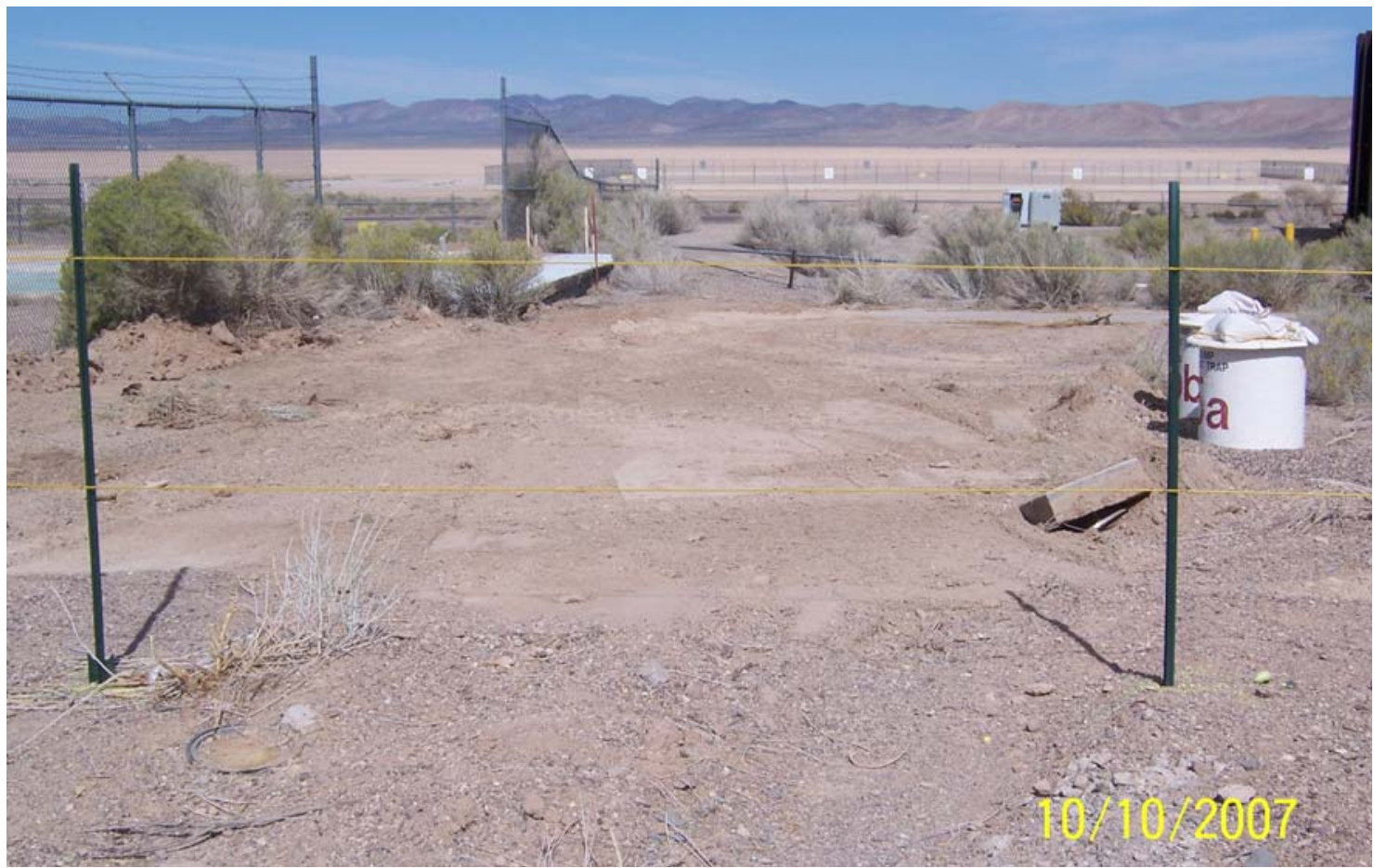

Photograph 8. CAS 06-07-01, Sump excavation, backfilled 


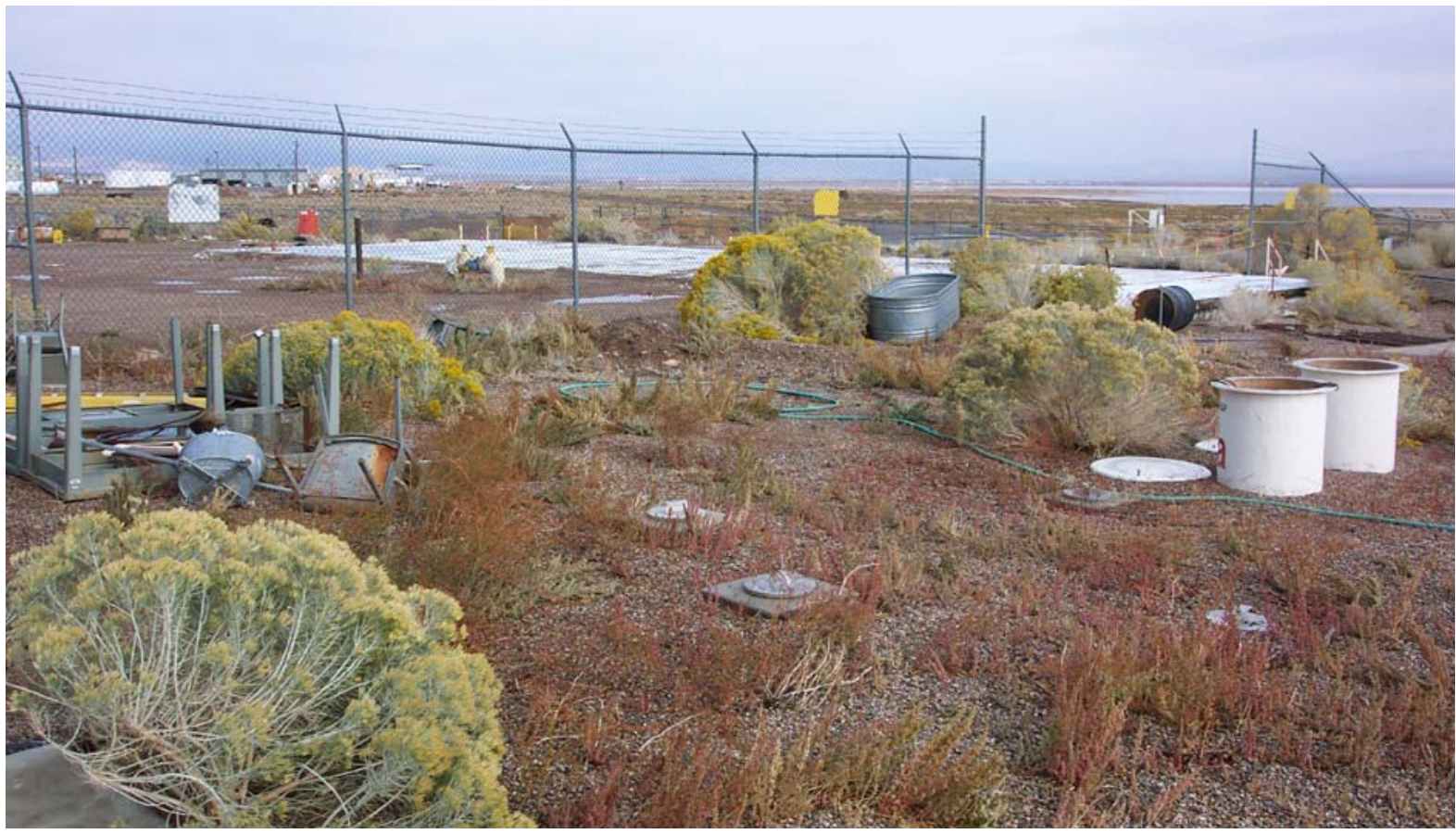

Photograph 9. CAS 06-07-01, Debris and cleanouts, before closure activities

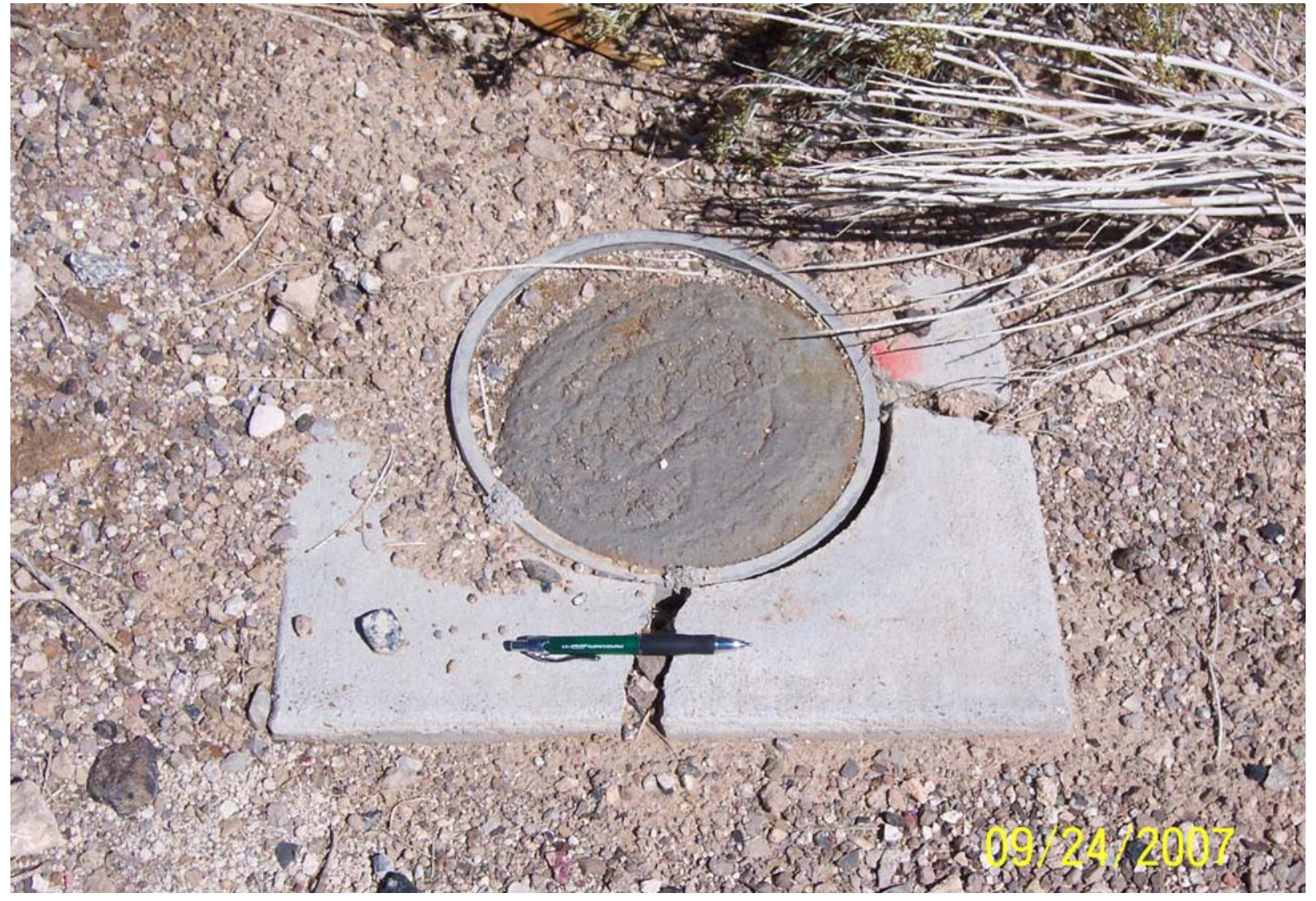

Photograph 10. CAS 06-07-01, Cleanout, grouted 


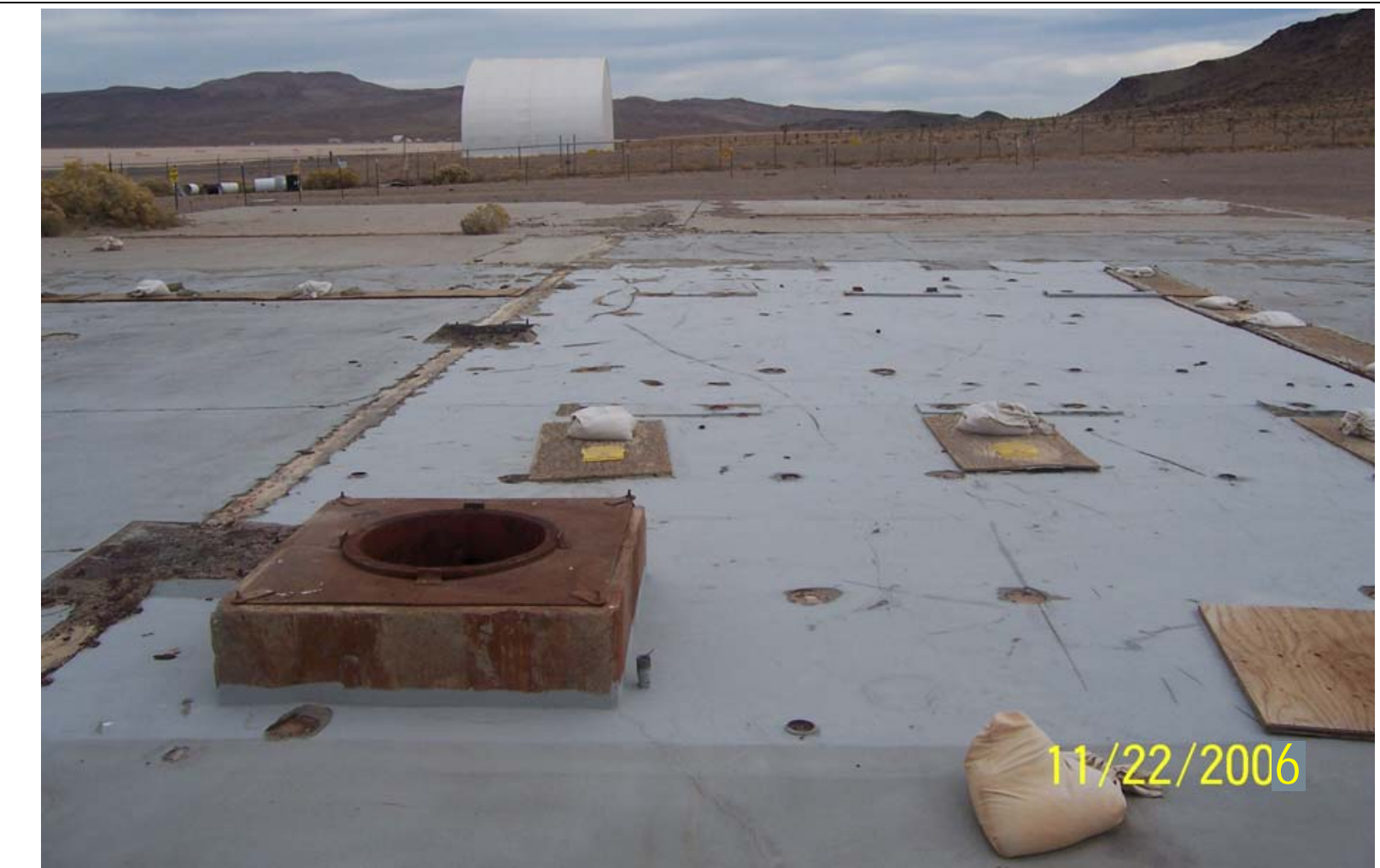

Photograph 11. CAS 06-07-01, Building 6-605 concrete pad, diversion box, trenches covered with plywood, before closure activities

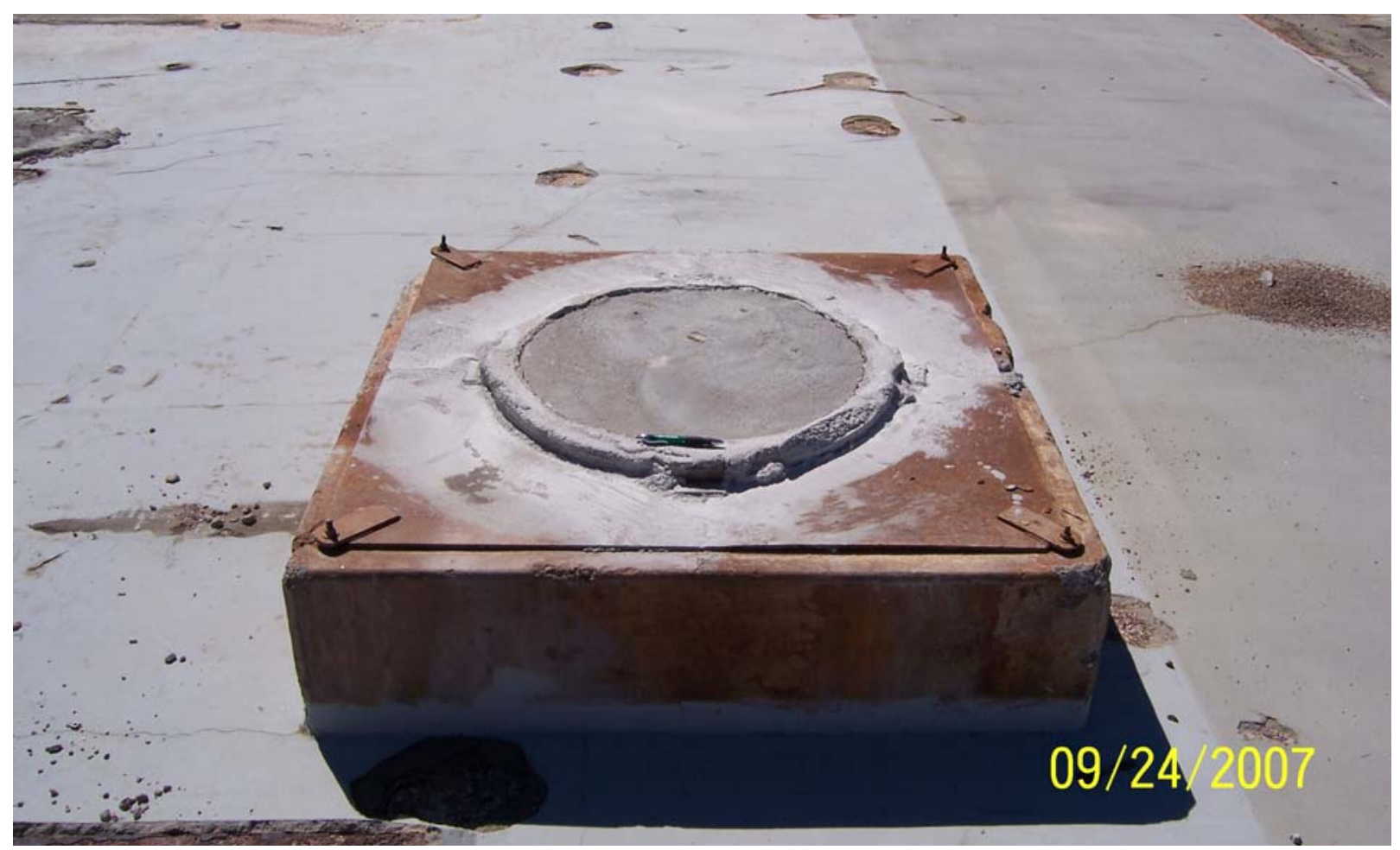

Photograph 12. CAS 06-07-01, Building 6-605 diversion box, grouted 


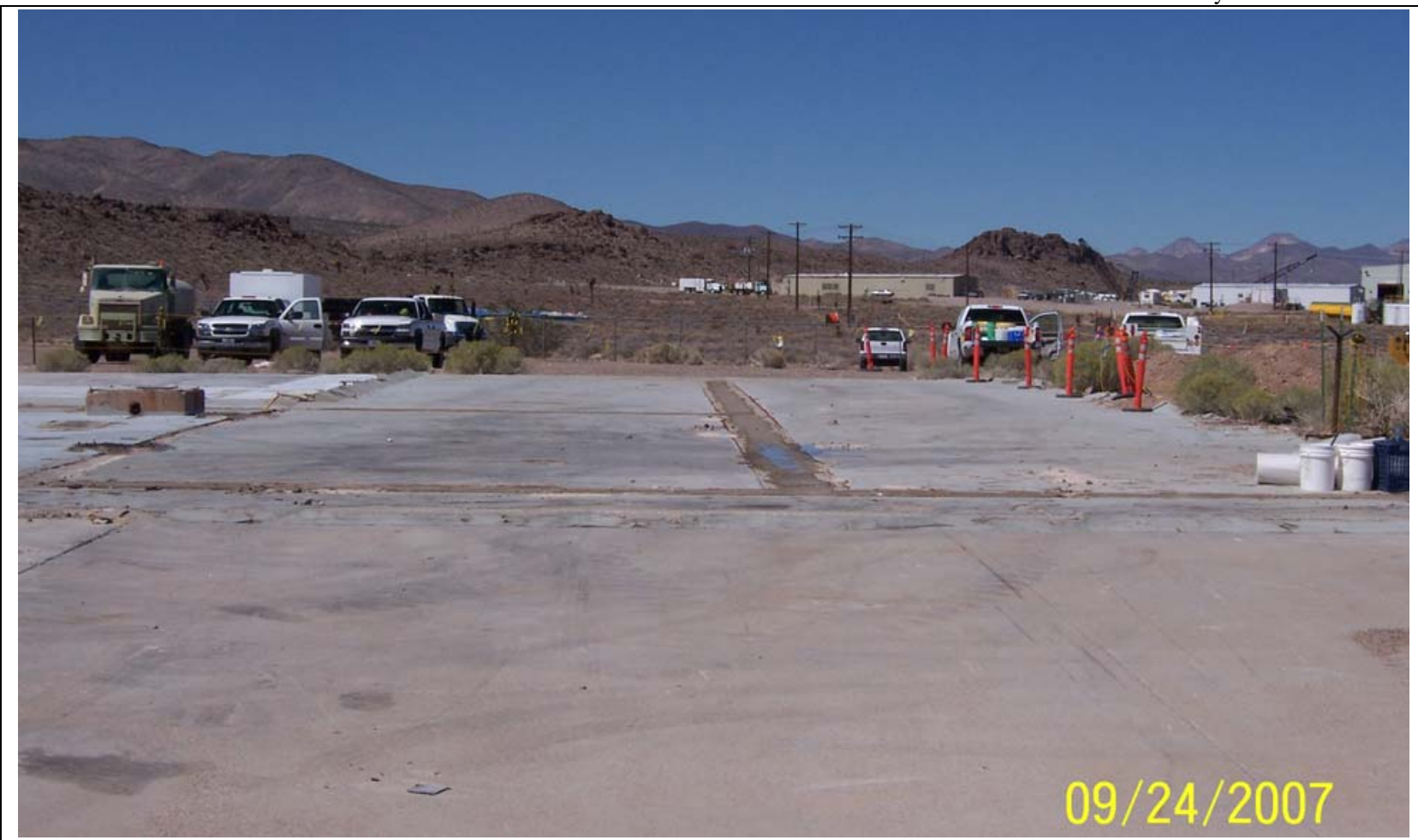

Photograph 13. CAS 06-07-01, Building 6-605 floor drain trenches, trenches grouted

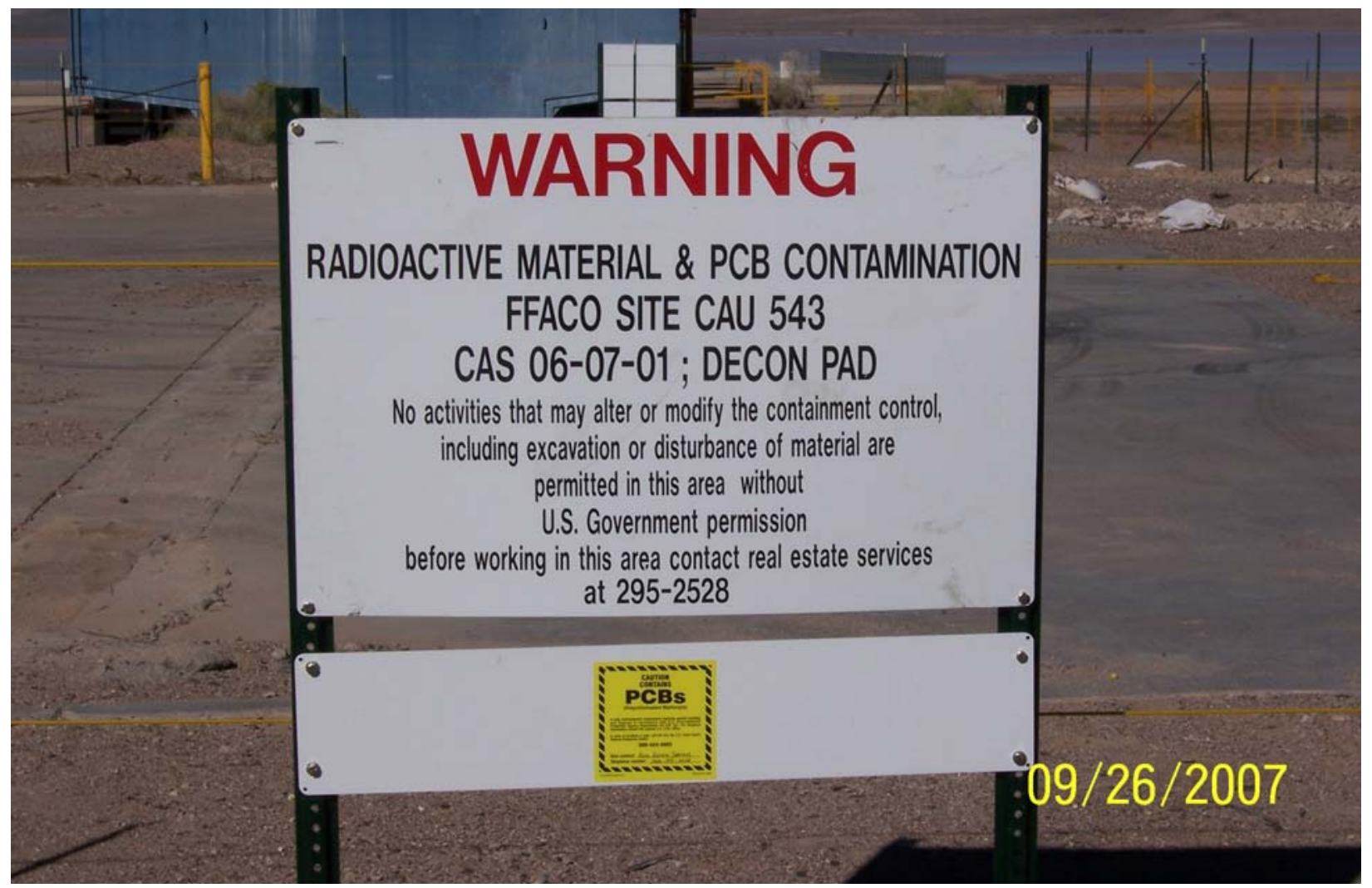

Photograph 14. CAS 06-07-01, Building 6-605 use restriction (UR) and polychlorinated biphenyl (PCB) signs 


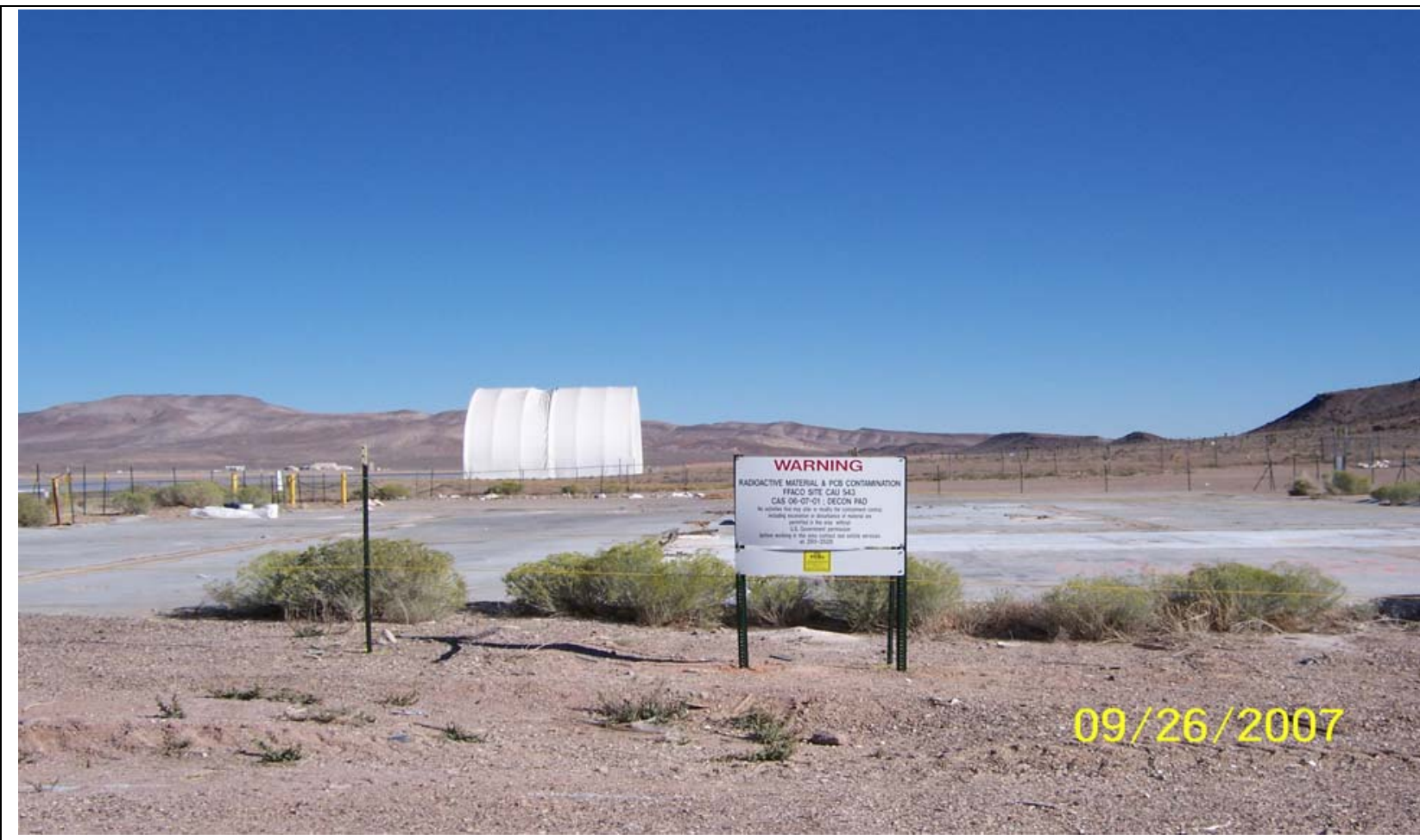

Photograph 15. CAS 06-07-01, Building 6-605 Fencing and UR sign

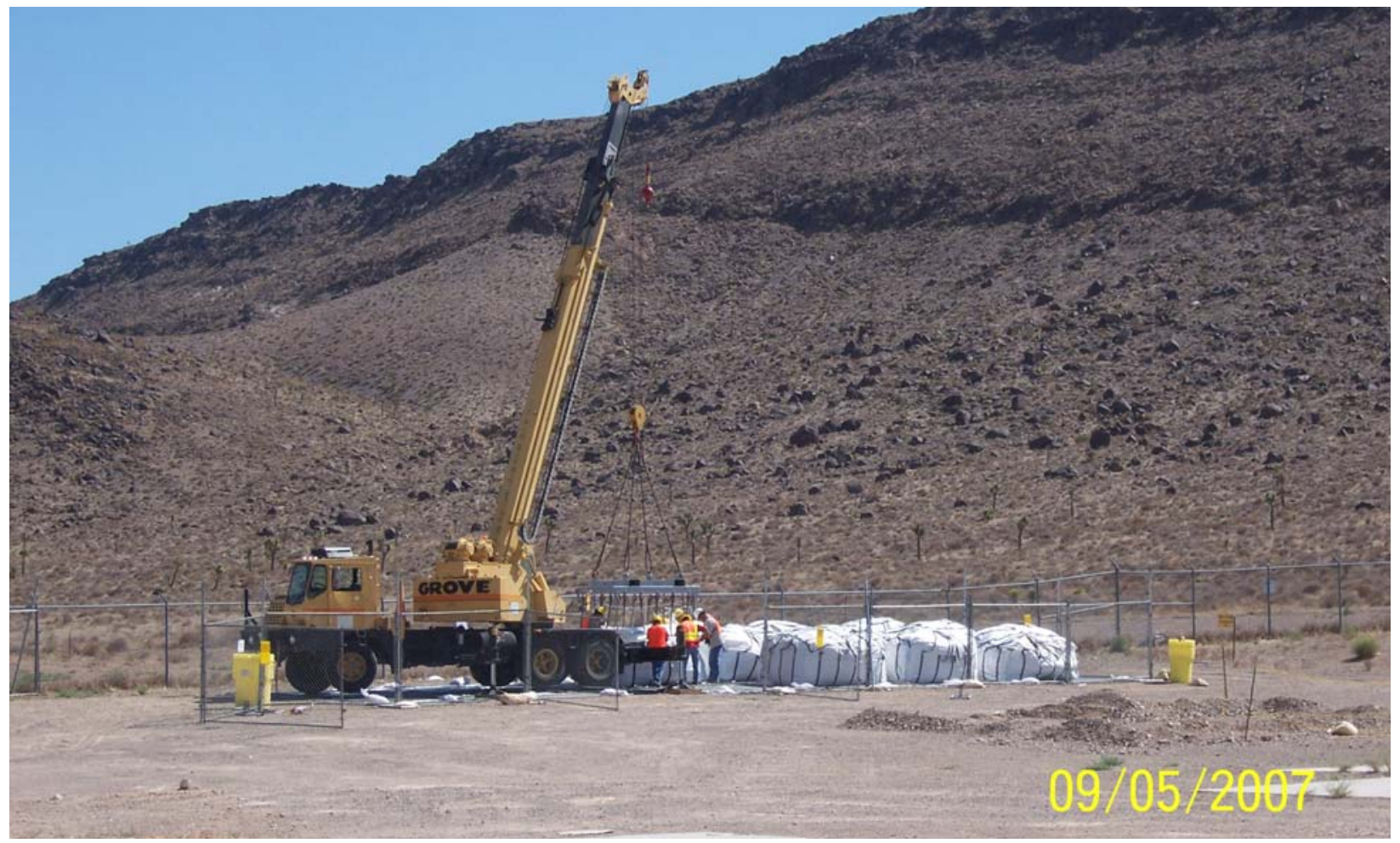

Photograph 16. CAS 06-07-01, Moving mixed waste into hazardous waste accumulation area 


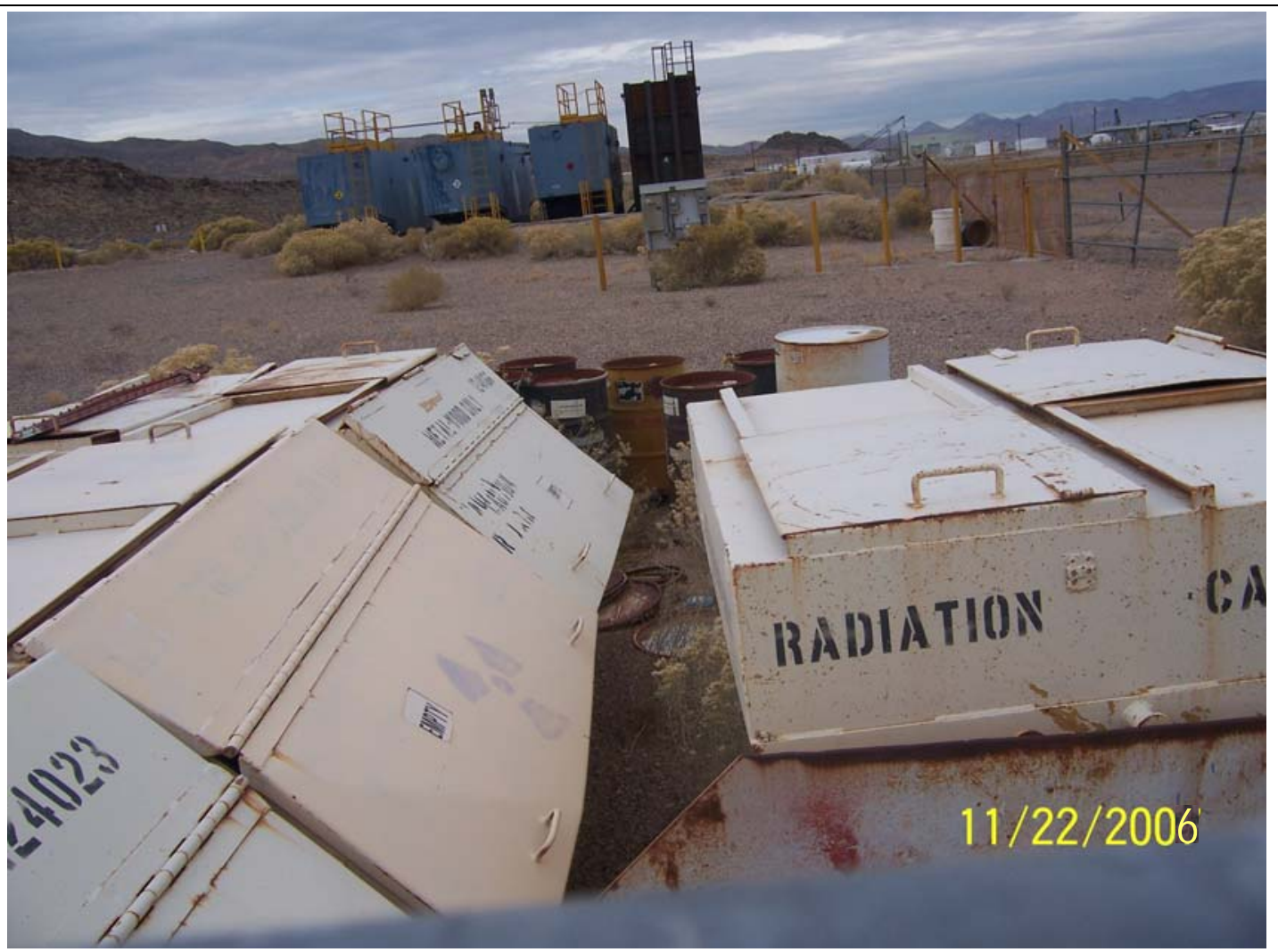

Photograph 17. CAS 06-07-01, Debris, luggers and drums, before closure activities

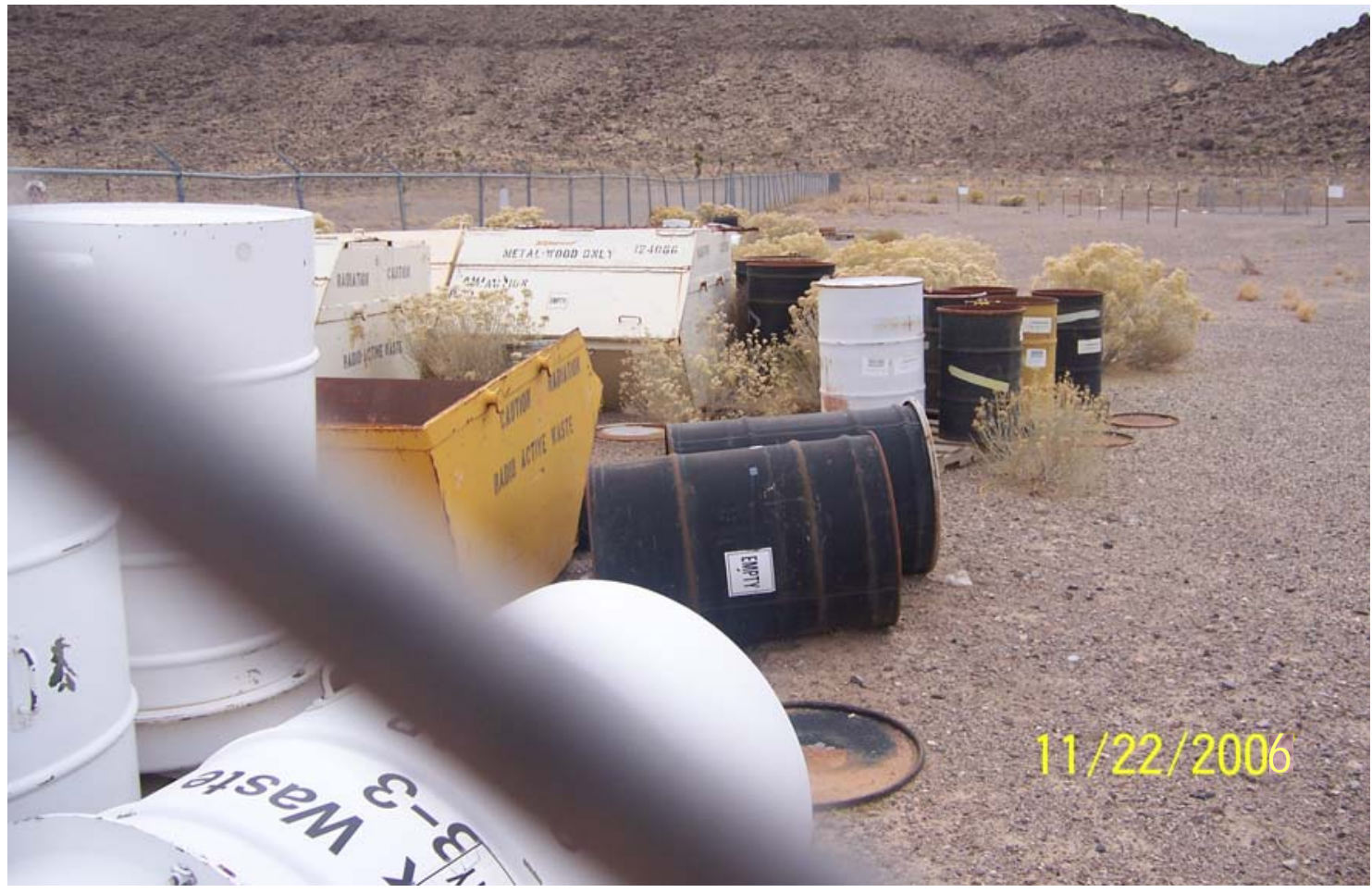

Photograph 18. CAS 06-07-01, Debris, luggers and drums, before closure activities 


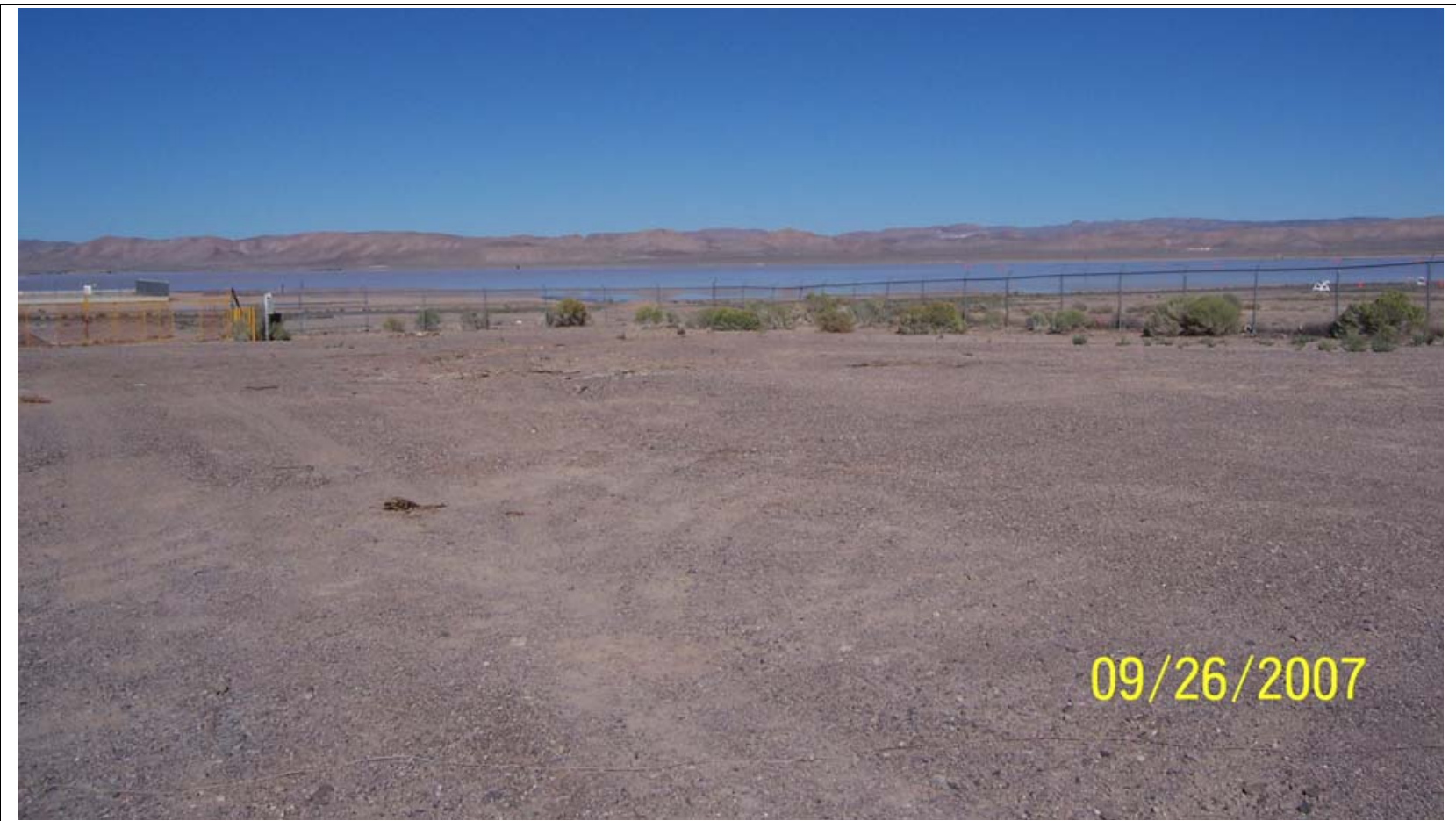

Photograph 19. CAS 06-07-01, Lugger and drum debris area, after closure activities

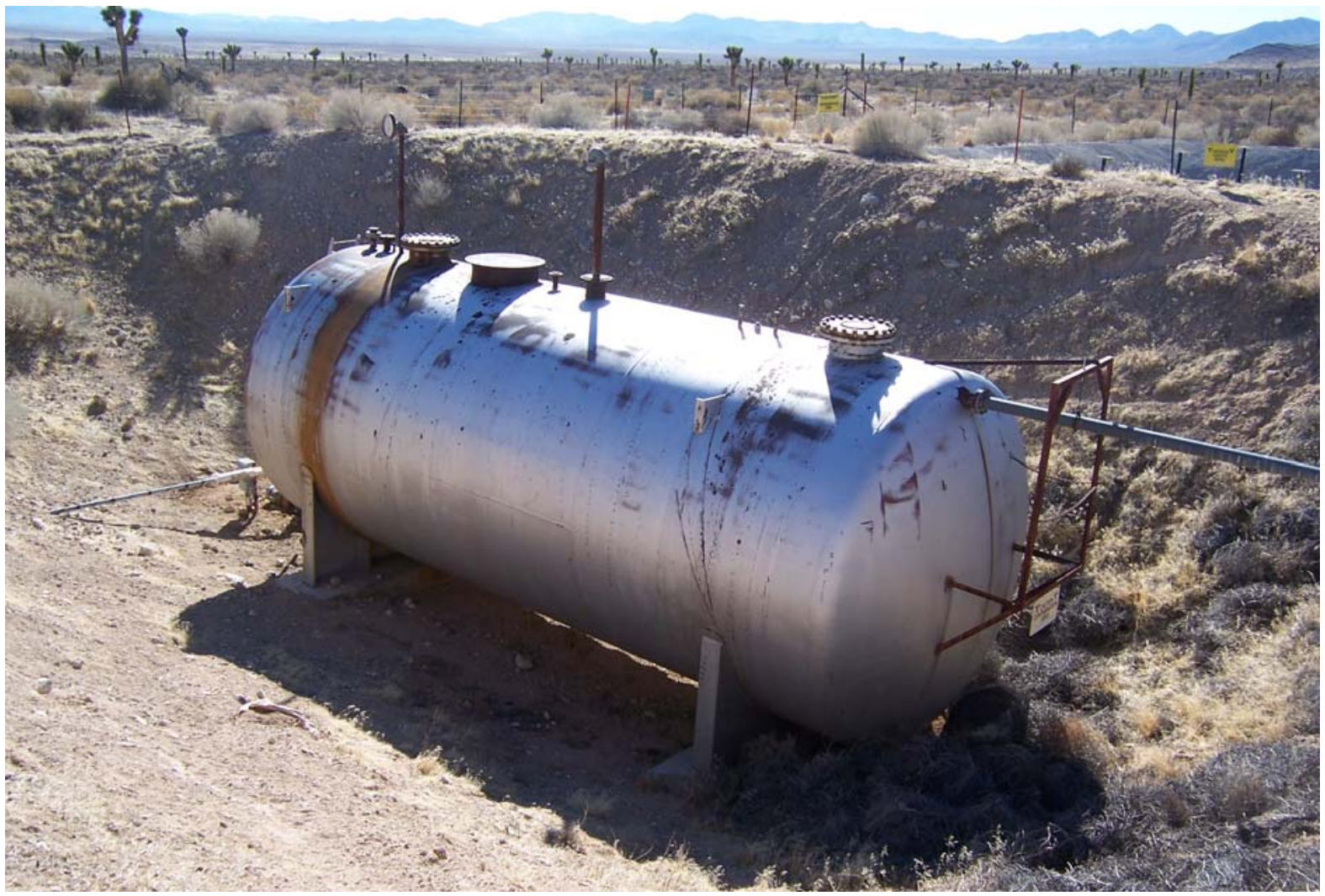

Photograph 20. CAS 15-01-03, Aboveground Storage Tank (AST), showing piping coming in from right (north) and going to fill stand (to east) 


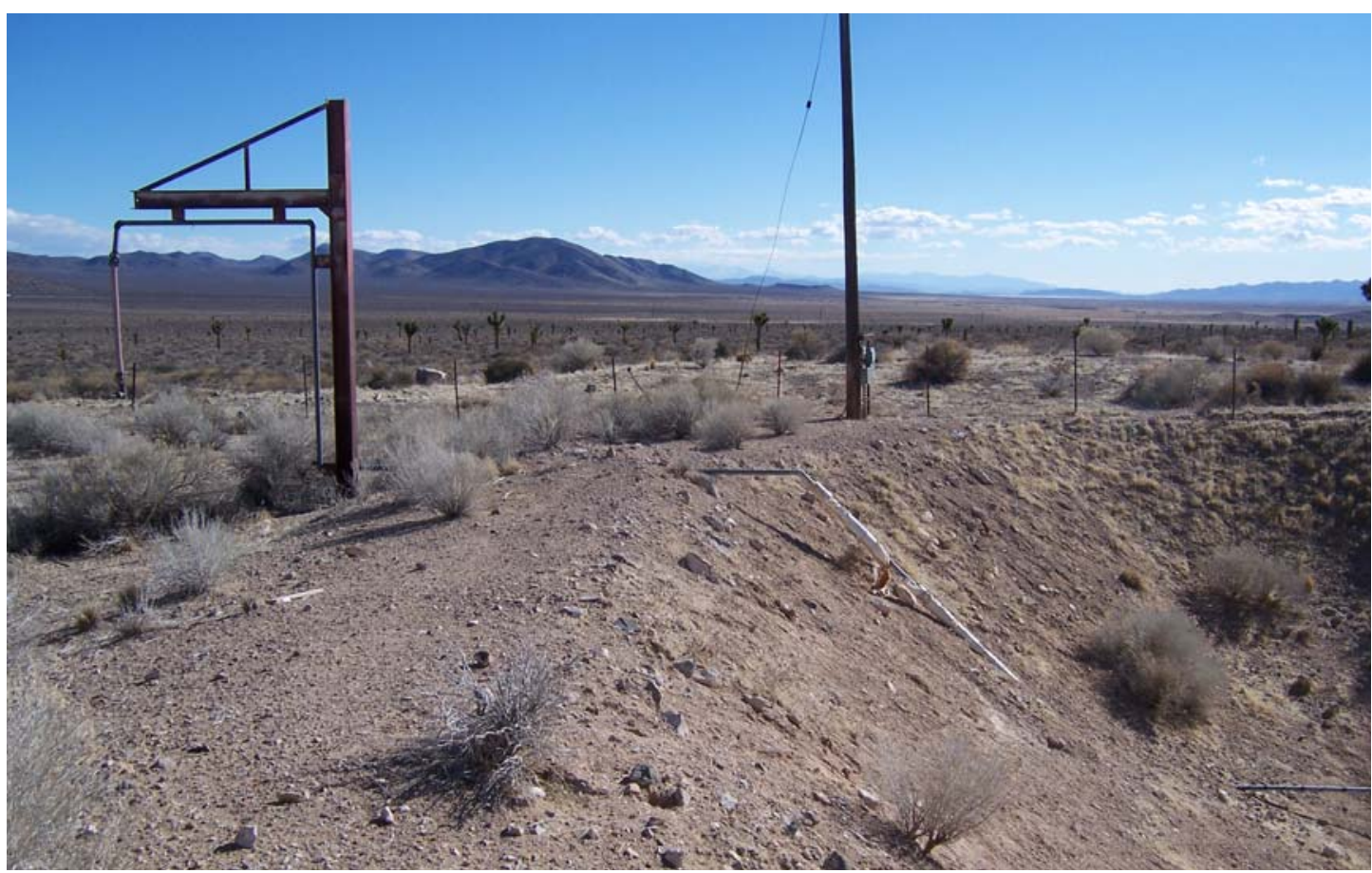

Photograph 21. CAS 15-01-03, Fill stand and associated piping to AST

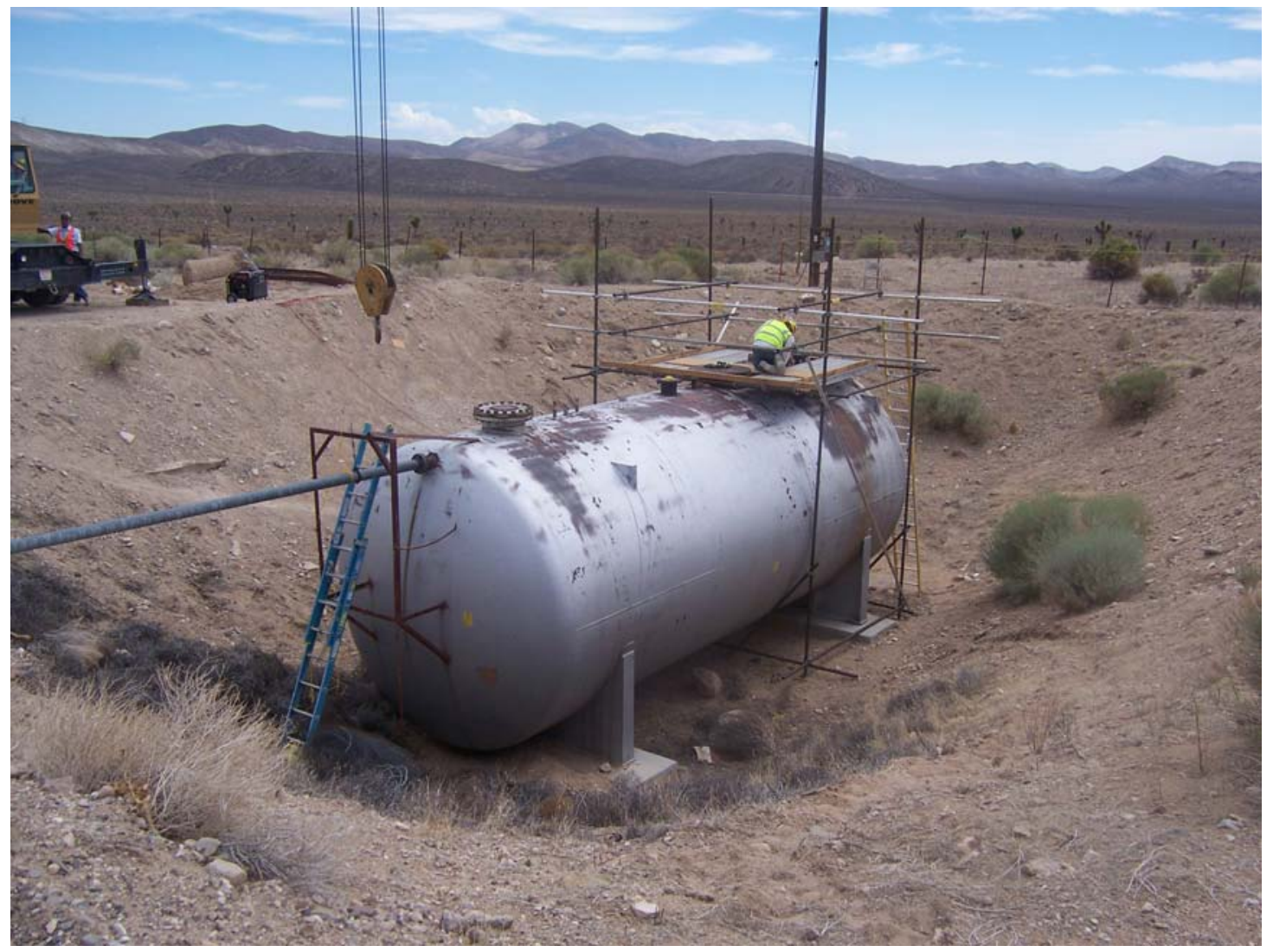

Photograph 22. CAS 15-01-03, AST scaffolding, checking tank contents 


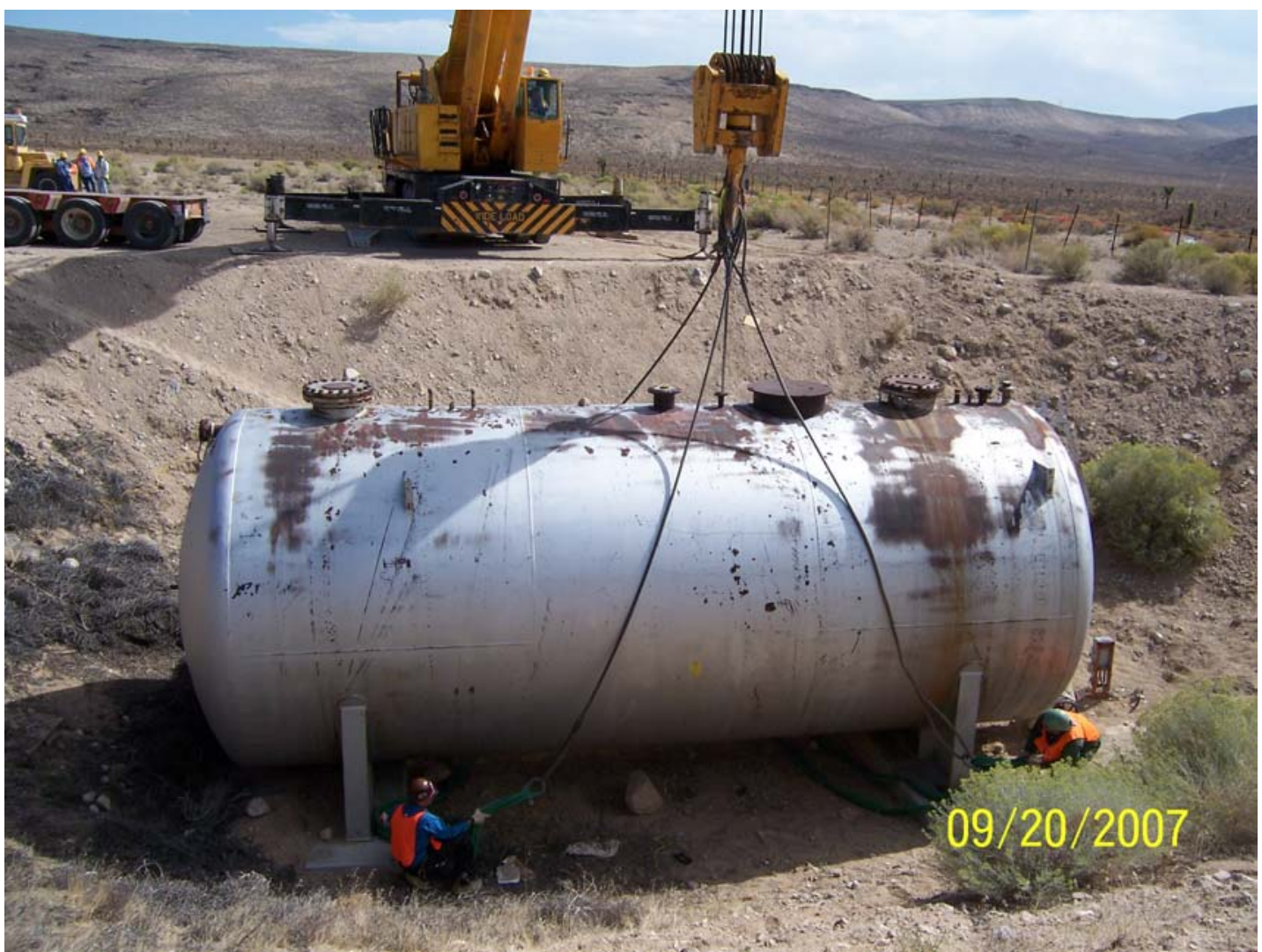

Photograph 23. CAS 15-01-03, Rigging AST for removal

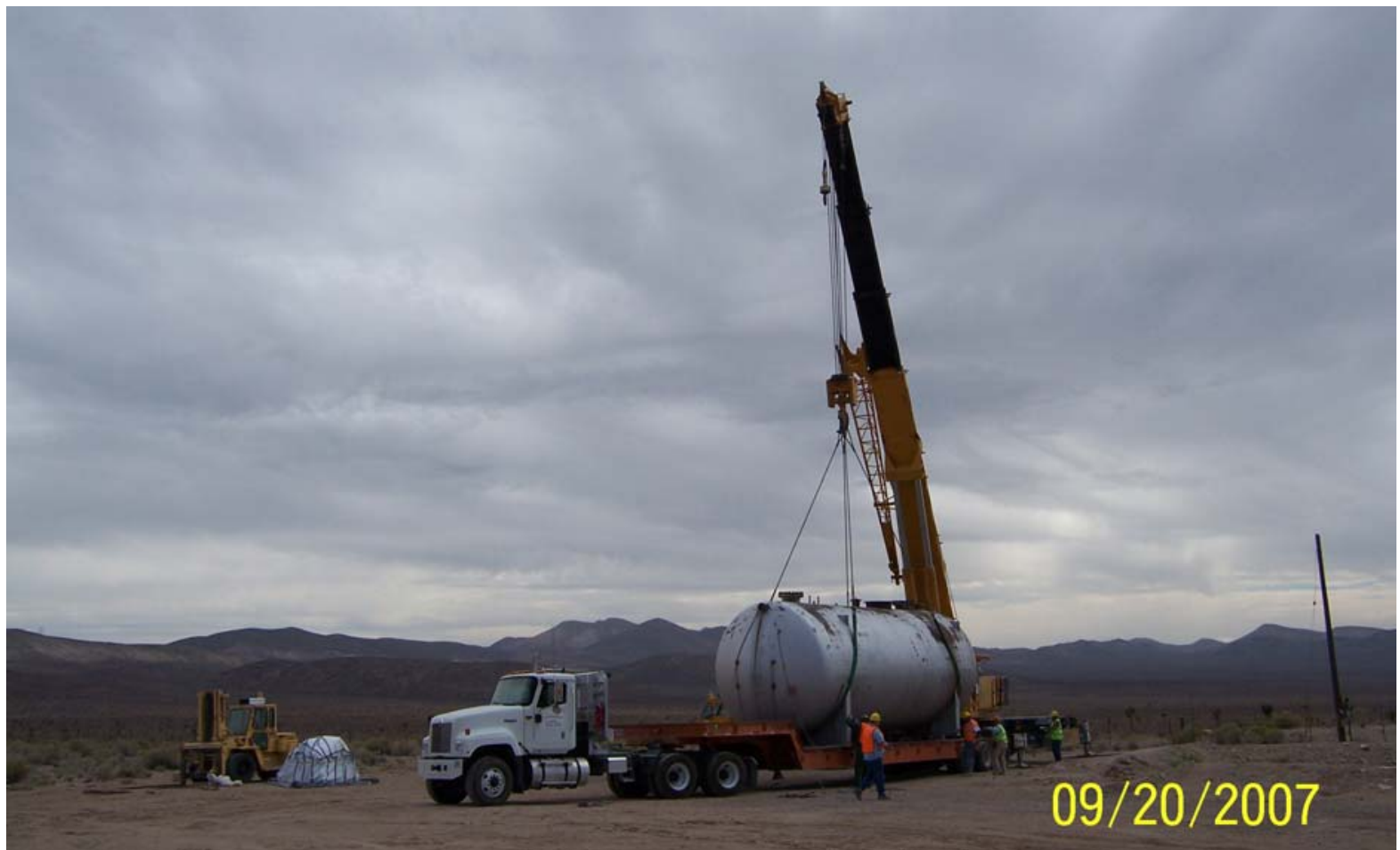

Photograph 24. CAS 15-01-03, Placing AST on flatbed trailer 


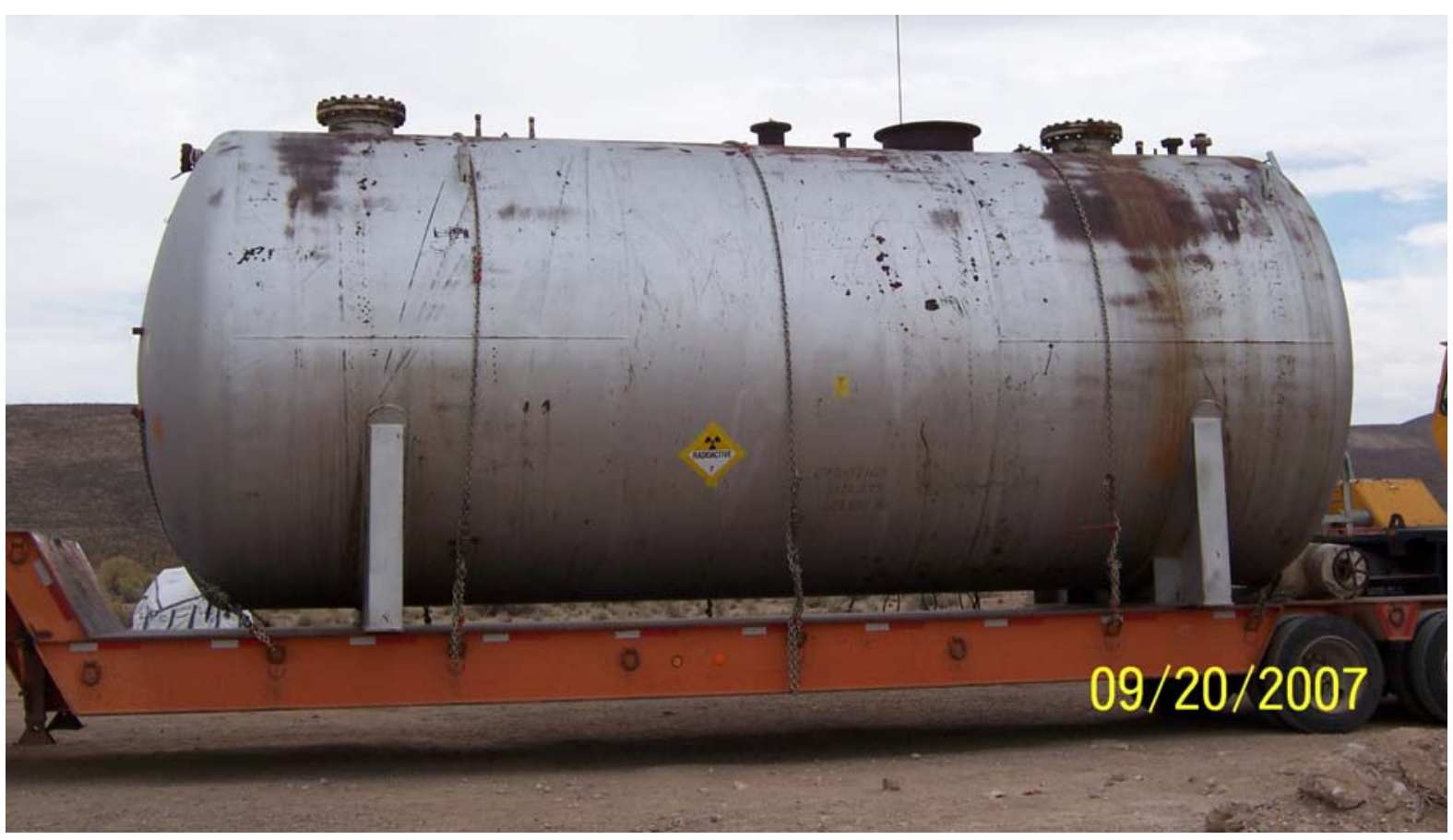

Photograph 25. CAS 15-01-03, AST on flatbed trailer, prepared to transport

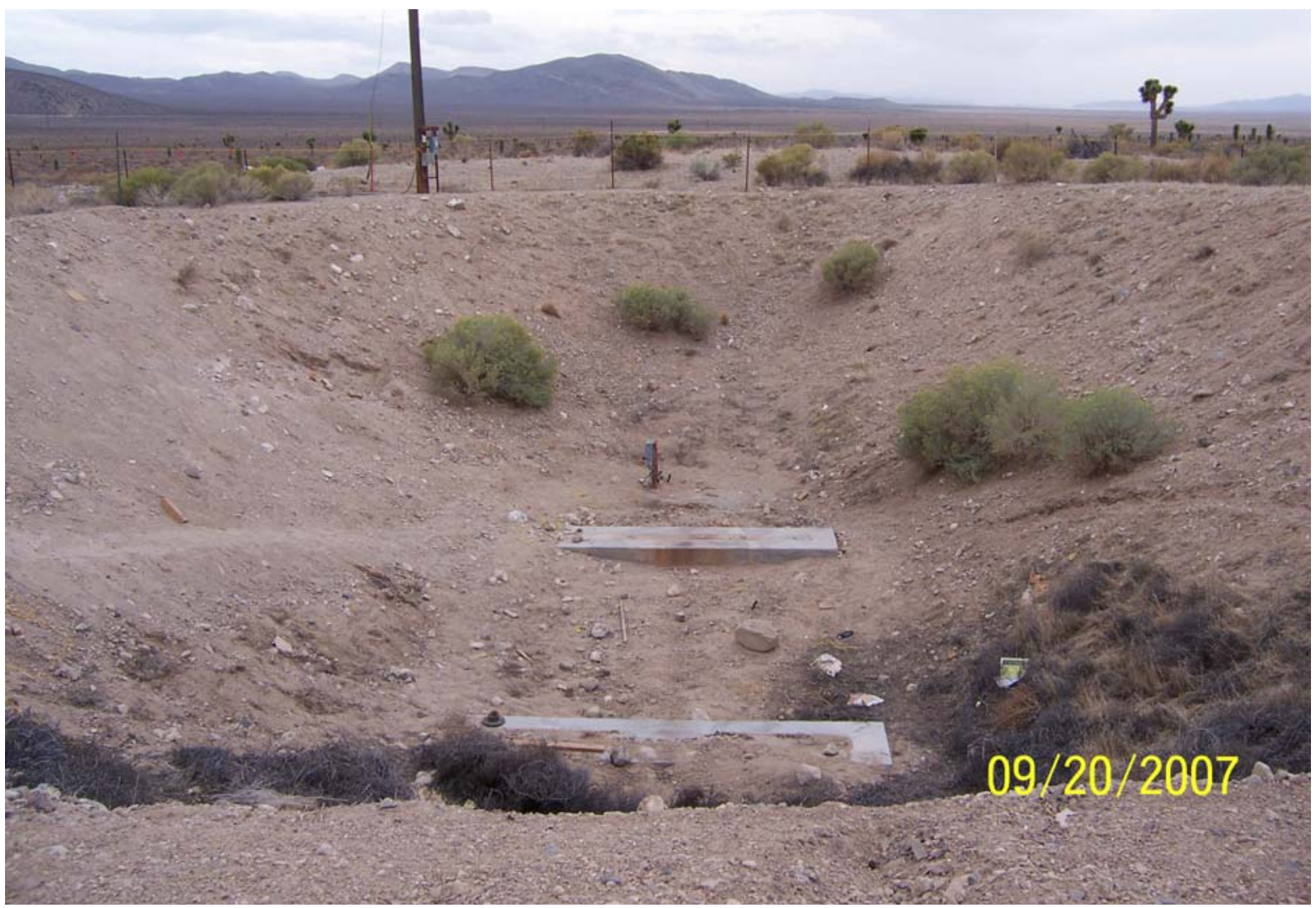

Photograph 26. CAS 15-01-03, AST depression after AST has been removed 


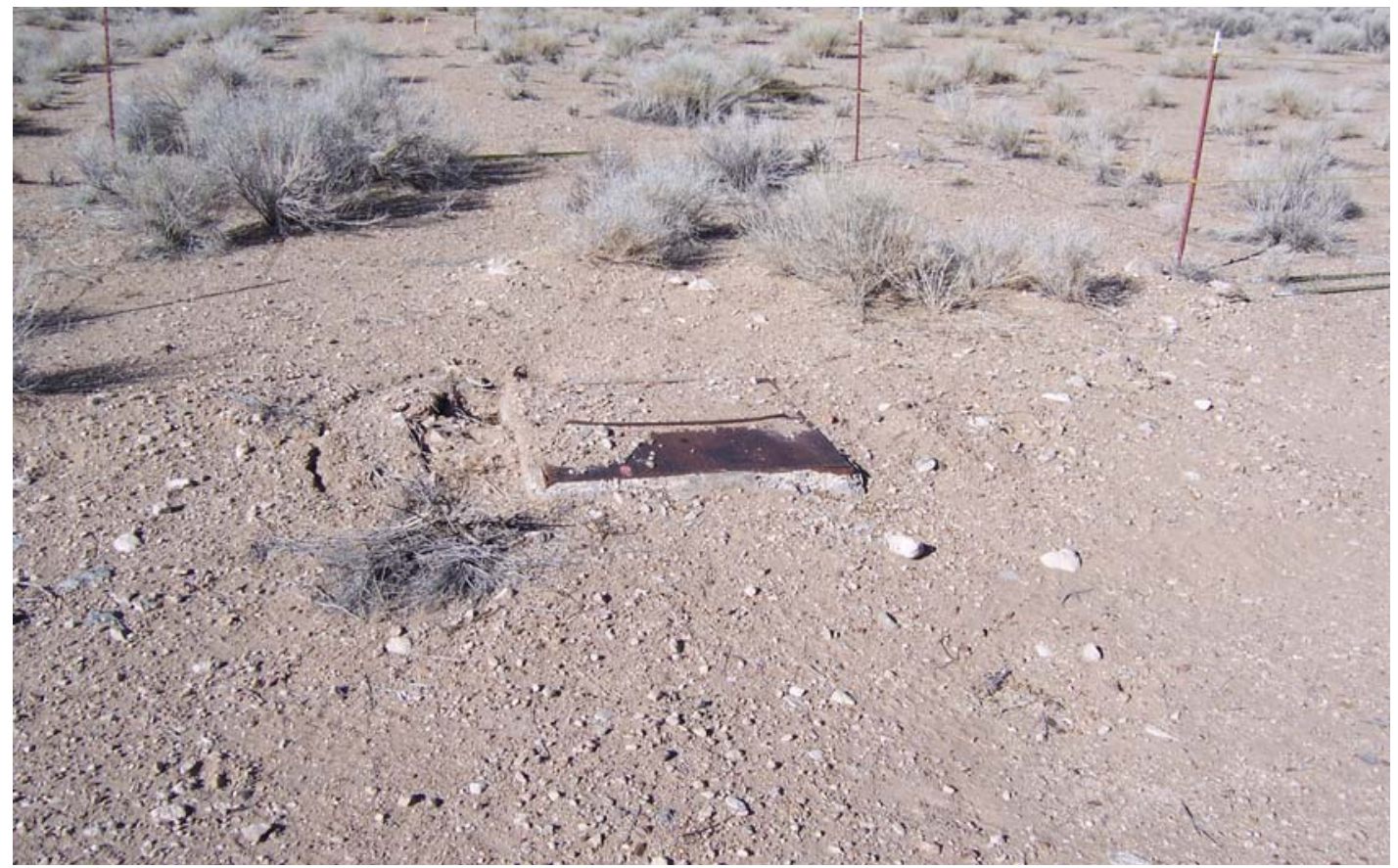

Photograph 27. CAS 15-01-03, Distribution box, before closure activities

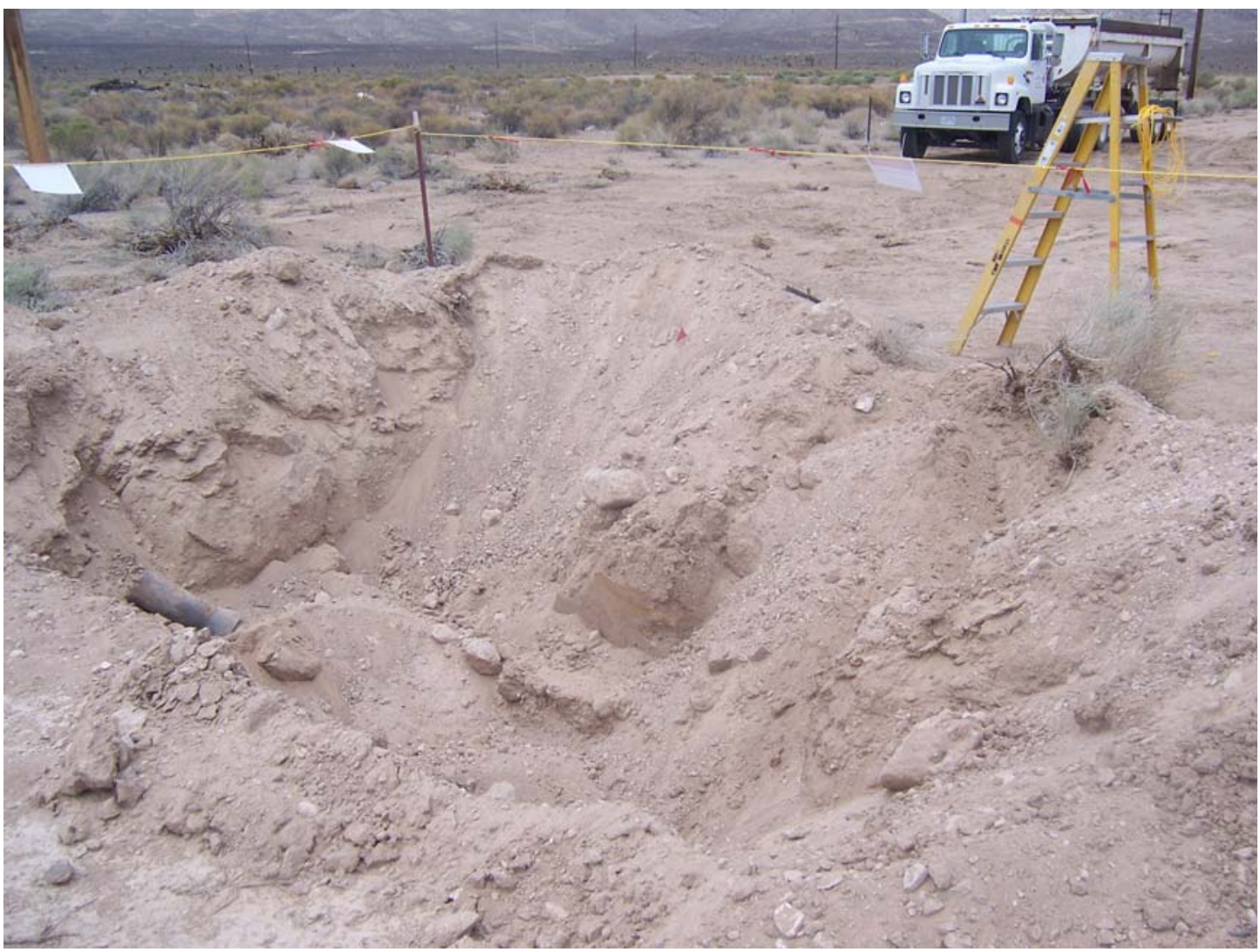

Photograph 28. CAS 15-01-03, Distribution box excavation, after box removal 


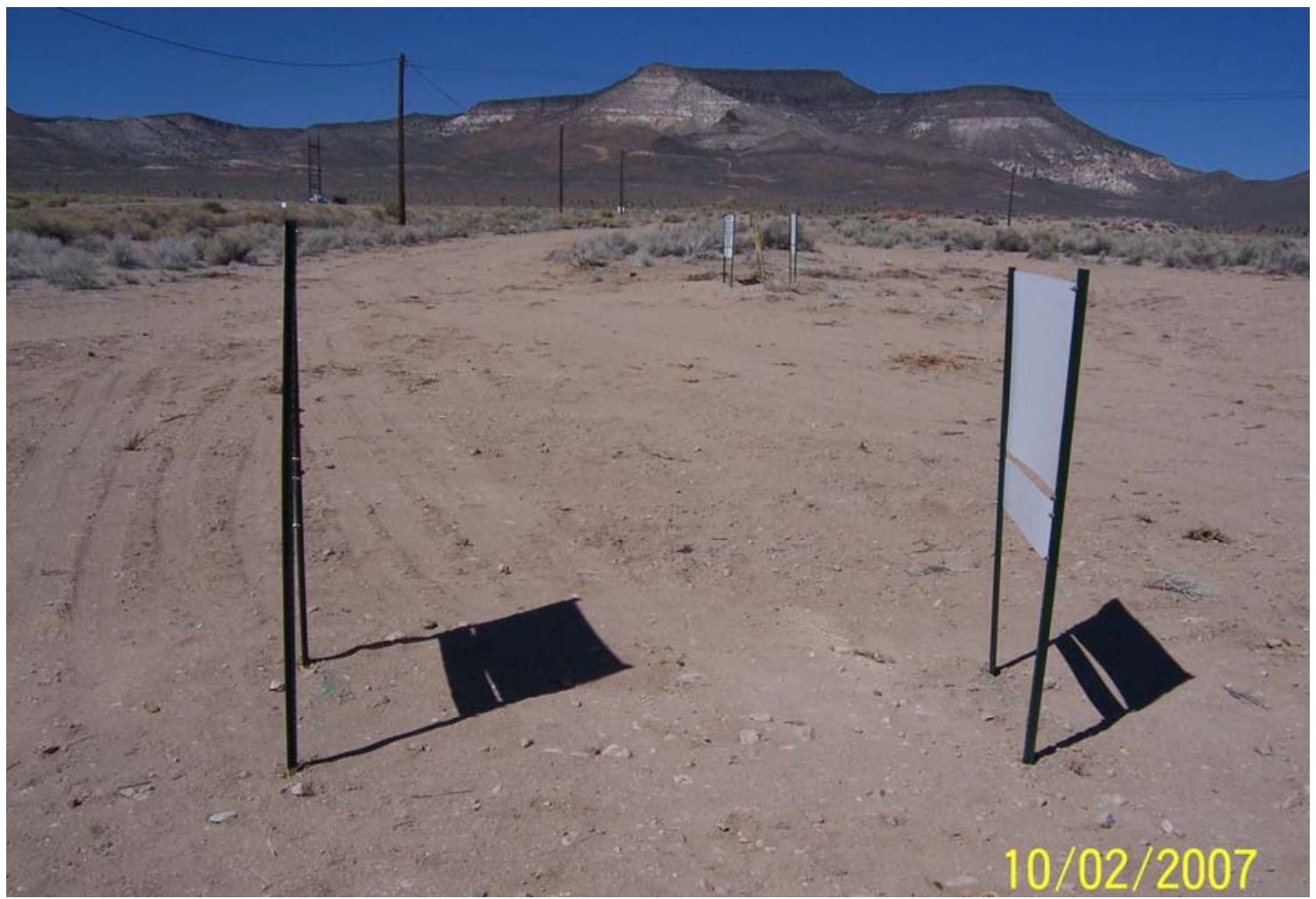

Photograph 29. CAS 15-01-03, Distribution box excavation, backfilled

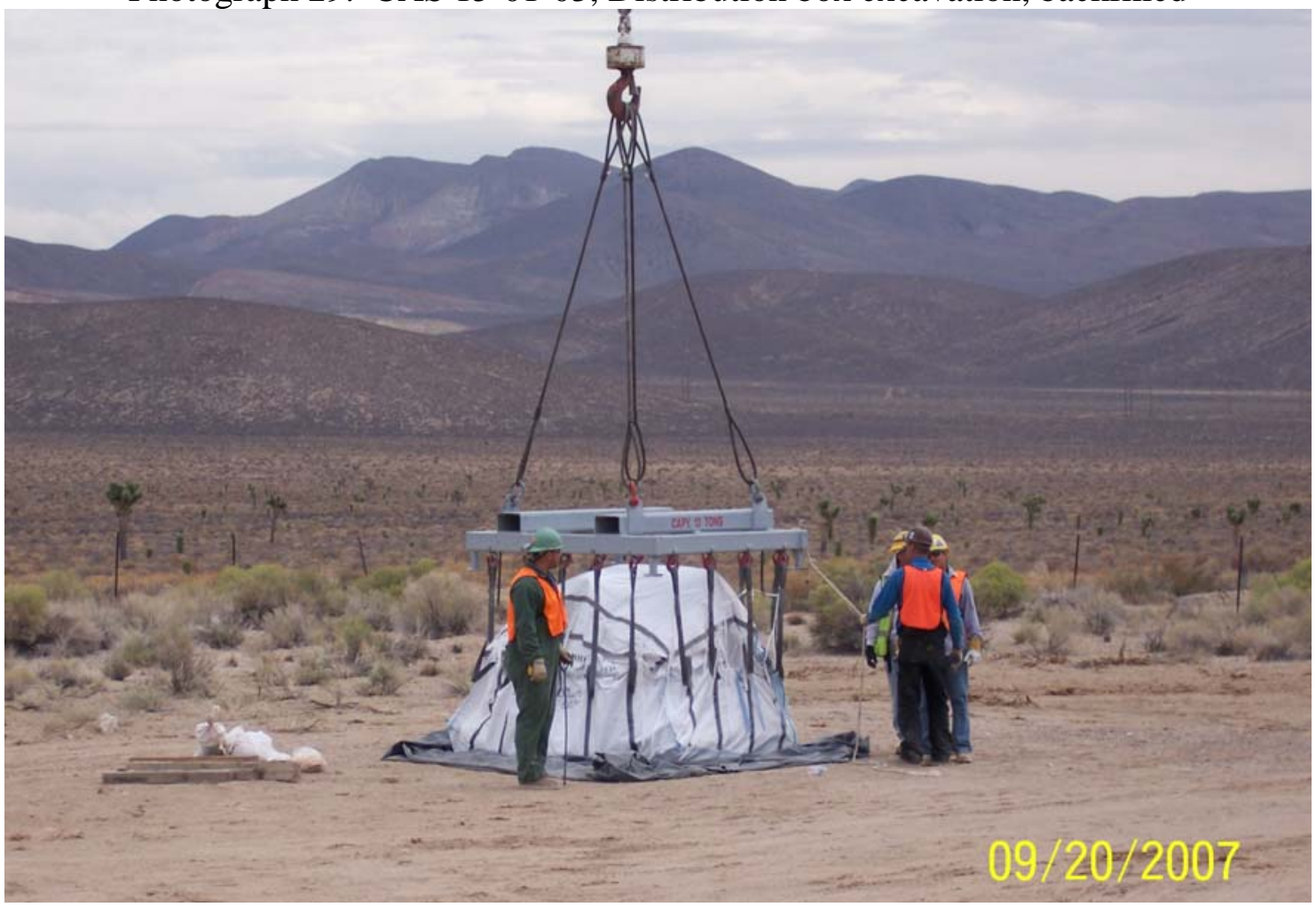

Photograph 30. CAS 15-01-03, Distribution box low-level waste (LLW) being prepared for lifting 


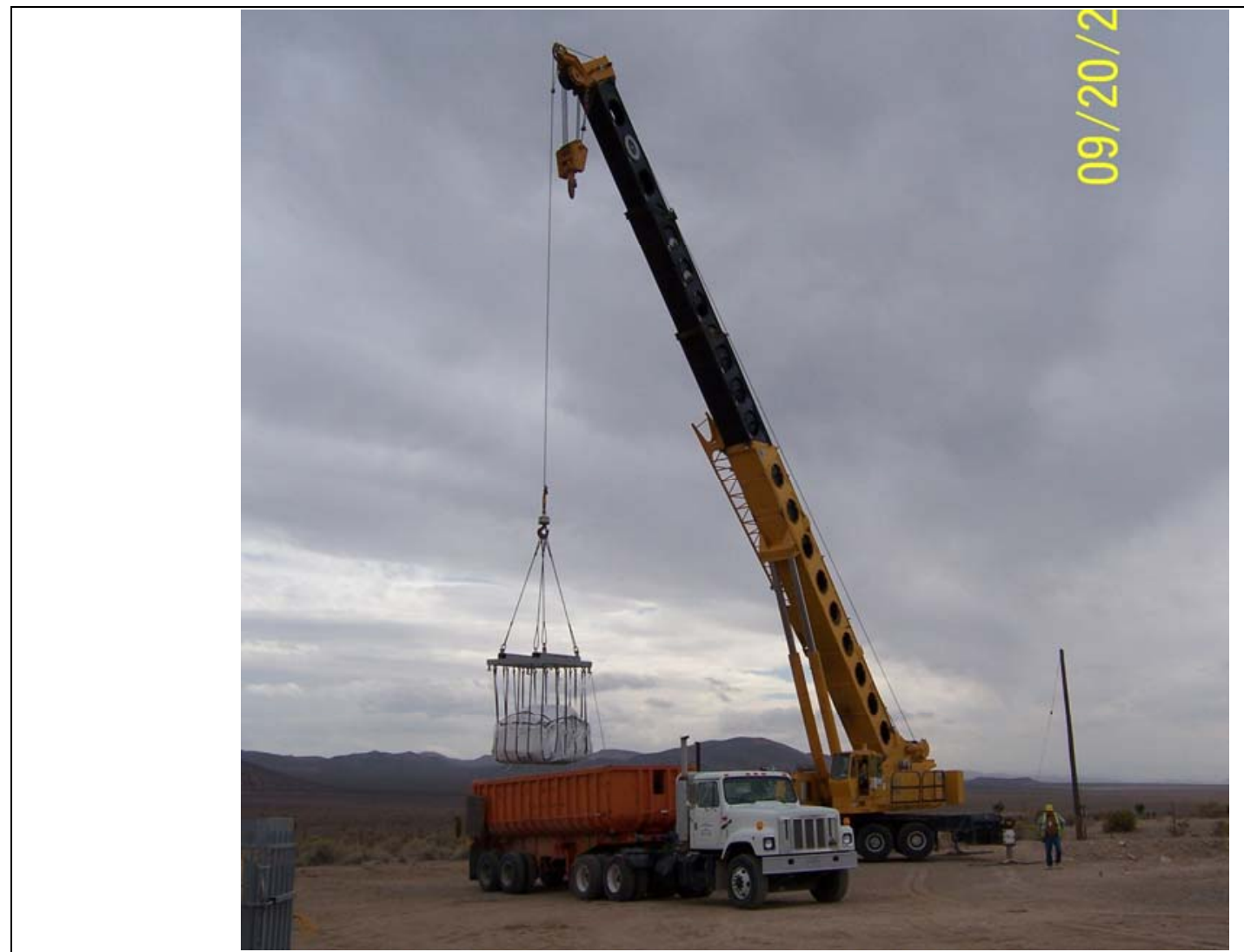

Photograph 31. CAS 15-01-03, Distribution box LLW loading onto transportation vehicle

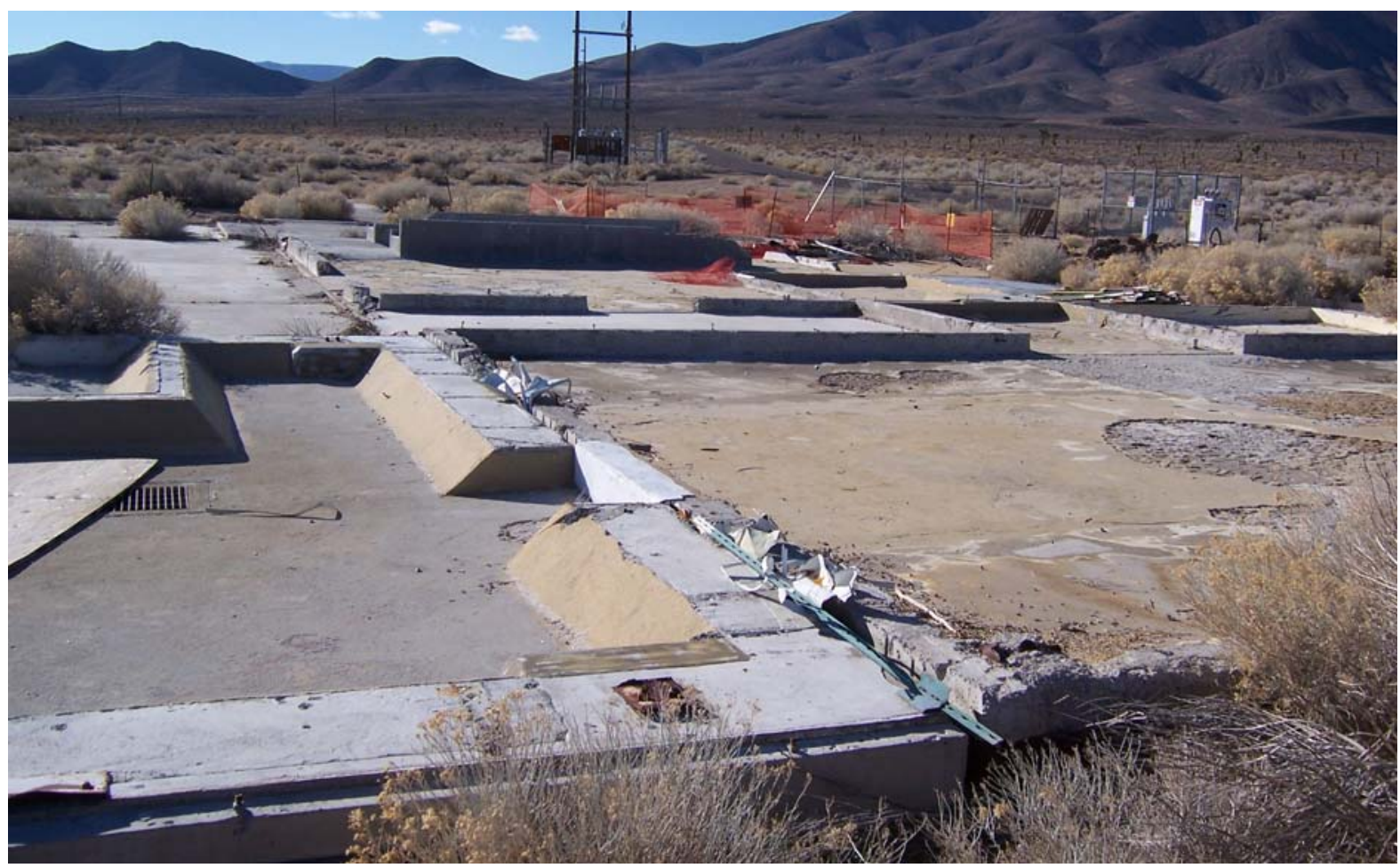

Photograph 32. CAS 15-01-03, Building 15-06 pad, before closure activities 


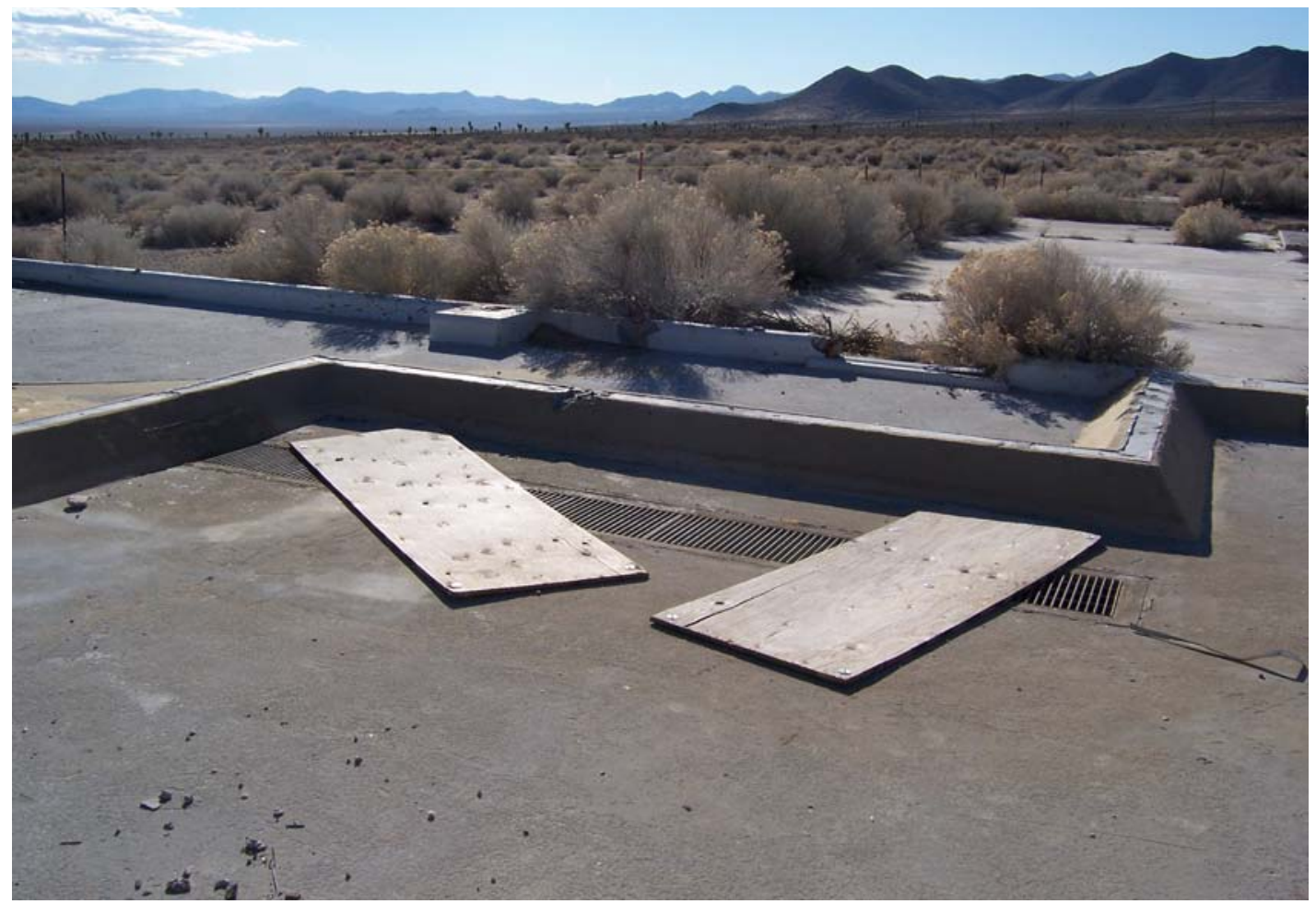

Photograph 33. CAS 15-01-03, Building 15-06 floor drain trenches, with wood debris, before closure activities

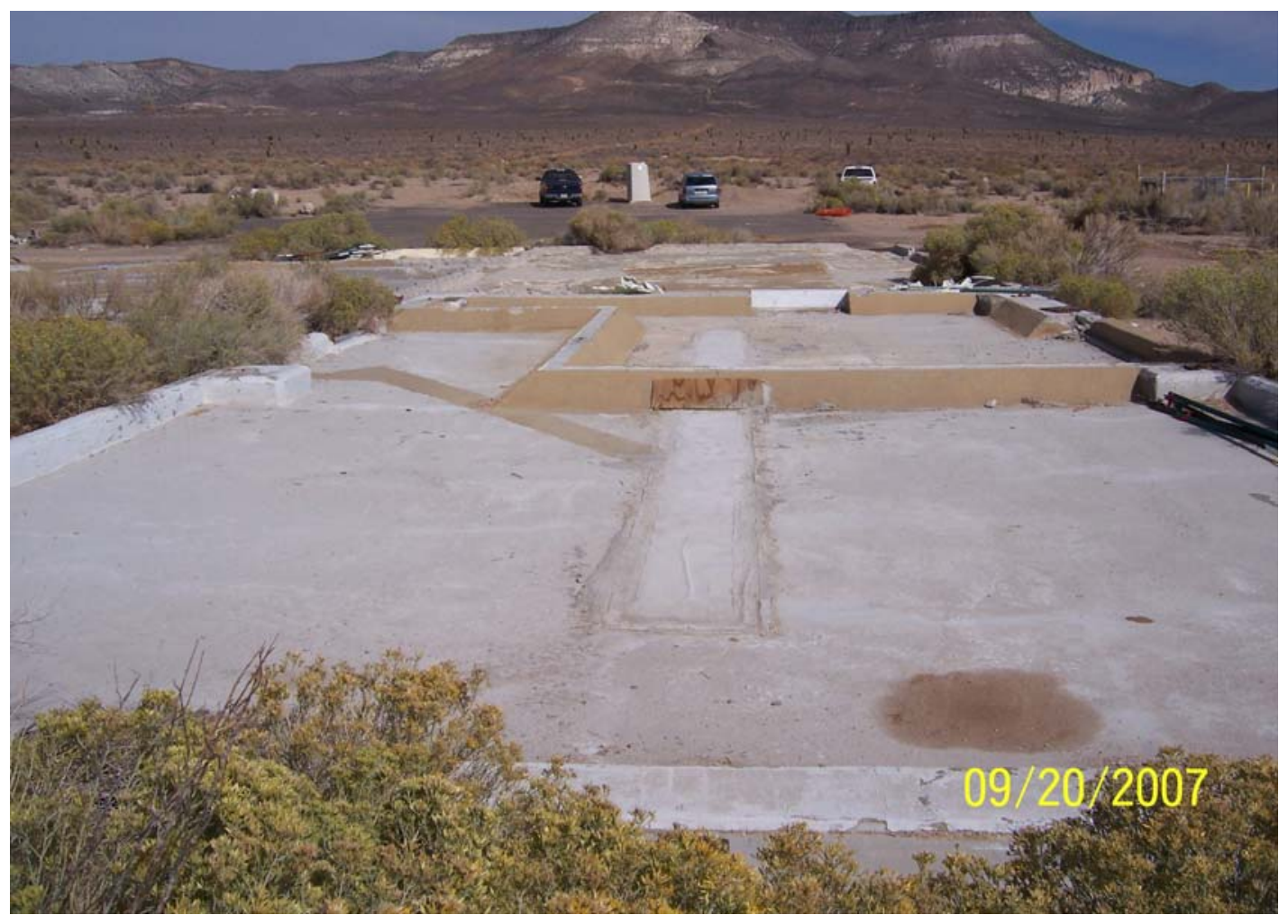

Photograph 34. CAS 15-01-03, Building 15-06 pad with floor drain trenches grouted 


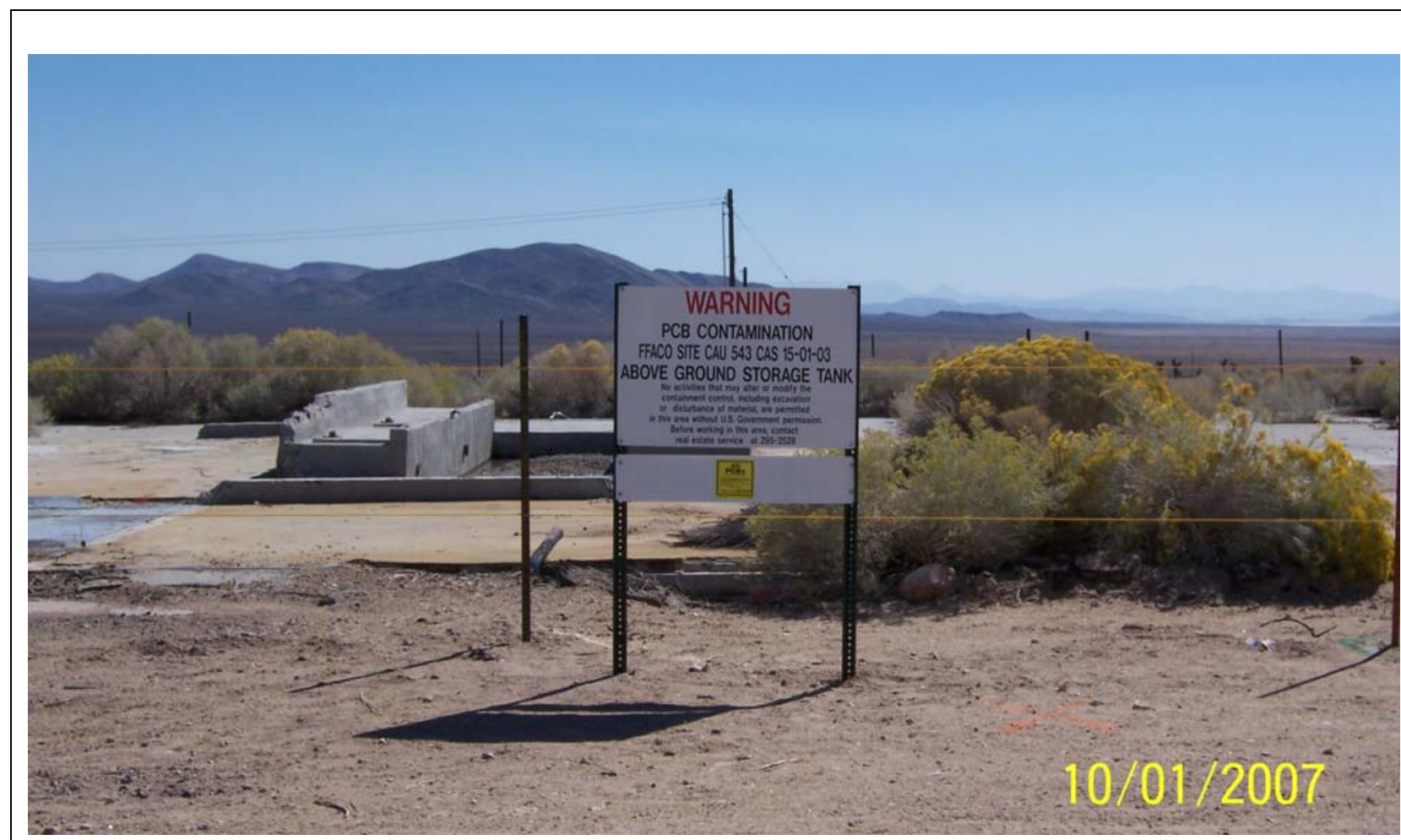

Photograph 35. CAS 15-01-03, Building 15-06 UR and PCB signs on UR fencing

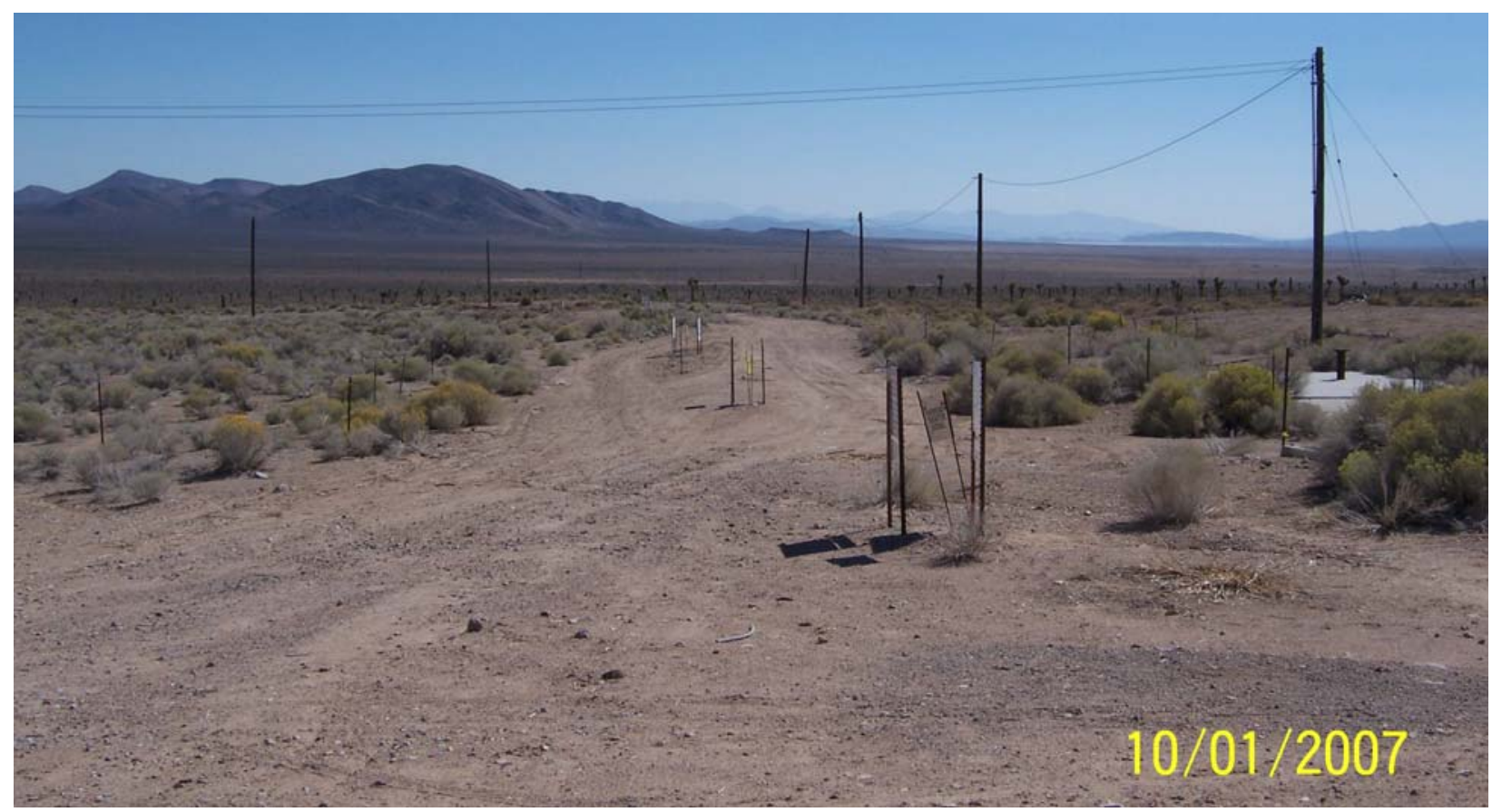

Photograph 36. CAS 15-01-03, UR, PCB, and URMA signs posted over underground piping 


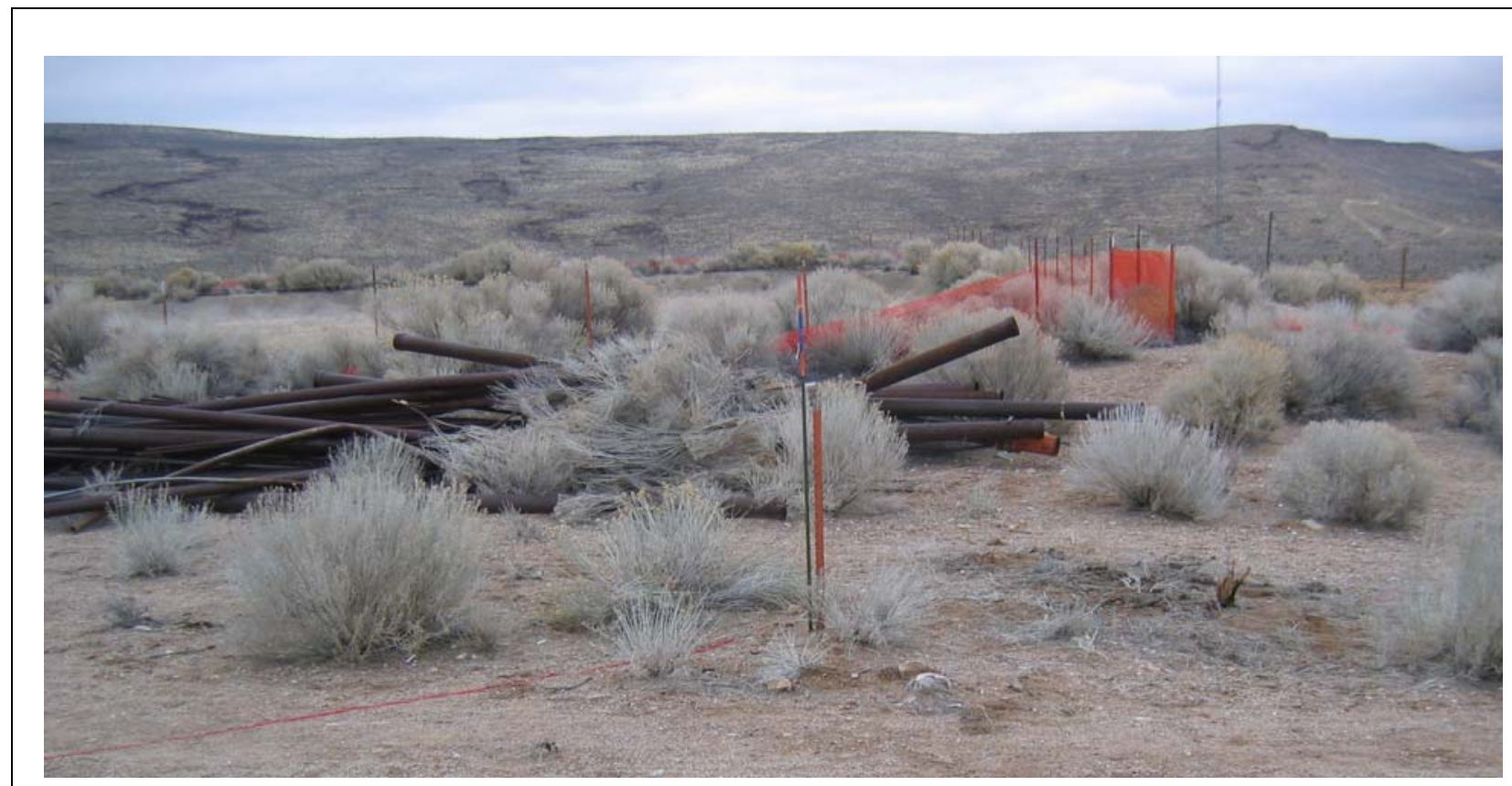

Photograph 37. Piping debris northeast of CAS 15-01-03 Building 15-06 pad, before closure activities

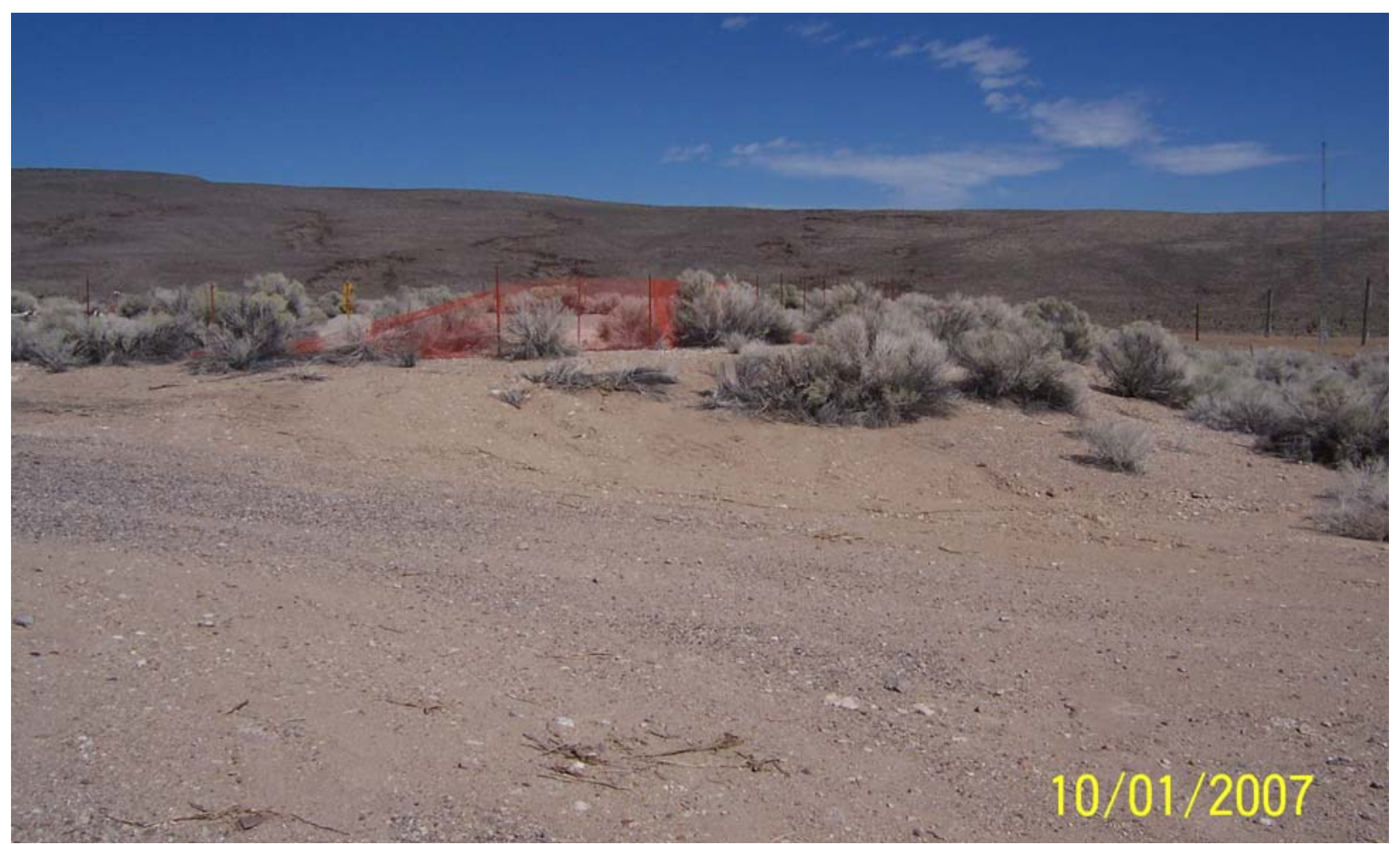

Photograph 38. Piping debris area northeast of CAS 15-01-03 Building 15-06 pad, after closure activities 


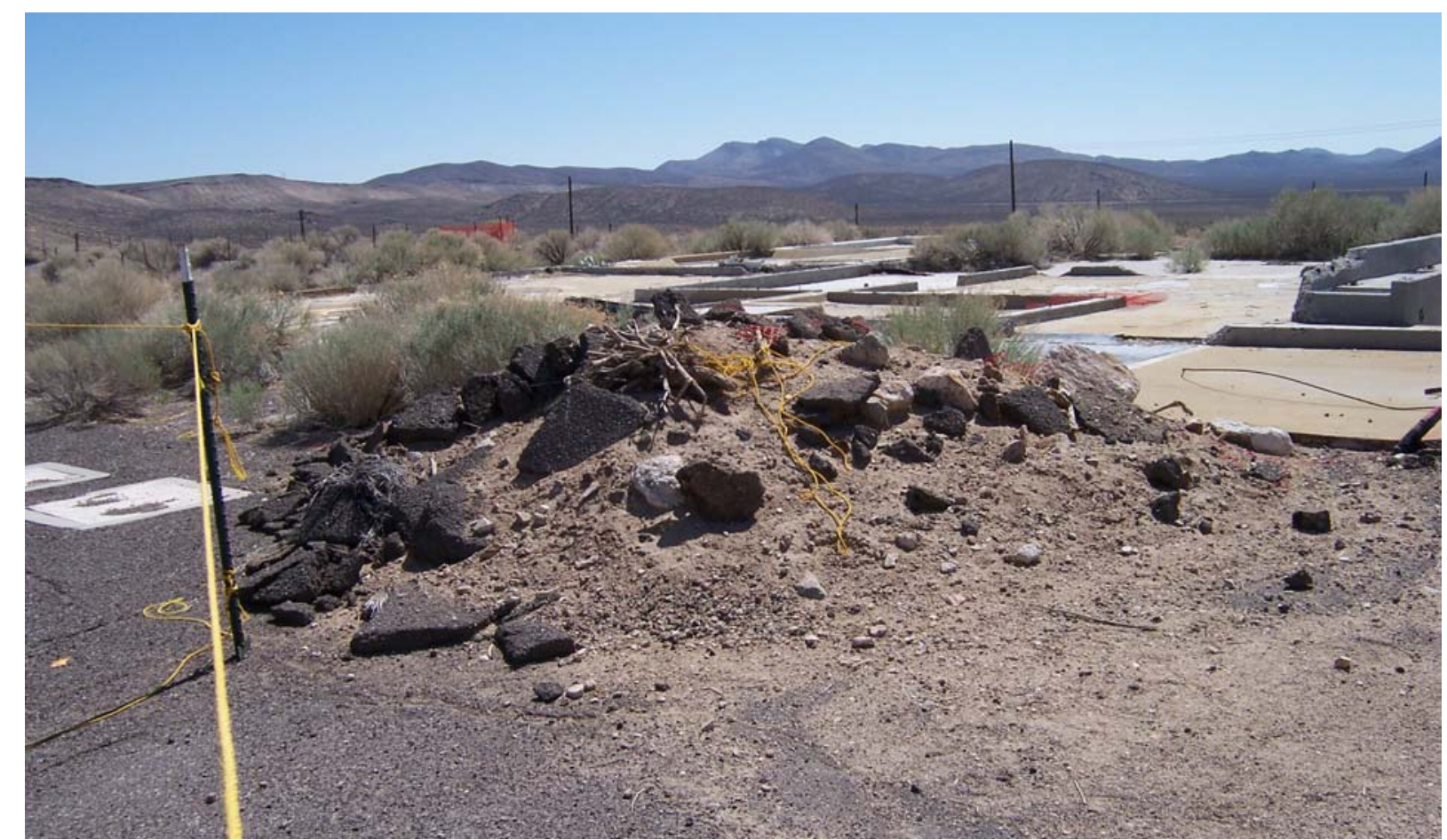

Photograph 39. Asphalt debris pile north of CAS 15-01-03 Building 15-06 pad, before closure activities

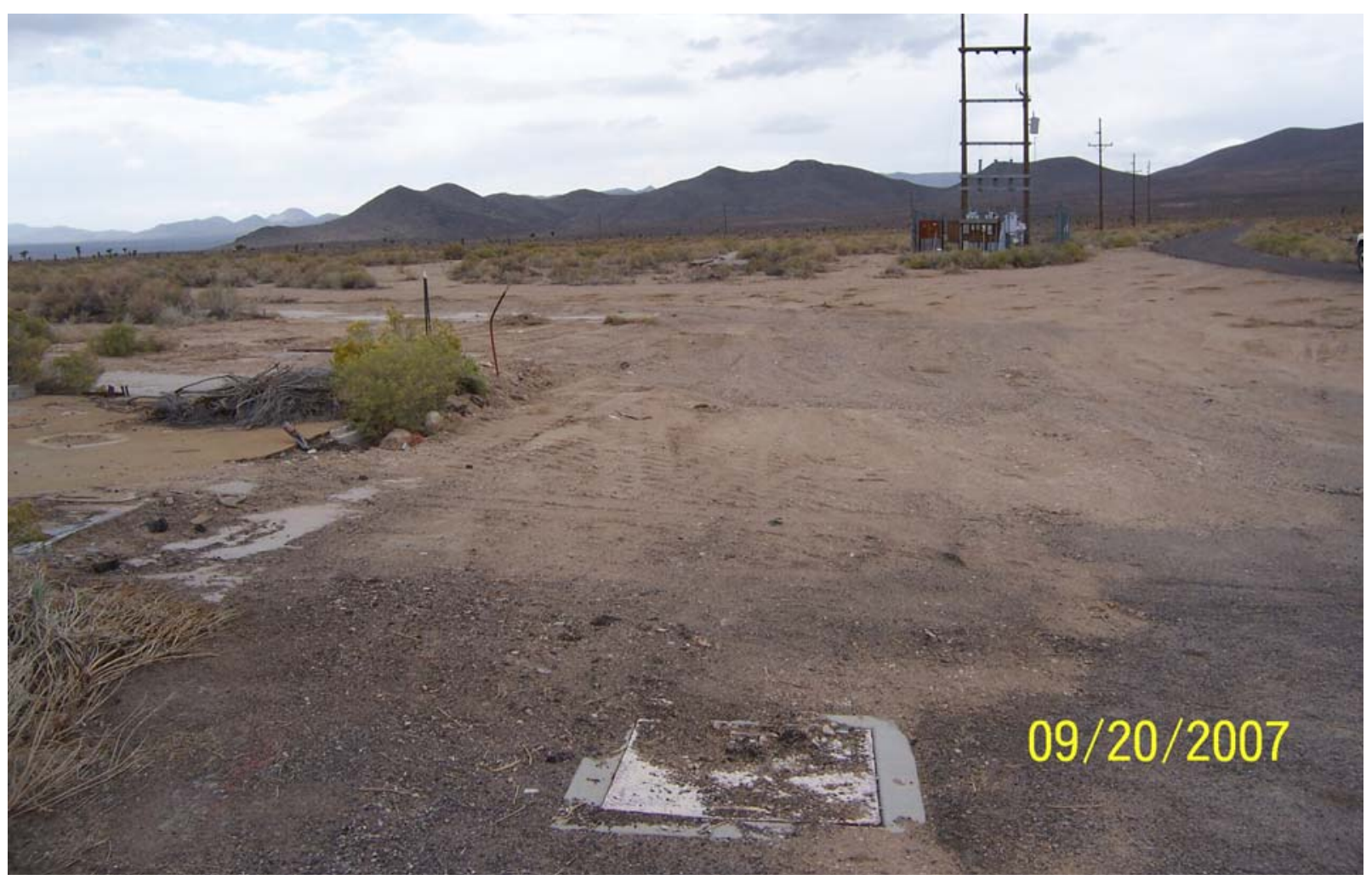

Photograph 40. Asphalt debris area north of CAS 15-01-03 Building 15-06 pad, after closure activities 


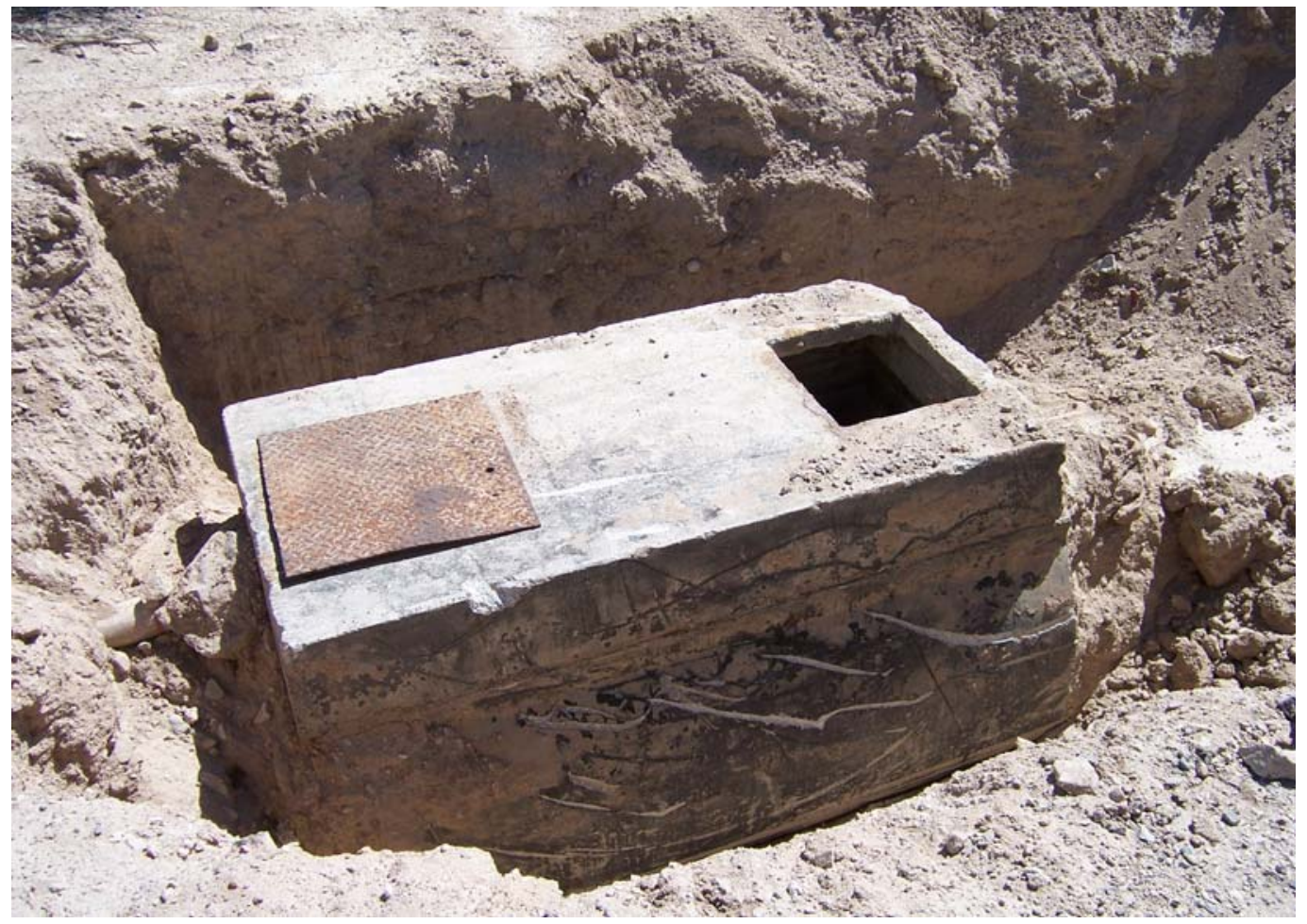

Photograph 41. CAS 15-04-01, Septic tank, exposed during closure activities

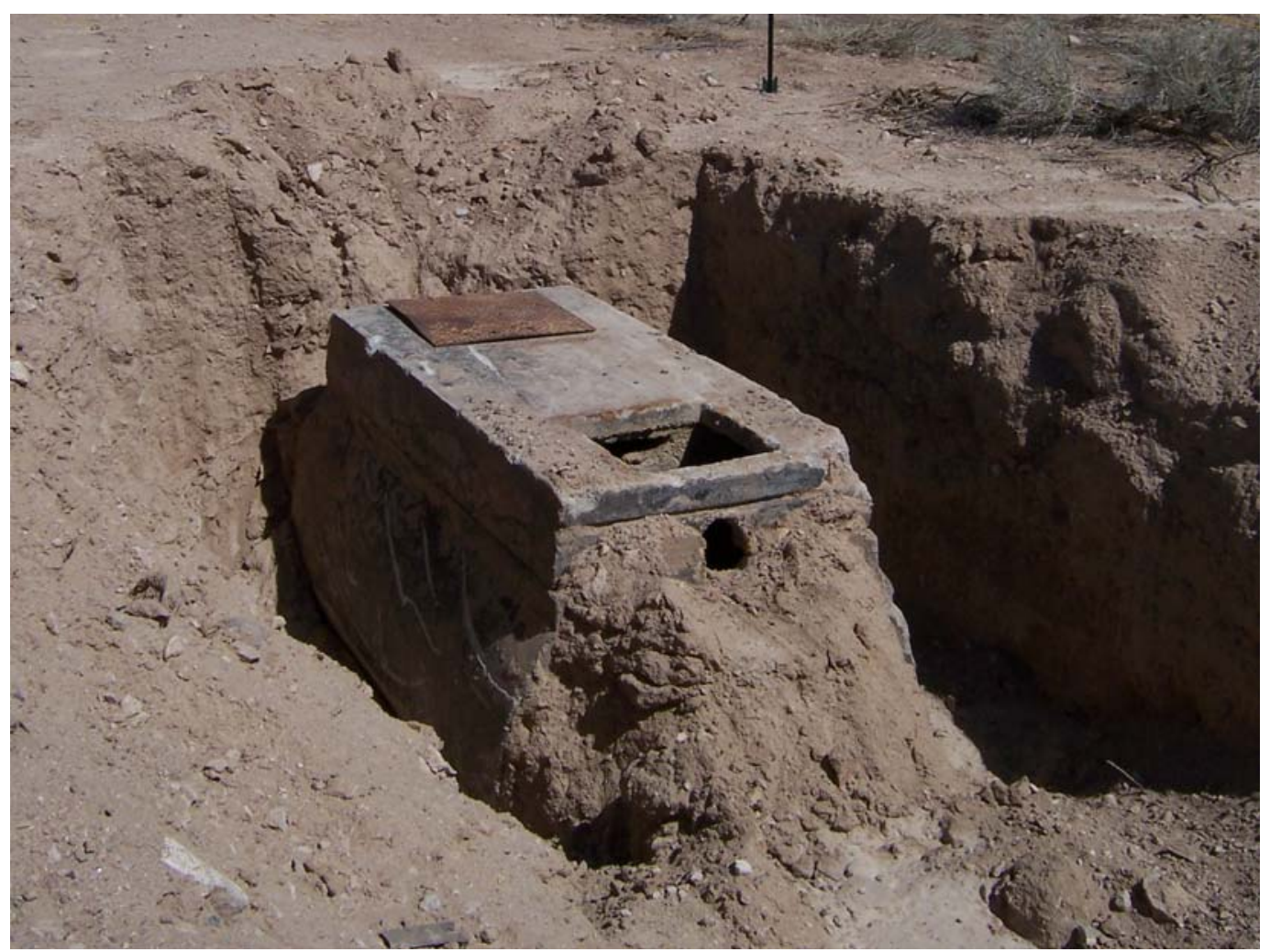

Photograph 42. CAS 15-04-01, Septic tank, excavated 


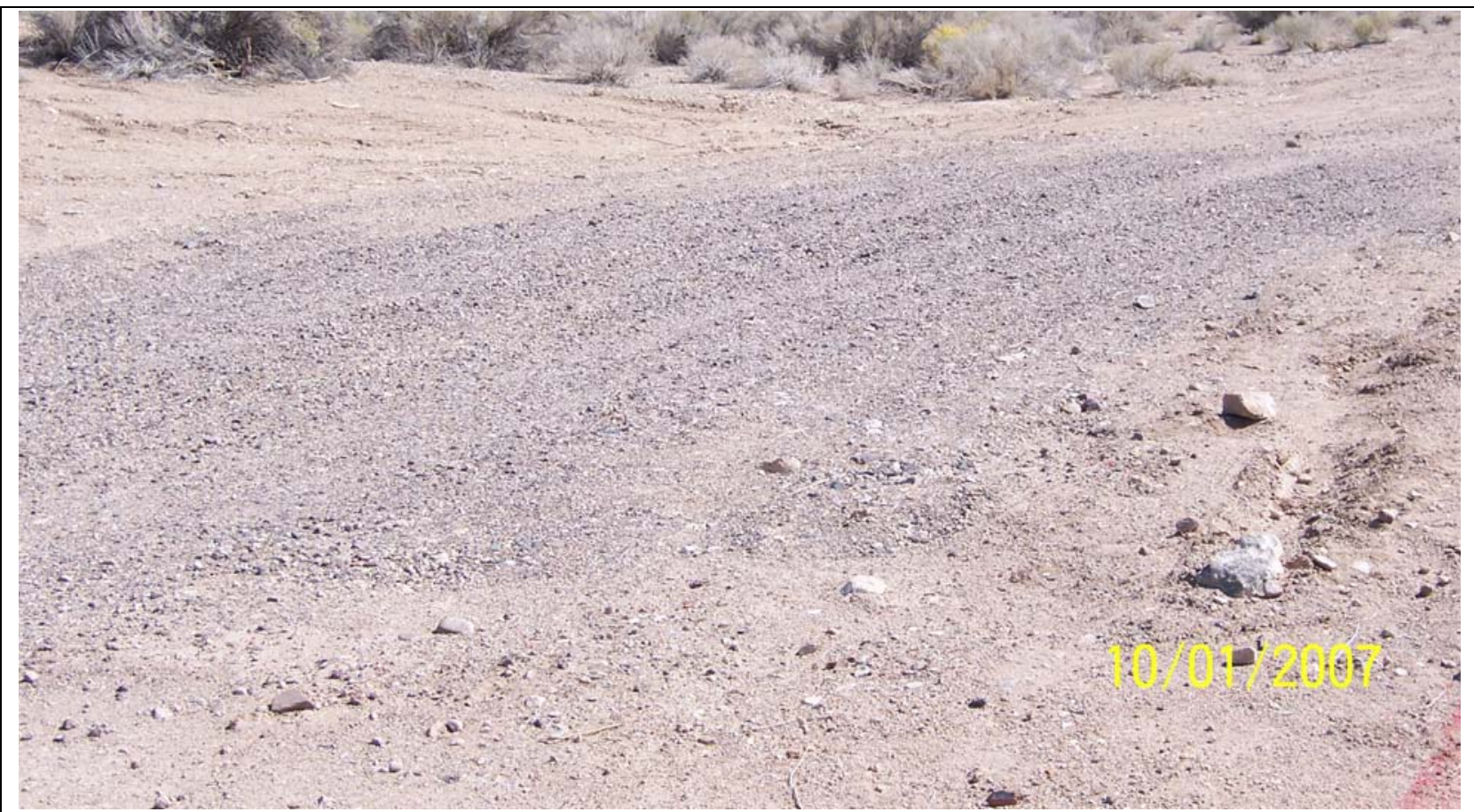

Photograph 43. CASs 15-04-01 and 15-05-01, Septic tank and distribution box excavations, backfilled

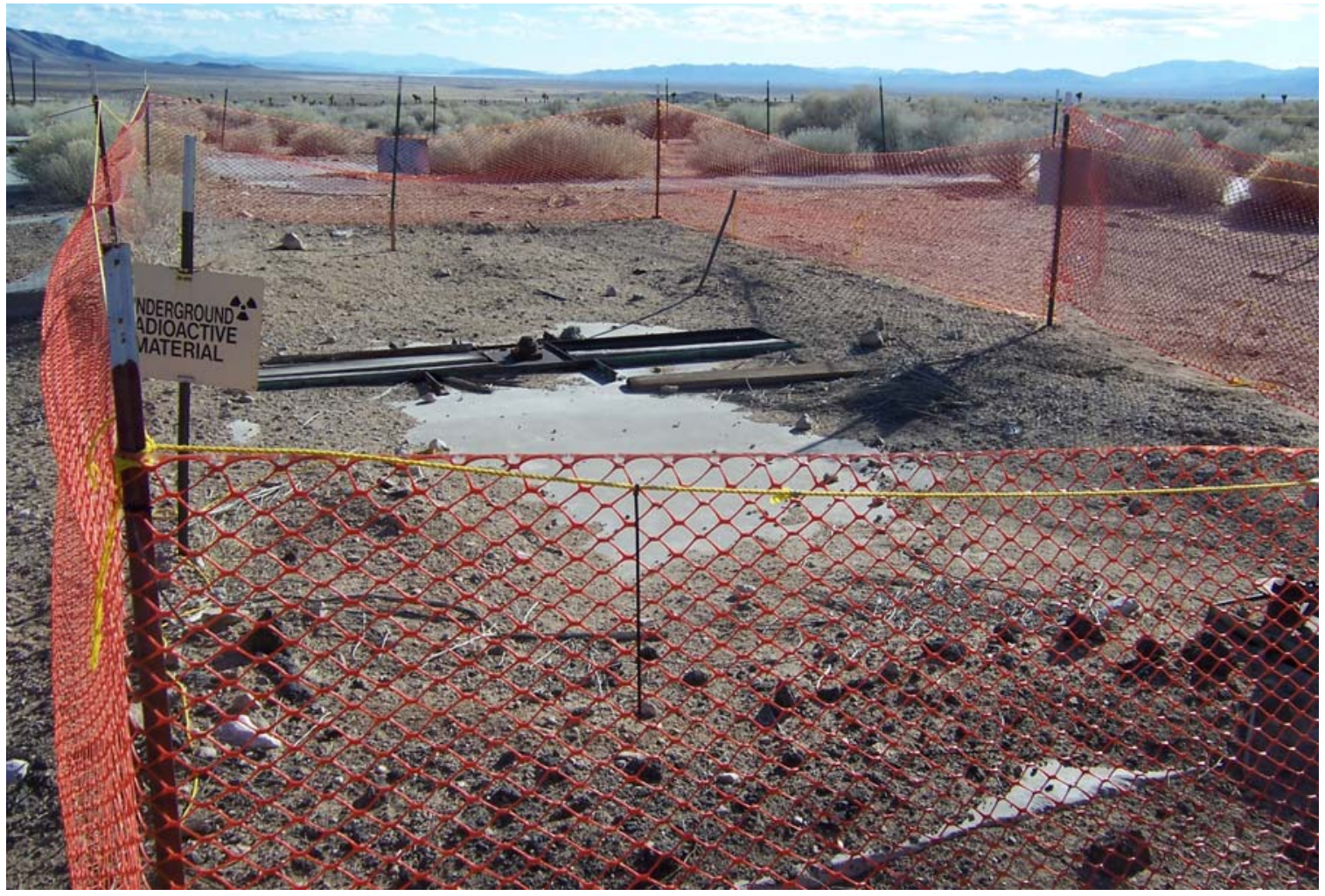

Photograph 44. CAS 15-08-01, Liquid manure tank top, including debris, before closure activities 


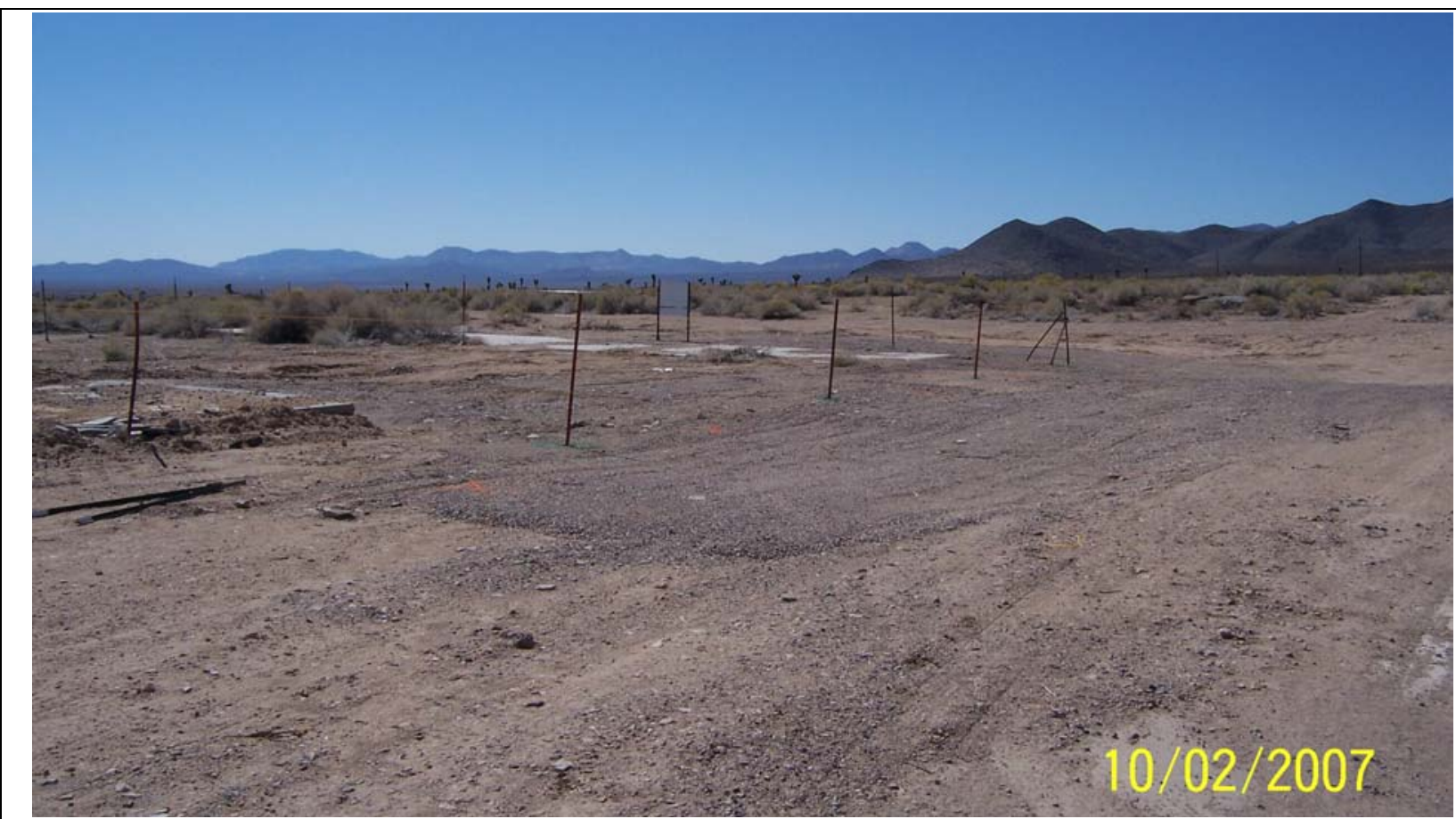

Photograph 45. CAS 15-08-01, Liquid manure tank excavation, backfilled

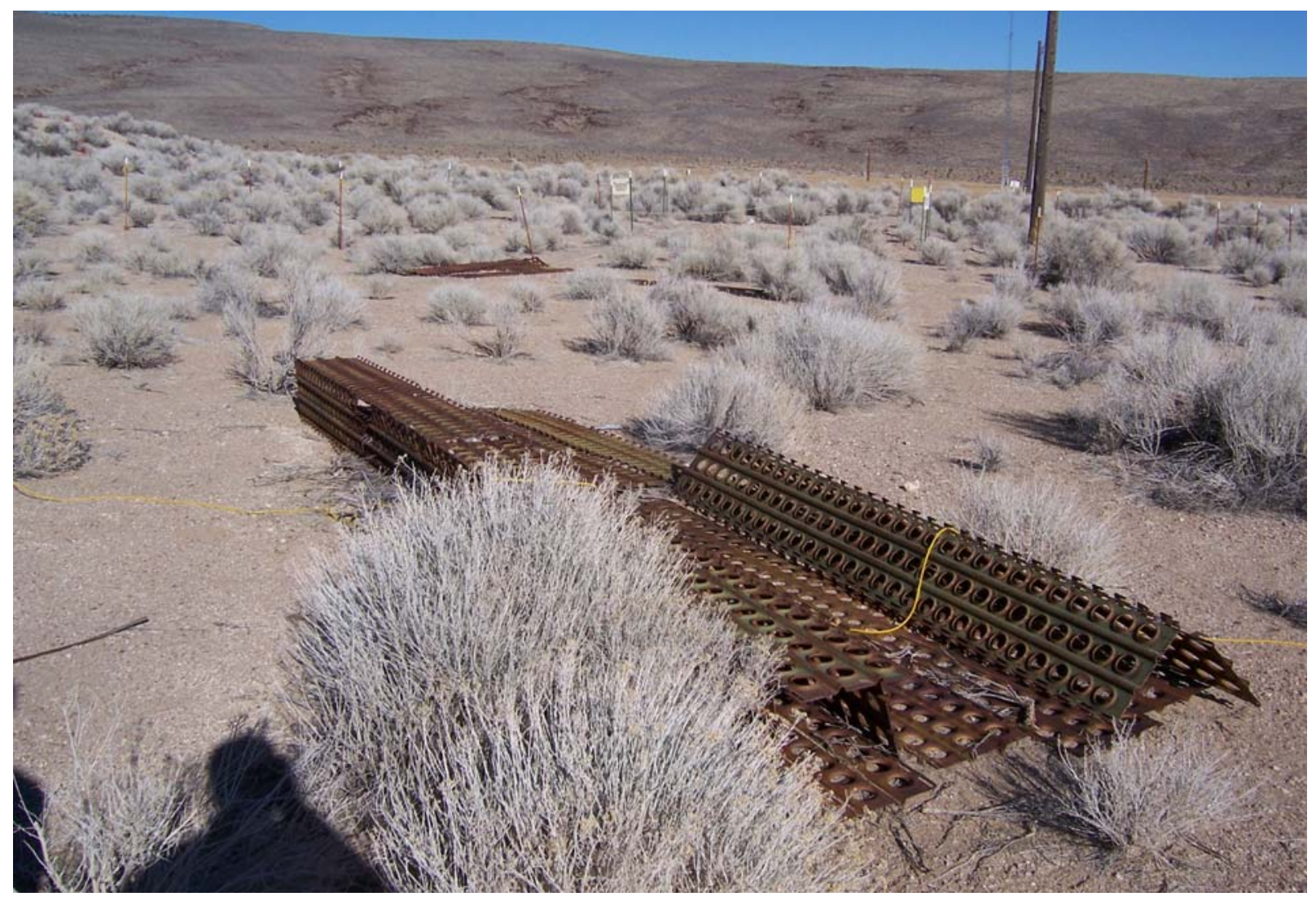

Photograph 46. CAS 15-23-01, Steel planking and other debris, before closure activities 


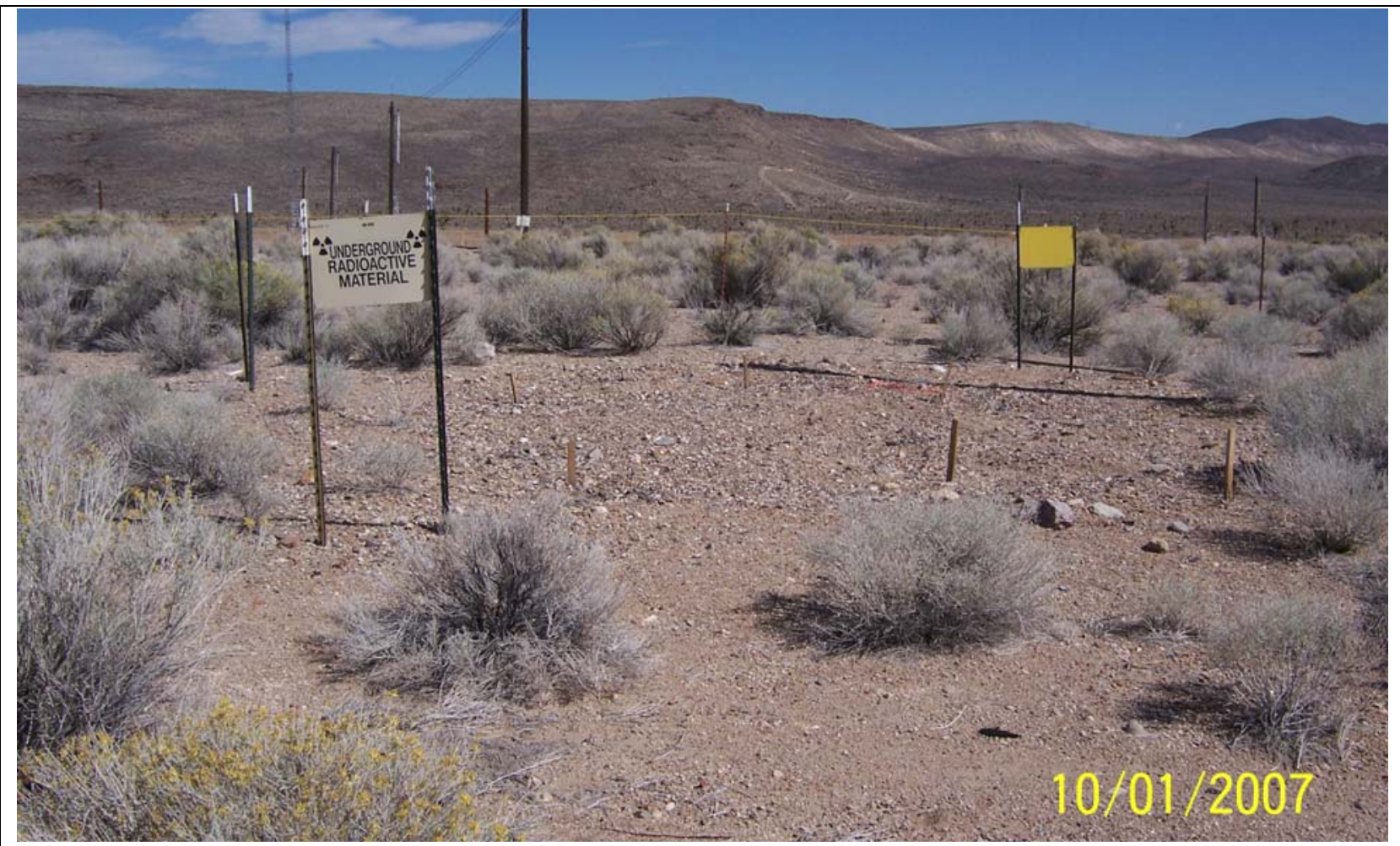

Photograph 47. CAS 15-23-01, After debris removal

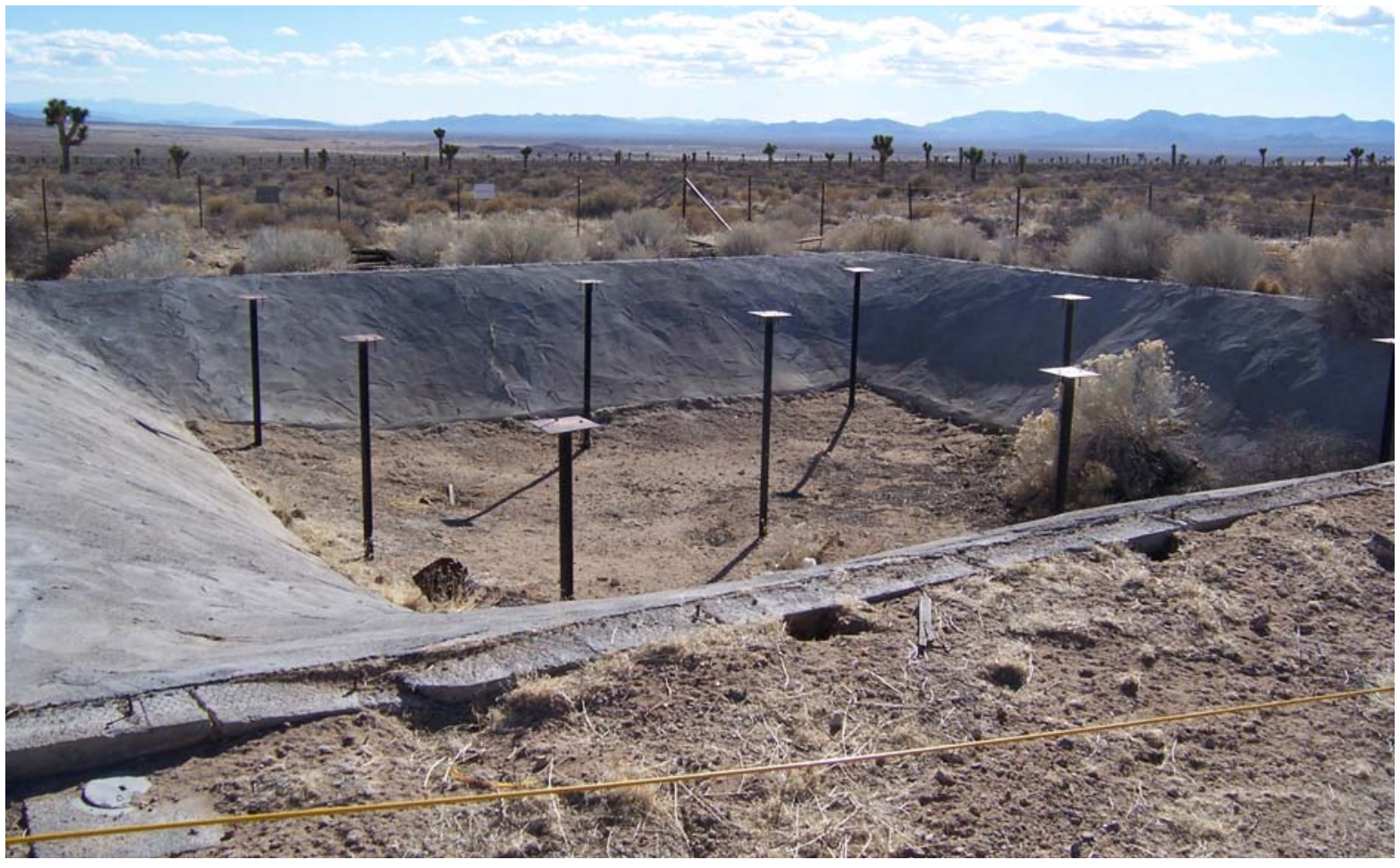

Photograph 48. CAS 15-23-03, Sump, before closure activities 


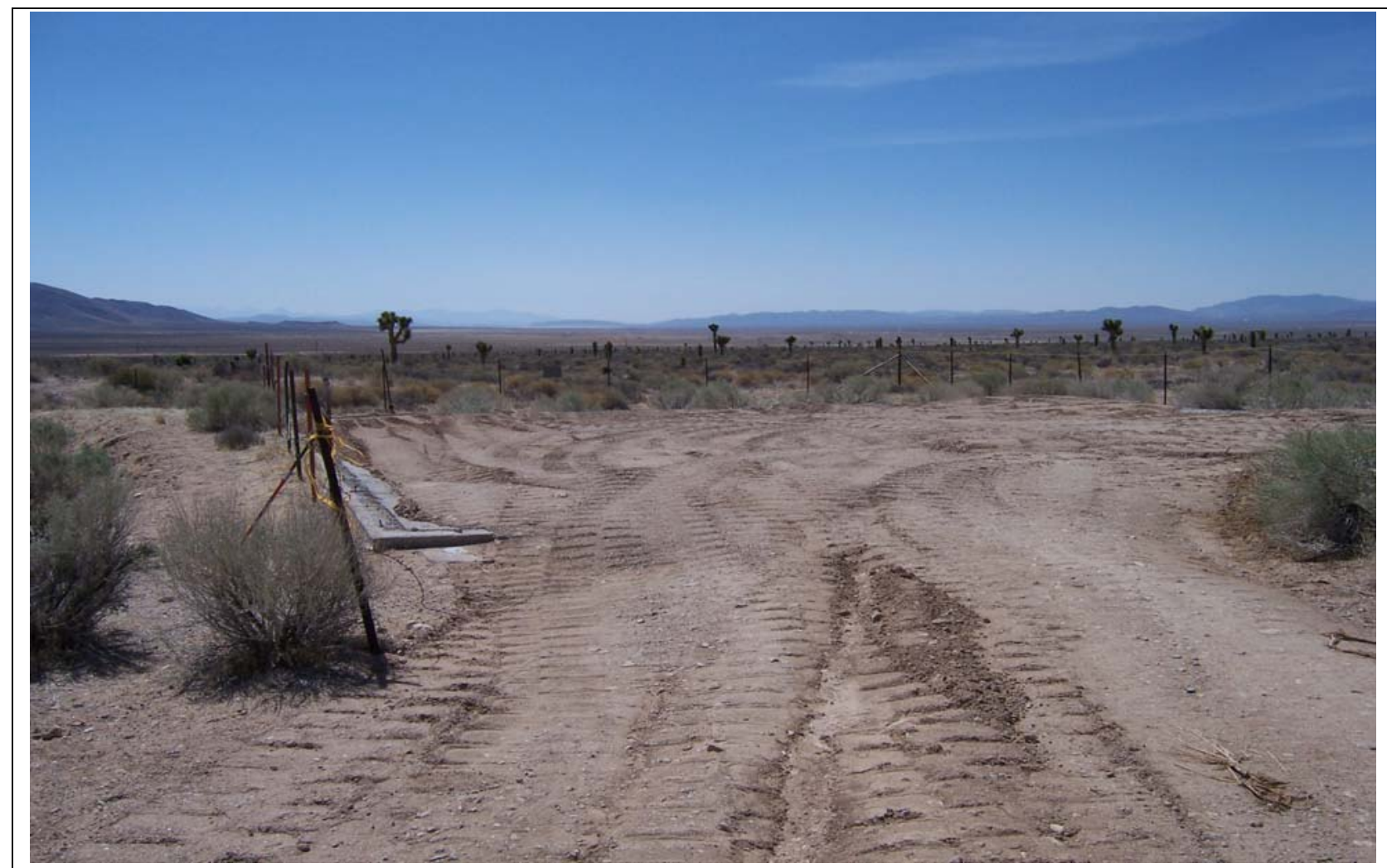

Photograph 49. CAS 15-23-03, Sump, partially filled, with concrete perimeter partially exposed

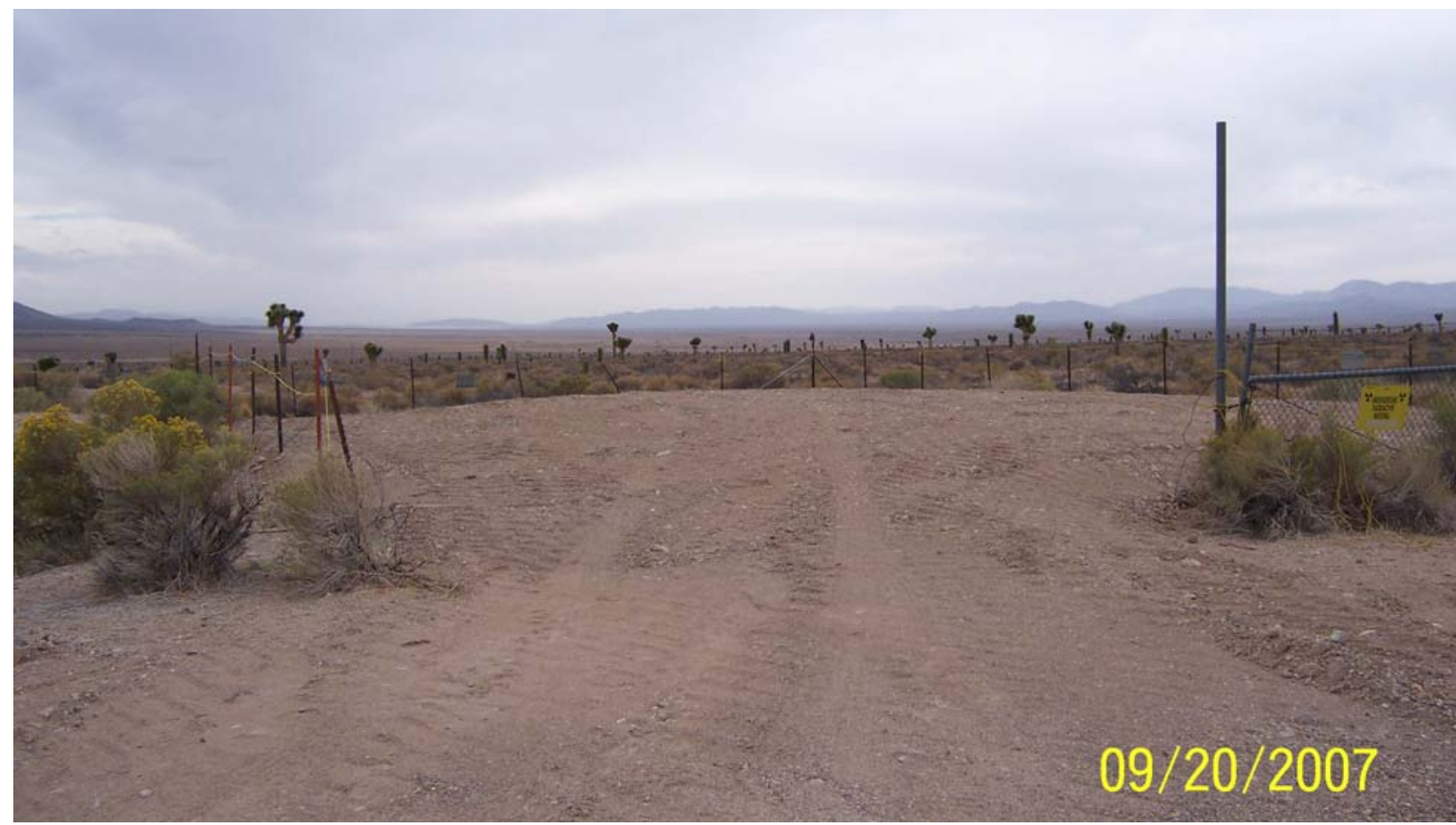

Photograph 50. CAS 15-23-03, Sump, final backfilled area 


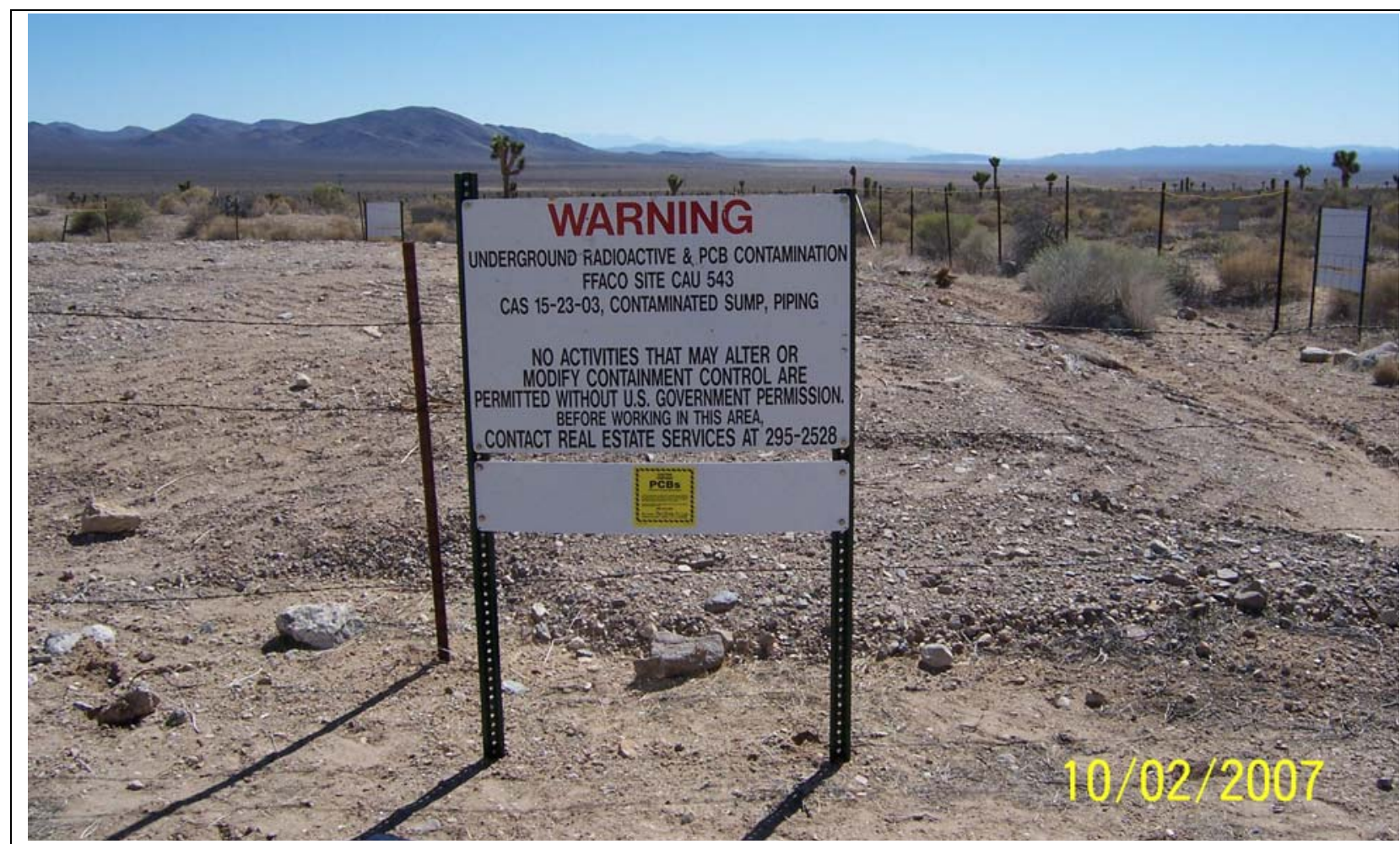

Photograph 51. CAS 15-23-03, UR signs posted around perimeter of sump

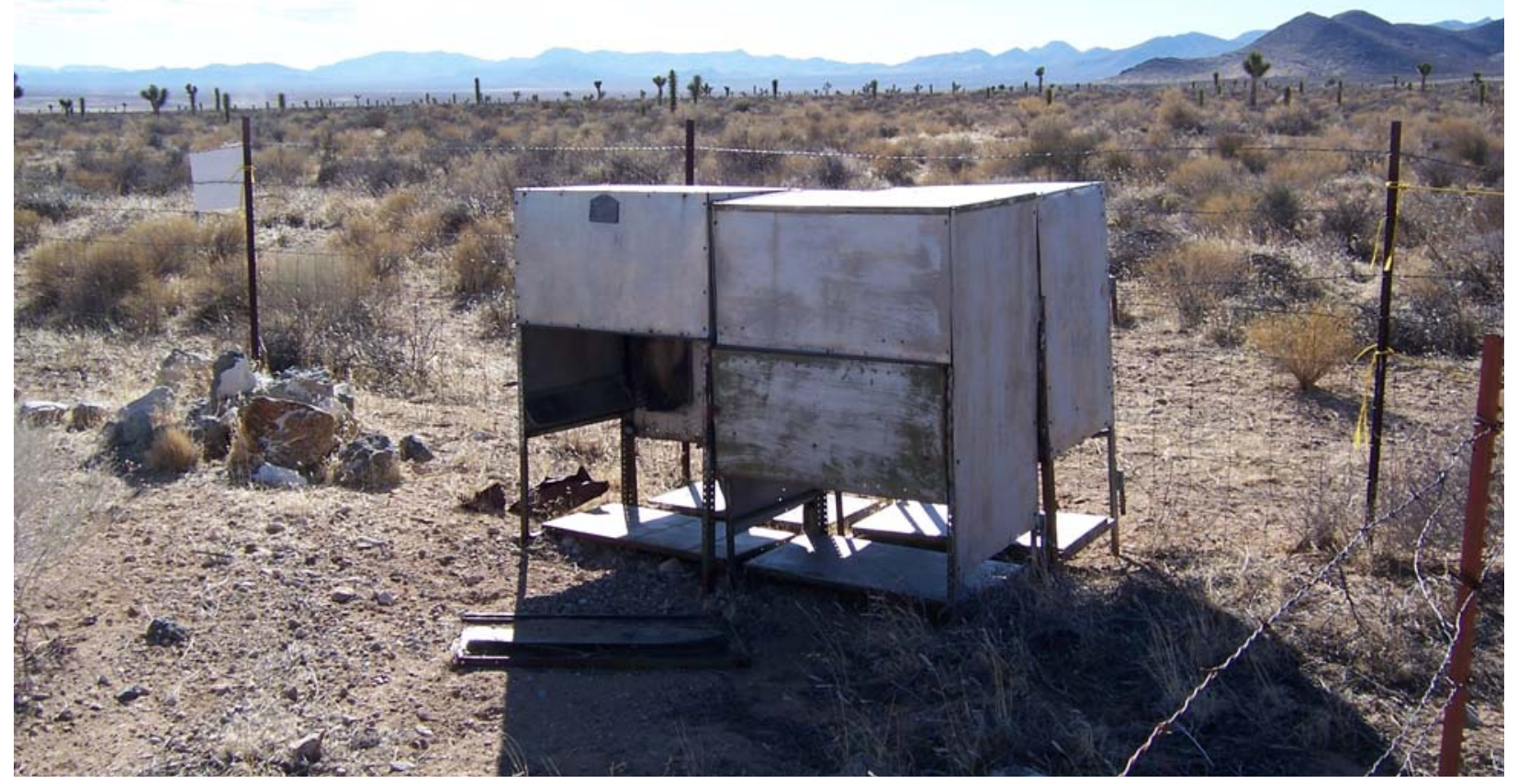

Photograph 52. CAS 15-23-03, Cabinet debris, before closure activities 
Closure Report - CAU 543

Section: Appendix D

Revision: 0

Date: January 2008

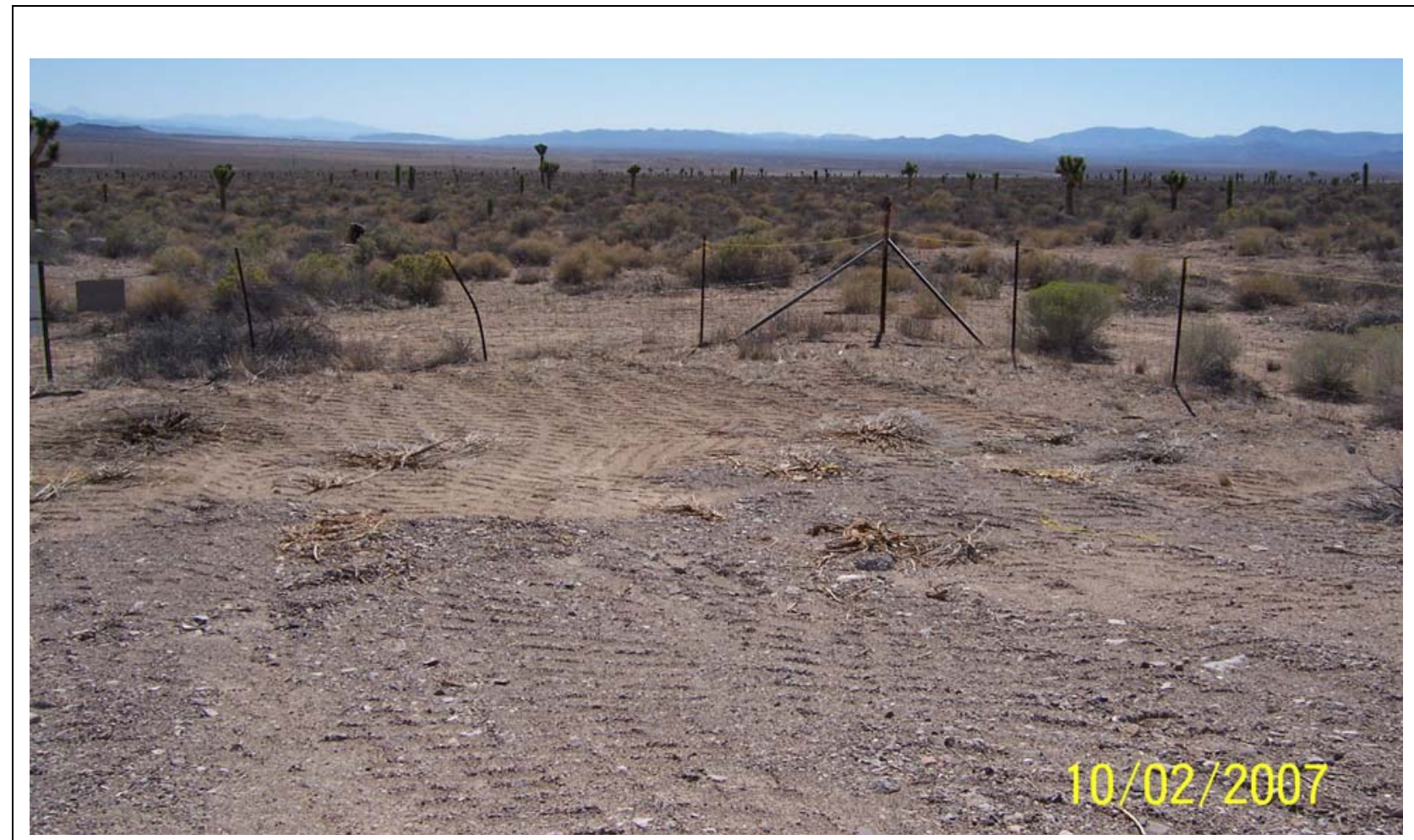

Photograph 53. CAS 15-23-03, Debris area, after closure activities 
Closure Report - CAU 543

Section: Appendix D

Revision: 0

Date: January 2008

THIS PAGE INTENTIONALLY LEFT BLANK 
Date: January 2008

\section{APPENDIX E}

\section{USE RESTRICTION DOCUMENTATION}


Closure Report - CAU 543

Section: Appendix E:

Revision: ()

Date: January 2008

THIS PAGE INTENTIONALLY LEFT BLANK 


\section{CAU Use Restriction Information}

CAU Number/Description: CAU 543: Surface Debris, Waste Sites, and Burn Area (TTR)

Applicable CAS Numbers/Descriptions: CAS 06-07-01: Decon Pad

Contact (organization/project): NNSA/NSO Federal Sub-Project Director

Surveyed Area (UTM, Zone 11, NAD 27, meters):

\begin{tabular}{|c|c|c|}
\hline UR PoINTS & NoRTHING & EASTING \\
\hline \hline South-1 Survey Point & $4,087,941.145$ & $585,738.772$ \\
\hline South-2 Survey Point & $4,087,949.463$ & $585,726.340$ \\
\hline South-3 Survey Point & $4,087,938.791$ & $585,719.180$ \\
\hline South-4 Survey Point & $4,087,946.640$ & $585,707.759$ \\
\hline South-5 Survey Point & $4,087,958.482$ & $585,716.052$ \\
\hline West Corner & $4,087,974.481$ & $585,691.838$ \\
\hline North Corner & $4,088,000.688$ & $585,709.026$ \\
\hline East Corner & $4,087,968.213$ & $585,757.301$ \\
\hline
\end{tabular}

Survey Date: $\underline{10 / 25 / 2007}$ Survey Method (GPS, etc): $\underline{\text { GPS }}$

Site Monitoring Requirements: Visual inspections of fence and postings

Required Frequency (quarterly, annually?): Annual

If Monitoring Has Started, Indicate last Completion Date: N/A

\section{Use Restrictions}

The future use of any land related to this Corrective Action Unit (CAU), as described by the above surveyed location, is restricted from any DOE or Air Force activity that may alter or modify the containment control as approved by the state and identified in the CAU Closure Report or other CAU documentation unless appropriate concurrence is obtained in advance.

Comments: See the Closure Report for additional information on the condition of the site(s) and any monitoring and/or inspection requirements. This use restriction applies to the former Building 6-605 concrete foundation plus 10 feet laterally outward in all directions. The use restriction applies to $\mathrm{PCB}$ and radioactive contamination of the pad and surrounding soil. 
Submitted By: L/s/ Kevin Cabble

Date: $\angle-3-08$

cc with copy of survey map (paper and digital (dgn) formats):

CAU Files ( 2 copies) 


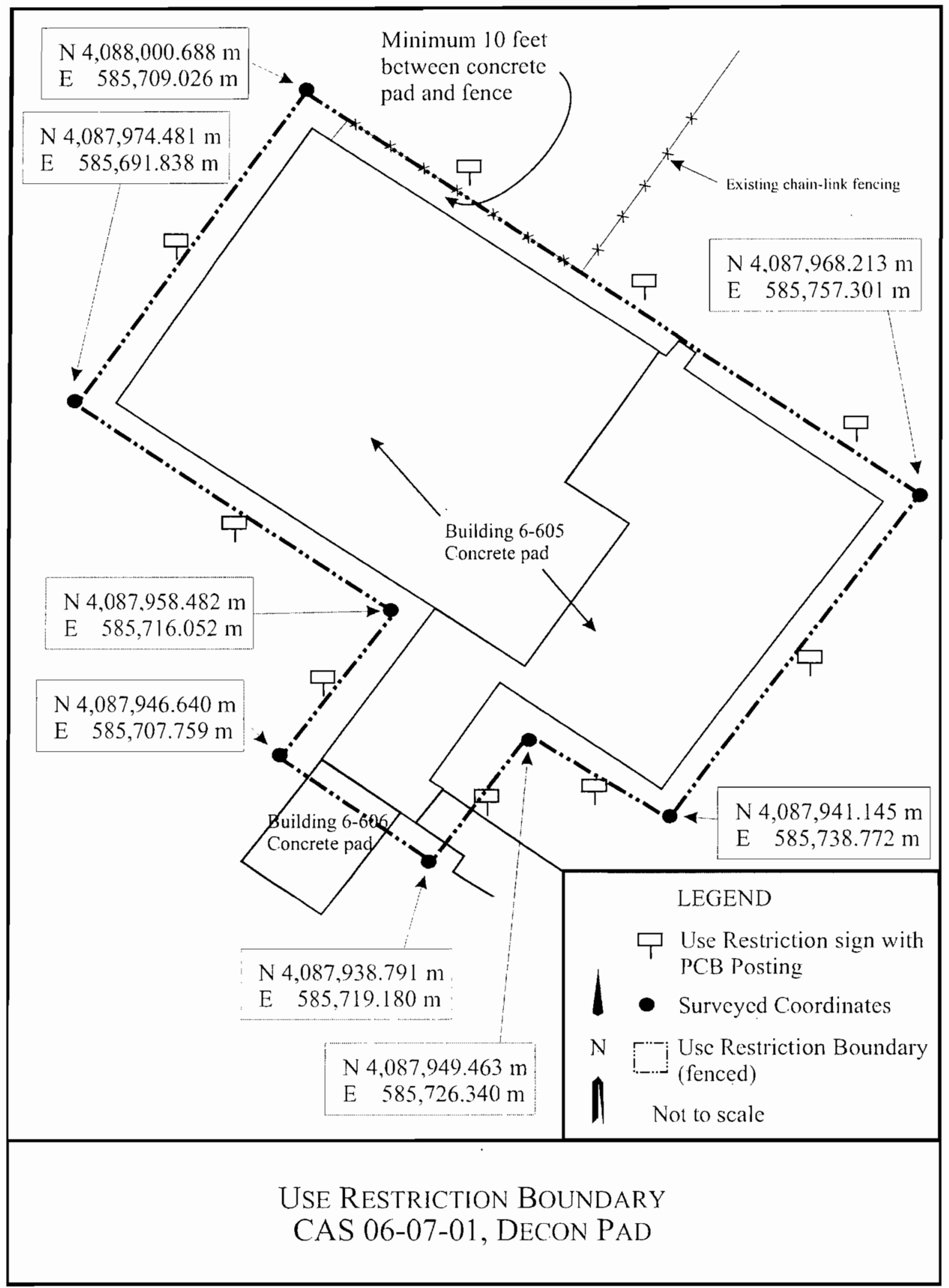


Closure Report - CAU 543

Section: Appendix F

Revision: (o

Datc: January 2008

THIS PAGE INTENTIONALLY LEFT BLANK 


\section{CAU Use Restriction Information}

CAU Number/Description: CAU 543: Surface Debris, Waste Sites, and Burn Area (TTR)

Applicable CAS Numbers/Descriptions: CAS 15-01-03: Aboveground Storage Tank

Contact (organization/project): NNSA/NSO Federal Sub-Project Director

Surveyed Area (UTM, Zone 11, NAD 27, meters):

\begin{tabular}{|c|c|c|}
\hline UR PoINTS & NORTHING & EASTING \\
\hline \hline Southeast Corner & $4,118,271.245$ & $585,102.289$ \\
\hline South-1 Survey Point & $4,118,270.313$ & $585,098.520$ \\
\hline South-2 Survey Point & $4,118,058.336$ & $585,169.760$ \\
\hline South-3 Survey Point & $4,118,050.734$ & $585,182.455$ \\
\hline South-4 Survey Point & $4,118,049.279$ & $585,181.158$ \\
\hline South-5 Survey Point & $4,118,057.395$ & $585,167.846$ \\
\hline South-6 Survey Point & $4,118,269.425$ & $585,094.393$ \\
\hline Southwest Corner & $4,118,261.956$ & $585,053.810$ \\
\hline Northwest Corner & $4,118,283.210$ & $585,046.973$ \\
\hline Northeast Corner & $4,118,298.531$ & $585,094.087$ \\
\hline
\end{tabular}

Survey Date: $10 / 25 / 2007 \quad$ Survey Method (GPS, etc): $\underline{\text { GPS }}$

Site Monitoring Requirements: Visual inspections of fence and postings

Required Frequency (quarterly, annually?): Annual

If Monitoring Has Started, Indicate last Completion Date: N/A

\section{Use Restrictions}

The future use of any land related to this Corrective Action Unit (CAU), as described by the above surveyed location, is restricted from any DOE or Air Force activity that may alter or modify the containment control as approved by the state and identified in the CAU Closure Report or other CAU documentation unless appropriate concurrence is obtained in advance.

Comments: See the Closure Report for additional information on the condition of the site(s) and any monitoring and/or inspection requirements. This use restriction applies to the former Building 15-06 concrete foundation and underground piping between the 
building foundation and the former location of the Aboveground Storage Tank. The use restriction applies to PCB contamination of the pad and underground piping.

Submitted By: /s/. Kevin Cabble Date: $3-68$

cc with copy of survey map (paper and digital (dgn) formats):

CAU Files ( 2 copies) 


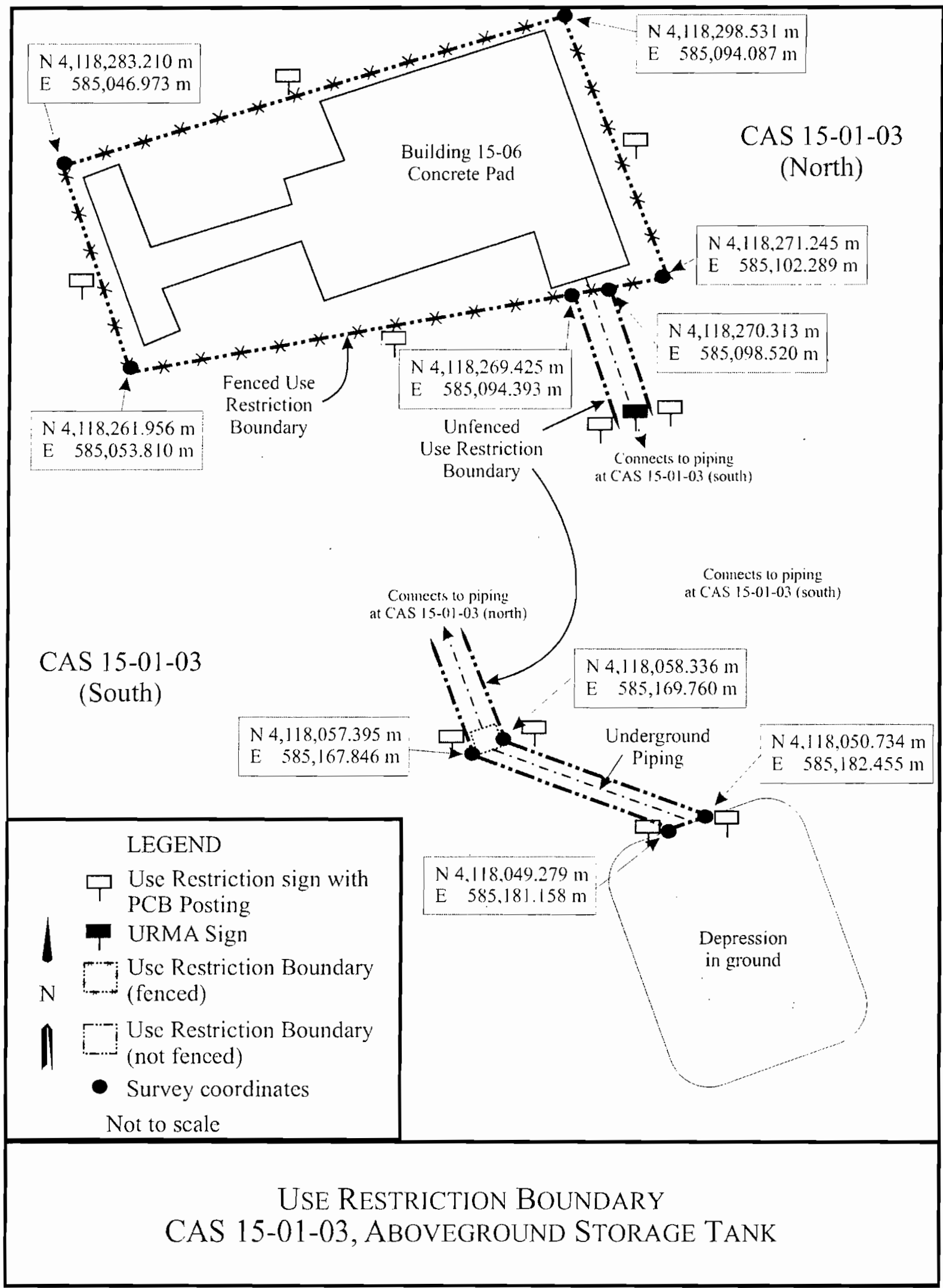


Closure Reporl - CAU 543

Section: Appendix E:

Revision: 0

Date: January 2008

THIS PAGE INTENTIONALLY LEFT BLANK 


\section{CAU Use Restriction Information}

CAU Number/Description: CAU 543: Surface Debris, Waste Sites, and Burn Area (TTR)

Applicable CAS Numbers/Descriptions: CAS 15-23-03: Contaminated Sump. Piping

Contact (organization/project): NNSA/NSO Federal Sub-Project Director

Surveyed Area (UTM, Zone 11, NAD 27, meters):

\begin{tabular}{|c|c|c|}
\hline UR POINTS & NORTHING & EASTING \\
\hline \hline Southeast Corner & $4,118,015.096$ & $585,182.593$ \\
\hline Southwest Corner & $4,118,009.417$ & $585,165.061$ \\
\hline Northwest Corner & $4,118,038.950$ & $585,155.628$ \\
\hline North-1 Survey Point & $4,118,042.498$ & $585,169.359$ \\
\hline North-2 Survey Point & $4,118,057.393$ & $585,167.791$ \\
\hline North-3 Survey Point & $4,118,058.354$ & $585,169.760$ \\
\hline Northeast Corner & $4,118,040.912$ & $585,175.531$ \\
\hline
\end{tabular}

Survey Date: $\underline{10 / 25 / 2007}$ Survey Method (GPS, etc): $\underline{\text { GPS }}$

Site Monitoring Requirements: Visual inspections of postings

Required Frequency (quarterly, annually?): Annual

If Monitoring Has Started, Indicate last Completion Date: N/A

\section{Use Restrictions}

The future use of any land related to this Corrective Action Unit (CAU), as described by the above surveyed location, is restricted from any DOE or Air Force activity that may alter or modify the containment control as approved by the state and identified in the CAU Closure Report or other CAU documentation unless appropriate concurrence is obtained in advance.

Comments: See the Closure Report for additional information on the condition of the site(s) and any monitoring and/or inspection requirements. This use restriction applies to the sump and underground piping between the sump and the former location of a distribution box associated with CAS 15-01-03. The use restriction applies to PCB and radiological contamination of the sump and underground piping. 
Submitted By: /s/ Kevin Cabble Date: $-3-68$ cc with copy of survey map (paper and digital (dgn) formats): CAU Files ( 2 copies) 


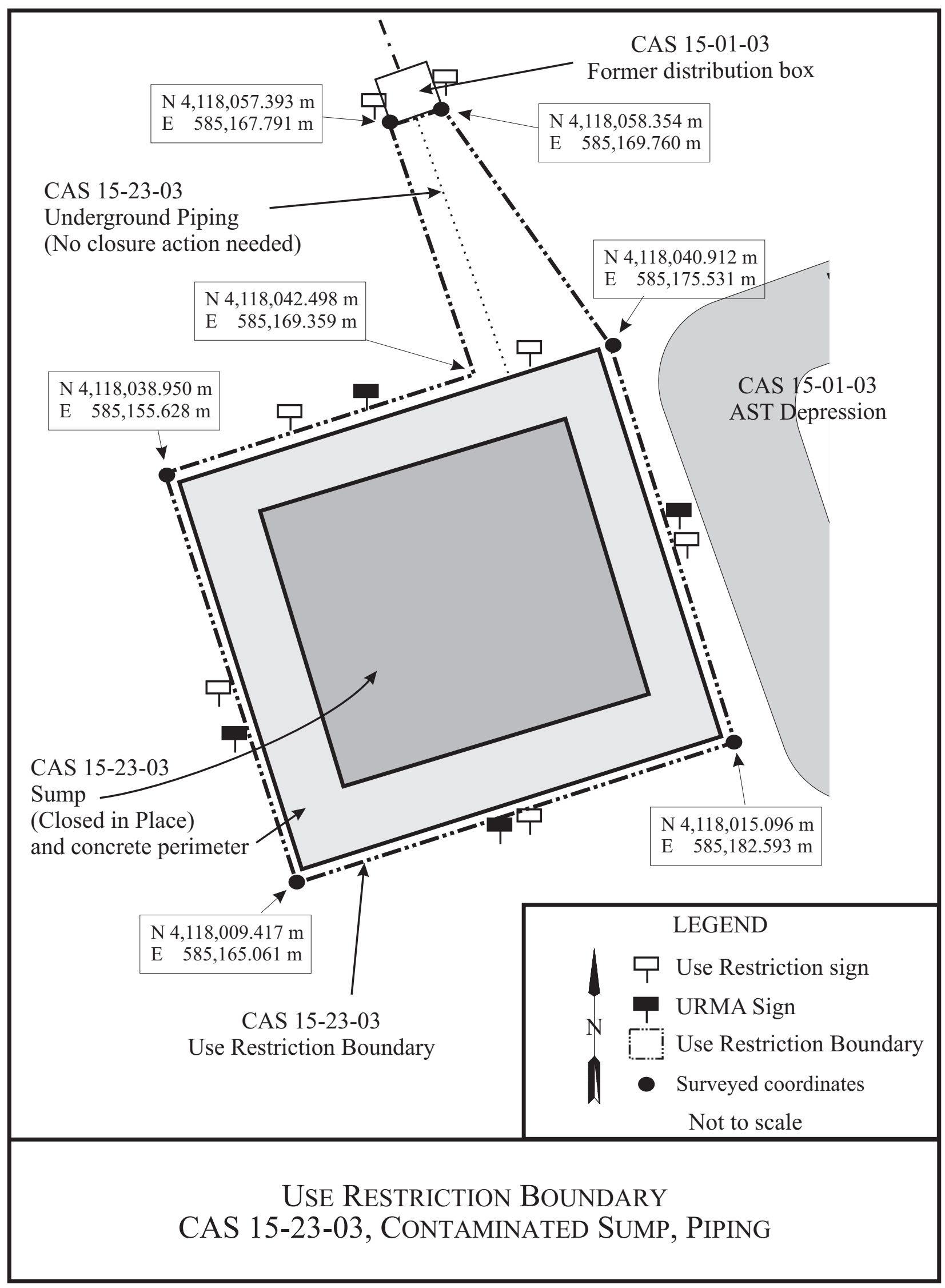


Closure Report - CAU 543

Section: Appendix E

Revision: 0

Date: January 2008

THIS PAGE INTENTIONALLY LEFT BLANK 


\section{LIBRARY DISTRIBUTION LIST}


Closure Report - CAU 543

Section: Library Distribution List

Revision: 0

Date: January 2008

THIS PAGE INTENTIONALLY LEFT BLANK 


\section{LIBRARY DISTRIBUTION LIST}

U.S. Department of Energy

National Nuclear Security Administration

Nevada Site Office

Technical Library

P.O. Box 98518, M/S 505

Las Vegas, NV 89193-8518

U.S. Department of Energy

Office of Scientific and Technical Information

P.O. Box 62

Oak Ridge, TN 37831-0062

Southern Nevada Public Reading Facility

c/o Nuclear Testing Archive

P.O. Box 98521, M/S 400

Las Vegas, NV 89193-8521

Manager, Northern Nevada FFACO

Public Reading Facility

c/o Nevada State Library \& Archives

Carson City, NV 89701-4285
1 (Uncontrolled, electronic copy)

1 (Uncontrolled, electronic copy)

2 (Uncontrolled, electronic copies)

1 (Uncontrolled, electronic copy) 
Closure Report - CAU 543

Section: Library Distribution List

Revision: 0

Date: January 2008

THIS PAGE INTENTIONALLY LEFT BLANK 